UNIVERSIDADE DE SÃO PAULO

FACULDADE DE ECONOMIA, ADMINISTRAÇÃO E CONTABILIDADE DEPARTAMENTO DE ADMINISTRAÇÃO

IMPLANTAÇÃO E RESULTADOS DE PROGRAMA DE QUALIDADE EM UNIVERSIDADE PÚBLICA:

ESTUDO DE CASO DA UNIVERSIDADE DE SÃO PAULO

Olga Maria Zulzke de Miranda

Orientadora: Profa. Dra. Ana Cristina Limongi-França

SÃO PAULO

2010 
Prof. Dr. João Grandino Rodas

Reitor da Universidade de São Paulo

Prof. Dr. Hélio Nogueira da Cruz

Vice-Reitor da Universidade de São Paulo

Prof. Dr. Carlos Roberto Azzoni

Diretor da Faculdade de Economia, Administração e Contabilidade

Prof. Dr. Adalberto Américo Fischmann

Chefe do Departamento de Administração

Prof. Dr. Lindolfo Galvão de Albuquerque

Coordenador do Programa de Pós-Graduação em Administração 
OLGA MARIA ZULZKE DE MIRANDA

\title{
IMPLANTAÇÃO E RESULTADOS DE PROGRAMA DE QUALIDADE EM UNIVERSIDADE PÚBLICA: \\ ESTUDO DE CASO DA UNIVERSIDADE DE SÃO PAULO
}

\author{
Tese de Doutorado apresentada ao \\ Departamento de Administração da Faculdade \\ de Economia, Administração e Contabilidade \\ da Universidade de São Paulo, como requisito \\ para a obtenção do título de Doutora em \\ Administração.
}

Orientadora: Profa. Dra. Ana Cristina Limongi-França

SÃo PAULO

2010 


\section{FICHA CATALOGRÁFICA}

Elaborada pela Seção de Processamento Técnico do SBD/FEA/USP

\section{Miranda, Olga Maria Zulzke de}

Implantação e resultados de programa de qualidade em universidade pública : estudo de caso na Universidade de São Paulo / Olga Maria Zulzke de Miranda. -- São Paulo, 2010.

$401 \mathrm{p}$.

Tese (Doutorado) - Universidade de São Paulo, 2010.

Orientadora: Ana Cristina Limongi-França.

1. Qualidade total 2. Administração pública 3. Mudança organizacional 4. Universidade pública I. Universidade de São Paulo.

Faculdade de Economia, Administração e Contabilidade II. Título.

CDD - 658.562 
Ao meu marido Alcides, pela compreensão, carinho e suporte integral a esse meu projeto, às minhas filhas Denise e Nadine e ao meu genro Daniel, pelo apoio e incentivo permanentes. 

O espaço é para lembrar e agradecer. As horas de desalento foram muitas e forte a vontade de deixar tudo perecer diante de um trabalho que parecia impossível de ser concluído. Idas e vindas, com as leituras infindáveis, os autores se sucedendo em contradições, os paradigmas arraigados sendo substituídos; as incertezas das conclusões e a certeza de saber menos à medida que se lia mais.

Nessa caminhada, encontrei estímulo, apoio e incentivo em um grupo grande de pessoas; algumas delas foram mais presentes e constantes, outras mais distantes, embora tivessem trazido a palavra certa no momento preciso, para me ajudar a vencer o desafio. Aos que nomeio aqui e aos anônimos colaboradores apresento meu carinho, minha gratidão e sincero reconhecimento.

Expresso meus profundos agradecimentos a minha orientadora, Profa. Dra. Ana Cristina Limongi-França, pela confiança e incentivo para eu fazer um doutorado, propiciando uma nova dimensão em meus conhecimentos.

Ao Prof. Dr. Hélio Nogueira da Cruz, com quem tive a oportunidade de aprender muito no trabalho conjunto de longos anos, complementado, nesta tese, com sugestões feitas no Exame de Qualificação.

Ao Prof. Dr. Hélio Janny Teixeira pelos comentários valiosos, também na mesma oportunidade, como membro da Banca Examinadora.

Um agradecimento especial aos entrevistados da pesquisa de campo: ex-dirigentes da USP, ex-diretores e funcionários técnicos administrativos das Unidades de Ensino e Pesquisa, dirigentes e técnicos administrativos da UNICAMP e da UNESP.

Ao Prof. Edson Riccio que me auxiliou no meu intento de fazer uma parte do doutorado na França, assim como ao Prof. Drouvot, professor da Université Pierre Mendès-France, de Grenoble, que facilitou os trâmites burocráticos para isso. Ao Prof. Didier Retour, da mesma Universidade, que me aceitou como sua orientanda e com o qual pude entender de forma diferente minha tese.

Relaciono um elenco de pessoas que me ajudaram neste desafio e assumo que cada uma delas saberá que tijolo da construção me ajudou a colocar no levantamento bibliográfico, na reflexão teórica e na execução formal desta tese. Coloquei em prática minha crença no trabalho participativo e aprendi muito com a colaboração de cada um. Meus agradecimentos a: Ailton Bruno, Dirce Regados, Dulcinéia Jacobini, Gláucia dos Santos, Prof. Guilherme Ary Plonsky, Prof. José Carlos de Aquino, Ivone Robles, Lu Medeiros, Luiz Silva dos Santos, Profa. Marilda Nagamini, Prof. Mauri de Oliveira, Milena Neves, Prof. Nicolau Reinhard, Profa. Nildes Pitombo Leite, Regina Marcelino e Sheila Mazzeo. 

"A verdadeira viagem da descoberta consiste não em buscar novas terras, mas em ver as mesmas terras com novos olhares."

Marcel Proust

Escritor francês

$(1871-1922)$ 



\section{RESUMO}

Esta tese teve como objetivo realizar uma retrospectiva histórica do processo de implantação e dos resultados de um Programa de Qualidade e Produtividade, aplicado a uma universidade pública. A contribuição desta tese é relevante pela sistematização de um grande conjunto de dados dispersos que, organizados, preservam a memória desse Programa na Universidade de São Paulo (USP), dão transparência às ações de um órgão público e propiciam o aprendizado organizacional. Metodologicamente é caracterizado como um estudo de caso, de natureza exploratória com abordagem qualitativa, abrangendo, com maior ênfase, o período de 1996 a 2006. Utilizaram-se levantamentos de dados primários, com entrevistas a docentes exdirigentes e funcionários técnicos administrativos da USP e pesquisa documental. Acrescidos com a observação participante da pesquisadora, foram evidenciados aspectos relativos ao contexto em que foi instituído, seu processo, conteúdo, resultados e avaliação sobre o Programa, segundo percepção dos entrevistados. Os achados desta pesquisa mostraram a influência do Programa de Qualidade em aspectos tangíveis e intangíveis da organização. São tangíveis os aumentos das relações alunos por professor e alunos por funcionários, assim como redução de gastos em utilidades. Nos resultados intangíveis, o Programa foi significativo para a formação de uma nova mentalidade nos funcionários e outros aspectos ligados à mudança da cultura organizacional nas atividades meio. Revelaram-se ocorrências frequentes, alterações em aspectos comportamentais e administrativos tais como: a melhoria na qualificação e profissionalização dos recursos humanos, maior participação, interação e envolvimento dos funcionários e maior atenção a aspectos de qualidade de vida no trabalho. Observou-se que o Programa de Qualidade e Produtividade refletiu, também, no processo de Avaliação Institucional, incentivando o desenvolvimento de Planos e Metas, das Unidades e dos Departamentos da USP. Conclui-se que o registro, sistematizado nesta tese, colabora na reconstrução histórica de uma trajetória institucional, visando à melhoria da universidade e da gestão pública, uma vez que o Programa na USP teve a função de estratégia mobilizadora para mudanças organizacionais e tal função deve ser continuamente repensada para atender às novas condições de um ambiente externo dinâmico.

Palavras-chave: Qualidade Total. Administração Pública. Mudança Organizacional. Universidade Pública. 



\begin{abstract}
This thesis aimed to produce a historical overview of the implementation process and of the results of a Quality and Productivity Program at a public university. The contribution of this work is relevant because it systematizes a large set of dispersed data, which, once organized, conserve the history of this Program at the University of São Paulo (USP), give transparency to the actions of a government institution and foster organizational learning. In methodology terms, it is a qualitative case study of an exploratory nature, encompassing primarily the 1996 -2006 period. The thesis used a survey of primary data collected through interviews with professors who headed the quality program process and with technical administrative USP staff. Documental research was also employed. The interviews, coupled with the observations of the participating researcher, aimed to evidence certain aspects of the context in which the Program was instituted, as well as its process, content, results and evaluation, according to the perception of the interviewees. The findings of this research showed the influence of the Quality Program on both tangible and intangible aspects of the organization. The tangible ones concerned an increase of the students per professor and students per employee ratios, as well as cost reduction in utilities. Regarding the intangible results, the Program was significant in shaping a new mentality among the employees and other aspects linked to changes in the organizational culture and support activities. Changes in behavioral and administrative aspects were frequently observed, such as: the improvement of the qualification and professionalization of human resources; the increased participation, interaction and involvement of the employees; and the increase of attention being paid to aspects of the quality of life at work. The observations also indicated that the Quality and Productivity Program had an impact on the Institutional Evaluation process, encouraging the development of plans and targets at the university's units and departments. The conclusion of the work indicates that the systematized records provided by this thesis contribute to the historical reconstruction of the institution's development path, with a view to improving the university and public administration. The Quality Program at USP was a strategy designed to mobilize the system toward organizational changes and new mobilization strategies must be continuously rethought in order to fulfill the new dictates of a dynamic external environment.
\end{abstract}

Key words: Total Quality. Public Administration. Organizational Change. Public University. 



\section{RÉSUMÉ}

Cette thèse a pour objet de dresser une rétrospective historique du processus de mise en place et des résultats d'un Programme de Qualité et de Productivité appliqué à une université publique. La contribution de cette thèse est pertinente par la systématisation d'un grand ensemble de données dispersées qui, une fois organisées, préservent la mémoire de ce Programme au sein de l'Université de São Paulo (USP), confèrent transparence aux actions d'un organisme public et rendent possible un apprentissage organisationnel. Méthodologiquement, il s'agit d'une étude de cas de nature exploratoire, à approche qualitative, qui couvre et met en exergue la période de 1996 à 2006. Des relevés de données primaires ont été mis à profit - notamment des entretiens de professeurs anciens-dirigeants et d'employés des secteurs techniques et administratifs de l'USP - en parallèle avec une recherche documentaire. Outre l'observation participante de la chercheuse, il a été mis l'accent, au gré de la perception des interviewés, sur les aspects du contexte dans lequel ont été institué le processus, le contenu, les résultats et l'évaluation du Programme. Les résultats montrés par cette recherche ont signalé l'influence du Programme de Qualité sur des aspects tangibles et intangibles de l'organisation. De manière tangible, on a pu constater l'augmentation du nombre d'élèves par professeur et du nombre d'élèves par employé, ainsi que la réduction des dépenses des services d'appui. Quant aux résultats intangibles, on peut dire que le Programme a fait levier sur l'apparition d'une nouvelle mentalité chez les employés et sur d'autres aspects inhérents au changement de culture organisationnelle dans les activités secondaires ou dérivées. On a noté la survenue fréquente de modifications dans les aspects comportementaux et administratifs tels que: l'amélioration de la qualification, la professionnalisation des ressources humaines, la hausse de la participation, l'interaction et l'implication des employés ainsi qu'une sensibilité accrue envers les aspects de la qualité de vie au travail. On a remarqué que le Programme de Qualité et de Productivité a eu également une influence sur le processus d'évaluation institutionnelle en encourageant le développement de plans stratégiques et sur les objectifs à atteindre au sein des Unités et des Départements de l'USP. Vu que le Programme au sein de l'USP a eu l'effet d'une stratégie mobilisatrice porteuse de changements organisationnels, on peut conclure que le registre, tel que systématisé dans cette thèse, collabore à la reconstruction historique d'une trajectoire institutionnelle qui cible l'amélioration de l'Université et de la gestion publique. Il apparaît, par ailleurs, que cette fonction doit être continuellement repensée pour répondre aux nouveautés apportées par un environnement extérieur dynamique.

Mots-clés: Qualité totale. Administration publique. Changement organisationnel. Université publique. 



\section{SUMÁRIO}

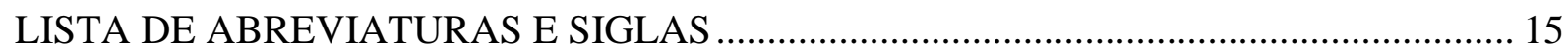

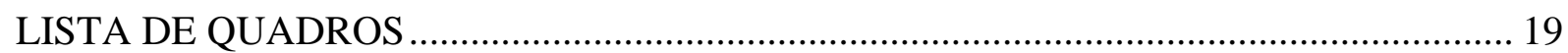

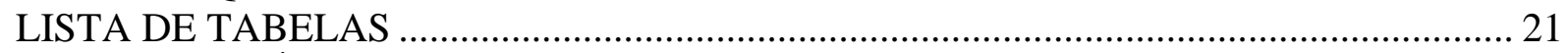

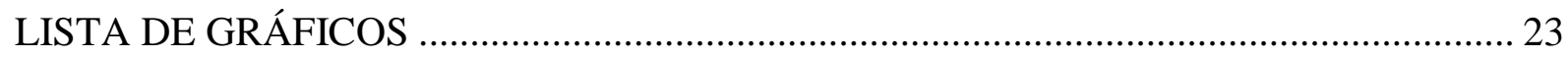

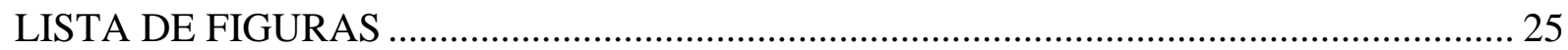

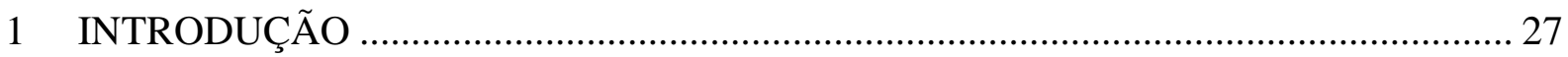

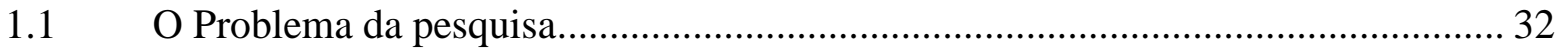

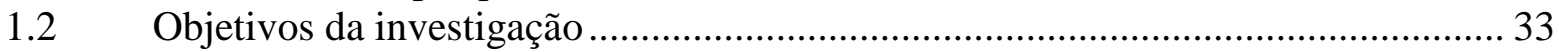

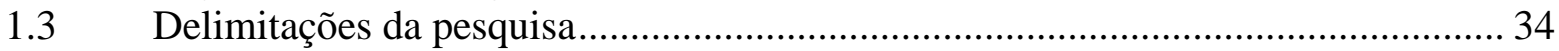

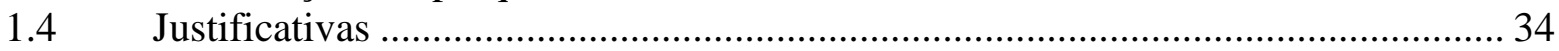

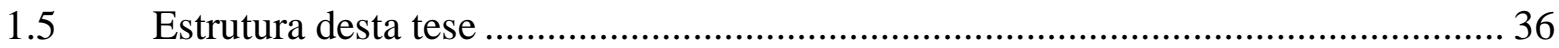

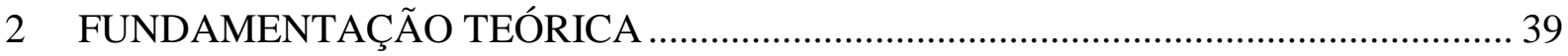

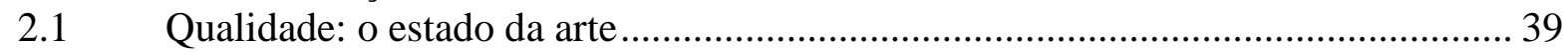

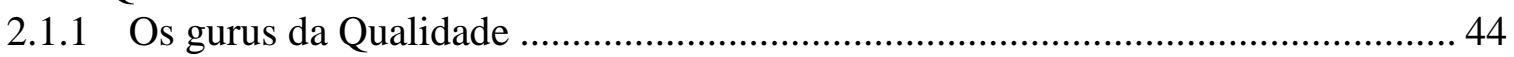

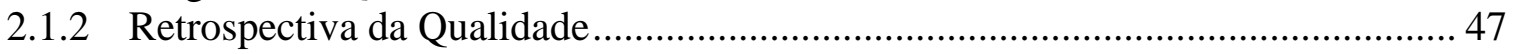

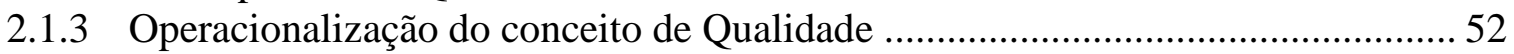

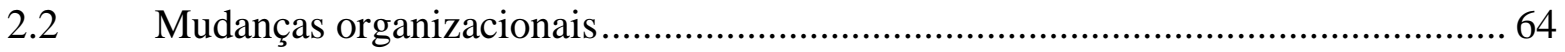

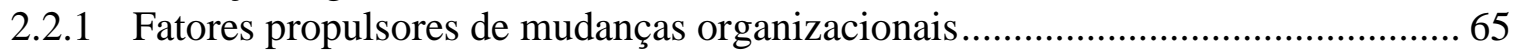

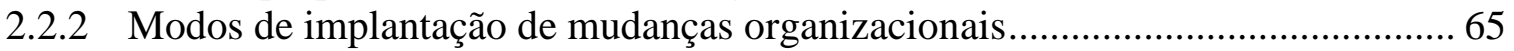

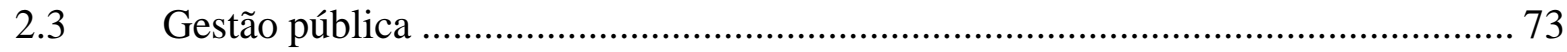

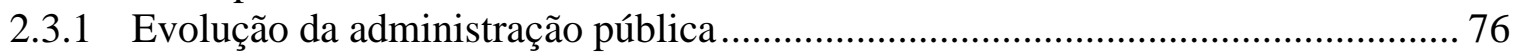

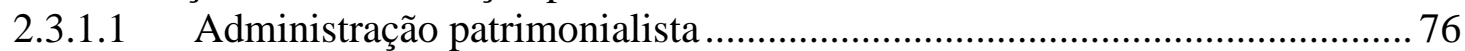

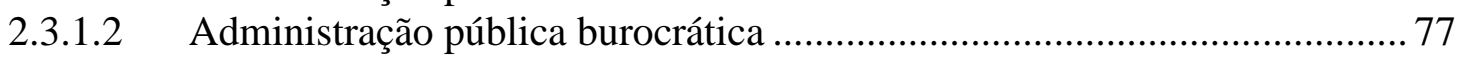

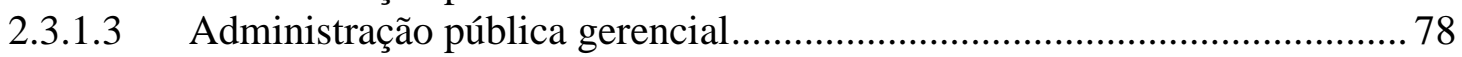

2.3.2 Qualidade e seu entrelaçamento com a administração pública .............................. 80

2.3.3 Programa de Qualidade no Estado de São Paulo ................................................... 91

2.4 A Universidade Pública ................................................................................ 101

2.4.1 A universidade e seu entrelaçamento com a qualidade .................................... 110

2.4.2 Programa de Qualidade e Produtividade nas universidades estaduais paulistas 112

2.4.2.1 A Universidade Estadual de Campinas................................................... 112

2.4.2.2 A Universidade Estadual Paulista Júlio de Mesquita Filho ...................... 115

2.4.2.3 A Universidade de São Paulo ....................................................................... 117

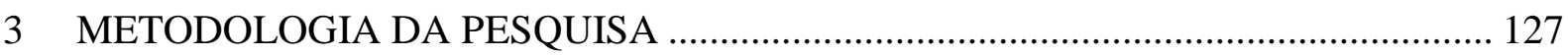

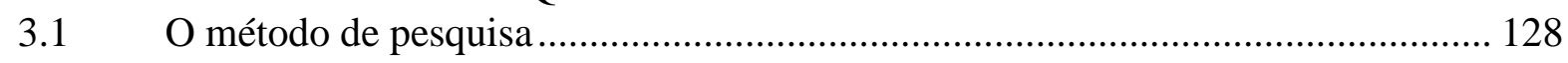

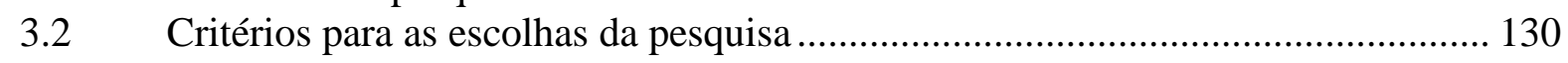

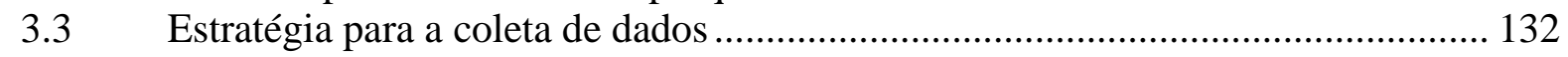

3.4 Procedimentos para tratamento e análise dos dados............................................ 134

3.5 Distribuição das questões do roteiro de entrevista por categoria de análise.......... 137

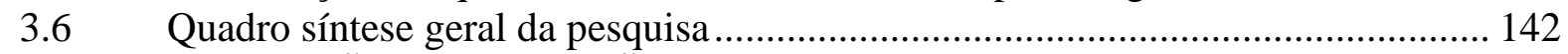

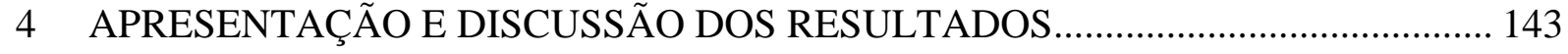

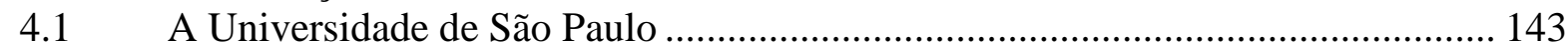

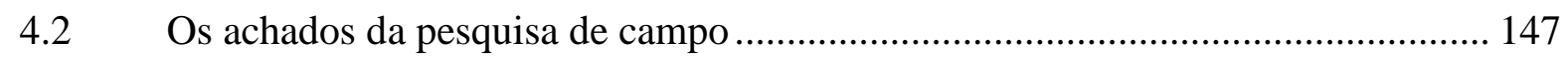

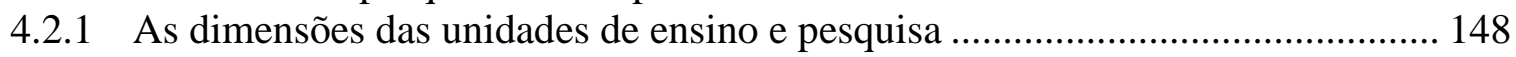

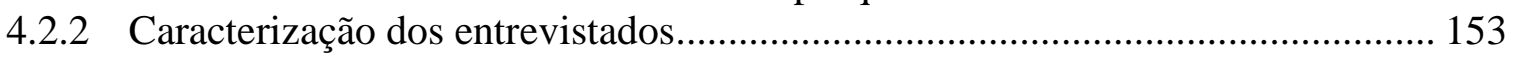

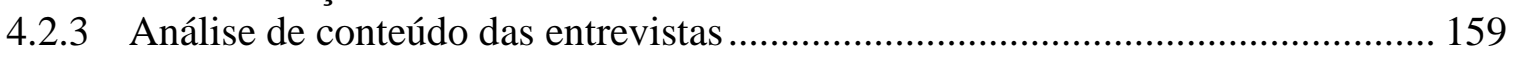

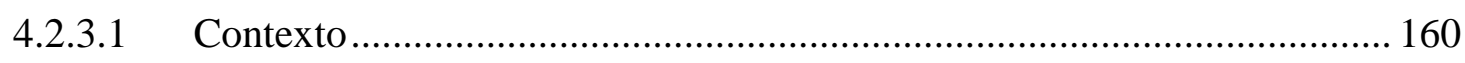

4.2.3.2 Conteúdo do Programa de Q\&P ......................................................... 170 


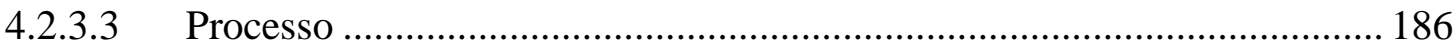

4.2.3.4 Resultados do Programa de Qualidade e Produtividade da USP .............. 214

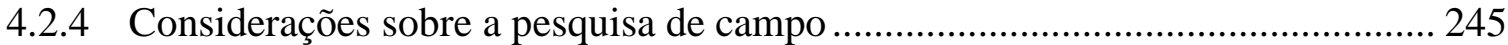

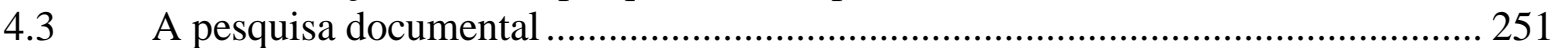

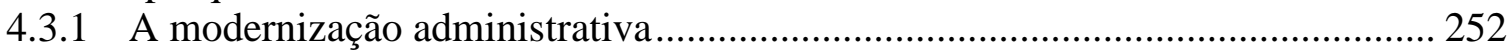

4.3.2 O Programa de Qualidade e Produtividade na USP ........................................... 253

4.3.2.1 Resultados do Programa de Qualidade e Produtividade ............................ 268

4.3.2.2 Considerações sobre a pesquisa documental ........................................... 274

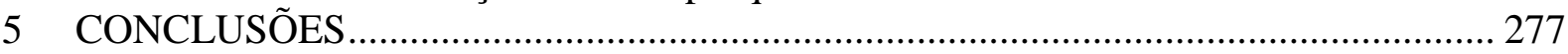

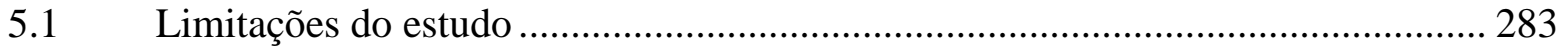

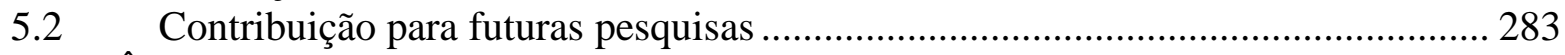

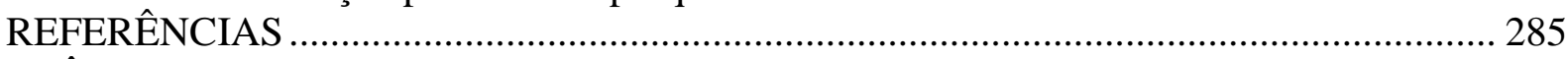

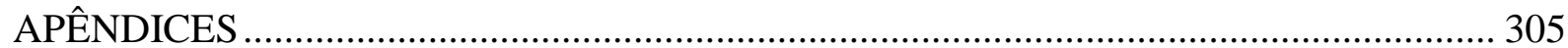




\section{LISTA DE ABREVIATURAS E SIGLAS}

\begin{tabular}{|c|c|}
\hline ABNT: & Associação Brasileira de Normas Técnicas \\
\hline CAPES: & Coordenação de Aperfeiçoamento de Pessoal de Nível Superior \\
\hline CCE: & Centro de Computação Eletrônica \\
\hline CCS: & Coordenadoria da Comunicação Social \\
\hline CECAE: & $\begin{array}{l}\text { Coordenadoria Executiva de Cooperação Universitária e de Atividades } \\
\text { Especiais }\end{array}$ \\
\hline CENA: & Centro de Energia Nuclear na Agricultura \\
\hline CEPEUSP: & Centro de Práticas Esportivas da USP \\
\hline CIAGRI: & Centro de Informática de Agricultura \\
\hline CIPA: & Comissão Interna de Prevenção de Acidentes \\
\hline CODAGE: & Coordenadoria de Administração Geral \\
\hline COP: & Comissão de Orçamento e Patrimônio \\
\hline COPAVO: & Comissão Permanente para Apuração de Acidentes com Veículos Oficiais \\
\hline COSEAS: & Coordenadoria de Assistência Social \\
\hline CGQP: & Comissão de Gestão de Qualidade e Produtividade \\
\hline DA: & Departamento de Administração \\
\hline DF: & Departamento de Finanças \\
\hline DFA: & Delegacia Federal da Agricultura \\
\hline DI: & Departamento de Informática \\
\hline DIBD: & Divisão de Biblioteca e Documentação \\
\hline DRH: & Departamento de Recursos Humanos \\
\hline EACH: & Escola de Artes, Ciências e Humanidades \\
\hline EBAP: & Escola Brasileira de Administração Pública \\
\hline ECA: & Escola de Comunicações e Artes \\
\hline ED: & Editora da USP \\
\hline EE: & Escola de Enfermagem \\
\hline EEFE: & Escola de Educação Física e Esporte \\
\hline EEFERP: & Escola de Educação Física e Esporte de Ribeirão Preto \\
\hline EEL: & Escola de Engenharia de Lorena \\
\hline EERP: & Escola de Enfermagem de Ribeirão Preto \\
\hline EESC: & Escola de Engenharia de São Carlos \\
\hline EFQM: & European Foundation for Quality Management \\
\hline EP: & Escola Politécnica \\
\hline ESALQ: & Escola Superior de Agricultura Luiz de Queiroz \\
\hline FAU: & Faculdade de Arquitetura e Urbanismo \\
\hline FCAV: & Fundação Carlos Alberto Vanzolini \\
\hline FCF : & Faculdade de Ciências Farmacêuticas \\
\hline FCFRP: & Faculdade de Ciências Farmacêuticas de Ribeirão Preto \\
\hline FD: & Faculdade de Direito \\
\hline FDRP: & Faculdade de Direito de Ribeirão Preto \\
\hline FE: & Faculdade de Educação \\
\hline FEA: & Faculdade de Economia, Administração e Contabilidade \\
\hline FEARP: & Faculdade de Economia, Administração e Contabilidade de Ribeirão Preto \\
\hline FFLCH: & Faculdade de Filosofia, Ciências e Letras de Ribeirão Preto \\
\hline FFLCH: & Faculdade de Filosofia, Letras e Ciências Humanas \\
\hline FIA: & Fundação Instituto de Administração \\
\hline FIPE: & Fundação Instituto de Pesquisas Econômicas \\
\hline FM: & Faculdade de Medicina \\
\hline
\end{tabular}




\begin{tabular}{|c|c|}
\hline FMRP: & Faculdade de Medicina de Ribeirão Preto \\
\hline FMVZ: & Faculdade de Medicina Veterinária e Zootecnia \\
\hline FO: & Faculdade de Odontologia \\
\hline FOB: & Faculdade de Odontologia de Bauru \\
\hline FORP: & Faculdade de Odontologia de Ribeirão Preto \\
\hline FPNQ: & Fundação Prêmio Nacional da Qualidade \\
\hline FSP: & Faculdade de Saúde Pública \\
\hline FZEA: & Faculdade de Zootecnia e Engenharia de Alimentos \\
\hline GEFIM: & Gestão Financeira e de Materiais \\
\hline GEINFO: & Gestão de Informática \\
\hline GESEC: & Gestão de Secretárias \\
\hline GESPE: & Gestão de Pessoas \\
\hline \multicolumn{2}{|c|}{ GESPÚBLICA: Gestão Pública } \\
\hline GQVT: & Grupo de Qualidade de Vida no Trabalho \\
\hline GIACAD: & Grupo de Integração de Assistentes Acadêmicos \\
\hline HRAC: & Hospital de Reabilitação de Anomalias Craniofaciais \\
\hline HU: & Hospital Universitário \\
\hline IAG: & Instituto de Astronomia, Geofísica e Ciências Atmosféricas \\
\hline IB: & Instituto de Biociências \\
\hline ICB: & Instituto de Ciências Biomédicas \\
\hline ICMC: & Instituto de Ciências Matemáticas e de Computação \\
\hline IEB: & Instituto de Estudos Brasileiros \\
\hline IF: & Instituto de Física \\
\hline IFSC: & Instituto de Física de São Carlos \\
\hline IGc: & Instituto de Geociências \\
\hline IME: & Instituto de Matemática e Estatística \\
\hline IO: & Instituto Oceanográfico \\
\hline IP: & Instituto de Psicologia \\
\hline IQ: & Instituto de Química \\
\hline IQSC: & Instituto de Química de São Carlos \\
\hline ISO: & International Organization for Standartization \\
\hline MAC: & Museu de Arte Contemporânea \\
\hline MBNQA: & Malcolm Baldrige National Quality Award \\
\hline MP: & Museu Paulista \\
\hline NGT: & Nominal Group Technique \\
\hline NIST: & National Institute of Standards and Technology \\
\hline NUPES: & Núcleo Universitário de Pesquisas do Ensino Superior \\
\hline PECE: & Programa de Educação Continuada em Engenharia \\
\hline PBQP: & Programa Brasileiro de Qualidade e Produtividade \\
\hline PCAB: & Prefeitura do Campus de Bauru \\
\hline PCALQ: & Prefeitura do Campus Luiz de Queiroz \\
\hline PCASC: & Prefeitura do Campus de São Carlos \\
\hline PDCA: & Plan, Do, Check, Act \\
\hline PNQ: & Prêmio Nacional da Qualidade \\
\hline PPQP: & Programa Permanente de Qualidade e Produtividade \\
\hline PQGF: & Prêmio de Qualidade do Governo Federal \\
\hline PQSP: & Programa de Qualidade no Serviço Público \\
\hline PURA: & Programa de Uso Racional da Água \\
\hline PURE: & Programa para o Uso Eficiente de Energia \\
\hline Q\&P: & Qualidade \& Produtividade \\
\hline
\end{tabular}


QPAP: $\quad$ Qualidade e Participação na Administração Pública

QT:

Qualidade Total

QVT:

Qualidade de Vida no Trabalho

RUSP: $\quad$ Reitoria da Universidade de São Paulo

SABESP: $\quad$ Saneamento Básico do Estado de São Paulo

SEGES:

SESA:

SG:

SIBi:

Secretaria de Gestão do Ministério do Planejamento

SVOC:

Serviço Especial de Saúde de Araraquara

TCMSP:

Secretaria Geral

Sistema Integrado de Bibliotecas

TQ:

Serviço de Verificação de Óbitos da Capital

TQM: $\quad$ Total Quality Management

TUSP: $\quad$ Teatro da USP

UNESP: Universidade Estadual Paulista "Júlio de Mesquita Filho"

UNICAMP: Universidade Estadual de Campinas

USP: $\quad$ Universidade de São Paulo 



\section{LISTA DE QUADROS}

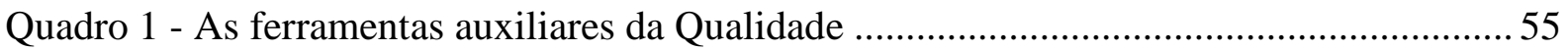

Quadro 2 - Síntese dos fundamentos do Prêmio Nacional da Qualidade................................. 62

Quadro 3 - Retrospectiva da Qualidade na gestão pública desde 1990 ................................ 91

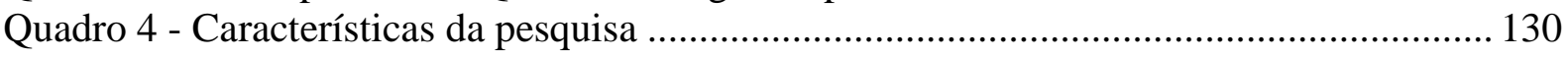

Quadro 5 - Distribuição das questões comuns aos Roteiros Tipo 1 e Tipo 2 ........................ 138

Quadro 6 - Distribuição dos dados complementares do Roteiro Tipo 2 …........................... 138

Quadro 7 - Módulos de Qualidade ................................................................................. 139

Quadro 8 - Consolidação das etapas da pesquisa ................................................................. 142

Quadro 9 - Evolução de indicadores de desempenho da USP em 1996 e 2008 ...................... 145

Quadro 10 - Unidades de ensino e pesquisa e ano de criação/incorporação à USP............... 149

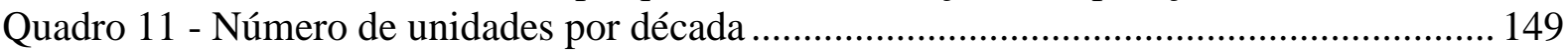

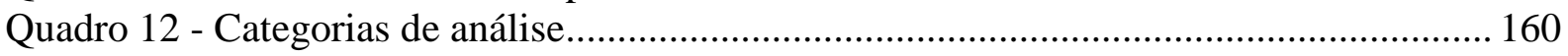

Quadro 13 - Percepção dos entrevistados sobre melhorias administrativas............................ 267

Quadro 14 - Descrição dos Grupos de Ação de Melhorias (GAMs) ...................................... 273 



\section{LISTA DE TABELAS}

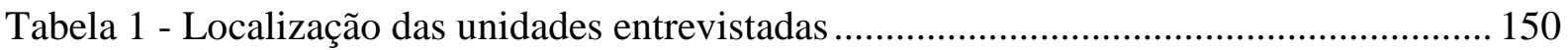

Tabela 2 - Área de concentração do conhecimento............................................................... 150

Tabela 3 - Porte da unidade por alunos graduação em 1996 e 2007 ..................................... 151

Tabela 4 - Porte da unidade por alunos de pós-graduação em 1996 e 2007 ........................... 151

Tabela 5 - Distribuição por faixa de número de docentes em 1996 e 2007 ............................ 152

Tabela 6 - Distribuição por faixa de número de servidores técnicos administrativos

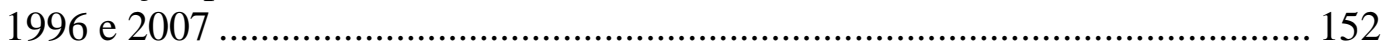

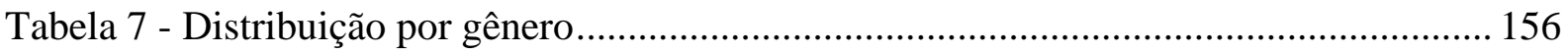

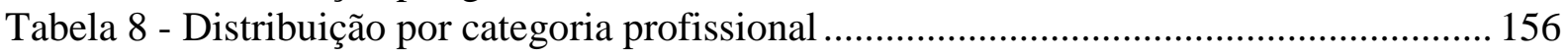

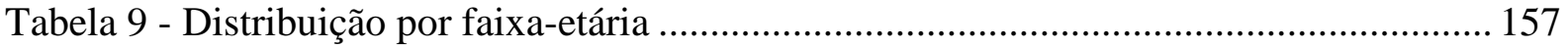

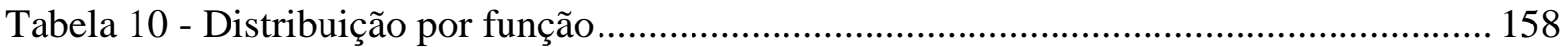

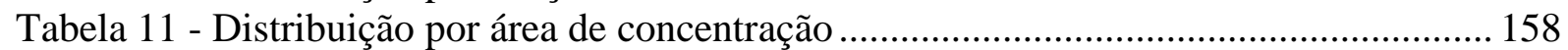

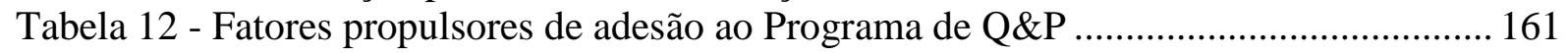

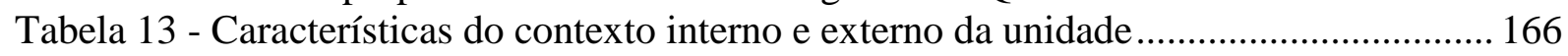

Tabela 14 - Expectativas quanto ao conteúdo do Programa de Q\&P .................................... 173

Tabela 15 - Inclusão de qualidade de vida no trabalho no Programa de Qualidade ............... 178

Tabela 16 - Significado de Qualidade de Vida no Trabalho .................................................. 179

Tabela 17 - Existência de atividades formais do Programa de Qualidade .............................. 181

Tabela 18 - Conteúdo das atividades formais do Programa de Q\&P ................................... 182

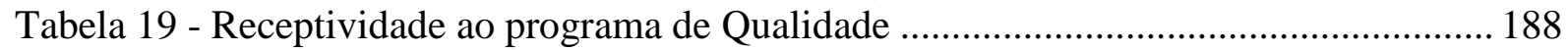

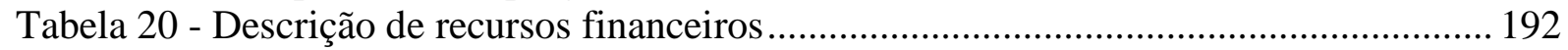

Tabela 21 - Existência de estrutura administrativa do Programa de Q\&P............................. 194

Tabela 22 - Estrutura administrativa do Programa de Q\&P................................................. 195

Tabela 23 - Poder decisório do Programa de Qualidade ........................................................ 199

Tabela 24 - Combinações do poder decisório ................................................................... 200

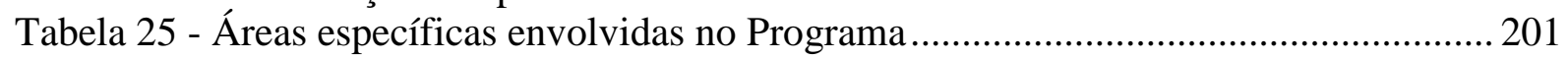

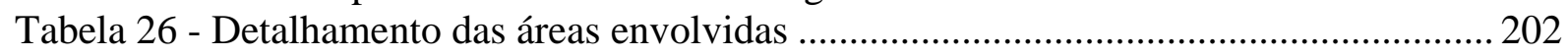

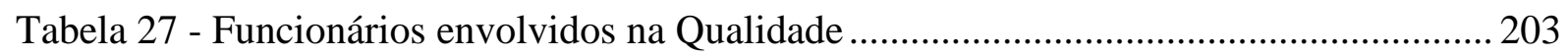

Tabela 28 - Curso de Qualidade para técnicos administrativos: 1996 - 2006....................... 205

Tabela 29 - Método para identificar necessidades de melhorias na unidade ......................... 208

Tabela 30 - Tipo de método para levantamento de necessidades de melhorias .....................209

Tabela 31 - Monitoramento dos resultados do Programa de Qualidade ................................ 211

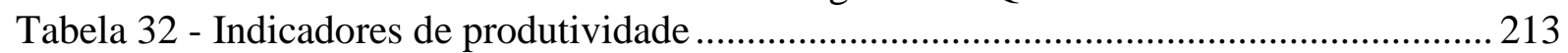

Tabela 33 - Experiências positivas da Qualidade............................................................. 216

Tabela 34 - Problemas apontados pelos técnicos administrativos para oprograma de

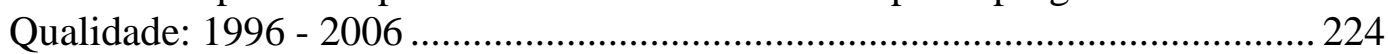

Tabela 35 - Impactos nos módulos de Qualidade ............................................................. 226

Tabela 36 - Avaliação do programa pelos docentes dirigentes ........................................... 231

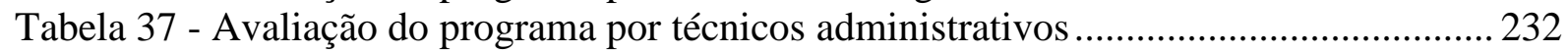

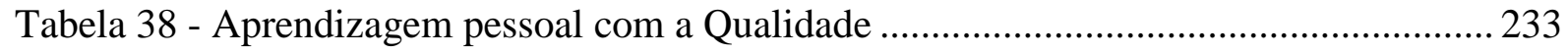

Tabela 39 - Aprendizagem organizacional com a Qualidade ............................................... 234

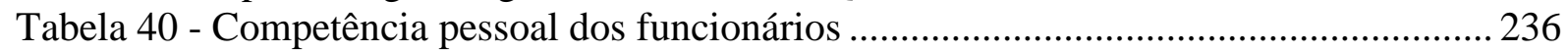

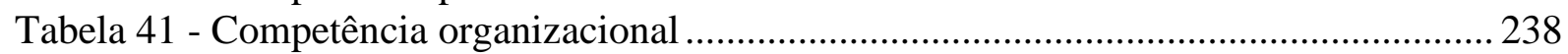

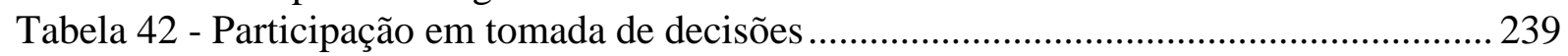

Tabela 43 - Interação entre funcionários na unidade ....................................................... 240

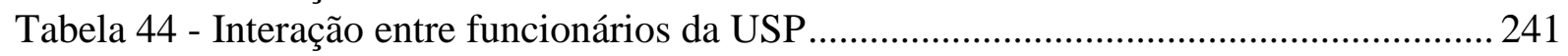

Tabela 45 - Atividades de Qualidade de Vida no Trabalho ................................................. 243

Tabela 46 - Descrição de Qualidade de Vida no Trabalho ................................................... 244 
Tabela 47 - Comparação de expectativas, atividades formais e experiências positivas ........ 247

Tabela 48 - Consolidação das Comissões Internas de Qualidade .......................................... 256

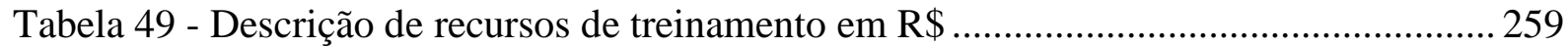

Tabela 50 - Encontros da Qualidade: 1996-2005 ….................................................................. 264 


\section{LISTA DE GRÁFICOS}

Gráfico 1 - Classificação das unidades/ órgãos por nível de gestão (*)................................ 124

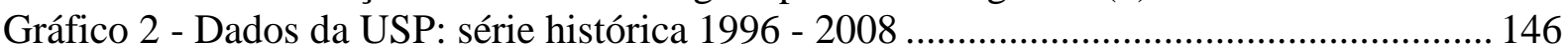

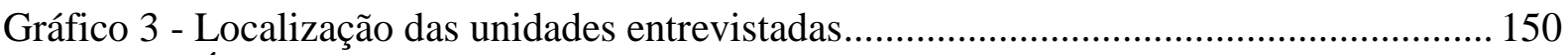

Gráfico 4 - Área de concentração do conhecimento ............................................................ 150

Gráfico 5 - Evolução da comunidade das unidades pesquisadas .......................................... 153

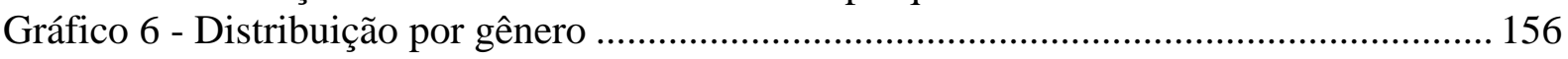

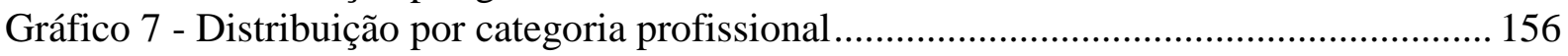

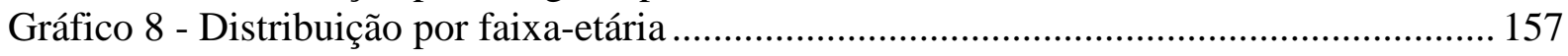

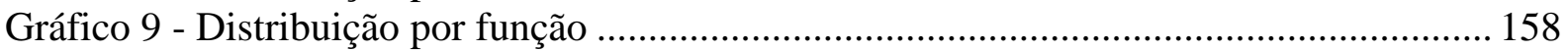

Gráfico 10 - Distribuição por área de concentração de formação ........................................... 158

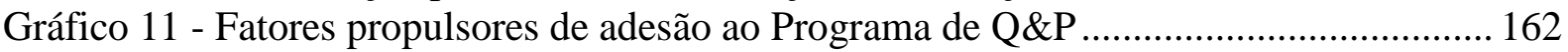

Gráfico 12 - Percepção do contexto externo e interno ............................................................. 166

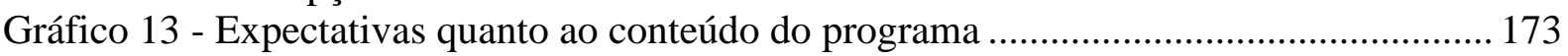

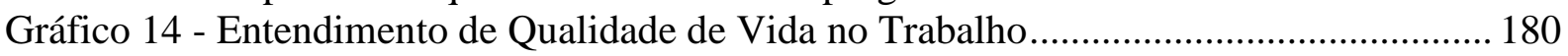

Gráfico 15 - Atividades formais do Programa de Qualidade ................................................ 183

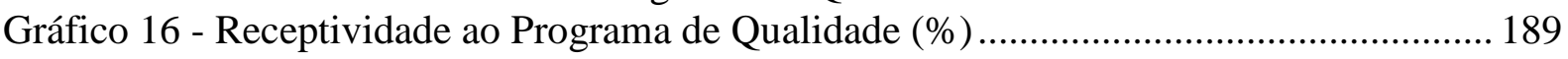

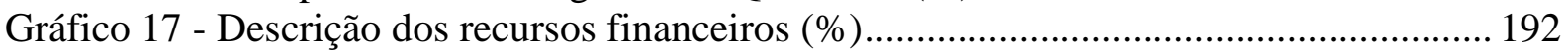

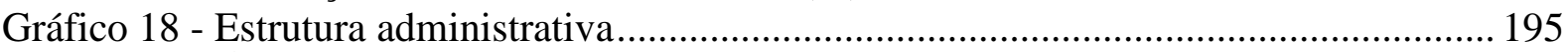

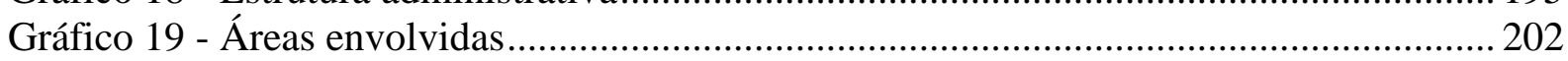

Gráfico 20 - Curso de Qualidade para técnicos administrativos: 1996 - 2006 ...................... 206

Gráfico 21 - Métodos de levantamento de necessidades de melhorias .................................. 209

Gráfico 22 - Experiências positivas da Qualidade 1996 - 2006 ............................................ 216

Gráfico 23 - Problemas apontados pelos técnicos administrativos para o ............................. 224

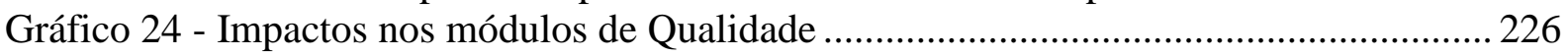

Gráfico 25 - Avaliação do programa pelos docentes dirigentes........................................... 231

Gráfico 26 - Avaliação do programa por técnicos administrativos....................................... 232

Gráfico 27 - Comparação de expectativas, atividades formais e experiências positivas ....... 248

Gráfico 28 - Comparação de expectativas (T1) e experiências positivas (T3) ...................... 249

Gráfico 29 - Descrição de utilização de recursos de treinamento ........................................... 259

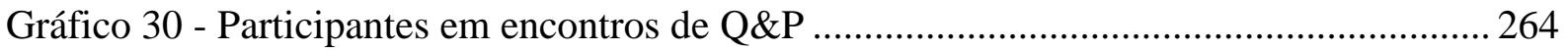





\section{LISTA DE FIGURAS}

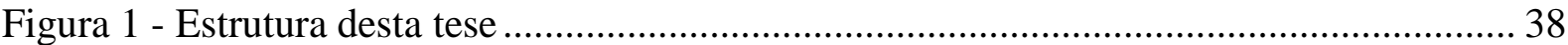

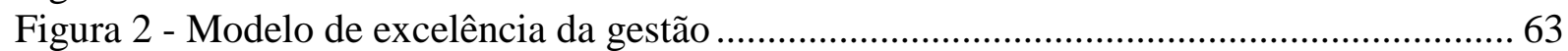

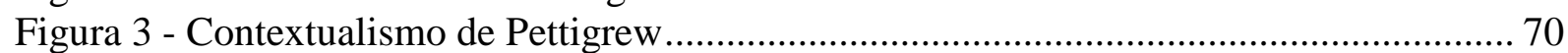

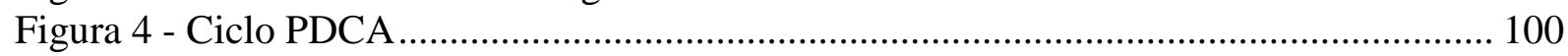

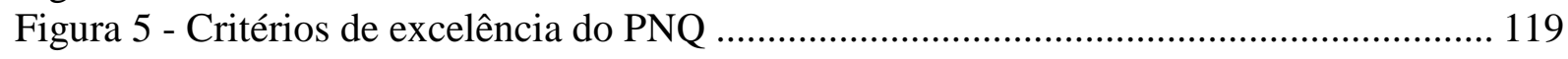





\section{INTRODUÇÃO}

A qualidade pode ser um elemento de mudança para trazer melhorias à gestão e à Universidade Pública? Qualidade, mudanças organizacionais, gestão pública e universidade pública são temas, dentre tantos outros, que estão presentes em reflexões sobre o bem-estar social.

A qualidade como um meio de melhoria do uso dos recursos públicos; as mudanças organizacionais, necessárias para acompanhar o movimento histórico da sociedade; a gestão pública, que influencia a vida de todos e da qual poucos têm controle; a universidade pública, que constitui esperança para o desenvolvimento de muitos e à qual poucos têm acesso.

Como visualizar a interação desses elementos para participar como agente da transformação de algo sempre incompleto que exigirá um contínuo aperfeiçoamento? Como interceder para contribuir para o desenvolvimento do país?

Para resgatar a qualidade como um meio de melhoria do uso dos recursos públicos, retoma-se o movimento da Qualidade Total, que contemplava novas formas de gerenciamento de organizações privadas, com o objetivo de melhorar seu desempenho e competitividade. Teve seu início nos anos oitenta, nos Estados Unidos e na Europa, e foi implementado em grandes empresas. No final da mesma década, ganhou mais notoriedade no Brasil e avançou para as empresas estatais.

A Qualidade Total é, por vezes, caracterizada como uma nova filosofia de gerenciamento, uma teoria de administração ou simplesmente um conjunto articulado de princípios, práticas e técnicas gerenciais, já existentes no corpo da Teoria da Administração. Para muitos é mais um modismo gerencial, tal como tinham sido no passado, o desenvolvimento organizacional, a administração por objetivo, a reengenharia etc.. Conforme Dean e Bowen (1994, p. 390), três princípios básicos estão presentes na Qualidade Total: “o foco no cliente, a melhoria contínua e o trabalho em equipe; cada princípio é implementado por um conjunto de práticas que, por sua vez, são suportadas por uma matriz de técnicas." 
Na sua evolução, o conceito de Qualidade Total expandiu-se, acolhendo, também, o conceito de Qualidade Pessoal e, consequentemente, o de Qualidade de Vida no Trabalho, incluindo aspectos comportamentais e de satisfação de expectativas individuais, visando à concretização de resultados da empresa, segundo Albuquerque e Limongi-França (1998). Limongi-França (1996) desenvolveu um Modelo de Indicadores Empresariais de Qualidade de Vida BPSO, separando ações de QVT, conforme os critérios denominados de Biológico, Psicológico, Social e Organizacional. Resumidamente, idêntico ao modelo citado, o critério Biológico refere-se à promoção da saúde e segurança, controle de riscos ambientais e atendimento às necessidades físicas em geral. $\mathrm{O}$ critério Psicológico volta-se à promoção da autoestima e do desenvolvimento de capacidades pessoais e profissionais. O critério Social abrange oferta de benefícios sociais obrigatórios e espontâneos e criação de oportunidades de lazer, esportes e cultura. $\mathrm{O}$ critério Organizacional liga-se à valorização da imagem institucional, dos serviços e produtos e do relacionamento da organização com os empregados.

Atualmente, o apelo da Qualidade Total, como forma gerencial, está bastante reduzido, conquanto alguns de seus princípios já estejam internalizados em muitas organizações. Mais recentemente, pode-se dizer que a Qualidade Total tomou novos matizes, segmentando-se e aparecendo no ambiente organizacional com outras denominações como: inovação; gestão do conhecimento; gestão por competências; qualidade de vida no trabalho; responsabilidade social e sustentabilidade socioambiental.

Segundo Dean e Bowen (1994), aos críticos da Qualidade Total pode-se argumentar que muitos de seus princípios são congruentes com a moderna Teoria da Administração, principalmente no que se refere à liderança, gerenciamento de recursos humanos, planejamento estratégico da qualidade e análise de informações.

De qualquer forma, quando foi aplicada, a Qualidade Total funcionou como um agente de mudança cultural nas organizações. Ela trazia, em seu bojo, alterações, entre outras, nas formas de produção de produtos e serviços e nas relações de trabalho.

A abertura do Brasil ao mercado externo, no início dos anos noventa, acelerou o processo de Qualidade Total internamente nas empresas privadas e ganhou reforço em ações dos governos federal e estadual. No governo federal, no contexto do Programa Brasileiro de Qualidade e Produtividade (PBQP), foi criado o Sub-Programa de Qualidade e Produtividade nas 
entidades e órgãos públicos, com o objetivo de "torná-los mais eficientes na administração dos recursos públicos e mais voltados para o atendimento às demandas da sociedade, do que para os seus processos burocráticos internos." (Brasil. Cadernos GESPÚBLICA, 2006, n. 1, p. 7).

$\mathrm{Na}$ esteira dessa estratégia do governo federal, os Estados, igualmente, começaram a se mobilizar. No Estado de São Paulo, um decreto do governador Mário Covas, em dezembro de 1995, instituiu o Programa de Qualidade e Produtividade nas organizações públicas estaduais, com a finalidade de "propiciar ao cidadão o atendimento eficaz de suas necessidades, por meio de um processo de melhoria contínua e permanente dos serviços prestados, com redução de custos e ganhos de produtividade." (São Paulo. Decreto Estadual n. 40.536, de 12/12/1995)

Cabe considerar que, apesar de muitas tentativas de reformas empreendidas no mundo, na América Latina e no Brasil, a gestão pública tem sido, constantemente, objeto de muitas críticas ao seu funcionamento e o governo não tem deixado de insistir em reformas, nem sempre bem sucedidas. O cientista político Arcaya (1994), quando comenta sobre os rumos da reforma do Estado na América Latina, expressa a tese de que

\footnotetext{
A tendência clássica do Estado latino-americano tem sido a centralização e a concentração de autoridade. Este fenômeno tem sido acompanhado, nos últimos cinqüenta anos, por sua expansão reguladora e interventora e pelo crescimento de uma burocracia ineficiente e partidária. Em consequiência, a reforma do Estado deve orientar-se em direção oposta, ou seja, para a descentralização política e administrativa, para a descentralização das decisões e, como é evidente, para uma drástica reforma da burocracia para elevar sua qualidade técnica e neutralizar sua tendência partidária.
}

Conforme Hahn (1998), todos os experimentos mais divulgados de reforma do Estado têm, como diretrizes comuns, a desconcentração, a descentralização e o aumento da racionalidade administrativa, em contraposição ao comprometimento político dos setores burocráticos. São eles elementos de uma visão ortodoxa de administração pública, conforme classificação elaborada por Martins (1996).

Esse autor trabalha com três modelos típicos de administração: visão ortodoxa ou tradicional; visão liberal, próxima ao laissez-faire, e visão empresarial, em que predominam as regras do mercado e o cidadão é visto como consumidor. Nessa última visão, ainda se estabelece uma dicotomia entre política e administração, concentrada na reforma dos meios, prevendo a construção de instituições fortes, baseadas em carreiras, capacidade gerencial, autonomia, 
responsabilização, ênfase nos cidadãos e capacidade do aparato público para desenvolver e implementar políticas nas várias esferas de atuação do Estado.

Martins (1996) considera, ainda, que a crise contemporânea da administração pública corresponde à incapacidade política e administrativa do Estado para deliberar e implementar, com efetividade, aquilo que é definido como certo e bom para o bem-estar dos cidadãos. $\mathrm{O}$ engenho político e administrativo consiste em transitar com maior flexibilidade entre os vários paradigmas, notadamente o tradicional e o racional. $\mathrm{O}$ padrão tradicional de administração pública brasileira supõe um comprometimento clientelístico da burocracia, seja a dos altos escalões, seja a do "baixo clero", na utilização de cargos como moeda de troca política.

A esse modelo contrapõe-se o padrão racional do Estado neutro e universal, instrumentalizado por funcionários de carreira, com ascensão baseada no mérito e que mantém com a chamada classe política relações de independência e impessoalidade.

As mudanças que se observam na administração pública contemporânea, ao menos nos países mais desenvolvidos, resultam em maior aproximação do aparato burocrático público e o cidadão. Assumindo várias formas, o cerne da mudança está na tendência de uma maior democratização da administração, que contemple as aspirações dos cidadãos.

Com o objetivo de atender melhor ao cidadão, uma grande reforma do Estado foi proposta por Bresser-Pereira, em 1995. Nela estava embutida a "reforma administrativa", pela qual se alterariam procedimentos, normas e processos usuais da administração pública governamental, que não implicam fazer coisas diferentes, isto é, mudar o campo de atuação da administração, mas fazer as mesmas coisas de modo diferente, na direção de um aprimoramento ou desenvolvimento da função pública nos seus segmentos, segundo Hahn (1998).

Como sinônimo de "reforma administrativa", pode-se, também, utilizar a expressão "reforma do setor público", significando alterações internas na burocracia, não se modificando as relações entre a administração pública e a sociedade que a sustenta. Como relatado por Hahn (1998), a década de 80 presenciou, em muitas burocracias públicas do mundo industrializado, 
uma urgência reformista na direção de mudar o Estado para aproximá-lo democraticamente da cidadania, ao mesmo tempo em que acomodava as demandas do mercado.

A Nova Gestão Pública ou New Public Management (NPM) ${ }^{1}$, conhecida também como gerencialismo, era imperativa, na medida em que, segundo Rezende (1998), havia uma escassez de recursos financeiros, uma economia cada vez mais globalizada e competitiva, a crise do Estado burocrático, uma demanda por melhores serviços públicos, em um contexto de expansão da democracia. Na dimensão administrativa, a reforma do Estado procurava atender a uma série de disfunções típicas das organizações do setor público, geradas pelo modelo burocrático clássico, tais como: centralização; rigidez de procedimentos e padronizações; apego às regras e reduzida orientação aos resultados. Essas disfunções geravam uma combinação indesejável de altos custos com baixo desempenho dos serviços públicos. Daí, a necessidade de mudanças para a inclusão de novos modelos gerenciais e administrativos, combinando burocracia e democracia. A melhoria para o Estado moderno passa a ser orientada por três eixos: 1) a Qualidade, no atendimento ao consumidor-cidadão; 2) A Eficiência, representada pela ideia de atendimento ao menor custo possível e 3) a Efetividade, representada pela ideia de que, no setor público, as organizações podem ser orientadas por resultados claramente definidos.

$\mathrm{Na}$ universidade pública, as intercorrências dessa nova orientação foram numerosas e complexas. Ao mesmo tempo em que as faculdades e universidades privadas aumentam em número e abrangência, muitas delas com qualidade questionável, as universidades públicas, teoricamente redutos de melhor ensino, são procuradas por uma clientela maciça que jamais poderá ser atendida na sua totalidade. A pressão da sociedade por mais vagas nas universidades públicas brasileiras faz parte do contexto da década de 90.

Um mecanismo, ainda que paliativo, que permite certo avanço, dentro desse contexto, é investir mais no funcionamento das universidades, de tal forma que, sem prejuízo em sua qualidade, possa atender a mais clientes/cidadãos. Dados do INEP (2009) mostram a evolução do número de Instituições do Ensino Superior (IES), no Brasil. Em 2003, há o registro de 1.859 IES, enquanto, em 2007, esse número aumentou em 23\%, atingindo 2.281 unidades

\footnotetext{
O New Public Management, segundo Barzelay (2000), como um conceito, origina-se de análise de ideias acadêmicas que estiveram na agenda para a mudança organizacional em vários países, entre os quais Inglaterra, Canadá, Estados Unidos, Suécia, Alemanha e Austrália, durante os anos 80.
} 
públicas e privadas. As mudanças organizacionais, oriundas da implantação da gestão pela qualidade, seriam um dos elos que permitiriam dar à gestão pública e à universidade pública um atendimento mais efetivo à sociedade.

Assim, o Programa de Qualidade e Produtividade na Universidade de São Paulo (USP) entrou nesse contexto, uma vez que o Decreto Estadual, já referido, vinha corroborar a estratégia que o então Reitor queria imprimir à sua gestão. A USP, como autarquia de regime especial, desde 1989 gozava de autonomia acadêmica e administrativa e, nessa condição, tal como outros órgãos públicos, precisava, também, de uma administração mais eficiente para melhor utilização de seus recursos.

Hoje, o tema da qualidade, tal como apareceu na década de 80 e 90 está quase esgotado. Todavia, suas aplicações, principalmente no setor da educação no país e notadamente em universidades não tiveram o registro e a divulgação merecidas e guardam importância permanentemente. O presente trabalho documentou e teve entre outros objetivos, o de sistematizar e fixar como memória organizacional a experiência ocorrida com a adoção de um Programa de Qualidade e Produtividade, naquela que é considerada, a mais importante universidade pública do Brasil. Essa experiência registrada constitui uma memória de informações que pretende contribuir para a compreensão e orientação de alternativas de gestão no espaço público do Estado e do País.

\subsection{O Problema da pesquisa}

A reforma do Estado preconizada por Bresser-Pereira (1998) trouxe muitos elementos novos para a gestão das instituições públicas. Entre as formas de gerenciamento para as organizações, a filosofia de Qualidade Total apresentava-se com um grande êxito, na década de 90. Derivada da forma japonesa de gerenciar indústrias, a Qualidade Total foi transposta, com adaptações, para o setor de serviços privados e públicos e, em especial, para as universidades. Dentro de uma orientação federal, o Governo do Estado de São Paulo, igualmente, também instituiu um Programa de Qualidade para "dar atendimento ao cidadão", pelo Decreto Estadual n. 40.536, de 12/12/1995, apresentado em Anexos. 
A universidade pública, ainda que apresentasse uma formatação administrativa diferenciada positivamente, em relação a outros órgãos públicos, também precisava de ajustes, no seu funcionamento organizacional.

Com esses argumentos, elaboram-se as questões de pesquisa:

\section{- Como um programa de Qualidade pode ser implementado em uma universidade pública?}

- Qual a percepção dos atores quanto aos seus resultados na instituição?

\subsection{Objetivos da investigação}

$\mathrm{Na}$ Universidade, podem-se diferenciar atividades fins e atividades meio; nas primeiras, incluem-se as atividades ligadas diretamente ao ensino, pesquisa e extensão, executadas por docentes; para dar suporte a essas áreas acadêmicas, há um conjunto grande de atividades na esfera técnico-administrativa, interpretadas como atividades meio, que são exercidas por funcionários técnico-administrativos. Cargos administrativos da alta administração são, em geral, atribuídos a docentes.

A investigação, portanto, tem como objetivo principal:

- Resgatar o histórico da implantação de uma experiência que carrega elementos inovadores em termos de administração pública.

Para a consecução desse propósito, esta pesquisa tem como objetivos específicos:

1. elucidar sob uma perspectiva histórica e atual, a implantação do Programa de Qualidade e Produtividade em uma universidade pública;

2. identificar contexto, conteúdo, processo e resultados dessa experiência, na percepção de seus administradores;

3. sistematizar os resultados do Programa de Qualidade e Produtividade. 


\subsection{Delimitações da pesquisa}

Esta pesquisa está delimitada ao resgate de um processo de implementação de um programa de qualidade em uma universidade pública, com ênfase no período abrangido de 1996 a 2006. A Universidade de São Paulo (USP) foi analisada em profundidade em 12 de suas 40 Unidades de Ensino e Pesquisa. A escolha das Unidades tomou como critério aquelas que, por registros existentes, tivessem demonstrado um envolvimento especial com o Programa de Qualidade e Produtividade instituído na USP. Elas eram representativas de todas as áreas do conhecimento e se situavam na capital e no interior.

A comunidade universitária é composta, basicamente, de um conjunto de três atores; docentes, alunos e funcionários. O levantamento de dados primários foi delimitado a uma amostra de: docentes, ex-dirigentes e funcionários técnico-administrativos, em sua maioria de nível superior.

Com esta pesquisa, espera-se contribuir para o conhecimento, pelo registro e descrição, do fenômeno Programa da Qualidade e Produtividade, ocorrido na Universidade de São Paulo. Esta tese contribui para a preservação da memória da instituição como um item para a transparência das ações de um órgão público e para o aprendizado organizacional; pretende, ainda, com seu relato, contribuir para o aperfeiçoamento da gestão pública e, por extensão, à gestão universitária.

\section{$1.4 \quad$ Justificativas}

A qualidade na gestão pública é sempre um tema atual e relevante, na medida em que a vida dos cidadãos está influenciada pelas suas práticas. Afunilando-se o tema para a qualidade da universidade pública, o tema persiste em relevância, uma vez que um contingente cada vez maior da população procura o ensino superior. Para uma modernização administrativa, a universidade vale-se, continuamente, de vários mecanismos de aperfeiçoamento, entre os quais formas de gerenciamento inovadoras e mais modernas. A filosofia da qualidade teve, na década de 90, essa perspectiva de melhoria e inovação. 
Do ponto de vista teórico, o assunto qualidade teve a força de um mantra para gerentes e executivos de organizações contemporâneas; foi, também, objeto de muitas publicações acadêmicas, conforme Reeves e Bednar (1994), o que releva a questão de sua importância e pertinência, sobretudo em períodos abrangidos nas duas últimas décadas do século XX.

A gestão da Qualidade Total implica mudança cultural significativa, em aspectos técnicos (ferramentas, estatísticas, normas da série ISO etc.) e, principalmente, em aspectos comportamentais (cooperação, confiança, trabalhos em equipes etc.). $O$ entendimento aprofundado dessa situação poderá facilitar futuras implementações de inovações administrativas, que venham a interferir em posturas, comportamentos e valores institucionais.

Além do tema da Qualidade ser, ainda, relevante nas organizações, pesam, sobretudo, na escolha do tema, condições de ordem pessoal.

Uma tese é, ao mesmo tempo, o encontro com muitos autores e um encontro consigo mesma. Muitas vezes, a pesquisadora sente-se sozinha e, ao mesmo tempo, rodeada de amigos e colegas apoiadores. No fundo, sabe-se que a "filha", a tese, é de sua total responsabilidade e o peso é grande. Ela é concebida e faz-se de tudo para desenvolvê-la bem como em uma gestação, muito lentamente, até vê-la acabada na sua forma final, para vir à luz, quando poderá, então, cumprir seu próprio objetivo: trazer ao mundo dos saberes um tijolo a mais na construção contínua e inacabada do conhecimento.

Encontrar, no torvelinho de fontes, os elementos-chave que colaborem no traçado de linhas mestras do trabalho, nem sempre é um caminho linear: idas e voltas, caminhos sem saída, becos e atalhos, montes e vales são os encontros usuais do percurso. A imagem recorrente para a escolha da teoria condizente com um trabalho de pesquisa é a de um verdadeiro garimpo de diamantes: com minas de grande extensão, como a Internet, redes de pesquisa, bibliografia, bancos de dados e associados, o que torna realmente difícil encontrar as pedras efetivamente valiosas.

O motivo pessoal mais forte que moveu o pesquisador para o assunto desta tese foi o desejo de conhecer em maior profundidade a organização em que trabalhou grande parte de sua vida profissional. A expectativa era de que tal conhecimento pudesse ser transmitido aos atuais 
membros da Universidade e aos que virão, propiciando, em um esforço coletivo, o aperfeiçoamento da USP e, por extensão, o aperfeiçoamento das universidades e das instituições públicas.

Se a tese é algo para fazer avançar o conhecimento, também deve ser alguma coisa que dê prazer a quem a elabora. Muitas vezes, a dificuldade é grande e a sua construção só chega ao término se há uma motivação forte de vencer o desafio e de se entregar à paixão. Daí a escolha do tema ser extremamente pessoal e de valor afetivo para quem a elabora.

A pesquisadora sempre se sentiu atraída por estimular o desenvolvimento de potencial das pessoas, se não em sala de aula, com as pessoas que lhe eram próximas, como colegas, amigos e funcionários. Indagava-se como conseguir um melhor aproveitamento, no bom sentido, do potencial intelectual das pessoas da organização? Deparou-se, várias vezes, com a observação de que "o que mais se desperdiça na organização é talento humano" e admitia que essa afirmação não estava longe de situações reais observadas.

Se o movimento da Qualidade veio para, entre outros objetivos, evitar desperdício e retrabalho, procurar também otimizar e valorizar o potencial humano na organização está incluído naqueles objetivos. A nova organização pós-burocrática deverá fazer aflorar e aproveitar mais o potencial dos funcionários.

\subsection{Estrutura desta tese}

Esta tese está dividida em 5 Capítulos, Referências, Apêndices e Anexos. No primeiro capítulo, por meio de uma introdução ao tema, é apresentada a contextualização do problema da pesquisa, os objetivos da investigação, delimitações da pesquisa, justificativas para a escolha do tema e a estruturação da tese.

O Capítulo 2, de Fundamentação Teórica, expõe conceitos básicos pertinentes ao escopo da tese: o Estado da Arte da Qualidade, seus gurus e retrospectiva histórica, assim como a operacionalidade de seus conceitos, pelos modelos de excelência de gestão. Considerando que a Qualidade provoca mudanças organizacionais, discorre-se sobre esse tema e, para 
contextualizar o problema da pesquisa, apresentam-se aspectos da gestão pública e seu histórico no Brasil, no Estado de São Paulo, e as condições da universidade pública.

Os Procedimentos Metodológicos adotados são tratados no Capítulo 3: aí se define o universo de pesquisa, elucidando-se o que a literatura traz sobre o tipo de metodologia adotada; justificam-se a escolha pelo estudo de caso, de natureza qualitativa; o modelo conceitual e operacional da pesquisa; a estratégia de coleta dos dados primários e secundários; os instrumentos de coleta utilizados nas entrevistas e a estratégia de tratamento e análise dos dados. Para a pesquisa de campo, utilizam-se estatísticas descritivas para variáveis quantitativas e análise de conteúdo para a parte qualitativa.

O Capítulo 4 descreve a instituição em estudo, apresentam-se e discutem-se os achados de pesquisa, advindos dos dados primários e da pesquisa documental.

O Capítulo 5, de Conclusões, discorre sobre alguns aspectos de maior relevância emergentes da pesquisa e da experiência profissional da pesquisadora, que durante mais de 15 anos se dedica a atividades ligadas a reformas e mudanças institucionais em universidades públicas.

Além das Referências, incluem-se, como Apêndices, os Roteiros de Entrevistas; a Linha do Tempo com registro de ações do Programa de Qualidade na USP e nas Unidades; a relação de palestras e atividades dos Encontros da Qualidade, a relação de publicações ligadas ao Programa de Qualidade da USP, um levantamento de artigos do Jornal da USP, sobre o tema, de 1996 - 2007 e a Relação de Monografias, feitas por funcionários USP, no Curso de Tecnologias e Gestão da Qualidade, Escola Politécnica/PECE. Como Anexos, estão incluídos os Organogramas da Instituição, objeto da tese e a Legislação, pertinente ao estudo.

A Figura 1, a seguir, sumariza, em linhas gerais, a estrutura desta tese. 


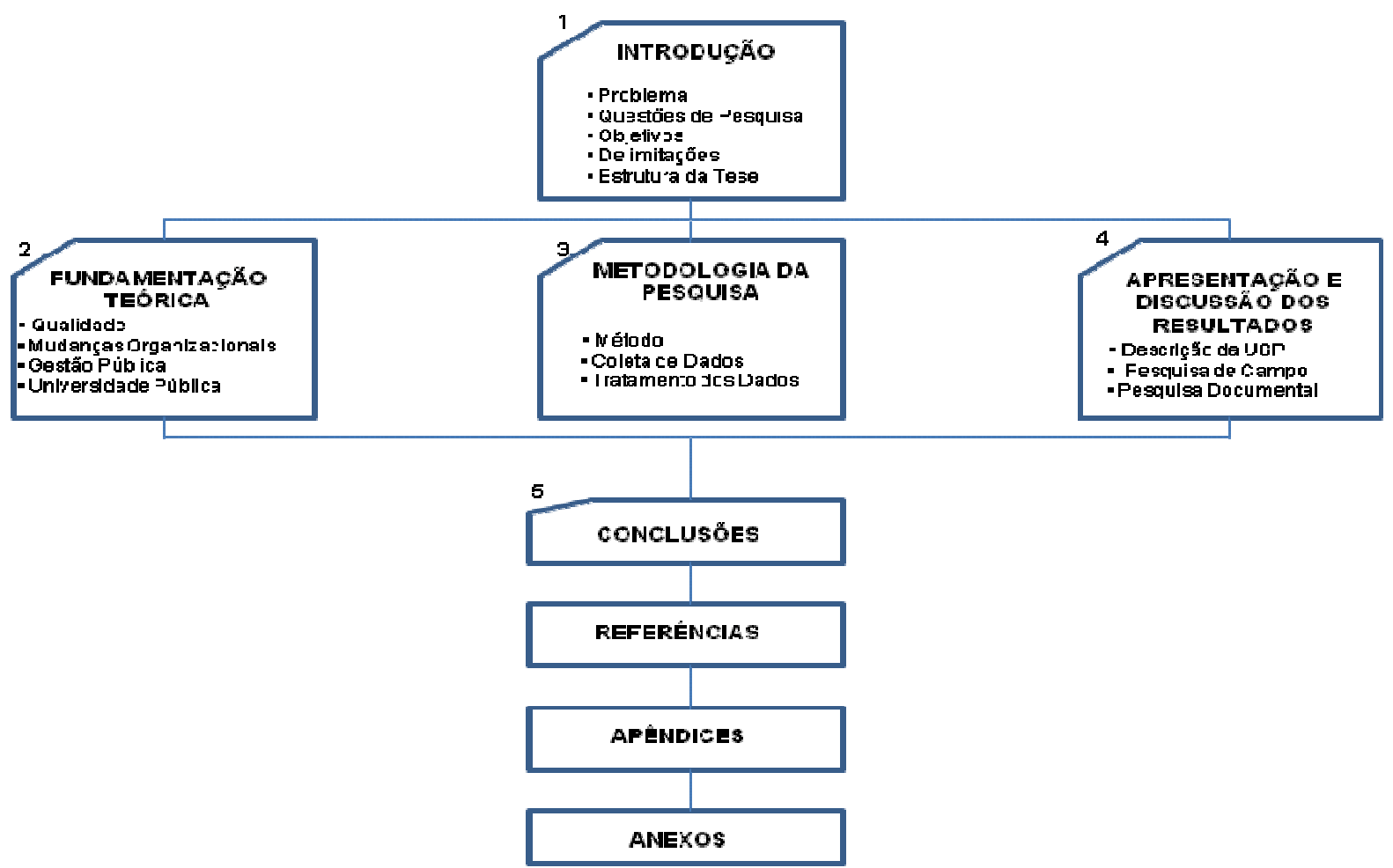

Figura 1 - Estrutura desta Tese 


\section{FUNDAMENTAÇÃO TEÓRICA}

Esse capítulo estrutura o quadro teórico no qual a pesquisa se insere. É apresentado um panorama sobre a Qualidade, abordando seu conceito e estado da arte; evocam-se os principais autores internacionais e nacionais envolvidos no tema e tratados como gurus da Qualidade e uma retrospectiva dos movimentos de Qualidade nos Estados Unidos, Japão e Brasil; faz-se um apanhado genérico sobre mudanças organizacionais e foca-se a gestão pública e suas implicações com a Qualidade, apresentando a legislação pertinente à Qualidade no Brasil e no Estado de São Paulo. Completa o quadro um contexto sobre a Universidade Pública. Todo esse conjunto deve fornecer elementos para compreender o fenômeno da Qualidade que atingiu, inicialmente, o segmento industrial e, gradativamente, passou ao setor de serviços, em organizações privadas e instituições públicas, atingindo a universidade.

\subsection{Qualidade: o estado da arte}

A literatura contemporânea sobre o tema não chega a um acordo conclusivo sobre a palavrachave Qualidade; não há uma definição global de Qualidade, aceita universalmente. Consenso é que diferentes definições de Qualidade são apropriadas a diferentes circunstâncias. Para Garvin (1992, p. 3), como conceito a Qualidade é conhecida "há milênios" e, só nos últimos anos do século XX, aparece ligada a uma função de gerência formal e à utilização de técnicas destinadas a melhorar o desempenho industrial e à melhoria das organizações de serviços, privadas ou públicas. Ainda para Garvin (1992, p. 47), Qualidade é um termo facilmente mal entendido e seus sinônimos vão do "luxo e mérito à excelência e valor"; assinala, também, que várias disciplinas, como a filosofia, a economia, o marketing e a gerência de operações, se utilizam do termo Qualidade, tratando-o de formas diferentes. Saraph, Benson e Schroeder (1989) fazem referência a mais de 120 prescrições, quando se trata de um efetivo gerenciamento da Qualidade.

Tomado sozinho, o termo Qualidade designa um conteúdo neutro, que se torna expressivo quando associado a atributos como: ruim; boa; superior e excelente. Excelência, numa hierarquia, significa o "topo" da Qualidade, estar à frente de um conjunto, superar competidores na área de atuação; excelência é, principalmente, uma diferenciação positiva. 
Algumas definições começam circunscrevendo o universo que a qualidade trata, inicialmente voltada às organizações industriais.

Por sua vez, Reeves e Bednar (1994), também, observam que: "uma definição uniforme de Qualidade não tem resultados consistentes”; os autores reagruparam as definições segundo o que significavam: conformidade às especificações, adequação ao uso, controle de perdas ou, ainda, o atendimento das necessidades do cliente. Cada uma das acepções do termo Qualidade surgiu e se alterou ao longo do tempo, amparadas pelos gurus da época; foram, igualmente, modificadas por eles mesmos, em resposta às mudanças envolvidas no contexto em que se aplicavam. Portanto, a noção de Qualidade descreve uma variedade de fenômenos que se especificam ao sabor das solicitações mutantes e constantes das organizações.

Garvin (1992, p. 48) identificou cinco abordagens diferentes para uma definição de qualidade: a transcendental, na qual Qualidade é sinônimo de excelência inata; a baseada em produto, pela qual Qualidade é uma variável precisa e mensurável; baseada no usuário, na qual sua avaliação é subjetiva; baseada na produção, se a Qualidade se apresenta conforme o planejado e, baseada no valor, quando combinando conceitos de excelência e valor, a Qualidade é definida pelas variáveis custos e preços.

Hoje, Qualidade é um termo que passou a fazer parte do jargão das organizações, independentemente do ramo de atividade e abrangência de atuação pública ou privada. A principal diferença entre a abordagem do início do século XX e a atual é que a Qualidade, agora, está relacionada às necessidades e aos anseios dos clientes. Seja qual for o porte da empresa, observam-se programas de Qualidade e de melhoria de processos na maioria dos setores econômicos. Além disso, a concepção moderna de Qualidade engloba a ideia do envolvimento de cada empregado, como responsável pelo melhoramento contínuo do processo de produção e de serviços, notadamente pela eliminação de duplicação de esforços e de retrabalho, pelas mudanças na concepção do trabalho ou de procedimentos.

Organizações eficientes e eficazes, com padrões de Qualidade elevados nos seus produtos e serviços, já tinham sido objeto dos princípios da administração científica de Frederick Winslow Taylor (1987). É possível identificar no sistema de Gerenciamento da Qualidade Total a integração dos princípios da administração científica de Taylor, os princípios na 
escola de relações humanas e uma abordagem sistêmica das organizações, em todas as dimensões da empresa: métodos; processos; tecnologia; pessoas etc..

Os princípios que emergiram dos estudos de Hawthorne, dando maior atenção ao ser humano nas organizações foi incorporado pelas práticas administrativas mais modernas e também fazem parte do repertório dos princípios advogados no gerenciamento pela Qualidade Total.

Segundo Carvalho e Tonet (1994, p. 140):

Ao mesmo tempo em que se enfatiza o estudo das tarefas, os controles estatísticos e os planos de melhoria crescente, busca-se envolver os empregados da empresa mediante técnicas de sensibilização, motivação e participação no esforço global de melhoria dos processos de trabalho, enquanto articulam-se estratégia de transação como meio ambiente maximizador de resultados.

Ainda que não seja universal, a ABNT NBR 8402, de 1994, substituída pela ISO 9000:2000, descrevia como "Qualidade Total o modo de gestão de uma organização, centrado na qualidade, baseado na participação de todos os seus membros, visando ao sucesso no longo prazo, por meio da satisfação do cliente e dos benefícios para todos os membros da organização e sociedade".

Todo um esforço de mudança é orquestrado tendo, em seu bojo, a implantação de programas para incluir na instituição a chamada "cultura da qualidade".

O conceito de gestão da Qualidade Total abrange uma busca contínua de melhoria de todos os elementos do sistema organizacional como forma de garantir sua sobrevivência e seu crescimento. Admitindo-se que a Qualidade depende de todos os componentes do sistema e do ambiente da empresa, busca-se gerenciar a Qualidade das entradas, dos processos, dos produtos e das relações internas da empresa. (CARVALHO; PALADINI, 2005; DOUCET, 2007; FALCONI CAMPOS, 1989, 1992, 2009; JURAN, 1997; MOLLER, 1996; OUCHI, 1986; SHIBA e outros, 1997).

A participação, variável de análise predominante nos estudos da corrente humanística da administração, desempenha um papel importante nesse conjunto. Ela contribui para elevar o moral dos empregados, despertando-lhes a motivação e o compromisso para realizar um 
trabalho bem feito. As transformações propostas em programas de Qualidade Total implicam uma profunda mudança de mentalidade social, o que reflete na cultura das organizações.

Representada como uma filosofia de mudança, a Qualidade tem muito em comum com um modelo cultural, aquele do universo construído e interpretativo. As modalidades são negociadas entre os atores a fim de integrar suas necessidades às da organização. A Qualidade é constitutiva de uma nova ordem produtiva, segundo Munro, apud Harrison (1999).

Em retrospectiva da Qualidade, observa-se a recorrência em muitos trabalhos acadêmicos acerca de profundas mudanças sociais, demográficas e tecnológicas que ocorreram, sobretudo, nas duas últimas décadas do século XX. Não só as mudanças são significativas como também é cada vez mais acelerada a velocidade com que elas acontecem. Assim, para Hayes (1995, p. 2), a nova economia mundial é influenciada pela combinação de três fatores principais: a globalização; as tecnologias avançadas, geralmente relacionadas à informação e a rede de parcerias, em que os resultados-chave e bens produtivos são, primordialmente, intelectuais, como a informação e o conhecimento.

Com a globalização que incorporou todos os povos do mundo em uma sociedade mundial, segundo Haesbaert (1990), estabeleceu-se, também, uma nova ordem mundial, diferente do mundo de dois pólos, que vigorava após a Segunda Guerra Mundial; surgiu um mundo multipolarizado, constituído por megablocos econômicos ou blocos de poder. Novas configurações políticas, econômicas, sociais e culturais formaram-se de maneira desigual na sociedade, influenciando e realimentando o processo de globalização.

Refletindo o contexto vigente, as organizações passaram a viver, também, em um ambiente no qual a competição está mais acirrada em uma abrangência mundial e a orientação empresarial para o mercado consumidor torna-se uma questão de sobrevivência. As organizações ficaram com a questão permanente de saber para onde deveriam se direcionar para conseguir o domínio do mercado e qual a direção mais adequada a seguir dentro de um mundo em constante mudança.

Portanto, a transformação acelerada que vigora no mundo, exige de organizações privadas e públicas uma capacidade organizacional maior para se adaptar às novas estruturas; segundo Robbins (1999, p. 407), "é preciso desenvolver uma capacidade contínua de adaptação à mudança." 
A mudança organizacional passa a ser um aspecto de rotina e contínua no cotidiano das organizações; torna-se necessária à sobrevivência da empresa diante de um mercado global, competitivo e mutante. Como observam Mintzberg, Lampel e Ahlstrand (2000, p. 106), "afinal de contas tudo muda, os ambientes desestabilizam-se, os nichos desaparecem e as oportunidades banalizam-se." Alguns autores complementam salientando que "a mudança nunca começa porque ela nunca pára."

Apoiadas por novas teorias organizacionais alteram-se, em consequência, também as formas administrativas ou modelos de gestão; aparecem padrões como o Downsizing, Empowering, Reengenharia e a Gestão da Qualidade Total, entre outros. Em especial, a Gestão da Qualidade Total (TQM) gera transformações nas estruturas organizacionais, nos processos e comportamentos afetando o desempenho da organização; em seu nome, propõem-se alterações no processo decisório e os canais de comunicação passam a ser mais abrangentes e valorizados.

O inusitado poderio econômico japonês das décadas de 70 e 80 chamou a atenção mundial para o método de gerenciamento da Qualidade Total, que havia sido bastante utilizado pelas empresas japonesas, assessoradas pelos consultores americanos Deming e Juran. Nos anos 70, a indústria japonesa despontara no mercado internacional como altamente competitiva, produzindo bens de qualidade. Os produtos japoneses mostravam-se nitidamente superiores aos seus similares em qualidade, preços e custos de assistência técnica e manutenção.

Segundo Fey e Gogue (1984), a grande expansão do movimento da Qualidade a partir dos anos 70 está principalmente ligada a um contexto marcado pelo aumento da concorrência internacional, portanto, associado a uma dimensão econômica. Como os mercados estavam saturados e o potencial de produção era superior ao potencial de consumo, o grande diferencial passou a ser a melhor qualidade dos bens e serviços. Logo, o grande sucesso econômico do Japão passou a ser referência e reforçou o movimento da Qualidade Total.

Inicialmente, em muitas organizações, o movimento da Qualidade foi visto como uma moda; entretanto, ele trazia, em seu bojo, a perspectiva de grandes melhorias das organizações, para fazer face à situação competitiva que dominava o cenário internacional. 


\subsubsection{Os gurus da Qualidade}

São sistematicamente apresentados como mestres ou gurus da Qualidade aqueles que desenvolveram ou disseminaram esse modelo de Gestão da Qualidade Total (TQM): os americanos William Edward Deming, Joseph M. Juran, Armand V. Feigenbaum e Phillip Crosby, além do japonês Kaoru Ishikawa. No Brasil, Vicente Falconi Campos é um dos gurus mais citados na disseminação da filosofia da Qualidade. Segundo Garvin (1992), nos Estados Unidos, a escola americana é capitaneada por Juran, guardando muita influência do taylorismo. A escola japonesa é liderada, principalmente, pelos princípios de Deming, no que diz respeito aos métodos estatísticos e à valorização das pessoas no processo. A escola europeia tem por base a padronização preconizada pelas normas ISO, iniciadas em 1987, renovadas periodicamente e adotadas como referencial para a Qualidade.

Para Deming (1990, p.IX), talvez o guru mais celebrado da Qualidade, a proposta da Gestão da Qualidade Total é modificar, ou melhor, revolucionar totalmente o estilo de gestão das empresas:

Tal transformação não é nem um trabalho de reconstrução, nem de revisão. Exige uma estrutura inteiramente nova, em todos os níveis [...] A transformação deverá ocorrer a partir de um esforço direcionado. [...] como ficará óbvio, far-se-á igualmente necessária a transformação das relações entre as autoridades públicas e a indústria

As transformações implícitas e explícitas embutidas nos programas de Qualidade são inúmeras. A filosofia central de Deming concentra-se em quatorze itens prescritivos, seus princípios da Qualidade Total, publicados pela primeira vez, em 1981/1982. O alvo dessas prescrições deve atingir todos os participantes da organização e vários deles têm uma destinação especial aos altos executivos ou alta gerência. Alguns dos itens estão voltados para práticas comportamentais e outros objetivam a mudança da infraestrutura organizacional e do sistema cultural. Alguns pontos, implicitamente, advogam práticas metodológicas, incluindo o uso de instrumentos específicos e métodos estatísticos no design, gerenciamento e melhoria de processos, produtos e serviços. Outros promovem o contínuo treinamento do pessoal, com o intuito de aumentar seu enriquecimento intelectual e competência para o trabalho. Outros, ainda, indicam uma cultura aberta, de confiança e colaboração, nas quais todos os níveis trabalham juntos para conseguir objetivos comuns que garantam a sobrevivência da organização. 
Assim, a liderança tem um papel fundamental para assegurar o sucesso da Qualidade do gerenciamento. Cabe aos líderes a responsabilidade de criar e comunicar uma visão que faça mover a empresa para uma melhoria contínua e prover um suporte formal e informal que permita a criação e sustentabilidade de um sistema organizacional que seja receptivo às práticas do processo de gerenciamento. Anderson e outros (1994, p. 480) reforçam que

[...] a efetividade do método de gerenciamento de Deming é conseguida a partir dos esforços da liderança para promover visão de longo prazo para a organização, cooperação e aprendizagem organizacional, para facilitar a implementação de práticas no processo de gerenciamento, as quais, quando implementadas, suportam a satisfação dos consumidores e a sobrevivência da organização por meio da sustentação do compromisso dos empregados e melhoria contínua de processos, produtos e serviços.

Para Deming (1990), a Qualidade está ligada à conformidade das exigências e necessidades do consumidor. Como essas se alteram continuamente, as especificações, igualmente, se alteram constantemente. $\mathrm{O}$ autor vai mais longe e explora a necessidade da utilização de instrumentos de controle estatístico da Qualidade e não a simples inspeção do produto. Qualidade pode, também, ser vista como um modelo de gerenciamento de organizações, buscando eficiência e eficácia organizacionais. Visa ao melhoramento nos negócios, nas atividades técnicas, para, ao mesmo tempo, permitir que seja alcançada a satisfação dos consumidores, a eficiência de recursos humanos e menores custos. Preocupa-se, também, com aspectos humanísticos, depositando confiança e respeito nos empregados; valoriza o ser humano e promove sua participação no processo de Gestão da Qualidade.

O gerenciamento da Qualidade Total tem como objetivo a maior eficiência organizacional, medida por meio de indicadores de desempenho organizacional e a ativação de um processo de melhoria contínua. Para ele, a Qualidade torna-se a estratégia básica para a competitividade em escala mundial e é elemento fundamental na busca da eficácia de qualquer organização e seu crescimento de mercado e lucratividade.

Os pontos da filosofia de Deming atravessam as fronteiras dos departamentos ou áreas funcionais da organização: recursos humanos; gerenciamento estratégico; compras e controle de processos e incluem, ainda, os fornecedores e os clientes.

Joseph Juran (1992) concebe vários significados para a Qualidade: inicialmente, associava-a à "adequação ao uso", porque os clientes esperam coisas diferentes dos mesmos produtos e 
serviços; a Qualidade não é um conceito abstrato, mas está no domínio do usuário; outros significados remetem a "desempenho do produto" e "ausência de falhas". O desempenho do produto é resultado de suas características e do atendimento ao cliente. Produtos com falhas criam insatisfação dos clientes, acompanhada de reclamações e retrabalho.

Garvin (1992, p. 14) narra que, em 1951, Juran publicou o livro Quality Control Handbook, publicação que se tornou uma referência no tema; propunha a economia da Qualidade, ou seja, tratava do "grau da qualidade suficiente", que chamou de "ouro da mina"; os custos das falhas, consideradas o "ouro da mina" poderiam ser drasticamente reduzidos investindo-se na melhoria da Qualidade.

Tornou-se clássica a Trilogia de Juran, que considerava três pressupostos básicos para a execução do gerenciamento da Qualidade: Planejamento da Qualidade; Controle da Qualidade e Melhoria da Qualidade. No Planejamento da Qualidade, pensa-se em produtos e processos para atender as necessidades do cliente. No Controle da Qualidade, avalia-se o desempenho real da Qualidade e compara-se com as metas propostas. A Melhoria da Qualidade significa a elevação do desempenho real conseguida por etapas: estabelecer infraestrutura necessária; identificar necessidades específicas para melhorar; estabelecer equipe apta e responsável para executar o projeto e fornecer recursos, motivação e treinamento para diagnosticar as causas; estimular o estabelecimento de soluções e ter controles para manter os ganhos.

Cada um dos processos da Trilogia é essencial para o gerenciamento da Qualidade, sendo que Juran coloca a melhoria da Qualidade no topo das prioridades do gestor. Separar o planejamento e a execução é uma noção obsoleta, remontando aos princípios tayloristas.

Em 1956, o engenheiro americano, Armand V. Feigenbaum, escreveu o livro "Total Quality Control: engineering and management", Controle da Qualidade Total (TQC) e introduziu um novo conceito, ampliando as responsabilidades dos Órgãos de Controle de Qualidade nas empresas para todos os setores e empregados da organização. Segundo Feigenbaum (1995), TQC é um sistema eficaz concebido para que cada um dos setores da organização dê sua contribuição ao desenvolvimento, manutenção e melhoria da Qualidade. É fundamental o reconhecimento de que são os clientes que julgam a qualidade do produto e não a própria empresa; o foco dessa abordagem são os clientes e a satisfação de suas expectativas. A partir 
dessa fase é que o cliente, enquanto consumidor, passa a ser parte integrante do referencial da Qualidade Total, que deve identificar as necessidades dos clientes e satisfazê-las.

Zero Defeito foi o último movimento importante na era da Garantia da Qualidade, tendo Philipp Crosby como uma das figuras mais importantes. Sua abordagem privilegia a melhoria da Qualidade e a ausência de defeitos no produto. Para Crosby (1986, p. 17), garantir a Qualidade significa "induzir as pessoas a fazer melhor tudo aquilo que devem fazer; as pessoas incluem tanto a alta administração como as camadas inferiores da organização.” Além de desenvolver um aferidor de maturidade da gerência da Qualidade, Crosby (1986), ainda, alerta para a necessidade de uma mudança de cultura para o esforço de melhoria da Qualidade; é um processo lento e demorado, centrado em atitudes gerenciais internas e externas à empresa, que deve seguir, em todas as organizações aproximadamente os mesmos 14 passos que elenca: 1) comprometimento da gerência; 2) equipe de melhoria da Qualidade; 3) cálculo de Qualidade; 4) avaliação do custo da Qualidade; 5) conscientização; 6) ação corretiva; 7) comitê especial para o programa zero defeitos; 8) treinamento de supervisores; 9) dia zero defeitos; 10) estabelecimento de metas; 11) remoção de causa de erros; 12) reconhecimento; 13) conselhos da Qualidade e 14) fazer tudo de novo.

Crosby (1986) reforça a importância dos gestores para o sucesso da Qualidade: “as iniciativas da qualidade devem vir de cima para baixo, lideradas pelo exemplo; isso exige a empenho da gestão de topo e a formação técnica dos empregados em instrumentos de melhoria da qualidade."

\subsubsection{Retrospectiva da Qualidade}

No contexto mundial, Estados Unidos e Japão são os dois países que mais se destacaram no tema da Qualidade. O primeiro, pela hegemonia econômica que ostentava desde o século XIX e até meados do século XX, alicerçado pela qualidade exigida principalmente na produção em massa, pela indústria bélica e posteriormente pela indústria automobilística. O Japão, pelo notável crescimento econômico que conseguiu após sua derrota na Segunda Guerra Mundial, causando certa apreensão à concorrência americana.

Para o histórico da Qualidade nos Estados Unidos, Garvin (1992, p.3) propõe uma classificação, já clássica, de quatro "eras da qualidade”, evoluídas regularmente sem grandes 
inovações marcantes: a) Inspeção; b) Controle Estatístico da Qualidade, c) Garantia da Qualidade e d) Gestão Estratégica da Qualidade. Todas elas estão inter-relacionadas e cada uma delas agrega características da fase anterior e amplia sua abrangência, conforme sua própria evolução e exigências do desenvolvimento organizacional. São seus elementos-chaves a busca da produtividade/lucratividade e o controle; em sua concepção de gestão estratégica incorpora uma abordagem mais participativa e uma perspectiva holística.

A era da Inspeção, a inspeção formal, está relacionada com o surgimento da produção em massa e a necessidade de peças passíveis de troca, no início do século XIX, garantindo a uniformidade diante de uma padronização estabelecida. O controle da Qualidade por inspeção está relacionado à complexidade do sistema industrial que ocorreu durante a Primeira Guerra Mundial. Nele encontram-se os princípios desenvolvidos no início do século XX por Frederick W. Taylor, considerado filósofo e "pai” da Administração Científica. Para Taylor (1987), a administração científica, em grande parte, consiste em preparar e fazer a tarefa; estão aí combinados quatro grandes princípios fundamentais de administração: 1ำ desenvolvimento de uma verdadeira ciência; 2o seleção científica do trabalhador; 3o sua instrução e treinamento científico e 4ำ cooperação íntima e cordial entre a direção e os trabalhadores. Os princípios da administração científica foram elementos fundamentais transpostos para a Qualidade Total.

Na era seguinte, a do Controle Estatístico da Qualidade, a ideia era controlar o processo por meio de ferramentas e técnicas estatísticas, tendo, assim, uma maior "uniformidade do produto com menos inspeção", segundo Carvalho e Paladini (2005). Em 1930, nos Estados Unidos, Walter A. Shewhart (1989), matemático, trouxe para a empresa norte-americana, Bell Telephone Laboratories métodos estatísticos para o controle da Qualidade; sua obra “Economic Control of Quality of Manufactured Product”, lançada em 1931, marcou essa era da Qualidade nos Estados Unidos. A estatística apareceu, então, como um meio de racionalização da organização e se incorporou aos princípios da administração científica da fase anterior. Shewhart, também, propôs o ciclo PDCA (Plan, Do, Check, Act), que se tornou um clássico para as atividades de análise e solução de problemas, segundo Carvalho e Paladini (2005, p. 3).

A terceira era, na classificação de Garvin (1992, p. 13), a da Garantia da Qualidade, coincide com o final da II Guerra Mundial, quando a Qualidade já conquistara seu lugar e o objetivo 
principal era a prevenção de problemas. Fazem parte dessa fase a utilização da quantificação dos Custos da Qualidade (Juran), o Controle Total da Qualidade - TQC (Feigenbaum) e a Engenharia da Confiabilidade e o Zero Defeito (Crosby).

Completando as eras da Qualidade de Garvin (1992), a Gestão Estratégica da Qualidade, não é bem fixada no tempo, embora possam se estimar os anos 80 para o início dessa fase; ela incorpora todas as etapas anteriores e amplia sua abordagem; a questão deixa de ser atributo puramente do produto e passa a dar ênfase às necessidades do mercado e do cliente; a gerência superior, também, deve estar envolvida; voltada para o estabelecimento de objetivos, pela elaboração do planejamento estratégico e pela mobilização de toda a organização.

Segundo Garvin (1992, p. 28), “era preciso uma visão perspectiva mais voltada para fora para se conseguir o comprometimento da alta gerência, cujos interesses eram estratégicos e competitivos." Como mudam, continuamente, as necessidades dos clientes, as metas da Qualidade, também, se tornam alvos móveis, que devem ser reformulados em níveis cada vez mais altos. O objetivo passa a ser a melhoria contínua e a alta gerência tem que ter participação ativa no processo. Transforma-se aí em uma função gerencial, incorporando, igualmente, questões ligadas às relações humanas, entre as quais o fortalecimento da comunicação, a formação do espírito de equipe e a manutenção de padrões éticos elevados.

O histórico da Qualidade no Japão apresenta características diferenciadas, em relação à história americana. Até o fim da Segunda Guerra Mundial, os produtos japoneses eram vistos como baratos e de baixa qualidade; vigorava, apenas, o princípio da Inspeção, no conceito das eras de Garvin. Após 1945, a JUSE (União da Ciência e Engenharia Japonesa), entidade sem fins lucrativos e símbolo da Qualidade no Japão, dentro do esforço de reconstrução nacional, tomou medidas que trouxeram profundas alterações na economia japonesa. A seu convite Deming e Juran, americanos, estiveram no Japão para ajudá-los a superar os problemas com a Qualidade.

Começou a ser amplamente utilizado o controle estatístico da Qualidade e adotada uma abordagem sistemática de solução de problemas, conhecida como PDCA (Plan, Do, Check, $A c t$ ), que, embora tenha recebido o nome de Ciclo de Deming, havia sido proposto pelo americano Shewhart, em 1931. 
Joseph Juran, também americano, esteve no Japão em 1954 e alimentou os japoneses com conceitos sobre planejamento, fluxo organizacional, responsabilidade gerencial para a Qualidade e a necessidade de estabelecer metas e objetivos para as melhorias.

Outro personagem que se destaca com certa importância no cenário da Qualidade no Japão é Kaoru Ishikawa, que a partir de 1962 criou e incentivou o desenvolvimento de Círculos de Controle da Qualidade (CCQ). Com a implantação dos Círculos de Controle da Qualidade, os japoneses criaram as condições necessárias para a participação dos empregados no processo de análise e solução de problemas ligados ao trabalho, o que tem demonstrado ser muito eficiente como gerador de uma consciência voltada para a Qualidade. Segundo Turchi (1997, p. 14), "a percepção de controle da qualidade como uma responsabilidade de todos os trabalhadores da empresa introduz uma dimensão cultural e organizacional ao conceito de qualidade." Ishikawa é considerado, também, o criador do Diagrama de Causa Efeito, sinônimo de Diagrama de Ishikawa, ferramenta da Qualidade, largamente utilizada nas ações dos CCQ. (FARIA, 1984; MELLO; MACEDO; MEDEIROS, 2008).

Kaoru Ishikawa (1985, p. 18) observou, ironicamente, que o Japão incorporou os primeiros conceitos de Qualidade que serviram para que o "exército empresarial japonês" ocupasse o mercado norte-americano a partir da década de 70, dessa vez, não pelo uso da força, mas da competência.

Tomando-se como referência a classificação das eras de Garvin (1992), pode-se inferir que vigorou, no Japão até 1945, a era da inspeção e, de 1945 a 1960, a era de Controle Estatístico da Qualidade, com a incorporação dos conceitos de Deming e Juran. A partir de 1960, o Japão passou à Gestão Estratégica da Qualidade, com enfoque nacional em educação e treinamento destinado à maioria e com a inclusão de Controle da Qualidade e Círculos de Controle da Qualidade (CCQ) em toda a empresa.

Ainda que extremamente destacada a atuação dos citados dois consultores americanos no Japão, Garvin (1992) alerta que a contribuição desses consultores não pode ser desmerecida, mas não deve ser exagerada. "Eles sozinhos não explicam a revolução da qualidade do Japão, suas idéias, embora poderosas, seriam anunciadas em qualquer outra parte com pequenos efeitos." Juran (1992), na mesma linha observa que os americanos podem ter sido os 
catalizadores, porém os japoneses desenvolveram um movimento da Qualidade que foi muito especial e só deles, com uma grande contribuição de elementos próprios da cultura japonesa.

No Brasil, a Qualidade Total foi difundida nas empresas desde a década de 70 e ganhou mais força, na década de 90, após a abertura da economia ao comércio internacional. As empresas mais expostas à concorrência tiveram que empreender modificações internas em sua organização, estrutura, formas de trabalho e participação dos funcionários. Muitas das inovações gerenciais criaram certa polêmica, uma vez que associavam participação e trabalho em grupos com intensificação de trabalho e exploração do potencial de conhecimento do trabalhador e aplicação de princípios da administração científica de Taylor (1987). A adesão de um número considerável de empresas ao método japonês de gestão, não foi acompanhada de muitos trabalhos relatando essa experiência no Brasil.

Uma das vertentes que teve maior disseminação no Brasil foi a certificação ISO $9000^{2}$, norma com reconhecimento internacional de Qualidade. A certificação da Qualidade dava à empresa maior credibilidade no mercado, ainda que não garantisse sua sobrevivência e sucesso. Daí muitas empresas se complementarem com outros programas, tal como o de Qualidade Total e outros assemelhados. A Associação Brasileira de Normas Técnicas (ABNT) é o Fórum Nacional de Normalização; ela traduz as normas da série ISO 9000 criadas pela International Organization for Standardization (ISO), que estabeleciam uma série de padrões internacionais para gestão e garantia da Qualidade, complementares aos padrões do produto. Elas tinham como objetivo orientar as empresas na implantação de sistemas da gestão da Qualidade para fornecer produtos de acordo com as necessidades dos clientes e obter o aumento da produtividade, decorrente da redução de desperdícios, da redução de produtos não conformes e da redução de retrabalho na execução das atividades.

Falconi Campos (1992, p. 2) é um dos mais conhecidos gurus de disseminação da Qualidade no Brasil. Sua atuação esteve ligada à Fundação Christiano Ottoni, de Minas Gerais e, em seguida, à Fundação de Desenvolvimento Gerencial (FDG). A qualidade dos produtos ou serviços é medida pela satisfação do cliente e contribui igualmente para incrementar a produtividade, entendida como taxa de valor agregado. Na empresa privada, essa taxa é dada pelo quociente entre o faturamento e os custos (diretos e indiretos da produção) e constitui o

2 A expressão ISO 9000 designa um grupo de Normas Técnicas que estabelecem um Modelo de Gestão da Qualidade para qualquer tipo de organização. 
índice de produtividade, segundo Falconi Campos (1992, p. 3). Para ele, o Total Quality Control (TQC) ou Controle da Qualidade Total é um sistema gerencial voltado à sobrevivência da empresa, que reconhece a necessidade das pessoas e estabelece padrões para $\mathrm{o}$ atendimento dessas necessidades, visando manter e melhorar sempre o atendimento a elas, utilizando-se de uma visão estratégica com abordagem humanística. O TQC caracteriza-se pelo envolvimento de todos os altos dirigentes com a questão da Qualidade e, também, em programas intensivos de treinamento para o seu gerenciamento, extensivo a todos na empresa; investe, ainda, na modernização de métodos e processos mediante a normalização de procedimentos.

O cliente é uma figura nova e central na temática da Qualidade; é sinônimo de consumidor ou cidadão ou qualquer um que recebe ou é afetado pelo produto, processo ou serviço. Clientes podem ser internos ou externos. Clientes externos são afetados pelo produto e não são membros da empresa que o produz; neles se incluem quem compra o produto, órgãos governamentais de regulamentação e o público que pode ser afetado. Clientes internos são membros da empresa que fazem o produto e podem ser afetados por ele. Dentro das organizações cada trabalhador ou funcionário é fornecedor e cliente ao mesmo tempo. $\mathrm{O}$ trabalho individual é parte de um processo interligado que deve sempre resultar em um produto final executado coletivamente. Nas tarefas mais simples, deve-se ter a responsabilidade de entregá-las de tal forma que atendam a necessidade de quem as recebe, dando sequência ao serviço.

Outros aspectos sobre o movimento da Qualidade no Brasil serão abordados ao se tratar da Qualidade na gestão pública.

\subsubsection{Operacionalização do conceito de Qualidade}

Segundo Harrison (1999), a qualidade é uma chave que permite fazer mudanças na empresa, notadamente no plano dos relacionamentos sociais e na organização do trabalho: o cliente é levado em conta na determinação dos relacionamentos internos da empresa e a cooperação entre os atores apresenta-se como o princípio organizador dos laços sociais. Dada a heterogeneidade cultural e social das empresas há uma diversidade de escolhas sobre as representações e práticas da Qualidade, ou seja, a TQM mobiliza os agentes da empresa em um processo de mudança, que pode adquirir várias formas e dimensões, segundo o que estiver 
incluído como seu objeto. O mesmo estímulo Qualidade será interpretado diferentemente pelos atores segundo seus conhecimentos e saberes. Para o mesmo autor um processo de transformação pela Qualidade Total apresenta modalidades diferentes na construção de suas aplicações e nas formas de cooperação que dela decorrem. Pode-se lembrar que Saraph, Benson e Schroeder (1989) referenciaram 120 prescrições diferentes da Qualidade, vindas da literatura. As práticas e as representações da Qualidade manifestam significados variáveis, segundo os agentes e segundo os estabelecimentos, em que o processo se implanta. Dentro da empresa, as representações da Qualidade são socialmente elaboradas e concorrentes para a construção de uma realidade comum a uma coletividade. (FERNANDES, 1996; MARTINS: TOLEDO, 1998).

Segundo Spencer apud Harrison (1999), toda iniciativa de melhoria da Qualidade começa pela compreensão das necessidades dos clientes; integram-se aos processos organizacionais as entidades externas, clientes e fornecedores externos; os gestores têm a responsabilidade de criar um clima e um sistema propício à melhoria do produto e do serviço; os empregados são responsáveis por tomarem decisões e desenvolverem as atividades necessárias à melhoria da Qualidade no interior do sistema concebido pelos gestores; o desenho da estrutura organizacional é alterado em um modelo horizontal que começa com os fornecedores e termina com os clientes; as equipes são organizadas por processo, para facilitar o cumprimento das tarefas; a mudança, a melhoria contínua e a aprendizagem são encorajadas. Idealmente, os membros da organização são motivados a desconstruir o status quo.

Tendo essas noções como base, como iniciar Programas da Qualidade e Produtividade? Para Harrison (1999) um processo de implantação dos programas de Qualidade pode ser estruturado, segundo duas grandes dimensões:

- dimensão técnica: baseada no uso de ferramentas de medida de resultados; é a corrente técnico-gerencial, com poucas modificações na estrutura de tomada de decisões, promove-se o desenvolvimento de ferramentas técnicas;

- dimensão social: baseada nas transformações das relações entre os atores organizacionais, promovendo transformações nas relações de trabalho e nos relacionamentos na organização do trabalho, assim como a mobilização dos membros da organização.

Para Falconi Campos (1992, p. 177), a implantação de um programa de Qualidade é um processo de aprendizado e deve estar sempre adaptado às necessidades, usos e costumes da 
instituição que o adota. Sem regras rígidas ele nada mais é do que um aperfeiçoamento do gerenciamento já existente. $\mathrm{O}$ autor acrescenta alguns pontos essenciais como norteadores: o processo é top-down, ou seja, é implantado de cima para baixo e de responsabilidade indelegável da autoridade máxima da instituição. Sendo um programa que implica mudança comportamental e cultural deve estar associado a um grande esforço de educação e treinamento. São, portanto, condições básicas de mudança a liderança contínua e a educação.

Um seminário deve marcar o início do programa, com o comprometimento do dirigente máximo e explicação das razões para se empreender o programa; devem-se seguir aos participantes da organização várias formas de educação e treinamento. O benchmarking, visitando outras organizações com programas semelhantes é também importante. Deve-se constituir um grupo central de implantação do Programa, um Coordenador, estabelecer políticas, estratégias e metas. Quando a organização é muito grande, faz-se necessário constituírem-se grupos locais para auxiliarem o grupo central de implantação.

Ainda Falconi Campos (1992, p. 186) lembra que a implantação de um Programa de Qualidade "é um processo de mudança de maneira de pensar e um processo de mudança comportamental, e como tal necessita de tempo e muita educação e treinamento. A educação é a alavanca para todo processo de mudança.” Por educação entenda-se a aquisição de um novo conhecimento, diferentemente de treinamento que é a prática do uso do conhecimento. A experiência japonesa mostra que é razoável pensar em implantação de um Programa de Qualidade em um período de 5 a 6 anos.

A implantação de Programas de Qualidade prevê, também, a organização de eventos, para que as pessoas apresentem o que estão fazendo, seus avanços, problemas e as soluções encontradas, para que sirvam de aprendizado a outros.

Dentro da educação para a Qualidade, além de seus princípios, deve ser incluída a dimensão técnica da Qualidade, ou seja, um conjunto de técnicas, práticas e ferramentas, consideradas elementos auxiliares para a organização e para a análise da Qualidade, de uma maneira sistemática e estruturada. O Quadro 1, a seguir, sumariza algumas ferramentas da Qualidade. 
Quadro 1 - As ferramentas auxiliares da Qualidade

\begin{tabular}{|c|c|c|}
\hline & Descrição & Classificação \\
\hline Fluxograma & Representação gráfica com os passos de um processo & \multirow{5}{*}{$\begin{array}{l}\text { Ferramentas } \\
\text { Tradicionais da } \\
\text { Qualidade }\end{array}$} \\
\hline Diagrama de Pareto & $\begin{array}{l}\text { Gráfico de barras verticais para determinar prioridades de } \\
\text { problemas a resolver }\end{array}$ & \\
\hline Histograma & Envolve medição de dados e identifica variação no processo & \\
\hline $\begin{array}{l}\text { Diagrama de Causa e } \\
\text { Efeito ou Diagrama } \\
\text { de Ishikawa } \\
\text { ("espinha de peixe") }\end{array}$ & $\begin{array}{l}\text { Relação entre um efeito e todas as causas possíveis para sua } \\
\text { ocorrência }\end{array}$ & \\
\hline $5 \mathrm{~W} 2 \mathrm{H}$ & $\begin{array}{l}\text { Facilita a elaboração de um plano de ação respondendo a } \\
\text { 5Ws: What? (O quê?) When? (Quando?) Where? (Onde?) } \\
\text { Why? (Por quê?) Who? (Quem?) } 2 \text { Hs: How? (Como?) How } \\
\text { much? (Quanto?) }\end{array}$ & \\
\hline $\begin{array}{l}\text { Diagrama de } \\
\text { Relações }\end{array}$ & $\begin{array}{l}\text { Mostra fatores relevantes em uma situação complexa, } \\
\text { indicando relações lógicas entre eles por meio de setas }\end{array}$ & \multirow{4}{*}{$\begin{array}{l}\text { Ferramentas } \\
\text { Gerenciais da } \\
\text { Qualidade }\end{array}$} \\
\hline Diagrama de Árvore & $\begin{array}{l}\text { A partir de um objetivo primário, mostra o encadeamento de } \\
\text { todos os objetivos secundários e meios necessários para } \\
\text { atingi-los }\end{array}$ & \\
\hline Matriz de Priorização & $\begin{array}{l}\text { Estabelece uma ordem numérica de prioridade para possíveis } \\
\text { soluções, tarefas e questões }\end{array}$ & \\
\hline Matriz GUT & $\begin{array}{l}\text { Permite quantificar causas de problemas, segundo gravidade, } \\
\text { urgência e tendência (GUT) }\end{array}$ & \\
\hline $\begin{array}{l}5 \mathrm{~S} \text { (os } \mathrm{S} \text { vêm de } \\
\text { palavras japonesas) }\end{array}$ & $\begin{array}{l}\text { Programa de gerenciamento participativo que objetiva criar } \\
\text { condições de trabalho adequadas a todas as pessoas em todos } \\
\text { os níveis hierárquicos da organização. Inclui: seiri (descarte); } \\
\text { seiton (arrumação); seisso (limpeza) e seiketsu (saúde) e } \\
\text { shitsuke (disciplina). }\end{array}$ & \multirow{5}{*}{$\begin{array}{l}\text { Práticas e } \\
\text { Métodos para a } \\
\text { Melhoria da } \\
\text { Qualidade }\end{array}$} \\
\hline Brainstorming & $\begin{array}{l}\text { Exercício de raciocínio para englobar todos os aspectos do } \\
\text { problema ou da solução em um mínimo de tempo }\end{array}$ & \\
\hline $\begin{array}{l}\text { Nominal Group } \\
\text { Technique (NGT) }\end{array}$ & $\begin{array}{l}\text { Técnica de brainstorming para levantamento e priorização de } \\
\text { ações para planejamento ou resolução de problemas }\end{array}$ & \\
\hline Ciclo PDCA & $\begin{array}{l}\text { Método de controle de processos (caminho para atingir metas } \\
\text { estabelecidas), com } 4 \text { fases: P (Plan, de planejamento); D } \\
\text { (Do, de execução); C (Check, de verificação) e A (Act de } \\
\text { ação corretiva) }\end{array}$ & \\
\hline $\begin{array}{l}\text { Círculos de Controle } \\
\text { de Qualidade (CCQ) }\end{array}$ & $\begin{array}{l}\text { Grupos de funcionários que voluntariamente se reúnem para } \\
\text { conduzir atividades de controle de qualidade, dentro ou não } \\
\text { da mesma área de trabalho }\end{array}$ & \\
\hline $\begin{array}{l}\text { Quality function } \\
\text { Deployment (QFD) }\end{array}$ & $\begin{array}{l}\text { Sistema para projetar um produto ou serviço, baseado nas } \\
\text { exigências do cliente, com a participação de membros de } \\
\text { todas as funções da organização do fornecedor }\end{array}$ & \multirow{3}{*}{ Metodologias } \\
\hline $\begin{array}{l}\text { Total Quality } \\
\text { Management (TQM) }\end{array}$ & $\begin{array}{l}\text { Gestão da Qualidade Total, extensão lógica da maneira em } \\
\text { que a prática da qualidade tem evoluído }\end{array}$ & \\
\hline $\begin{array}{l}\text { Balanced Score Card } \\
\text { (BSC) }\end{array}$ & $\begin{array}{l}\text { Integra indicadores financeiros e não financeiros e garante } \\
\text { uma perspectiva abrangente do desempenho das áreas } \\
\text { críticas de gestão }\end{array}$ & \\
\hline $\begin{array}{l}\text { Série de Normas ISO } \\
9000: 2000\end{array}$ & $\begin{array}{l}\text { Conjunto de normas que formam um modelo de gestão da } \\
\text { qualidade para organizações }\end{array}$ & \multirow{4}{*}{ Série de Normas } \\
\hline $\begin{array}{l}\text { Série de Normas } \\
14000\end{array}$ & $\begin{array}{l}\text { Conjunto de normas que estabelecem diretrizes sobre a área } \\
\text { da gestão ambiental nas organizações }\end{array}$ & \\
\hline OSHAS 18001:2007 & $\begin{array}{l}\text { Conjunto de normas para implementação de sistemas de } \\
\text { gestão de segurança e higiene ocupacional }\end{array}$ & \\
\hline $\begin{array}{l}\text { Sistema Integrado de } \\
\text { Gestão (SIG) }\end{array}$ & $\begin{array}{l}\text { Diferentes normas aplicadas de forma integrada. Ex: ISO } \\
\text { 9001:2000, OSHAS 18001:2007 e ISO 14001:2004 }\end{array}$ & \\
\hline Benchmarking & $\begin{array}{l}\text { Processo contínuo de comparação de produtos, serviços e } \\
\text { práticas empresariais entre os mais fortes concorrentes ou } \\
\text { empresas reconhecidas como líderes }\end{array}$ & $\begin{array}{l}\text { Método para a } \\
\text { melhoria da } \\
\text { Qualidade } \\
\end{array}$ \\
\hline
\end{tabular}

Fonte: Adaptado de Melo; Macedo; Medeiros, 2008 
Quando se reflete sobre o Estado da Arte da Qualidade, não há conceito universalmente aceito sobre o tema e o que ela inclui tem variado no tempo. Essa nebulosidade do conceito, cuja operacionalidade era difícil às organizações, levou ao desenvolvimento de modelos de Qualidade ou de modelos de excelência de gestão, no qual se basearam, em seguida, os prêmios de Qualidade, conferidos às organizações com excelência organizacional.

Os modelos relacionados à excelência, entendida como o máximo da Qualidade organizacional, podem ser interpretados como um padrão possível de ser usado por uma grande massa de organizações em todo mundo, como um pré-requisito para organizações globais ou de classe mundial. Os modelos ao estabelecerem padrões, definem plataformas de requisitos básicos, voltados para racionalizar relações de negócios, definindo uma linguagem comum e uma filosofia concernente à Qualidade.

Tais modelos são tipicamente genéricos e não prescritivos, especificando o que o Sistema de Qualidade deve cobrir e não como deve ser implantado. Assim, as organizações têm flexibilidade para projetar seu próprio sistema de qualidade, obedecendo a padrões gerais, mas contemplando sua estrutura, cultura, nomenclatura e processos existentes. Eles servem, também, para medir o nível da qualidade organizacional, pontuando e classificando as organizações por meio de gradações, fases ou etapas, que devem ser, sucessivamente, vencidas para se conseguir a excelência organizacional.

Segundo Carvalho e Paladini (2005), os modelos de excelência são referenciais para um prêmio de abrangência nacional, interpretado como um mecanismo de incentivo às empresas, para estruturarem sua gestão, na busca da excelência em qualidade, produtividade e competitividade.

São significativos para esta tese os prêmios de Qualidade, notadamente: o prêmio americano, Malcolm Baldrige National Quality Award (MBNQA) e o brasileiro, Prêmio Nacional da Qualidade (PNQ).

Em meados da década de 80, o aumento da concorrência japonesa estimulou o governo americano a estudar mais profundamente as causas do sucesso econômico japonês. Imaginava-se que um maior conhecimento sobre as empresas consideradas de classe mundial 
permitiria às organizações americanas a identificação de práticas estruturadas que tivessem maiores possibilidades de sucesso no ambiente competitivo e globalizado da época.

O estudo identificou, então, alguns fundamentos essenciais para o sucesso de uma organização, dando base para a estruturação do prêmio americano de Qualidade Malcolm Baldrige (Malcolm Baldrige National Quality Award - MBNQA), que foi criado em 1987, por uma lei do Congresso americano. Tendo como base um modelo sistêmico de excelência de gestão, o prêmio objetivava reconhecer com um troféu as organizações que tivessem feito melhorias significativas em seus produtos e serviços. (BALDRIGE NATIONAL QUALITY PROGRAM，2006; BROWN，1995; GARVIN，1991; HART; SCHLESINGER， 1991; JAMES, 1997; JASINKY, 1998; VOKURKA, 2000).

O enfoque da Qualidade considera que uma organização é constituída por pessoas e processos e deve ser estruturada em função das demandas e do atendimento das necessidades desses seus diversos agentes internos e externos. Esses agentes internos e externos são, geralmente, representados pelos próprios acionistas ou proprietários, pelos clientes da organização, pela força de trabalho, pelos fornecedores e pela comunidade e sociedade. A comunidade é a parcela que recebe as ações da organização enquanto a sociedade tem um sentido mais amplo e recebe as ações da organização ou os efeitos decorrentes dessas ações. Daí que o modelo de Qualidade adotado tinha como objetivo: avaliar uma organização, de forma sistêmica, com relação às práticas de gestão utilizadas e os resultados organizacionais, de forma a atender às necessidades de todos os stakeholders (partes interessadas); foi estabelecido um conjunto de critérios e itens que a organização deveria cumprir por meio de suas práticas, o que daria subsídios para melhorar o desempenho da gestão organizacional e conduziriam a resultados de excelência.

$\mathrm{Na}$ esteira do prêmio americano, outros países adotaram práticas semelhantes e desenvolveram seus próprios prêmios à semelhança do prêmio americano, no final dos anos oitenta e início da década de noventa. Na Europa, em 1988 foi instituído o Prêmio Europeu da Qualidade (EFQM) e na Ásia e América Latina também surgiram modelos derivados do prêmio americano. O Brasil, dada a sua inserção na economia mundial, no início da década de 90, também se aliou a esse movimento e iniciou, em 1992, o Prêmio Nacional da Qualidade (PNQ), baseado igualmente no modelo americano e administrado pela Fundação Prêmio Nacional da Qualidade (FPNQ). 
Além desse, no Brasil, outros prêmios de Qualidade, também, foram instituídos com abrangência regional, tais como: o Prêmio Gaúcho da Qualidade, para o Rio Grande do Sul; o Prêmio Paulista de Qualidade da Gestão, para o Estado de São Paulo e outros. Um prêmio especial para as organizações públicas foi instituído em 1998, denominado de Prêmio de Qualidade no Serviço Público (PQGF) e renomeado, em 2005, para Prêmio Nacional da Gestão Pública (GESPÚBLICA). Todos eles têm em comum os fundamentos da administração contemporânea, consolidados em um modelo de gestão, que contempla critérios, subdivididos em itens e alíneas.

O desempenho das organizações já tinha sido objeto do Deming Prize, instituído no Japão, em 1951, e pioneiro do primeiro prêmio de Qualidade lançado no mundo. Embora muito importante no Japão, não teve a mesma irradiação em outros países. Hoje, segundo Miguel (2001; 2004), o Prêmio Deming homenageia tanto organizações privadas como públicas que tenham implementação de sucesso em suas atividades de Qualidade.

Como já referenciado, alarmado com o avanço da indústria japonesa, o Congresso Americano estabeleceu pela Lei Pública 100-107, de 1987, o Malcolm Baldrige National Quality Award (MBNQA), Prêmio Nacional de Qualidade Malcolm Baldrige, segundo Brown (1995). Tinha como objetivo principal a melhoria da competitividade das empresas americanas, por meio da conscientização para a Qualidade, do reconhecimento dos resultados de excelência no desempenho das empresas americanas e da publicação desses resultados de sucesso das empresas premiadas, para a troca de informações e experiências. A primeira premiação ocorreu em 1988.

O processo do prêmio é administrado pelo Instituto Nacional de Padrões e Tecnologia (National Institute of Standards and Tecnology - NIST), órgão do Departamento do Comércio Americano, e com a American Society of Quality (ASQ) auxiliando na aplicação, revisão do processo e preparação dos documentos e outras providências administrativas, conforme Vokurka e outros (2000). O nome do Prêmio é emprestado de Malcolm Baldrige, ex-Secretário do Comércio entre 1981 e 1987 e morto tragicamente em um acidente de rodeio; sua excelência administrativa contribuiu para o aperfeiçoamento da eficiência e eficácia do governo americano. 
A estratégia conceitual do prêmio é a criação de critérios de consenso que projetam valores claros, colocam padrões altos, focalizam requisitos-chaves para a excelência organizacional e criam meios de avaliar o progresso relativo a esses requisitos. Do ponto de vista institucional o uso de critérios constitui uma base para comunicações consistentes dentro e nas organizações de todos os tipos. Parte importante do processo é o compartilhamento de informações pelos ganhadores do Baldrige Award.

Em depoimento, encontrado em Brown (1995), o professor David Garvin, da Universidade de Harvard, e um dos grandes teóricos da Qualidade, afirma que o Prêmio de Qualidade Malcolm Baldrige foi o mais importante catalisador para a transformação de empresas norteamericanas. Reformulou o pensamento e o comportamento dos gerentes que passaram a seguir os padrões preconizados pelos critérios Baldrige como um guia para administrar uma empresa bem-sucedida.

Os valores essenciais nos critérios Baldrige em 1995 eram: liderança; qualidade orientada ao cliente; melhoria contínua e aprendizado; participação e desenvolvimento dos funcionários; resposta rápida; qualidade do projeto e prevenção; visão de longo prazo; gerenciamento baseado em fatos; desenvolvimento de parcerias; responsabilidade e cidadania corporativa e orientação aos resultados. Dada a dinâmica da sociedade, das próprias organizações e do aprendizado obtido com sua aplicação, o modelo tem sido revisto e alterado constantemente. Assim, em 2006, os critérios do modelo já estavam diferenciados em relação a 1995 e assinalavam os seguintes valores e conceitos: liderança visionária; excelência dirigida ao cliente; aprendizado individual e organizacional; valorização dos empregados e parceiros; agilidade; foco no futuro; gerenciamento da inovação; gerenciamento por fatos; responsabilidade social; foco em resultados e criação de valor e perspectiva sistêmica.

O Prêmio Americano de Qualidade tem três categorias diferentes: negócios (business: subdividido em manufatura, serviços e pequenas empresas); saúde (health care) e educação (education, incluindo adaptações para instituições de ensino fundamental, básico e superior).

A categoria do Prêmio Baldrige, na área da educação, refletia um consenso nacional da necessidade de melhorar a qualidade da educação, em direção à excelência educacional, e as organizações educacionais eram consideradas como empresas. Pretendia-se atuar com dois focos: a entrega de um melhor valor educacional aos alunos e a melhoria da eficácia geral da 
escola, em relação a seus recursos e capacidades. São conceitos centrais nessa categoria: liderança; informação e análise; planejamento estratégico e operacional; desenvolvimento e gerenciamento de recursos humanos; gerenciamento do processo comercial e educacional; resultados do desempenho da Escola; foco em estudantes e satisfação de estudantes e stakeholders. Em 1995, o Prêmio Malcolm Baldrige para as organizações educacionais foi implementado em versão piloto e, em 1997, foi oficializado como referencial para a avaliação da Qualidade de organizações educacionais nos EUA.

Os critérios do Baldrige serviram, também, no Brasil como referência para a implementação de programas de excelência na educação. George, apud Taragano (1996) afirma que os critérios desse sistema da qualidade funcionam mais ou menos como um mapa de melhoria, colocando sua organização na rota certa para que você possa atingir os seus objetivos.

Esses critérios ainda têm uma importância redobrada, nesta tese, porque serviram de referência aos balizadores instituídos para o Serviço Público, em 1996, e foram adotados, com adaptação ao setor educacional, na esfera da Universidade de São Paulo, conforme consta do Relatório de Atividades (1996). Para reforçar esse referencial em um dos encontros que a Comissão de Gestão da Qualidade e Produtividade promoveu, em 14 de maio de 1997, uma conferencista americana convidada relatou o caso de aplicação e implantação dos critérios desse Prêmio na Universidade State Technical Memphis, compartilhando essa experiência de aplicação dos critérios, para melhoria de instituições de ensino.

Conforme publicação FNQ (2006), a Fundação Nacional da Qualidade (FNQ) é uma entidade privada e sem fins lucrativos; criada em outubro de 1991, por 39 organizações privadas e públicas de renome nacional e internacional, administra o Prêmio Nacional da Qualidade (PNQ) e todas as atividades decorrentes do processo de premiação, que é feito anualmente, em todo o território nacional e tem por missão:

[...] promover a conscientização para a qualidade e produtividade das empresas produtoras de bens e serviços e facilitar a transmissão de informações e conceitos relativos às práticas e técnicas modernas, e bem-sucedidas, da gestão da qualidade, inclusive com relação aos Órgãos da Administração Pública, por meio do Prêmio Nacional da Qualidade, mais recentemente a Fundação alterou sua missão para: disseminar os fundamentos da excelência em gestão para o aumento de competitividade das organizações e do Brasil. 
O Modelo de Excelência de Gestão da FNQ tem sido bastante adotado e aceito pelo mercado; proporciona flexibilidade; é apresentado em linguagem simples; não é prescritivo de ferramentas e práticas de gestão específicas; serve para avaliação e diagnóstico e também se aplica ao desenvolvimento de sistema da gestão de qualquer tipo de organização, pública ou privada, com ou sem fins lucrativos, de porte pequeno, médio ou grande.

Conforme a publicação Critérios de Excelência da FNQ (2006), o Prêmio Nacional da Qualidade busca promover um amplo entendimento dos requisitos para alcançar a excelência do desempenho, melhorando a competitividade e, ao mesmo tempo, compartilhando informações sobre métodos e sistemas da gestão que tiveram sucesso, em função das estratégias adotadas.

Os fundamentos de excelência expressam conceitos reconhecidos internacionalmente e que se traduzem em práticas encontradas em organizações líderes de Classe Mundial. Os doze fundamentos em que se baseiam os Critérios de Excelência da FNQ (2006) são: visão sistêmica, aprendizado organizacional; proatividade; inovação; liderança e constância de propósitos; visão de futuro; foco no cliente e no mercado; responsabilidade social; gestão baseada em fatos; valorização das pessoas; abordagem por processos e orientação para resultados, descritos no Quadro 2 que se segue: 
Quadro 2 - Síntese dos fundamentos do Prêmio Nacional da Qualidade

\begin{tabular}{|c|c|c|}
\hline 1 & Visão sistêmica & $\begin{array}{l}\text { Relações de interdependência entre os diversos } \\
\text { componentes de uma organização, bem como entre a } \\
\text { organização e o ambiente externo. }\end{array}$ \\
\hline 2 & Aprendizado organizacional & $\begin{array}{l}\text { Busca e alcance de um novo patamar de conhecimento, } \\
\text { por meio de percepção, reflexão, avaliação e } \\
\text { compartilhamento de experiências. }\end{array}$ \\
\hline 3 & Proatividade & $\begin{array}{l}\text { Capacidade da organização de se antecipar às mudanças } \\
\text { de cenários e às necessidades e expectativas dos clientes } \\
\text { e das demais partes interessadas. }\end{array}$ \\
\hline 4 & Inovação & $\begin{array}{l}\text { Implementação de novas ideias geradoras de um } \\
\text { diferencial competitivo. }\end{array}$ \\
\hline 5 & $\begin{array}{l}\text { Liderança e constância de } \\
\text { propósitos }\end{array}$ & $\begin{array}{l}\text { Comprometimento dos líderes com os valores e } \\
\text { princípios da organização; capacidade de construir e } \\
\text { implementar estratégias e um sistema de gestão que } \\
\text { estimule as pessoas a realizar um propósito comum e } \\
\text { duradouro. }\end{array}$ \\
\hline 6 & Visão de Futuro & $\begin{array}{l}\text { Compreensão dos fatores que afetam o negócio e o } \\
\text { mercado no curto e no longo prazo, permitindo o } \\
\text { delineamento de uma perspectiva consistente para o } \\
\text { futuro desejado pela organização. }\end{array}$ \\
\hline 7 & Foco no cliente e no mercado & $\begin{array}{l}\text { Conhecimento e entendimento do cliente e do mercado, } \\
\text { visando à criação de valor de uma forma sustentada para } \\
\text { o cliente e maior competitividade nos mercados. }\end{array}$ \\
\hline 8 & Responsabilidade social & $\begin{array}{l}\text { Atuação baseada em relacionamento ético e transparente } \\
\text { com todas as partes interessadas, visando ao } \\
\text { desenvolvimento sustentável da sociedade, preservando } \\
\text { recursos ambientais e culturais para futuras gerações, } \\
\text { respeitando a diversidade e promovendo a redução das } \\
\text { desigualdades sociais. }\end{array}$ \\
\hline 9 & Gestão baseada em fatos & $\begin{array}{l}\text { Tomada de decisões com base na medição e análise do } \\
\text { desempenho, levando-se em consideração as } \\
\text { informações disponíveis, incluindo os riscos } \\
\text { identificados. }\end{array}$ \\
\hline 10 & Valorização das pessoas & $\begin{array}{l}\text { Compreensão de que o desempenho da organização } \\
\text { depende da capacitação, motivação e bem-estar da força } \\
\text { de trabalho e da criação de um ambiente de trabalho } \\
\text { propício à participação e ao desenvolvimento das } \\
\text { pessoas. }\end{array}$ \\
\hline 11 & Abordagem por processo & $\begin{array}{l}\text { Compreensão e gerenciamento da organização por meio } \\
\text { de processos, visando à melhoria do desempenho e à } \\
\text { agregação de valor para as partes interessadas. }\end{array}$ \\
\hline 12 & Orientação para resultados & $\begin{array}{l}\text { Compromisso com a obtenção de resultados que } \\
\text { atendam, de forma harmônica e balanceada, às } \\
\text { necessidades de todas as partes interessadas na } \\
\text { organização. }\end{array}$ \\
\hline
\end{tabular}

Fonte: Fundação Nacional da Qualidade (2006)

Em sua primeira versão de 1991, o modelo adotado pela Fundação Prêmio Nacional da Qualidade, conservou os mesmos critérios do Prêmio americano Malcolm Baldrige. Com o tempo, o modelo foi se alterando e os critérios do Prêmio em 2006, contemplados no Modelo de Excelência da Gestão da FPNQ, estava constituído por 8 critérios: 1) Liderança; 2) 
Estratégias e Planos; 3) Clientes; 4) Sociedade; 5) Informação e Conhecimento; 6) Pessoas; 7)

Processos e 8) Resultados. O Modelo está representado pelo diagrama da Figura 2:

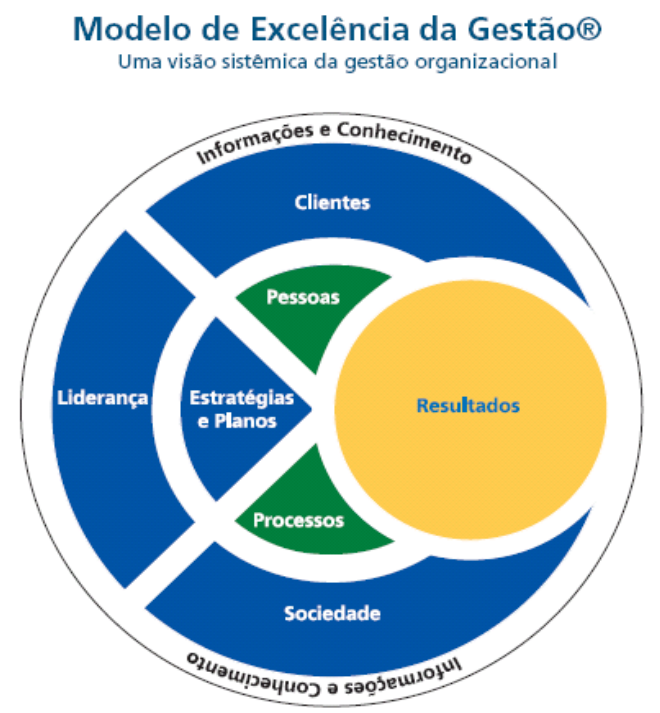

Figura 2 - Modelo de excelência da gestão

Fonte: Fundação Nacional da Qualidade, 2006

A organização do círculo representa a organização, considerada como um sistema orgânico, adaptável ao ambiente externo. Sugere que os elementos do Modelo, imersos em um ambiente de informação e conhecimento, se relacionam de forma harmônica e integrada, voltados para a geração de resultados.

Usando como referência os Critérios de Excelência do Prêmio Nacional da Qualidade, de 1996, e os Balizadores da Qualidade para o Serviço Público, o Programa Permanente de Qualidade e Produtividade (1997) fez uma publicação, que incluía um Questionário de Mapeamento de Características da Qualidade e Produtividade ${ }^{3}$. Tal questionário permitia uma autoavaliação inicial das Unidades e Órgãos, para identificação de oportunidades de melhorias, priorização de ações a serem realizadas e elaboração de um Plano Diretor da Qualidade e Produtividade. Visava, também, o fortalecimento de uma linguagem comum quanto à qualidade e produtividade, permitindo um maior intercâmbio de boas práticas.

3 O Questionário foi elaborado em conjunto com a Comissão de Gestão de Q\&P da USP, tendo como base uma versão elaborada por Carmen Sílvia Araújo e Hélio Janny Teixeira, professor do Departamento de Administração da FEA/USP. 
O framework elaborado no Questionário, construído e apresentado na publicação da Comissão de Q\&P da USP, traduzia um esforço do Programa de Qualidade e Produtividade na adaptação dos "preceitos genéricos da qualidade” à situação da Universidade.

Os sete Módulos de Qualidade, contemplados no Questionário, abrangiam: Liderança; Planejamento; Foco no cliente; Informação e Análise; Desenvolvimento e Gestão de Pessoas; Gestão de Processos e Parcerias e Alianças. Combinado com os Balizadores da Qualidade no Serviço Público esse questionário serviu, também, como quadro de referência para a análise de conteúdo da pesquisa de campo feita nesta tese.

Ao se tentar operacionalizar esses conceitos na organização, ela pode sofrer modificações na sua estrutura, relações de trabalho, processos, razão pela qual o tema de mudanças organizacionais é tratado com maior detalhamento a seguir.

\subsection{Mudanças organizacionais}

O tema de mudanças organizacionais é, por si só, de grande amplitude e complexidade. Sua inclusão justifica-se porque programas de qualidade e produtividade provocam mudanças na cultura organizacional.

Observa Wood Jr. (2004) que não há opção à mudança; gradativamente as organizações necessitam assumir uma postura proativa em substituição à atitude reativa. Para esse autor mudança organizacional é "qualquer transformação de natureza estrutural, estratégica, cultural tecnológica, humana ou de outro componente, capaz de gerar impacto em partes ou no conjunto da organização. São atividades intencionais, pró-ativas e direcionadas para a obtenção de metas organizacionais.”

Adotar estratégias de mudança que obtenham sucesso envolve compreender aspectos do ambiente, dos indivíduos e da organização como um todo. Dessa forma, identificar variáveis do contexto que estariam provocando as mudanças é uma vantagem para os gerenciadores da mudança, na medida em que esse conhecimento facilita a condução e a implantação de mudanças e maximiza oportunidades de incremento da eficiência da organização. (BENNIS, 
1976; BERNOUX, 2004; COURPASSON, 1998; DOLCI, 2005; JUDSON, 1980; LAWRENCE; LORSCH, 1972; WOOD JR., 2004).

\subsubsection{Fatores propulsores de mudanças organizacionais}

Diversos conceitos e abordagens sobre mudança organizacional são encontrados em Wood Jr. (2004, p. 23) e vários autores abordam os fatores que catalisam a mudança: duas situações podem ser identificadas como propulsoras da mudança da cultura organizacional. A primeira advém do ambiente externo, seja pela necessidade de retração ou expansão da organização, às crises econômicas da empresa, à ação de movimentos sociais ou do Estado e, também, às mudanças tecnológicas. A segunda situação vem do contexto interno da organização, quando da mudança de dirigentes e cargos-chaves, na introdução de novos processos de trabalho e de políticas internas.

Por seu lado, Herzog (1991) classifica em três as situações capazes de provocar mudança: crises e problemas; novas oportunidades e novas diretrizes internas e externas. Harari (1991) percebe a mudança como um processo caracterizado pelo princípio de melhoria contínua, enquanto Huey (1991) justifica a necessidade de mudança para que a inércia organizacional seja vencida, empregando os conceitos desenvolvidos por Thomas Kuhn (2003) sobre quebra de paradigmas na Ciência. Robbins (1999) apresenta seis aspectos específicos que atuam como desencadeadores de mudança: a natureza da força de trabalho; a tecnologia; os choques econômicos; a concorrência; as tendências sociais e a política mundial. Para Pettigrew (1987), os fatores capazes de precipitar mudanças organizacionais são, basicamente, externos e internos. Como fatores externos incluem-se mudanças no ambiente de negócios e recessão econômica e fatores internos estão ligados à inércia organizacional à estrutura da organização e ao ambiente interno em geral.

\subsubsection{Modos de implantação de mudanças organizacionais}

Com relação aos modos de implantação das mudanças, Fleury (1993) considera que as organizações mudam, mas as mudanças são quase sempre limitadas, rotineiras, havendo uma tendência à estabilização e manutenção dos valores básicos e relações de poder vigentes. 
De acordo com Pettigrew (1990), uma mudança estratégica deve ser vista como um processo humano complexo, em que todos desempenham sua parte: a percepção diferenciada; as buscas por eficiência e poder; as habilidades de liderança visionária; a duração das mudanças e processos sutis que gradativamente preparam o momento propício de apoio para a mudança e, então, a implementação vigorosa da mudança. Dessa forma, planejamento e implementação são duas fases importantes e que se complementam em um processo de mudança. (OBADIA; VIDAL e MELO, 2007).

Conforme Okumus (2003), na implantação de uma nova estratégia organizacional devem ser considerado no conteúdo estratégico (strategic content), alguns fatores-chaves de adoção: a coerência com a direção estratégica da instituição; a definição clara dos objetivos; o conhecimento dos desenvolvedores da estratégia e o impacto potencial em projetos já em andamento e outros projetos futuros. No processo organizacional de implantação de uma nova estratégia, deve-se, também, considerar o planejamento operacional (preparar e planejar a implementação das atividades; participação e feedback de diferentes níveis de gerenciamento e áreas funcionais; receptividade e resistências); recursos: o processo de assegurar que no tempo certo os recursos financeiros, treinamento e conhecimento estarão disponíveis; pessoas: recrutar um novo staff, prover treinamento e incentivo para funcionários relevantes; tipos de atividades de treinamento para desenvolver e preparar gerentes relevantes e funcionários; incentivos relacionados à implementação da estratégia e suas implicações; impacto das políticas e práticas de Recursos Humanos na implementação da nova estratégia. Comunicação: mecanismos para enviar mensagens formais e informais sobre a nova estratégia. Controle e feedback: mecanismos formais e informais que permitam que os esforços e resultados da implementação sejam monitorados e comparados contra determinados objetivos.

Por sua vez, Gagliardi (1986) identifica três tipos de mudanças culturais nas organizações: mudanças revolucionárias; aparente ou cosmética e gradual. São revolucionárias, quando novos valores incorporados são antagônicos aos anteriores, gerando um processo radical de destruição dos elementos simbólicos e redefinição completa das práticas organizacionais. $\mathrm{Na}$ mudança aparente ou cosmética, as alterações são superficiais, com o intuito de preservar a cultura; pode-se pensar em uma maquiagem de mudança, bastante frequentes, não podendo nem mesmo ser qualificada como mudança cultural. Na mudança gradual ou incrementalismo cultural, os valores novos são incorporados de modo complementar aos existentes, 
ampliando-se o leque de alternativas para a solução de problemas; não há grandes transformações e tampouco alterações profundas nos pressupostos básicos; não há traumas; não há altos níveis de ansiedade e propicia uma maior disposição das pessoas procurarem formas alternativas de solucionar os problemas.

Dolci (2005) considera que duas variáveis interferem na implementação de programas de mudança: concomitância e velocidade das mudanças. No incrementalismo lógico, analisado por Quinn (1980), não há o rompimento brusco com as formas pelas quais a organização está moldada, enquanto o radicalismo busca a transformação total; o radicalismo na mudança presume a necessidade de descontinuar, opondo-se ao incrementar. Conforme Demers, Hafsi e Jorgensen (1996), para ser radical, a mudança interfere em todas as principais partes de uma organização e ocorre de forma descontínua em, no mínimo, um dos seguintes elementos: ideologia; estratégia ou arranjos estruturais. O radicalismo, na mudança, opera com a ideia central de romper com a evolução natural dos sistemas organizacionais, percebendo as organizações como propícias à inércia, à acomodação e ao desaparecimento. Nesse caso, a mudança radical funciona como a reação à morte e à decadência, conforme Motta (1998).

Segundo Gersick (1991), as mudanças cumulativas, incrementais não explicam a evolução de empresas; ele sugere que se entenda a evolução organizacional à luz da perspectiva do "paradigma do equilíbrio interrompido" (punctuated equilibrium paradigm). Segundo esse paradigma, na organização devem ocorrer curtos momentos de transformação radical, seguido de longos períodos de estabilidade, quando ocorrem as mudanças incrementais.

Para Mintzberg, Ahlstrand e Lampel (2000), as mudanças podem variar de uma micromudança a uma macromudança. A micromudança é dirigida, apenas, a uma parte da organização, enquanto a macromudança visa à organização inteira. Uma micromudança pode ter macroconsequências, uma vez que ações, inicialmente isoladas, podem conduzir a padrões significativos de ação. Por outro lado, há três tipos de abordagens básicas ao processo de mudança: programática; conduzida e evoluída. A mudança programática é mais previsível que a mudança orgânica.

A mudança planejada é programática: existe um sistema ou conjunto de regras a ser seguido. Podem ser programas de melhoria da Qualidade e treinamento (micro) até programas de desenvolvimento organizacional e planejamento estratégico (mais macro). 
A mudança conduzida é guiada: um indivíduo ou grupo pequeno, usualmente numa posição influente de autoridade, supervisiona a mudança e garante que ela aconteça. Aí estão incluídos programas de racionalização, reestruturação e revitalização organizacionais; seus fatores de mudança advêm de contextos estratégico, organizacional e emocional.

A mudança evoluída é orgânica: ela acontece ou pelo menos é guiada por pessoas que não têm posições de autoridade significativa. Nessa última condição, cabe à direção da organização apenas o papel de proporcionar (controlar) o ambiente necessário à mudança pretendida, porém, sendo orgânica, tem ela menos controle sobre os resultados.

Wood Jr. (2004) observa que até poucos anos atrás os programas de mudança eram exceções nas organizações, uma vez que elas não privilegiavam atitudes inovadoras. Apenas mais recentemente consideram-se inovações gerenciais no centro da busca pela competitividade ou no caso de organizações públicas como uma pressão de Estado pela otimização, do uso do recurso público e do atendimento ao cidadão.

No que tange ao modelo de mudança organizacional, para Pettigrew (1979), a organização é um sistema social construído e formado de um conjunto de significados compartilhados. Querer a implantação de "cultura da qualidade" significa alterar a cultura organizacional e incluir novos significados que precisam ser compartilhados.

O conceito de cultura organizacional, tal como encontrado em Stevanato (1997), é estruturalmente complexo e consiste em um conjunto de pressupostos implícitos, que são internalizados como verdades pelos membros da organização. Uma vez que o grupo tenha convivido durante algum tempo, os seus pressupostos irão se alinhar com outros, gerando um padrão cultural. Essa padronização dos pressupostos básicos torna-se, então, mais profundo e fortemente internalizado o nível da cultura em função das necessidades humanas de consistência e ordem. Essas características da cultura dão uma ideia de como seria "difícil, ameaçador, doloroso e incerto conduzir um processo de mudança".

Para Pettigrew (1979), a cultura da organização apresenta-se em dois níveis: no primeiro deles, mais profundo e difícil de ser transformado, estão contidas as crenças e pressupostos pelos quais a organização funciona internamente e como ela se relaciona com seu ambiente 
externo; no segundo nível, encontram-se as manifestações da cultura, com seus sistemas administrativos e estrutura, passíveis de uma modificação mais fácil.

Schein $(1984$, p. 244) traz algumas outras questões sobre o que vem a ser uma mudança cultural:

\begin{abstract}
Como a cultura afeta cada processo de mudança? Será que a cultura muda em si mesma nesse processo? E o que é entendido por mudança de cultura? Por exemplo, quando falamos em mudança cultural, entendemos mudanças comportamentais, mudanças de valores, ou mudanças nos pressupostos? Entendemos mudanças em todo o paradigma ou em apenas um conjunto de pressupostos? Quanto tem que mudar e em que nível antes de considerarmos isto uma real mudança na cultura? Sob que condições é cada mudança desejável ou possível? Se um processo de mudança reforça algum elemento da cultura, isto é mudança de cultura?
\end{abstract}

Segundo Pettigrew (1990, p. 145), a cultura organizacional pode ser gerenciada, "com a maior dificuldade"; as crenças básicas da organização podem ser alteradas pela influência dos principais tomadores de decisão da instituição.

Para Sainsaulieu, apud Fleury (1993), a empresa é constituída por um tecido de grupos que possuem suas formas próprias de representação, uma relação particular com a empresa e o trabalho, um patrimônio comum de experiência, não sendo, portanto, possível falar de cultura da empresa, mas de cultura de grupos. Qualquer estratégia prática para mudar a cultura organizacional terá que envolver pensamento e ação, tanto no nível das crenças básicas como no de suas manifestações culturais.

A tendência geral, na maioria das organizações, é de preservação da cultura, ou seja, procurase equacionar os problemas que surgem com os padrões culturais vigentes.

Pichault e Nizet (2000), ao descreverem um quadro teórico do contextualismo de Pettigrew (1990), observam que a mudança, para se realizar, apoia-se em três conceitos-chave e suas inter-relações: o conteúdo; o contexto e o processo. 


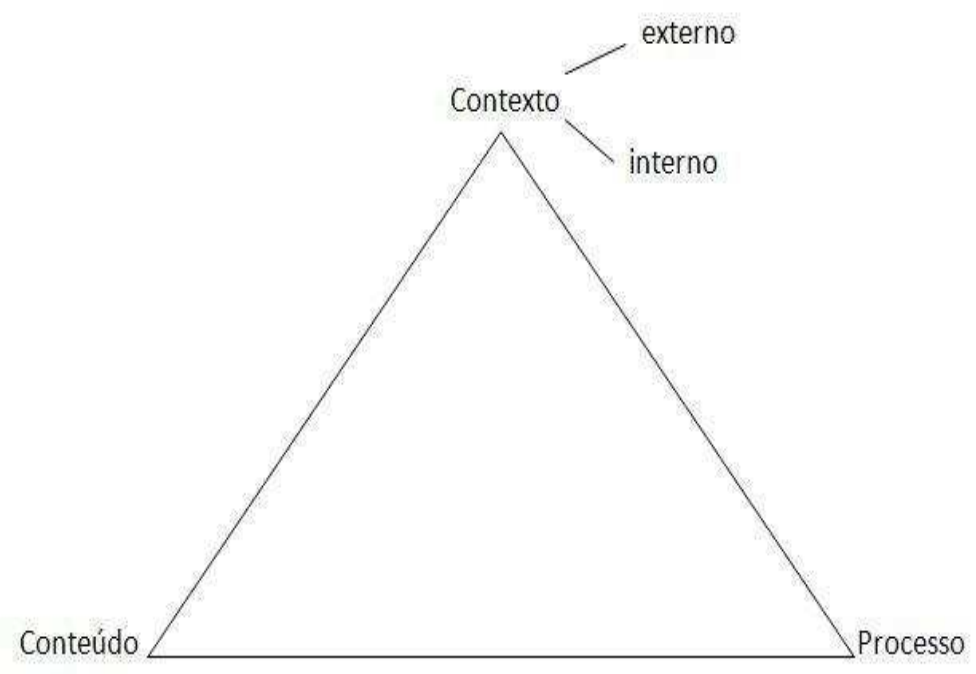

Figura 3 - Contextualismo de Pettigrew

Fonte: Pettigrew, 1990, p.145

Por conteúdo, entenda-se o domínio concernente pela mudança ou aquele que o pesquisador está analisando. O contexto designa os fatores suscetíveis de influenciar o conteúdo e sua evolução. Aqui Pettigrew (1990), distingue os fatores próprios da organização, ou seja, os fatores internos e aqueles que são devidos ao ambiente, os fatores externos. No contexto externo, compreendem-se: ambiente social; econômico e político no qual a empresa se relaciona, por exemplo, a ação do Estado e suas políticas econômicas e sociais; o segundo contexto é de natureza interna e constitui-se da estrutura, cultura e contexto político; aí se incluem mudanças da cúpula diretiva das organizações, as políticas mercadológicas e financeiras, recursos humanos, formas de organização e gestão do trabalho.

Um programa de Qualidade implica, entre outras especificações a serem adotadas pelo coletivo dos servidores ou colaboradores, integração e participação maior na definição do que é trabalhar com qualidade, atender o cliente etc.. Se diferentes técnicas e programas existem para alcançar a qualidade e a produtividade, são pontos comuns a eles: a estratégia da organização; o atendimento ao cliente; a maior eficiência nos processos e a responsabilidade compartilhada pelo cumprimento das metas.

Os aspectos internos e externos do contexto apresentam, ao mesmo tempo, uma dimensão objetiva e subjetiva. A dimensão objetiva pode ser captada por dados observáveis, enquanto a dimensão subjetiva refere-se à maneira como os atores do processo priorizam, valorizam, 
interpretam os elementos dos diversos contextos (por discursos, dados que são divulgados na organização etc.).

O processo da mudança trata das iniciativas nas quais alguns atores procuram desenvolver a situação para uma ou outra direção, outros a estabilizam, e das relações de poder que se desenvolvem entre eles.

Pettigrew (1990, p. 147) resume seu pensamento nos parágrafos a seguir:

O processo de mudança refere-se às ações, reações e interações das várias partes interessadas, na medida em que procuram alterar a empresa em seu estágio presente tendo em vista o futuro. Portanto, o quê da mudança está contido no item conteúdo, muito do porquê da mudança deriva de uma análise do contexto interno e externo, e o como da mudança pode ser compreendido pela análise do processo.

A ação para modificar as estratégias e culturas das empresas é muito mais dependente da habilidade para ligar não apenas o quê da mudança ao contexto externo da empresa, mas também ligar e moldar tais sugestões à política interna e contexto da empresa e gerenciar tais conexões dentro da empresa por meio de considerações hábeis a respeito do processo administrativo.

As três variáveis - conteúdo, contexto e processo - estão em estreita inter-relação, principalmente o contexto e o processo. Do ponto de vista contextualista, considera-se que os jogos dos atores estão restritos, pelo menos em parte, pelo contexto, mas, ao mesmo tempo, pela dimensão subjetiva, eles a constroem e também a transformam.

Nesta tese, o conteúdo refere-se à implantação de um Programa de Qualidade e Produtividade, com princípios e ferramentas clássicas da Qualidade Total. Há condições evidentes de mudanças no contexto externo para adoção do programa de qualidade, o decreto do governador instituindo o programa de qualidade nos órgãos públicos em 1995, além de condições internas a serem pesquisadas. O processo é considerado como a forma de implantação do programa de qualidade, incluindo atores, forma de condução, recursos, ações e suas inter-relações.

Apud Pichault e Nizet (2000), a Teoria das Configurações de Mintzberg fornece elementos para analisar os contextos internos. As organizações podem, em primeiro lugar, ser descritas sob diferentes ângulos levando-se em conta a maneira como o trabalho é dividido e coordenado. Existem diferentes mecanismos de coordenação cuja importância varia segundo as organizações: a supervisão direta, quando um responsável dá as ordens e supervisiona a 
realização do trabalho ou o ajustamento mútuo, quando os trabalhadores discutem entre eles o trabalho a executar; ou ainda a padronização dos procedimentos, quando as máquinas já estão programadas e fixam de antemão os gestos dos trabalhadores.

Mintzberg oferece, ainda, referências sobre os objetivos das organizações; ele propõe uma distinção entre os objetivos da missão e os objetivos do sistema. Os objetivos da missão estão centrados no produto ou no serviço ofertado ao cliente (acolher bem, oferecer produtos e serviços de qualidade etc.), enquanto os objetivos do sistema são concernentes aos resultados que a organização busca para ela mesma (sua sobrevivência, seu crescimento, seu lucro, seu atendimento a políticas públicas etc.).

É relevante ressaltar que, para Pettigrew (1990), gerenciar ou alterar a cultura organizacional envolve complexidade, o que dificulta sua administração e consequentemente a mudança. Fleury e Fischer (1990) endossam a posição de Pettigrew sobre a dificuldade e complexidade em desvendar e gerenciar a cultura organizacional, acrescentando que o termo gerenciar se desdobra em quatro etapas: planejar; organizar; controlar e avaliar. Quando o gerenciamento é direcionado à manutenção da cultura, os programas de treinamento organizacional e ambientação são reforçadores de padrões culturais da organização. Quando o gerenciamento da cultura objetiva uma mudança, seu controle é questionável, uma vez que todo processo de mudança cultural é incerto, no que se refere ao seu efetivo resultado e ao tempo demandado para a internalização de novos valores.

Em todo processo de mudança, é necessária a adoção de estratégias para enfrentar possíveis resistências. Algumas considerações acerca das condições que facilitariam a implementação das mudanças organizacionais são levantadas por vários autores. De maneira geral, a participação dos funcionários no planejamento da mudança, a previsão de comportamentos de resistência, a abordagem sistêmica na implementação, entre outros, são fatores frequentemente levantados. Tolovi (1994) elenca um conjunto de fatores de insucessos de programas de qualidade, encabeçado pelo não envolvimento da alta direção (causa psicossocial), assim como desinteresse do nível gerencial. Outros fatores se sucedem, podendo-se citar como causas técnicas: o planejamento inadequado; a falta de apoio técnico e o sistema de remuneração inconsistente; como causas educacionais: o treinamento precário e a escolha inadequada de multiplicadores; como causas psicológicas: a ansiedade por resultados e o descuido com a motivação. 


\subsection{Gestão pública}

A seção procura conceituar, inicialmente, alguns termos relevantes para o desenvolvimento do trabalho: administração; administração pública; serviço público; cliente e servidor público.

Começando pelo termo administração, Drucker (1984) o define como a realização de cinco operações básicas, que juntas resultam na integração dos recursos em um organismo viável e em desenvolvimento: fixar objetivos; dividir o trabalho e atribuir responsabilidades aos membros da organização; motivar e comunicar, pelas políticas de gestão de pessoas o relacionamento entre elas; medir, avaliar e formar pessoas. Teixeira; Salomão e Teixeira (2010, p. 8), inspirados em conceito de economia definem administrar de forma simples e sucinta: "administrar é reunir e aplicar, da melhor forma possível, os recursos disponíveis." Montana e Charnov (1993) a definem como "o ato de trabalhar com e por meio de pessoas para realizar os objetivos tanto da organização quanto de seus membros.” Já Robbins e Coulter (1998), a tratam como "o processo de fazer com que as atividades sejam realizadas eficiente e eficazmente com e por meio das pessoas."

Quando adjetivada com o termo "pública", que a remete a povo, a administração pública, ainda que não tenha um conceito fixado com precisão, pode ser entendida de várias formas.

Para Medauar (1998, p. 44), a

administração pública como objeto do direito administrativo está inserida no Poder Executivo. Pode ser considerada sob um ângulo funcional e organizacional: no seu aspecto funcional, administração pública significa um conjunto de atividades do Estado, que auxiliam as instituições políticas de cúpula no exercício de suas funções do governo, que organizam a realização das finalidades públicas, produzindo bens e utilidades para a população: como educação, saúde, limpeza pública etc. Sob o ângulo organizacional, Administração Pública representa o conjunto de órgãos e entes estatais que produzem serviços, bens, utilidades para a população, auxiliando as instituições políticas de cúpula no exercício das funções de governo.

O objetivo final da administração pública é realizar da melhor forma as práticas administrativas do governo, para servir melhor aos interesses públicos, aos ideais e às necessidades da sociedade.

No Plano Diretor da Reforma do Aparelho do Estado (1995), elaborado pelo Ministério da Administração e Reforma do Estado (MARE), foi adotado como gestão pública "todo 
aparelho do Estado pré-orientado à realização de seus serviços, visando à satisfação de necessidades coletivas" (Instrumento de Avaliação da Gestão Pública, 2001, MP). Essa definição é coerente com a nova relação que se propõe que exista entre o Estado e a sociedade, na qual se vê o cidadão como contribuinte de impostos e como cliente de seus serviços. Os resultados da ação do Estado são considerados bons não porque os processos administrativos estão sob controle e são seguros, mas porque as necessidades do cidadãocliente estão sendo atendidas. (ABRÚCIO, 1997; BRASIL, 1995, 1997; MARTINS, 1997).

Para facilitar o entendimento de alguns termos, seguem-se definições para: serviço público; cliente e servidor público, conforme encontrada em Leite (1994).

\begin{abstract}
Serviço público: "todo aquele prestado pela Administração ou por seus delegados, sob normas ou controles estatais, para satisfazer necessidades essenciais ou secundárias da coletividade, ou simples conveniência do Estado" (Meirelles, 1993, p. 290). Por seu aspecto dinâmico e flexível, atende às exigências de clientes, em qualquer tempo e lugar; expressa ainda atenção às atividades que são da simples conveniência do Estado. São serviços públicos aqueles prestados pelo poder público diretamente ou sob regime de concessão ou permissão.

Cliente: Juran (1992, p. 18) o define como "qualquer um que recebe ou é afetado pelo produto ou processo". Contempla tanto clientes externos, os afetados pelo serviço, mas que não integram a instituição, quanto os clientes internos, os afetados pelo serviço e que integram a instituição. Expressões como usuários, cliente externo ou simplesmente cidadão ou cliente, são utilizados como sinônimos nesta tese.

Servidor público: "aquele que, pertencendo ou não ao quadro do funcionalismo, exerce oficialmente cargo ou função pública", segundo Ferreira (1995, p. 1577). O termo, mantendo o mesmo significado, poderá ser substituído por funcionário público, cliente interno, cidadãoservidor ou simplesmente servidor.
\end{abstract}

Em uma pesquisa da FUNDAP, sobre Estudos da administração pública paulista, publicada em 1981, era registrado como um fato da sociedade brasileira das últimas décadas, a necessidade de uma rápida adequação das instituições do serviço público às exigências de uma atuação eficiente. Existia uma pressão da sociedade como um todo, obrigando instituições de serviço público a demonstrar, efetivamente, os resultados ante a clientela; para tanto ficava evidenciada a necessidade de reorganização administrativa, de aquisição de novos equipamentos e adoção de novos métodos na prestação de serviços públicos.

Em publicação de 2005, quase 25 anos após o texto da FUNDAP, Martins (2005) observa que “a gestão pública contemporânea caracteriza-se por um universo institucional em rápido movimento e crescente complexidade." Cita algumas causas como escassez de recursos no setor público, complexidade maior de estilo de governo, importância do mercado 
internacional no setor público, orientação de curto prazo do processo decisório, insuficiência de mecanismos transparentes de informação e de avaliação de políticas, os problemas de implementação em um contexto de fragmentação institucional.

Além desses dois enfoques, observa-se, também, em Teixeira e Santana (1994) que "a administração pública tem como característica específica uma relação de responsabilidade direta com o processo histórico global que se dá no desenvolvimento da sociedade." Em função dessa afirmativa sua missão deve estar redefinida em permanência, a partir de novos imperativos, de cada sociedade, em um dado momento, sem o que pode comprometer uma "capacidade sinérgica".

Diante dessas ideias pode-se inferir a necessidade constante de se ter a administração pública sob uma perspectiva histórica, reposicionando-a de acordo com contingências dos movimentos da sociedade, à qual deve servir; sua complexidade e as mudanças constantes na sociedade exigem, portanto, mudanças também constantes na gestão pública.

Segundo Lima (2007, p. 17),

\footnotetext{
à luz de documentos legais, percebe-se um mudar constante no ambiente interno da administração pública: são mudanças relativas a pessoas, a estruturas e órgãos e entidades que têm pouco a ver com uma transformação de valores e práticas do setor público, embora muitas delas declarem tais objetivos.
}

Estar em constante mudança e em reformas administrativas já vem de longa data na história da administração pública do País. Observa-se, contudo, que dada a morosidade dos mecanismos de mudança no aparato público, o atendimento à sociedade parece estar sempre em defasagem em relação às suas expectativas.

A Universidade e em particular a Universidade de São Paulo, como uma organização pública, que presta serviços de educação, esteve e está também sujeita às exigências da sociedade e tem sofrido ao longo de sua história pressões para mudanças, tanto na sua parte científica e pedagógica como na sua modernização administrativa. Para adaptar-se às exigências de seus cidadãos-clientes e/ou seguir orientações governamentais tem na sua trajetória procurado instituir diversos mecanismos para seu aperfeiçoamento. O Programa de Qualidade e Produtividade foi um desses mecanismos e será tratado em capítulo próprio. 


\subsubsection{Evolução da administração pública}

Ajustada a um contexto histórico, Bresser-Pereira (1998) classifica a administração pública, sob três formas: a) patrimonialista; b) burocrática e c) gerencial, descritas a seguir. As três formas, ainda que sequenciais no tempo, coexistem em maior ou menor densidade, conforme o estado de desenvolvimento político das sociedades.

Esse quadro é importante ser apresentado para analisar o contexto histórico e características da administração pública vigente que impactaram na Universidade de São Paulo, uma instituição criada em 1934, que, com sua autonomia em 1989, teve uma responsabilidade ainda maior quanto ao aperfeiçoamento de sua administração. O Programa de Qualidade e Produtividade veio atuar a partir de 1996, como um reforço para essa transformação gerencial e cultural.

\subsubsection{Administração patrimonialista}

Bresser-Pereira (1998, p. 20) caracteriza a administração patrimonialista como sendo do Estado, mas não pública, uma vez que não visa ao interesse público. É encontrada em Estados pré-capitalistas, em monarquias absolutistas que antecederam ao capitalismo e à democracia. Nela está confundido o patrimônio privado com o patrimônio público. Ainda persiste, apresentando vestígios em regimes democráticos imperfeitos por meio do clientelismo.

Complementa a ideia de administração patrimonialista a observação de Faoro (2001) que a identifica historicamente pelo:

[...] aparecimento da burguesia desvinculada da terra, capaz de financiar a mercancia, há o aparecimento de um órgão centralizador dirigente que conduz as operações comerciais, como empresa sua: o príncipe [...] com as Grandes Navegações, o Estado torna-se uma empresa do príncipe, que intervém em tudo [...]. Estão lançadas às bases do capitalismo de Estado.

Ao que Bresser-Pereira (1998) acrescenta:

[...] no patrimonialismo, o Aparelho do Estado funcionava como uma extensão do poder do soberano, e seus auxiliares, servidores, possuíam o status de nobreza real. Os cargos são considerados prebendas e a res publica não é diferenciada da res principis.

Ainda Bresser-Pereira (1998) observa que essa é uma abordagem fortemente vinculada aos interesses individuais e não aos do Estado; favorece a corrupção e o nepotismo, que 
pressionadas pelo capitalismo e pela democracia se tornam fortes e irreversíveis, criam importante distinção entre o Estado e a sociedade, fazendo da administração pública patrimonialista, "uma excrescência inaceitável".

\subsubsection{Administração pública burocrática}

Para Bresser-Pereira (1998), a administração pública burocrática surgiu na segunda metade do século XIX, na época do Estado liberal, como forma de combater a corrupção e o nepotismo patrimonialista. Ao romper com o patrimonialismo lançou as bases para uma administração profissional. "Ela está baseada em um serviço civil profissional, na dominação racional-legal weberiana e no universalismo de procedimentos, expresso em normas rígidas de procedimento administrativo". São seus princípios orientadores: a profissionalização e previsibilidade; racionalidade da divisão de trabalho; a hierarquia de autoridade; a legalidade de normas e regulamentos; padronização de rotinas e procedimentos; a impessoalidade nas relações; o formalismo; competência técnica; a ideia de carreira; o reconhecimento do mérito, em síntese, o poder racional-legal.

Os controles administrativos, visando evitar a corrupção e o nepotismo estão sempre $a$ priori. Parte-se de uma desconfiança prévia nos administradores públicos e nos cidadãos que a eles dirigem demandas, razão pela qual atuam sempre controles rígidos dos processos.

Para Faoro (2001), o controle dentro da burocracia torna-se a garantia de poder para o Estado, transformando-se na sua razão de ser, fazendo com que ocorra a perda da real identidade do Estado, que se volta para si mesmo e deixa de servir a sociedade em seus anseios e orientação. O Estado burocrático por sua determinação no controle dos abusos cria estruturas pesadas e normativas, ocasionando inflexibilidade e pouca agilidade da máquina estatal no atendimento das demandas impostas pela sociedade e por um contexto global a cada dia mais exigente de organizações flexíveis e ágeis em responder às mudanças do meio.

A reforma burocrática no Brasil data do final da década de 30 (1936 - 1938) e configurou-se como um meio-termo entre a modernização e a síndrome cultural-populista, segundo Martins (1997). Para os altos escalões havia acessos mediante concursos, carreira e promoção, baseada em critérios de mérito e salários adequados; para o nível médio e inferior a norma era admissão por indicação clientelista. 
Para Lima (2007), embora exista uma versão leiga que associa administração burocrática a "excesso de controle, apego a papel e a arquivos, processos de decisão e de prestação de serviços extremamente lentos", a reforma burocrática no Brasil significa eficiência, rompendo com padrões patrimonialistas existentes até a década de 30 .

\subsubsection{Administração pública gerencial}

Conforme Bresser-Pereira (1998), na segunda metade do século XX, em razão do aumento das funções econômicas e sociais do Estado, bem como por razões do desenvolvimento tecnológico e da crescente globalização da economia mundial desenvolveu-se a Administração Pública Gerencial.

Constituiu-se, então,

[...] um quadro teórico e uma prática administrativa que, nos quadros da democracia, visam modernizar o Estado e tornar sua administração pública mais eficiente e mais voltada para o cidadão-cliente. A eficiência da administração pública - a necessidade de reduzir custos e aumentar a qualidade dos serviços, tendo o cidadão como beneficiário - tornou-se, então, essencial.

A reforma do aparelho do Estado, tema central no Brasil, em 1995, com a posse do presidente Fernando Henrique Cardoso, passou a ser orientada predominantemente, pelos valores da eficiência e qualidade na prestação de serviços públicos e pelo desenvolvimento de uma cultura gerencial nas organizações. Isso iria constituir em rompimento com a administração pública burocrática, ainda que se mantivessem alguns princípios, como os mecanismos de admissão, segundo rígidos controles por mérito, manutenção da estrutura de remuneração, carreira e avaliação constante de desempenho e treinamento sistemático. A grande diferença com relação ao setor privado estaria na forma de controle, que passaria a ser baseado nos resultados e não mais nos processos. No modelo gerencial, o Estado passaria a concentrar suas estratégias na clara e precisa definição dos objetivos que o administrador público teria que atingir em sua área. (ANGARITA, 2002; BARZELAY, 2000; BRASIL, 1997; BRESSER-PEREIRA， 1996， 1998，2004; BRESSER-PEREIRA; PACHECO， 2005; BRESSER-PEREIRA; SPINK, 2006; FERNANDES, 2002). 
Conforme verificado em Lima (1999):

[...] o paradigma gerencial contemporâneo, fundamentado nos princípios da confiança e da descentralização da decisão, exige formas flexíveis de gestão, horizontalização de estruturas, descentralização de funções, incentivos à criatividade. Contrapõe-se à ideologia do formalismo e do rigor técnico da burocracia tradicional. À avaliação sistemática, à recompensa pelo desempenho, e a capacitação permanente, que já eram características da boa administração burocrática, acrescentam-se os princípios da orientação para o cidadão-cliente, do controle por resultados, e da competição administrada.

Algumas características definem a administração pública gerencial: funcionários públicos são merecedores de confiança; a criatividade e a inovação são parte integrante; contrato de gestão é o instrumento mediante o qual se faz o controle sobre os órgãos descentralizados; descentralização financeira do ponto de vista políticos regionais e locais; descentralização administrativa, por meio de delegação de autoridade para os administradores públicos transformados em gerentes crescentes autônomos; a estrutura é formada por poucos níveis hierárquicos, ao invés de estruturas piramidais; as organizações assumem formas flexíveis, ao invés de unitárias e monolíticas, nas quais as ideias de multiplicidade, de competição administrativa e de conflito não tenham lugar; controle é feito por resultados, a posteriori, ao invés do controle rígido, passo a passo, dos processos administrativos e a administração é voltada ao atendimento do cidadão, ao invés de ser referenciada a si própria.

Segundo Lima (1999), a administração pública gerencial tende a tornar-se um paradigma no mundo desenvolvido; traz uma definição clara de objetivos para cada unidade da administração; apregoa a descentralização da decisão, permitindo maior flexibilidade e agilidade nas adaptações à mudança; adota estruturas organizacionais mais leves, promovendo o aumento na participação dos processos decisórios; adota valores que reorientam as funções do Estado para a sua razão de ser; mostra-se capaz de promover o aumento da qualidade e da eficiência dos serviços sociais oferecidos pelo setor público.

Rosenberg (2002, p. 43) ratifica algumas dessas mesmas ponderações:

[...] a administração pública gerencial se contrapõe à burocracia partindo do princípio que não existe a necessidade de procedimentos rígidos e prega a descentralização com delegação de autoridade ao gestor público.

Teoricamente, como uma forma mais avançada de administração, a administração pública gerencial está ainda longe de ser unanimidade, como filosofia ou como prática no serviço 
público, uma vez que aniquila formatos padrões e previsíveis da burocracia e dificulta os casuísmos da ainda existente administração patrimonialista. A mudança cultural exigida para adoção de novos traços da cultura é um processo de muito longo prazo.

\subsubsection{Qualidade e seu entrelaçamento com a administração pública}

A percepção do novo papel do Estado, que tomou conta na década de 80, levou a se desenhar um novo modelo de administração pública para as sociedades industriais modernas. Przeworski (1996) afirma que o objetivo das reformas do Estado é construir instituições que reforcem, no aparato público, as funções desejáveis e o impeçam de realizar as funções não desejáveis; a tarefa da reforma é equipar o Estado com instrumentos efetivos de intervenção e incentivar os servidores públicos a agir na direção do interesse público.

Da perspectiva desta pesquisa, o objetivo mais abrangente das reformas propostas para a administração pública paulista é o do aumento da eficiência da burocracia na direção de serviços de melhor qualidade, para atendimento ao cliente da organização pública.

Já na década de 90, a palavra qualidade aparece com frequência no discurso de dirigentes públicos. Fala-se na melhoria da qualidade do ensino, da saúde, dos transportes e da segurança. Debate-se, inclusive, a responsabilidade do governo de preservar, por meio de políticas ambientais, a qualidade de vida das populações presentes e futuras. Proliferam no País cursos, palestras, encontros e seminários para preparar gerentes e profissionais para trabalhar com os princípios e ferramentas da Gestão da Qualidade, segundo Carvalho (1994, p. 139).

Em meados dessa década, a professora Carvalho (1994, p. 137) da Escola Brasileira de Administração Pública (EBAP) escreve em seu artigo: "a crise em que se encontra a administração pública brasileira, com o sucateamento dos serviços essenciais, evidencia a necessidade de um esforço sistemático de melhoria desses serviços, por meio da implantação de uma nova filosofia de trabalho em que o compromisso com a qualidade seja um dos pilares básicos."

A adoção dessa nova filosofia, a Qualidade, pressupõe um esforço significativo de mudanças nos padrões culturais vigentes na administração pública de forma a viabilizar a introdução de 
práticas de trabalho mais eficientes e de modelos de gestão mais democráticos no serviço público.

O esforço de mudança deve estar alicerçado em uma visão sistêmica da organização, privilegiando, igualmente, tanto a modernização de métodos e processos de trabalho como o desenvolvimento das pessoas.

Essa "otimização conjunta" de mudanças deve levar a padrões de comportamento evidenciados pela cultura organizacional do serviço público a padrões mais compatíveis ao momento democrático do País.

Carvalho (1994, p. 138), ainda, orienta que é importante que a implantação de programas de qualidade seja precedida de uma

análise sociológica para identificação dos elementos da cultura e do clima organizacional prevalecente. Essa análise contribuirá para que programas de educação e treinamento, bem como os de racionalização e melhoria de procedimentos, sejam mais bem orientados, contribuindo para uma alteração positiva no quadro comportamental das organizações públicas. Instalar um estado de qualidade na administração pública exige ações sistêmicas, contínuas, muito bem planejadas, centradas no cliente ou usuário dos serviços públicos.

Para se gerar um estado de qualidade no setor público, Carvalho (1994, p. 144) elenca os seguintes passos:

a) criar uma cultura propícia ao estado de qualidade;

b) adquirir e usar tecnologia adequada e avançada;

c) investir na formação de quadros para a gestão pública;

d) implantar novos métodos de gestão com ênfase na participação;

e) investir na melhoria do desempenho das pessoas.

$\mathrm{Na}$ área da administração pública, a preocupação com a Qualidade está relacionada à questão da cidadania. A função da administração pública é prover a sociedade de bens e serviços que ela necessita; esses serviços já foram pagos anteriormente pelos cidadãos por meio dos impostos, taxas e contribuições, segundo Falconi Campos (1989). O mesmo autor ainda observa que nas sociedades democráticas, o fortalecimento da cidadania dá-se pelo clamor da 
população exigindo mais e melhores serviços públicos, cobrando melhor gestão dos recursos e do patrimônio público.

Na visão de Torquato Júnior e Araújo (2008, p.81), na administração pública os governantes adotam a Qualidade Total com o objetivo de melhorar o atendimento ao usuário e, ao mesmo tempo, diminuir a pressão dos gastos públicos sobre a economia, conseguindo, assim, uma máquina administrativa mais enxuta e flexível. Busca-se, também, alcançar níveis de excelência por meio da motivação dos funcionários, que passam a se sentir mais valorizados pela função que ocupam e, ainda, melhorar a imagem institucional perante a sociedade, que aspira por melhores serviços e saberá dar o devido reconhecimento.

Apesar das considerações comuns dos programas de qualidade, quando se deseja retratar a qualidade no serviço público é conveniente considerar que o setor público difere do setor privado em pontos essenciais. A gestão pública e eficiente, para ser excelente deve atender aos princípios constitucionais do artigo 37 da Constituição Federal: ser legal, impessoal, moral, pública e eficiente.

Conforme documento do Programa Nacional de Gestão Pública e Desburocratização GESPÚBLICA (2006), a legalidade diz respeito à estrita obediência à lei; nada pode ser feito, mesmo que dê bons resultados à revelia da lei. Por impessoalidade se entende que o tratamento dispensado aos cidadãos não pode ser diferenciado, a menos de casos previstos em lei; cortesia, rapidez no atendimento, confiabilidade e o conforto são requisitos de um serviço de qualidade e devem ser agregados a todos os usuários indistintamente. Relativo à moralidade, a gestão pública deve estar pautada por princípios morais de aceitação pública. A publicidade, a transparência dos dados e fatos é imprescindível para a indução do controle social. No seu último atributo, a eficiência tem o sentido de fazer o que precisa ser feito com o máximo de qualidade e ao menor custo possível.

Osborne e Gaebler (1994), no livro bastante citado na década de 90, "Reinventando o Governo", apresentam algumas diferenças significativas entre o setor privado e o setor público. O governo é democrático e aberto; por isso seus movimentos são mais lentos comparados aos da iniciativa privada, cujos administradores podem tomar decisões rapidamente, a portas fechadas. Da mesma forma, o setor público, muitas vezes, não pode 
alcançar o mesmo nível de eficiência do setor privado, pois precisa servir a todos igualmente, independente da capacidade de pagar pelo serviço prestado ou da demanda por esse serviço.

Quando se procura definir objetivos das instituições, sejam elas privadas ou públicas percebese as diferenças, como citado em Teixeira, Salomão e Teixeira (2010, p. 49):

[...] nas empresas privadas, o sistema de objetivos e indicadores da instituição geralmente tem foco econômico-financeiro, privilegiando a maximização da riqueza do acionista. Nas instituições públicas, o objetivo deve ser a maximização do valor socioeconômico ambiental, ou seja, uma representação do objetivo da sociedade.

Não se pode pensar em Qualidade no serviço público da mesma forma que se pensa no setor privado, embora haja semelhanças entre as duas atividades.

Em um contexto nacional, na área pública, os conceitos e modelos de Qualidade Total passaram a ter maior divulgação a partir do início de 1990, com o lançamento pelo governo do Programa Brasileiro de Qualidade e Produtividade (PBQP). O objetivo era de disseminar a filosofia da gestão pela Qualidade nas organizações públicas e privadas, visando estimular a modernização dos setores produtivos do País, aumentar a competitividade dos bens e serviços produzidos no País e viabilizar a sua inserção num contexto globalizado. Embora o Programa tenha privilegiado o setor privado, cujo desenvolvimento era vital para o programa neoliberal do presidente Fernando Collor, a área pública, também, foi contemplada com recursos do programa.

No setor público, a Gestão da Qualidade pode ser vista como um amplo processo de mudança cultural cujo principal objetivo é modificar as relações institucionais, transformando chefes e subordinados em parceiros que buscam atingir as metas da organização.

Cabe historiar o contexto para a emergência do Programa Brasileiro de Qualidade e Produtividade.

O processo de industrialização brasileira iniciou-se por volta de 1910 com a criação da indústria têxtil, de calçados e de alimentos e se estendeu até a $2^{a}$. Guerra Mundial. No final da década de 40, estabeleceram-se as indústrias estatais, principalmente as de mineração, siderurgia, petróleo e petroquímica. As multinacionais surgiram no final da década de 50, 
início dos anos 60, principalmente com as montadoras automobilísticas, conforme Fleury (1995).

Ainda para Fleury; Fleury (1995) esse cenário demonstrou que o desenvolvimento industrial brasileiro iniciou-se tardiamente, se for comparado com países da Europa e até mesmo com os Estados Unidos. Até final da década de 80, a competitividade da indústria brasileira não levava em conta parâmetros de qualidade e produtividade, além de, em certos segmentos, ser protegida pelo governo, como foi o caso da informática, em particular.

Na década de 90, iniciou-se a transição formal para uma nova etapa do desenvolvimento industrial coordenado pela política industrial do governo que procurou incentivar a competitividade. Além disso, para tanto, entre outras medidas, foram criados o Código de Defesa do Consumidor (CDC), pela Lei n. 8.078 de 11/09/1990 e o Programa Brasileiro de Qualidade e Produtividade (PBQP), instituído em 07/10/1990.

O Código de Defesa do Consumidor contemplava a responsabilidade do Estado na prestação de serviços públicos, refletindo em uma das mais importantes razões para que as organizações governamentais cumprissem suas obrigações contratuais (explícitas ou implícitas) e buscassem padrões de qualidade compatíveis com as exigências dos clientes, dos usuários, dos cidadãos e da sociedade.

O Programa Brasileiro de Qualidade e Produtividade previa um conjunto de subprogramas de conscientização e motivação para a qualidade e produtividade, desenvolvimento e difusão de métodos de gestão, capacitação de recursos humanos, adequação de serviços tecnológicos e articulação institucional, segundo o jornal Folha de São Paulo (08/11/1990), com o intuito de estimular a adoção de técnicas de administração empresarial que permitissem aumentar a produtividade das empresas brasileiras, tornando os seus preços mais competitivos e melhorar a qualidade de seus produtos. O então Presidente Fernando Collor, no mesmo artigo afirmava em solenidade no Palácio do Planalto: "Vamos provocar um choque de eficiência e qualidade em todo o ambiente econômico nacional." 
Para cada um dos subprogramas estavam previstas estratégias de:

a) Conscientização e motivação: campanhas de divulgação, mobilização de empresários, promoção de eventos técnicos, instituição de prêmios e divulgação dos indicadores de qualidade e produtividade.

b) Métodos de gestão: estímulo à modernização dos métodos de gestão empresarial, promoção de estudos e pesquisa, fomento à atividade de consultoria.

c) Recursos Humanos: treinamento de empregados, introdução de disciplinas voltadas para a busca da qualidade e da produtividade nos currículos escolares, estímulo à integração entre empresas e instituições de ensino, incentivo à pós-graduação em qualidade e produtividade.

d) Serviços tecnológicos: consolidação de laboratórios metrológicos, implantação de banco de dados confiáveis, integração entre os serviços tecnológicos e as entidades de defesa de consumidores.

e) Articulação Institucional: mobilização do poder de compra e financiamento do Estado, integração do programa com as políticas industrial e de comércio exterior, fortalecimento de órgãos de proteção ao consumidor.

O programa pressupunha uma mudança no papel do Estado em relação às empresas: em lugar de investir diretamente na qualidade e na produtividade por meio de incentivos, o governo seria um articulador de investimentos dos agentes econômicos com responsabilidade de condução do processo de reestruturação da indústria brasileira.

Foi instituído um Comitê para cuidar do Programa, comandados pelo Secretário-Geral da Presidência, representantes dos Ministérios da Economia e da Justiça, Secretaria de Ciência e Tecnologia e de Assuntos Estratégicos, empresários com agregação posterior de representantes de trabalhadores e consumidores.

No bojo do mesmo lançamento ficou instituído o ano de 1991 como o Ano Nacional de Qualidade e Produtividade, como um marco para simbolizar o início de um longo processo de mudança e modernização do País. A reprodução de parte de um texto de um folheto oficial da época relata que 


\begin{abstract}
A inserção do Brasil no contexto das economias mais desenvolvidas é função da capacitação de modernização da indústria [...]. A modernização industrial requer as adoção de novos métodos de gerenciamento da produção e de gestão tecnológica na empresa, bem como depende da capacidade de incorporação de novas tecnologias de produto e de processo na atividade produtiva [...] Qualidade e produtividade são hoje conceitos amplos. Representam uma nova filosofia de gestão empresarial que pretende conduzir todos os segmentos da empresa a uma postura pró-qualidade e produtividade, através de um compromisso de dirigentes e empregados, em todas as fases do processo produtivo (Brasil. PBQP, 1990, p.3).
\end{abstract}

Segundo Fleury (1993), o PBQP foi um programa de mobilização, com orientação estratégica única de agentes da sociedade que, organizados por setores da economia, realizou diagnóstico e implementou ações de melhorias. Dentro do PBQP foi criado o RHAE - Programa de Capacitação de Recursos Humanos em áreas Estratégicas, que passou a incluir em suas prioridades o apoio à capacitação dos recursos humanos na gestão da qualidade e produtividade.

A implantação de programas da Qualidade no setor público pressupunha, como primeiro passo, um esforço orientado para o conhecimento e análise da cultura organizacional predominante, visando redimensionar seus elementos para obtenção de maior compromisso das organizações com a sua clientela.

Também, a reforma do aparelho do Estado ou reforma administrativa no governo Fernando Henrique Cardoso, em 1995, impôs desafios à instituição pública, sobretudo no que concerne à melhoria da qualidade dos serviços prestados e à utilização racional dos recursos públicos, conforme Torquato Júnior e Araújo (2008).

Nesse contexto, podem ser observadas iniciativas em instituições públicas federais, estaduais e municipais no sentido de modernizar e qualificar o setor público. Na esfera federal destacam-se, entre outros, o Programa de Reestruturação e Qualidade dos Ministérios e o Programa da Qualidade e Participação na Administração Pública (QPAP), que integraram o Plano Diretor da Reforma de Aparelho do Estado (Brasil, 1997).

Lima (2007) descreve a trajetória da Qualidade Total à excelência na gestão pública, com o objetivo de submeter a gestão pública a uma ação transformadora; dividiu esse percurso em quatro períodos bem definidos e denominados: a) 1990 - 1995: Qualidade e Produtividade na Administração Pública; b) 1995 - 1998: Qualidade e Participação na Administração Pública; 
c) 1999 - 2004: Qualidade no Serviço Público; d) 2005 em diante, Programa Nacional de Gestão Pública e Desburocratização.

a) 1990 - 1995: Qualidade e Produtividade na Administração Pública (PBQP)

Em 1990, tal como já apresentado, o Governo instituiu o Programa Brasileiro da Qualidade e Produtividade (PBQP), a fim de sensibilizar e mobilizar o setor produtivo para fazer face à abertura comercial mundial, no mesmo ano.

Derivado desse programa aparece no mesmo ano (1990), com direcionamento ao setor público, o Sub-Programa da Qualidade e Produtividade da Administração Pública, com o propósito de implantar programas de qualidade e produtividade nos órgãos públicos; há ênfase na "melhoria de processos" e no "uso intensivo de ferramentas da qualidade", segundo Lima (2007). Passou-se a incentivar a construção de organizações públicas, voltadas ao cidadão, uma vez que ele é o destinatário das ações e dos serviços prestados pelas organizações públicas. O mesmo autor testemunha, nessa fase, um grande número de cursos, palestras e seminários focados para a questão; a estratégia necessária para o momento foi a de "mobilizar e capacitar os servidores públicos". Nessa etapa, o programa teve como ganho uma grande valorização do servidor via Qualidade: "mobiliza e sensibiliza o servidor, oferece uma série de treinamentos que não comprometendo as atividades de rotina, eram de maneira geral, bem-vindas." No entanto, acrescenta, "foram raros os casos de um programa eficaz em uma organização pública, exceção feita às empresas públicas e às sociedades de economia mista." O Programa atuou para si mesmo e não serviu de instrumento para processos de mudança.

\section{b) 1995 - 1998: Qualidade e Participação na Administração Pública (QPAP)}

Com a divulgação da reforma da administração pública, estabelecida no Plano Diretor da Reforma do Aparelho do Estado, em novembro de 1995, a gestão pela qualidade passou, também, por uma revisão. Um dos objetivos da Reforma era "aumentar a governança do Estado, ou seja, sua capacidade administrativa de governar com efetividade e eficiência, voltando a ação dos serviços do Estado para o atendimento dos cidadãos." (Plano Diretor, 1995). 
A Reforma do Aparelho do Estado, segundo o Plano deveria se realizar segundo três dimensões: institucional-legal; cultural e gerencial. Na dimensão institucional-legal, a Reforma não diferia muito de outras reformas anteriores, propondo novos modelos de instituições públicas (agências executivas e organizações sociais). A dimensão cultural e a gerencial apresentavam enfoques inovadores, propondo mudanças na administração pública, a partir de transformação de atitudes e estabelecimento de referenciais modernos de boa gestão pública. Entre eles se apregoava o resultado e a satisfação do cidadão, nunca antes existentes em reformas propostas.

Dentro desse contexto foi instituído, em 1996, o Programa da Qualidade e Participação na Administração Pública (QPAP), no qual os termos, qualidade e participação, definiam a orientação e a ênfase que se desejava dar. A ênfase na participação significava o envolvimento de todos os servidores com a melhoria do serviço público, com o compromisso de cooperação na busca de solução para os problemas, com o aperfeiçoamento contínuo e com a satisfação dos clientes (internos e externos). Já a Qualidade tinha no processo o seu centro prático de ação e compreendia a definição clara dos clientes, os resultados esperados, os indicadores de desempenho e de como fazer certo da primeira vez. Os fundamentos que norteavam o programa eram: satisfação do cliente; envolvimento de todos os servidores; gestão participativa; gerência de processos; valorização do servidor público; constância de propósitos; melhoria contínua e a não aceitação de erros. Todos os princípios vinham do referencial de programas de qualidade.

Dentro do Plano de Reforma, segundo Lima (2007) esse Programa era subsidiário, direcionado ao servidor público de nível operacional, com o objetivo de sensibilizá-lo para um bom atendimento às pessoas que procuravam os serviços públicos.

Aos poucos, os reformadores e todos os que acreditavam na proposta da Qualidade, verificaram que Qualidade era mais um estilo e uma teoria de gestão e não apenas uma técnica de mobilização para o bom atendimento.

Alterou-se, então a estratégia de ação do Programa e, deixando as técnicas e ferramentas da Qualidade, iniciou-se um trabalho em uma dimensão institucional, com foco no sistema de gestão, tendo em vista resultados. 
Em 1996, conforme observa Lima (2007), para fazer frente a essa nova expectativa optou-se pela utilização de Modelo de Excelência em Gestão (MEG), já amplamente utilizado no setor privado. Foi, então, criada na Fundação Prêmio Nacional da Qualidade (FPNQ), em dezembro de 1996, uma categoria de "Administração Pública", no Prêmio Nacional da Qualidade (PNQ).

No Brasil, a Fundação para o Prêmio Nacional da Qualidade foi precursora para o conceito de medição e avaliação da Qualidade nas empresas; em 1991, lançou os critérios do Prêmio Nacional da Qualidade, inspirada no Prêmio Americano da Qualidade: o Malcolm Baldrige Quality Award, criado em 1987 e já referenciado.

Com a instituição do PBQP e do PNQ, no Brasil houve evidentes e constantes esforços para a melhoria de produtos e serviços, tanto nos segmentos privados como públicos. Em especial, a criação da categoria "Administração Pública" pelo Prêmio Nacional da Qualidade (PNQ), representou um diferencial para a dinamização das ações voltadas à melhoria da qualidade da gestão organizacional pública, em direção a excelência de serviços.

Em 1998, dentro do programa de modernização do Estado, o então ministro Bresser-Pereira instituiu, especificamente, o Prêmio Qualidade do Governo Federal (PQGF). Era uma estratégia com a finalidade avaliar a qualidade da gestão das organizações públicas e de sensibilizar mais participantes e conseguir mais adesões; a autoavaliação em ciclos contínuos de melhoria e aprendizagem levaria a um aperfeiçoamento das organizações.

Esse modelo adotou como paradigma os Critérios de Excelência do Prêmio Nacional da Qualidade (PNQ), em uma versão adaptada para a realidade das organizações públicas federais. Segundo Batista (1999),

[...] avaliar a gestão de uma organização pública significa verificar o grau de adesão dos seus aspectos gerenciais mais importantes em relação a um referencial de gestão denominado, pelo Programa da Qualidade e Participação na Administração Pública, de Gestão pela Excelência.

O modelo de gestão pública adotado deveria orientar as organizações na transformação gerencial e, ao mesmo tempo, permitir avaliações comparativas de desempenho entre as organizações públicas e demais organizações no setor privado. 
A compreensão de que o "maior desafio no setor público brasileiro era de natureza gerencial, fez com que na década de 90 se buscasse um novo modelo de gestão pública focado em resultados e orientado para o cidadão", tal como apresentado nos Cadernos GESPÚBLICA (2006).

c) 1999 - 2004: Programa de Qualidade no Serviço Público (PQSP)

Segundo Lima (2007), em “1999 foi extinto o Ministério da Administração Federal e Reforma do Estado (MARE) e o comando da Reforma do Aparelho do Estado passou para o Ministério do Planejamento, Orçamento e Gestão, que a abandonou completamente.” Mesmo assim, o Programa contabilizou ganhos com adesões de organizações públicas do poder Legislativo e Judiciário e dos níveis estadual e municipal de governo.

Como conteúdo, o Programa passou a contar com ações voltadas para o estabelecimento de padrões de atendimento ao cidadão, de recursos e parcerias para a implantação de unidades de atendimento integrado e de avaliação de satisfação de usuários em serviços públicos.

Em 2000, o foco, então, passou a ser qualidade do atendimento ao cidadão e o Programa passou a chamar-se Programa de Qualidade no Serviço Público (PQSP).

\section{d) 2005 em diante}

Como marco mais recente, foi instituído pelo Decreto n. 5.378, de 23 de fevereiro de 2005, o Programa Nacional de Gestão Pública e Desburocratização - GESPÚBLICA, como uma fusão do Programa de Qualidade no Serviço Público e de Desburocratização, conforme documentos Anexos.

Nos Cadernos GESPÚBLICA (2006, n. 1), observa-se que o Programa GESPÚBLICA

[...] tem por propósito estimular a promoção da excelência da gestão pública brasileira. Seu impacto deve ser evidenciado em cada organização pública que implementar práticas de gestão cujos resultados sejam benéficos para o cidadão e para a competitividade sistêmicas do País. Entende que o "Programa Nacional de Gestão Pública e Desburocratização é um poderoso instrumento da cidadania, conduzindo cidadãos e agentes públicos ao exercício prático de uma administração pública ética, participativa, descentralizada, promotora do controle social e orientada paras resultados. 


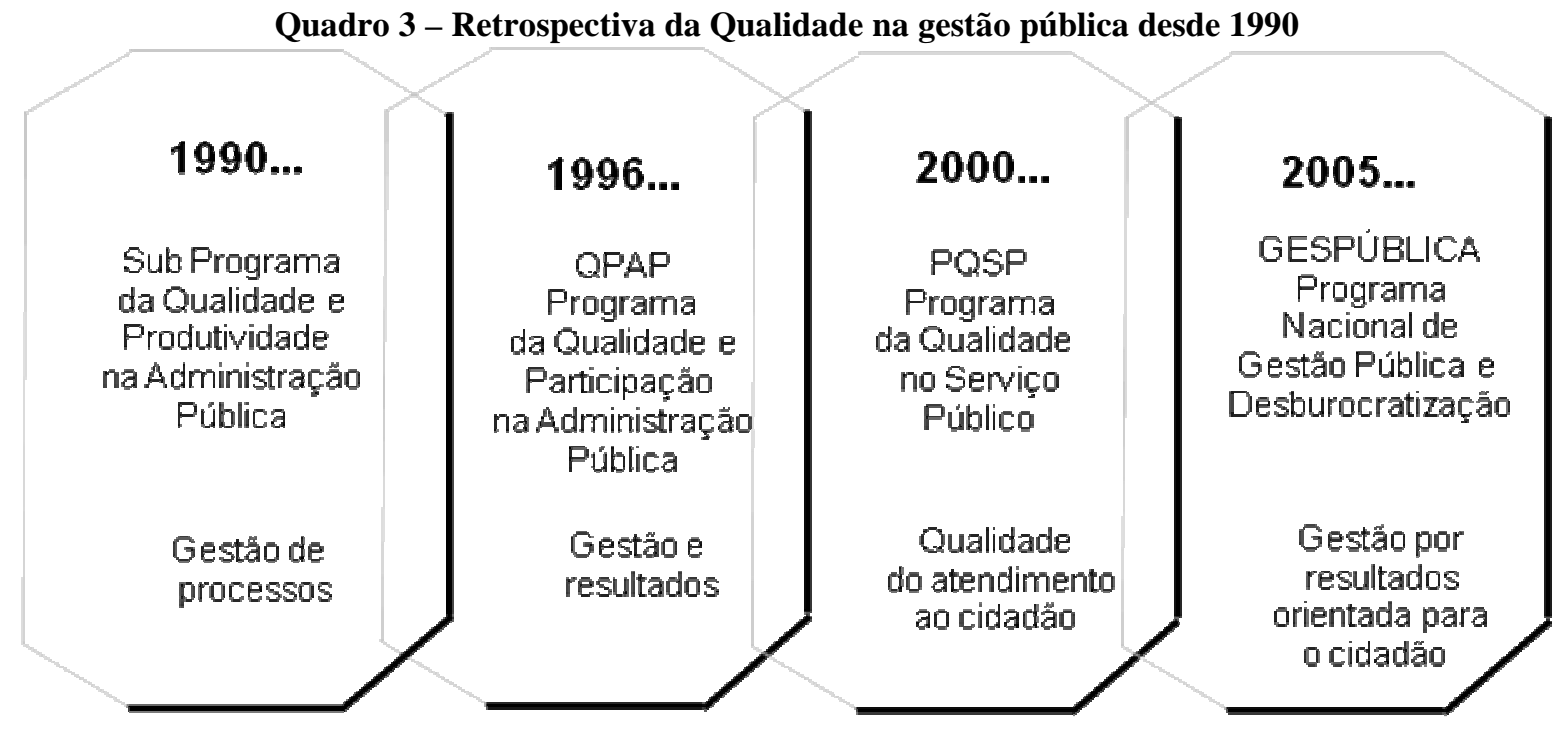

Fonte: Cadernos GESPÚBLICA, 2006, p. 7

Conforme observação dessa mesma fonte, os quatro marcos não são rupturas e sim mudanças incrementais e aperfeiçoamentos da concepção original do Programa, iniciado em 1990.

\subsubsection{Programa de Qualidade no Estado de São Paulo}

Em esferas estaduais, vários Estados brasileiros iniciaram seus programas específicos de Qualidade, entre os quais Minas Gerais, Rio Grande do Sul e São Paulo. Dado o interesse desta tese, o foco é voltado ao Programa do Estado de São Paulo.

No âmbito do Estado de São Paulo, o Programa Permanente de Qualidade e Produtividade no Serviço Público, foi instituído, para os órgãos públicos estaduais, pelo Governador Mário Covas, pelo Decreto n. 40.536 de 12 de dezembro de 1995. A íntegra do Decreto está Anexa. A Universidade de São Paulo, como órgão público estadual, alinhou-se a essa direção estratégica. O aprofundamento do modo de sua implantação e resultados na USP, contemplando contexto, processo e conteúdo formam o objeto desta tese.

Conforme observa Hahn (1998, p. 139)

[...] a reforma proposta pelo governo do Estado de São Paulo, na gestão Mário Covas representou uma tentativa de construir um novo modelo de administração pública estadual baseada em redução de custos, modernização gerencial dos dirigentes e busca de inovações institucionais para a solução de problemas enfrentados. 
Governos anteriores ao de Mário Covas tinham como marcas características uma divisão de trabalho preestabelecida, articulando agentes e grupos de interesse em torno dessas áreas. Essa prática inibia a realização de transformações efetivas.

Ainda em campanha, o então candidato ao governo do Estado de São Paulo, Mário Covas, afirmava em entrevista à imprensa: "Quero governar São Paulo, para revolucionar a administração pública. Vamos consertar o Estado.” Para isso, o governador pretendia como prioridade de governo, na área administrativa, a "radical transformação da estrutura de Governo e da organização da máquina estadual", mediante a aplicação de métodos empresariais modernos à gestão da coisa pública. Acrescentava, ainda, segundo Hahn (1998, p. 34), que

[...] o aparato administrativo de São Paulo haverá de incorporar aos seus procedimentos habituais o planejamento estratégico, a descentralização de decisões e recursos, a atribuição de responsabilidades, a procura de qualidade e produtividade nos serviços e a avaliação periódica do desempenho dos diferentes órgãos e dos resultados de cada projeto.

Assumindo o governo em janeiro de 1995, a equipe de transição do governo, usando metodologia de Planejamento Estratégico Situacional (PES), ${ }^{4}$ "planejar, agir, avaliar e responder", elaborou uma agenda inicial de governo, adotando um planejamento para implementação do projeto político que permitisse alcançar as transformações desejadas. Formulava-se uma visão prospectiva do Estado, no sentido de visualizar o que se chamava, na época, “o Estado que queremos”, conforme Hahn (1998, p. 36).

Ainda que houvesse diretrizes claras relativas à racionalização e modernização de estruturas e processos administrativos, não havia projetos de realização de reformas mais profundas; havia premissas gerais relativas ao desejo de compartilhar com a sociedade as tarefas de governo, democratizando as estruturas administrativas e aproximando o cidadão ao Estado.

Assim, entre muitas medidas de racionalização, que fogem ao escopo deste trabalho, no final de seu primeiro ano de mandato, em 12 de dezembro de 1995, o governador do Estado de São Paulo, Mário Covas, instituiu o Programa de Qualidade e Produtividade no Serviço Público Estadual, conforme decreto citado, que veio impactar nas Universidades públicas estaduais,

4 O PES é um método bastante usado no planejamento estratégico público e desenvolvido pelo economista chileno Carlos Matus. A metodologia é encontrada na publicação O Método PES, Entrevista com Matus, de Franco Huertas, Edições FUNDAP, São Paulo, 1996. 
uma vez que são autarquias do governo estadual. Conforme Hahn (1998, p. 81), “órgãos, divisões e departamentos do Estado foram organizados em comissões e comitês de qualidade; os resultados, tanto no que diz respeito à economia de recursos como à motivação dos funcionários foram impactantes."

O decreto abrangia todos os órgãos e entidades da Administração Pública Estadual, Direta e Indireta, inclusive as autarquias de regime especial, em que se inseriam as universidades estaduais: UNICAMP, UNESP e USP. O decreto tinha como objetivo "propiciar ao cidadão o atendimento eficaz de suas necessidades, por meio de um processo de melhoria contínua e permanente dos serviços prestados, com redução de custos e ganhos de produtividade."

Após várias considerações nas quais reforçava o compromisso do Governo com a Qualidade na relação Estado/Sociedade, o decreto indicava o servidor ou empregado público como o principal agente da promoção da melhoria da qualidade, reiterando que a implantação de programas de qualidade e produtividade era uma das prioridades da administração.

Para a consecução de seu objetivo, o Programa Permanente da Qualidade e Produtividade no Serviço Público desenvolveria suas atividades de forma contínua, sistemática e integrada, para melhorar a qualidade e alterar as espécies dos serviços prestados; propiciar o desenvolvimento das pessoas que trabalham nos diversos órgãos e entidades, em seus valores humanos e conhecimentos funcionais; obter o envolvimento e o comprometimento de todos os agentes públicos com a qualidade e produtividade; propiciar aos cidadãos os meios que lhes permitam exercer os seus direitos de receberem serviços com a necessária qualidade; minimizar os desperdícios e os erros; incorporar os avanços do conhecimento científico e tecnológico; promover os ajustamentos organizacionais que favoreçam a prestação de serviços com qualidade e produtividade e, finalmente, inovar nas maneiras de atender as necessidades do cidadão, simplificando procedimentos, inclusive de gestão, e procedendo às transformações essenciais à qualidade com produtividade.

A implantação do Programa de Qualidade na esfera do Governo do Estado de São Paulo, segundo o Manual de Orientação do Programa Estadual (1996), teve uma estrutura de decisão e apoio. Previa-se para o Programa a participação de todos, incluindo a alta administração e servidores públicos. A alta administração era representada pelo Conselho Superior da Qualidade e Produtividade e pelo Conselho de Coordenação da Unidade de Gestão Estratégica. O primeiro Conselho era composto por todos os Secretários do Estado e 
assessorava diretamente o Governador, que era seu Presidente. A ele competia o estabelecimento periódico de diretrizes e prioridades do Programa e o seu acompanhamento, provendo ajustes necessários. O Conselho de Coordenação da Unidade de Gestão Estratégica era formado por todos os Secretários Adjuntos, a quem cabia coordenar, orientar e avaliar o Programa e manter o Conselho Superior informado das atividades realizadas.

A participação dos servidores públicos era esperada em todas as entidades da Administração Direta e Indireta, inclusive nas autarquias de regime especial, nos Comitês Coordenadores da Qualidade e Produtividade e nas Comissões de Gestão da Qualidade e Produtividade. Os Comitês seriam presididos pelos Secretários Adjuntos das Secretarias de Estado e formados por um representante de cada Comissão de Qualidade existente. Tinham a competência de coordenar, avaliar, acompanhar e orientar a implementação do Programa pelas Comissões de Qualidade. Às Comissões de Gestão da Qualidade e Produtividade cabia promover a implementação do Programa, com a participação dos servidores, utilizando a metodologia mais adequada; manter os Comitês Coordenadores das respectivas Pastas informadas do andamento das atividades e avaliar periodicamente a implementação do programa, oferecendo subsídios para seu contínuo aperfeiçoamento.

A orientação técnica ao Programa era do Grupo Executivo da Qualidade e Produtividade, que forneceria suporte no desenvolvimento de atividades de sensibilização e mobilização para qualidade e produtividade, além de orientar e apoiar ações específicas em cada órgão ou entidade da Administração Pública Estadual. A Política de Qualidade de Estado de São Paulo, a ser seguida pelos órgãos públicos estaduais, deveria guiar-se pelos Balizadores da Qualidade do Serviço Público.

A elaboração desses Balizadores da Qualidade, assim como o Roteiro de implantação descritos no Manual de Orientação do Governo do Estado de São Paulo (1996) usou como base várias metodologias disponíveis no Brasil e no exterior, para a implantação de Programas de Qualidade. Tiveram como fontes os regulamentos referentes ao Prêmio Nacional da Qualidade, as normas internacionais ISO 9000 e o Prêmio de Qualidade do Presidente dos Estados Unidos, oferecido às organizações americanas do Serviço Público Federal, que tinham obtido os melhores resultados em programas de qualidade. A concepção do Programa teve, ainda, o suporte técnico de professores da Fundação Carlos Alberto 
Vanzolini, ligada à USP e da Fundação Christiano Ottoni, de Belo Horizonte, à qual pertencia Vicente Falconi Campos, já referenciado neste trabalho.

Relacionam-se, a seguir, os Balizadores da Qualidade para a Administração Pública do Estado de São Paulo, segundo o Manual de Orientação (1996). Tais Balizadores viriam a ser associados aos Critérios do PNQ, como diretrizes para a Política de Qualidade da USP, constituindo-se nos seus Módulos de Qualidade, os quais serão, assim, referenciados ao longo desta tese, uma vez que foram adotados como o framework para a análise da pesquisa de campo.

\section{1) O cliente final da administração pública é a sociedade}

Os órgãos públicos devem servir aos cidadãos-clientes e não terem como fio condutor a observância rígida de seus procedimentos. As necessidades dos cidadãos-contribuintes devem ser monitoradas para atender aos clientes intermediários e internos. Para isso, entre outras ações, faz-se necessário: definir clientes finais e intermediários e suas necessidades; avaliar reações de satisfação ou insatisfação do cliente, por meio de indicadores de desempenho e comparar metas estabelecidas e resultados; estabelecer canais de comunicação com o cliente para explicitar o nível de cumprimento do compromisso assumido em relação ao atendimento dos serviços, possibilitando comentários, reclamações e sugestões e facilitando o acesso do cliente aos serviços oferecidos.

\section{2) Cada um dos participantes da administração pública é responsável pela qualidade} Como a responsabilidade pela qualidade é de todos, todos os funcionários devem participar do Programa. Tal responsabilidade abrange a Alta Administração, a Média Administração (gerentes) e os funcionários de modo geral.

À Alta Administração, na qual se incluem os responsáveis pela visão estratégica de cada um dos órgãos públicos, cabe criar condições para que se desenvolva uma cultura voltada para o cliente final. Objetivos claros devem ser estabelecidos, direcionando-se a organização para esse fim; recursos humanos, materiais e financeiros necessários devem ser disponibilizados e presume-se o incentivo e avaliação contínua da Qualidade. Dentro dessas condições, cabe à Alta Administração: definir o compromisso da organização para com a melhoria da Qualidade e fornecer meios para que todos os 
funcionários conheçam e cumpram esse compromisso; delinear, implantar e acompanhar, de maneira crítica, o Programa de Qualidade, estabelecendo metas e prioridades e definindo os recursos humanos, materiais e financeiros necessários para que as metas propostas fossem cumpridas.

À Média Administração cabe manter essa cultura, por meio do desenvolvimento dos recursos humanos, da adequação dos processos e da verificação de sua efetividade e estabilidade. Deve, também, analisar, criticamente, o desempenho operacional da organização, definir métodos para avaliar os processos sob sua responsabilidade e estimular a criação de grupos de melhoria.

No nível operacional, caberia a cada funcionário a adoção de uma postura crítica e favorável à reconstrução contínua de suas próprias atividades diárias.

\section{3) A melhoria dos serviços públicos é obtida pela qualidade dos recursos humanos}

Como é por meio das pessoas que qualquer mudança organizacional se efetiva, é importante para o estabelecimento da Qualidade Total no serviço público, o envolvimento e comprometimento dos funcionários com essa tarefa. As pessoas devem ser estimuladas a desenvolver o seu potencial, tendo em vista cumprir as metas de satisfação manifestadas pelos clientes. Tal estímulo pode ser obtido pelo envolvimento, pela capacitação, pela mobilidade de funções e pelo aumento do poder de decisão (empowerment), cabendo à Alta Administração valorizar e reconhecer os méritos dos funcionários. Para se chegar a isso é necessário: instituir um Programa de Capacitação baseado nos conceitos e nas ferramentas básicas da Qualidade; incentivar gerentes a se tornarem agentes indutores do trabalho em equipe entre seus subordinados, em vez de simples controladores de atividades e cobradores de resultados; criar meios de valorização do funcionário, estimulando sua motivação para o trabalho e tornar os funcionários mais responsáveis por seu trabalho, explicando-lhes o que e como fazer, como avaliar e como aprimorar, levando-se em conta a autogestão.

4) O Programa da Qualidade e as decisões devem ser direcionados por indicadores, dados e fatos

A Administração deve tomar suas decisões fundamentadas em fatos e dados e para isso deve-se criar uma base de informações. Indicadores de desempenho devem ser 
estabelecidos e os resultados acompanhados e comparados às metas preestabelecidas. Os bons indicadores devem refletir de alguma forma a satisfação dos clientes internos, intermediários ou finais. Organizações semelhantes devem comparar seus parâmetros e indicadores, no sentido de estabelecer um benchmarking, uma referência comparativa, objetivando uma melhoria. Para isso, deve estabelecer: um sistema capaz de mostrar os processos críticos, monitorando-os por meio de indicadores e comparando-os às metas e prioridades estabelecidas pelos executores; um sistema de acompanhamento de indicadores críticos, baseado em dados e fatos, de tal forma que esses indicadores possam representar uma linguagem comum entre todos os níveis hierárquicos da organização; um sistema e um canal de comunicação na organização que informe, ajude a desdobrar e conscientize os envolvidos a respeito da evolução e contribuição de cada área para o alcance das metas; um sistema para a coleta de informações e reclamação dos clientes, seu tratamento, disposições imediatas, comunicação às funções envolvidas e a tomada de ações preventivas; uma avaliação crítica dos resultados dos indicadores para que sirva para reestruturar os processos, por meio de auditorias e/ ou benchmarking com organizações semelhantes.

\section{5) O aperfeiçoamento contínuo dos serviços, produtos e processos deve ser uma} atividade cotidiana no serviço público

As organizações modernas têm que enfrentar $o$ grande desafio de uma autotransformação para fazer face às exigências sempre renovadas dos seus clientes. Devem estimular a crítica contínua dos processos de trabalho para que, de forma participativa e dinâmica, as pessoas possam garantir, constantemente, um melhor modo de atender aos clientes; cabe aí o princípio da melhoria contínua ou do contínuo aperfeiçoamento. Faz-se necessário, igualmente, o uso intensivo de indicadores de eficácia dos processos, para direcionar a melhoria e o uso de ferramentas da qualidade, para a resolução efetiva dos problemas colocados. As medidas para atender a essa proposta dizem respeito a: implantação de estrutura organizacional voltada para o aprimoramento dos processos, formada por grupos de melhoria, com objetivos previamente determinados, com a participação direta do pessoal que executa as atividades; elaboração de metodologia para atuação dos grupos de melhoria, considerando-se indicadores relacionados à satisfação dos clientes e possíveis reclamações, para o aprimoramento de processos internos; criação de sistema de acompanhamento do trabalho de grupos de melhoria em todos os níveis da organização, 
de tal forma que os resultados obtidos sirvam de estímulo para a montagem de novos grupos; utilização, como prioritários na avaliação da média gerência, dos critérios relativos ao aprimoramento obtido a partir dos grupos de melhoria.

6) $O$ valor e o sacrifício de qualquer atividade devem ser constantemente monitorados

Toda concepção dos processos deve voltar-se para a busca do maior valor para o cliente final, intermediário ou interno. Deve-se pensar na diminuição dos sacrifícios aos quais ele pode ser exposto, pelos impostos e taxas ou por esperas inconvenientes ou ainda por dificuldades para obter um produto ou serviço. No âmbito interno, todos os custos são considerados como sacrifícios que somente devem ser aceitos se agregarem maior valor aos clientes finais, intermediários e internos. Deve-se, portanto: estabelecer um sistema para identificar e avaliar continuamente o sacrifício dos clientes para obter serviços/produtos desejados; reformular processos e desenvolver novos serviços/produtos, visando aumentar o valor do serviço prestado ao cliente e diminuir seu sacrifício; criar grupos de melhoria voltados à redução de custos, à simplificação dos processos e à redução do tempo de tramitação. Definir sistema para a coleta e o tratamento de dados, para a priorização e a tomada de decisões com vistas à redução de sacrifícios e ao aumento do valor dos serviços, por meio da participação dos funcionários e dos clientes finais (sociedade); estimular a Média Administração a repassar as normas de atuação aos subordinados, para que as decisões sejam tomadas mais rapidamente pelas próprias pessoas que operam os processos; criar canal de comunicação com os clientes finais para transmitir todas as informações necessárias para facilitar a obtenção do serviço.

\section{7) Bons resultados são decorrentes de processos controlados}

Processos de trabalho controlados são aqueles em que os resultados são estáveis e previsíveis. Para conseguir isso, cada área deve "fixar a tecnologia de trabalho", aprimorando e padronizando sua rotina diária. O ciclo contínuo de aprimoramento e padronização deve garantir processos estáveis, porem flexíveis, para futuros aperfeiçoamentos. Na melhoria dos processos, está implícita: a redução da burocracia (sacrifício para o contribuinte e para o cliente intermediário e interno) e do desperdício (tempo, recursos financeiros, materiais e humanos). A busca da Qualidade não se encerra com a diminuição das falhas e dos erros (ações corretivas), mas, principalmente, 
com ações preventivas, que impeçam a ocorrência de possíveis causas dos erros. São elas: utilização de método que organize os locais de trabalho, permitindo que as atividades sejam desenvolvidas em ambiente saudável, com menos esforço e maior satisfação dos funcionários (Programas 5S); estabelecimento de sistema de padronização, com a finalidade de planejar, executar e avaliar as atividades relacionadas aos processos críticos; definição das responsabilidades pela padronização e a regulação dos treinamentos necessários à implantação e à manutenção dessa padronização; priorização do diagnóstico das causas toda vez que for feita a análise dos indicadores ou dos problemas e reclamações, privilegiando medidas preventivas e evitando a reincidência, em vez da simples correção dos efeitos.

\section{8) Parcerias devem ser desenvolvidas para a satisfação do cliente final}

Para o cliente final, a impressão última sobre a qualidade de um serviço será igual à pior qualidade percebida por ele em qualquer uma das fases da cadeia de clientes e fornecedores internos. Por isso, a responsabilidade pela qualidade percebida pelo cliente final deve ser compartilhada por todos os envolvidos em todas as fases, que devem formar relações de parceria para que o objetivo final seja o melhor possível.

Uma vez que as necessidades dos clientes são cada vez maiores, parcerias com outras áreas do serviço público ou entidades privadas devem ser buscadas, para que se melhore a eficiência da cadeia de prestação de serviços. Tornam-se, então, obrigatórias a busca e

a implementação das melhorias tecnológicas, tornadas disponíveis a partir da: identificação das relações de parceria existentes, com fornecedores externos, subcontratados, clientes intermediários e outras esferas de governo, com prioridade para aquelas cuja influência para o cliente final seja maior; organização de grupos de melhoria para atuar junto ao cliente final (associações representativas), clientes intermediários, fornecedores, subcontratados e outras esferas de governo, com a função de traçar metas comuns e de elaborar as técnicas para alcançá-las; montagem de sistema de avaliação e seleção de fornecedores externos e internos, baseado na capacidade deles em atender aos requisitos da Qualidade previamente especificados ( e não apenas no preço); busca de novas formas de parceria, baseadas em novas tecnologias que permitam o melhor atendimento dos clientes; identificação e avaliação de novas formas de parceria, que garantam o acesso da sociedade aos serviços requeridos, independentemente da sua execução por órgãos públicos. 
Conforme o Manual de Orientação do Programa Permanente da Qualidade e Produtividade no Serviço Público (1996, p. 23), a estratégia de implantação a ser adotada baseava-se no ciclo de melhoria contínua, conhecido na literatura de gerenciamento pela Qualidade como ciclo de Deming ou ciclo PDCA (Plan/Do/Check/Act), já referenciado nesta pesquisa.

Consiste em: planejar o que deve ser feito e como deve ser feito; executar as atividades planejadas; verificar e medir se está sendo obtido o resultado esperado, identificando eventuais causas de divergência; em seguida redirecionar o Programa ou projeto, visando atingir os objetivos propostos. O ciclo deve ser retomado sempre, para que os objetivos sejam aperfeiçoados a cada rodada.

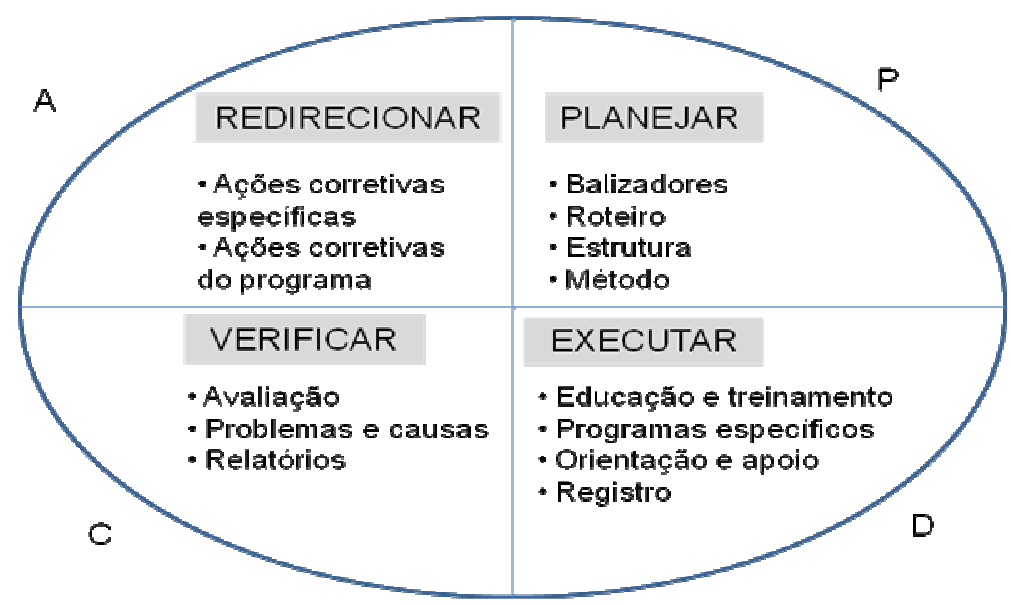

Figura 4 - Ciclo PDCA

Fonte: Governo do Estado de SP - PPQP (1996)

O PLANEJAR (PLAN) indica o que e como fazer: estabelecer os balizadores e roteiro de implantação, definindo princípios, estabelecendo conteúdos e condições para o desenvolvimento do Programa de Qualidade e Produtividade; implantar Comitês e/ou Comissões da Qualidade e Produtividade; definir método de implantação, desdobramento e acompanhamento do Programa e estabelecer metas de curto prazo.

A segunda fase de EXECUTAR (DO) é autoexplicativa: fazer o que foi definido para ser feito. Cabe a cada órgão a responsabilidade pelas ações relativas à implementação do Programa e o registro das ações, para permitir o seu acompanhamento. Farão parte das atividades: organizar eventos de sensibilização: seminários, palestra, conferências e 
workshops; realizar cursos de treinamento de pessoal e formação de multiplicadores; prover intercâmbio de experiências, em eventos; circulação de informação e montagem de casos; divulgar bibliografia específica e procurar, se necessário, assessoria externa especializada, com indicação do Grupo Executivo da Q\&P

A terceira fase, VERIFICAR (CHECK). O Programa será acompanhado pelo Grupo Executivo, para orientar as entidades, a fim de verificar o cumprimento das metas; aferir indicadores de desempenho; identificar problemas e suas causas elaborar sumários executivos, para encaminhamento ao Conselho Superior da Qualidade e Produtividade.

Completando o ciclo, o REDIRECIONAR (ACT) é feito a partir dos resultados da avaliação, quando serão definidas medidas de ajustes por meio de: plano de ações corretivas para os projetos de cada órgão/entidade e plano de ações corretivas para o andamento do programa.

A gestão pública está em constante alteração uma vez que deve atender a condições ambientais que mudam continuadamente. Considerando que, nesta tese, o foco recai sobre um tipo de órgão público particular, que é a universidade, cabe tratar desse tópico de forma específica.

\subsection{A Universidade Pública}

O tema Universidade além de ser vasto é extremamente complexo e cabe por si só para várias teses. O propósito de sua presença, neste trabalho, é dar apenas um panorama sobre a universidade pública.

A palavra universidade, no contexto do sistema educacional, é utilizada para caracterizar "uma instituição de ensino superior que compreende um conjunto de faculdades ou escolas para a especialização profissional e científica, e tem por função precípua garantir a conservação e o progresso nos diversos ramos do conhecimento, pelo ensino e pela pesquisa." (Ferreira, 1995). 
A Lei n. 9.394, de 20 de dezembro de 1996, conhecida como Lei das Diretrizes e Bases da educação nacional (BRASIL, 1996), define universidades de forma mais detalhada, conforme se apresenta no artigo 52:

As universidades são instituições pluridisciplinares de formação dos quadros profissionais de nível superior, de pesquisa e de extensão e de domínio e cultivo do saber humano, que se caracterizam por: I- produção intelectual institucionalizada mediante o estudo sistemático dos temas e problemas mais relevantes, tanto do ponto de vista científico e cultural, quanto regional e nacional; II - um terço do corpo docente, pelo menos, com titulação acadêmica de mestrado ou doutorado e III- um terço do corpo docente em regime de tempo integral.

Discorrendo sobre seu significado, Nogueira (2005, p. 29) descreve a razão de ser dessa instituição:

[...] a universidade existe para produzir conhecimento, gerar pensamento crítico, organizar e articular os saberes, formar cidadãos, profissionais e lideranças intelectuais. O desempenho dessas funções não é algo que pode ser resolvido no plano abstrato: não vive acima da sociedade e nem está desconectada dela. Em certa medida, cada época, cada sociedade e cada Estado têm a universidade que podem ter, por mais que a instituição universitária, por sua própria natureza, tenha luz própria e possa, justamente por isso, operar com alguma liberdade.

Para Chauí (2003, p. 35), a universidade pode ser vista sob duas dimensões: como instituição social e como organização. ${ }^{5}$ Como instituição social, a universidade exprime de maneira determinada a estrutura e o modo de funcionamento da sociedade de que é e faz parte. Não é uma realidade separada e sim uma expressão historicamente determinada. Com as conquistas sociais do século $\mathrm{XX}$, a educação e cultura passaram a fazer parte da cidadania e a universidade um dos instrumentos inseparáveis para a democracia e a democratização do saber. A partir de 1995, com a reforma do Estado, a universidade pública deixou de ser concebida como uma instituição social e um direito e passou a ser considerada como uma organização social prestadora de serviços, celebrando com o Estado um contrato de gestão, segundo Chauí (2003). Em sendo a universidade uma organização, é referida ao conjunto de meios (administrativos) particulares para a obtenção de um objetivo particular que a define; é regida por idéias de gestão, planejamento, previsão, controle e êxito. A autora mostra que a visão organizacional da universidade produziu o que Freitag (1996) chamou de universidade operacional; ela é avaliada por contratos de gestão, índices de produtividade; é calculada para ser flexível e está estruturada por estratégias e programas de eficácia organizacional. Destaca, ainda, que a qualidade é definida como competência e excelência cujo critério é o

5 Apud Chauí (1999, p. 218) a distinção entre instituição social e organização social é feita por Michel Freitag, em Le naufrage de l'Université, Paris, Editions de La Découverte, 1996. 
atendimento às necessidades de "modernização da economia e desenvolvimento social, e é medida pela produtividade orientada por três critérios: quanto a universidade produz, em quanto tempo produz e qual o custo do que produz."

Iniciada na Europa, ainda na Idade Média, a universidade consolidou-se como um agregado de pessoas possuidoras de certas qualidades e unidas pela missão de produzir e transmitir conhecimento, acumular e disseminar pensamento crítico, formar outras pessoas, jovens sobretudo, como cidadãos, profissionais e lideranças intelectuais. A universidade, de certa forma, recebe uma delegação da sociedade, que transfere a ela determinadas responsabilidades e incumbências. Por estar sempre socialmente referenciada, como instituição ela deve seguir às demandas e expectativas da sociedade, ainda que não se submeta passivamente a ela.

Reforça esse pensamento a observação de Marcovitch (1998, p. 22) de que “[...] a missão acadêmica é algo que se reconceitua a cada época e que jamais será definida com exatidão ao longo da história. As transformações mundiais em todas as áreas da atividade humana movem as estratégias acadêmicas."6

Mais recentemente, como organização a universidade pública tem procurado se sobrepor às mais diversificadas exigências da sociedade e do Estado. Para Nogueira (2005, p. 19)

[...] universidade é indispensável para o desenvolvimento tecnológico e científico, para a construção da autoconsciência social e a constituição da cidadania, assim como para a formação de profissionais especializados e lideranças intelectuais. Por outro lado, ainda foi convertida em alvo de expectativas sociais muito intensas, teve seu custo aumentado e passou a ser implacavelmente cobrada pelos governos. Pressionada por todos os lados e tendo que responder a um ambiente de mudanças fortes e aceleradas, a universidade tem se modificado de modo pouco orgânico, mais por suas partes (faculdades, departamentos e áreas), que como um todo. Seu contexto interno ficou inevitavelmente conturbado.

No mundo globalizado, o conhecimento tornou-se um bem de mercado e pode e deve ser obtido, uma vez que pode funcionar como um fator de ascensão social. O conhecimento, segundo Nogueira (2005) virou uma mercadoria e passou a integrar o mesmo circuito de produção e circulação de mercadorias. Com essa valorização do conhecimento, a universidade

6 São inúmeras as obras que tratam da história da universidade. O livro de Christophe Charle e Jacques Verger (1996) apresenta um panorama completo do desenvolvimento histórico da universidade, desde seu nascimento na Idade Média até a universidade dos dias de hoje. 
passa a ser procurada por um contingente cada vez maior de interessados que nem sempre consegue ser atendido.

Apud Maurício (2004), desde a segunda metade do século XIX, os países mais desenvolvidos vinham procurando implantar a escola pública, universal e gratuita, cabendo ao Estado essa função de "educador" para o povo. Segundo Romanelli (2000), as mudanças estabelecidas nas relações de produção e a maior concentração das populações nas cidades exigem medidas para se eliminar o analfabetismo e dar um mínimo de qualificação para o máximo de pessoas. O que ocorre é que, no capitalismo industrial, fica mais premente a necessidade de fornecer conhecimento a uma população cada vez mais numerosa, por exigências da própria produção e para ter maior condição de entrar no mercado de trabalho.

É possível, ainda, identificar uma pluralidade de instituições do ensino superior brasileiro, distinguindo-se desde sistemas grandes e complexos como a Universidade de São Paulo (USP) ou até pequenas escolas espalhadas pelo País. Pela sua natureza podem, então, serem classificadas como universidades, centros universitários, faculdades integradas, cursos ou faculdades isoladas; pela sua dependência legal, podem ser federais, estaduais, municipais ou particulares.

O Censo do Ensino Superior de 2009 (INEP, 2009) aponta a existência, em 2007, de 2281 instituições do ensino superior (IES), em todo o Brasil, mais que o dobro do número de instituições existentes em 1998. Das IES existentes, em 2007, 89\% são de instituições privadas e $11 \%$ de instituições públicas, das quais $4,6 \%$ são federais, $3,6 \%$ são estaduais e 2,7\% são municipais. Elas contam com 4 milhões e 880 mil estudantes, que representam cerca de $10 \%$ da população da faixa etária passível de frequentar o curso superior, uma vez que o número de matrículas também contempla adultos mais velhos, interessados em adquirir novas qualificações e títulos e conseguir melhor posicionamento no mercado de trabalho.

Do total de instituições de ensino superior (universidades, centros universitários e faculdades), 183 são universidades, que abrigam cerca de 2 milhões e 600 mil estudantes. Do total das universidades, 96 são públicas. O grande crescimento de matrículas encontra-se em instituições privadas e, sobretudo, em faculdades. 
No Brasil, a universidade pública propriamente dita foi instituída formalmente na década de 30 do século XX e organizada segundo os moldes europeus, conforme Schwartzman (1998). Também, nessa mesma época, iniciaram-se as primeiras instituições privadas, que aumentaram rapidamente em número. Após 1968, houve uma grande expansão do ensino superior privado, sobretudo na forma de instituições isoladas de ensino, expansão essa reduzida um pouco no período de 1973 - 1974 e retomada posteriormente. A maior parte das instituições federais, assim como as instituições estaduais paulistas, data de antes da década de 70. Nos anos 80 houve um pequeno crescimento de instituições estaduais no resto do País e só o setor privado continuou crescendo. (CUNHA, 2003).

Ainda para Schwartzman (1998), o grande aumento de demanda no ensino superior tem sido atendido quase que exclusivamente pelo setor privado. O setor público praticamente não cresce mais e o tamanho do setor privado é tanto maior quanto mais desenvolvida é a região do País, chegando a 90\% no Estado de São Paulo. A estagnação observada do setor público deve-se, aparentemente, a duas causas principais: o esgotamento da capacidade do governo federal e dos estaduais em investir mais no ensino superior, dado ser, do ponto de vista de formação de estudantes de graduação, um sistema dispendioso e improdutivo (alto custo per capita e baixa relação professor/aluno). Em segundo lugar, as instituições públicas dão grande ênfase na formação de profissões tradicionais e, em especial, nas universidades paulistas, para a pós-graduação e têm dificuldade em se expandir na graduação sem perda de qualidade.

Corrobora Macedo (2005, p.33) ao dar um panorama sobre as instituições de ensino superior:

[...] muitas instituições não universitárias, em sua maioria privadas, foram criadas para atender a uma demanda crescente por educação superior, que se verificara impossível de ser atendida pela universidade, pública ou privada, cuja expansão era limitada pelos altos custos acarretados pelo princípio da indissociabilidade do ensino, pesquisa e extensão e pela dificuldade de manter em níveis adequados o investimento requerido pelo sistema público.

Prenuncia-se uma incapacidade das instituições de ensino superior, públicas e privadas em atender às demandas e necessidades de uma educação superior de massa, dada a grande expansão do sistema. Um ensino superior de massa e de qualidade deveria ter uma taxa relativamente alta de alunos por professor, entre seus indicadores de produtividade e eficiência e isso deveria ser compensado por investimentos em materiais pedagógicos, qualificação de professores para o ensino, infraestrutura adequada para acesso remoto e fontes de informação, sistemas de treinamento e capacitação associados ao mercado de trabalho. 
No Estado de São Paulo, a situação é particularizada, pelo desenvolvimento universitário que aí se desenvolveu. Conforme Schwartzman (1998),

[...] como unidade mais rica da federação, o Estado de São Paulo teve condições de criar um sistema universitário muito mais bem estruturado e financiado que outros Estados e concentra hoje uma parte substancial da pesquisa e da pós-graduação do País, sobretudo em nível de doutorado. Além de recursos, o Estado de São Paulo tem uma tradição de autonomia em relação ao governo federal, que data pelo menos da década de 30, que fez com que ele mantivesse suas próprias instituições de ensino superior e pesquisa quando, a partir das décadas de 40 e 50 foi criado o sistema federal de ensino superior. A criação de universidades estaduais em outros Estados é mais recente, foi feita de forma complementar e como compensação a pouca capacidade de expansão do sistema federal e, sem a preocupação acadêmica que caracterizou, sobretudo as universidades estaduais de São Paulo: USP, UNICAMP e UNESP.

A USP é, para Schwartzman (1998), a instituição brasileira mais complexa do ponto de vista acadêmico e a universidade pública de maior número de alunos, com cerca de 80000 mil alunos em 2007. Embora continue complexa academicamente, foi ultrapassada em número de alunos por outras universidades privadas.

Observa Nogueira (2005, p. 33) que, ao longo dos anos 1990, tornou-se rotineira a acusação governamental, proveniente quase sempre da área econômica, de que o ensino superior público consome uma exagerada parcela do orçamento da educação, impossibilitando um melhor atendimento aos demais estágios educacionais. Acusada, também, de servir apenas a uma pequena porcentagem dos ricos, abriu-se um caminho para a redução dos investimentos estatais no ensino superior. Com menos recursos, a universidade pública precisa tornar-se mais eficiente, fazendo melhor uso dos recursos que recebe.

Segundo Buccelli (2005, p. 91), a autonomia universitária foi estabelecida pelo governo do Estado de São Paulo, a partir da promulgação do Decreto n. 29.598 de fevereiro de 1989, abrangendo a UNESP, UNICAMP e USP e envolvendo tanto os aspectos didáticos, científicos e disciplinares quanto à autonomia da gestão financeira, patrimonial e administrativa. No caso da autonomia financeira, o orçamento das universidades foi vinculado a um percentual da arrecadação do ICMS transferindo a elas a responsabilidade na formulação e execução das políticas de pessoal, de custeio e de investimento. O percentual inicial de 8,4\% evoluiu para 9\% em 1992 e 9,57\%, em 1995. (SILVA FILHO, 2006).

Do ponto de vista organizacional, as universidades são organizações muito complexas. A estrutura universitária compreende uma coletividade, na qual se inserem docentes-cientistas, 
alunos e técnicos administrativos, com separações bem marcantes entre eles. Para Zacarelli (1984), a estrutura organizacional que sobreviveu da Idade Média até agora é um modelo que separa, quase rigidamente, a atividade docente da atividade administrativa; "são duas estruturas sociais absolutamente distantes nas universidades de modelo europeu: a classe social docente e a dos administradores."

A universidade tem uma estrutura centralizada, formalizada e burocrática. A centralização refere-se à maneira como o poder é distribuído internamente na organização, ou seja, ao grau de concentração de poder na estrutura hierárquica. Na universidade pública, em geral, há muita ambiguidade no aspecto da centralização. O poder é distribuído por faculdades, departamentos, colegiados, conselhos superiores, câmaras de ensino, pesquisa e extensão etc.. É uma estrutura pesada, com trâmites burocráticos, que, em geral, levam a processos decisórios lentos, com grande dispersão de esforços, com duplicidade de ações e superposição de tarefas e esferas de decisão, levando à perda de qualidade no âmbito das atividades acadêmicas e administrativas. Essa condição remete muito à condição de organizações burocráticas, de alta hierarquização e nas quais quem é o chefe manda e os subordinados obedecem. Hardy e Fachin (2000) observam que o modelo burocrático é explicativo principalmente dos aspectos estruturais da universidade brasileira; ela apresenta um conjunto de características do modelo weberiano que pode ser encontrado na universidade, como a coordenação alcançada por meio da divisão de trabalho, as atividades padronizadas, os critérios impessoais utilizados, uma hierarquia administrativa visível e a existência de regras e regulamentos formais.

A formalização refere-se a todo o sistema normativo interno, aos regulamentos, às regras de promoção, aos planos de cargos e salários, à definição de e aos limites do exercício de autoridade, em seus diferentes níveis. A natureza diferente das atividades de docentes e dos técnicos administrativos enseja, por vezes, tratamento diferente no cumprimento às regras por essas duas categorias profissionais, podendo ser fonte de conflitos. Dada a autonomia e alto grau de liberdade que o docente reivindica para si, em função da tradição acadêmica, há grandes dificuldades de controle e acompanhamento das atividades desenvolvidas no âmbito das universidades. 
De certa forma um programa de qualidade, propondo estruturas mais flexíveis, democráticas e de maior permeabilidade horizontal, vinha romper com o equilíbrio, dado como líquido e certo na estrutura universitária. Daí poderem ser explicadas algumas resistências encontradas.

No que tange à burocracia na universidade, vale relembrar que as organizações públicas adotam comumente o modelo burocrático-legal racional, descrito por Max Weber. Segundo Motta, apud Bastos (1999, p. 207), burocracia é uma estrutura social na qual a direção das atividades fica a cargo de um aparelho impessoal hierarquicamente organizado, que deve agir segundo critérios impessoais e métodos racionais. Ela não é isenta de disfunções. Robert Merton (1970), cientista social americano, enfatiza nela a negligência ao fator humano, para o desempenho das organizações. Para o autor, as principais disfunções da burocracia estão na valorização excessiva dos regulamentos, no excesso de formalidade, na resistência à mudança, na despersonalização das relações humanas, na hierarquização do processo decisório, na exibição de sinais de autoridade e dificuldade no atendimento aos clientes. Em contraste, um modelo gerencial orgânico enfatiza a importância das pessoas na organização, releva a gestão participativa e firma-se como modelo mais condizente com o ideal democrático e com os paradigmas da administração moderna.

Maximiano (2002) descreve que a burocracia legal-racional, corresponde à do tipo mecanicista, é adequada para condições de ambiente relativamente estável, com tarefas especializadas e precisas e com uma hierarquia de controle bem definida. Nessas organizações, a visão de conjunto e a responsabilidade pela coordenação pertencem à alta administração. Em ambientes de condições instáveis, um segundo tipo de organização, o orgânico ou pós-burocrático, é o mais adequado; as organizações são mais flexíveis, pois os problemas complexos não podem ser resolvidos com pessoas de especialidade tradicionais, uma vez que existe uma contínua redefinição de tarefas. As pessoas e a natureza cooperativa do conhecimento são enfatizadas e não a especialização; prefere-se a interação e a comunicação de natureza informativa, no lugar de ordens, o que cria um mais alto grau de comprometimento com as metas da organização. É relevante, nesse caso, o conceito de gestão participativa, considerada como um dos paradigmas na moderna administração.

Mintzberg (1999) define cinco tipos de organização, identificadas como configurações estruturais: estrutura simples, burocracia mecanizada, burocracia profissional, forma divisionalizada e adhocracias. Cada uma dessas configurações tem características próprias. A 
universidade, nessa tipologia, enquadra-se em uma burocracia profissional, ou seja, utiliza padronização de habilidades de coordenação, a tomada de decisão é descentralizada, na dimensão vertical e horizontal e a autoridade apoia-se no poder de perícia, com ênfase na autoridade de natureza profissional. Para Mintzberg (1995, p. 208), “a burocracia profissional é uma estrutura inflexível, bem adequada para produzir trabalhos padronizados, mas inadequada para se adaptar a produção de novos." Essa especificidade explica em parte, as dificuldades para a implantação de mudanças na universidade. Morgan (2006) enquadra a universidade como "fenômeno complexo, paradoxal e ambíguo" e identifica a burocracia profissional proposta por Mintzberg (1995) como a estrutura mais adequada a universidades, ou seja, "organizações em que as pessoas com habilidades e capacidade-chave necessitam de grande quantidade de autonomia e liberdade de escolha para serem eficazes no seu trabalho.",

A Universidade é caracterizada pela pluralidade de áreas de trabalho, pós-graduação, pesquisa e extensão, além de atividades normais de ensino de graduação. Marcovitch (1998, p. 107) retrata a Universidade como uma estrutura coletiva. Os reitores, diretores e chefes de departamentos são dirigentes transitórios de uma instituição descentralizada. Cada um está subordinado a pelo menos um colegiado, que constitui elemento de contrapoder. Esse colegiado coletiviza o processo decisório. A grande questão é como conviver com essa descentralização com uma articulação profícua.

Do ponto de vista operacional, segundo Meyer (1988, p. 65), com frequência é observado como um sério problema, enfrentado nas universidades, a descontinuidade administrativa. "Com a troca de reitor, um novo grupo de dirigentes assume os postos chaves da organização, o que geralmente conduz a uma interrupção do processo de planejamento em andamento, quando existente”. Nova direção significa, em geral, pessoas diferentes, com idéias diferentes que querem deixar sua marca pessoal e descontinuam projetos, por vezes nem sequer avaliados. É importante existir um grupo permanente de técnicos e especialistas que, de forma sistemática, elaborem e acompanhem o processo de planejamento estratégico na universidade, para dar estabilidade à instituição, "sem maiores percalços ou interrupções face à alternância de poder".

7 O livro "Universidade em ruínas na república dos professores" (1999), organizado por Hélgio Trindade, pela Editora Vozes, traz um amplo debate sobre universidade, especialmente sobre a universidade pública, a sua inserção gradual na lógica neoliberal, a atuação do Banco Mundial, tendências e perspectivas. 


\subsubsection{A universidade e seu entrelaçamento com a qualidade}

Segundo Scroferneker (2000), o termo qualidade é polissêmico. Ele guarda diferentes significados que estão atrelados à perspectiva em que está sendo colocada. O significado de qualidade difere para o aluno, o docente ou o funcionário. Amaral (1994, p. 225) reforça esse posicionamento ao afirmar que "[...] a dificuldade em definir o que se entende por qualidade de uma instituição ou de um programa de ensino depende de quem a procura definir." A qualidade no ensino superior é um conceito relativo e multidimensional em relação aos objetos e atores do sistema universitário. Conclui a autora ao assinalar que o conceito de qualidade no ensino superior é um conceito difícil de ser definido de modo unívoco e homogêneo, dada sua natureza política, multidimensional e subjetiva; é necessário levar-se em conta uma variedade de critérios que se cruzam e interagem entre si.

Segundo Fuentes (1997), as orientações dadas para a educação superior é que se obtenha uma maior eficiência na gestão das universidades públicas e ligada a ela se faça avaliação de desempenho e se dê incentivos para aumentos de produtividade e da qualidade.

O questionamento da qualidade é um problema que surge à medida que a universidade não responde às expectativas da sociedade, nem às dos grupos que dela participam. (CORTE, 2006).

A política neoliberal do governo Fernando Henrique Cardoso, a partir de 1995, propiciou um grande aumento de estabelecimentos de ensino superior, predominantemente do setor privado. O papel do Estado redefine-se, em relação à educação superior: flexibiliza, descentraliza e concede facilidades para criação de instituições diversificadas em suas formas e processos. Todavia, como medida complementar e para preservar a qualidade na educação desses estabelecimentos o Ministério de Educação e Cultura tomou medidas concretas para controlar, fiscalizar os resultados e avaliar essas organizações. Uma manifestação concreta dessa preocupação foi a instituição do Programa de Avaliação Institucional das Universidades Brasileiras, PAIUB, em 1993, e o Exame Nacional de Cursos, conhecido como Provão, em 1996, ambos descontinuados e substituídos por outros mecanismos de avaliação. (DELPINO; BALZAN, 2007).

Para as universidades e centros universitários do sistema estadual de ensino, estaduais e municipais, o Conselho Estadual de Educação (CEE) fez, em 2000, uma deliberação pela qual 
regulamenta o processo de avaliação institucional contínuo e permanente, tendo como finalidade orientar, acompanhar e fiscalizar o desenvolvimento das instituições. Deve ser feita uma análise periódica do nível de desempenho e atualização institucional, quanto aos aspectos: eficácia e eficiência do ensino; importância dos programas de pesquisa, relevância da produção cultural e científica; eficácia da formação profissional; significado das ações comunitárias; condições gerais dos cursos de graduação e pós-graduação e qualidade da gestão administrativa e financeira.

Quando analisada, sob o aspecto organizacional, faz-se importante considerar a profissionalização dos quadros funcionais na universidade, que depende de três variáveis, segundo Marcovitch (1998, p. 1) a valorização do quadro humano e o reconhecimento da contribuição das pessoas, no passado e presente. Raras vezes o funcionário da Universidade é reconhecido publicamente pelo que realizou e é frequente transferir-se ao corpo docente e dirigente os méritos que são do quadro funcional; 2) valorizar o mérito pelo desempenho e não continuar na cultura do mérito igualitário e 3) implantar cursos preparatórios para os funcionários que vão ter posições de maior nível nas Unidades, para que tenham uma visão de conjunto da Universidade, conhecimento de legislação e treinamento gerencial. Deve-se pensar em um centro de formação e quadros profissionais.

Quanto aos dirigentes docentes, Marcovitch (1998, p. 174) pondera que não há modelos universalmente válidos, não há solução definitiva para essa escolha e o que se busca na Universidade é a solução menos perfeita, ou seja, a universidade possível. O ideal seria ter o dirigente que combinasse visão científica e capacidade gerencial. O cientista busca o desconhecido e o avanço da verdade; em seus métodos convivem disciplina e caos. De outro lado, o gestor apresenta uma cultura de racionalidade que predomina sobre o processo criativo; é mais analítico que intuitivo. O perfil de um dirigente depende do momento em que vive a instituição e o "perfil mais indicado do gestor é aquele que entende sua responsabilidade de execução, mantendo os olhos e ouvidos abertos para perceber os anseios dos outros." Acrescenta que seria desejável que, no comando de universidades e de outros órgãos do Estado, estivessem pessoas que conciliassem a responsabilidade individual e a interpretação das aspirações gerais. 
Segundo Leite (2008, p. 66)

[...] os gestores podem demonstrar comprometimento com valores, por meio de seus próprios comportamentos e pelo modo como reforçam o comprometimento de outros. O processo de mobilização do comprometimento deve ser iniciado no topo da organização dentro do círculo dos principais executivos, com abertura para que outros executivos participem do processo de reformulação da cultura organizacional e da internalização da visão nessa cultura.

Tais medidas relevam a importância da qualidade nas universidades tomadas nas duas dimensões: institucional e organizacional.

\subsubsection{Programa de Qualidade e Produtividade nas universidades estaduais paulistas}

O decreto do governador instituindo o Programa de Qualidade e no Estado de São Paulo Programa de Qualidade para órgãos públicos teve seus desdobramentos nas três universidades públicas estaduais: a Universidade de Campinas (UNICAMP), a Universidade Estadual Paulista (UNESP) e a Universidade de São Paulo (USP). Segue-se um relato sucinto da experiência de cada uma delas.

\subsubsection{A Universidade Estadual de Campinas}

A Universidade Estadual de Campinas, UNICAMP, é a menor dentre as três universidades do Estado de São Paulo. Foi fundada em 1966 e, atualmente, encontra-se em seis campi, dos quais o principal está em Campinas. Seu Anuário Estatístico (2009), com base de dados de 2008, assinala a existência de 20 Unidades de Ensino e Pesquisa, que disponibilizam 58 cursos de graduação e 139 cursos de pós-graduação. Foram oferecidas 3.310 vagas para a graduação. No mesmo ano, havia 32.214 estudantes matriculados, dos quais 16.984 eram alunos de graduação e 15.230 de pós-graduação. Conta com 7.841 funcionários técnicos administrativos e do total de seu corpo docente, de 1727 professores, $98 \%$ deles têm título de doutor ou acima. Ela concentra $15 \%$ da produção científica brasileira e cerca de $10 \%$ dos títulos de pós-graduação dados no País.

Pela Portaria GR 030/96, complementada pela Portaria GR 056/97, logo após o decreto do governador Mário Covas em 12 de dezembro de 1995, a UNICAMP iniciou seu Programa de Qualidade e designou uma Comissão composta de professores (entre os quais o Pró-Reitor de 
Desenvolvimento Universitário) e servidores (entre os quais a Coordenadora Geral de Administração e o Diretor de Recursos Humanos), para estabelecer diretrizes, coordenar e orientar a avaliação institucional, já em curso antes da deliberação do Conselho Estadual de Educação (CEE). Lembrando que a qualidade não se faz por decreto, o Relatório Geral do Conselho de Orientação Técnica, CONORT (1998, p. 4), observava que "sem dúvida o decreto veio possibilitar a integração de iniciativas isoladas em busca da qualidade existentes dentro da Universidade e o estímulo da comunidade para refletir sobre o assunto qualidade."

A composição do CONORT incluía funcionários técnicos administrativos, coordenados por um professor. A esse Conselho competia à indução do Programa de Qualidade na comunidade da Universidade, com divulgação de estudos de caso, seminários, definição de estratégia de divulgação e apoio no atendimento dos balizadores, além de fornecimento de suporte técnico e metodológico, o acompanhamento gerencial por meio de avaliações periódicas. Iniciando seus trabalhos em julho de 1996, teve como primeira ação a elaboração de entrevistas para a identificação de iniciativas já existentes ligadas à Qualidade Total. Foi organizado, em novembro do mesmo ano, um Fórum Permanente de Qualidade, divulgando iniciativas existentes e levantando expectativas quanto ao Programa. Foi oferecido curso de MASP (Metodologia de Análise e Solução de Problemas) aos interessados e foram organizadas diversas palestras de Sensibilização para a Qualidade, destinadas a todos os funcionários da UNICAMP.

Em 1997, solicitou-se a todas as Unidades e Órgãos que indicassem um coordenador local da qualidade com a competência de coordenar, orientar, avaliar e acompanhar a implementação do Programa.

O CONORT (1998, p. 6) elaborou uma metodologia, com um "conjunto de atividades necessárias à alavancagem da gestão da qualidade, pretendendo buscar o processo de melhoria apoiando e criando uma linguagem comum em toda a Universidade, sem tolher a criatividade ou autonomia das diversas Unidades/Órgãos."

O lançamento oficial do Programa foi feito em 14 de abril de 1997 com o objetivo de dinamizar a Qualidade na UNICAMP, integrando iniciativas isoladas e divulgando os resultados obtidos e também de ampliar a dimensão da Qualidade por toda a organização, na busca da melhoria contínua de seus processos de trabalho e da Qualidade de Vida da sua 
comunidade. Seguiram-se palestras de sensibilização, curso de ferramentas básicas da qualidade, noções sobre qualidade total e encontro de coordenadores da qualidade.

Segundo um dos entrevistados da UNICAMP, com a troca de reitor em 1998 foi dada uma nova feição ao Programa de Qualidade e a partir de abril de 2002, com outra mudança, iniciou-se a sensibilização para a filosofia do Planejamento Estratégico (PLANES), impulsionada pela Deliberação CEE n. 004/2000, que estabelecia regras para a avaliação institucional das universidades públicas do Estado.

A publicação da Coordenadoria Geral da Universidade (outubro/2004) relata com maiores detalhes o Projeto de Avaliação Institucional da UNICAMP, seu histórico e forma de organização. Incluía avaliação interna e externa de atividades de pesquisa, ensino (graduação e pós-graduação) e extensão, além de atividades administrativas e de gestão. Foi feita a sensibilização, com palestras e conferências e publicado um "gibi" sobre Planejamento Estratégico.

O comando do PLANES, ficou, inicialmente, com o Coordenador Geral da Universidade, que era a mesma pessoa que havia sido Pró-Reitor de Desenvolvimento Universitário e coordenador do Programa de Qualidade, em 1996. O trabalho do PLANES prosseguiu, uma vez que o Pró-Reitor transformou-se, em seguida, em Reitor e manteve a mesma filosofia. Em 2004, conforme publicação da Coordenadoria Geral da Universidade (Nov/2004), consolidaram-se conceitos de missão, princípios, valores, visão de futuro e áreas estratégicas da UNICAMP. Em função disso definiram-se programas e linhas a serem seguidas pelas Unidades e Órgãos. As unidades acadêmicas locais de planejamento e colaboradores (professores, técnicos administrativos e estudantes) dão retorno das ações empreendidas e fazem uma revisão das ações. O Planejamento Estratégico é discutido institucionalmente e complementa-se com a Avaliação Institucional. Em 2009, foi desenvolvido o terceiro ciclo de Planejamento Estratégico; por ele, parte do orçamento da Universidade está associada às ações indicadas pelo PLANES. Atualmente o processo de planejamento estratégico está incorporado no dia a dia da Universidade. (UNICAMP, 2008). 


\subsubsection{A Universidade Estadual Paulista Júlio de Mesquita Filho}

A Universidade Estadual Paulista Júlio de Mesquita Filho, UNESP, é outra das universidades estaduais públicas e foi criada em 1976, para atender a necessidade de se ter um ensino superior público no interior paulista. Em 2009, ela estava distribuída em 15 campus, sediados em 15 municípios do Estado de São Paulo, inclusive na Capital, segundo o Plano de Desenvolvimento Institucional da UNESP (2009, p. 18). É composta de 26 Faculdades e Institutos, que oferecem cursos de graduação e de pós-graduação. Dados de 2008 de seu Anuário Estatístico (2009) registram 122 cursos de graduação e 192 de pós-graduação; estavam matriculados 35.026 alunos na graduação e 12.946 nos programas de pós-graduação stricto sensu e 2.344 alunos nos cursos de pós-graduação lato sensu. Seu quadro de docentes ativos é composto de 3.425 professores, sendo 84,3\% deles em Regime de Dedicação Integral à Docência e à Pesquisa (RDIDP); conta, ainda, com 6.880 servidores técnicos administrativos.

Para atender ao decreto de 12 de dezembro de 1995, do governador do Estado, sobre a Qualidade, em 14/02/96, pela Portaria n. 31, a UNESP (1998) instituiu uma Comissão de Gestão da Qualidade e Produtividade, formada pelos Pró-Reitores de Administração, Graduação, Pesquisa e Extensão. Em nome da Qualidade, foram organizados, a partir de 1996, encontros em vários campi, palestras sobre ISO 9000 e Gestão da Qualidade Total; cursos de: Gestão da Qualidade, incluindo módulos de Qualidade e Cultura Organizacional; Diagnóstico Organizacional e Autoavaliação com base nos critérios do PNQ; curso de Relacionamento Pessoal, Comunicação Verbal, Mudanças de Paradigmas, Qualidade no Atendimento ao Cliente, Qualidade e Competência em equipe; trabalhos na área de Relações Sociais no trabalho e Comunicação no Trabalho.

Em uma nova gestão iniciada em 16/07/1997, o Programa Permanente de Gestão da Qualidade (PPGQ) na UNESP, abrangendo Reitoria, Unidades Universitárias, Administração Geral de Bauru e Botucatu, Unidades Complementares e Fundações, foi relançado em 18/03/98 por meio da Portaria do Reitor, UNESP n. 47, de 18/03/98, com o objetivo de "melhorar continuamente todos os processos de trabalho para o aprimoramento da comunidade universitária e a melhoria da qualidade dos serviços oferecidos pela UNESP." O PPGQ foi instituído no bojo do Programa implantado pelo Governo do Estado de São Paulo e seguiu cumprindo-o como um dos projetos previstos no Plano de Gestão (1997 - 2000), aprovado pelo Conselho Universitário, segundo publicação da UNESP, Caderno 1: A busca 
contínua da excelência (1998, p. 3). O aspecto mais importante do PPGQ era o de poder identificar e destacar na Universidade os comportamentos culturais que expressassem qualidade.

Em 1999, por força da crise econômica nacional, houve muitas medidas para a redução de gastos e o Programa de Qualidade integrava os esforços para a redução das despesas. O PPGQ na UNESP foi fundamentado nos critérios de excelência do Prêmio Nacional da Qualidade (PNQ), adaptado para educação superior, nas diretrizes do decreto estadual 40.536 de 12 de dezembro de 1995. O PPGQ tinha como meta a "busca da excelência no atendimento e na prestação dos serviços oferecidos aos cidadãos, ao menor custo possível."

Consolidou como objetivos gerais:

[...] contribuir para a melhoria de qualidade nos serviços oferecidos pela Universidade; motivar o corpo docente e técnico administrativo por meio da distribuição de responsabilidades e do incentivo a tomada de decisões e apoiar os processos de mudança que visem o aprimoramento das pessoas e dos métodos e processos de trabalho, utilizando racionalmente os recursos existentes, segundo UNESP. (1998, p. 6)

Além de elencar alguns objetivos específicos, enfatizava, também, a observância dos princípios: envolvimento de todos, docentes e técnicos administrativos; formulação de estratégias de longo prazo; satisfação do usuário e do usuário interno; gestão de informações e análise crítica do desempenho da organização; desenvolvimento e capacitação de pessoas; gestão de pessoas e resultados.

Ao instituir o Programa de Qualidade, o Reitor, também, dispôs sobre sua estrutura, formando: a) um Conselho Superior do PPGQ, presidido por ele mesmo; b) uma unidade de assessoramento técnico e de operacionalização, a Secretaria Executiva (SEQual); c) Comitês Diretores das Unidades (CDU), formados a critério do Diretor da Unidade e d) os Grupos Executivos Locais (GEQual).

Dada a grande dispersão geográfica da UNESP, caracterizada como universidade multicampi, algumas Unidades levaram à frente o Programa e outras não adotaram a nova filosofia. $\mathrm{O}$ Programa teve uma força maior em seu início, por ter tido um vice-reitor que o encampou, deu importância ao Programa e criou-se um grupo em cada Unidade da UNESP. 
A gestão seguinte à instituição do Programa reforçou a questão de cursos para funcionários, inclusive com assessoria do SENAC, segundo depoimento do entrevistado da Universidade. Os critérios iniciais do Malcolm Baldrige ficaram pouco enfatizados. Há três anos, em 2007, iniciou-se o Plano de Desenvolvimento Institucional (PDI), que levou um ano e meio para ser elaborado e continua até hoje. Segundo o entrevistado:

[...] é uma nova roupagem da qualidade com princípios semelhantes; é a mesma qualidade inicial de outra forma: é comum ainda usar-se princípios e ferramentas da qualidade, como gestão de processos e Diagrama de Ichikawa.

O início desse processo deu-se com a pergunta: "O que a UNESP pretende ser em 2020?" Todos se envolveram para a elaboração do PDI, resgataram o histórico da UNESP, sua missão e visão de futuro, dimensões que se pretende focar (ensino de graduação; ensino de pósgraduação; pesquisa; extensão universitária; planejamento, finanças e infraestrutura; gestão e avaliação acadêmico-administrativa) com objetivos e ações; definiram-se programas e tempos a serem executados. Atualmente, o PDI contempla 15 grandes projetos que têm orçamento próprio. São eles: 1) Gestão de Recursos Humanos; 2) Gestão do Desenvolvimento; 3) Saúde e Higiene Ocupacional e Perícia Médica; 4) Incentivo à Consolidação da Pesquisa; 5) Infraestrutura de Pesquisa; 6) Avaliação do Ensino da Graduação; 7) Aplicação e Diversificação do Acesso à Universidade; 8) Aperfeiçoamento do Ensino de Graduação; 9) Integração da Extensão Universitária com o Ensino e a Pesquisa; 10) Atendimento às demandas sociais; 11) Inserção do corpo docente na Pós-Graduação; 12) Avaliação da PósGraduação; 13) Excelência no Ensino de Pós-Graduação; 14) Preservação da Memória e 15) Internacionalização da UNESP.

\subsubsection{A Universidade de São Paulo}

Sabe-se que a implantação de um Programa de Qualidade não se faz por Decreto, mas o Decreto do governador Mário Covas serviu como incentivador para o início do Programa de Qualidade e Produtividade. A Universidade de São Paulo, diante dele, incorporou o Programa em sua estratégia, por meio de uma Portaria de seu Reitor, na época. (USP. Relatório de gestão do Reitor Flávio Fava de Moraes, 1997).

A adoção do Programa de Qualidade e Produtividade na Universidade de São Paulo foi acompanhada com a criação de uma Comissão de Gestão de Qualidade e Produtividade 
(CGQP) ou como Comissão Central de Qualidade ou, simplesmente, como Comissão de Qualidade, constituindo-se no Grupo Executivo da Qualidade, com a incumbência de cuidar da gestão e da operacionalização do Programa na USP.

Após várias reuniões, a Comissão fixou como suas atribuições: a) sensibilizar e mobilizar a comunidade USP em temas relacionados à qualidade e à produtividade; b) institucionalizar as Comissões Internas de Qualidade e Produtividade; c) difundir conceitos e metodologias da qualidade e produtividade; d) facilitar a troca de experiências e a aprendizagem coletiva; e) levantar problemas, sugestões e ações de melhoria e f) manter a vinculação com o Programa Permanente de Qualidade e Produtividade do Serviço Público do Estado de São Paulo.

A Comissão de Gestão do Programa de Qualidade e Produtividade foi formada, inicialmente, por cinco docentes, sob a presidência de um deles e, em um segundo momento (1997), foi incluído um participante técnico-administrativo. Essa Comissão, com algumas trocas em sua composição, manteve-se até fevereiro de 2006. Ainda que não aparecesse na estrutura administrativa formal, em seu início, a CGQP esteve ligada à Coordenadoria Geral de Administração (CODAGE) da USP, responsável por questões administrativas da Universidade como um todo. Pode-se supor que o seu posicionamento na estrutura organizacional da USP tenha sinalizado às unidades o tipo de melhorias a serem empreendidas pelo Programa de Qualidade e Produtividade. Em 2001, passou a ser vinculada à Vice-Reitoria da USP, posicionamento esse que facilitava, também, a interlocução com todas as Unidades e órgãos da Universidade.

A Comissão adotou, ainda, como Política da Qualidade da USP, os Critérios do Prêmio Nacional da Qualidade (PNQ) combinados com os já descritos Balizadores de Qualidade do Serviço Público do Estado de São Paulo e denominados, nesta tese, de Módulos de Qualidade. Em 1996, eram considerados Critérios de Excelência do PNQ: 1) Liderança; 2) Planejamento; 3) Foco no cliente; 4) Informação e análise; 5) Desenvolvimento e gestão de pessoas; 6) Gestão de processos e 7) Parcerias e alianças. Esses Módulos de Qualidade foram apresentados na publicação Questionário para Mapeamento de Características da Qualidade e Produtividade da CGQP (1997), como referências para a identificação de oportunidades de melhorias. O seu resultado poderia constituir-se nas bases para a elaboração de um Plano Diretor de Qualidade e Produtividade nas Unidades e Órgãos. Os Módulos de Qualidade podem ser visualizados na Figura 5, a seguir. 


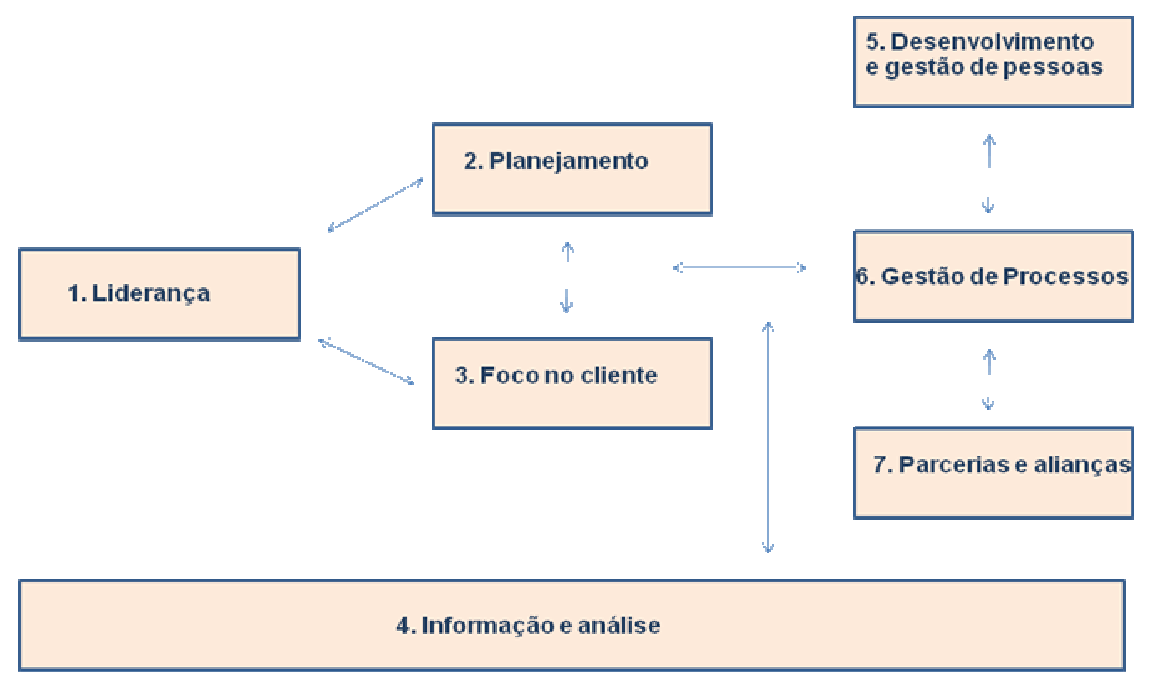

Figura 5 - Critérios de excelência do PNQ

Fonte: Questionário para Mapeamento de Características de Qualidade e Produtividade (1997, p. 13)

Descrevem-se os Módulos de Qualidade, que associam Critérios do PNQ e Balizadores do Serviço Público do Estado de São Paulo. (USP. Programa Permanente de Q\&P, v.3,1997).

1) LIDERANÇA: Balizador 2. Cada um dos participantes da administração pública é responsável pela qualidade.

A liderança, o nível hierárquico mais alto na Unidade/Órgão, de forma participativa, reforça a missão e os valores da Universidade e da Unidade/Órgão, sinalizando a todos os interessados (incluindo governo, sociedade, comunidade, alunos, docentes, funcionários e parceiros) os propósitos da organização. Há uma preocupação da liderança com questões relativas à qualidade e produtividade, não apenas quanto à atividade-meio, mas, também, à atividade-fim, sendo fortemente orientada para as atividades de ensino, pesquisa e serviços associados. São criados mecanismos e estruturas que viabilizem a gestão participativa e a integração entre as funções, facilitando a aprendizagem coletiva e permitindo uma flexibilidade capaz de responder às novas necessidades e oportunidades. No PNQ, incluem-se, nesse critério, o Sistema de Liderança, a Cultura da Excelência e a Análise do desempenho da organização. 


\section{2) PLANEJAMENTO:}

Há um envolvimento da liderança da Unidade/Órgão no alinhamento de todos os funcionários, docentes ou não, quanto aos rumos da organização, coerente com a missão e as condicionantes locais. O planejamento é sistemático e participativo, com avaliações periódicas e atualização do planejamento, quando necessário. As ações são priorizadas em função do impacto no atendimento da satisfação das partes interessadas. O critério do PNQ registra a formulação e a implementação das estratégias.

3) FOCO NO CLIENTE: Balizador 1. O cliente final da administração pública é a sociedade.

A Unidade/ Órgão está comprometida com a melhoria da satisfação de seus clientes externos (governo, sociedade, contribuinte, familiares de alunos e outras instituições de ensino superior) e com o desenvolvimento e aperfeiçoamento de ensino, pesquisa e serviços oferecidos. O foco está nas reais necessidades da sociedade em termos de mercado e cidadania. A Unidade/ Órgão mantém canais efetivos de comunicação entre as funções e esferas internas e os clientes, estando próxima e atenta às suas expectativas e necessidades atuais e futuras. No critério do PNQ, incluem-se: a imagem e conhecimento do mercado; o relacionamento com clientes; a responsabilidade socioambiental e a ética e o desenvolvimento social.

4) INFORMAÇÃO E ANÁLISE: Balizador 4. O Programa da Qualidade e as decisões devem ser direcionados por indicadores, dados e fatos.

São estabelecidos mecanismos de utilização de dados e informações para a melhoria das atividades de ensino, de pesquisa e dos serviços oferecidos. Existe um sistema estruturado de informações e dados e é definido, claramente, como ele será utilizado para a melhoria do desempenho. No critério do PNQ, contempla-se a gestão das informações na organização, a gestão de informações comparativas e a gestão dos ativos intangíveis. 
5) DESENVOLVIMENTO E GESTÃO DE PESSOAS: Balizador 3. A melhoria dos serviços públicos é obtida pela qualidade dos recursos humanos.

Existe um alinhamento do planejamento e das práticas de recursos humanos com os planos e estratégias da Unidade/ Órgão. Todos os funcionários são incentivados a participar da melhoria do desempenho, do crescimento pessoal e institucional. Há uma contínua preocupação com o ambiente de trabalho e satisfação dos funcionários, incluindo identificação de fatores que podem afetar, adversamente, o desempenho das atividades. Incluem-se, nesse critério do PNQ, os sistemas de trabalho, a capacitação e desenvolvimento e a qualidade de vida no trabalho (QVT).

\section{6) GESTÃO DE PROCESSOS:}

Balizador 5. O aperfeiçoamento contínuo dos serviços, produtos e processos deve ser uma atividade cotidiana no serviço público.

Balizador 6. O valor e o sacrifício de qualquer atividade devem ser constantemente monitorados.

Balizador 7: Bons resultados são decorrentes de processos controlados.

Os processos são executados de forma controlada e padronizada. Há um contínuo monitoramento dos processos, sempre com ênfase na prevenção de problemas potenciais ou reais. Partindo dos objetivos das Unidades/Órgãos, os processos-chaves de trabalho são estabelecidos visando a eficiência, eficácia e adaptabilidade às características e condicionantes de cada Unidade ou Órgão. O desempenho de seus requisitos-chave é monitorado e, se necessário, aplicam-se ações corretivas para evitar-se recorrência de problemas. Há forte orientação para a redução de tempo de ciclo de processos, proporcionando melhoria em sua eficiência e eficácia. A cada modificação de processo ou procedimento, quer por questões legais, quer por aperfeiçoamentos, analisa-se o impacto da modificação nas diferentes áreas e planeja-se sua introdução e acompanhamento. Nesse critério do PNQ, incluem-se a gestão de processos principais e de apoio, a gestão do relacionamento com fornecedores e a gestão econômicofinanceira. 
7) PARCERIAS E ALIANÇAS: Balizador 8: Parceiros devem ser desenvolvidos para a satisfação do cliente final.

A Unidade/Órgão estabelece parcerias internas e externas que melhor atendam à realização de suas metas globais. As parcerias externas incluem relacionamentos duradouros com outras instituições de ensino, empresas, associações comerciais, organizações comunitárias e de serviço social, com fornecedores, entre outras, que podem complementar e fortalecer a realização dos objetivos das Unidades e Órgãos da USP.

Desde seu início, a filosofia do Programa de Qualidade e Produtividade da USP apregoava uma total liberdade e autonomia para a forma de condução dos Programas locais. Foi e era reconhecido que existem diferenças culturais substanciais nas Unidades e Órgãos da USP e diferenças na capacidade de absorção de novas tecnologias. Em vista disso, eram esperadas diferentes abordagens para o Programa de Qualidade. As ações de qualidade que se desenvolveram e que são objeto deste trabalho confirmaram esse pressuposto; são múltiplas e das mais diferentes naturezas, atendendo a um ou mais dos critérios/balizadores prescritos.

Tal como as outras duas Universidades, com a deliberação do CEE em 2000 para que fosse feita a Avaliação Institucional nas Universidades, o Programa de Qualidade na USP foi reforçado na sua parte acadêmica e ganhou uma vertente para se elaborar o planejamento estratégico nas Unidades e Órgãos da Universidade. Segundo o Relatório de Gestão 2001 2005, da Vice Reitoria (2005), de 199 Departamentos da USP, 198 fizeram sua autoavaliação, propondo um Plano de Metas ou Plano de Desenvolvimento Acadêmico. Esses planos foram consolidados internamente em um único Plano de Metas de cada Unidade, abrangendo um período de 5 a 10 anos, a contar de 2003. A Comissão Permanente de Avaliação (CPA) foi responsável pela condução do processo. Há publicações específicas que tratam do tema: USP. Processo de Avaliação Institucional da Universidade de São Paulo 2003 - 2005 (2005) e Almeida (2004).

Em dez anos de atividades, o Programa Permanente de Qualidade e Produtividade da USP contabilizou um conjunto grande de atividades. Por iniciativa da CGQP da USP, foram promovidos 12 encontros de Qualidade e Produtividade, abrangendo um público de cerca de 2.030 pessoas. Foram feitas oito publicações, registrando as atividades da Comissão de 
Gestão de Q\&P e também as Iniciativas de Qualidade relatadas pelas Unidades e Órgãos da USP. Houve o apoio a projetos estruturados das Unidades e Órgãos, que dentro de suas particularidades, desenvolveram muitas atividades diferenciadas.

O Programa de Qualidade, na sua forma inicial, vigorou até 23 de fevereiro de 2007 quando foi substituído pelo GESPÚBLICA USP, Gestão Estratégica e Desburocratização na Administração da USP, instituído pela Portaria GR n. 3735, conforme documento apresentado nos Anexos. $\mathrm{Na}$ mesma data, foi instituída a Comissão Central do GESPÚBLICA USP, com o objetivo de formular seu planejamento das ações e coordenar e avaliar sua execução. (BIANCHI; MIRANDA, 2007).

O objetivo do GESPÚBLICA USP pode ser sumarizado como "a busca na otimização de procedimentos e o aperfeiçoamento da prestação de serviços da Universidade aos cidadãos e à sociedade.” A participação de Unidades e Órgãos da USP no GESPÚBLICA USP foi voluntária; as Unidades que manifestaram a vontade de integrarem-se ao Programa tiveram uma assessoria externa para elaborarem uma primeira autoavaliação de sua gestão, que foi validada externamente por um consultor voluntário do GESPÚBLICA, ligado ao Ministério do Planejamento, Orçamento e Gestão do Governo Federal. Em seguida, foi recomendado que fizessem um Plano de Melhoria de Gestão, a ser executado no prazo de um ano.

As atividades do Programa GESPÚBLICA USP estão, conceitualmente, baseadas em um Modelo de Excelência em Gestão Pública, com critérios semelhantes aos Critérios do Modelo de Excelência do Prêmio Nacional da Qualidade (PNQ), que serviram como diretrizes no Programa de Qualidade e Produtividade, em 1996. São eles: Liderança, Estratégia e Planos, Cidadãos e Sociedade, Informação e Conhecimento, Pessoas, Processos e Resultados.

Para a operacionalização da autoavaliação das Unidades foi utilizado um instrumento de 250 pontos, para organizações que estão iniciando a implementação da autoavaliação continuada. Uma oficina de autoavaliação é feita com o objetivo de verificar o grau de aderência das práticas de gestão existentes e resultados da instituição, em relação ao referencial do Modelo de Excelência em Gestão adotado pelo GESPÚBLICA. Por gestão, entende-se a capacidade de condução da missão da instituição, em um sistema integrado de 
práticas de planejamento, organização, direção e controle. Uma gestão de qualidade é evidenciada por práticas de gestão da organização e os resultados decorrentes dessas práticas. Uma gestão de qualidade é uma gestão de resultados, na qual o sistema está voltado para a consecução dos objetivos estratégicos da organização; tem como principal característica a busca permanente da melhor combinação entre insumo, ação e resultado.

Conforme o Relatório de Gestão USP 2005 - 2009 (2009), os resultados de 53 autoavaliações das Unidades e Órgãos da USP indicaram a seguinte distribuição, em relação ao estágio em que se encontram por nível de gestão:

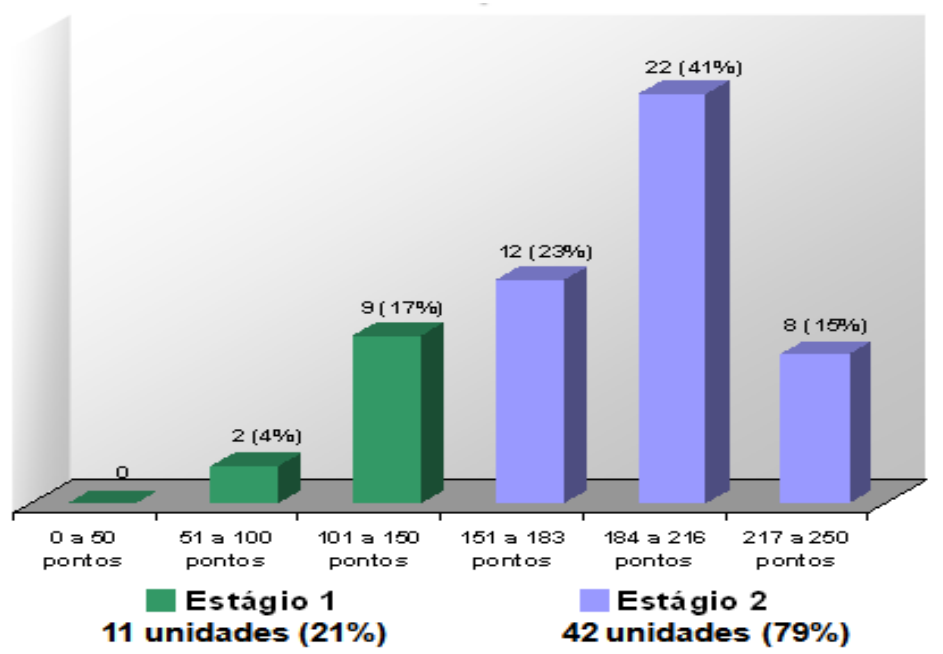

Gráfico 1 - Classificação das unidades/ órgãos por nível de gestão (*) Fonte: Relatório de Gestão 2005 - 2009 (2009)

(*) Segundo critérios das faixas de pontuação global do Instrumento para Avaliação da Gestão Pública do GESPÚBLICA (2006)

Por Estágio 1 entende-se um patamar muito preliminar de desenvolvimento de práticas de gestão; não se pode considerar que os resultados decorram de práticas implementadas. $\mathrm{O}$ Estágio 2 indica a existência de práticas em primeiros estágios de desenvolvimento e implementação, existindo lacunas significativas na aplicação da maioria delas. Começam a aparecer alguns resultados decorrentes da aplicação das práticas implementadas, com algumas tendências favoráveis.

Com base nos resultados da autoavaliação, cada unidade da USP selecionou alguns requisitos que, na sua interpretação, precisavam ter suas práticas melhoradas e elaborou seu Plano de 
Melhoria de Gestão (PMG), constituído de metas e ações para a melhoria do sistema de gestão.

O caso USP será oportunamente mais detalhado, uma vez que essa universidade constitui o principal objeto do estudo de caso desta tese. 



\section{METODOLOGIA DA PESQUISA}

Esse capítulo detalha os métodos e técnicas adotados para a realização desta tese. Ele discute o método de pesquisa e sua abordagem, os critérios para as escolhas de pesquisa e apresenta o modelo operacional utilizado: estratégia de coleta de dados; procedimentos para tratamento e análise dos dados.

Um mesmo objeto de estudo pode ser analisado sob diversos ângulos e produzir a partir daí tipos diferentes de conhecimento. A escolha do enfoque metodológico de um estudo de caso sinaliza que o interesse está na descrição e na compreensão dos processos que compõem o fenômeno estudado e sua integração ao contexto existente. O fenômeno a ser estudado nesta tese é a implantação de um Programa de Qualidade na Universidade de São Paulo, a maior e mais antiga das três universidades públicas do Estado de São Paulo, com ênfase no período de 1996 a 2006.

No sentido de ter um quadro geral do fenômeno ocorrido nas duas outras universidades públicas estaduais foram feitas entrevistas, por telefone, com duas pessoas da Universidade de Campinas (UNICAMP) e uma pessoa da Universidade Estadual Paulista Júlio de Mesquita Filho (UNESP). Na UNICAMP foram entrevistados: um ex-Reitor e um funcionário técnico administrativo, integrante do Grupo Técnico de Planejamento Estratégico. Na UNESP, foi entrevistado, pessoalmente, o ex-Secretário Executivo do Programa Permanente de Gestão da Qualidade (PPGQ) e atual Assessor Técnico do Plano de Desenvolvimento Institucional (PDI). Essas entrevistas vieram confirmar o processo de escolha da tese, delimitando, para o estudo de caso, a Universidade de São Paulo (USP).

Para a USP, a pesquisa abrangeu levantamento e análise de dados primários e secundários. Como pesquisa de campo, para a coleta de dados primários foi feita uma série de entrevistas com ex-docentes dirigentes e funcionários técnicos administrativos de 12 Unidades de Ensino e Pesquisa. O objetivo era exploratório para compreender em profundidade, na percepção dos entrevistados, como havia sido a implantação e os resultados do Programa de Qualidade e Produtividade na Universidade de São Paulo, ocorrido a partir de 1996. 
A problemática desta pesquisa ancora-se no quadro teórico contextualista desenvolvido por Pettigrew (1990), como modelo de análise dos fenômenos de mudança organizacional. O modelo articula-se em torno de três conceitos centrais: o contexto externo e interno; o processo e o conteúdo do fenômeno estudado. Além do fato de a pesquisadora trabalhar nessa organização e ter participado do processo em estudo, de forma complementar foi feita uma pesquisa documental, usando como fonte de evidências, relatórios, jornais, arquivo de atas de reuniões, publicações, vídeos e transcrições de palestras. Esse conjunto está tratado de forma descritiva e histórica após a apresentação dos resultados da pesquisa de campo.

\subsection{O método de pesquisa}

A natureza da pesquisa depende do objetivo definido. Selltiz e outros (2005) propõem a classificação de três grupos de pesquisa: estudos exploratórios; descritivos e estudos que verificam hipóteses causais ou explicativas. Uma pesquisa pode iniciar-se como exploratória, continuar como descritiva e, por fim, tornar-se explicativa. Yin (2005) observa que a pesquisa exploratória tem como principal finalidade desenvolver, esclarecer e modificar conceitos e ideias, tendo em vista a formulação de novas teorias, modelos e hipóteses pesquisáveis em estudos posteriores. São do tipo aproximativo, acerca de determinado fato e têm como objetivo proporcionar uma visão geral. (GIL, 2002; GOODE, 1979; VERGARA, 2008).

Por sua vez, Creswell (2002) acrescenta que a abordagem ou enfoque da pesquisa pode ser: qualitativo; quantitativo ou misto. A distinção entre os dois primeiros enfoques nem sempre é clara, como observam Easterby-Smith e outros (1999). A abordagem qualitativa faz uso de narrativas, fenomenologia, etnografia, grounded theory e estudos de caso. A natureza desta pesquisa é qualitativa, utilizando-se do método de estudo de caso, com base em dados primários e secundários.

Vários autores caracterizam os traços essenciais da pesquisa qualitativa. Denzin e Lincoln (2006) sugerem que a pesquisa qualitativa envolve uma abordagem interpretativa e natural do mundo. Para Richardson (1999) procedimentos qualitativos objetivam possibilitar o entendimento das particularidades do comportamento dos indivíduos, nos seus locais naturais. Triviños (1987) destaca que a pesquisa qualitativa tem a característica de observar o ambiente natural como fonte direta dos dados e ter o pesquisador como instrumento-chave. Godoy 
(1995) salienta que a pesquisa qualitativa envolve a obtenção de dados descritivos sobre pessoas, lugares e processos interativos, pelo contato direto do pesquisador com a situação estudada, compreendendo o fenômeno, segundo a perspectiva dos sujeitos participantes da situação em estudo. Em estudos, sob uma abordagem qualitativa, para Pettigrew (1992) o contexto do fenômeno é muito importante.

Para Creswell (2002), o paradigma qualitativo tem o propósito de compreender uma situação social particular; é um processo investigativo, em que o pesquisador, gradualmente, constrói o sentido de um fenômeno social por contrastar, comparar, replicar e classificar o objeto do estudo. A adoção dessa abordagem requer a imersão no local escolhido para o estudo, entrar no mundo dos informantes e procurar as suas perspectivas e os seus significados. Isso é plenamente conseguido no estudo em questão, uma vez que os entrevistados participaram ativamente do fenômeno estudado e a própria pesquisadora foi atuante, na maior parte do tempo, no objeto da pesquisa.

O método de estudo de caso, de acordo com Richardson (1999) permite descrever a complexidade de determinado problema e analisar em maior profundidade o comportamento dos indivíduos, considerados os processos dinâmicos vividos pelos grupos sociais. Isso vai ao encontro da definição de Eisenhardt (1989), a qual considera esse método uma estratégia de pesquisa focada na compreensão da dinâmica de um ambiente particular. Para Yin (2005), essa estratégia é escolhida quando se colocam questões do tipo "como" e o "por quê", acrescentando-se o desejo de compreender fenômenos sociais complexos e lida com uma ampla variedade de evidências: entrevistas e pesquisa documental como relatórios, jornais, arquivo de atas de reuniões, publicações, vídeos, transcrições de palestras, entre outros. (COLLIS; HUSSEY, 2005; MARTINS, 2006).

Se para Yin (2005), estudos de casos atendem aos objetivos de fornecer descrição, testar ou gerar teorias, para Eisenhardt (1989, p. 448), “o propósito de um relatório de caso não é representar o mundo, mas representar o caso." Stake (2003), também, reforça o ambiente de estudo de caso, partindo da premissa de que se pode adquirir um conhecimento adequado do fenômeno a partir da exploração intensa de um único caso.

Como os estudos de caso normalmente fazem uso de diversas fontes de evidências, é relevante que os dados possam convergir e beneficiar-se de sua diversidade. A triangulação 
dos dados é salientada por Triviños (1987), para obter maior abrangência na descrição, explicação e compreensão do foco de estudo e também por Stake (2003), para reduzir a probabilidade de erro de interpretação. A presente pesquisa fez triangulação metodológica ao se utilizar de diferentes técnicas, como entrevistas, análise documental e observação participante.

Os documentos de relatos históricos, que fazem parte da pesquisa documental, referentes ao período de instituição e implementação do Programa de Qualidade e Produtividade na USP, além de portarias e outras publicações, têm a função de propiciar um entendimento do fenômeno como um todo, dado que cada um deles aborda suas facetas diferenciadas.

As descrições desses vários autores para o significado de um estudo de caso apontam que a escolha metodológica feita para esta tese é pertinente para o problema de pesquisa, tendo em vista suas características, listadas no Quadro 4.

\section{Quadro 4 - Características da pesquisa}

- Ocorre no local natural do fenômeno, onde o pesquisador conduz a pesquisa.

- Usa métodos interativos e humanísticos para a coleta de dados: entrevistas, documentos e observação participante.

- É de natureza interpretativa, porque o pesquisador pretende descrever e analisar dados por categorias ou temas, fazendo sua interpretação e delineando conclusões sob o seu ponto de vista pessoal.

- Desenvolve um raciocínio multifacetado, interativo e simultâneo; o processo de pensamento é dedutivo e indutivo, com um ciclo de idas e voltas aos dados coletados e analisados para a questão de pesquisa.

Fonte: Adaptado de Creswell (2002)

\subsection{Critérios para as escolhas da pesquisa}

A Universidade de São Paulo, tal como as outras duas universidades públicas do Estado de São Paulo, teve seu Programa de Qualidade e Produtividade, instituído após o decreto citado do governador Mário Covas, em 1995. Todavia, a continuidade desse Programa na USP, por um tempo mais longo que as demais, propiciou melhores condições para o entendimento do fenômeno a ser estudado. Programas dessa natureza exigem um tempo de maturação para que possam ser evidenciados e avaliados. Não se pode, ainda, deixar de considerar a facilidade de acesso aos entrevistados e à documentação existente na USP, uma vez que a pesquisadora 
trabalha na instituição, vivenciou e participou de grande parte do fenômeno em evidência. Daí a escolha da Universidade de São Paulo como objeto do estudo de caso em profundidade.

O nível de análise do estudo é organizacional e o indivíduo, participante da organização, pelo seu discurso transmite informações sobre o fenômeno estudado. Como unidade de observação a escolha recaiu em integrantes da Universidade, docentes e funcionários técnicos administrativos. Para a pesquisa de campo, foram realizadas entrevistas com pessoas que desempenharam um papel importante na implantação do Programa de Qualidade na USP e nas Unidades de Ensino e Pesquisa. As entrevistas com componentes da alta administração (docentes dirigentes) foram feitas com: um ex-reitor da Universidade; um ex-coordenador da Coordenadoria de Administração Geral (CODAGE), que também foi vice-reitor e presidente da Comissão de Gestão da Qualidade e Produtividade e ex-diretores das Unidades de Ensino e Pesquisa. Como servidores técnicos administrativos foram entrevistados, predominantemente, os titulares de cargos de assistentes técnicos de direção, que dentro da estrutura administrativa da Universidade são os que auxiliam de forma mais próxima os diretores no gerenciamento da organização e são, portanto, praticamente cogestores nas Unidades de Ensino e Pesquisa.

O critério de escolha das Unidades participantes da pesquisa foi o conhecimento da existência de experiências significativas sobre o fenômeno estudado. A documentação existente sobre o Programa de Qualidade e Produtividade na USP deu subsídio para essa escolha. A participação da pesquisadora no processo em estudo permite observar que o Programa em análise foi amplamente documentado em todas as suas fases. Isso se aplica à abordagem macrogerencial, registrada pela Comissão de Gestão da USP, que atuava em uma dimensão estratégica. Há registros do Programa em vídeos, fitas cassete (mídia comum na época), atas de reunião, publicações específicas, jornais internos e pesquisas de monitoramento, feitas pela Comissão que conduzia o Programa de Q\&P na Universidade.

Para a análise dos dados relacionaram-se os achados da pesquisa com a estrutura cognitiva da tese, elaborada com base nos autores consultados. O modelo usado para dar suporte à estrutura analítica para a compreensão dos processos de mudança cultural nas organizações foi o de Pettigrew (1990), que leva em conta três eixos principais: o contexto; o conteúdo e o processo da mudança. Resultados e avaliação, pela percepção dos entrevistados, foram itens incluídos pela pesquisadora, seguindo o modelo de Okumus (2003), para a implantação de novas estratégias nas organizações. 
Resgatando da fundamentação teórica, o contexto, segundo Pettigrew (1990), abrange uma dimensão externa, referente ao ambiente econômico, político e social em que a organização atua. $\mathrm{O}$ contexto interno refere-se à estrutura, à cultura organizacional e ao contexto político da organização, por meio dos quais as ideias de mudança devem fluir. O conteúdo reporta-se às áreas específicas de mudança que estão sendo examinadas. $\mathrm{O}$ processo de mudança referese às ações, reações e interações das várias partes interessadas, à medida que procuram alterar a organização em seu estágio presente, tendo em vista o futuro.

Portanto, o "por que" da mudança deriva de uma análise do contexto interno e externo, o "que" da mudança faz parte do conteúdo e o "como" da mudança, pode ser compreendido pela análise do processo.

No caso em pauta, o conteúdo da mudança está sintetizado no Programa de Qualidade e Produtividade da USP. O estudo toma como grade principal de análise, os Módulos de Qualidade, apresentados na publicação da Comissão de Gestão da Qualidade da USP (1997), que por meio de um questionário orientou o Mapeamento de Características da Qualidade e Produtividade das Unidades e Órgãos. Retomam-se os Módulos de Qualidade da Fundamentação Teórica, em que os Critérios de Excelência do Prêmio Nacional da Qualidade (1996) combinados aos Balizadores da Qualidade no Serviço Público (1996) foram classificados como: 1) Liderança; 2) Planejamento; 3) Foco no Cliente; 4) Informação e Análise; 5) Desenvolvimento e Gestão de Pessoas; 6) Gestão de Processos e 7) Parcerias e Alianças.

\subsection{Estratégia para a coleta de dados}

Segundo Mattar (2002), os dados podem ser classificados em dois grupos: primários e secundários. Dados primários são aqueles que ainda não foram coletados, ou seja, aqueles que são ou estão na posse dos pesquisados. As fontes são pessoas com informações sobre o objeto de pesquisa. Os dados secundários são aqueles já coletados, tabulados e analisados para outros fins, tais como: relatórios; publicações; jornais; atas; portarias etc..

Como instrumento para a coleta dos dados primários foi elaborado um questionário, que contemplava um Roteiro de Entrevista, a ser seguido em entrevista face a face. O questionário 
foi respondido pelo entrevistado e as respostas registradas pelo pesquisador foram, simultaneamente, gravadas, para posterior transcrição, objetivando maior fidedignidade do conteúdo registrado.

A entrevista é uma técnica investigativa que permite maior exploração histórica da organização, das opiniões, motivações, expectativas, percepções e interpretações da realidade organizacional. Para Gil (1999, p. 117), a entrevista pode ser classificada como "uma técnica em que o investigador se apresenta frente ao investigado e lhe questiona com perguntas, com o objetivo de obtenção dos dados que interessam à investigação. A entrevista é, portanto, uma forma de interação social."

Por sua vez, Berger e Luckmann (2005, p. 57-58) reforçam que o processo de entrevista é um processo direto de interação social em que os discursos produzidos face a face permitem reconstruir os acontecimentos. Os autores observam:

Falo como penso e o mesmo faz meu interlocutor na conversa. Ambos ouvimos o que cada qual diz virtualmente no mesmo instante, o que torna possível e contínuo, sincronizado e recíproco o acesso às nossas duas subjetividades, uma aproximação intersubjetiva na situação face a face que nenhum outro sistema de sinais pode reproduzir. Mais ainda, ouço a mim mesmo à medida que falo. Meus próprios significados subjetivos tornam-se objetiva e continuamente alcançáveis por mim e ipso facto passam a ser "mais reais" para mim.

O instrumento de coleta de dados primários foi, portanto, a entrevista semiestruturada, com Roteiro de Entrevista, que permitisse abordar as questões de pesquisa. Foram utilizados dois diferentes Roteiros de Entrevista (Tipo 1 e Tipo 2): o primeiro deles para docentes e o outro para servidores técnicos administrativos, ambos reproduzidos nos Apêndices. (LAKATOS; MARCONI, 2005).

O Roteiro de Entrevista Tipo 1, para docentes, era composto de 25 questões, das quais 23 abertas e 2 fechadas e 5 variáveis de identificação. O Roteiro de Entrevista Tipo 2, para técnicos administrativos, continha um conjunto adicional de questões em relação à dos docentes, uma vez que eles possuíam mais elementos sobre as condições operacionais, resultados da implantação do Programa e percepção de mudanças ocorridas no período. Além disso, os dados referentes às características pessoais foram mais detalhados. Na maioria dos casos, esses entrevistados acompanharam por mais tempo o Programa de Qualidade do que os próprios diretores de Unidades, que por Estatuto da Universidade, são substituídos a cada 
quatro anos. O Roteiro de Entrevista Tipo 2 era formado das mesmas questões do primeiro Roteiro com 43 questões complementares, fechadas e abertas relativas às Atividades de Treinamento, Participação na Comissão de Qualidade e Produtividade, Aprendizagem, Competência, Participação em Tomada de Decisões, Interação entre funcionários, Qualidade de Vida no Trabalho, além de 13 questões de identificação.

Para cada uma das formulações do instrumento de coleta de dados foi realizado um pré-teste, apresentando-se o modelo a três pessoas que analisaram e avaliaram o entendimento das questões. Houve algumas sugestões de pequenas alterações, que foram realizadas.

A coleta de dados primários foi feita em um período post-facto. O estudo é considerado como ex-post facto, na medida em que a investigação empírica se faz no presente, sobre um fato acontecido no passado e que eventualmente o fenômeno perdura até o presente.

A coleta de dados secundários originou-se de várias fontes: site institucional da USP; matérias publicadas em jornais; revistas e livros sobre o assunto; Atas de Reunião; documentos e publicações específicas da Comissão de Gestão de Qualidade da USP e vídeos de Encontros da Qualidade. Registros pontuais significativos, também, foram obtidos com monografias elaboradas por funcionários técnicos administrativos da USP. Tais monografias faziam parte da exigência para a conclusão de Curso de Master Business Administration (MBA) de Gestão e Tecnologias da Qualidade, promovido pela Escola Politécnica da USP, por meio do PECE, ao qual participaram cerca de 120 funcionários da Universidade. A relação das monografias encontra-se no Apêndice. Além disso, foi feito pela pesquisadora, em junho de 2008, um levantamento sistemático de sites de todas as Unidades de Ensino e Pesquisa da USP.

\subsection{Procedimentos para tratamento e análise dos dados}

Os dados da pesquisa de campo, complementados com dados do Anuário Estatístico da USP de 1997, 2008 e 2009, foram organizados em três partes:

1) Dimensões das Unidades de Ensino e Pesquisa da USP;

2) Características da Amostra de Entrevistados;

3) Análise de Conteúdo e Discurso do Sujeito Coletivo. 
Na primeira das partes, são apresentadas as Dimensões das Unidades de Ensino e Pesquisa da USP, que caracterizam as unidades amostrais. Aí se incluem as variáveis: ano de criação (extraída do Anuário Estatístico da USP); localização (capital e interior); área de concentração do conhecimento (ciências biológicas, exatas e humanas); porte da Unidade; número de matrículas na graduação; número de matrículas na pós-graduação; número de professores e número de servidores técnicos administrativos (dados de 1996 e 2007 do Anuário Estatístico da USP). Complementa-se o quadro de descrição das Unidades com um gráfico de uma série histórica que permite visualizar a evolução das unidades pesquisadas em relação ao número de alunos (graduação e pós-graduação) e de seus recursos humanos (docentes e servidores técnicos administrativos), tal como é apresentado para a Universidade como um todo.

Na segunda parte, consolidam-se os dados sobre as Características da Amostra dos entrevistados, com as variáveis: gênero; categoria profissional; faixa etária; função e área de formação. Algumas variáveis adicionais, extraídas dos dados de identificação do questionário Tipo 2, para os funcionários técnicos administrativos, também foram incluídas nesse bloco, como: tempo de vida profissional; tempo de USP; tempo de Unidade; tempo na função e escolaridade.

Na terceira parte, faz-se a Análise de Conteúdo dos achados de pesquisa das variáveis qualitativas, segundo as quatro categorias já mencionadas: contexto; conteúdo; processo e resultados/avaliação e apresenta o Discurso do Sujeito Coletivo para algumas variáveis.

Os dados primários, extraídos de questões fechadas, foram registrados em uma planilha eletrônica Excel e teve um tratamento estatístico feito pelo SPSS - Statistical Package for the Social Sciences. Optou-se por apresentar para cada questão individualmente os cálculos de frequência absoluta e relativa, assim como os gráficos correspondentes.

Os dados primários, referentes à parte qualitativa da pesquisa de campo, foram objeto de análise de conteúdo, conforme técnica descrita por Bardin (1994), com uma interpretação social dos discursos. Os discursos dos entrevistados foram organizados por questões e dentro delas categorizados, de forma a poder observar as visões particulares do fenômeno estudado. 
Segundo Bardin (1994):

A análise de conteúdo é um conjunto de instrumentos metodológicos cada vez mais sutis em constantes aperfeiçoamentos, que se aplicam aos discursos extremamente diversificados; é ainda um conjunto de técnicas de análise de comunicação visando a obter, por procedimentos sistemáticos e objetivos de descrição do conteúdo das mensagens, indicadores (quantitativos ou não) que permitam a inferência de conhecimentos relativos às condições de produção e recepção destas mensagens.

Ainda para a mesma autora:

A decodificação de um documento pode utilizar-se de diferentes procedimentos para obter o significado profundo dos conteúdos emergentes, entre estes se evidencia a decomposição do texto, privilegiando um aspecto de análise, a exemplo da classificação de acordo coma categorização temática, a análise categorial.

Por ser interpretativa, a prática da análise de discurso não pode ser reduzida a uma série de passos, aplicados mecanicamente. Todavia, segundo Bardin (1994), de forma geral na análise de conteúdo podem ser identificadas três etapas básicas, que foram seguidas nesta pesquisa: a) pré-análise; b) exploração do material e c) tratamento dos dados, inferência e interpretação. Essas três etapas permitem categorizar as falas dos entrevistados e situá-las dentro das categorizações. Na primeira fase, há uma leitura cuidadosa e recorte das partes relevantes de todas as entrevistas; em seguida, define-se uma codificação segundo categorias significativas e aglutinam-se os resultados em categorias semelhantes; finaliza-se com a análise e interpretação dos resultados.

Complementando, segundo Harrison (1999), a codificação dos dados para uma análise qualitativa pode ser efetuada, em uma primeira etapa, com uma codificação aberta, que consiste em separar, comparar e categorizar os dados. As categorias são comparadas uma à outra e as semelhantes são agrupadas quando elas se aproximam de um fenômeno semelhante. A codificação de inferência é a segunda etapa que consiste em estabelecer os laços entre as categorias e situá-las dentro de um contexto que representa um conjunto particular de condições nas quais as estratégias de ações são tomadas.

Utilizando-se do esquema interpretativo de Pettigrew (1990), a partir das quatro categorias de análise para a interpretação dos dados: contexto; conteúdo; processo e resultados/avaliação, as falas dos entrevistados forneceram os elementos para uma categorização interna, dos discursos feitos em resposta a cada pergunta. Em particular, como grade fechada de análise de 
duas perguntas do conteúdo do Programa (Questão 02 e 15) e de resultados (Questão 18) foram usados para categorização interna os Módulos de Qualidade.

Para as questões pertinentes, as respostas foram agrupadas por categoria profissional, ou seja, segundo os respondentes fossem dirigentes docentes ou técnicos administrativos.

Seguem-se, a cada uma das questões qualitativas uma tabela, um gráfico e a reprodução de fragmentos selecionados dos entrevistados, que ilustram as categorias existentes.

As questões qualitativas, referentes só aos técnicos administrativos, foram tratadas pelo método do Discurso do Sujeito Coletivo (DSC), tal como descrito em Lefrève e Lefrève (2003). O Discurso do Sujeito Coletivo (DSC) é uma estratégia metodológica que visa tornar mais clara uma dada representação social. Segundo Lefrève e Lefrève (2003, p. 19 - 20) o

discurso do Sujeito Coletivo (DSC) é um discurso síntese, que reduz a variabilidade discursiva empírica, buscando reconstruir, com pedaços dos discursos individuais, como em um quebracabeça, tantos discursos-síntese quantos julgue necessários para expressar uma dada figura, ou seja, um dado pensar ou representação social sobre um fenômeno. O DSC representa, sob uma forma de discurso, como os indivíduos reais, concretos pensam; ele contempla as idéias centrais dos discursos individuais e todos reunidos, de uma forma sintética busca a reconstituição da representação social.

\subsection{Distribuição das questões do roteiro de entrevista por categoria de análise}

O Quadro 5, a seguir, apresenta a distribuição das questões do Roteiro de Entrevista e a sua correspondência à grade fechada das categorias de análise. O primeiro dos quadros identifica as questões comuns aos Roteiros do Tipo 1 e Tipo 2. O Quadro 6 contém as questões complementares elaboradas, somente, para servidores técnicos administrativos. 
Quadro 5 - Distribuição das questões comuns aos Roteiros Tipo 1 e Tipo 2

\begin{tabular}{|c|c|c|c|c|c|c|c|c|c|c|c|c|c|c|c|c|c|c|c|c|c|c|c|c|c|c|c|c|c|c|}
\hline \multirow{2}{*}{\multicolumn{2}{|c|}{ CATEGORIA DE ANÁLISE }} & \multicolumn{29}{|c|}{ QUESTÕES DO ROTEIRO (Q) } \\
\hline & & \multirow{2}{*}{1} & \multirow{2}{*}{2} & \multirow{2}{*}{3} & \multirow{2}{*}{4} & \multirow{2}{*}{5} & \multirow{2}{*}{6} & 7 & \multirow{2}{*}{8} & \multirow{2}{*}{9} & \multirow{2}{*}{\multicolumn{2}{|c|}{10}} & & \multirow{2}{*}{12} & \multirow{2}{*}{13} & \multirow{2}{*}{14} & & 16 & \multirow{2}{*}{17} & \multirow{2}{*}{18} & \multirow{2}{*}{19} & \multirow{2}{*}{20} & \multirow{2}{*}{21} & \multirow{2}{*}{\multicolumn{2}{|c|}{22}} & \multirow{2}{*}{23} & \multirow{2}{*}{24} & 25 & 26 & Total \\
\hline 1 & Contexto & & & & & & & 7 & & & & 11 & & & & & 1. & & & & & & & & & & & & & 2 \\
\hline 2 & Conteuido & & & & & & & & & & & & & & & & & & & & & & & & & & & & & 4 \\
\hline 3 & Processo & & & & & & & & & & & & & & & & & & & & & & & & & & & & & 11 \\
\hline 4 & Resultado/Avaliação & & & & & & & & & & & & & & & & & & & & & & & & & & & & & 5 \\
\hline
\end{tabular}

Quadro 6 - Distribuição dos dados complementares do Roteiro Tipo 2

\begin{tabular}{|c|c|c|c|c|c|c|c|c|c|c|c|c|c|c|c|c|c|c|c|c|c|c|c|c|c|}
\hline \multirow{2}{*}{\multicolumn{2}{|c|}{ CATEGORIA DE ANÁLISE }} & \multicolumn{24}{|c|}{ QUESTÕES DO ROTEIRO } \\
\hline & & 27 & 28 & 29 & 30 & 31 & 32 & 33 & 34 & 35 & 36 & 37 & 38 & 39 & 40 & 41 & 42 & 43 & 44 & 45 & 46 & 47 & 48 & 49 & Total \\
\hline \multirow[t]{7}{*}{4} & Resultado/Avaliação & & & & & & & & & & & & & & & & & & & & & & & & 1 \\
\hline & Treinamento & & & & & & & & & & & & & & & & & & & & & & & & 3 \\
\hline & Participação & & & & & & & & & & & & & & & & & & & & & & & & 6 \\
\hline & Aprendizagem & & & & & & & & & & & & & & & & & & & & & & & & 4 \\
\hline & Competencia & & & & & & & & & & & & & & & & & & & & & & & & 4 \\
\hline & Interação & & & & & & & & & & & & & & & & & & & & & & & & 3 \\
\hline & QVT & & & & & & & & & & & & & & & & & & & & & & & & 2 \\
\hline
\end{tabular}

QVT: Qualidade de Vida no Trabalho

As questões 50 a 69, incluídas no Roteiro Tipo 2, referem-se a Dados Gerais de Identificação e a pergunta 70, de caráter opcional, para comentários gerais do entrevistado.

As questões Q02, Q15 e Q18, para efeito de localização temporal, são tratadas como pertencentes a:

- 1- Fase: (T1). Início do Programa (Questão 02: Expectativas de Conteúdo);

- 2- Fase: (T2). Rotina do Programa (Questão 15: Atividades Formais) e

- 3- Fase: (T3). Final do Programa (Questão 18: Experiências Positivas)

As respostas dadas a essas três questões, assim como para as questões Q24 e Q25, relativas a impactos do Programa, foram classificadas segundo aderência aos Módulos de Qualidade, já apresentados na fundamentação teórica e resumidos pelo Quadro 7, a seguir: 
Quadro 7 - Módulos de Qualidade

\begin{tabular}{|c|l|l|}
\hline No & \multicolumn{1}{|c|}{ Módulos de Qualidade } & \multicolumn{1}{|c|}{$\begin{array}{c}\text { Critérios e } \\
\text { Balizadores }\end{array}$} \\
\hline 1 & Liderança e Envolvimento & C1 e B2 \\
\hline 2 & Planejamento & C2 \\
\hline 3 & Foco no Cliente e Sociedade & C3 e B1 \\
\hline 4 & Informação e Análise & C4 e B4 \\
\hline 5 & Desenvolvimento e Gestão de Pessoas & C5 e B3 \\
\hline 6 & Gestão de Processos & C6, B5, B6 e B7 \\
\hline 7 & Parcerias e Alianças & C7 e B8 \\
\hline C1 a C7 - Critérios do PNQ (1996) \\
B1 a B8 - Balizadores do Serviço Público (1996)
\end{tabular}

As questões Q02 e Q15 estão incluídas na Categoria de Análise 2 - Conteúdo do Programa de Q\&P e Q18, Q24 e Q25 inserem-se na Categoria de Análise 4 de Resultados/Avaliação do Programa. Em Considerações sobre a Pesquisa de Campo, as 3 fases apreciadas para efeito de análise, nos três momentos do Programa de Qualidade e Produtividade da USP e identificadas como T1, T2 e T3, são comparadas pelos Módulos de Qualidade, por meio de gráficos de síntese de resultados.

Estão discriminadas, a seguir, para cada uma das categorias de análise, as questões que as compõem.

\section{a) Categoria de Análise 1: Contexto}

Nessa categoria, procura-se examinar quais os fatores propulsores e o contexto existente para o início da adesão ao Programa. Para responder a essa questão incluem-se as questões:

Q01 Por que a Unidade na sua gestão aderiu ao Programa de Qualidade USP?

Q05 Qual era o contexto (interno/externo) da Unidade na época?

\section{b) Categoria de Análise 2 - Conteúdo}

Incluem-se na Categoria de Análise 2, sobre Conteúdo do Programa as questões:

Q02 O que se esperava do Programa em linhas gerais, como conteúdo?

Q03 A Qualidade de Vida no Trabalho (QVT) estava incluída nesse conteúdo?

Q04 O que significava para você Qualidade de Vida no Trabalho?

Q15 Existiam atividades formais denominadas ou vindas do Programa de Qualidade? 


\section{c) Categoria de Análise 3 - Processo}

Para conhecer o processo de implantação do Programa de Qualidade e Produtividade da USP foram contempladas questões relativas ao modelo de implantação, recursos: financeiros e humanos, estrutura, metodologia, monitoramento e indicadores de produtividade.

Q06 Como foi o modelo de implantação do processo de qualidade na Unidade?

Q07 Como se lembra da receptividade interna ao Programa de Qualidade?

Q08 Havia recursos financeiros alocados para o Programa?

Q09 Se sim, era alguma porcentagem específica do orçamento?

Q10 Foi delineada uma estrutura administrativa para sustentá-lo?

Q11 Havia um poder decisório definido para o Programa?

Q12 Existiam áreas específicas envolvidas no Programa?

Q13 Existiam funcionários especialmente envolvidos com as atividades da Qualidade?

Q14 Havia métodos para identificar necessidades de melhorias na Unidade?

Q16 Existia um monitoramento dos resultados das atividades do Programa de Qualidade?

Q17 Existiam indicadores de produtividade na Unidade?

\section{d) Categoria de Análise 4 - Resultados/Avaliação}

Para essa categoria de análise, relativa a Resultados/Avaliação, incluem-se questões sobre experiências positivas e negativas, avaliação e percepção de valor/impacto e conceitos do Programa, emitidos por dirigentes e técnicos administrativos.

Q18 Cite 3 experiências positivas que ocorreram na sua Unidade, em função do Programa de Q\&P.

Q18.1 Cite 3 experiências negativas que ocorreram na sua Unidade, em função do Programa de Q\&P.

Q22 Que conceito daria para o Programa na Unidade na sua gestão?

Q23 Acompanhou o Programa após sair da Unidade?

Q23a Que conceito daria para o Programa na Unidade na gestão seguinte a sua?

Q23b Que conceito daria para o Programa na gestão atual?

Q24 Para dirigentes: o que foi o Programa de Q\&P para sua gestão? Teve valor/impacto para a Unidade e para a USP? Para o governo? Para a sociedade? De que natureza? Onde? Como? Explique. 
Q25 Para técnicos administrativos: o que tem sido o Programa de Q\&P para a Unidade? Teve valor/impacto para a Unidade e para a USP? Para o governo? Para a sociedade? De que natureza? Onde? Como? Explique.

Q27 Para técnicos administrativos: o que foi o Programa para você do ponto de vista pessoal e profissional?

Nessa categoria de Resultados/Avaliação também estão incluídas questões referentes a Treinamento e mudanças em Aprendizagem pessoal e organizacional, Competência pessoal e organizacional, Participação em Tomada de Decisões, Interação entre funcionários na Unidade e na USP e Qualidade de Vida no Trabalho (QVT). Elas foram aplicadas, apenas, aos servidores técnicos administrativos e as questões correspondentes podem ser visualizadas no Quadro 6 de Distribuição dos dados complementares do Roteiro Tipo 2, já apresentado.

Os conceitos atribuídos ao Programa de Q\&P, pelos dirigentes, para sua gestão, para a gestão seguinte e para a gestão atual (2008), foram apresentados em uma só tabela, com as categorias fechadas em: excelente; bom e regular/insuficiente. Os conceitos emitidos ao Programa por técnicos administrativos foram apresentados, com as mesmas categorias, para os períodos fechados de 1996 a 2000; 2001 a 2005 e 2006 a 2008.

As mudanças ocorridas na USP, na percepção dos entrevistados, com relação à aprendizagem pessoal e organizacional, competência pessoal e organizacional, participação em tomada de decisões administrativas, interação entre funcionários dentro da Unidade e entre funcionários da USP e atividades de qualidade de vida no trabalho foram levantadas para cada item por uma questão fechada e uma aberta. As questões fechadas foram quantificadas pelas suas categorias, enquanto as questões abertas foram tratadas com o Discurso do Sujeito Coletivo (DSC). Após leitura de todas as respostas abertas compôs-se um texto único, como uma narrativa, em que são reproduzidas as falas dos respondentes, como se fosse uma única voz, retiradas redundâncias, quanto ao conteúdo.

Com tais procedimentos, discorre-se na Apresentação e Discussão dos Resultados sobre os significados dos achados de pesquisa.

A pesquisa documental recebeu uma sistematização descritiva das diferentes fases do processo, discorrendo sobre os principais fatos que emergiram do levantamento do histórico 
do Programa de Qualidade e Produtividade da USP. É complementada com Linhas do Tempo com as Atividades do Programa na USP e nas Unidades e Órgãos, de 1996 - 2006, apresentadas nos Apêndices.

\subsection{Quadro síntese geral da pesquisa}

O quadro síntese geral da pesquisa, denominado de matriz de amarração, completa o capítulo indicando as etapas e os itens principais da pesquisa. Segundo Telles (2001, p. 65) a

matriz de amarração é um instrumento de análise que objetiva avaliar a coerência das relações estabelecidas entre as dimensões e decisões de encaminhamento de uma pesquisa e desse modo, indicar a consistência metodológica da intervenção científica.

\begin{tabular}{|c|c|c|c|c|}
\hline $\begin{array}{l}\text { OBJETIVO } \\
\text { GERAL }\end{array}$ & $\begin{array}{l}\text { QUESTÕES } \\
\text { DE } \\
\text { PESQUISA }\end{array}$ & $\begin{array}{l}\text { FUNDAMENTAÇÃO } \\
\text { CONCEITUAL }\end{array}$ & $\begin{array}{c}\text { TÉCNICA E } \\
\text { INSTRUMENTO } \\
\text { DE COLETA }\end{array}$ & $\begin{array}{c}\text { TÉCNICA } \\
\text { DE } \\
\text { ANÁLISE }\end{array}$ \\
\hline $\begin{array}{l}\text { Investigar } \\
\text { resultados de } \\
\text { um } \\
\text { Programa de } \\
\text { Qualidade e } \\
\text { Produtividade, } \\
\text { pelo seu resgate } \\
\text { histórico }\end{array}$ & $\begin{array}{l}\text { Principal } \\
\text { Como um } \\
\text { programa de } \\
\text { Qualidade } \\
\text { pode ser } \\
\text { implementado } \\
\text { em uma } \\
\text { universidade } \\
\text { pública } \\
\text { Auxiliar } \\
\text { Qual a } \\
\text { percepção dos } \\
\text { atores quanto } \\
\text { aos efeitos do } \\
\text { programa na } \\
\text { instituição? }\end{array}$ & $\begin{array}{c}\text { Qualidade } \\
\text { Mudanças } \\
\text { Organizacionais } \\
\text { Gestão Pública }\end{array}$ & $\begin{array}{l}\text { Roteiro de entrevista: } \\
\text { - ex-dirigentes } \\
\text { - servidores } \\
\text { técnicos } \\
\text { administrativos } \\
\text { Literatura } \\
\text { Vídeos } \\
\text { Sites das Unidades } \\
\text { Observação } \\
\text { Participante }\end{array}$ & $\begin{array}{l}\text { Análise de } \\
\text { Conteúdo } \\
\text { Análise } \\
\text { Documental } \\
\\
\text { Discurso do } \\
\text { Sujeito } \\
\text { Coletivo }\end{array}$ \\
\hline
\end{tabular}

Fonte: Adaptação de Telles, 2001 


\section{APRESENTAÇÃO E DISCUSSÃO DOS RESULTADOS}

Descreve-se, inicialmente, de forma sucinta, a Universidade de São Paulo, seguida da apresentação e discussão dos resultados da pesquisa de campo e da pesquisa documental, discorrendo sobre os principais fatos que emergiram do levantamento do histórico do Programa de Qualidade e Produtividade da USP.

\subsection{A Universidade de São Paulo}

A Universidade de São Paulo (USP) é uma das maiores formadoras de professores para o magistério superior do país, levando-se em consideração a graduação e seus cursos de pósgraduação. Ela é a mais antiga e a maior universidade dentre as três universidades públicas do Estado de São Paulo.

A USP foi criada em 25 de janeiro de 1934, quando o então governador do Estado de São Paulo, Armando de Salles de Oliveira, com uma comissão composta por pessoas notáveis da época, assinou o Decreto-lei 6.283. Aspirava, então, ser a primeira universidade no País, digna desse nome, com uma qualidade incomparável às melhores do mundo. Conforme Schwartzman (2006, p. 25):

\footnotetext{
[...] além desse ideal cultural e científico, a USP tinha outra ambição, a de contribuir para reconquistar a liderança nacional que São Paulo havia perdido com a Revolução de 1932. Para fazer isso, fundadores da Universidade, Júlio de Mesquita e Teodoro Ramos à frente, foram buscar os melhores talentos que conseguiriam encontrar na Europa e criaram de fato, uma das melhores instituições de ensino superior e pesquisa no Brasil e na América Latina, tanto na formação profissional quanto na pesquisa científica, assim como no prestígio e reconhecimento que a Universidade tem diante da sociedade.
}

Ela nasceu, conforme o site da USP, com o intuito de "promover a pesquisa e o progresso da ciência, por meio da formação de especialistas em todos os ramos da cultura e em todas as profissões de base científica ou artística."

A USP foi formada em sua origem por sete escolas tradicionais já existentes (ESALQ, EP, FCF, FD, FM, FMVZ e FO) e uma nova unidade, a Faculdade de Filosofia, Ciências e Letras. Três dessas escolas iniciadoras da USP, a Escola Politécnica, a Faculdade de Ciências 
Farmacêuticas e a Faculdade de Medicina Veterinária e Zootecnia são participantes desta pesquisa.

De acordo com o artigo $2^{\circ}$ do USP. Estatuto USP (2005), ela tem como fins:

I - promover e desenvolver todas as formas de conhecimento, por meio de ensino e da pesquisa; II - ministrar o ensino superior visando à formação de pessoas capacitadas ao exercício da investigação e do magistério em todas as áreas do conhecimento, bem como à qualificação para as atividades profissionais e

III - estender à sociedade os serviços indissociáveis das atividades de ensino e de pesquisa.

Para atingir os seus fins de ensino, pesquisa e extensão nos níveis de graduação e pósgraduação, a USP apresenta, pela base de dados de 2008, de seu Anuário Estatístico (2009): 40 unidades de ensino e pesquisa; 7 centros e institutos especializados; 19 órgãos de direção e serviço; 4 museus e 2 hospitais.

As unidades de ensino estão distribuídas em sete campi universitários, sendo um na Capital e os outros nas cidades do Interior: Bauru; Piracicaba; Pirassununga; Ribeirão Preto; São Carlos e Lorena. A Cidade Universitária Armando de Salles Oliveira, na capital, concentra a infraestrutura administrativa da Universidade e 19 unidades de ensino e pesquisa. Na cidade de São Paulo, encontram-se, ainda, quatro grandes unidades de ensino, localizadas fora do campus universitário. Quatro unidades (ICMC, IFSC, FMRP e FCFRP) de dois dos campi do interior (São Carlos e Ribeirão Preto) integraram a pesquisa.

A Universidade de São Paulo tem como entidade mantenedora o Governo do Estado de São Paulo; é uma autarquia de regime especial, com autonomia didático-administrativa, disciplinar e de gestão financeira e patrimonial. A Reitoria, órgão que superintende todas as atividades universitárias é composta por: Gabinete do Reitor, Gabinete do Vice-Reitor e Ouvidoria; Prós-Reitorias de Graduação, Pós-Graduação, Pesquisa e Cultura e Extensão Universitária; Secretaria Geral e Coordenadorias, além de outros Órgãos.

Para dar suporte às atividades fins, a USP possui infraestrutura administrativa extensa e segundo seu Estatuto tem como Órgãos centrais: o Conselho Universitário (Co); os Conselhos Centrais: Conselho de Graduação, Conselho de Pós-Graduação, Conselho de Pesquisa e Conselho de Cultura e Extensão Universitária; a Reitoria; 4 Pró-Reitorias (Graduação, Pós- 
Graduação, Pesquisa e Cultura e Extensão) e o Conselho Consultivo. Os organogramas da USP, da Reitoria e de Unidade de Ensino e Pesquisa são apresentados nos Anexos.

O Estatuto USP (2005) estabelece a estrutura e competência dos órgãos que compõem a Reitoria, bem como do Conselho Universitário.

O Quadro 9 mostra a evolução de alguns dos principais indicadores de desempenho da Universidade de São Paulo, em dois momentos: 1996, data do início do fenômeno analisado nesta tese e em 2008, ano de término de levantamento dos dados primários.

Quadro 9 - Evolução de indicadores de desempenho da USP em 1996 e 2008

\begin{tabular}{|l|r|r|r|}
\hline \multicolumn{1}{|c|}{ Indicador } & $\mathbf{1 9 9 6}$ & $\mathbf{2 0 0 8}$ & $\begin{array}{c}\text { Variação (\%) } \\
\mathbf{1 9 9 6 / 2 0 0 8}\end{array}$ \\
\hline Unidades de Ensino e Pesquisa & 35 & 40 & 14,28 \\
\hline Cursos de Graduação & 129 & 238 & 84,50 \\
\hline Cursos de Pós-Graduação & 476 & 611 & 28,36 \\
\hline Cursos de Mestrado & 257 & 316 & 22,96 \\
\hline Cursos de Doutorado & 219 & 295 & 34,70 \\
\hline Vagas oferecidas no ano & 6.872 & 10.302 & 49,91 \\
\hline Alunos matriculados na graduação & 32.963 & 55.863 & 69,47 \\
\hline Alunos matriculados na pós-graduação & 20.524 & 25.495 & 24,22 \\
\hline Alunos matriculados no Mestrado & 12.091 & 13.229 & 9,41 \\
\hline Alunos matriculados no Doutorado & 8.433 & 12.266 & 45,45 \\
\hline Alunos Especiais de Pós-Graduação & 2.927 & 5.824 & 98,98 \\
\hline Docentes & 4.953 & 5.638 & 13,83 \\
\hline Porcentagem de docentes com título de Doutor ou superior & 83,0 & 97,4 & 17,35 \\
\hline Porcentagem de Docentes com dedicação integral (RDIDP) & 75,9 & 82,9 & 9,22 \\
\hline Publicações Brasil e exterior (*) & 2.044 & 8.654 & 323,39 \\
\hline Total de Técnicos administrativos & 14.729 & 15.438 & 4,81 \\
\hline Técnico administrativo superior & 2.863 & 3.395 & 18,58 \\
\hline Técnico administrativo técnico & 6.235 & 7.029 & 12,73 \\
\hline Total de alunos matriculados por docente ativo & 10,8 & 14,4 & 33,33 \\
\hline Total de alunos matriculados por servidor não docente ativo & 3,6 & 5,3 & 47,22 \\
\hline (*) & & & \\
\hline
\end{tabular}

(*) Indexados no Institute of Science Information (ISI)

Fonte: Adaptado do Anuário Estatístico da USP (1997 e 2009)

Como se pode observar no quadro anterior, a USP ostenta uma tendência crescente na maior parte de seus indicadores. É fundamental destacar, no período, o expressivo aumento no número de cursos $(84,50 \%)$ e no número de vagas oferecidas $(49,91 \%)$, resultado de um atendimento à forte demanda da sociedade. Sobressai-se, também, o grande aumento do número de publicações $(323,39 \%)$, influenciado pelo maior rigor e exigência de critérios de 
avaliação da $\mathrm{CAPES}^{8}$. Em contrapartida, o número de docentes e o número de técnicos administrativos tiveram um crescimento pequeno, se comparado aos outros aumentos, o que impactou nos valores das medidas clássicas de produtividade da Universidade: relação de total de alunos matriculados por docente ativo $(33,33 \%)$ e total de alunos matriculados por servidor não docente ativo (47,22\%). Os percentuais maiores em 2008 denotam uma relação de maior aproveitamento dos recursos humanos da Universidade.

O Gráfico 2 permite a visualização de uma série histórica (1996 - 2008) de dados da USP, referentes ao número:

- $\quad$ de matrículas na graduação;

- de matrículas na pós-graduação, incluindo alunos especiais;

- de professores;

- $\quad$ de servidores técnicos administrativos.

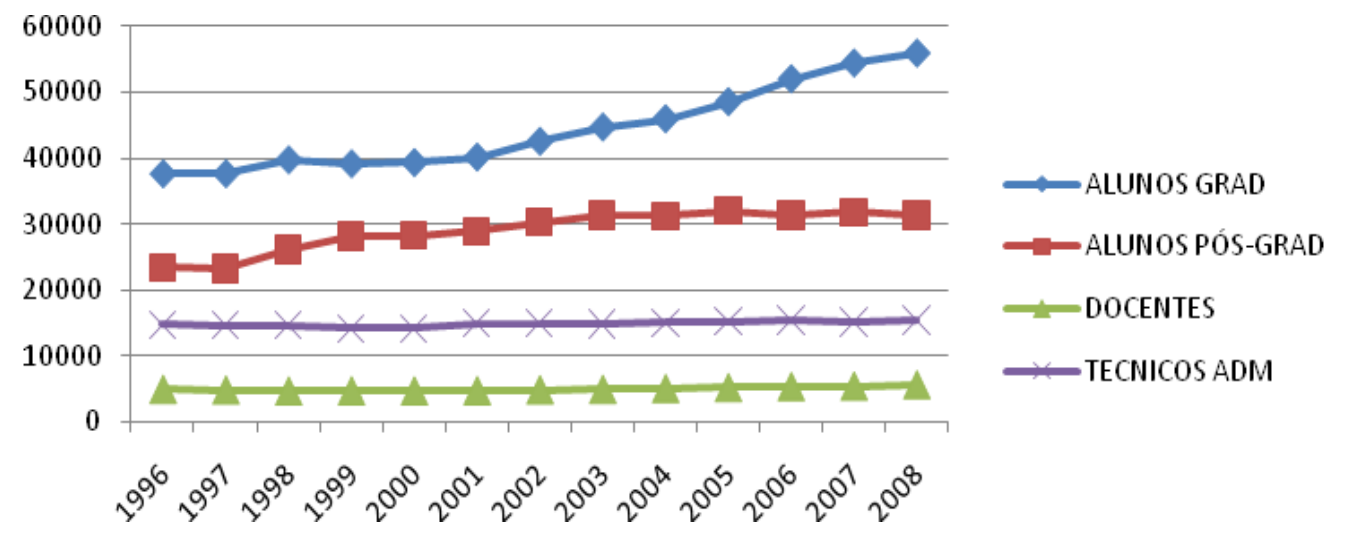

Gráfico 2 - Dados da USP: série histórica 1996 - 2008

Fonte: Anuário Estatístico da USP (1997 e 2009)

De modo geral, pode-se notar uma tendência de aumento no número de alunos de graduação e de pós-graduação, no período de 1996 a 2008, e uma relativa estabilidade no que diz respeito ao número de docentes e técnicos administrativos.

8 A CAPES, fundada em 1951, subsidia o Ministério da Educação na formulação de políticas nacionais para a área de pós-graduação, visando sua melhoria, pela avaliação, divulgação, formação de recursos e promoção da cooperação científica internacional. 
Atualmente, a USP é a maior instituição pública de ensino superior e de pesquisa do País e mantém-se como principal centro gerador e difusor de conhecimentos na sua categoria. Por meio de seus indicadores, pode-se avaliar o alcance desses objetivos. Ela forma grande parte dos mestres e doutores do corpo docente do ensino particular brasileiro e carrega um rico lastro de realizações, evoluindo nas áreas da educação, ciência, tecnologia e artes.

\subsection{Os achados da pesquisa de campo}

A pesquisa de campo realizou-se durante oito meses, de janeiro a agosto de 2008. A coleta de dados primários baseou-se em entrevistas com informantes-chaves, que consumiram 32 horas de gravação. As respostas foram transcritas em 176 páginas e ordenadas por pergunta do questionário. Foram entrevistados docentes dirigentes e funcionários técnicos administrativos da USP que tiveram participação fundamental no processo de implantação do Programa de Qualidade e Produtividade da Universidade.

Tal como descrito na Metodologia, para maior clareza na apresentação do conjunto de dados levantados, optou-se por dividir os resultados da pesquisa de campo em três partes.

Na primeira das partes, apresentam-se as Dimensões das Unidades de Ensino e Pesquisa da USP, que foram objeto da pesquisa: ano de criação; localização (capital e interior); área de concentração do conhecimento (ciências biológicas, exatas e humanas); porte da Unidade (dados de 1996 e 2007). Para essa última variável e no sentido de verificar se o porte das Unidades foi alterado entre 1996 e 2007, registram-se, também, para esses dois anos, o número de alunos de graduação e de pós-graduação, o número de docentes e o número de servidores técnicos administrativos. Complementa-se o quadro de descrição das Unidades com um gráfico de uma série histórica que permite visualizar a evolução das unidades pesquisadas em relação ao número de alunos (graduação e pós-graduação) e de seus recursos humanos (docentes e servidores técnicos administrativos), tal como foi apresentado para a Universidade como um todo.

Na segunda parte, consolidam-se os dados sobre as Características da Amostra, apresentadas pelas variáveis: gênero; categoria profissional; faixa etária; função e por área de concentração da formação. Algumas variáveis adicionais, como: tempo de vida profissional; tempo de USP; 
tempo de Unidade; tempo na função e escolaridade são apresentadas para os funcionários técnicos administrativos.

$\mathrm{Na}$ terceira parte, apresentam-se os achados de pesquisa, especificados para a Análise de Conteúdo: contexto; conteúdo; processo e resultados/avaliação do Programa de Qualidade e Produtividade da USP. Para cada uma dessas categorias de análise existe um conjunto de questões já relacionadas nos Quadros 5 e 6, do capítulo de Metodologia.

\subsubsection{As dimensões das unidades de ensino e pesquisa}

A primeira parte de apresentação dos achados de pesquisa de campo contempla as Dimensões das Unidades de Ensino e Pesquisa.

O trabalho fixou-se em 12 Unidades de Ensino e Pesquisa da USP, escolhidas pelo critério de maior evidência de trabalhos na área da Qualidade. O estudo incorporou unidades localizadas na Capital e em dois campi do Interior (São Carlos e Ribeirão Preto), classificadas nas três áreas de concentração de conhecimento (ciências biológicas, humanas e exatas) e de diferentes portes, em função do número de alunos de graduação e de pós-graduação.

O Quadro 10, a seguir, evidencia, em ordem cronológica crescente, o ano de Criação/Incorporação à USP de suas 40 Unidades de Ensino e Pesquisa, existentes em 2009. Estão em destaque e assinaladas com asterisco as Unidades que foram objeto da pesquisa. 
Quadro 10 - Unidades de ensino e pesquisa e ano de criação/incorporação à USP

\begin{tabular}{|c|l|c|}
\hline Número & \multicolumn{1}{|c|}{ Unidade } & Ano \\
\hline 01 & EP $^{*}$ & 1934 \\
\hline 02 & ESALQ & 1934 \\
\hline 03 & FCF* & 1934 \\
\hline 04 & FD & 1934 \\
\hline 05 & FFLCLH & 1934 \\
\hline 06 & FM & 1934 \\
\hline 07 & FMVZ & 1934 \\
\hline 08 & FO & 1934 \\
\hline 09 & FSP & 1938 \\
\hline 10 & FEA & 1946 \\
\hline 11 & IAG & 1946 \\
\hline 12 & EESC & 1948 \\
\hline 13 & FAU & 1948 \\
\hline 14 & FMRP & 1948 \\
\hline 15 & FOB & 1948 \\
\hline 16 & IO & 1951 \\
\hline 17 & EE & 1963 \\
\hline 18 & EERP & 1964 \\
\hline 19 & ECA & 1966 \\
\hline 20 & EEFE $*$ & 1969 \\
\hline
\end{tabular}

\begin{tabular}{|c|l|c|}
\hline Número & \multicolumn{1}{|c|}{ Unidade } & Ano \\
\hline 21 & FE & 1969 \\
\hline 22 & IB & 1969 \\
\hline 23 & ICB & 1969 \\
\hline 24 & IF* & 1969 \\
\hline 25 & IGc & 1969 \\
\hline 26 & IME & 1969 \\
\hline 27 & IP & 1969 \\
\hline 28 & IQ & 1969 \\
\hline 29 & ICMC* & 1971 \\
\hline 30 & FFCLRP & 1974 \\
\hline 31 & FCFRP & 1982 \\
\hline 32 & FORP & 1982 \\
\hline 33 & FZEA & 1992 \\
\hline 34 & IFSC & 1994 \\
\hline 35 & IQSC & 1994 \\
\hline 36 & FEARP & 2002 \\
\hline 37 & EACH & 2004 \\
\hline 38 & EEL & 2006 \\
\hline 39 & EEFERP & 2007 \\
\hline 40 & FDRP & 2007 \\
\hline & &
\end{tabular}

(*) Unidades pesquisadas

Fonte: Adaptado do Anuário Estatístico da USP, São Paulo, 2009

Das Unidades que foram objeto da Pesquisa, nove estão entre as mais antigas e tradicionais da USP, incluídas ou criadas até 1970. Três delas foram instituídas de 1971 a 1994.

Esses mesmos dados foram redistribuídos, consolidando-se o número de Unidades criadas por décadas.

Quadro 11 - Número de unidades por década

\begin{tabular}{|c|c|c|c|c|}
\hline Década & Frequência & $\begin{array}{c}\text { Frequência } \\
\text { acumulada }\end{array}$ & Porcentagem & $\begin{array}{c}\text { Porcentagem } \\
\text { acumulada }\end{array}$ \\
\hline $1934-1940$ & 9 & 9 & 22,5 & 22,5 \\
\hline $1941-1950$ & 6 & 15 & 15,0 & 37,5 \\
\hline $1951-1960$ & 1 & 16 & 2,5 & 40,0 \\
\hline $1961-1970$ & 12 & 28 & 30,0 & 70,0 \\
\hline $1971-1980$ & 2 & 30 & 5,0 & 75,0 \\
\hline $1981-1990$ & 2 & 32 & 5,0 & 80,0 \\
\hline $1991-2000$ & 3 & 35 & 7,5 & 87,5 \\
\hline $2001-2007$ & 5 & 40 & 12,5 & 100,0 \\
\hline TOTAL & 40 & 40 & 100,00 & \\
\hline
\end{tabular}

Fonte: Adaptado do Anuário Estatístico da USP, São Paulo, 2009 
Observe-se que cerca de $70 \%$ das Unidades foram criadas ou incorporadas à USP até a década de 70. A partir de 80 o incremento de unidades novas mostra-se lento até 2000: de 1971 a 1994, sete unidades foram incorporadas, respondendo por $17,5 \%$ das Unidades da USP. A partir de 2001 e até 2007 iniciam-se ou incorporam-se novas unidades de ensino, representando $12,5 \%$ das unidades existentes.

Quanto à localização das Unidades incluídas na pesquisa:

Tabela 1 - Localização das unidades entrevistadas

\begin{tabular}{|c|c|c}
\hline Localização & Freq. & \% \\
\hline Capital & 8 & 66,7 \\
\hline Interior & 4 & 33,3 \\
\hline TOTAL & 12 & 100,0 \\
\hline
\end{tabular}

Gráfico 3 - Localização das unidades entrevistadas

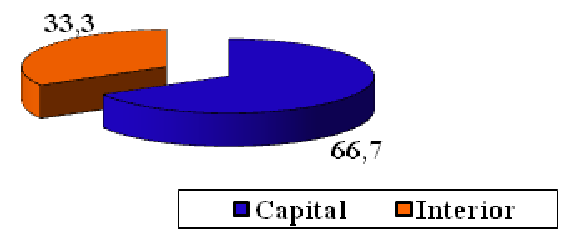

Fonte: Dados da pesquisa, 2010

Como se pode observar, dois terços das Unidades da USP, foco da pesquisa, localizam-se na Capital.

Com relação à área de concentração do conhecimento, as Unidades de Ensino e Pesquisa podem ser classificadas distinguindo-se as áreas de Ciências Biológicas, Ciências Exatas e Humanas. Neste trabalho, incluem-se no primeiro grupo: EEFE; FCF; FCFRP; FMRP e FMVZ. Ao grupo das Ciências Exatas pertencem: EP; IAG; ICMC; IF e IFSC. Fazem parte do grupo de Ciências Humanas as Unidades FAU e FEA.

Tabela 2 - Área de concentração do conhecimento

Gráfico 4 - Área de concentração do conhecimento

\begin{tabular}{c|c|c}
\hline Área de Concentração & Freq. & \% \\
\hline Biológica & 5 & 41,7 \\
\hline Exata & 5 & 41,7 \\
\hline Humana & 2 & 16,6 \\
\hline TOTAL & 12 & 100,0 \\
\hline
\end{tabular}

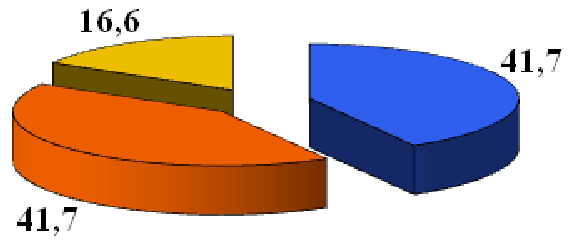

口Biológica aExata aHumana 
Para a finalidade do estudo, a variável Porte da Unidade de Ensino e Pesquisa foi tratada como uma função de duas variáveis: do número de alunos de graduação e do número de alunos de pós-graduação. Foi classificado como Porte Pequeno, unidades de até 500 alunos de graduação e de pós-graduação; Médio, de 501 a 1000 alunos e Grande de 1001 a 4600 alunos.

Tabela 3 - Porte da unidade por alunos graduação em 1996 e 2007

\begin{tabular}{l|c|c|c|c}
\hline \multicolumn{1}{c|}{ Porte $(*)$} & $\mathbf{1 9 9 6}$ & $\mathbf{2 0 0 7}$ & $\mathbf{1 9 9 6}$ & $\mathbf{2 0 0 7}$ \\
\hline & Freq. & Freq. & $\mathbf{\%}$ & $\mathbf{\%}$ \\
\hline Pequeno & 6 & 4 & 50,0 & 33,3 \\
\hline Médio & 2 & 3 & 16,7 & 25,0 \\
\hline Grande & 4 & 5 & 33,3 & 41,7 \\
\hline TOTAL & $\mathbf{1 2}$ & $\mathbf{1 2}$ & $\mathbf{1 0 0 , 0}$ & $\mathbf{1 0 0 , 0}$ \\
\hline
\end{tabular}

(*) Porte:

- Pequeno: até 500 alunos de graduação;

- Médio: de 501 a 1000 alunos;

- Grande: de 1001 a 4600 alunos de graduação.

Fonte: Adaptado do Anuário Estatístico da USP, São Paulo, 1997 e 2008

Duas unidades de pequeno porte passaram para o nível acima, o mesmo ocorrendo com uma unidade de porte médio.

Quando se analisa o porte da Unidade em relação ao número de alunos de Pós-Graduação, a distribuição é apresentada pela Tabela 4:

Tabela 4 - Porte da unidade por alunos de pós-graduação em 1996 e 2007

\begin{tabular}{l|c|c|c|c}
\hline \multicolumn{1}{c|}{ Porte (*) } & $\mathbf{1 9 9 6}$ & $\mathbf{2 0 0 7}$ & $\mathbf{1 9 9 6}$ & $\mathbf{2 0 0 7}$ \\
\hline Pequeno & Freq. & Freq. & $\mathbf{\%}$ & $\boldsymbol{\%}$ \\
\hline Médio & 7 & 6 & 58,3 & 50,0 \\
\hline Grande & 4 & 3 & 33,3 & 25,0 \\
\hline TOTAL & 1 & 3 & 8,4 & 25,0 \\
\hline
\end{tabular}

(*) Porte:

- Pequeno: unidades de até 500 alunos de pós-graduação;

- Médio: de 501 a 1000 alunos;

- Grande: de 1001 a 4600 alunos de pós-graduação.

Fonte: Adaptado do Anuário Estatístico da USP, São Paulo, 1997 e 2008

A alteração do porte das unidades em estudo incidiu em três unidades, uma de pequeno porte e duas de médio porte que se deslocaram para um nível superior, evidenciando o crescimento de alunos de pós-graduação no período. 
Para completar o quadro de caracterização das Unidades pode-se, ainda, levantar as variáveis relativas a Recursos Humanos, ou seja, número de docentes e servidores técnicos administrativos. Para simplificar, classifica-se essa variável por faixas de valores, segundo Tabela 5:

Tabela 5 - Distribuição por faixa de número de docentes em 1996 e 2007

\begin{tabular}{l|c|c|c|c}
\hline \multirow{2}{*}{ Faixa } & $\mathbf{1 9 9 6}$ & $\mathbf{2 0 0 7}$ & $\mathbf{1 9 9 6}$ & $\mathbf{2 0 0 7}$ \\
\cline { 2 - 5 } & Freq. & Freq. & $\mathbf{\%}$ & $\mathbf{\%}$ \\
\hline Até 100 & 6 & 6 & 50,0 & 50,0 \\
\hline De 101 - 200 & 4 & 4 & 33,3 & 33,3 \\
\hline De 201 - 600 & 2 & 2 & 16,7 & 16,7 \\
\hline TOTAL & $\mathbf{1 2}$ & $\mathbf{1 2}$ & $\mathbf{1 0 0 , 0}$ & $\mathbf{1 0 0 , 0}$ \\
\hline
\end{tabular}

Fonte: Adaptado do Anuário Estatístico da USP, São Paulo, 1997 e 2008

Não houve alteração do quadro de faixas do número de docentes entre 1997 e 2007.

Tabela 6 - Distribuição por faixa de número de servidores técnicos administrativos 1996 e 2007

\begin{tabular}{l|c|c|c|c}
\hline \multirow{2}{*}{ Faixa } & $\mathbf{1 9 9 6}$ & $\mathbf{2 0 0 7}$ & $\mathbf{1 9 9 6}$ & $\mathbf{2 0 0 7}$ \\
\cline { 2 - 5 } & Freq. & Freq. & $\mathbf{\%}$ & $\mathbf{\%}$ \\
\hline Até 100 & 1 & 2 & 8,4 & 16,7 \\
\hline De $101-200$ & 7 & 6 & 58,3 & 50,0 \\
\hline De $201-600$ & 4 & 4 & 33,3 & 33,3 \\
\hline TOTAL & $\mathbf{1 2}$ & $\mathbf{1 2}$ & $\mathbf{1 0 0 , 0}$ & $\mathbf{1 0 0 , 0}$ \\
\hline
\end{tabular}

Fonte: Adaptado do Anuário Estatístico da USP, São Paulo, 1997 e 2008

Observe-se uma ocorrência de redução do número de funcionários em uma das Unidades.

Da mesma forma que foi feito para a USP, apresenta-se Gráfico 5, a seguir, que reflete a evolução de algumas variáveis no período de 1996 a 2007, em relação ao número:

- de matrículas na graduação;

- $\quad$ de matrículas na pós-graduação;

- de professores;

- de servidores técnicos administrativos. 


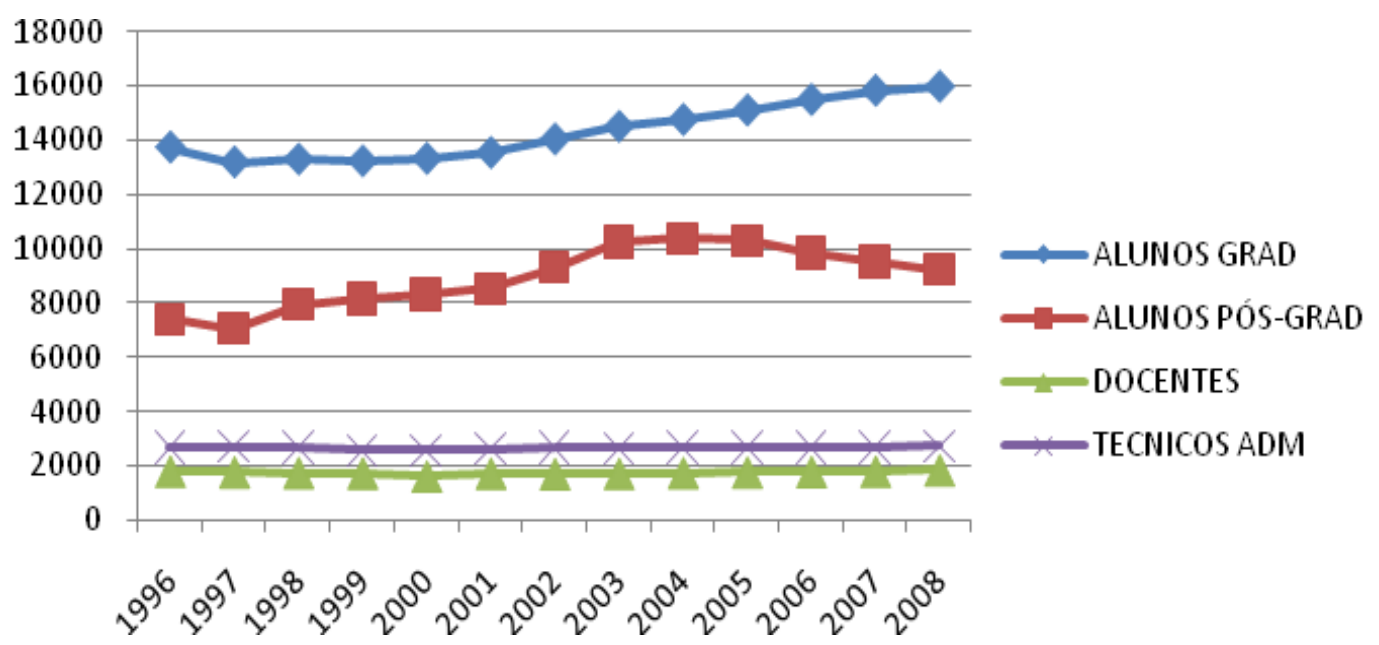

Gráfico 5 - Evolução da comunidade das unidades pesquisadas

Fonte: Adaptado do Anuário Estatístico da USP, São Paulo, 1997 e 2009

Tal como para a USP, observe-se nas Unidades pesquisadas uma tendência de estabilidade para o número de docentes e técnicos administrativos. Com relação aos alunos de graduação, a tendência de crescimento é contínua, enquanto para a pós-graduação, após uma tendência crescente de 1997 a 2004, há uma ligeira queda no crescimento do número de alunos, a partir de 2004.

\subsubsection{Caracterização dos entrevistados}

Nessa segunda parte, os achados da pesquisa fixam-se nas Características dos Entrevistados, apresentadas pelas variáveis: gênero (masculino e feminino); categoria profissional (docente e servidor técnico administrativo); faixa etária (28 - 40 anos; 41 - 50; 51 - 60 e acima de 60 anos); função (dirigente; assistente técnico de direção e outro) e por área de concentração da formação (ciências biológicas, exatas e humanas). Algumas variáveis adicionais, como: tempo de vida profissional; tempo de USP; tempo de Unidade; tempo na função e escolaridade são apresentadas para os funcionários técnicos administrativos.

A seguir, é caracterizado o perfil da amostra de 36 entrevistados, que incluiu 16 docentes, exdirigentes, e 20 funcionários técnicos administrativos da Universidade de São Paulo. Entre os docentes, incluíram-se: um ex-Reitor da USP (1993 - 1997), que iniciou o Programa de Qualidade e Produtividade na Universidade; um ex-Coordenador Geral da Administração (CODAGE) e também Vice-Reitor (2001 - 2005), que acumulou por dez anos (1996 - 2005), a Presidência da Comissão de Qualidade e Produtividade e 14 ex-diretores de 12 Unidades de 
Ensino e Pesquisa, que atuaram em diferentes períodos, na vigência oficial do Programa de Qualidade na USP, até março de 2007. Como funcionários técnicos administrativos, foram entrevistados, em grande maioria, assistentes técnicos de direção das mesmas Unidades a que pertenciam os diretores entrevistados e responsáveis pelo Programa de Qualidade nas Unidades de Ensino e Pesquisa.

Uma entrevista complementar, feita com um funcionário técnico administrativo da Reitoria, foi descartada, porque se optou por retirar da pesquisa esse órgão de direção, inicialmente incluído, e do qual o entrevistado fazia parte. A exclusão foi feita porque esse órgão possuía características muito diferenciadas em relação às Unidades de Ensino e Pesquisa analisadas.

O delineamento inicial da pesquisa previa entrevistas só com assistentes técnicos de direção. No decorrer do processo foi detectada a necessidade de um ajuste a essa condição, uma vez que o titular da assistência técnica de direção, à época da pesquisa, era novo na função e não tinha elementos para discorrer sobre fatos do passado. A solução adotada foi a de chamar um funcionário mais antigo que tivesse participado do fenômeno em estudo; nesse caso um só questionário para a Unidade foi respondido pelos dois funcionários. Entre os docentes entrevistados, dois já eram aposentados, o mesmo ocorrendo com um dos funcionários entrevistados.

Dos 30 funcionários técnicos administrativos entrevistados, $70 \%$ disseram ter tido participação contínua (Questão 31) nas atividades das Comissões Internas de Qualidade.

Quanto ao local das entrevistas, a maior parte delas, com ex-dirigentes e diretores, foi realizada no local de trabalho dos entrevistados. Essa situação não ocorreu quando os exdiretores já estavam aposentados e para dois dirigentes do interior. Nesses casos, a entrevista foi feita em locais no campus da Cidade Universitária de São Paulo e dois dirigentes enviaram as respostas por e-mail. Com relação aos servidores técnicos administrativos, as entrevistas também foram feitas em seus locais usuais de trabalho. Mesmo para entrevistas em dois campi do interior, (Ribeirão Preto e São Carlos), a pesquisadora deslocou-se para entrevistar os servidores nos locais de trabalho. Quatro representantes de duas unidades do interior responderam ao questionário por meio eletrônico. 
Portanto, seis dos respondentes do interior, após um contato telefônico da pesquisadora, enviaram suas respostas ao Roteiro de Entrevista por $e$-mail, o que não pode ser configurado como entrevista propriamente dita.

Observe-se, também, que, em uma das Unidades, o ICMC, foram entrevistados três de seus ex-diretores (de 1994 a 2005), em uma tentativa de avaliação da pertinência ou não desse procedimento para as demais Unidades. Dentro de intuito exploratório deste trabalho havia o interesse em verificar se haveria maior entendimento do problema se fosse acompanhada uma mesma Unidade durante todo o tempo do Programa. Em vista dos resultados, optou-se por fazer, nessa fase da pesquisa, mais Unidades, para ter um conjunto maior de experiências, do que abranger um período mais longo de uma mesma Unidade.

No que se refere à duração das entrevistas, excetuando-se os casos respondidos por e-mail, a duração de 30 entrevistas variou de 25 minutos a 2h10, com uma média geral de 70 minutos cada uma; duraram em média 55 minutos para os docentes dirigentes e 1h20 para outros servidores. O maior tempo apresentado com entrevistas de funcionários técnicos administrativos pode ser justificado pelo conjunto complementar de questões, incluído no Roteiro de Entrevista.

Em uma primeira abordagem, são apresentadas as características de todos os entrevistados (docentes dirigentes e técnicos administrativos) da amostra, distribuídos pelas variáveis: gênero (masculino e feminino); categoria profissional (docente e servidor técnico administrativo); faixa etária (28 - 40 anos; 41 - 50; 51 - 60 e acima de 60 anos); função (dirigente; assistente técnico de direção e outro) e por área de concentração da formação (ciências biológicas, exatas e humanas). 
Quanto ao gênero dos entrevistados:

Tabela 7 - Distribuição por gênero

Gráfico 6 - Distribuição por gênero

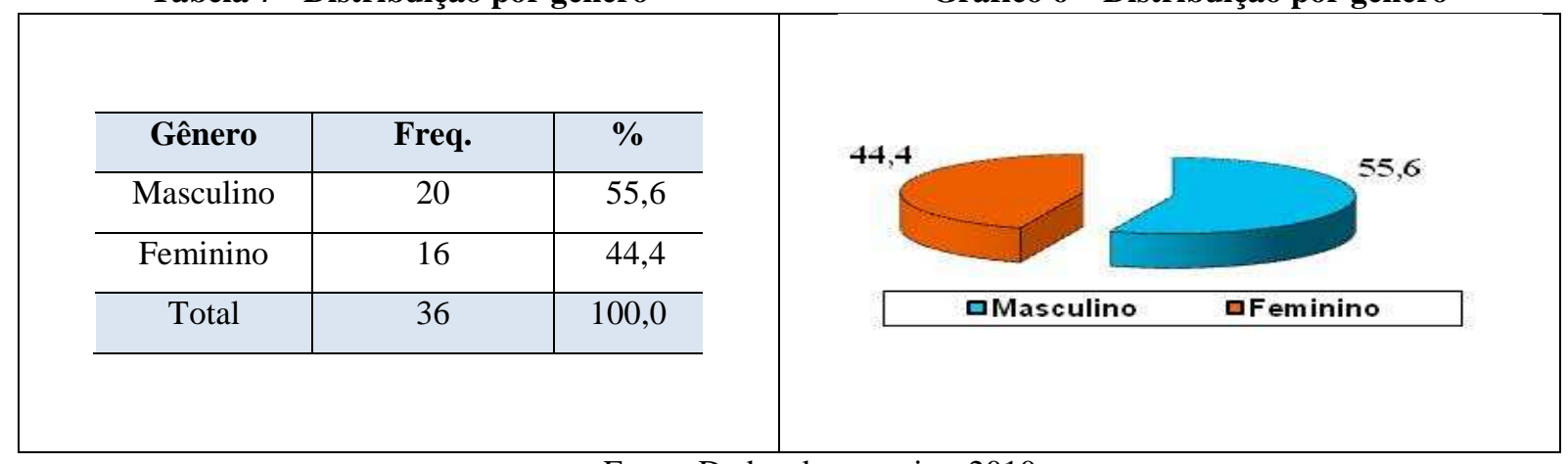

Fonte: Dados da pesquisa, 2010

A variável categoria profissional compreende dois tipos de funcionários ou servidores da Universidade: docentes dirigentes e técnicos administrativos.

Tabela 8 - Distribuição por categoria profissional

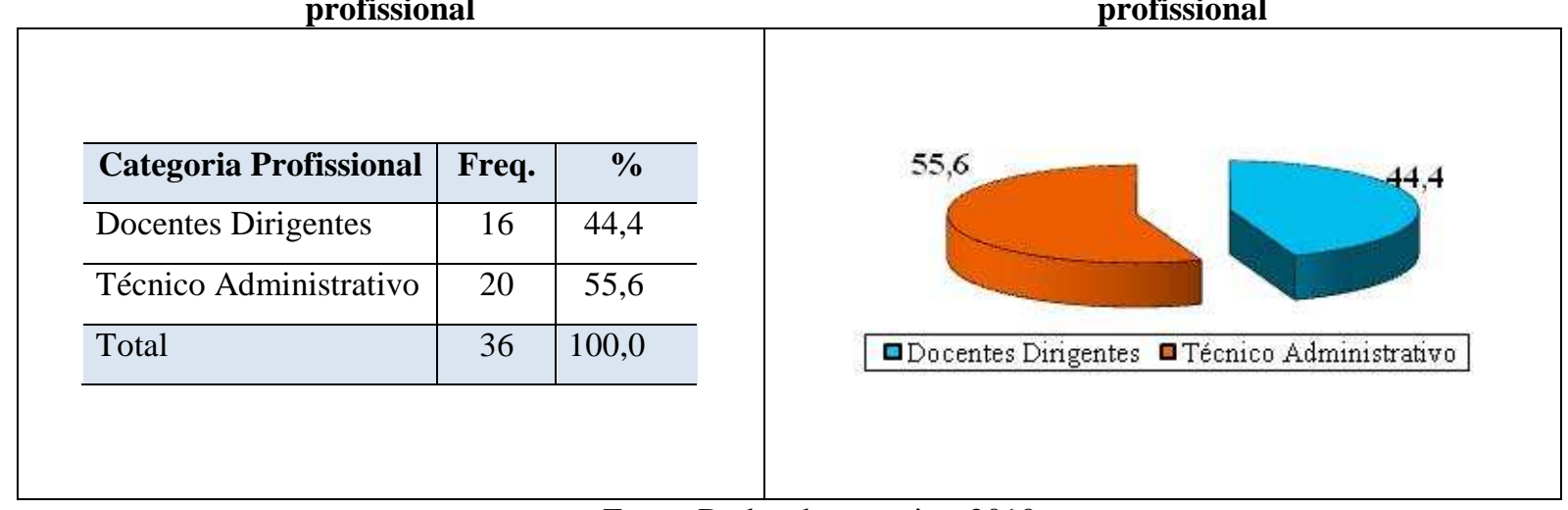

Fonte: Dados da pesquisa, 2010
Gráfico 7 - Distribuição por categoria profissional

55,6

Docentes Dirigentes 口Técnico Administrativo

A Tabela 9, a seguir, explora a variável idade, agrupada por faixa-etária. Os dados registraram uma idade média de 61 anos para docentes dirigentes e 46 anos para os técnicos administrativos, apontando a seguinte distribuição: 


\begin{tabular}{|c|c|c|c|c|c|}
\hline Faixa Etária & Freq. & $\%$ & \multirow{6}{*}{$\underbrace{27,8}_{27,8}$} & & \multirow{6}{*}{33,3} \\
\hline 28 a 40 & 4 & 11,1 & & & \\
\hline 41 a 50 & 12 & 33,3 & & & \\
\hline 51 a 60 & 10 & 27,8 & & & \\
\hline Acima de 60 & 10 & 27,8 & & & \\
\hline Total & 36 & 100,0 & & & \\
\hline & & & $\mathbf{2} 28 \mathrm{a} 40$ & 다 a 60 & 口Acima de 60 \\
\hline
\end{tabular}

Fonte: Dados da pesquisa, 2010

É de se observar que predominam integrantes nas faixas etárias acima de 40 anos $(88,9 \%)$. Isso se verifica porque os entrevistados ocupam cargos da alta administração da Universidade, caso dos dirigentes docentes; os técnicos administrativos são em sua maior parte assistentes de direção, cargos em geral ocupados por funcionários mais experientes e, portanto, com idade mais elevada. Docentes dirigentes, para ocupar o cargo de Reitor ou de Diretor, têm como exigência a condição de "professor titular", o último estágio da carreira docente, condição essa associada a uma idade mais alta.

Quanto à função, a escolha dos entrevistados foi feita pela sua maior participação no fenômeno em estudo. Essa escolha recaiu basicamente em dirigentes, todos eles docentes e em funcionários, na sua maior parte assistentes técnicos de direção, sejam eles administrativos, acadêmicos ou financeiros. Os assistentes técnicos de direção, pela sua estabilidade na função e proximidade com o dirigente da Unidade exercem um papel de grande influência nas decisões estratégicas da Unidade. Isso se deve à sua relativa autonomia em relação ao órgão central e pela rotatividade de gestão da Diretoria da Unidade, que troca a cada quatro anos. Quatro entrevistados ocupavam outras funções. 
Tabela 10 - Distribuição por função

Gráfico 9 - Distribuição por função

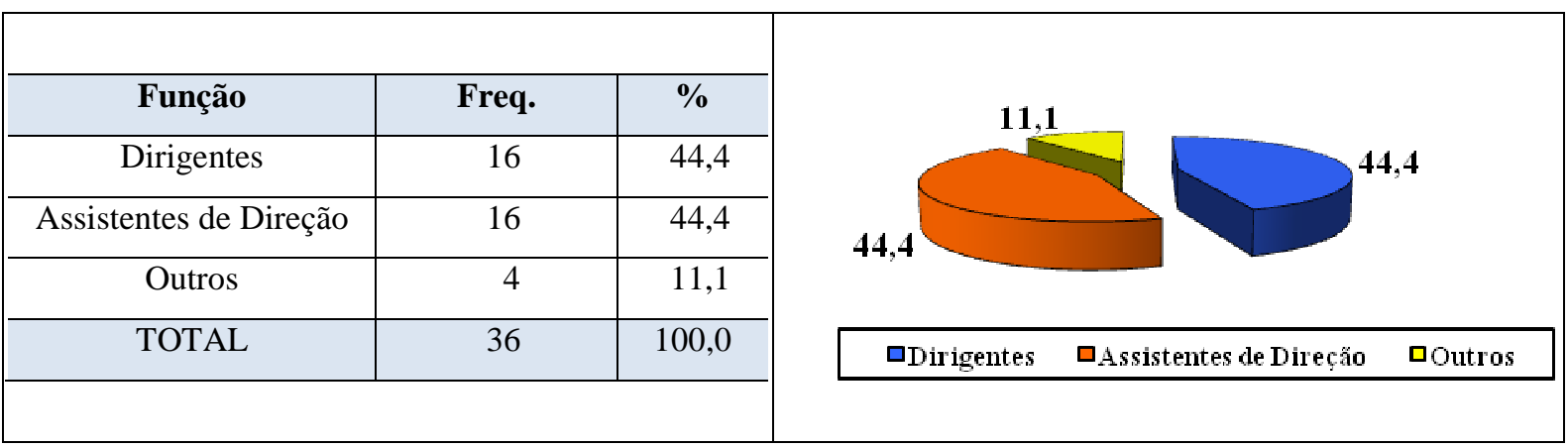

Fonte: Dados da pesquisa, 2010

Quanto à Área de Concentração da Formação dos entrevistados, seguiu-se a mesma classificação das Unidades: área de ciências biológicas, exatas e humanas.

Tabela 11- Distribuição por área de concentração de formação

\begin{tabular}{|l|c|c|c|}
\multicolumn{2}{c|}{ de formação } & concentração de formação \\
\hline \multicolumn{2}{|c|}{ Área de Formação } & Freq. & $\%$ \\
\hline Biológicas & 7 & 19,4 \\
\hline Exatas & 11 & 30,6 \\
\hline Humanas & 18 & 50,0 \\
\hline \multicolumn{2}{|c|}{ Total } & 36 & 100,0 \\
\hline \multicolumn{2}{|c}{} \\
\hline
\end{tabular}

Fonte: Dados da pesquisa, 2010

No que refere aos funcionários técnicos administrativos, o Roteiro Tipo 2 solicitava dados complementares (cargo de supervisão, anos de vida profissional, tempo de trabalho na USP, na Unidade e na função e grau de instrução), incluídos na Identificação, que consolidados, descrevem-se a seguir:

- $\quad 75 \%$ dos entrevistados tinham cargo de supervisão, com média de 26 subordinados, com mínimo de dois e máximo de 70 subordinados;

- média de 27 anos de vida profissional ativa, com mínimo de 12 anos e máximo de 36 anos;

- $\quad$ média de 22 anos de USP, com um mínimo de 10 e máximo de 30 anos;

- $\quad$ tempo médio na Unidade de 17 anos, com mínimo de 5 e máximo de 30 anos; 
- tempo médio na função de 6 anos, com mínimo de menos de um 1 e máximo de 14 anos;

- $\quad 70 \%$ não trabalharam em outra Unidade da USP;

- $\quad 100 \%$ têm curso superior;

- $\quad 80 \%$ têm algum curso de especialização.

Como se pode observar, a amostra de funcionários técnicos administrativos exerce, em sua maioria, cargo de supervisão; têm muitos anos de vida profissional, muitos deles, exclusivamente na USP e a grande maioria (70\%) é relativamente estável na mesma Unidade. Essas características permitem reforçar que os entrevistados apresentam, portanto, uma fraca mobilidade profissional e um percurso relativamente estável dentro da mesma Unidade. Todos têm grau de instrução superior e alta porcentagem deles, também, tem curso de especialização, o que sinaliza um pessoal com alta escolaridade e potencialmente qualificado para a área administrativa.

\subsubsection{Análise de conteúdo das entrevistas}

A terceira parte, referente à Análise de Conteúdo das Entrevistas, é evidenciada pelas categorias de análise: Contexto; Conteúdo do Programa de Q\&P; Processo e Resultados e Avaliação. As tabelas apresentam as respostas para docentes dirigentes e técnicos administrativos, em separado e os gráficos são feitos para o total dos entrevistados.

O Contexto abrange o externo e interno. O Conteúdo do Programa de Q\&P tomou por base uma combinação dos Critérios do Prêmio Nacional da Qualidade (PNQ) com os Balizadores da Qualidade no Serviço Público, denominados nesta tese de Módulos de Qualidade, já apresentados. O Processo contemplava a implantação propriamente dita do Programa de Qualidade, considerando estrutura, receptividade, recursos, pessoas, treinamento e monitoramento. Resultados e Avaliação continham as questões de experiências da qualidade; conceitos do Programa emitidos pelos dirigentes e técnicos administrativos; impactos e valor do Programa para ambas as categorias e variáveis direcionadas aos servidores técnicos administrativos, referentes a: Treinamento; Participação em Tomada de Decisões; Aprendizagem; Competência; Interação e Qualidade de Vida no Trabalho (QVT). 
O Quadro 12 mostra o esquema analítico, especificando as Categorias de Análise e as respectivas questões do Roteiro de Entrevista:

Quadro 12 - Categorias de análise

\begin{tabular}{|c|c|c|}
\hline Identificação & Categoria de Análise & Pergunta do Roteiro da Entrevista \\
\hline A & Contexto & 01,05 \\
\hline B & Conteúdo & $02,03,04,15$ \\
\hline C & Processo & 06 a 14, 16, 17 \\
\hline D & Resultados/Avaliação & $18,18.1,22$ a 25,27 \\
\hline
\end{tabular}

\subsubsection{Contexto}

A primeira categoria de análise (A), que emerge do modelo de Pettigrew (1990) para processos de mudança, trata do contexto interno e externo da organização. Pretendia-se levantar as condições ambientais em seus aspectos políticos, econômicos, sociais e organizacionais. A questão foi de difícil entendimento pelos entrevistados e as respostas foram bastante dispersas. Foi levantado esse item com os entrevistados mediante as questões 01 e 05.

Observe-se que os depoimentos dos entrevistados são seguidos das siglas DIR ou TAD, conforme sejam respostas de dirigentes ou de técnicos administrativos; os números que acompanham as siglas são de uma lista reservada para uma identificação eventual dos entrevistados.

Questão 01: A Unidade aderiu ao Programa de Q\& P? Por quê?

Com exceção de um único técnico administrativo, todos os respondentes confirmaram a adesão da Unidade ao Programa de Qualidade. Na resposta discordante, o depoente se manifestou de forma incisiva:

[...] nas administrações anteriores não havia uma Comissão de Qualidade formada. Houve pessoas que fizeram o curso de Qualidade na Reitoria, mas não havia uma Comissão voltada para a Qualidade, na Unidade. Foi criado um grupo que foi por terra e acabou não avançando nesse processo. O Programa começou há uns quatro anos com a adesão da Biblioteca. (TAD 11) 
O primeiro item da primeira categoria de análise procurou levantar com os entrevistados quais as motivações, o porquê da Unidade, em um dado instante decidir adotar o Programa de Qualidade e Produtividade da Universidade de São Paulo, que foi instituído em 1996, pela portaria GR- 2.985 de 29/01/96. Quais as motivações para adotar essa estratégia? Quais os fatores propulsores para essa adesão?

A Tabela 12, referente à Questão 1, do Roteiro de Entrevista, mostra os indutores da adesão, na visão de docentes dirigentes e técnicos administrativos. Os respondentes podem ter dado mais de um motivo para a adesão, respostas múltiplas, o que justifica o número de respostas maior que a de respondentes, no caso dos dirigentes. Quando houve, no caso dos técnicos administrativos, para uma mesma Unidade, a presença de dois entrevistados, o consenso entre os dois prevaleceu como uma única resposta da Unidade.

Tabela 12 - Fatores propulsores de adesão ao Programa de Q\&P

\begin{tabular}{l|c|c|c|c|c|c}
\hline & \multicolumn{2}{|c|}{$\begin{array}{c}\text { Docentes } \\
\text { Dirigentes }\end{array}$} & $\begin{array}{c}\text { Técnicos } \\
\text { Administrativos }\end{array}$ & \multicolumn{2}{c}{ TOTAL } \\
\hline $\begin{array}{c}\text { Fatores } \\
\text { Propulsores }\end{array}$ & Freq. & $\mathbf{\%}$ & Freq. & $\%$ & Freq. & \% \\
\hline Regulamentação & 5 & 25,0 & 3 & 37,5 & 8 & 28,6 \\
\hline Eficiência & 4 & 20,0 & 3 & 37,5 & 7 & 25,0 \\
\hline Continuidade & 4 & 20,0 & 0 & 0,0 & 4 & 14,3 \\
\hline Modernização & 3 & 15,0 & 0 & 0,0 & 3 & 10,7 \\
\hline Recursos Humanos & 2 & 10,0 & 0 & 0,0 & 2 & 7,1 \\
\hline Liderança & 0 & 0,0 & 2 & 25,0 & 2 & 7,1 \\
\hline Modismo & 1 & 5,0 & 0 & 0,0 & 1 & 3,6 \\
\hline Seguir exemplos & 1 & 5,0 & 0 & 0,0 & 1 & 3,6 \\
\hline TOTAL & $\mathbf{2 0}$ & $\mathbf{1 0 0 , 0}$ & $\mathbf{8}$ & $\mathbf{1 0 0 , 0}$ & $\mathbf{2 8}$ & $\mathbf{1 0 0 , 0}$ \\
\hline Font Dados da pesqu
\end{tabular}

Fonte: Dados da pesquisa, 2010 


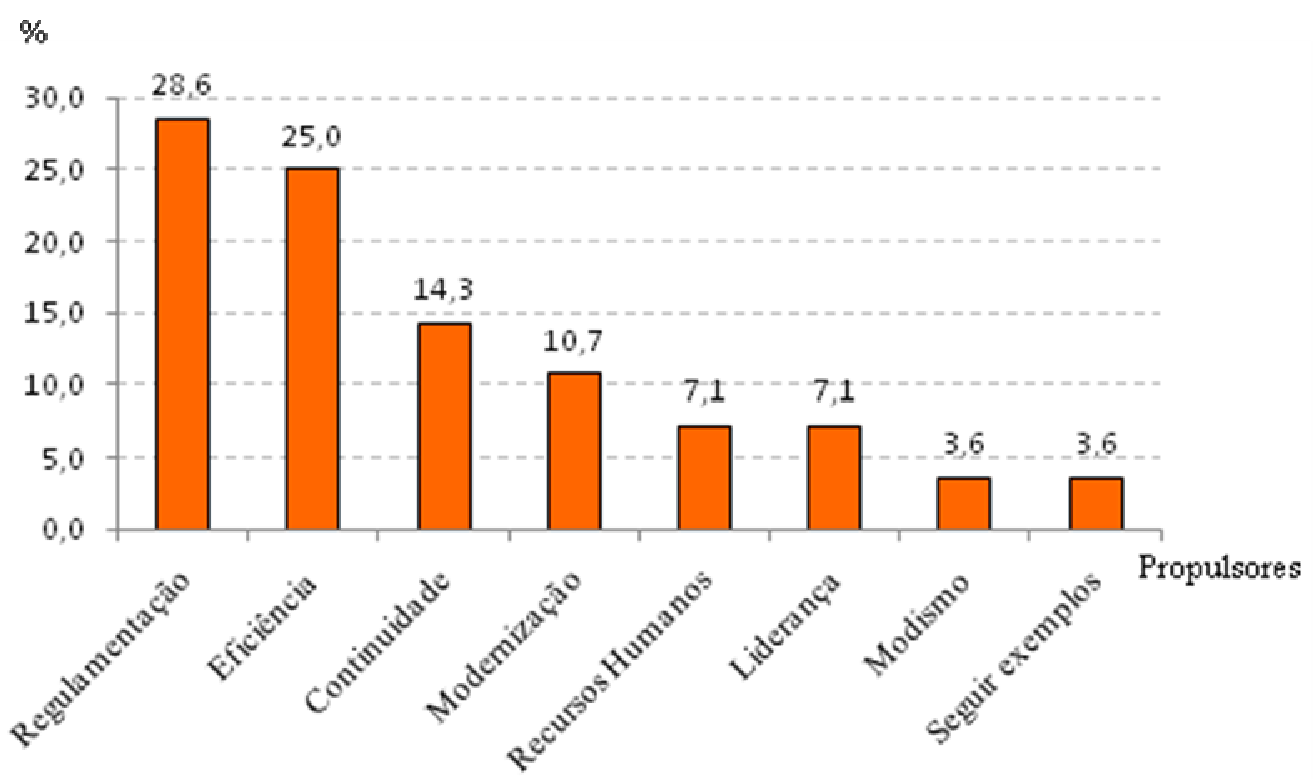

Gráfico 11 - Fatores propulsores de adesão ao Programa de Q\&P

Nesse elenco de respostas, no que diz respeito aos dirigentes, é importante observar que eles administraram suas Unidades em diferentes fases do Programa, variável essa que influi nas respostas à questão. $\mathrm{O}$ início do mandato dos dirigentes entrevistados estava equitativamente distribuído em dois períodos: oito dirigentes iniciaram o seu mandato entre 1993 e 2000 e outros oito, de 2001 a 2002.

Os autores, tratados na fundamentação teórica, em especial Wood Jr (2004, p. 23) e Pettigrew (1987), indicam que as situações propulsoras de mudança na cultura organizacional estão ligadas ao ambiente externo e interno. Como causas externas incluem-se: a necessidade de retração ou expansão da organização; as tendências sociais e políticas; as mudanças tecnológicas; a ação de movimentos sociais ou de regulamentação do Estado. A segunda situação vem do contexto interno da organização, quando da mudança de dirigentes e cargoschaves, na introdução de novos processos de trabalho, de mudanças de diretrizes internas ou para romper uma inércia organizacional.

$\mathrm{O}$ resultado da pesquisa mostra que, em maior porcentagem, 28,6\% dos entrevistados apontaram como motivo da adesão o "atendimento ao decreto do Governador ou da Universidade", ou seja, estava implícito aí o cumprimento de uma regulamentação legal, o que caracteriza uma causa externa à organização. As justificativas de "tornar a administração mais moderna e inovadora", "melhorar a gestão", "usar melhor os recursos públicos", "melhorar a operação das atividades meio", "organizar os procedimentos", emitidas por sete 
dos entrevistados, são respostas que remetem a causas internas para uma mudança organizacional. Eficiência e outros conceitos genéricos de programas de qualidade total assim como o atendimento aos Balizadores contemplados no Programa de Qualidade no Serviço Público e adotados pela Universidade estão contidos nas respostas. Quatro diretores, que administraram suas unidades mais tardiamente em relação ao início do Programa, justificaram a adoção do programa porque ele já existia e então deram continuidade; um deles adotou-o por já desejar seguir outras Unidades, nas quais já vira bons resultados. Alguns entrevistados levantaram argumentos ligados a recursos humanos, com a expectativa de "promover maior participação dos funcionários" e também "minimizar problemas com eles". O modismo da qualidade fazia parte do discurso de excelência a ser atingida pelas organizações; a excelência na universidade era segmentada em excelência acadêmica, de serviços e operacional (agilidade administrativa). Dois dos técnicos administrativos justificaram a adesão para atender à vontade do diretor. Como se pode observar, há razões de várias naturezas para a adesão ao Programa de Qualidade e Produtividade, com grande ênfase no fator externo que funciona como uma força propulsora ou uma oportunidade aproveitada pelos dirigentes para provocar uma mudança na cultura da organização.

Há certa concordância entre as respostas dos docentes dirigentes e dos técnicos administrativos de que os fatores propulsores de maior ocorrência são a regulamentação e a expectativa de maior eficiência na administração. Os outros fatores são bastante diferentes entre uma categoria profissional e outra.

O Reitor da USP, na gestão 1993 a 1997, reforçou, no seu depoimento, a estratégia de adesão ao Programa de Qualidade do Governo do Estado, instituído pelo decreto $\mathrm{n}^{\circ} 40.536$, do governador Mario Covas em 12 de dezembro de 1995, pelo fato de que ela vinha ao encontro de diretrizes já traçadas para sua gestão. Na sua resposta, o dirigente máximo da instituição atende, segundo Okumus (2003), a um dos requisitos-chaves na adoção de uma nova estratégia, que é a coerência com os rumos organizacionais, no caso a USP, que já detinha um histórico de excelência acadêmica.

Como se pode depreender dos depoimentos, de modo geral, os dirigentes aceitam a proposta do Programa de Q\&P como algo positivo que poderia ajudar a resolver problemas existentes; que fariam melhor uso do dinheiro público; que já dera certo em outras unidades; que 
representava um sistema de gerenciamento valorizado na época, o modelo japonês; definiam, ainda, o Programa como algo que vinha com a conotação de modernidade e inovação.

Alguns relatos individuais e fragmentos do discurso dos entrevistados contextualizam as respostas:

No início da gestão, em novembro de 1993, já pensava que seria interessante ter um programa que organizasse os procedimentos na Universidade: pensava em um Programa de Organização Institucional. Em 95 o governador Covas lançou a idéia do Programa de Qualidade, que foi acrescentado da palavra Produtividade. Confesso que a palavra produtividade não era muito simpática porque existem, no ethos da Universidade, pessoas que acham que a palavra produtividade tem uma conotação de um desempenho de produtivismo e que a Universidade não deveria ter um indicador de produtos; ela é mais reflexiva e intelectual. A verdade é que o mundo mudou e a sociedade hoje cobra da universidade e quer saber o que ela faz para o país, o que representa para a nação porque afinal é ela que paga os impostos, que sustenta a Universidade. Não pode mais se fechar em uma torre de marfim. A universidade ainda não tem censura sob o ponto de vista acadêmico, mas ela tem compromissos e a passagem dos alunos na universidade não pode ser em vão. Como saber que não foi em vão? Primeiro, perguntando aos alunos, para saber da satisfação do usuário e segundo, ver onde eles foram parar. A USP já fez 12 presidentes da República, sendo 11 da Faculdade de Direito e um da Filosofia; temos também presidentes do Tribunal Federal, Comissões de Justiça, Ministro de Relações Exteriores e lideranças que se formam. Na verdade a palavra produtividade do Programa não é boa, mas mesmo nas universidades internacionais, os alunos são considerados "produtos" que se oferecem à sociedade. Então o nome do Programa da USP acabou ficando com a palavra Produtividade. A Universidade não tinha que obedecer ao decreto, porque tinha sua autonomia, mas não tinha por que desobedecer, inclusive porque já vinha de encontro ao que queríamos fazer. Naquela época a Marilena Chauí fez um artigo fazendo uma distinção entre o que era organização, que cuida do lucro e da produtividade, e a instituição, que cuida das pessoas. O programa que a USP havia idealizado continha as duas palavras: Organização e Institucional. (DIR 16)

O Programa de Qualidade foi uma medida do governo; a USP, como subordinada ao governo do Estado, tinha que aderir, e aderiu também porque viu como uma boa oportunidade para fazer algo que a USP devia fazer, pois iria melhorar a gestão institucional, torná-la mais moderna, mais eficiente, mais agradável, adotando as práticas que outras organizações privadas e também públicas vinham adotando: o sistema de gerenciamento japonês, que estava muito presente e fez uma grande diferença na indústria automobilística. Isso formava um pano de fundo que era estimulante. (DIR 15)

Cabe ressaltar a observação do primeiro depoimento quanto à conotação, de certa forma, pejorativa da palavra produtividade no ethos da Universidade. Isso talvez explique o fato de que, na USP, ficou conhecido como Programa de Qualidade, omitindo-se deliberadamente ou não a palavra Produtividade.

Diretores de algumas Unidades de Ensino e Pesquisa, de várias gestões entre 1996 e 2005, em seus testemunhos levantaram como pontos de referência entre outros, a necessidade de "participação de todos os segmentos", "ouvir os alunos, os professores e os funcionários", "continuar com coisas que davam resultado". Outra vez essas motivações coincidem com um 
dos Balizadores: “cada um dos participantes da administração pública é responsável pela qualidade."

A administração pública, onde se insere a USP, precisa fazer mais e melhor com os recursos públicos; na universidade pública o objetivo é o aprimoramento do uso do recurso público. (DIR 09)

[...] já tinha essa preocupação de qualidade desde antes do programa da USP e logicamente aderi a essa orientação da Reitoria, para uma gestão mais moderna; qualidade é uma ferramenta de gestão e não uma grife, um modismo; não pode haver uma gestão moderna sem haver um programa de qualidade na instituição. (DIR 11)

Continuei a adesão. Quando assumi a direção decidi que iria continuar com todas as coisas da antiga diretoria que eram boas, que estavam dando bom resultado; este era um Programa que nós mantivemos. (DIR 05)

Apostei na época nesta idéia do Programa porque eu havia visto resultados em algumas Unidades. (DIR 06)

A principal motivação foi porque fizemos uma mudança do local do Departamento, o que trouxe vários conflitos entre os funcionários por misturar populações vindas de diferentes lugares que não trabalhavam juntas e tiveram que passar a trabalhar juntas. (DIR 10)

Entre as motivações dos técnicos administrativos, pelos depoimentos pode-se supor que as razões dadas parecem estar mais ligadas a uma aceitação de determinações de níveis superiores do que da consciência do que efetivamente um Programa dessa natureza poderia trazer. Estruturas burocráticas na Universidade não davam, sobretudo no passado, espaço para os funcionários agirem com autonomia. Além disso, um Programa de Qualidade é, por sua própria essência, uma decisão top-down, ou seja, vem do topo às bases e pede participação de todos os funcionários para sua operacionalização.

O Programa foi implantado na USP e foi solicitado que as Unidades instituíssem uma Comissão para implantar o Programa. (TAD 04)

A Unidade aderiu em 1996. O trabalho de qualidade já existia e a Comissão foi formada para atender a uma solicitação da Reitoria e do próprio Estado. (TAD 05)

Aderiu porque achava que ia melhorar o trabalho, os serviços e diminuir o retrabalho; a Unidade tem por meta melhorar sempre ou se manter em um nível de padrão elevado dentro da USP. (TAD 09) 
Questão 05: Qual o contexto interno e externo da Unidade na época?

Tabela 13 - Características do contexto interno e externo da unidade

\begin{tabular}{l|l|c|c|c|c|c|c}
\hline & \multicolumn{1}{|c|}{} & \multicolumn{1}{|c|}{$\begin{array}{c}\text { Docentes } \\
\text { Dirigentes }\end{array}$} & \multicolumn{2}{|c|}{$\begin{array}{c}\text { Técnicos } \\
\text { Administrativos }\end{array}$} & \multicolumn{2}{c}{ TOTAL } \\
\hline Contexto & \multicolumn{1}{|c|}{ Características } & Freq. & $\%$ & Freq. & \% & Freq. & $\%$ \\
\hline Interno & $\begin{array}{l}\text { Dificuldade de gerenciamento de } \\
\text { funcionários/desmotivação }\end{array}$ & 4 & 23,5 & 1 & 8,3 & 5 & 17,2 \\
\hline Interno & $\begin{array}{l}\text { Burocracia/busca de melhor qualidade } \\
\text { interna e resultados }\end{array}$ & 2 & 11,8 & 2 & 16,7 & 4 & 13,8 \\
\hline Interno & $\begin{array}{l}\text { Exemplos de sucesso do Programa na } \\
\text { USP }\end{array}$ & 1 & 5,9 & 3 & 25,0 & 4 & 13,8 \\
\hline Interno & Esgotamento do sistema de gestão & 1 & 5,9 & 2 & 16,7 & 3 & 10,3 \\
\hline Externo & Programa do Estado & 1 & 5,9 & 2 & 16,7 & 3 & 10,3 \\
\hline Interno & Insatisfação de alunos & 2 & 11,8 & & 0,0 & 2 & 6,9 \\
\hline Interno & $\begin{array}{l}\text { Desejo de maior participação dos } \\
\text { funcionários }\end{array}$ & 1 & 5,9 & 1 & 8,3 & 2 & 6,9 \\
\hline Externo & Pressão da sociedade & 2 & 11,8 & 0 & 0,0 & 2 & 6,9 \\
\hline Interno & Cultura de funcionalismo público & 1 & 5,9 & 0 & 0,0 & 1 & 3,4 \\
\hline Interno & Necessidade de maior profissionalização & 1 & 5,9 & 0 & 0,0 & 1 & 3,4 \\
\hline Interno & Inércia conservadora & 1 & 5,9 & 0 & 0,0 & 1 & 3,4 \\
\hline Interno & Ausência de cultura de treinamento & 0 & 0,0 & 1 & 8,3 & 1 & 3,4 \\
\hline & TOTAL & $\mathbf{1 7}$ & $\mathbf{1 0 0 , 0}$ & $\mathbf{1 2}$ & $\mathbf{1 0 0 , 0}$ & $\mathbf{2 9}$ & $\mathbf{1 0 0 , 0}$ \\
\hline
\end{tabular}

Fonte: Dados da pesquisa, 2010

\section{Caracteristicas}

Dificuldade de gerenciamento de funcionário sidesmotivação Burocracia/busca de melhor qualidade interna e resultados Exemplos de sucesso do Programa na USP Esgotamento do sistema de gestão

Programa do Estado Insatisfação de alunos Desejo de maior participação dos funcionários Pressão da sociedade Cultura de funcionalismo público Necessidade de maior profissionalização Inércia conservadora Ausência de cultura de treinamento

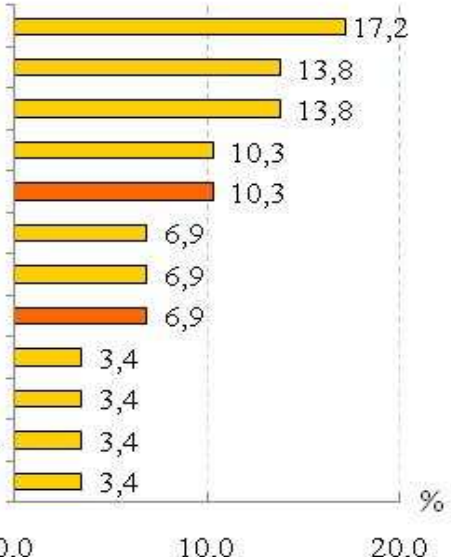
0,0 10,0 
Pode-se, nessa questão, entender, como contexto externo, o Programa adotado pelo Estado ou mesmo a pressão da sociedade para melhorar os serviços públicos de modo geral e no caso da Universidade, em particular, ampliar vagas para os alunos.

Os outros itens tendem para um contexto interno favorável para uma mudança. No que se refere à liderança havia um esgotamento quanto ao sistema de gestão dominante, extremamente burocrático, com um poder assimétrico em favor dos docentes. Isso é congruente com a classificação de universidade dada por Mintzberg (1999), como uma burocracia profissional. Docentes viam alguns funcionários com cultura de funcionalismo público, no seu aspecto pejorativo. A qualificação dos funcionários, recrutados nem sempre por critérios muito rigorosos, não atendia mais às crescentes exigências de uma universidade com autonomia, que precisava ter maior controle sobre os resultados de seus processos; a organização exigia mais profisssionalização de seu quadro de funcionários e aspirava à excelência administrativa, em moldes compatíveis com a excelência acadêmica de que gozava a instituição. A maior produtividade era um dos alvos a alcançar, tanto na parte administrativa quanto na área acadêmica. A desburocratização, almejada desde há muito tempo na administração pública, como corolário de eficiência, voltava como mais uma das metas a perseguir.

Do ponto de vista dos funcionários, havia uma percepção de desmotivação, ao lado de um desejo de maior participação. Por outro lado, novas práticas gerenciais em ascensão, como era o caso da filosofia da qualidade, permeavam as empresas privadas e as organizações públicas, desde o início da década de 90. O maior reforço para a adoção dessas novas práticas gerenciais intensificou-se com a abertura do país à concorrência internacional com o Programa Brasileiro de Qualidade e Produtividade, em 1990, no governo Collor. Vinha o gerenciamento pela qualidade com um discurso de maior participação dos funcionários, de desenvolvimento dos recursos humanos com incorporação da cultura do treinamento e maior atenção às condições de qualidade de vida no trabalho com reflexos na produtividade. Os alunos demonstravam, também, insatisfação e taxas de evasão eram altas em algumas Unidades. O Planejamento Estratégico passou a ser utilizado em algumas unidades, assim como outras técnicas da Qualidade. Fazia parte do contexto interno da Universidade, como em toda organização grande e complexa, uma inércia conservadora. Na medida em que algumas Unidades viam resultados positivos em outras que adotaram os princípios da qualidade, também se estimularam a seguir passos semelhantes. 
Seguem-se alguns depoimentos dos respondentes:

[...] havia um grande estímulo externo para adoção de programas de qualidade. O governador Covas formalizou o Programa no Estado de São Paulo em decorrência da pressão que havia na sociedade, para que essas novas práticas gerenciais e uma nova forma de encarar o trabalho fossem adotadas. A experiência internacional mostrava que esse era um caminho bastante promissor. Internamente havia profissionais e professores que trabalhavam no tema e viram na USP, seu lugar de trabalho, uma oportunidade de avançar seus conhecimentos e melhorar a produtividade da Universidade. (DIR 15)

Valeu mais o contexto interno de burocracia e a busca da excelência; nosso interesse inicial era focado na USP; a qualidade e a importância da ambiência. (DIR 16)

No contexto interno o objetivo era a maior profissionalização nos trabalhos. No contexto externo no nosso campus visávamos melhorar nossa aproximação com as outras unidades seja do ponto de vista administrativo e do ponto de vista acadêmico. (DIR 03)

A Universidade percebeu que ela devia atender a demanda por expansão de vagas de graduação que era e é uma necessidade dos jovens do Brasil; uma taxa baixa de $11 \%$ de jovens entre 18 e 24 anos no Brasil está na Universidade. Então para atender a demanda social a Unidade fez melhor, aumentou a atividade do docente sem comprometer o rendimento acadêmico dele e tornar mais eficaz e eficiente a universidade pública; é uma forma de melhorar a gestão; aumentar $160 \%$ o número de alunos de graduação com cerca de $30 \%$ o corpo docente, você está aprimorando o recurso humano; é uma forma de qualidade. Esse era um dos contextos; existia um movimento legítimo e necessário para a qualidade e a USP participou do processo ativamente e exigiu a melhoria da qualidade. (DIR 09)

Na parte administrativa do processo de gestão, muita gente não levou a sério, porque o Brasil já teve várias iniciativas; o Brasil já teve mesmo um Ministério da Desburocratização; então falar em desburocratizar, agilizar, cada década tem um nome, mas o fenômeno é o mesmo que vem da nossa origem ibérica, portuguesa, que gosta de papel e carimbo. $\mathrm{O}$ que foi feito na Unidade dependeu muito da iniciativa do Diretor e das assistentes, da parte de gestão interna. Uma saída do docente para o exterior a Universidade prevê que passe na Congregação, com pareceristas e leva mais de 30 dias; nós fazíamos igual em 4 ou 5 dias. Tem alguns componentes que são políticos. Há uma inércia conservadora, tanto para mudar objetivos fins como para o objetivo meio, por razões diferentes. (DIR 09)

O Planejamento Estratégico é onde o programa de qualidade estava inserido. Tínhamos uma falta de motivação de conseguir bons alunos, não só no Brasil, mas no mundo todo. Internamente a escola passava uma discussão muito forte, porque nossos alunos não estavam motivados? Por que há uma insatisfação grande dos alunos? Por que estamos assistindo a uma desistência grande dos alunos? Estávamos passando por um processo de mudanças, do ponto de vista interno e externo, muito sensíveis. O Planejamento Estratégico veio fazer um diagnóstico da situação e depois propor alterações, no aspecto qualidade, definindo as diretrizes. A qualidade é ferramenta de gestão. (DIR 11)

Não era um contexto muito diferente de outras Unidades da USP e de muitos locais de trabalho, sobretudo, os de funcionalismo público. As pessoas estavam desmotivadas; você notava isso pela reclamação constante e isso vinha de uma insatisfação do que está sentindo de seu local de trabalho; em parte, o contexto era muito isso. Tive contato também com projeto da EDUSP, IAG e outros e pelo menos o que eles me mostraram na época e na atitude dos funcionários deles também me motivou. (DIR 06)

A Unidade vinha de um sistema de contratação de funcionários onde mais do que qualificação do funcionário, o que se levava em consideração era a "indicação" do funcionário por parentes, amigos e não pela própria qualificação. Existiam pequenos "feudos" de funcionários e quando assumi era extremamente difícil quebrar os feudos para poder reorganizar a estrutura para eles trabalharem em conjunto para a Unidade e a USP. Era difícil trabalhar sem recursos de pessoas 
qualificadas. [...] importante trabalhar com objetivos definidos, com motivação dos funcionários, principalmente que vão executar o programa e a satisfação do usuário final. (DIR 08)

[...] tínhamos feito uma pesquisa de clima organizacional na nossa unidade e percebi que um programa de qualidade somava com o que a gente pretendia na gestão; tínhamos problemas na formação de líderes e precisava também de programas de humanização, momentos de confraternização, momentos para criar laços, para melhorar nosso relacionamento interpessoal; as atividades ajudaram muito neste sentido; inclusive até para saber o que cada um fazia na Unidade. (DIR 14)

Existia um bom relacionamento com o pessoal, tanto funcionários, como entre os professores e entre essas duas categorias. Mas, no início não tínhamos esse programa de qualidade nem a abordagem da motivação funcional. Tivemos oportunidade de contratar um pessoal que veio fazer um trabalho direcionado para os funcionários da Unidade. (DIR 07)

Não havia a cultura do treinamento; só havia os treinamentos da Reitoria. Os treinamentos depois eram mais focados em Qualidade de Vida e ferramentas da Qualidade. A verba de treinamento veio em 1996, para dar um impulso. (TAD 02)

A aceitação por parte do dirigente é fundamental. (TAD 07)

As pessoas estavam completamente desmotivadas e não comprometidas; a Unidade estava completamente abandonada, cada um fazendo o que queria e não acreditando mais em nada. Eu já conhecia algumas Unidades que já estavam bem avançadas e fazendo coisas interessantes na área da qualidade; elas serviram de modelo. (TAD 10)

As pessoas desenvolviam o seu trabalho, procuravam fazer o melhor de si, mas de uma forma desordenada e não sabem se no final o trabalho vai ter qualidade; a pessoa se entregou e a qualidade pode não sair tão boa, daí ela se desmotiva. Este era o contexto da Faculdade e da Biblioteca antes da aplicação de um programa de qualidade e de um sistema de gestão. Havia uma forma desordenada do trabalho, que não gerava resultado satisfatório. Outras Unidades que estavam fazendo alguma coisa nesse sentido obtinham mais resultado. $\mathrm{O}$ retorno externo era só de reclamações. Quando a ESALQ ganhou o prêmio, eles se perguntaram: o que a ESALQ faz de diferente de mim? Ela não faz diferente: vai ver que ela faz de uma forma ordenada, de uma forma planejada. O funcionário da ESALQ não é melhor que o funcionário daqui; ele só trabalha de uma forma ordenada e planejada. Com a qualidade a visão externa do seu trabalho e a visão interna do trabalho fica melhor; consegue ter um resultado melhor. (TAD 12)

A Qualidade estava em alta; era um período onde estava se fazendo muita coisa em outras unidades e a gente não; a biblioteca ia muito bem e por que não tentar alguma coisa no instituto? Inveja não é a palavra adequada, mas porque não tentar fazer algo também bom? (TAD 13)

Havia uma percepção generalizada de que os métodos de gestão até então utilizados já não atendiam satisfatoriamente à demanda vigente. Externamente percebia-se um grande interesse voltado para ações de melhoria da qualidade de gestão, primeiramente no Governo do Estado e na USP (FEA e Vice-Reitoria). (TAD 17)

No que concerne ao contexto, portanto, a inércia conservadora é muito forte em organizações grandes e complexas como a universidade. O decreto do governo do Estado para instituir um Programa de Q\&P surgiu como uma regulamentação e oportunidade para justificar, perante a comunidade universitária, a necessidade de mudanças. Tendo a USP um histórico de excelência acadêmica, era reconhecido que as atividades administrativas, principalmente após a autonomia universitária, em 1989, precisavam de algumas revisões e aperfeiçoamentos. A 
universidade, por princípio, é um ambiente em que autonomia e liberdade são muito valorizadas e qualquer cerceamento delas tende a ser contestado.

Enfim, a existência de um decreto para implantar algo novo na Universidade pode ser um elemento decisivo para deflagrar uma ação mais vigorosa dentro de um órgão público. Condições desfavoráveis internas, como disfunções da burocracia, insatisfação de funcionários e centralização, embora indesejadas e incômodas, não têm por si só uma força suficiente para provocar mudanças em organizações grandes e complexas. O decreto funcionou, na época, como uma força propulsora e mobilizadora de mudanças.

\subsubsection{Conteúdo do Programa de Q\&P}

A segunda categoria de análise (B) diz respeito ao Conteúdo do Programa de Qualidade a ser evidenciado pelas questões 02, 03, 04 e 15 do Roteiro de Entrevista.

Segundo Okumus (2003), entre os fatores de implantação de uma nova estratégia organizacional, é relevante: a) haver no seu conteúdo a coerência com a direção estratégica da instituição; b) o conhecimento dos desenvolvedores da estratégia e a definição clara dos objetivos e c) participação de todos os níveis de gerência. Essas três condições estiveram presentes no Programa de Qualidade e Produtividade da USP: a) a Universidade é considerada a melhor universidade de pesquisa do País e prima pela manutenção de sua excelência; b) ela contou com a assessoria no Programa de duas de suas Fundações especializadas em administração e em certificações de qualidade: a Fundação Instituto de Administração e a Fundação Vanzolini e definiu, em 2003, dez grandes diretrizes institucionais, amplamente divulgadas; c) na USP, inicialmente, os diretores e depois os assistentes técnicos de direção assumiram o processo do Programa de Qualidade e Produtividade, sempre quando endossados pelos Diretores.

As diretrizes dadas pela alta administração da USP sobre o conteúdo a ser considerado no Programa de Qualidade e Produtividade teve como bases: a) o Decreto Estadual, que instituiu o Programa de Qualidade, que dava como seu objetivo "o atendimento eficaz das necessidades do cidadão e uma melhoria contínua e permanente dos serviços prestados, com redução de custos e ganhos de produtividade"; b) os Critérios do Prêmio Nacional da Qualidade (PNQ), que foram alicerçados no Prêmio de Qualidade Americano Malcolm 
Baldrige (1995) e c) os Balizadores da Qualidade no Serviço Público, segundo Programa Permanente de Qualidade e Produtividade no Serviço Público (1996).

Os Módulos de Qualidade, tal como descritos na Metodologia, servem como grade fechada para tratar as questões de Expectativas quanto ao conteúdo do Programa, Atividades Formais do Programa e Experiências Positivas, que identificam três fases do Programa de Qualidade e Produtividade:

- $\quad$ 1- Fase: (T1). Início do Programa (Questão 02: Expectativas de Conteúdo);

- 2- Fase: (T2). Rotina do Programa (Questão 15: Atividades Formais) e

- 3- Fase: (T3). Final do Programa (Questão 18: Experiências Positivas)

Como observa um entrevistado:

O Modelo de Qualidade seguiu os padrões usuais; o Baldrige era um referencial e tinham os pilares; eles (os teóricos do Programa) fizeram um esforço de adaptar esses pilares ao contexto da universidade pública estadual paulista, com bastante flexibilidade, associada à autonomia que ela tem. (DIR 15)

A filosofia era de total liberdade a cada uma das Unidades para trabalharem em torno dessas diretrizes. Todavia, era bastante reforçado em primeiro lugar, a necessidade do envolvimento e participação de todos, da cúpula à base; em segundo lugar, o "foco no cliente", entendido em um sentido amplo que abarcava toda a sociedade e os múltiplos públicos que gravitam em torno dos serviços que a universidade oferece e um terceiro ponto a melhoria contínua pela prática do Ciclo de Deming (PDCA), que aparece como elemento-chave em qualquer programa de qualidade e já reforçado nas orientações dadas pelo Governo do Estado. Essas diretrizes gerais tiveram diferentes interpretações ou conteúdos, nas Unidades que adotaram o Programa.

Dentro da pesquisa feita, para a identificação desse conteúdo, quatro questões foram levantadas: expectativas do conteúdo do Programa; inserção de Qualidade de Vida no Trabalho (QVT); significado de QVT e atividades formais vindas do Programa de Qualidade. 
Elas se apresentavam no Roteiro de Entrevista da seguinte forma:

Q02 O que esperava do Programa, em linhas gerais, como conteúdo?

Q03 A Qualidade de Vida no Trabalho estava inserida nesse conteúdo?

Q04 O que significava QVT?

Q15 Existiam atividades formais denominadas ou vindas do Programa de Qualidade?

Pelas respostas à Q02, um grande elenco de termos traduzia um conjunto de expectativas para o Programa, em sua maioria positivas e genéricas: "melhoria da instituição": "desenvolvimento institucional", "melhoria em todas as áreas", "melhoria dos processos de trabalho", "melhorar a qualidade de nossos produtos e serviços", "organização do trabalho", "alavancar a melhoria de serviços", "evitar retrabalho", "desburocratização" e "redução de burocracia". Associado a recursos humanos registravam-se: expectativas de "pessoas mais envolvidas", "mais motivação", "mais participação das pessoas", "pessoas mais ativas", "trabalhar com união", "melhoria no que se refere às pessoas", "ambiente melhor de trabalho", "interação entre as pessoas", "fazer treinamento", entre outras.

A nomenclatura que emerge está fortemente congruente com a linguagem da qualidade total, evidenciada pelos gurus apresentados na fundamentação teórica: o envolvimento de todos da organização, a participação em tomada de decisões, a maior motivação e compromisso, a cooperação, o treinamento das pessoas, o melhor ambiente de trabalho, a melhoria contínua dos processos de trabalho e a eliminação do desperdício e do retrabalho.

A Tabela 14, a seguir, classifica e sumariza as respostas para as expectativas do conteúdo esperado para o Programa de Qualidade, utilizando-se como categoria de análise a grade já referida.

Questão 02: O que esperava do Programa, em linhas gerais, como conteúdo?

As respostas identificam expectativas, que foram denominadas, para fins de análise, de $1^{\mathrm{a}}$ fase do Programa de Qualidade (T1). 
Tabela 14- Expectativas quanto ao conteúdo do Programa de Q\&P

\begin{tabular}{|c|c|c|c|c|c|c|}
\hline & Expectativas (T1) & $\begin{array}{c}\text { Critérios e } \\
\text { Balizadores }\end{array}$ & $\begin{array}{c}\text { Docentes } \\
\text { Dirigentes }\end{array}$ & $\begin{array}{l}\text { Técnicos } \\
\text { Admin. }\end{array}$ & \multicolumn{2}{|c|}{ TOTAL } \\
\hline & Módulos de Qualidade & & Freq. & Freq. & Freq. & $\%$ \\
\hline 1 & Liderança e Envolvimento & $\mathrm{C} 1$ e B2 & 4 & 4 & 8 & 18,2 \\
\hline 2 & Planejamento & $\mathrm{C} 2$ & 3 & 0 & 3 & 6,8 \\
\hline 3 & Foco no Cliente e Sociedade & $\mathrm{C} 3$ e B1 & 1 & 1 & 2 & 4,5 \\
\hline 4 & Informação e Análise & $\mathrm{C} 4 \mathrm{e} \mathrm{B} 4$ & 1 & 0 & 1 & 2,3 \\
\hline 5 & Desenvolvimento e Gestão de Pessoas & $\mathrm{C} 5$ e $\mathrm{B} 3$ & 8 & 6 & 14 & 31,8 \\
\hline 6 & Gestão de Processos & $\begin{array}{c}\text { C6, B5, B6 e } \\
\text { B7 } \\
\end{array}$ & 7 & 9 & 16 & 36,4 \\
\hline \multirow[t]{2}{*}{7} & Parcerias e Alianças & $\mathrm{C} 7$ e B8 & 0 & 0 & 0 & 0,0 \\
\hline & TOTAL & & 24 & 20 & 44 & 100,0 \\
\hline
\end{tabular}

C1 a C7 - Critérios do PNQ (1996)

B1 a B8 - Balizadores do Serviço Público (1996)

Fonte: Dados da pesquisa, 2010

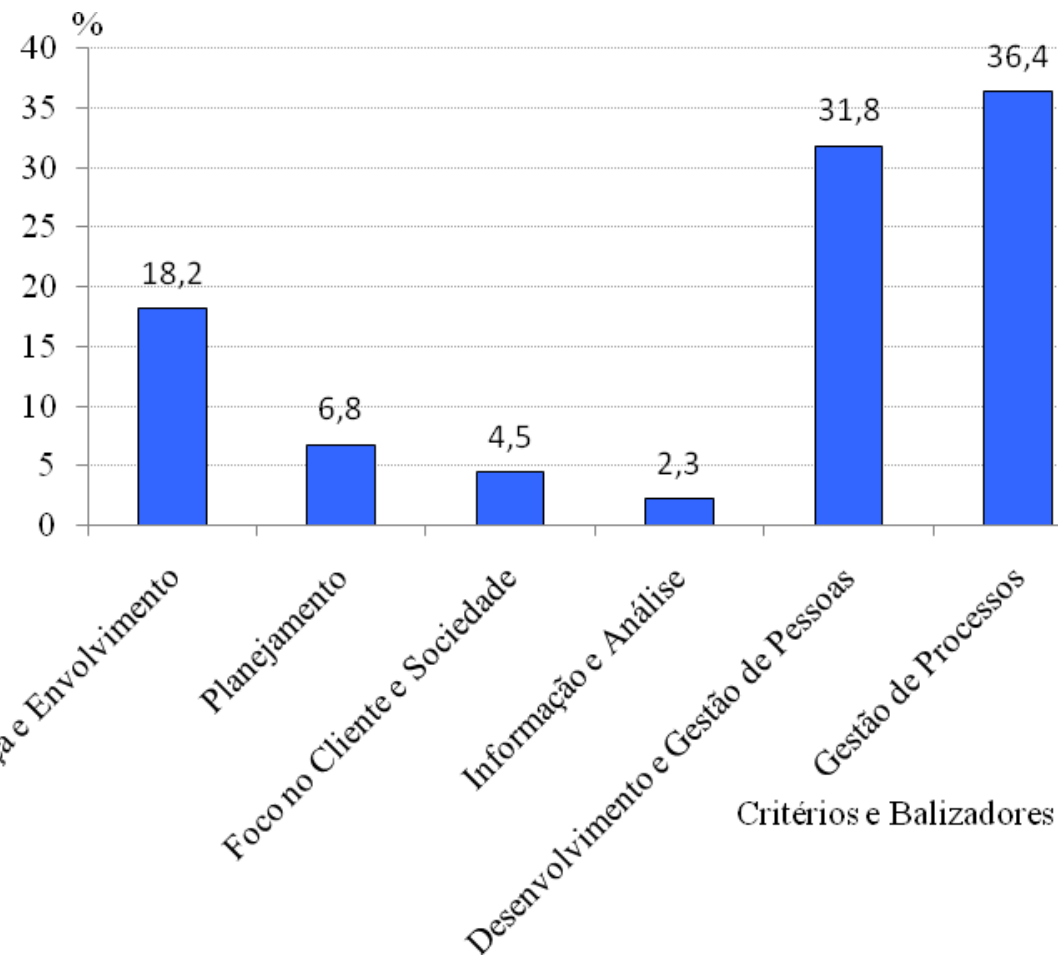

Gráfico 13 - Expectativas quanto ao conteúdo do programa

Fonte: Dados da pesquisa, 2010 
Para melhorar a visualização no Gráfico 13, a categoria correspondente a Parcerias e Alianças foi retirada, por apresentar frequência zero de incidência, nas respostas dos entrevistados.

Como se observa a maior expectativa era com relação ao Módulo 6, relativo ao critério de Gestão de Processos $(36,4 \%)$, aí incluindo o aperfeiçoamento contínuo dos serviços, produtos e processos, sua monitoração e controle. Em segundo lugar, posicionavam-se as expectativas referentes às pessoas e qualidade dos recursos humanos $(31,8 \%)$. Seguiam-se, pela ordem, as expectativas relativas aos Módulos de Liderança (18,2\%), de Planejamento (6,8\%), de Foco no Cliente e Sociedade (4,5\%) e Informação e Análise (2,3\%).

No Módulo 1, de Liderança, associado ao Balizador 2 - Cada um dos participantes da administração pública é responsável pela qualidade, encontram-se os depoimentos:

[...] mobilizar a comunidade interna, funcionários, docentes e a própria congregação foram os caminhos. (DIR 09)

O motivo era integrar pessoas, que elas tivessem uma participação na gestão, e incentivar a criação das pessoas que se sentindo mais envolvidas, pudessem contribuir mais na Unidade e na USP. Eu esperava em termos de conteúdo um avanço em relação ao envolvimento das pessoas; nas novas idéias que vieram surgindo, mais participação das pessoas de várias áreas. (TAD 01)

[...] envolvimento dos funcionários e trabalhar com união. (TAD 04)

O primeiro passo foi identificar, na visão de um grupo de docentes, alunos e funcionários, as principais iniciativas que poderiam atender às diversas necessidades de desenvolvimento institucional. (TAD 17)

Esperava que o Programa sensibilizasse a comunidade para a importância da qualidade no trabalho, criando um ambiente que proporcionasse ações de melhoria. (TAD 19)

Alguns depoimentos, ainda que não exaustivos, contextualizam a inserção das expectativas no Módulo 2 de Planejamento, sem associação aos Balizadores do Serviço Público. Podem ser enquadrados os registros:

[...] Levantamos as prioridades e o tempo que teríamos para enfrentar tais e tais problemas. Se pensa fazer tudo, não faz nada. Começamos pela parte de motivação e depois fizemos um levantamento que possibilitou a elaboração do Primeiro Plano Diretor da Unidade, que apresentamos na nossa gestão. O material feito no Encontro foi apostilado e distribuído para todos os alunos, professores e funcionários. Elaboramos um questionário e pedimos ainda sugestões e quisemos saber qual era a posição deles. (DIR 01)

Eu esperava na linha de qualidade uma contínua e ininterrupta atuação buscando atender as diretrizes estabelecidas. Era importante a USP definir algumas diretrizes e ela definiu suas dez diretrizes, que era importante para as Unidades acompanharem. As atividades na Unidade foram se encaminhando em direção a isso. (DIR 11) 
O Módulo 3, de Foco no Cliente, está associado ao Balizador 1. O cliente final da administração pública é a sociedade.

Estão incluídos, nessa categoria, aspectos ligados à sustentabilidade ambiental, no sentido de que a universidade se preocupa em preservar o ambiente para a sociedade ${ }^{9}$. Na Universidade de São Paulo, o Programa USP Recicla, apoiado depois pelo Programa de Qualidade e Produtividade, mobiliza ações nesse sentido.

Sua ilustração se encontra nos depoimentos:

A palavra que surgia na moda era a procura da excelência e a qualidade era sinônimo de excelência; a USP era e é considerada uma ilha de excelência. Havia três pontos básicos desejados: excelência acadêmica; excelência dos serviços e excelência operacional. No primeiro item, da excelência acadêmica, já tinha isto e acabou tendo uma maturidade crescente porque começaram a surgir indicadores da excelência acadêmica em relação à modernidade dos currículos, em relação ao desempenho da pesquisa e de interações com programas sociais, que é um pouco o tripé, de ensino, pesquisa e extensão. Embora este tripé esteja na Constituição, como indissociáveis, e, portanto, uma universidade de excelência deve ter desempenho nessas três áreas, não faz muito tempo, não se sabia exatamente o que medir, para se saber se o desempenho tinha ou não excelência. Surgiram então indicadores, de como avaliar o ensino que é um pouco mais difícil, ou de avaliar a pesquisa que tem indicadores mais conhecidos e até mesmo indicadores de interação social. A excelência de serviços guarda uma relação indissociável com os usuários. (DIR 16).

[...] necessidade de ter a satisfação do usuário final. (DIR 08)

O objetivo de gestão pública é diferente; a empresa privada quer o lucro para o acionista ou o dono; na universidade pública o objetivo é o aprimoramento do recurso público. ( DIR 09)

Expectativa de embasamento para as atividades dos programas institucionais, como o PURA e PURE, que atendiam necessidades específicas de economia de água e energia. Que o conteúdo da Qualidade abrangesse essas necessidades e pudesse transformar a teoria na prática. (TAD 08)

O Módulo 4, de Informação e Análise, associado ao Balizador 4 - O Programa da Qualidade e as decisões devem ser direcionadas por indicadores, dados e fatos, recebem evidências nos registros:

No que diz respeito a excelência de serviços tivemos uma prioridade que foi a área de informática; tínhamos o Centro de Computação Eletrônica (CCE), que cuidava da infra-estrutura de informática da USP e criou-se uma Coordenadoria de Informática (CCI), que deveria pensar no futuro da informática para a Universidade. Foi formado por pessoas de absoluta qualidade na área; foi relevante, pois eles nos diziam o que a USP devia fazer para acompanhar o desenvolvimento e tinha uma meta: melhorar a comunicação. Isto porque a comunicação interfere em dois capítulos básicos da Universidade: um é o conteúdo e para isso a Universidade já tinha o rádio, jornal e eventos; na nossa gestão criou-se o canal universitário, a TV USP em 1997. Tínhamos que ter

9 A questão da sustentabilidade ambiental passou a ser incluída na agenda das organizações principalmente após a Conferência das Nações Unidas para o Meio Ambiente e o Desenvolvimento, realizada no Rio de Janeiro entre 3 e 14 de junho de 1992, passando a ser conhecida como ECO-92 ou Rio 92. 
meios de mostrar o conteúdo que a USP possuía e, além do conteúdo, cuidar de uma coisa em que éramos amadores, que é como se estabelece a relação entre os diversos segmentos: docentes, funcionários, estudantes e o público em geral; os meios citados, televisão, rádio e jornal, têm que ter um jeito especial no modo que faz a comunicação, para que ela transite entre as pessoas; ela tem que ter um ritmo, uma natureza e um tom para que atinja os seus objetivos; ela tem que ter um clima; às vezes você tem todos os meios mas eles acabam não sensibilizando - o jornal é jogado no lixo, o pessoal não vê televisão, o pessoal não vai ao cinema; é preciso ter um profissionalismo dentro disto, para que as coisas aconteçam; conteúdo e natureza dos meios são indissociáveis. (DIR 16)

O Módulo 5 diz respeito ao Desenvolvimento e Gestão de Pessoas, associado ao Balizador 3 -

A melhoria dos serviços públicos é obtida pela Qualidade dos recursos humanos.

Incluem-se, nesse Módulo, os aspectos ligados à qualidade de vida no trabalho e condições de ambiência que atendem ao cliente interno. Alguns registros mostram sua aderência a esse Módulo:

O conteúdo para um Programa de Qualidade é tornar as pessoas ativas, com mais iniciativa, com mais preparação técnica, mais democrática, procurar o consenso; fomos sempre apoiados pelos melhores especialistas da área que, em muitos casos, eram professores da própria USP; fomos buscar como se faz Programa de Qualidade; estabelecemos assim os rumos deste projeto. (DIR 15)

[..].necessidade de trabalhar com motivação dos funcionários, principalmente que vão executar o programa. (DIR 08)

Esperávamos obter apoio para projetos que já tínhamos planejado e também participar de outras iniciativas institucionais, como nas áreas de treinamento de funcionários. (DIR 04)

Muita coisa foi aparecendo que a gente não esperava: precisávamos ter algo dentro da instituição que motivasse um pouco mais os funcionários de cada setor para a realização de suas atividades. Queria que o próprio funcionário enxergasse quão importante era o seu trabalho e ele era para a instituição e que essa importância trouxesse uma satisfação para ele. Queria ter funcionários trabalhando totalmente engajados na proposta da unidade e da USP. (DIR 05)

Um dos objetivos iniciais do Programa era fazer treinamento de multiplicadores de qualidade; implantar esse programa e aprender um pouco as ferramentas. O conteúdo era ainda a avaliação de ergonomia e o Boletim Informativo da Unidade. (TAD 13)

A expectativa era de melhoria no que se refere às pessoas, uma maior interação entre elas e todos olhando na mesma direção; entendendo ainda que buscavam um ambiente melhor de trabalho; uma rotina nova que trouxesse redução de burocracia e evitar retrabalho. Tudo isso está dentro da mesma panela da qualidade. Dando um motivo, sob a bandeira da qualidade (reciclagem de lixo etc), aproxima as pessoas. (TAD 07)

Na parte operacional, queríamos também outras coisas, como a gestão do ambiente, a ambiência, e qualidade dos prédios e o campus como um todo. (DIR 16)

[...] que as pessoas tivessem boas condições ambientais para exercer suas funções e que se tornassem mais eficientes e produtivas em função desse Programa. (DIR 05)

[...] observar como estavam as instalações, em termos de insalubridade, segurança, prédios e equipamentos. (DIR 13) 
Sob o Módulo 6, de Gestão de Processos, incluíam-se os Balizadores 5, 6 e 7:

5- O aperfeiçoamento contínuo dos serviços, produtos e processos deve ser uma atividade cotidiana no serviço público.

6- O valor e o sacrifício de qualquer atividade devem ser constantemente monitorados.

7- Bons resultados são decorrentes de processos controlados.

Para esses balizadores, podem-se associar os depoimentos:

A excelência operacional é intervir em como a instituição funciona e o que mais incomodava - era a burocracia e continua incomodando. Tem duas burocracias principais na USP: a acadêmica, como, por exemplo, a dificuldade de mudar currículo (vai do Departamento para a Congregação, para a Pró-Reitoria de Pós Graduação etc.); registro de diplomas; fazer concurso; tempo para resolver recursos acadêmicos etc.; e a burocracia administrativa: não é vinculada ao ensino e pesquisa, mas sim às regras externas, normas e leis e às da própria universidade: compras, decisões da Consultoria Jurídica, processos, tempo de sindicâncias de 2 a 3 anos, eram coisas da administração que me irritavam muito: lentidão, leis da licitação (não depende da USP e deve ser cumprida): muitas empresas entravam em alguma licitação, uma ganhava, as outras entravam com recurso e isso atrasava o processo. Burocracia sempre foi irritante para quem faz ciência; a lógica dentro da cabeça das pessoas que fazem pesquisa as irritam mais; elas não suportam que o óbvio não aconteça. Na Constituição diz-se que a universidade tem autonomia administrativa, financeira e didática, mas ela é relativa; não é que a Universidade queira ser soberana, mas ela deveria ter a responsabilidade e arcar com isto e pagar pelos seus erros. Nessa parte operacional, queríamos uma agilidade administrativa e que as coisas fossem mais expeditas. (DIR 16)

Tinha expectativa muito grande de que fosse melhorar as atividades administrativas. Na USP é difícil tomar decisões administrativas; essa coisa de colegiados é muito difícil. (DIR 12)

Esperava que houvesse uma dinamização do ponto de vista administrativo. (DIR 05)

[...] tínhamos uma preocupação com a qualidade das nossas atividades fins: ensino, pesquisa e extensão. No ensino tivemos além da questão liga à metodologia da aprendizagem e informática, tivemos programas que visavam melhorar as condições em que você trabalha a docência, pesquisa e extensão. (DIR 13)

Normalmente se espera uma melhoria geral; eu penso na questão da organização: melhorar os processos de trabalho; a organização é um ponto importante para que todo o restante aconteça; a parte de processo pode ser um fator de stress muito grande. A minha expectativa era de melhoria em termos de operação. ( TAD 16)

Expectativa de uma rotina nova que buscasse redução de burocracia; evitar retrabalho; tornar mais séria as atividades; diversas ações, tudo isso está dentro da mesma panela da qualidade. (TAD 07)

Esperava-se alavancar a melhoria de serviços da Faculdade. (TAD 05).

A gente esperava ter conhecimentos e ferramentas para implantar ações que viessem melhorar a qualidade de nossos produtos e serviços, seja em um processo pequeno ou na Unidade como um todo. [...] para que isso pudesse ser melhor para a Universidade e para nós mesmos (TAD 12)

Normalmente se espera uma melhoria geral; eu penso na questão da organização: melhorar os processos de trabalho, porque na medida em que os processos melhorem traz reflexo para a pessoa no trabalho, a sua satisfação e por conseqüência na qualidade de vida dela; a organização é um 
ponto importante para que todo o restante aconteça; a parte de processo pode ser um fator de stress muito grande. A minha expectativa era de melhoria em termos de operação. (TAD 15)

O primeiro passo foi identificar as principais iniciativas que poderiam atender às diversas necessidades de desenvolvimento institucional. (TAD 17)

Uma das melhores impressões que uma universidade pode gerar para a sociedade como um todo é a beleza e o cuidado com seu campus: a limpeza dos prédios, a qualidade dos jardins, isto impressiona mais que o conceito da própria universidade, porque quando os pais e alunos vêm conhecer a Universidade o impacto que eles têm é dessa fotografia que a Universidade oferece. Isso faz parte de uma excelência operacional, que é a excelência de gestão, excelência de administração ou ainda a excelência de serviços (academic support). (DIR 16)

Quanto ao Módulo 7, Parcerias e Alianças, que estava associado ao Balizador 8 - Parceiros devem ser desenvolvidos para a satisfação do cliente final, não houve registro de expectativas nesse sentido nas entrevistas realizadas.

A inclusão sobre Qualidade de Vida no Trabalho (QVT) nas expectativas de conteúdo do Programa foi provocada pela Questão 03.

Questão 03: A Qualidade de Vida no Trabalho estava presente nas preocupações do Programa de Qualidade?

A Tabela 15 sumariza as respostas obtidas, para a Questão 03:

Tabela 15 - Inclusão de qualidade de vida no trabalho no Programa de Qualidade

\begin{tabular}{c|r|r|r|r|r|c}
\hline \multirow{2}{*}{$\begin{array}{c}\text { QVT incluída no } \\
\text { conteúdo }\end{array}$} & \multicolumn{2}{|c|}{$\begin{array}{c}\text { Docentes } \\
\text { Dirigentes }\end{array}$} & \multicolumn{2}{c|}{$\begin{array}{c}\text { Técnicos } \\
\text { Administrativos }\end{array}$} & \multicolumn{2}{|c}{ TOTAL } \\
\cline { 2 - 7 } & Freq. & $\%$ & Freq. & $\%$ & Freq. & $\%$ \\
\hline Sim & 12 & 75,0 & 8 & 66,7 & 20 & 71,4 \\
\hline Não & 4 & 25,0 & 4 & 33,7 & 8 & 28,6 \\
\hline TOTAL & $\mathbf{1 6}$ & $\mathbf{1 0 0 , 0}$ & $\mathbf{1 2}$ & $\mathbf{1 0 0 , 0}$ & $\mathbf{2 8}$ & $\mathbf{1 0 0 , 0}$ \\
\hline
\end{tabular}

Fonte: Dados da pesquisa, 2010

Como se pode observar para, 71,4\% dos respondentes a Qualidade de Vida no Trabalho estava incluída no Programa de Qualidade. Os depoimentos detalham as justificativas para esse percentual, relacionando-se essa inclusão com "valorização do funcionário"; "integração entre os funcionários"; "boas condições para exercer bem as funções"; "ginástica coletiva", "treinamento contínuo"; "aprimoramento das habilidades técnicas"; "todos se sentirem bem 
dentro da escola"; "uso de dinâmica de grupo"; "pesquisas para aferir o QVT"e "trabalhar como equipe".

Dentre as respostas dadas pelos docentes, 12 disseram que a QVT estava presente e 4 responderam negativamente. Dentre essas últimas respostas foi registrado que QVT "não era o primeiro foco" ou que "isso não era explícito", mas foi complementado que ela "sempre esteve presente", ainda que não explicitado e que "muitas iniciativas iam em direção da melhoria da qualidade de vida no trabalho". Foi, portanto, uma das dimensões que o Programa da USP sempre enfatizou e com o tempo foi ganhando um foco maior na vida institucional. Como uma das linhas de pesquisa da FEA é ligada à Qualidade de Vida no Trabalho e a professora responsável foi uma colaboradora importante do Projeto da Qualidade na USP, houve influência para o fortalecimento desse enfoque no Programa da USP. A referida professora foi citada por ter feito inúmeras palestras nas unidades da USP, o que veio reforçar esse tema, dentro do contexto interno do Programa de Qualidade.

Questão 04: O que significa Qualidade de Vida no Trabalho para você?

O significado da Qualidade de Vida no Trabalho, respondidas na Questão 04, estão consolidadas na tabela a seguir.

Tabela 16 - Significado de Qualidade de Vida no Trabalho

\begin{tabular}{|c|c|c|c|c|c|c|}
\hline \multirow[t]{2}{*}{ Significado de QVT } & \multicolumn{2}{|c|}{ Dirigentes } & \multicolumn{2}{|c|}{$\begin{array}{c}\text { Técnicos } \\
\text { Administrativos } \\
\end{array}$} & \multicolumn{2}{|c|}{ TOTAL } \\
\hline & Freq. & $\%$ & Freq. & $\%$ & Freq. & $\%$ \\
\hline Ginástica coletiva e laboral & 2 & 15,4 & 3 & 27,3 & 5 & 20,8 \\
\hline $\begin{array}{llll}\text { Reconhecimento do valor } & \text { do } \\
\text { trabalho/auto-estima/satisfação } & \end{array}$ & 2 & 15,4 & 2 & 18,2 & 4 & 16,7 \\
\hline $\begin{array}{l}\text { Treinamento/Seminários/ } \\
\text { Palestras }\end{array}$ & 3 & 23,1 & 1 & 9,1 & 4 & 16,7 \\
\hline $\begin{array}{lll}\begin{array}{l}\text { Condições } \\
\text { adequados }\end{array} & \text { ergonômicas/ Móveis } \\
\end{array}$ & 0 & 0,0 & 3 & 27,3 & 3 & 12,5 \\
\hline Integração de pessoas & 1 & 7,7 & 2 & 18,2 & 3 & 12,5 \\
\hline Melhorar condições de trabalho & 1 & 7,7 & 0 & 0,0 & 1 & 4,2 \\
\hline Motivação & 1 & 7,7 & 0 & 0,0 & 1 & 4,2 \\
\hline Trabalhar em equipe & 1 & 7,7 & 0 & 0,0 & 1 & 4,2 \\
\hline Melhoramento da Carreira & 1 & 7,7 & 0 & 0,0 & 1 & 4,2 \\
\hline $\begin{array}{lll}\text { Pesquisa de satisfação } & \text { com } \\
\text { funcionários } & & \\
\end{array}$ & 1 & 7,7 & 0 & 0,0 & 1 & 4,2 \\
\hline TOTAL & 13 & 100,0 & 11 & 100,0 & 24 & 100,0 \\
\hline
\end{tabular}

QVT: Qualidade de Vida no Trabalho

Fonte: Dados da Pesquisa, 2010 


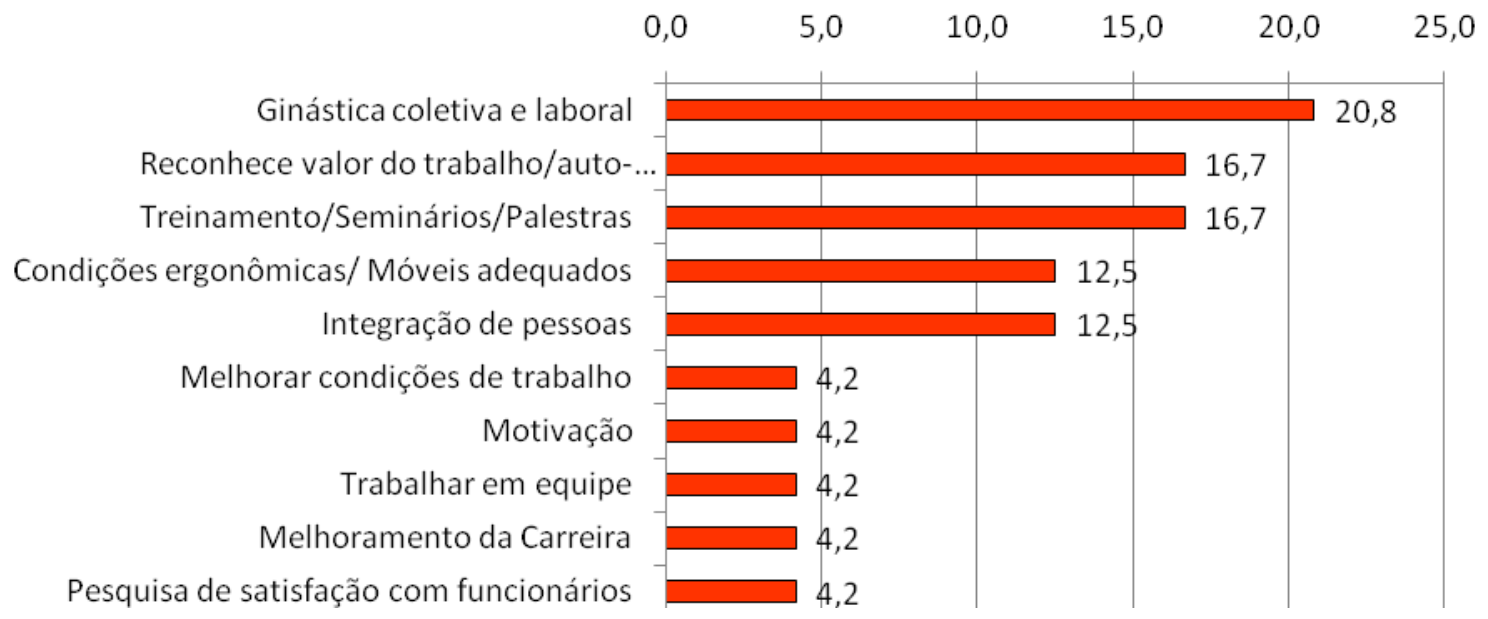

Gráfico 14 - Entendimento de Qualidade de Vida no Trabalho

O foco ligado à Qualidade de Vida no Trabalho era bastante diversificado entre os respondentes. Esperava-se que o Programa contribuísse para uma boa qualidade de vida dos funcionários, docentes e alunos da Unidade, no sentido de que eles tivessem boas condições de exercer suas funções e se tornassem mais eficientes e produtivos em função desse Programa.

Foram relatadas "iniciativas para melhorar as condições de trabalho" (sistemas na intranet, por exemplo); "treinamento"; "melhorar o ambiente de trabalho" (galeria de fotos), "festa (happy hour) mensal com lembranças para os aniversariantes do mês"; "ouvidoria" etc..

Seguem-se alguns depoimentos selecionados:

Esperava que o programa contribuísse para uma boa qualidade de vida dos funcionários e docentes do Instituto e dos alunos também. (DIR 05)

Nós já tínhamos algumas coisas implementadas do Programa de Qualidade e houve daí uma adequação às necessidades e estratégias específicas da Unidade. Houve toda uma preocupação com a Qualidade de Vida de funcionários, professores e alunos; fizemos diversas pesquisas para ir aferindo isso. (DIR 13)

O Programa faz com que o funcionário entenda a importância de seu trabalho para a instituição e começa a ser reconhecido; isso por si só já é uma melhora na qualidade de vida de trabalho; é preciso também trazer a integração dos funcionários, entre os setores, docentes e funcionários; assim você cria um ambiente melhor. (DIR 08)

Realizamos diversas atividades visando principalmente à motivação do funcionário. Eram programas muito bem direcionados para que o funcionário se inserisse integralmente nas propostas da Unidade. (DIR 07)

A QVT está na valorização do indivíduo e principalmente trabalhar com espírito de equipe. (DIR 08) 
A qualidade de vida do trabalho foi o aprimoramento de habilidades técnicas, melhoramento na carreira, integração entre as pessoas. (DIR 09)

Havia um programa de ginástica coletiva, que se manteve por vários anos. Depois apareceram outros tipos de ginástica. Esses momentos servem não só para as pessoas relaxarem, cuidarem de si próprias um pouco como também desenvolvem o companheirismo. (DIR 10)

Tínhamos uma preocupação com Qualidade de Vida; instituímos a ginástica laboral em paralelo com Programa geral da Reitoria; tivemos o apoio da Comissão Central com a parceria do CEPEUSP; a Unidade foi a primeira a ter o programa de ginástica laboral, junto com a Reitoria. (TAD 01)

Sim; desde o início realizamos Seminários Anuais, o que vem acontecendo até agora [2008]; já realizamos 12. Os primeiros seminários foram voltados à Qualidade de Vida; a Profa. Ana Cristina Limongi foi das primeiras a vir prestigiar nossos eventos, com palestra voltada à QVT. Nos primeiros eventos vieram palestrantes externos também com temas de QVT e ferramentas da Qualidade. (TAD 02)

Sem dúvida a QVT estava incluída. Ficamos mais horas no trabalho do que em casa; no trabalho os móveis devem ser adequados; ter lugar adequado para alimentação; fazer trabalhos de interação entre setores para melhorar a gestão do trabalho; fazer fluir mais rapidamente. (TAD 07)

Com certeza; não existe qualidade, sem qualidade de vida; se um funcionário não está bem satisfeito consigo mesmo ele não trabalha bem; em um programa de qualidade tudo está envolvido, tanto a qualidade do trabalho como a qualidade de vida do funcionário. (TAD 12).

Sim, no sentido do projeto da ergonomia para avaliar as condições ergonômicas. (TAD 13)

Dentre as várias ações desenvolvidas foi implantado o Programa de Ginástica Laboral, como forma de propiciar o bem estar físico dos servidores docentes e não-docentes. (TAD 19)

Não explicitamente, mas implicitamente, sempre esteve; todos os móveis da escola eram de 35 anos atrás e foram trocados; as cadeiras eram rasgadas isso era qualidade de vida, mas não se pensava nela para fazer isso. (TAD 10)

A QVT não estava explicitada no Programa. Esperava-se que o Programa pudesse trazer mais eficiência e eficácia ao trabalho e como conseqüência maior auto-estima, orgulho e satisfação a todos: fornecedores dos serviços e colaboradores. (TAD 17)

A análise do conteúdo do Programa de Qualidade prossegue com as atividades que se constituíram como rotina nas Unidades.

Questão 15: Existiam atividades formais denominadas ou vindas do Programa de Qualidade?

Tabela 17 - Existência de atividades formais do Programa de Qualidade

\begin{tabular}{c|r|r|r|r|r|r}
\hline \multirow{2}{*}{$\begin{array}{c}\text { Atividades } \\
\text { Formais }\end{array}$} & \multicolumn{2}{|c|}{$\begin{array}{c}\text { Docentes } \\
\text { Dirigentes }\end{array}$} & \multicolumn{2}{c|}{$\begin{array}{c}\text { Técnicos } \\
\text { Administrativos }\end{array}$} & \multicolumn{2}{c}{ TOTAL } \\
\cline { 2 - 7 } & Freq. & \multicolumn{1}{c}{$\%$} & \multicolumn{1}{c}{ Freq. } & \multicolumn{1}{c}{$\%$} & \multicolumn{1}{c}{ Freq. } & \% \\
\hline \multirow{2}{*}{ Sim } & 13 & 92,9 & 7 & 63,6 & 20 & 80,0 \\
\hline Não & 1 & 7,1 & 4 & 36,4 & 5 & 20,0 \\
\hline TOTAL & $\mathbf{1 4}$ & $\mathbf{1 0 0 , 0}$ & $\mathbf{1 1}$ & $\mathbf{1 0 0 , 0}$ & $\mathbf{2 5}$ & $\mathbf{1 0 0 , 0}$ \\
\hline
\end{tabular}

Fonte: Dados da pesquisa, 2010 
Do total de 25 respostas válidas, $80 \%$ responderam que o Programa tinha atividades formais. Dos 14 diretores entrevistados, 92,9\% declararam que havia atividades formais, ligadas ao Programa de Qualidade, enquanto 63,6\% dos técnicos administrativos fizeram a mesma afirmação. Dentre as atividades formais para o Programa, as de maior ocorrência, foram atividades de treinamento e realização de palestras dirigidas aos funcionários; houve ainda indicação de atividades ligadas à avaliação ergonômica do local de trabalho; preocupação e medidas concretas para dar acessibilidade aos portadores de deficiências; participação em programas institucionais como USP Recicla, PURE, atividades da CIPA; atividades ligadas à qualidade de vida no trabalho como: ginástica, motivação de funcionários, atividades de integração dos funcionários, melhoria de qualidade em cada um dos setores e para atender melhor aos funcionários foram realizadas "pesquisas de clima organizacional e de satisfação".

As respostas à Q15, classificadas pelos Módulos de Qualidade, identificam atividades formais, que, para fins de análise, se consideraram como $2^{\mathrm{a}}$ fase do Programa de Qualidade, ou seja, T2, a fase em que as atividades da Qualidade ficaram consolidadas na rotina organizacional.

Tabela 18 - Conteúdo das atividades formais do Programa de Q\&P

\begin{tabular}{r|l|c|c|c|c|c}
\hline & \multicolumn{1}{|c|}{ Atividades Formais (T2) } & $\begin{array}{c}\text { Critérios e } \\
\text { Balizadores }\end{array}$ & $\begin{array}{c}\text { Docentes } \\
\text { Dirigentes }\end{array}$ & $\begin{array}{c}\text { Técnicos } \\
\text { Administrativos }\end{array}$ & \multicolumn{2}{c}{ TOTAL } \\
\hline & \multicolumn{1}{|c|}{ Módulos de Qualidade } & & Freq. & Freq. & Freq. & \% \\
\hline 1 & Liderança e Envolvimento & C1 e B2 & 1 & 2 & 3 & 10,3 \\
\hline 2 & Planejamento & C2 & 2 & 0 & 2 & 6,9 \\
\hline 3 & Foco no Cliente e Sociedade & C3 e B1 & 2 & 2 & 4 & 13,8 \\
\hline 4 & Informação e Análise & C4 e B4 & 0 & 2 & 2 & 6,9 \\
\hline 5 & Desenvolvimento e Gestão de Pessoas & C5 e B3 & 9 & 5 & 14 & 48,3 \\
\hline 6 & Gestão de Processos & C6,B5,B6eB7 & 2 & 2 & 4 & 13,8 \\
\hline 7 & Parcerias e Alianças & C7 e B8 & 0 & 0 & 0 & 0 \\
\hline & TOTAL & & $\mathbf{1 6}$ & $\mathbf{1 3}$ & $\mathbf{2 9}$ & $\mathbf{1 0 0 , 0}$ \\
\hline
\end{tabular}

C1 a C7 - Critérios do PNQ

B1 a B8 - Balizadores do Serviço Público (1996)

Fonte: Dados da pesquisa, 2010 


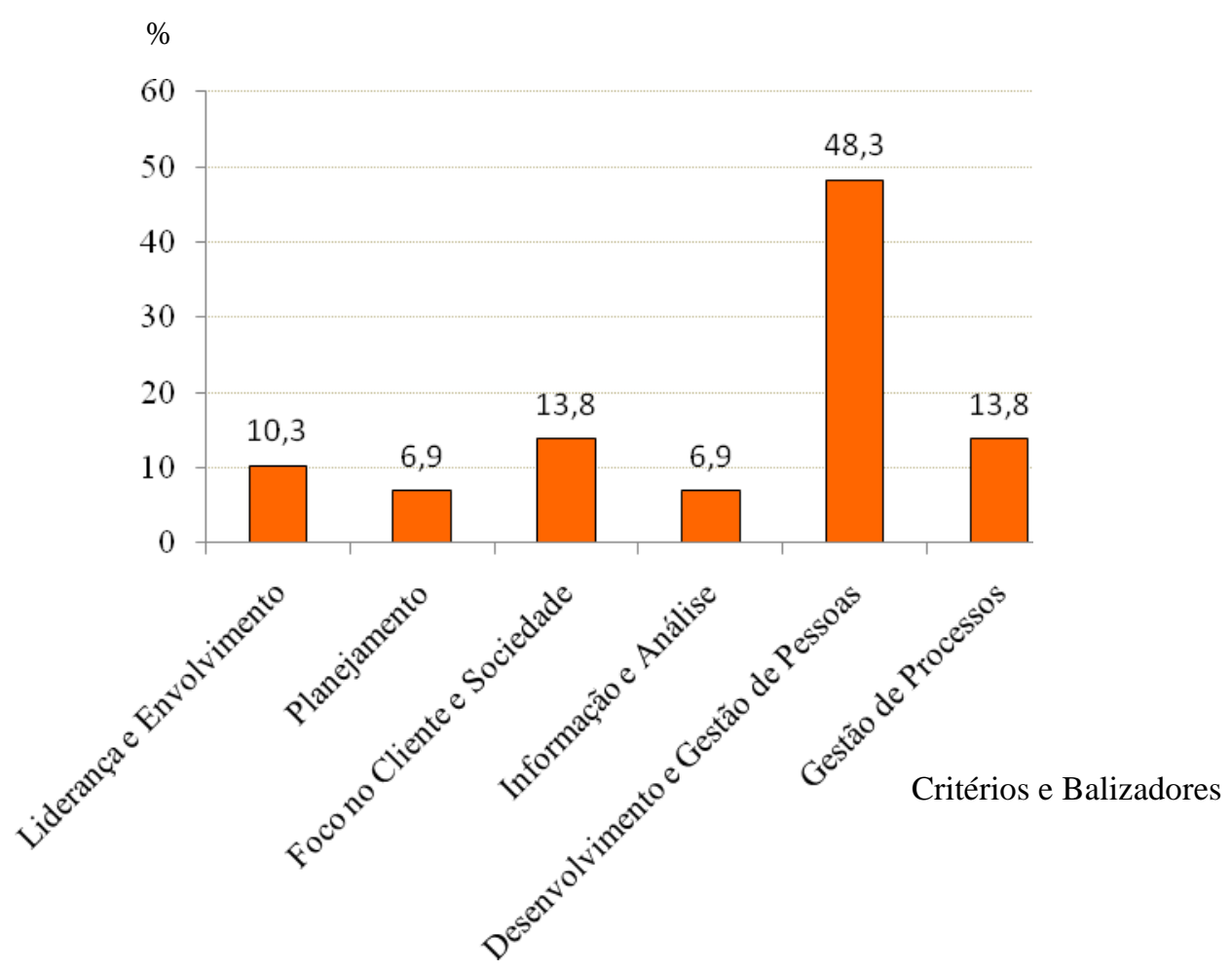

Gráfico 15 - Atividades formais do Programa de Qualidade Fonte: Dados da pesquisa, 2010

As atividades explicitadas como de Sustentabilidade Ambiental e Qualidade de Vida no Trabalho foram incluídas, respectivamente, em Foco no Cliente e Sociedade e em Desenvolvimento e Gestão de Pessoas.

Dentre as atividades formais, que estavam mais vinculadas às ações do Programa de Qualidade e Produtividade, destacam-se aquelas ligadas ao Módulo de Desenvolvimento e Gestão de Pessoas (48,3\%). Seguem-se, por ordem, Foco no Cliente e Sociedade e Gestão de Processos, cada uma delas com 13,8\% das indicações de atividades; liderança e envolvimento $(10,3 \%)$ e Planejamento e informação e Análise, cada uma com 6,9\%.

Alguns depoimentos ilustram as atividades formais, segundo os Módulos de Qualidade da Tabela 18.

No Módulo 1, de Liderança, associado ao Balizador 2 - Cada um dos participantes da administração pública é responsável pela qualidade, podem ser identificados os depoimentos: 
Com os Workshops procurava-se reunir todas as pessoas, e dava uma chacoalhada. No primeiro workshop foram 32 pessoas, os chefes e professores que tinham cargo de direção; no segundo workshop já foi todo mundo e os chefes ficaram dois dias e os outros ficaram um dia para se revezarem e todos poderem ir; no terceiro foi todo mundo, ao mesmo tempo; no $4^{\circ}$ ano todo mundo em Pirassununga; até o terceiro workshop não era obrigatório, mas a gente procurava fazer todos irem, sem obrigá-los; no último deles, neste ano [2008] foi facultativo e mesmo assim a adesão foi boa; foram 70 pessoas de um universo de 85 pessoas. (TAD 15)

Qualquer tipo de programa de cursos e encontros era aberto a todos os funcionários, dos três níveis. Fazíamos sempre no nosso maior auditório para poder levar mais pessoas; nunca houve um bloqueio por conta dos departamentos, nem das chefias para que eles fizessem o treinamento. Criou-se uma cultura muito importante nesse sentido, todos participam e as chefias não interferem. (TAD 02)

\author{
Módulo 2, de Planejamento, sem associação aos balizadores do Serviço Público. Podem ser \\ enquadrados os registros:
}

As atividades para a Qualidade foram os programas que vieram do Planejamento Estratégico. (DIR 11)

Em 2002, todos os chefes de departamento, diretor e vice-diretor fizeram curso de Planejamento Estratégico; eu sinto que quando fomos discutir o Planejamento Estratégico e o Plano de Metas de cada departamento, já tinha um clima organizacional muito fértil para discussão. Tanto é que o nosso Plano de Metas foi muito rico. Isso ajudou nossa unidade a alavancar, a ter foco e saber exatamente o que ela queria e alinhada às diretrizes da Universidade. Foi um momento que propiciou a todos uma visão sistêmica; propiciar a todos o estabelecimento do que queríamos e o que faríamos; foram estabelecidos objetivos, metas, ações e indicadores. Houve uma ação conjunta, não só dos docentes e também um plano não só discutido em congregação ou CTA; foi construído junto, discutido junto e foi distribuída a responsabilidade para todos. Isso deu uma força muito grande para nossa Unidade. Tinham atividades formais regulares: cursos e integração e articulação entre as pessoas. (DIR 09)

\title{
O Módulo 3, de Foco no Cliente está associado ao Balizador 1 - O cliente final da
} administração pública é a sociedade.

Uma coisa que se tornou rotina foi a avaliação interna dos setores. Sistematicamente os setores são avaliados pelos usuários pela internet. Todos os alunos e funcionários são convidados a preencherem o questionário; as críticas são levadas aos setores que tomam conhecimento delas e uma avaliação da avaliação; as criticas têm um objetivo construtivo. É interessante que cada setor saiba exatamente o que pensa o seu usuário e como o seu serviço está sendo recebido. Isso continua até hoje. Isso não é usual na Universidade. Temos avaliação individual, institucional, mas isso é uma avaliação do serviço. (DIR 05)

Foi formado um trabalho para melhorar a comunicação no Instituto; temos até um estagiário cuidando disso, para melhorar a comunicação (interna, externa, institucional) do Instituto. (DIR 05)

O Módulo 4, de Informação e Análise, associado ao Balizador 4 - O Programa da Qualidade e as decisões devem ser direcionadas por indicadores, dados e fatos podem estar incluídos nos depoimentos: 
A questão dos registros: foi muito importante a constituição do hábito de fazer agenda e memória das reuniões; elaboração de formulários e documentação do trabalho. As pessoas não tinham o hábito de fazer isso. Por mais que não utilizem as ferramentas da qualidade elas conseguem fazer um registro. Alguns saíram do papel e fizeram sistemas informatizados para registrar; tudo isso veio com a nova visão do programa. (TAD 01)

Atividades de implantação de formulários, tínhamos técnicas já pré-definidas, com formas de serem aplicadas; aplicava as técnicas da forma que vinham, e se depois víamos que elas não se aplicavam da forma que vinham nós adaptávamos à nossa realidade, tinham nomenclatura prédefinida. A Biblioteca aprendeu 12 técnicas diferentes, que os consultores recomendavam para gente; eles ensinavam e depois a gente adotava aqui. Existiam atividades formais para serem desenvolvidas. (TAD 12)

\section{O Módulo 5, de Desenvolvimento e Gestão de Pessoas, associado ao Balizador 3 - A melhoria} dos serviços públicos é obtida pela Qualidade dos recursos humanos, pode ser projetado para as ações elencadas nos depoimentos:

Treinamento de inglês e outros treinamentos. Eu era da Comissão de treinamento e a própria Comissão de Qualidade era responsável pelo treinamento; eu era o suplente do PURE e também membro do USP Recicla. A Comissão agregava várias ramificações das atividades do Instituto, de modo que as coisas que se discutiam ali tinham um encaminhando porque ali estava também o executor. Então isso deu muita agilidade e expediente para os trabalhos se realizarem. Um fator negativo de uma Comissão é não ter o respaldo do dirigente e não ter meios para fazer as coisas se encaminharem. (TAD 15)

Os Seminários da Qualidade e o treinamento, que trazíamos para cá com empresas externas. Isso passou a ser um trabalho da Comissão de Qualidade. Fazíamos pesquisa no final dos treinamentos e era levada ao CTA. (TAD 02)

Não havia atividades formais; só as palestras, os encontros, dia da Secretária, a Profa. Ana Cristina Limongi, palestras motivacionais. Isso era o alimento para nos sentirmos unidos; vamos nos mobilizar; o povo confiava e tínhamos crédito; não tinha esse nome, mas qualidade era nosso target. (TAD 07)

Tinham as atividades vindas da avaliação ergonômica, o boletim e o treinamento de multiplicadores. (TAD 13)

Havia atividades até anteriormente à formação do Programa. Tínhamos um bom programa do USP Recicla, do PURE, a CIPA; tinha também o T\&D (Treinamento e Desenvolvimento). Demos sempre muita ênfase a T\&D e tínhamos também um programa de ginástica e de relaxamento. (DIR 06)

Um pessoal especializado trabalhava no setor motivacional que estava vinculado diretamente ao Programa de Qualidade; o pessoal vinha e realizava trabalhos e esse grupo também organizava também trabalhos fora da Unidade e a gente indicava os funcionários para participar. (DIR 07)

Foi a implantação do treinamento, das reuniões e do workshop de nível gerencial, organizado pela USP. (DIR 08)

Eram a ginástica laboral, cursos amplos e iniciativas de segurança no trabalho. (DIR 12)

Atividades formais regulares: os cursos e integração e articulação entre as pessoas. (DIR 09)

Capacitação e desenvolvimento das pessoas. Repetimos três vezes o evento "Pratas da Casa"; os encontros de gestão também eram muito importantes; fizemos em segmentos para os departamentos em separado, depois só a administração; depois todos juntos, três ao todo, um a 
cada ano; sempre para alinhar as atividades; pesquisa de clima organizacional. Isso foi decisivo e fundamental. Fizemos o encontro: "O que somos, o que podemos e o que queremos ser", para definir a missão, visão de futuro, o que foi ótimo. (DIR 14)

Existe um Regimento interno na Comissão. As atividades ficaram restritas aos cursos e treinamentos. A Comissão de Qualidade se formou em subcomissões: Comissão Assessora de RH e Comissão de Reciclagem; nesta última havia mesmo alunos, que gostavam muito de participar. Em gestão mais recente havia a ginástica laboral e o seminário voltado à Qualidade. (TAD 04)

Sob o Módulo 6, de Gestão de Processos, incluíam-se os Balizadores 5, 6 e 7:

5- O aperfeiçoamento contínuo dos serviços, produtos e processos deve ser uma atividade cotidiana no serviço público.

6- O valor e o sacrifício de qualquer atividade devem ser constantemente monitorados.

7- Bons resultados são decorrentes de processos controlados.

Os depoimentos podem ensejar um enquadramento na grade de análise:

Cada um procurava melhorar a qualidade do seu setor. (DIR 10)

Uma coisa que se tornou rotina foi a questão da ergonomia; a compra de móveis segue agora um padrão estabelecido junto com um funcionário que já tinha trabalhado numa fábrica de móveis. (DIR 05)

Uma técnica que veio e foi implantada tal como veio e está dando muito certo, foi o $5 \mathrm{~S}$; foi adotada uma vez cada 6 meses e agora uma vez por ano; fazíamos o Dia da Bermuda, quando a Biblioteca fica fechada e todos organizavam o seu setor. (TAD 12)

Quanto ao Módulo 7, de Parcerias e Alianças, associado ao Balizador 8 - Parceiros devem ser desenvolvidos para a satisfação do cliente final, não houve registro de atividades formais nesse sentido, entre os depoimentos dos entrevistados.

Para minimizar resistência diante de formatações únicas, as diretrizes dadas pelo Programa de Qualidade foram bastante genéricas, dando liberdade e autonomia às Unidades, o que deu margem a uma série de representações da qualidade extremamente diversificadas, segundo as especificações e interesses de cada uma dessas Unidades.

\subsubsection{Processo}

A terceira categoria de análise (C) é o Processo. Ao se descrever o Processo de implantação do Programa de Qualidade, segue-se a orientação de implantação de uma nova estratégia, 
segundo Okumus (2003). Deve-se considerar: o planejamento operacional, que inclui o preparo para a implementação das atividades; a participação e feedback de diferentes níveis de gerenciamento e áreas funcionais, considerando sua receptividade e resistências; os recursos humanos e materiais; quanto às pessoas: selecionar, prover treinamento e incentivo para funcionários relevantes no processo; avaliar impactos das políticas e práticas de Recursos Humanos na implementação da nova estratégia (a avaliação de desempenho individual passou a dar valor à participação em iniciativas institucionais); a comunicação, pelos mecanismos para enviar mensagens formais e informais sobre a nova estratégia; o controle e feedback, com mecanismos formais e informais que permitem que os esforços e resultados da implementação sejam monitorados e comparados com determinados objetivos.

O levantamento sobre o Processo de implantação de Qualidade na Unidade e suas características foi aferido por um elenco de questões:

Questão 06: Como foi o Modelo de Implantação do Processo de Qualidade?

Questão 07: Como se lembra da receptividade interna ao Programa de Qualidade?

Questão 08: Havia recursos financeiros alocados ao Programa?

Questão 09: Os recursos eram porcentagem específica do orçamento?

Questão 10: Foi delineada uma estrutura administrativa para sustentá-lo?

Questão 11: Havia um poder decisório definido para o Programa?

Questão 12: Existiam áreas específicas envolvidas no Programa?

Questão 13: Existiam funcionários especialmente envolvidos com a Qualidade?

Questão 14: Havia métodos para identificar necessidades de melhorias na Unidade?

Questão 16: Existia um controle ou monitoramento dos resultados das atividades do Programa de Qualidade?

Questão 17: Existiam indicadores de produtividade na Unidade?

Questão 06: Como foi o Modelo de Implantação do Processo de Qualidade?

Com relação à Questão 06, referente ao Modelo de Implantação do Programa de Qualidade, existia um modelo geral preconizado pela própria portaria de instituição do Programa na USP, GR- 2.985, de 29/ 01/96, induzindo à formação de Comissões Internas de Qualidade. Todavia, nas Unidades, o Programa tomou diferentes formas, constituindo-se em comissões compostas só de docentes, só de funcionários técnico-administrativos, de comissões mistas, incluindo 
alunos ou tomando outras configurações, como pode ser identificado nas respostas dos entrevistados. Aspectos específicos da implantação são levantados nas outras questões sobre o Processo.

Um comentário sobre o modelo de implantação merece destaque:

[...] o processo era o convencimento, conquistar corações e mentes e discutir modelos; criamos os Grupos de Controle da Qualidade; por um processo de círculos concêntricos; você vai tentando cooptar pessoas para participar; ocorreu como na história das religiões: Maomé começou em Meca e foi expandindo; o catolicismo começou na Palestina, em Roma e foi expandindo; esse é um processo de cooptação de corações e mentes; ele é um processo como uma onda. (DIR 09)

O depoente levanta a questão de mudança cultural por meio de grupos, tal como registrado por Fleury (1993), seguindo Sainsaulieu, que observa que qualquer estratégia prática para mudar a cultura organizacional terá que envolver pensamento e ação, tanto no nível das crenças básicas como de suas manifestações culturais.

Para se investigar quanto o Programa foi aceito pela comunidade, foi feita a pergunta:

Questão 07: Como se lembra da receptividade interna ao Programa de Qualidade?

Tabela 19 - Receptividade ao Programa de Qualidade

\begin{tabular}{|c|c|c|c|c|c|c|}
\hline \multirow[b]{2}{*}{ Receptividade ao Programa } & \multicolumn{2}{|c|}{ Dirigentes } & \multicolumn{2}{|c|}{$\begin{array}{c}\text { Técnicos } \\
\text { Administrativos }\end{array}$} & \multicolumn{2}{|c|}{ TOTAL } \\
\hline & Freq. & $\%$ & Freq. & $\%$ & Freq. & $\%$ \\
\hline $\begin{array}{l}\text { Muito boa /boa/positiva/entusiasmo pela } \\
\text { participação }\end{array}$ & 10 & 66,7 & 6 & 54,5 & 16 & 61,5 \\
\hline $\begin{array}{l}\text { Não foi unânime/ visão conflitiva/ } \\
\text { precisou convencimento grande }\end{array}$ & 4 & 26,7 & 0 & 0,0 & 4 & 15,4 \\
\hline Aceitação nem boa nem ruim & 1 & 6,7 & 2 & 18,2 & 3 & 11,5 \\
\hline Bastante resistência/ Descrédito e difícil & 0 & 0,0 & 3 & 27,3 & 3 & 11,5 \\
\hline TOTAL & 15 & 100,0 & 11 & $\mathbf{1 0 0 , 0}$ & 26 & 100,0 \\
\hline
\end{tabular}

Fonte: Dados da pesquisa, 2010 


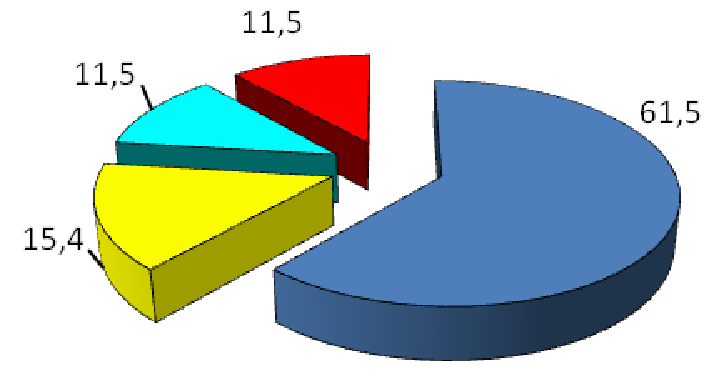

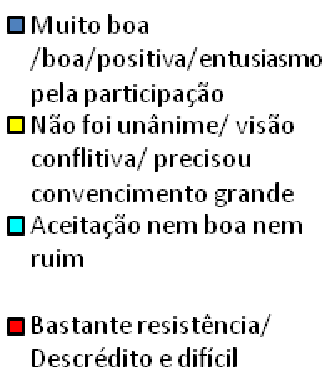

Gráfico 16 - Receptividade ao Programa de Qualidade (\%) Fonte: Dados da pesquisa, 2010

\section{Os dirigentes observam:}

A receptividade foi surpreendentemente muito boa; as poucas críticas não vieram por documentos; sabíamos de oitiva que alguns diziam "isso não leva a nada" e dizíamos sempre "leva sim", só que precisa ser devagarzinho, porque temos que mudar uma cultura e que cultura é essa? É a de "cada um fazendo sua parte a instituição ganha"; vai levar sim mas não é do dia para a noite e essas reuniões que a CODAGE promovia de reunir as pessoas, a quantidade de sugestões foi enorme; algumas eram muito ingênuas mas algumas foram aproveitadas e incorporadas; se valorizava a ousadia e o interesse em se manifestar. Tínhamos também a convicção de que era importantíssimo a continuidade do programa porque é um programa de interesse permanente. O Programa da Qualidade foi seminal para essa nova cultura. (DIR 16)

A implantação do Programa contou com o apoio decisivo do Reitor; a primeira reunião teve uma presença muito significativa, apresentando idéias e procuramos manter um sistema em que as unidades mantinham sua autonomia e poderiam aderir ao Programa de Qualidade, indicando seus membros, mas era algo que não se integrava na estrutura formal da Universidade; não era incompatível com a estrutura atual; o responsável final era o diretor da Unidade, mas elas tinham vida própria. As pessoas eram indicadas para as Comissões e foram submetidas a treinamento; às vezes o diretor apoiava e virava projeto dele e outros tinham menor dedicação. Na universidade os mandatos de diretores de Unidade são espalhados no tempo. Então quando se começa um processo desses alguns diretores estavam no começo de mandato outros no final de mandato e mais preocupados com outras coisas; então o convencimento potencial para esse projeto é um tema trabalhoso que envolve tempo e nem todo mundo estava envolvido no projeto todo tempo. (DIR 15)

Eu me lembro muito bem que todos eles funcionaram como agentes divulgadores do que ocorreu [reunião para elaboração de Plano Diretor] e do entusiasmo que refletia amor à instituição. (DIR 01)

Eu acho que foi boa; houve uma frequência elevada nas reuniões, as pessoas estranhavam um pouco que o Diretor estivesse lá participando e as pessoas tem tendência a dizer que não querem perder tempo com isso mas com o Diretor presente elas sentem que é importante; isso ajudou a manter por um tempo razoável o interesse no Programa em andamento; até que as coisas entrassem em funcionamento. O Programa foi mais voltado aos funcionários. No começo tinha um número bastante razoável de professores que participaram com alguma regularidade, mas depois se cansaram um pouco porque as questões não eram da sua área. (DIR 10)

A receptividade interna foi muito boa, principalmente depois que foram criados canais de comunicação dos usuários com a comissão. A possibilidade de que cada um pudesse apresentar sugestões e observações sobre fatos ligados ao Instituto, como manutenção, situações de risco etc. O Instituto aumentou assim muito o número de olhos que observavam cada detalhe de sua área. (DIR 03) 
Foi muito boa; o Programa foi sempre muito bem recebido. A Unidade já havia aderido ao Programa e nunca houve nenhuma objeção ou crítica. O programa foi bem aceito pela comunidade; o ambiente era tal que se eu tivesse uma posição de não continuar o programa eu teria talvez uma resistência. (DIR 05)

Foi muito boa; dava para se sentir que os funcionários estavam motivados com essa proposta. $\mathrm{O}$ programa em si e a motivação tiveram o envolvimento de outras Comissões; a CIPA também participou desse programa realizando cursos, palestras; fazem a Semana de Prevenção de Acidentes na Unidade, com grande motivação e aproximadamente $40 \%$ do pessoal participava das atividades; isso estava inserido no Programa de Qualidade. (DIR 07)

Internamente, $2 / 3$ da comunidade acadêmica acatou o Programa. Existe na universidade uma inércia conservadora; as instituições tradicionais como as universidades, as religiões e as forças armadas têm coisas diferentes entre si, mas em comum têm a inércia conservadora; isso é bom em alguns momentos na Universidade para manter valores, como o respeito ao conhecimento, ao ensino, mas também essa inércia conservadora com bons princípios pode ser ruim em termos de gestão; manter rituais. (DIR 09)

Eu diria que foi como toda coisa nova precisou de um convencimento muito grande; para uma parte importante da população da Escola a qualidade é uma coisa bem compreendida no trabalho, e é uma ferramenta para atingir os seus objetivos. (DIR 11)

Não foi uma receptividade unânime; um projeto desse tipo não é aceito por todo mundo; a comunidade é muito grande e você tem que procurar aperfeiçoar; tirar o melhor que você pode; eu usei uma estratégia, que muita gente criticou; comecei o Programa só com os funcionários e dirigido a eles, pensando num segundo momento atingir os professores. Eu procurei liberar os funcionários de seus chefes imediatos para essa ação; deixá-los bem à vontade; então eu tirei os professores fora e disse: "vamos fazer um programa mais voltado ao corpo funcional". Eu acho que deu certo e agora nós já temos vários professores que estão se engajando no Programa. (DIR 06)

Existiu uma visão conflitiva: ao mesmo tempo em que um pessoal reclama de agilidade, existe a desconfiança e do já vi isso antes. Depende da iniciativa do Diretor; de uma maneira geral houve certa empatia; talvez os funcionários participaram mais porque respeitam mais a hierarquia que o corpo docente; porque tem um outro componente na gestão de qualidade: primeiro que a Universidade não tem patrão; é diferente de uma empresa e outro componente da Universidade pela sua natureza intrínseca; a Universidade é o espaço da crítica; e no espaço da crítica muitos ou um grupo significativo de docentes acham que entendem de tudo, inclusive de qualidade; o funcionário, quando o Diretor diz vamos fazer o processo de qualidade ele obedece mais, o docente questiona. (DIR 09)

A receptividade interna foi interessante; ao mesmo tempo em que agradava um grupo, o outro não entendia o que estava acontecendo, e achava que era perda de tempo. A medida que as atividades vinham acontecendo essas pessoas descobriram que não era como pensavam; foi uma oportunidade rica para descobrirem a ginástica laboral; os docentes reclamavam que os técnicos estavam chegando 20 minutos atrasados, mas depois viam que o técnico chegava tão animado e tão feliz que ele tinha um funcionário mais inteiro do que antes; com o tempo foram sentindo que isso era até mais respeito pelo ser humano; são pessoas que precisam de atenção; precisam de momentos de descontração com os colegas; no final houve uma mudança da cultura e muitos tiveram a oportunidade de entender a importância de um programa de qualidade. (DIR 14) 
Quanto aos técnicos administrativos há um olhar diferente sobre essa receptividade ao Programa.

Aqui na Unidade foi muito boa; em 1998, foi feito um primeiro workshop de competência, que integrou as várias áreas do Instituto e se conseguiu enxergar os papéis de cada uma. Deu para se entender um pouco dos conceitos de qualidade. (TAD 15).

Algumas pessoas foram positivas; outras foram completamente contra e depois que começou a gente percebia que algumas pessoas que por mais que fossem estratégicas no local não tinham afinidade como o que estávamos fazendo; então elas solicitaram dispensa; tivemos algumas baixas e hoje vejo que isso é natural; nem todos têm afinidades com essas questões e outras pessoas acabaram entrando, depois com o programa já em andamento. (TAD 14).

Houve um pouco de rejeição de alguns docentes que não entenderam o espírito do Programa de Qualidade, mas isso logo foi desfeito e os docentes absorveram muito bem; por questão de cultura, a aceitação e a participação dos funcionários foram maciças; a dos docentes em muito menor escala, pela própria natureza do trabalho. (TAD 02)

Eu sentia duas reações: em algumas pessoas havia o descrédito, não se acreditava mais; outros lembravam o antigo Diretor e falavam que era legal e a grande maioria achava que o Programa de Qualidade era nada. Não houve uma mobilização. (TAD 10)

Não foi boa nem ruim; foi uma expectativa. O projeto foi muito bem-vindo para grande parte dos funcionários. Os docentes tiveram um envolvimento pequeno, porque estão sempre ocupados em diversas atividades; a adesão foi bastante boa dos funcionários. A dificuldade é manter as pessoas estimuladas até hoje. (TAD 13)

Houve bastante resistência por parte de docentes e funcionários, havia necessidade de trabalhar esta questão com argumentos para persuasão. Uma minoria de funcionários, a Diretoria, a Comissão do Programa de Qualidade e as Chefias dos Departamentos aderiram. (TAD 17)

Quanto aos recursos financeiros para o Programa, as questões 08 e 09 dão informações para esse item. Não era, segundo entrevista dada pelo Presidente da Comissão de Qualidade ao Jornal da USP (1996, n. 350, p.3) um "projeto pensado para se colocar vastos recursos financeiros para se fazer coisas, mas sim estimular e articular iniciativas que ampliassem a contribuição social da Universidade". Todavia, se fosse necessária a aplicação de recursos haveria meios de encontrá-los. Do ponto de vista administrativo, a alocação de recursos sinaliza a importância dada pela alta administração ao que se quer implantar:

Questão 08: Havia recursos financeiros alocados ao Programa?

Os documentos consultados e a vivência na Comissão de Gestão de Qualidade e Produtividade da USP permitem considerar que ainda que não houvesse uma alocação direta de recursos para o Programa, nenhuma ação deixou de ser feita por falta de recursos financeiros. Os projetos estruturados e bem justificados sempre foram acolhidos e houve recursos liberados para sua operacionalização. 
Diz em depoimento o Reitor que instituiu o Programa de Q\&P:

[...] a excelência acadêmica está muito ligada a ter meios; não se pode cobrar excelência e produtividade se não se oferecem os meios. (DIR 16)

De 27 respondentes a essa questão, nove deles, ou seja, 33,3\% do total afirmaram que "havia recursos financeiros" e outros 18 , totalizando 66,7\%, disseram "não haver recursos". Quando eles explicam melhor essa questão, o percentual dos que responderam que "existia recursos" aumenta e apontam detalhes que devem ser observados:

Tabela 20 - Descrição de recursos financeiros

\begin{tabular}{l|c|c|c|c|c|c}
\hline & \multicolumn{2}{|c|}{$\begin{array}{c}\text { Docentes } \\
\text { Dirigentes }\end{array}$} & \multicolumn{2}{c|}{$\begin{array}{c}\text { Técnicos } \\
\text { Administrativos }\end{array}$} & \multicolumn{2}{c}{ TOTAL } \\
\hline \multicolumn{1}{c|}{ Recursos } & Freq. & \multicolumn{1}{c}{$\%$} & Freq. & \multicolumn{1}{c}{$\%$} & Freq. & \multicolumn{1}{c}{$\%$} \\
\hline $\begin{array}{l}\text { Sim/ Sim, quando } \\
\text { solicitado }\end{array}$ & 9 & 69,2 & 4 & 50,0 & 13 & 61,9 \\
\hline $\begin{array}{l}\text { Verba de } \\
\text { treinamento }\end{array}$ & 3 & 23,1 & 2 & 25,0 & 5 & 23,8 \\
\hline $\begin{array}{l}\text { Recursos de projetos } \\
\text { específicos }\end{array}$ & 1 & 7,7 & 1 & 12,5 & 2 & 9,5 \\
\hline Recurso SIBi & & 0,0 & 1 & 12,5 & 1 & 4,8 \\
\hline TOTAL & $\mathbf{1 3}$ & $\mathbf{1 0 0 , 0}$ & $\mathbf{8}$ & $\mathbf{1 0 0 , 0}$ & $\mathbf{2 1}$ & $\mathbf{1 0 0 , 0}$ \\
\hline Font
\end{tabular}

Fonte: Dados da pesquisa, 2010

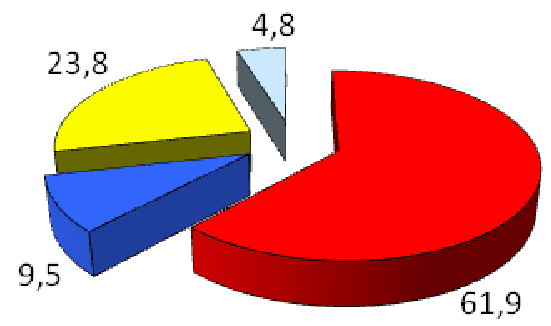

Sim/Sim, quando solicitado

$\square$ Recursos projetos especificos

$\square$ Verba de treinamento

口Recurso SIBi

Gráfico 17 - Descrição dos recursos financeiros (\%)

Fonte: Dados da pesquisa, 2010

As manifestações dos dirigentes são ilustrativas:

Sim, fizemos um projeto que foi encaminhado à Reitoria e conseguimos um recurso para o Programa. Começamos com esse recurso que foi obviamente muito importante para o início das atividades; e também usamos recursos da Unidade, quando necessário. (DIR 06)

De certa forma sim, conseguidos com verbas de pesquisa, recursos industriais que foram alocados para isso; não havia recursos orçamentários para isso, eram extra-orçamentários. (DIR 11) 
Diretamente para o Programa, não, mas a verba de treinamento passou a ser administrada pela Comissão Interna de Gestão da Qualidade, que se mantém e atua até hoje e administra as atividades de qualidade e de Treinamento. (TAD 16)

Não havia uma dotação, mas a diretoria fornecia recursos do orçamento do Instituto ou buscava na reitoria, de acordo com os projetos apresentados. (DIR 04)

Não havia muito dinheiro, mas tinha muito apoio da Comissão Central de Qualidade; não havia um recurso sistemático voltado para isso; mas quando precisei consegui o apoio. (DIR 05)

Não diretamente; apenas para cursos destinados aos funcionários. A Comissão de Qualidade é que começou a gerenciar. (DIR 12)

Não havia recursos específicos para o Programa, mas a Diretoria contribuía, dava apoio na realização dos eventos e do treinamento. Quando houve a verba de treinamento, a Comissão de Qualidade apresentou um Programa de Treinamento para a Diretoria e a verba ficou totalmente destinada à Comissão de Qualidade para o treinamento. (TAD 02)

Havia um recurso do SIBi, que pagou a Consultoria para que nos aprendêssemos a fazer e por parte da Unidade ela alocou recursos para equipamentos, quadros e treinamento e outras coisas que foram necessárias, como local adequado, data show, etc. (TAD 12)

Na Unidade conseguimos com os diretores o que se necessitava. No SIBi, a gente conseguiu junto à Reitoria uma linha para aplicar. Por exemplo, com a pesquisa, em um dos estudos da Qualidade detectamos que os usuários estavam insatisfeitos com os acervos da USP, porque eram desatualizados com relação aos livros; então o Reitor, concedeu um valor especial para que se pudesse atualizar o acervo e comprar toda bibliografia básica que os usuários estavam reclamando; conseguimos recursos e uma alínea específica para atualizar o parque de informática. (TAD 12)

Questão 09: Os recursos eram porcentagem específica do orçamento?

Quanto à questão 09, que diz respeito à porcentagem do orçamento para o Programa de Qualidade, unanimemente os respondentes informaram que não havia uma porcentagem do orçamento dedicado ao Programa de Qualidade. Uma única referência específica foi de que uma alínea especial, destinada a treinamento dos funcionários, passou a ser alocada diretamente às Unidades, a partir de 1996, data de início do Programa de Qualidade. O montante dessa alínea era definido pela Comissão Orçamentária e de Planejamento (COP), dentro de alguns critérios, que consideravam o número de funcionários, entre outros.

Para a verificação da estrutura administrativa que atuou no Programa de Qualidade foi feita a questão 10 . 
Questão 10: Foi delineada uma estrutura administrativa para sustentar o Programa de Qualidade e Produtividade?

A inclusão dessa pergunta tem por finalidade verificar como foi atribuída a gestão do Programa de Q\&P dentro da Universidade: a pessoa ou órgão responsável e a localização do responsável na estrutura de poder.

Deve-se considerar a estrutura administrativa para o Programa de Q\&P da Universidade como um todo e para as Unidades individualmente. As respostas, a seguir, enfocam a estrutura administrativa no âmbito das Unidades.

A grande maioria seguiu as orientações da portaria vigente na Universidade e instituiu suas Comissões Internas de Qualidade e Produtividade, que vieram a ser a espinha dorsal do Programa. Elas eram compostas de docentes, funcionários e, posteriormente, em algumas Unidades incluíram-se alunos. Em geral, a Presidência da Comissão ficava a cargo de um docente. Tal escolha reflete o sistema de poder e status na Universidade, no qual os docentes são considerados por alguns quase como uma "casta" superior a quem se confere sempre o poder legítimo. Conforme Zacarelli (1984), a estrutura da Universidade apresenta separações bem marcantes entre a atividade docente e a atividade administrativa; "são duas estruturas sociais absolutamente distantes nas universidades de modelo europeu: a classe social docente e a dos administradores."

Tabela 21 - Existência de estrutura administrativa do Programa de Q\&P

\begin{tabular}{|c|c|c|c|c|c|c|}
\hline \multirow{2}{*}{$\begin{array}{c}\text { Estrutura } \\
\text { Administrativa }\end{array}$} & \multicolumn{2}{|c|}{$\begin{array}{c}\text { Docentes } \\
\text { Dirigentes }\end{array}$} & \multicolumn{2}{|c|}{$\begin{array}{c}\text { Técnicos } \\
\text { Administrativos }\end{array}$} & \multicolumn{2}{|c|}{ TOTAL } \\
\hline & Freq. & $\%$ & Freq. & $\%$ & Freq. & $\%$ \\
\hline Sim & 8 & 50,0 & 6 & 54,5 & 14 & 51,9 \\
\hline Não & 8 & 50,0 & 5 & 45,5 & 13 & 48,1 \\
\hline TOTAL & 16 & 100,0 & 11 & 100,0 & 27 & 100,0 \\
\hline
\end{tabular}

Fonte: Dados da pesquisa, 2010

A Tabela 21 permite observar que aproximadamente a metade dos respondentes, docentes e técnicos administrativos, disseram "ter" $(51,9 \%)$ e "não ter" $(48,1 \%)$ estrutura administrativa para o Programa. O que é possível depreender dos depoimentos é que em nenhuma das Unidades foi instituída uma "caixinha" na estrutura formal da Unidade, para cuidar da 
qualidade. As atividades ficaram distribuídas entre os assistentes, o Diretor e seus assistentes ou mesmo entre os membros da Comissão de Qualidade ou ainda com grupos de trabalho, ligados a um projeto específico. Na prática, em algumas Unidades a maior atividade gerencial do Programa recaia sobre o assistente administrativo ou eventualmente para o assistente financeiro ou acadêmico, de forma isolada ou conjunta. Quando não houve constituição de uma Comissão formal, um grupo específico com apoio do Diretor assumiu o Programa.

Portanto, na maior parte dos casos não houve a instalação de uma estrutura formal ou tampouco uma estrutura independente e paralela para cuidar do Programa de Q\&P. Todavia, em qualquer situação o responsável estava localizado próximo à alta hierarquia da Unidade. Em um único caso atípico em uma Unidade, foi criada a Assistência de Qualidade e Gestão, incluída em organograma, que teve uma vida efêmera e foi descontinuada, quando houve mudança de diretoria.

Tabela 22 - Estrutura administrativa do Programa de Q\&P

\begin{tabular}{l|r|r|r|r|r|r}
\hline \multirow{2}{*}{ Estrutura Administrativa } & \multicolumn{2}{c}{$\begin{array}{c}\text { Docentes } \\
\text { Dirigentes }\end{array}$} & \multicolumn{2}{c|}{$\begin{array}{c}\text { Técnicos } \\
\text { Administrativos }\end{array}$} & \multicolumn{2}{c}{ TOTAL } \\
\cline { 2 - 7 } & Freq. & \multicolumn{1}{c}{$\%$} & Freq. & \multicolumn{1}{c}{$\%$} & Freq. & \% \\
\hline Comissão Interna de Q\&P & 5 & 41,7 & 4 & 40,0 & 9 & 40,9 \\
\hline Assistente (s) & 2 & 16,7 & 2 & 20,0 & 4 & 18,2 \\
\hline Diretor e grupo & 1 & 8,3 & 0 & 0,0 & 1 & 4,5 \\
\hline Assistência de Qualidade e Gestão & 1 & 8,3 & 1 & 10,0 & 2 & 9,1 \\
\hline Sem Comissão de Qualidade & 3 & 25,0 & 3 & 30,0 & 6 & 27,3 \\
\hline TOTAL & $\mathbf{1 2}$ & $\mathbf{1 0 0 , 0}$ & $\mathbf{1 0}$ & $\mathbf{1 0 0 , 0}$ & $\mathbf{2 2}$ & $\mathbf{1 0 0 , 0}$ \\
\hline
\end{tabular}

Fonte: Dados da pesquisa, 2010

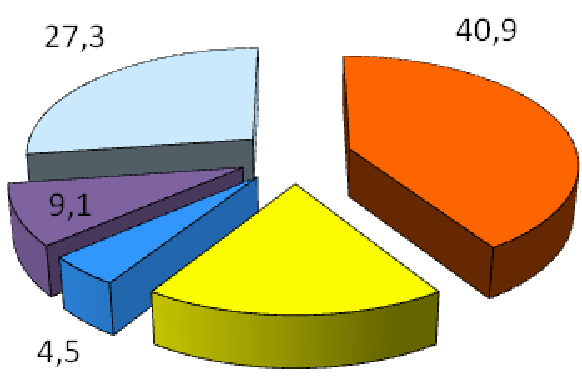

18,2 $\square$ Comissão Interna Q\&P

$\square$ Assistente (s)

$\square$ Diretor e grupo

Assistência de Qualidadee Gestão

Gráfico 18 - Estrutura administrativa

Fonte: Dados da pesquisa, 2010 
Deve-se considerar que essa situação representa uma fotografia da Unidade em um dado instante. Algumas Unidades que, inicialmente, foram enquadradas em uma situação podem ter mudado de status no decorrer do tempo, o que se pode constatar inclusive, quando se faz uma triangulação com documentos da Comissão Central da Qualidade, que tinham registros de todas as Comissões existentes em todos os períodos.

O que se pode inferir é que o processo é dinâmico por natureza e guarda ainda uma maior instabilidade pelo fato de o Programa de Qualidade não ter tido guarida na estrutura formal da Universidade, ou seja, não foram incorporados ao organograma formal da Unidade.

Quando se incluíam os assistentes, em geral era o assistente administrativo o responsável, uma vez que os recursos humanos de modo geral estão ligados ao titular dessa função.

Os depoimentos dos diretores dão algumas observações esclarecedoras:

Não havia uma estrutura específica. Havia teoricamente o assistente administrativo, que seria responsável por atividades ligadas à manutenção dos prédios, equipamento, a CIPA e tudo mais. (DIR 13)

Não foi criada uma estrutura independente, separada da estrutura formal, existente. Todo o grupo respondia diretamente à direção (diga-se diretor), logicamente com uma assessoria especial para isso. (DIR 11)

A Comissão Interna de Qualidade é atuante até hoje. O coordenador é um professor indicado pelo Diretor, que tem experiência em qualidade na indústria. (DIR 05)

Desde o início estava centrado na esfera da assistência administrativa. Com o tempo, fomos ampliando com docentes e os servidores. Os docentes não se envolvem. (DIR 12)

O programa teve sempre muito apoio da Diretoria; não houve uma estrutura separada; ele foi tão bem aceito que foi incorporado pela instituição. Hoje ele faz parte da cultura. Não houve portaria definindo funções para a Comissão. Não havia um engessamento das atividades. (TAD 02)

Não com recursos humanos extra. A gente montou uma equipe de trabalho com os recursos existentes. Montamos uma estrutura interna em que cada pessoa era gerente de uma técnica; quando ela soubesse bem essa técnica ele podia ensinar, convencer e repassar a técnica para os demais. O que a Biblioteca fez e foi bacana é que a gente não deixava eternamente o líder na mesma técnica; os líderes foram fazendo rodízio nas técnicas; elas eram gerentes da técnica e tinham vices ou assistentes em outra técnica. Todos os funcionários aprenderam todas as técnicas; mesmo os auxiliares foram gerentes de técnica, as menos elaboradas, e foram ensinar o bibliotecário que era nível superior. Existe também uma técnica de marketing interno; por ele se divulga em ata e coloca no mural quando uma pessoa assume o posto de "gerente" de técnica; fica documentado; coloca no currículo; a gente criou internamente o rodízio para as técnicas; é uma forma de convencer para a mudança de cultura; quando passa a ser gerente ele percebe as dificuldades do outro e não faz mais críticas porque sabe quão difícil é fazer aquilo. As pessoas se sentem importantes quando são gerentes de técnicas. (TAD 12) 
Observações dos entrevistados registram que "na grande maioria das Comissões a presidência era atribuída a um docente" e que "ter uma Comissão muito numerosa não era produtivo". Considerando dados da publicação Década (2006), o número médio de componentes de 27 Comissões Internas de Q\&P nas Unidades de Ensino era de 7 participantes, a moda de 5 componentes, com uma amplitude de variação de 3 a 17 pessoas.

Onde não havia Comissão, os assuntos relativos à Qualidade eram tratados diretamente pelo Diretor e assistentes e em uma das Unidades incluía a área de Recursos Humanos.

Em uma das Unidades foi mencionada a existência de um Ouvidor, como função instituída em 1997, nessa Unidade, antes mesmo de ser obrigatória em todo órgão público (1999) e na USP, em particular, em 29/03/2001, pela Resolução n. 4827. No caso, o Ouvidor acumulava essa função com a de Presidente da Comissão de Qualidade, o que lhe dava uma posição privilegiada de atuação.

Algumas Comissões de Qualidade tiveram sua ação articulada com outras Comissões que também tinham objetivos correlatos, tais como a CIPA (Comissão Interna de Proteção de Acidentes) e a Comissão de Dejetos Laboratoriais, entre outras.

Muitas Comissões de Qualidade foram oficializadas por Portaria Interna do Diretor, uma maneira usual dentro da Universidade de tornar um ato formal. Além disso, algumas delas se propuseram a um Regulamento escrito, com normas e formas de operação. Em pesquisa feita em sites de algumas unidades, como, por exemplo, ICMC, FAU e IFSC, nos regulamentos adotados, em geral se descreviam a missão, valores e objetivos, a constituição e competência da Comissão Interna e outras disposições gerais.

A escolha de componentes da Comissão Interna de Qualidade foi objeto de considerações específicas de alguns entrevistados, que citaram explicitamente a importância dessa escolha e as características desejáveis para a inclusão de seus membros: membros que tivessem poder decisório e de grande participação na Unidade; representantes docentes dos departamentos, assistentes e secretária da Diretoria; representantes de todos os setores e também acertar no perfil das pessoas, incluindo pessoas que possam convencer os funcionários a se engajarem no processo. 
Seguem-se alguns depoimentos selecionados:

[...] procurei escolher as pessoas que eu achava que dariam mais certo, que tinham uma motivação para isso, então essa parte foi muito cuidadosa; é preciso acertar na Comissão que vai coordenar os trabalhos. A escolha das pessoas para a Comissão é importante: é preciso procurar colocar representantes de todos os setores e também acertar no perfil das pessoas, as mais motivadas, mais comunicativas e que tenham bom contato com a maioria dos funcionários; pessoas simpáticas e fáceis de lidar na convivência no dia a dia; essas coisas são importantes quando se coloca uma Comissão que vai até convencer os funcionários a se engajarem no processo. (DIR 06)

\title{
A experiência, o conhecimento da área em questão e a representatividade também foram considerados por um depoente:
}

\begin{abstract}
Indiquei como coordenador um professor, que tem experiência em qualidade na indústria, e ele fez um trabalho muito bom. Ele queria analisar os processos, como eles se desenvolvem e que os processos tivessem um tratamento mais paralelo, que evoluíssem simultaneamente; ele pediu que cada setor escolhesse um tipo de processo significativo no setor para que se fizesse uma experiência; queria ver como evolui o processo, criticá-lo e aperfeiçoá-lo. (DIR 05)
\end{abstract}

Tentei fazer na Comissão uma estrutura representativa dos departamentos e laboratórios. Isso é muito importante na Unidade que tem um contingente grande de funcionários. Os trabalhos da Comissão de Qualidade efetivamente começaram quando foi colocada como coordenadora uma professora, que já vinha de uma área de Qualidade, com experiência anterior. (DIR 12)

$\mathrm{Na}$ escolha dos docentes para comporem a Comissão, eles eram de departamentos distintos, mas todos eles envolvidos com a Qualidade. Eles foram escolhidos a dedo, porque já tinham essa vocação; não houve uma pressão nem necessidade de imposição externa; ela aconteceu naturalmente. (TAD 02)

Quanto ao aspecto de delegação, note-se, também, pelos relatos uma amplitude grande nas gradações de liberdade de ação para as Comissões: desde aquela que vai da total autonomia para a ação ou uma supervisão discreta do Diretor até a participação direta do Diretor como Presidente da Comissão, ao qual tudo está subordinado.

Se você tem um grupo, ele tem que ter o poder de decisão; se tem um grupo e ele não é dotado de certa autoridade, de poder de decisão, ele acaba não sendo efetivo. A Comissão de Qualidade, cujo coordenador era indicado pelo Diretor, era um professor e cuidava de fazer o Programa. Eu interferia pouco nas ações da Comissão porque as pessoas faziam isso com muita competência; acompanhava de perto e trocava algumas idéias; em geral eles tinham meu apoio porque eu sentia que eles estavam fazendo um bom trabalho; era a Comissão de Qualidade que decidia e que propunha. (DIR 05)

Tinha uma Comissão e eu, quando Diretora, resolvi ser a Presidente da Comissão; fui ver como era a estrutura em outra Unidade e sempre fazendo benchmarking não perde muito tempo, aprende e pode avançar mais rápido; depois também sempre observava o que a Comissão Interna da Reitoria fazia, em termos de Qualidade. (DIR 14) 
O aspecto de consultoria externa foi também considerado por alguns dos entrevistados:

[...] uma pessoa da Secretaria do Planejamento do Estado apresentou uma palestra e fiquei extremamente satisfeito com as idéias dela com a forma como ela colocou para os funcionários o que era o que ser funcionário público no Brasil de hoje e o que devia ser mudado. De uma forma elegante colocou as falhas de nosso funcionalismo e pela maneira serena, firme e até humorada como ela colocou o problema. (DIR 06)

O trabalho da consultoria é importante; a pessoa que chega motiva e coloca certo respeito; uma pessoa de dentro que proponha se reunir para discutir qualidade, os outros já olham com certa desconfiança: o próprio colega quer impor qualidade a mim. Agora com uma pessoa externa que vai conduzir o processo é diferente, não é meu concorrente. (DIR 11)

Foi preciso arrumar um modelo para a qualidade e isso é uma dificuldade. Não quisemos contratar firmas de consultoria com modelo de empresa privada. $\mathrm{Na}$ Universidade os objetivos são diferentes e buscamos um modelo próprio, adaptado ao nicho cultural e acadêmico da Unidade. Escolher o modelo e mobilizar a comunidade interna, funcionários, docentes e a própria congregação foram os caminhos. O aprimoramento de gestão não se faz de cima para baixo; é um processo cultural da instituição, seja ela pública ou privada. Outro aspecto que consideramos é que não quisemos contratar e trazer modelos de qualidade, porque os objetivos da universidade pública são diferentes da universidade privada e da empresa privada; quisemos adaptar o modelo ao perfil da USP como uma universidade pública e com as características da Unidade. (DIR 09)

Não houve consultoria externa. Até pensamos em fazer com uma Fundação, mas tinha todo o problema de licitação e concorrência; e a burocracia é implacável; quando ele colocou essa idéia começou a vir parente de funcionários e várias empresas pequenas de fundo de quintal já tinham se proposto a fazer o trabalho e certamente ganhariam; então desisti da consultoria, cortei o mal pela raiz. (DIR 12)

Tivemos uma assessoria com outras bibliotecas no SiBi e fomos implantando as técnicas aos poucos. (TAD 12)

Eu sinto falta da consultora, quando se estava em uma situação conflitante sempre recorria a ela; agora não tem. A presença de um consultor é importante, mesmo que seja da USP. (TAD 13)

A Questão 11 trata do poder decisório definido para o Programa. A indagação sobre o poder decisório, em alguns casos, confunde-se com a própria estrutura administrativa.

Questão 11: Havia um poder decisório definido pelo Programa?

Tabela 23 - Poder decisório do Programa de Qualidade

\begin{tabular}{c|r|r|r|r|r|r}
\hline \multirow{2}{*}{$\begin{array}{c}\text { Poder } \\
\text { decisório }\end{array}$} & \multicolumn{2}{|c|}{$\begin{array}{c}\text { Docentes } \\
\text { Dirigentes }\end{array}$} & \multicolumn{2}{c|}{$\begin{array}{c}\text { Técnicos } \\
\text { Administrativos }\end{array}$} & \multicolumn{2}{c}{ TOTAL } \\
\cline { 2 - 7 } & Freq. & $\%$ & Freq. & \multicolumn{1}{c|}{$\%$} & Freq. & $\%$ \\
\hline Sim & 11 & 73,3 & 9 & 81,8 & 20 & 76,9 \\
\hline Não & 4 & 26,7 & 2 & 18,2 & 6 & 23,1 \\
\hline TOTAL & $\mathbf{1 5}$ & $\mathbf{1 0 0 , 0}$ & $\mathbf{1 1}$ & $\mathbf{1 0 0 , 0}$ & $\mathbf{2 6}$ & $\mathbf{1 0 0 , 0}$ \\
\hline
\end{tabular}

Fonte: Dados da pesquisa, 2010 
Ainda que 76,9\% de 26 entrevistados tivessem respondido afirmativamente quanto à existência de um poder decisório para o Programa de Qualidade, só 22 deles identificaram o foco desse poder. A Tabela 24 especifica as várias combinações relatadas pelos entrevistados:

Tabela 24 - Combinações do poder decisório

\begin{tabular}{l|r|r|r|r|r|r}
\hline \multirow{2}{*}{ Poder decisório } & \multicolumn{2}{c|}{$\begin{array}{c}\text { Docentes } \\
\text { Dirigentes }\end{array}$} & \multicolumn{2}{c|}{$\begin{array}{c}\text { Técnicos } \\
\text { Administrativos }\end{array}$} & \multicolumn{2}{c}{ TOTAL } \\
\cline { 2 - 7 } & Freq. & \multicolumn{1}{c}{$\%$} & Freq. & \multicolumn{1}{c}{$\%$} & \multicolumn{1}{c}{ Freq. } & \multicolumn{1}{c}{$\%$} \\
\hline Diretor e Comissão Q\&P & 8 & 66,7 & 7 & 70,0 & 15 & 68,2 \\
\hline Assistente (s) & 2 & 16,7 & 1 & 10,0 & 3 & 13,6 \\
\hline Diretor e Assistentes & 1 & 8,3 & 2 & 20,0 & 3 & 13,6 \\
\hline Professor Designado pelo Diretor & 1 & 8,3 & 0 & 0 & 1 & 4,5 \\
\hline TOTAL & $\mathbf{1 2}$ & $\mathbf{1 0 0 , 0}$ & $\mathbf{1 0}$ & $\mathbf{1 0 0 , 0}$ & $\mathbf{2 2}$ & $\mathbf{9 9 , 9}$ \\
\hline
\end{tabular}

Fonte: Dados da pesquisa, 2010

Na maioria dos casos, 68,2\% de 22 respostas válidas, o poder decisório concentra-se no Diretor com os assistentes, que participam também da Comissão. Nessa questão, não houve referências explícitas à participação de outros docentes, como chefes de departamento ou de outras comissões. Um dos diretores cita que a Comissão de Qualidade tinha "total autonomia" e o papel do Diretor era "simplesmente homologatório".

Seguem-se os depoimentos de diretores e técnicos administrativos:

A Comissão contava com o apoio e incentivo da Diretoria. Não obstante, por ser comissão assessora, as decisões eram submetidas ao Diretor. (DIR 03)

Informalmente atuavam o diretor o Assistente Administrativo e o Presidente da Comissão. (DIR 04)

O poder decisório era com a Comissão; eles sugeriam e as coisas passavam por mim; em geral as coisas chegavam até mim e a minha atitude era mais homologatória. (DIR 05)

A Comissão decidia e eu não alterava as decisões, mas eu regularmente participava das reuniões da Comissão e acompanhava o Programa. Havia um Relatório verbal da Comissão para a direção do Instituto. (DIR 08)

Logo que assumi a direção da Unidade o que eu quis foi a participação direta das 3 assistentes; eu me reunia diariamente com elas, no final da tarde, para uma avaliação; cada uma apresentava o que era necessário para cada um dos setores que eram responsáveis; assim foi tendo condições de ir discutindo o Programa de Qualidade e a palavra final era sempre a do diretor da Unidade. (DIR 07)

Havia uma Comissão composta por docentes e funcionários e também o poder da autoridade do Diretor. O Diretor não se metia no que eles quisessem fazer. Eles tinham liberdade para fazer; tinha o apoio; eu discutia com eles, mas o programa era deles. Um programa deste vai surgindo e tem vida própria; o Diretor tem que dar grau de liberdade total para a Comissão. (DIR 09) 
A Comissão interagia comigo para consultar sobre o que queriam fazer: se podiam fazer as coisas, dar determinada tarefa a alguém, o descarte de objetos inúteis etc.; para implantar isso sempre pediam a autorização do Diretor e o encorajamento. (DIR 10)

A gente se espelhava nas outras unidades e na Reitoria para fazer alguma coisa. A gente tinha pouca criatividade, mas aproveitava dos outros. (DIR 14)

O poder decisório, entre os técnicos administrativos era visto por eles, nos seguintes depoimentos:

A Comissão decidia sempre e o apoio do Diretor era irrestrito. (TAD 07)

A Comissão como um todo decidia. O Diretor queria estar sempre a par de tudo. (TAD 13)

A Comissão tem certa autonomia para encaminhar as questões, cursos, treinamentos, projetos etc, sempre com a concordância de Dirigente da Unidade; o grupo deve ter autonomia senão não pode fazer nada. (TAD 15)

Ressalte-se em todos esses depoimentos o grande poder do dirigente para incentivar ou abortar o processo. Em segundo lugar, fica sempre destacada a figura do docente para coordenar o processo; era um docente, na maioria das vezes, que presidia a Comissão de Qualidade. Os técnicos administrativos, de modo geral, operacionalizam as decisões tomadas.

Quanto às áreas específicas envolvidas no Programa, a questão 12 responde.

Questão 12: Existiam áreas específicas envolvidas no Programa?

Tabela 25 - Áreas específicas envolvidas no Programa

\begin{tabular}{c|r|r|r|r|r|r}
\hline \multirow{2}{*}{ Áreas específicas } & \multicolumn{2}{|c|}{$\begin{array}{c}\text { Docentes } \\
\text { Dirigentes }\end{array}$} & \multicolumn{2}{c|}{$\begin{array}{c}\text { Técnicos } \\
\text { Administrativos }\end{array}$} & \multicolumn{2}{c}{ TOTAL } \\
\cline { 2 - 7 } & Freq. & \multicolumn{1}{c|}{$\%$} & \multicolumn{1}{c}{ Freq. } & \multicolumn{1}{c}{$\%$} & Freq. & \% \\
\hline \multirow{2}{*}{ Sim } & 13 & 78,6 & 8 & 72,7 & 19 & 76,0 \\
\hline \multirow{2}{*}{ Não } & 3 & 21,4 & 3 & 27,3 & 6 & 24,0 \\
\hline TOTAL & $\mathbf{1 4}$ & $\mathbf{1 0 0 , 0}$ & $\mathbf{1 1}$ & $\mathbf{1 0 0 , 0}$ & $\mathbf{2 5}$ & $\mathbf{1 0 0 , 0}$ \\
\hline
\end{tabular}

Fonte: Dados da pesquisa, 2010

Houve dezenove (76\% de 25 respostas válidas) respostas confirmando a existência de áreas envolvidas, que eram eminentemente gerenciais e, sobretudo, áreas administrativas. A Tabela 26 detalha essas áreas. 
Tabela 26 - Detalhamento das áreas envolvidas

\begin{tabular}{l|c|c|c|c|c|c}
\hline & \multicolumn{2}{c|}{$\begin{array}{c}\text { Docentes } \\
\text { Dirigentes }\end{array}$} & \multicolumn{2}{c|}{$\begin{array}{c}\text { Técnicos } \\
\text { Administrativos }\end{array}$} & \multicolumn{2}{c}{ TOTAL } \\
\hline \multicolumn{1}{c|}{ Áreas envolvidas } & Freq. & $\%$ & Freq. & $\%$ & Freq. & $\%$ \\
\hline $\begin{array}{l}\text { Áreas gerenciais } \\
\text { (acadêmica, administrativa e } \\
\text { financeira) }\end{array}$ & 4 & 50,0 & 2 & 25,0 & 6 & 37,5 \\
\hline $\begin{array}{l}\text { Treinamento } \\
\text { Alguns setores }\end{array}$ & 1 & 12,5 & 2 & 25,0 & 3 & 18,8 \\
\hline $\begin{array}{l}\text { Questão ambiental } \\
\text { (consumo de energia, } \\
\text { reciclagem de lixo etc.) }\end{array}$ & 1 & 12,5 & 1 & 12,5 & 2 & 12,5 \\
\hline $\begin{array}{l}\text { Infraestrutura } \\
\text { Biblioteca }\end{array}$ & 1 & 12,5 & 1 & 12,5 & 2 & 12,5 \\
\hline TOTAL & 0 & 0,0 & 1 & 12,5 & 1 & 6,3 \\
\hline Font: Dados & $\mathbf{8}$ & $\mathbf{1 0 0 , 0}$ & $\mathbf{8}$ & $\mathbf{1 0 0 , 0}$ & $\mathbf{1 6}$ & $\mathbf{1 0 0 , 0}$ \\
\hline
\end{tabular}

Fonte: Dados da pesquisa, 2010

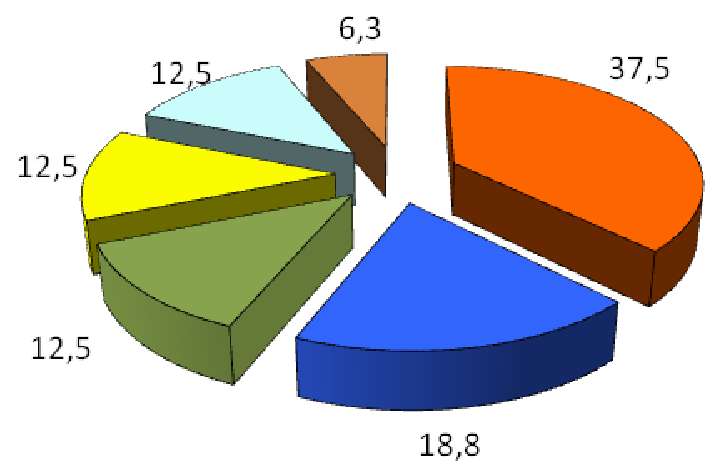

$\square$ Áreas gerenciais (acadêmica, administrativa e financeira)

口Treinamento

$\square$ Alguns setores

口Questão ambiental (consumo energia, reciclagem lixo etc)

$\square$ Infra estrutura

口Biblioteca

Gráfico 19 - Áreas envolvidas

Fonte: Dados da pesquisa, 2010

Os dirigentes se manifestam:

As propostas iniciais de melhoria de serviços priorizaram alguns setores, definindo as áreas sobre as quais os esforços seriam dirigidos. A maioria das iniciativas visava à melhoria contínua da prestação dos serviços da Unidade a sua comunidade usuária e ao uso racional das utilidades públicas da USP (energia elétrica, água, telefone). (DIR 03)

O que a gente priorizou foi a área administrativa. (DIR 07)

O que houve foi um levantamento de opinião até para cooptar os corações e mentes. Por exemplo, os mais votados para melhorar foram: infra-estrutura de salas de aula, recursos tecnológicos e atendimento pelas seções administrativas, melhoramento do sistema de compras, técnicofinanceiro, assinaturas de processos; diminuição de número de assinaturas nos processos de compra diminuição de 160 procedimentos mensais e gerou 8 horas de economia de trabalho por mês, para a Diretoria; roteiro para tramitação do processo para execução de reformas e de serviços de engenharia; treinamento em informática houve então uma área montada para isso com metas. (DIR 09) 
Houve uma época em que havia a preocupação com consumo e economia de energia (PURE). Havia pessoas que eram encarregadas para ver se tinham lâmpadas demais acesas e também de reciclagem de lixo (USP Recicla). Os programas que vinham de fora, a gente absorvia, implantava e fazia funcionar, da melhor forma possível. Fizemos também coisas internas, como controlar ramais de telefone, para ver aqueles que gastavam demais e orientar para o controle e cortar o acesso ao telefone se reincidisse no gasto alto. (DIR 10)

Nós inicialmente colocamos o Programa de Qualidade dentro do Planejamento Estratégico mexendo com a parte administrativa, de graduação e com a parte de pesquisa. (DIR 11)

Os depoimentos dos técnicos administrativos reforçam essas escolhas já indicadas pelos dirigentes:

A área administrativa era particularmente envolvida com atividades: serviços gerais, gráfica; os departamentos tinham uma participação modesta e a parte financeira também foi trabalhada porque as pessoas já tinham a visão do GEFIM. As áreas mais resistentes eram o ensino e a área acadêmica. (TAD 01)

Em determinado momento se abraçou a questão ambiental; então todos os departamentos passaram a atuar mais dentro do projeto para desenvolver a nossa certificação da ISO 14000. Foi nesse momento que a Comissão de Qualidade agregou o trabalho dela com o de outras quatro Comissões existentes que já vinham desenvolvendo trabalhos na área de segurança do trabalho e segurança ambiental; passaram a ser 5 comissões que trabalhavam para um único projeto: o Sistema de Gestão Ambiental. (TAD 02)

Treinamento, condições de trabalho, instalações, procedimentos, melhoria e agilidade dos processos; no RH viam a possibilidade de transferência dos funcionários. (TAD 04)

Só a Biblioteca; e dentro da Biblioteca todos os setores foram envolvidos; ninguém ficou de fora, até mesmo os estagiários são treinados para que conheçam a linguagem do sistema de gestão, para conhecer o sistema, a linguagem do sistema e todas as técnicas; aqui não se trabalha com setores e sim, UGBs, ou seja, Unidades Gerenciais Básicas. (TAD 12)

Avaliação ergonômica, Boletim informativo e o treinamento de multiplicadores. (TAD 13)

Outra pergunta relativa ao processo de implantação do Programa de Qualidade diz respeito aos atores envolvidos, uma vez que são as pessoas que efetivamente vão ou não vão executar as novas ações pretendidas. Para isso, foi indagado na questão seguinte:

Questão 13 - Existiam funcionários especialmente envolvidos com as atividades da Qualidade?

Tabela 27 - Funcionários envolvidos na Qualidade

\begin{tabular}{c|c|c|c|c|c|c}
\hline \multirow{2}{*}{$\begin{array}{c}\text { Funcionários } \\
\text { específicos }\end{array}$} & \multicolumn{2}{|c|}{$\begin{array}{c}\text { Docentes } \\
\text { Dirigentes }\end{array}$} & \multicolumn{2}{c|}{$\begin{array}{c}\text { Técnicos } \\
\text { Administrativos }\end{array}$} & \multicolumn{2}{c}{ TOTAL } \\
\cline { 2 - 7 } & Freq. & \multicolumn{1}{c}{$\%$} & Freq. & \multicolumn{1}{c}{$\%$} & Freq. & \multicolumn{1}{c}{$\%$} \\
\hline Sim & 8 & 53,3 & 5 & 45,5 & 13 & 50,0 \\
\hline Não & 7 & 46,7 & 6 & 54,5 & 13 & 50,0 \\
\hline TOTAL & $\mathbf{1 5}$ & $\mathbf{1 0 0 , 0}$ & $\mathbf{1 1}$ & $\mathbf{1 0 0 , 0}$ & $\mathbf{2 6}$ & $\mathbf{1 0 0 , 0}$ \\
\hline
\end{tabular}

Fonte: Dados da pesquisa, 2010 
O que se pode depreender das respostas é que não havia, em nenhuma das Unidades pesquisadas, funcionários alocados exclusivamente no Programa ou nas atividades da Qualidade. Em um único caso, em uma das Unidades foi criada a Assistência de Qualidade e Gestão, descontinuada quando houve troca de dirigente na Unidade. As atividades do Programa de Q\&P eram consideradas como uma atuação extra às atribuições usuais dos funcionários. Um maior envolvimento foi identificado com os assistentes técnicos de direção, sobretudo o assistente administrativo, a quem se considerava pertencer essas atribuições. Um dos diretores admitiu que o pessoal das áreas especializadas era quem menos se envolvia. Em uma das Unidades foi citado que informalmente, também atuavam o Diretor e o Presidente da Comissão Interna de Qualidade. Em uma das Unidades foi mencionado que também atuavam alunos, como estagiários.

As Comissões eram em sua grande maioria de funcionários e, em geral, eram presididas por um docente, como já foi referenciado.

\title{
Comenta um Diretor:
}

\begin{abstract}
Evitamos ter um grupo separado da estrutura. Os funcionários que participavam também tinham suas atribuições e também faziam parte desses programas; todos os funcionários que participavam inclusive os assessores diretos da diretoria também tinham atividades administrativas rotineiras; não havia uma pessoa em separado; a equipe fazia atividades rotineiras também; todos tinham sua função e a parte de qualidade; não era um corpo distinto, separado. (DIR 11)
\end{abstract}

Algumas das Unidades pesquisadas declararam que tiveram ajuda de uma consultoria externa. Alguns consultores externos, pela ligação que tinham com a Unidade, concederam generosamente essa consultoria e outros foram remunerados. Outra Unidade declarou declinar da consultoria externa pela dificuldade operacional em contratar esse serviço. Por outro lado, um Diretor declarou que:

[...] não seria possível fazer o trabalho sem consultoria porque é preciso um olhar externo, não envolvido na rotina para conseguir entender nosso problema. Não é uma crítica à equipe da casa; é uma constatação; é preciso ter um consultor externo para esse olhar externo; uma pessoa que não está na rotina, que veja e possa acompanhar. (DIR 11)

Nesse caso, a visão dos assistentes difere um pouco da dos dirigentes. Para duas Unidades, havia o envolvimento de funcionários de todos os níveis e funções. O chefe da área participava e desdobrava os trabalhos com outros funcionários, ligados a ele. 
Ainda que na Comissão de Qualidade só tivesse o trabalho da assistente administrativa, indiretamente havia trabalho e envolvimento de vários outros funcionários da administração por ocasião dos treinamentos e eventos, tais como os representantes de treinamento da Reitoria, representantes da área acadêmica e da área financeira. (TAD 02)

Todos os funcionários da Biblioteca, dentro de suas funções; dividiam as atribuições do Sistema de Gestão com a rotina de seu trabalho. (TAD 12)

Fizemos uma renovação da Comissão com 12 pessoas, para agregar multiplicadores. Nem sempre é possível agregar todo mundo; as pessoas estão sempre muito ocupadas; então pegamos as pessoas que estavam disponíveis. A proposta foi: aumentar a Comissão; todo mundo tem uma responsabilidade [...]; é difícil conseguir liberação dos chefes. (TAD 13)

Só para a Qualidade não. (TAD 16)

Funcionários dos diversos níveis (superior, técnico e básico) de diversas funções foram envolvidos com as atividades da Qualidade. Foram envolvidos primeiramente funcionários da área financeira e no decorrer do tempo as demais áreas (acadêmica e administrativa) inclusive a Pós-Graduação. (TAD 17)

As atividades de qualidade realizadas pelos servidores envolvidos eram somadas às suas atribuições diárias. (TAD 19)

Quanto ao treinamento dos funcionários técnicos administrativos pode ser avaliado com os dados extraídos das questões do Bloco 2 do Roteiro de Entrevistas dos Técnicos Administrativos - Atividades de Treinamento e Desenvolvimento.

Tabela 28 - Curso de Qualidade para técnicos administrativos: 1996 - 2006

\begin{tabular}{l|c|c|c|c|c}
\multicolumn{1}{c|}{ Cursos } & Sim & \% & Não & \% & TOTAL \\
\hline Específicos de Q & 16 & 88,9 & 2 & 11,1 & 18 \\
\hline Q na Reitoria & 15 & 88,2 & 2 & 11,1 & 17 \\
\hline Q na Unidade & 17 & 85,0 & 3 & 16,7 & 20 \\
\hline Q fora da Unidade & 14 & 82,4 & 3 & 16,7 & 17 \\
\hline Q fora da USP & 14 & 82,4 & 3 & 16,7 & 17 \\
\hline Presencial & 14 & 82,4 & 3 & 16,7 & 17 \\
\hline A Distância & 11 & 64,7 & 6 & 33,3 & 17 \\
\hline Q: Qualidade & & & & &
\end{tabular}

Q: Qualidade

Fonte: Dados da pesquisa, 2010 


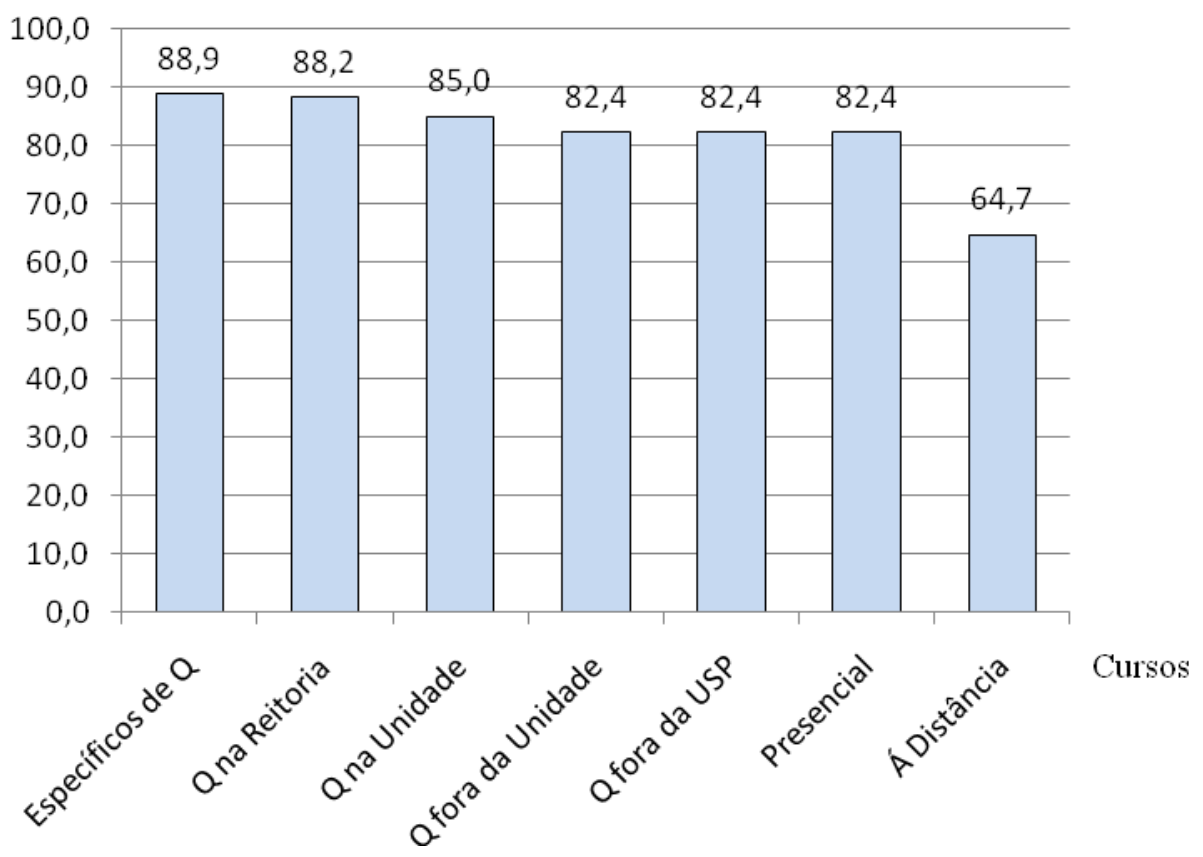

Gráfico 20 - Curso de Qualidade para técnicos administrativos: 1996 - 2006

Como pode ser observado, as porcentagens indicando a ocorrência dos técnicos administrativos a cursos de qualidade, sinalizam uma formação bastante abrangente nessa área, beneficiando-se os funcionários técnicos administrativos de cursos de várias origens: na USP, fora dela ou na Unidade. Os cursos à distância foram os menos frequentados. Cabe aí uma sinalização para que essa modalidade seja mais explorada no futuro, no sentido de abranger um maior número de pessoas.

Os entrevistados, na questão 30, fazem alguns comentários sobre o treinamento recebido:

O que foi relevante neste período foi o treinamento de multiplicadores da Qualidade na Reitoria; foi uma semente plantada; ao fazer o curso a pessoa se incentivava, se sensibilizava e voltava contaminada. O curso de MBA de Qualidade da Poli trouxe muito conhecimento técnico e novas habilidades. A Universidade não tem uma Política de treinamento geral e nem de recursos. (TAD 01)

Treinamentos são muito importantes; ele amplia o espectro de conhecimento das pessoas e a relação delas com as outras; o treinamento fora da USP é muito importante; nós levamos os nossos funcionários para fazer treinamento fora da USP, para que eles conheçam o mundo lá fora; aqui temos um mundo diferenciado, o mundo corporativo; é preciso conhecer o outro lado, as outras pessoas. (TAD 02)

Inexiste uma política de treinamento e desenvolvimento. As palestras vêm aos soluços; são isoladas, e ainda muito espaçadas e desconectadas. O processo tem que ser contínuo e desvinculado da gestão; tem que ter um plano escrito. Precisa haver uma política que transcenda as 
gestões. Antes os docentes não deixavam fazer treinamento no horário de expediente. Não se tinha a visão. (TAD 07)

Um grande patrimônio da universidade são recursos humanos e falta uma política para que se possa trabalhar em conjunto e melhorar o potencial de recursos humanos, para não docentes. Falta uma política da administração central para trabalhar em conjunto e minimizar os problemas da área de RH; essa política não pode ser só distribuir dinheiro. (TAD 07)

A USP e a Reitoria precisam incentivar as Unidades a implantarem um sistema de gestão e precisam subsidiar recursos para as Unidades se capacitem para fazerem isso. O que é fácil para uma unidade é difícil para outra. A Reitoria, o governo do Estado, ou quem for, deveria subsidiar conhecimento para os dirigentes, para que as unidades possam fazer uma boa gestão. Os novos dirigentes desconhecem as normas do governo e do Estado. Não pode haver descontinuidade. Cada momento que muda a direção da Universidade e das Unidades, às vezes há uma descontinuidade. Um Plano Diretor seria necessário, para que se possa continuar nas próximas administrações. (TAD 12)

A forma de sistemática de cálculo do recurso de treinamento pela Comissão de Orçamento e Patrimônio (COP) deveria ser mudada; acaba privilegiando as Unidades mais inchadas; deveria ter uma ponderação; as unidades enxutas foram prejudicadas com o critério adotado para a dotação na alínea de treinamento, que é o parque de informática e o número de funcionários não docentes; as unidades maiores são mais bem agraciadas. (TAD 16)

Os cursos promovidos pela USP foram de excelente qualidade, ministrados por especialistas no assunto. (TAD 17)

Cabe uma observação sobre a formação do administrador docente da Universidade comentada pelos entrevistados. Os cargos de maior responsabilidade na USP são ocupados, em geral, por docentes. Todavia, segundo Marcovitch (1998), o cientista tem um perfil criativo que nem sempre combina com a racionalidade e o atendimento a normas e procedimentos que são exigidos na área administrativa. É importante que o dirigente entenda sua responsabilidade de execução e mantenha olhos e ouvidos abertos para perceber os anseios dos outros e atender as normas existentes.

Quanto a métodos para identificar necessidades de melhorias foi feita a questão 14.

Questão 14: Havia métodos para identificar necessidades de melhorias na Unidade?

Outro item constante do processo de mudança é o da identificação de necessidades ou oportunidades de melhorias, na terminologia da Qualidade Total. Para conhecer como isso era feito pela Unidade, que métodos eram utilizados, foi feita a tabela a seguir que mostra as respostas obtidas e, em seguida, um detalhamento dos métodos. 
Tabela 29 - Método para identificar necessidades de melhorias na unidade

\begin{tabular}{c|r|r|r|r|r|c}
\hline \multirow{2}{*}{ Método } & \multicolumn{2}{|c|}{$\begin{array}{c}\text { Docentes } \\
\text { Dirigentes }\end{array}$} & \multicolumn{2}{c|}{$\begin{array}{c}\text { Técnicos } \\
\text { Administrativos }\end{array}$} & \multicolumn{2}{c}{ TOTAL } \\
\cline { 2 - 7 } & Freq. & $\%$ & Freq. & \multicolumn{1}{c}{$\%$} & Freq. & $\%$ \\
\hline \multirow{2}{*}{ Sim } & 12 & 80,0 & 10 & 90,9 & 22 & 84,6 \\
\hline Não & 3 & 20,0 & 1 & 9,1 & 4 & 20,0 \\
\hline TOTAL & $\mathbf{1 5}$ & $\mathbf{1 0 0 , 0}$ & $\mathbf{1 1}$ & $\mathbf{1 0 0 , 0}$ & $\mathbf{2 6}$ & $\mathbf{1 0 0 , 0}$ \\
\hline
\end{tabular}

Fonte: Dados da pesquisa, 2010

De 26 respondentes, 84,6\% (22) responderam haver método para a identificação de necessidades de melhoria; os técnicos administrativos (90,9\%), em uma maior porcentagem que os diretores $(80,0 \%)$ responderam afirmativamente.

A escolha para as ações de qualidade a serem priorizadas e operacionalizadas era feita utilizando-se de vários métodos, desde os mais triviais, corriqueiros e "caseiros", como foram chamados, até aqueles prescritos entre as ferramentas e técnicas da Qualidade. Conforme depoimentos dos entrevistados, entre eles estavam: caixa de sugestões, reclamações orais, reuniões, encontros de integração, workshop para levantamento de necessidades de capacitação de servidores; reunião de assistentes; pesquisa de levantamento de clima organizacional; benchmarking em outras unidades; reuniões de planejamento e brainstorming, usando nominal group technique (NGT).

Os mecanismos utilizados para os procedimentos operacionais da Comissão eram: reuniões para discussão dos problemas existentes; levantamento de necessidades; instituição de um ouvidor; jornal; caixa de sugestões; projetos e demandas transitavam da comissão para a comunidade e vice-versa; a Comissão de Qualidade que decidia e que propunha; o processo era o convencimento, conquistar corações e mentes e discutir modelos; "esse é um processo de cooptação de corações e mentes; ele é um processo como uma onda; qualidade foi um dos programas dentro do Planejamento Estratégico"; "sempre fazendo benchmarking; não perde muito tempo e aprende e pode avançar mais rápido"; "sempre observando o que a Comissão Interna da Reitoria fazia, em termos de Qualidade; de pessoas que valorizavam essas atividades e estavam engajadas para isso" 
As reuniões relatadas eram feitas esporadicamente ou como rotina, com os membros da Comissão de Qualidade, com o Diretor e as Assistentes ou, ainda, com docentes e funcionários; em uma Unidade foi relatada que havia reuniões, com a Consultoria Externa. Três Unidades relataram terem promovido reuniões especiais e pontuais para elaboração de Plano Diretor e Planejamento Estratégico, com grande número de funcionários. Outro depoente comenta sobre a regularidade das reuniões: "toda última $5^{\text {a }}$. feira do mês a Comissão faz a reunião; pode ter reuniões extras, mas desde o começo do ano fazemos um planejamento para todas as reuniões do ano."

Tabela 30 - Tipo de método para levantamento de necessidades de melhorias

\begin{tabular}{|c|c|c|c|c|c|c|}
\hline \multirow[t]{2}{*}{ Tipo de Método } & \multicolumn{2}{|c|}{$\begin{array}{l}\text { Docentes } \\
\text { Dirigentes }\end{array}$} & \multicolumn{2}{|c|}{$\begin{array}{c}\text { Técnicos } \\
\text { Administrativos }\end{array}$} & \multicolumn{2}{|c|}{ TOTAL } \\
\hline & Freq. & $\%$ & Freq. & $\%$ & Freq. & $\%$ \\
\hline $\begin{array}{l}\text { Reuniões: Comissão de Qualidade, } \\
\text { Diretor/ Informais/ Encontros }\end{array}$ & 5 & 35,7 & 5 & 33,3 & 10 & 34,5 \\
\hline $\begin{array}{l}\text { Caixa de sugestões/ Ouvidor/ } \\
\text { Reclamações orais/e-mail }\end{array}$ & 2 & 14,3 & 4 & 26,7 & 6 & 20,7 \\
\hline Reunião de Planejamento & 3 & 21,4 & 1 & 6,7 & 4 & 13,8 \\
\hline Pesquisa interna & 2 & 14,3 & 2 & 13,3 & 4 & 13,8 \\
\hline $\begin{array}{l}\text { Métodos da Qualidade } \\
\text { (Brainstorming/NGT/RINGI/GUT/ } \\
\text { Diagrama de Ishikawa) }\end{array}$ & 1 & 7,1 & 3 & 20,0 & 4 & 13,8 \\
\hline $\begin{array}{l}\text { Avaliação de desempenho e } \\
\text { necessidades de treinamento }\end{array}$ & 1 & 7,1 & 0 & 0,0 & 1 & 3,4 \\
\hline TOTAL & 14 & 100,0 & 15 & 100,0 & 29 & 100,0 \\
\hline
\end{tabular}

Fonte: Dados da pesquisa, 2010

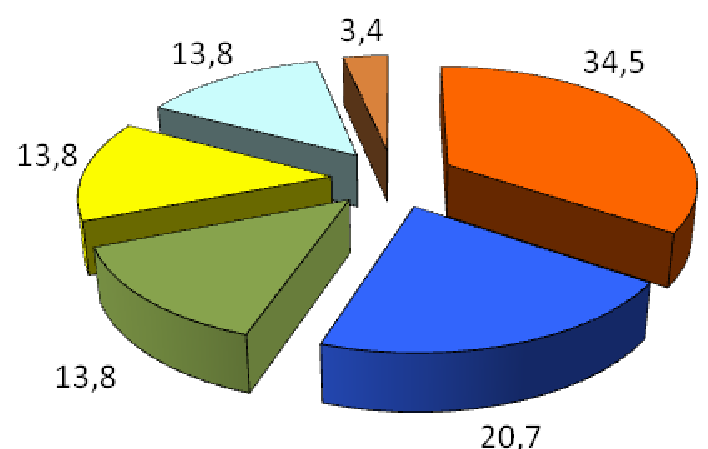

Gráfico 21 - Métodos de levantamento de necessidades de melhorias Fonte: Dados da pesquisa, 2010
Reuniōes: Comissão de Qualidade, Diretor/ informais/ encontros

$\square$ Caixa de sugestões/ Ouvidor/ reclamações orais/e-mail

$\square$ Reunião de Planejamento 
Seguem-se alguns registros:

A Comissão de Qualidade passou a ter um papel de ouvidor permanente. (DIR 05)

Foi preciso arrumar um modelo e isso é uma dificuldade, porque não existe um modelo para o objetivo meio; não quisemos contratar firmas de consultoria com modelo de empresa privada; na Universidade os objetivos são diferentes e buscamos um modelo próprio, adaptado ao nicho cultural e acadêmico da Unidade. Escolher o modelo e mobilizar a comunidade interna, funcionários, docentes e a própria congregação foram os caminhos; quisemos adaptar o modelo ao perfil da USP como uma universidade pública e com as características da Unidade. (DIR 09)

\section{As ações vieram do Planejamento Estratégico. (DIR 11)}

Não havia um método; era mais em função do que as pessoas conversavam com as outras, tendo feedback do que havia sido feito e do que as pessoas pensavam o que seriam atividades de qualidade; foi um programa bem participativo; uma gestão bem participativa, que a gente conversava para ter adesão. A gente se espelhava nas outras Unidades e na Reitoria para fazer alguma coisa. A gente tinha pouca criatividade, mas aproveitava dos outros. (DIR 14).

Em reunião se discutiam as sugestões de melhorias e as solicitações de cursos As sugestões chegavam de maneira informal, sob a forma de cartas, ofícios ou pessoalmente. Uma vez fizeram pesquisa com funcionários. (TAD 04)

Nós fizemos em diversas ocasiões pesquisas internas junto aos funcionários e à comunidade; em um dos anos fizemos pesquisa de satisfação para saber de questões administrativas, com docentes e funcionários para saber da qualidade dos serviços e ver da necessidade de melhorar. (TAD 02)

Nas reuniões; análise de solicitações, vindas por ofício, carta ou informalmente. Existe um Regimento Interno da Comissão. (TAD 04)

Encontros e reuniões e a Comissão tinha um papel de ouvidor permanente. Reclamações, reunião com diretor, reivindicações, caixa de sugestões etc. Serviço de Portaria era muito criticado e então fomos ver o que eles queriam; os usuários se manifestaram para dizer o que queriam. Esse canal era sempre permanente e sempre havia a disposição de atender conforme as solicitações. Fizemos um lugar de Achados e Perdidos. (TAD 07)

Era método caseiro; via reclamação oral. (TAD 09)

O Programa de Qualidade começou com a Biblioteca. Fiz o curso de Multiplicadores da Qualidade na Reitoria e a partir daí criou-se no SIBi uma Comissão para avaliar os produtos e serviços da Biblioteca, o PAC, e depois participamos para implantar um Sistema de Gestão na Biblioteca, nos moldes do sistema de gestão da ESALQ. Na USP, os administradores não têm formação administrativa propriamente dita. (TAD 12)

Usamos o sistema Ringi ${ }^{10}$ : quando toda a equipe reúne um dia para uma rodada de sugestões. Numa sala, com todos da biblioteca, a gente levanta quais são os pontos fortes (qualidade no atendimento, por exemplo) e fracos (limpeza está ruim, por exemplo) da Biblioteca. As pessoas anotam as sugestões em papeizinhos (post it); depois divide isso em classes de sugestões: limpeza, atendimento, acervo etc. Divide em grandes temas e há uma votação para a priorização desses temas. Qual for julgado o mais importante é o que deve ser atacado primeiro. (TAD 12)

Antes da qualidade não havia método. Na qualidade passamos a usar as ferramentas, brainstorming, GUT, Ichikawa; fizemos isso durante o treinamento e aí identificamos os

10 Segundo Yoshino (1968), o sistema ringi representa "uma filosofia básica de administração profundamente arraigada na tradição japonesa. A palavra ringi é formada de duas partes: rin, significando submeter uma proposição para um superior e receber sua aprovação e gi, significando deliberações e decisões". 
problemas para fazer os projetos. Sempre usava as ferramentas e ainda hoje quando o problema está muito confuso, a gente usa um GUT. (TAD 13)

Fazia avaliação dos setores; um setor era avaliado mensalmente e permitiam comentários, mas havia os canais: caixa de sugestões, o próprio ouvidor, e-mail, a Comissão Interna de Qualidade, sem um aspecto formalizado de perguntar para as pessoas. Na avaliação setorial: escolhia-se um setor, por exemplo, a Gráfica, e por 30 dias esse setor era avaliado por toda a comunidade do Instituto; pelos canais existentes ela se manifestava. A partir daí a Comissão Interna de Q\&P avaliava o que devia fazer; isso era divulgado por e-mail; os comentários eram compilados e o chefe conversava com o setor e via o que se devia fazer, em função das avaliações feitas. Isso tinha um cronograma. Todo mês era um setor; essa avaliação foi substituída pelo $e$-mural eletrônico e por e-mail (TAD 15)

[...] tivemos como norte o resultado do trabalho com a técnica NGT, uma técnica de brainstorming. O resultado da aplicação desta técnica facilitou, em princípio, a elaboração de uma lista de objetivos prioritários que nortearam as ações da Comissão de Qualidade da Unidade. (TAD 17)

Quanto ao acompanhamento do programa, as questões 16 e 17 indagavam sobre seu monitoramento e indicadores de desempenho existentes.

Questão 16: Existia um controle ou monitoramento dos resultados das atividades do Programa de Qualidade?

A Tabela 31 mostra as respostas à primeira dessas questões, que diz respeito ao monitoramento do Programa de Qualidade.

Tabela 31 - Monitoramento dos resultados do Programa de Qualidade

\begin{tabular}{c|r|r|r|r|r|c}
\hline \multirow{2}{*}{ 16- Monitoramento } & \multicolumn{2}{c|}{$\begin{array}{c}\text { Docentes } \\
\text { Dirigentes }\end{array}$} & \multicolumn{2}{c|}{$\begin{array}{c}\text { Técnicos } \\
\text { Administrativos }\end{array}$} & \multicolumn{2}{c}{ TOTAL } \\
\cline { 2 - 7 } & Freq. & $\%$ & Freq. & \% & Freq. & $\%$ \\
\hline \multirow{2}{*}{ Sim } & 10 & 66,7 & 8 & 72,7 & 18 & 69,2 \\
\hline Não & 5 & 33,3 & 3 & 27,3 & 8 & 30,8 \\
\hline TOTAL & $\mathbf{1 5}$ & $\mathbf{1 0 0 , 0}$ & $\mathbf{1 1}$ & $\mathbf{1 0 0 , 0}$ & $\mathbf{2 6}$ & $\mathbf{1 0 0 , 0}$ \\
\hline
\end{tabular}

Fonte: Dados da pesquisa, 2010

A afirmativa da existência de monitoramento dos resultados das atividades do Programa de Qualidade por 69,2\% dos respondentes precisa ser qualificada.

Enquanto as atividades fins (ensino, pesquisa e extensão) da Universidade, têm mesmo tradicionalmente indicadores, notadamente, para comporem o Anuário Estatístico, que existe na USP desde 1987, ou para atender a órgãos como a CAPES, que avaliam a Pós-Graduação, 
não é usual o uso de indicadores para as atividades administrativas, como pode ser sugerido pelos depoimentos. Em especial, não houve na maioria das Unidades um monitoramento sistemático e "profissional" das atividades desenvolvidas no Programa de Qualidade, mas algum feedback era dado aos participantes. Foi ressaltada por um Diretor a dificuldade em conseguir indicadores e acompanhá-los.

O mais frequente eram avaliações qualitativas feitas, por meio de conversas ou reuniões das Comissões de Qualidade, reuniões de assistentes e a direção da Unidade. Foram também apontados relatórios eventuais de participação em cursos, ginástica laboral e vacinações e também fotografias, de situações "antes" e "depois" de descartes resultados de ações do Programa 5S.

Comentam os diretores:

No Programa 5S havia um número de quantidade de coisas descartadas; havia fotos das salas "antes" e "depois" do descarte de coisas inúteis. Havia um relatório das atividades. (DIR 10)

Todos os projetos que foram sendo trabalhados tinham que ter metas, indicadores e monitoramento das ações. (DIR 13)

Existia um monitoramento de resultados para ver como as pessoas estavam recebendo as atividades que a gente fazia; se a atividade deveria ser repetida ou não; mas não de forma sistematizada, como manda o figurino. (DIR 14)

Um dos diretores relata o grande problema que era tratar essa questão.

Esse era um grande problema; precisamos definir diretrizes e indicadores; eles não são triviais e não temos modelos definidos ou adaptados para uma instituição de ensino; um deles era para medir a satisfação do nosso aluno de graduação; a internacionalização, a integração com outra Unidade, mas não tínhamos indicadores fortes. Demorou quase 6 meses para discutirmos que indicadores utilizar e como esses indicadores confiáveis podiam ser utilizados. (DIR 11)

Os assistentes fazem referências de monitoramento das atividades ocorrido em reuniões, em relatórios de participação em treinamentos, eventos, em vacinações, em atividades de ginástica laboral, ou mesmo "ao ouvir a voz do cliente".

Tínhamos as reuniões quinzenais e semanalmente com as assistentes e a Consultoria Externa, para fazer um monitoramento. (TAD 01)

Havia relatórios de participação nos treinamentos e eventos. Temos planilha em excel de todos eles. (TAD 02) 
O controle do que se procurava melhorar; ouvir a voz do cliente. Houve pesquisa para ver se o Professor estava sendo bem atendido, junto à UPD e à Assistência Acadêmica. (TAD 05)

Havia o controle da ginástica laboral, o número de participantes, número de cursos e de vacinações. (TAD 09)

Todos têm aplicação da técnica e um formulário de controle depois. Cada uma das técnicas tem o seu controle. Por exemplo, para o $5 \mathrm{~S}$ tem a folha de verificação, e é checada semanalmente para ver se está sendo cumprido. Para o PDCA tem o workshop para ver se as pessoas cumpriram as metas. Então todas as funções têm uma checagem depois. (TAD 12)

Na questão da avaliação dos setores, a Comissão tomava conhecimento do resultado, acionava o chefe da área, que conversava com o chefe do setor e que trazia resposta aos comentários. O que chegava por intermédio do ouvidor, ou Caixa de sugestões sempre a Comissão tomava conhecimento e debatia as questões. As coisas não ficavam restritas só aos mais próximos ao problema. Normalmente a Comissão trabalhava isso. (TAD 15)

Não sistematizado, na forma de planilha e divulgação dos resultados, mas fazíamos workshops, em uma tarde, fazíamos palestras e aí aproveitávamos a oportunidade para apresentar como estavam as coisas; isso atraía os mais descrentes. (TAD 13)

Questão 17: Existiam indicadores de produtividade na Unidade?

Complementando a questão anterior, em geral as respostas denotam uma preocupação com indicadores das atividades-fins, tradicionalmente levantados para compor o Anuário Estatístico. A questão 17 procurava saber da existência de indicadores de produtividade na Unidade.

Tabela 32 - Indicadores de Produtividade

\begin{tabular}{c|r|r|r|r|r|r}
\hline \multirow{2}{*}{$\begin{array}{c}\text { 17- Indicadores de } \\
\text { Produtividade }\end{array}$} & \multicolumn{2}{|c|}{$\begin{array}{c}\text { Docentes } \\
\text { Dirigentes }\end{array}$} & \multicolumn{2}{c|}{$\begin{array}{c}\text { Técnicos } \\
\text { Administrativos }\end{array}$} & \multicolumn{2}{c}{ TOTAL } \\
\cline { 2 - 7 } & Freq. & $\%$ & Freq. & $\%$ & Freq. & $\%$ \\
\hline \multirow{2}{*}{ Sim } & 10 & 76,9 & 10 & 90,0 & 20 & 83,3 \\
\hline Não & 3 & 23,1 & 1 & 9,1 & 4 & 16,7 \\
\hline TOTAL & $\mathbf{1 3}$ & $\mathbf{1 0 0 , 0}$ & $\mathbf{1 1}$ & $\mathbf{1 0 0 , 0}$ & $\mathbf{2 4}$ & $\mathbf{1 0 0 , 0}$ \\
\hline
\end{tabular}

Fonte: Dados da pesquisa, 2010 
Os depoimentos dos professores exemplificam a natureza dos indicadores:

Existem indicadores gerais da Universidade que a Unidade se preocupa em coletar, calcular e analisar, para definir metas, como por exemplo: ter nível pelo menos 5 nos programas de PG, depois de atingidos a meta agora é ir para 6 etc. (DIR 04)

Só os usuais: número de formados, publicações etc. (DIR 05)

Não existiam na área funcional. É uma coisa meio delicada colocar indicadores; se você coloca esses indicadores, falando na posição de diretor, os indicadores nem sempre são aceitos ou são aceitos com muita reserva e desconfiança. Dentro do Programa de Qualidade eles começam a ser colocados mais naturalmente, inclusive com a participação madura dos próprios funcionários. No Programa "5 S" os indicadores foram feitos pelos próprios funcionários; entre os próprios funcionários eles monitoravam os indicadores, um do outro. Então eu acho que é uma forma inteligente de montar indicadores, com o Programa de Q\&P. (DIR 06)

Tinham indicadores particularmente no setor de compras que foi muito avaliado e aprimorado para fluxo dos processos, levando em conta redução de procedimentos e redução de prazos. (DIR 09)

Foram uma grande dificuldade conseguir indicadores. (DIR 11)

Temos os indicadores do Plano de Metas; temos os indicadores acadêmicos; os de compra e também monitoramos o tempo que demora cada processo. A gente mudou uma série de processos, diminuindo o tempo: alguns processos que precisavam passar no CTA, ou não; diminuímos bastante os caminhos. (DIR 14)

Com exceção de assistentes de duas Unidades que relataram ter indicadores próprios, os indicadores de produtividade nas outras Unidades estavam restritos aos exigidos pelo Anuário Estatístico. Diga-se, de passagem, que esses indicadores são bastante completos e a maioria deles têm uma série que remonta a 1986, data do primeiro Anuário Estatístico editado.

Comentam os técnicos administrativos:

Só temos os Indicadores do Anuário. Isso é super importante para distribuir recursos, para avaliação de desempenho. Como se medir produtividade conforme as especificidades na instituição, cada Unidade é muito diferente. (TAD 07)

Sim, temos indicadores formais; agora o SIBi está estudando indicadores formais para as Bibliotecas da Universidade como um todo. No momento em que definimos o Sistema de Gestão tínhamos indicadores próprios, internos onde a gente dava uma meta aproximada e ia cedendo, apertando ou soltando, conforme a necessidade e fomos experimentando. Não tínhamos indicadores no Brasil ou no exterior os indicadores que pudéssemos usar, fomos experimentando. (TAD 12)

\subsubsection{Resultados do Programa de Qualidade e Produtividade da USP}

A última das categorias de categoria de análise (D) inclui os Resultados e Avaliação do Programa de Qualidade e Produtividade da USP. A implementação de um programa de 
qualidade apresenta resultados esperados e não esperados, tangíveis e intangíveis. Dado que existiram, no Programa de Q\&P da USP, diretrizes genéricas de conteúdo e considerando a autonomia, que era assegurada aos atores da implantação da estratégia, os resultados apontaram uma diversidade de ações, de natureza política, administrativa e comportamental, entre outras. Muitas dessas ações não são passíveis de mensuração o que levou a pesquisadora a indagar aos entrevistados suas percepções quanto aos resultados, impactos e avaliação que faziam do Programa.

Um conjunto de questões apresenta respostas a essas indagações:

Q18 Cite três experiências ocorridas em função do Programa de Qualidade

Q18.1 Cite três experiências negativas ocorridas em função do Programa de Qualidade Q22 a Q24 Conceito do Programa (pelos diretores e técnicos administrativos).

Q25 Impacto do Programa para a Unidade e para a USP

Q27 Impacto para você (técnico administrativo)

Q33 e Q34 Aprendizagem pessoal

Q35 e Q36 Aprendizagem organizacional

Q37 e Q38 Competência pessoal

Q39 e Q40 Competência organizacional

Q41 e Q42 Participação em tomada de decisões administrativas

Q43, Q44 e Q45 Interação entre funcionários dentro da Unidade e na USP

Q46 e Q47 Atividades de Qualidade de Vida no trabalho

Com o intuito de dar uma estrutura uniforme para observar as experiências realizadas e compará-las com as expectativas ao Programa de Qualidade (Q02) e as Atividades Formais do Programa (Q15) foram classificadas as experiências positivas, (Q18), com a grade já utilizada de Módulos de Qualidade, que associa os Critérios do PNQ aos Balizadores da Qualidade no Serviço Público, já apresentados. Nem sempre foi possível classificar uma experiência em um único Balizador; nesse caso, a resposta foi desmembrada e enquadrada em mais de um Balizador.

Essa questão para fins de análise foi denominada como a Fase 3 ou Final do Programa de Qualidade e Produtividade na USP. 
Questão 18: Cite três experiências ocorridas em função do Programa de Qualidade?

Tabela 33 - Experiências positivas da Qualidade

\begin{tabular}{l|l|c|c|c|r|r}
\hline & \multicolumn{1}{|c|}{ Experiências Positivas } & $\begin{array}{c}\text { Critérios e } \\
\text { Balizadores }\end{array}$ & Dirigentes & $\begin{array}{c}\text { Técnicos } \\
\text { Admin. }\end{array}$ & \multicolumn{2}{|c}{ TOTAL } \\
\hline & & & Freq. & Freq. & \% & \% \\
\hline 1 & Liderança e Envolvimento & C1 e B2 & 5 & 0 & 5 & 8,9 \\
\hline 2 & Planejamento & C2 & 3 & 2 & 5 & 8,9 \\
\hline 3 & Foco no Cliente e Sociedade & C3 e B1 & 6 & 3 & 9 & 16,1 \\
\hline 4 & Informação e Análise & C4 e B4 & 1 & 2 & 3 & 5,4 \\
\hline 5 & Pessoas e Qualidade de RH & C5 e B3 & 12 & 11 & 23 & 41,1 \\
\hline 6 & Gestão de Processos & C6, B5, B6 e B7 & 8 & 3 & 11 & 19,6 \\
\hline 7 & Parcerias e Alianças & C7 e B8 & 0 & 0 & 0 & 0,0 \\
\hline & TOTAL & & $\mathbf{3 5}$ & $\mathbf{2 1}$ & $\mathbf{5 6}$ & $\mathbf{1 0 0 , 0}$ \\
\hline
\end{tabular}

C1 a C7 - Critérios do PNQ

B1 a B8 - Balizadores do Serviço Público (1996)

Fonte: Dados da pesquisa, 2010

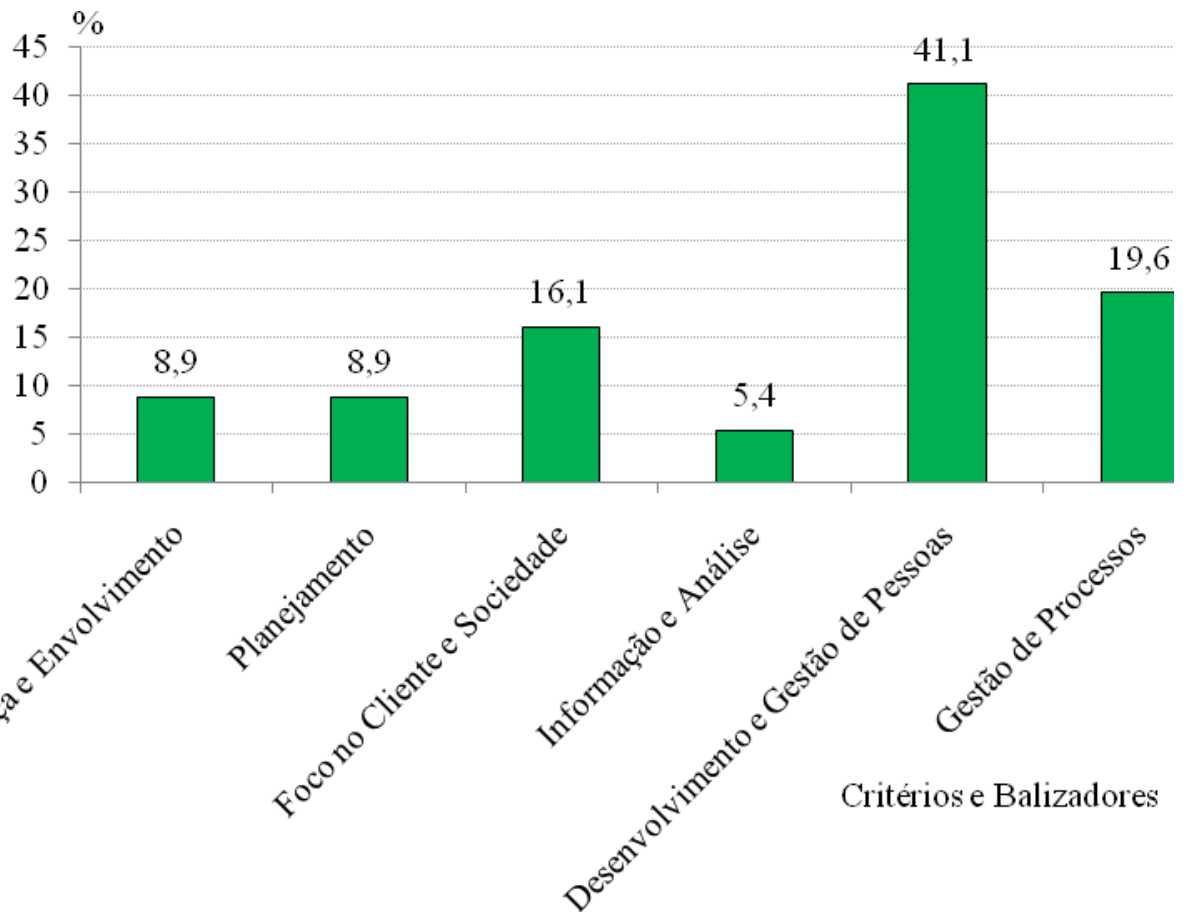

Gráfico 22 - Experiências positivas da Qualidade 1996 - 2006

Fonte: Dados da pesquisa, 2010

O Gráfico 22 permite observar que as experiências positivas mais frequentemente registradas podem ser projetadas para o Critério de Gestão e Desenvolvimento de Pessoas $(41,1 \%)$. Seguem-se ações que podem ser enquadradas na Gestão de Processos (19,6\%), Foco no Cliente e Sociedade $(16,1 \%)$, Liderança e Envolvimento $(8,9 \%)$ e Planejamento $(8,9 \%)$ e 
Informação e Análise (5,4\%). O Módulo de Parcerias e Alianças não foi objeto de referência pelos entrevistados.

O Módulo 1, Liderança, está associado ao Balizador 2 - Cada um dos participantes da administração pública é responsável pela qualidade.

Seguem-se depoimentos projetados nesse módulo, com experiências positivas do Programa:

Participação é importante em todo o processo de trabalho [...] depois da reunião (de planejamento) os funcionários vieram com espírito de participação, de colaboração, de soluções de problemas[...] (DIR 01)

O Workshop que fazemos de Interação de Competências; é bienal, com a participação tentativamente de todos os funcionários ou da maior parte deles, quase a totalidade, com a participação dos docentes envolvidos na administração, como o diretor, o vice-diretor, chefes de departamento e coordenadores de comissões (graduação, pós-graduação). A reunião é feita fora da Unidade. (DIR 05)

Um ponto importante foi o envolvimento dos funcionários e outra coisa que se iniciou foi a reunião na escola de um Simpósio anual; iniciamos em 2000 e depois isso continuou; foi realizado no ano passado o $9^{\circ}$ Simpósio; também isso deu condições para gerar uma publicação, o Manual de Biossegurança com a participação de todos os docentes da Faculdade; o livro teve uma repercussão muito grande na área; já tinha esgotado a primeira edição e foi reeditado; ele estava relacionado com a qualidade. Houve um envolvimento muito grande dos funcionários e uma motivação grande dos funcionários em participar do programa. (DIR 07)

As reuniões que tínhamos com as pessoas relatando suas atividades; as pessoas mais simples iam lá para expor suas idéias e suas sugestões; sabem que o trabalho delas é importante [...]. (DIR 10)

Módulo 2, de Planejamento, sem associação aos balizadores do Serviço Público.

Dentro desse Módulo foram citados como experiências:

O programa de planejamento estratégico teve como conseqüência uma significativa melhoria de relacionamento entre os vários setores da Unidade. Desde então este projeto tem sido repetido. (DIR 03)

Os chefes de seções e professores que desempenhavam posições importantes na Unidade foram reunidos em um hotel com a coordenação de uma especialista em recursos humanos para elaborar um programa de planejamento estratégico. Todas as propostas elaboradas foram implementadas. (DIR 11) 
O Módulo 3, de Foco no Cliente está associado ao Balizador 1, O cliente final da administração pública é a sociedade.

Para esse Módulo, podem-se evidenciar os registros:

Tem uma avaliação interna dos setores, quando sistematicamente os setores são avaliados pelos usuários pela internet. Todos os alunos e funcionários são convidados a preencherem o questionário; as críticas são levadas aos setores que tomam conhecimento delas e fazem uma avaliação da avaliação; às vezes as críticas não procedem, porque os usuários não conhecem a situação completa do setor; as criticas têm um objetivo construtivo. É interessante que cada setor saiba exatamente o que pensa o seu usuário e como o seu serviço está sendo recebido. Isso continua até hoje. Isso não é usual na Universidade: isso é uma avaliação do serviço. (DIR 05)

A instalação da Ouvidoria, antes mesmo da Administração Central. (DIR 03)

Deve ser observado que a instalação da Ouvidoria na USP deu-se em 29/03/2001, pela Resolução n. 4827 do então Reitor Prof. Jacques Marcovitch.

Tornar a Unidade totalmente acessível a todos os portadores de deficiência. Eu me orgulho disso. (DIR 03)

Gestão ambiental: substituição de todas as torneiras dos toaletes por torneiras temporizadas. (DIR 04)

Coleta Seletiva e reciclagem. (DIR 02)

Programa Boa Aula; com o intuito de atender melhor o professor; oferecer equipamento adequado e melhorias dos equipamentos; equipamentos de projeção; instalamos salas do Pró-aluno; da UPD; audio-visual; comunicação entre funcionários da Reitoria e da UPD. (TAD 05)

No Programa de Qualidade do SIBi os usuários não estavam satisfeitos com a atualização do acervo de livros das bibliotecas; então conseguimos uma verba suplementar para aquisição de bibliografia básica. Conseguimos junto à Reitoria uma alínea para aquisição de equipamentos por conta do Programa de Qualidade implantado; que foi uma ação muito proveitosa. (TAD 12)

Implantação de programas de treinamento para os usuários da Biblioteca, que pela pesquisa de qualidade foi detectado que os usuários não sabiam aproveitar do acervo; eles não sabiam usar os recursos que as bibliotecas dispunham e não aproveitavam tanto quanto poderiam. Implantamos treinamentos formais nas bibliotecas; conseguimos junto à Reitoria, que as bibliotecas fizessem também apresentações nas recepções aos calouros; dessem aulas; fizemos tutoriais dentro da página do SIBi, seguindo passo e passo e pudessem utilizar o recurso sem treinamento formal; ainda está lá para qualquer pessoa usar o recurso e também fez-se uma campanha Ainda na Campanha na Semana do Livro para a biblioteca a gente faz treinamento para demonstrar os recursos que temos. (TAD 12) 
O Módulo 4, de Informação e Análise, é associado ao Balizador 4 - O Programa da Qualidade e as decisões devem ser direcionadas por indicadores, dados e fatos recebe evidência no registro:

\begin{abstract}
A USP já tinha uma história de indicadores, com o Prof. Goldenberg, com seus números; o Anuário Estatístico era base de informações de seus indicadores. A Comissão de Qualidade sugeriu um conjunto de indicadores que foram incluídos no Anuário; fizemos folhetos, "USP em números" que é uma forma de comunicação significativa; é publicado anualmente em quatro línguas. Estimulamos também "Unidade em Números", que algumas Unidades preservam até hoje. Houve um esforço de sistematização das atividades, em jornais, experiências da USP em foruns, esforço de se manter a memória organizada; a divulgação da experiência da USP em outras universidades; uma parte disso fica e foi estimulado pelo Programa de Qualidade. Note, um grande aliado externo era a sociedade, que caminha nessa direção; nós não estamos na contramão; os estímulos externos nos apoiaram muito na nossa direção e nossas experiências eram bem acolhidas (DIR 15)
\end{abstract}

Nossa Unidade colaborou com a USP no sistema de atualização de patrimônio, que foi repassado para a CODAGE; tudo feito pela Intranet. Também fizemos e deixamos disponível para replicar: os sistemas de transporte (veículos e pedidos de viagem); reserva de sala; controle de mandato de comissões, da área acadêmica; controle de bolsistas; sistema de convênios e reservas de salas para reunião; saída de bens para a manutenção; chamados de consertos de informática e de infraestrutura. (TAD 15)

O aperfeiçoamento do sistema informatizado financeiro e de vários outros. (TAD 17)

O Módulo 5, de Desenvolvimento e Gestão de Pessoas, associado ao Balizador 3 - A melhoria dos serviços públicos é obtida pela Qualidade dos recursos humanos pode ser identificada nos registros:

O objetivo maior era aprimorar o relacionamento entre os diversos setores; eles tendem a funcionar isoladamente; a idéia seria estabelecer uma interface mais eficiente; o Workshop tem alguns efeitos colaterais muito bons; esse bom relacionamento tem conseqüências saudáveis; o simples fato de uma pessoa entender melhor o comportamento da outra é melhor para o ambiente. (DIR 03)

O Boletim da Unidade; virou um meio de comunicação interna muito eficiente e isso é muito bom, pois o pessoal conversa através dele; as pessoas apresentam suas idéias, abriu-se um espaço para a criatividade, para as pessoas escreverem; o pessoal está discutindo a língua portuguesa; cada número sai uma matéria sobre o bom uso da língua etc. \{...\} Ele está ganhando vida própria e promove uma integração e está cada dia mais criativo; esse Boletim virou um instrumento de divulgação e comunicação interna. (DIR 06)

Início de Jornal Interno impresso. (DIR 04)

Temos Projeto de Melhoria das Condições Ergonômicas e Treinamento de Servidores TécnicoAdministrativos. (DIR 05)

Eu dou o exemplo de um setor que mudou totalmente: a oficina; eu considero isso muito gratificante; envolvia doze funcionários e não havia um satisfeito; o quadro hoje é muito diferente, totalmente inverso (DIR 06).

Iniciamos o projeto de formação de multiplicadores da qualidade. (DIR 06) 
[...] não se tem condições de relacionar com números, mas o relacionamento do pessoal da faculdade a gente pode sentir que houve uma melhora muito grande. (DIR 07)

Tentamos melhorar a estrutura de redes de informática e treinamento dos funcionários em informática. O Programa faz com que o funcionário entenda a importância de seu trabalho para a instituição e começa a ser reconhecido por isso; isso por si só já é uma melhora na qualidade de vida de trabalho; é preciso também trazer a integração dos funcionários, entre os setores, docentes e funcionários; assim você cria um ambiente melhor. Eu acho que o Programa, hoje eu posso dizer atingiu, se não $100 \%$ da expectativa, atingiu os objetivos em relação a isso. (DIR 08)

Revisão das condições de segurança no trabalho; foi aproveitado também para inserir os programas de Segurança no Trabalho; fundiu e se articulou com a CIPA. A Unidade envolve processos perigosos e tem muita máquina etc. Também faziam cursos amplos e as atividades da Unidade RECICLA.; a comunicação continuou de forma virtual e no fim retomou, com um Boletim específico da Comissão de Qualidade. (DIR 12)

Uma melhoria das relações entre as pessoas. O Programa de Qualidade que foi feito, certamente, ajudou bastante; eu não sei dizer o quanto melhoraria se não tivesse o Programa, mas as pessoas com o tempo acabam se ajustando, se acomodando e o Programa acelerou bem o processo e deu para identificar as pessoas que tinham um bom desempenho e poderiam ser colocadas em determinadas situações de responsabilidades ou não. (DIR 10)

Programas de treinamento e desenvolvimento e acho que teve a participação dos programas formais do projeto da Qualidade; houve ainda um apoio às iniciativas extras dentro da Faculdade, como o Coral; houve uma tentativa nossa de melhoria do clima organizacional interno: ter a Faculdade como um lugar amigável, gostoso de vir trabalhar. Tivemos também o Programa de Bolsa de Estudos para os funcionários; eles entravam na Faculdade privada e não tinham como pagar. Para aprimorar a avaliação de desempenho dos nossos funcionários a cenourinha dada, que é a educação, foi importante. (DIR 13)

Prata da Casa: no saguão faziam exposição de uma semana de atividades com coisas que as pessoas faziam de melhor no outro lado da sua vida: bordado, escultura, quadros, cantavam, dançavam (uma aluna foi dançar a dança do ventre!), e os alunos também participavam. Alunos, professores e funcionários participaram. Durante uma semana todo dia às 5 horas da tarde começavam as apresentações. Treinamento: curso de liderança, motivação, temas relacionados às deficiências detectadas no clima organizacional; sempre em cima disso; quanto é importante forma de reconhecimento, que não é só dinheiro![...] gestão de pessoas, psicologia do trabalho, qualidade no atendimento. Encontro de gestão, eventos anuais. Ginástica laboral e ginástica de pausa, que foi muito interessante. (DIR 14)

Os funcionários técnicos administrativos expõem, tanto quanto os dirigentes, uma longa lista de experiências realizadas, em consonância com o desenvolvimento dos recursos humanos, nos aspectos de relações de trabalho, treinamento e qualidade de vida no trabalho.

O prêmio de treinamento para os funcionários e outro o Programa de Gestão Ambiental, que trouxe para nossa unidade uma expressão muito forte e nos colocou como benchmarking; o nosso programa está difundido em outras universidades; rendeu muitas visitas e palestras; fizemos palestras de apresentação de nosso trabalho e já fomos monografias de três alunos de MBA. (TAD 02).

Campanha de Vacinação contra gripe, anual, feita em duas etapas; ginástica laboral; cursos a partir do Levantamento de Necessidades de Treinamento; participação no USP RECICLA. CIPA, palestras SIPAT; Palestras de saúde; Dia da saúde bucal (dá um kit de higiene bucal) e dia do funcionário público; cartão de aniversário para aposentados, com dois ingressos de cinema e campanha do agasalho. Depois de alguns anos, agora os próprios funcionários cobram a campanha. Há o Café com o Diretor (a escola é dividida em setores e uma vez por mês um grupo 
toma café com o Diretor). Há aproximadamente 1000 funcionários entre docentes e não docentes. A cada 2 ou 3 meses há reunião aberta do Diretor com alunos e funcionários para discutir sobre temas em geral (acesso, reajuste). Fica sabendo das coisas que acontecem. Outro problema simples: só docentes tinham cartões de visita; os funcionários também quiseram o seus. Isso valoriza o funcionário. Ajuda de custo para freqüentar a primeira faculdade e cursinho. Já há funcionários fazendo curso aqui a escola. (TAD 08)

Um ciclo de palestras motivacionais sobre o Programa de Qualidade, para levantar o astral das pessoas, abordando "Comunicação", "Pensar diferente" e "Desperte o gigante interior", algo para mexer com as pessoas. Foi bastante positivo que fizemos um diagnóstico e vimos que a grande maioria dos nossos funcionários operacionais não tinha formação. Então houve um grande esforço e incentivo para que os funcionários, sem formação, fizessem o curso fundamental e o supletivo; mais de 50\% dos funcionários foram fazer o curso. Quando se formavam, a direção cumprimentava os formandos, colocava os nomes nos jornais; no início do curso dava incentivo e oferecia um kit aluno, com caderno, lápis etc. Ainda fizemos cursos de treinamento interno para motivar os funcionários. (TAD 10)

Fizemos Workshop de competência; o programa de Ergonomia, que está andando ainda; observamos aspectos de má postura nas pessoas, como falar ao telefone, uma inadequação de mobiliário e não conformidade. Houve sugestão para trazer um especialista para falar sobre isso e fizemos um encontro de um dia. $\mathrm{O}$ assunto teve repercussão muito grande. Até hoje as pessoas entram em contato conosco para saber como foi feito; estabeleceu-se uma estratégia; contratamos um pessoal que veio fazer um diagnóstico; eles viram todos os ambientes, fizeram um laudo e apontaram situações-problemas, que prejudicavam o trabalho dos funcionários e fizeram recomendações; fizemos mais 2 palestras e de uma forma bem didática eles mostraram com fotos o que observaram no dia a dia e encaminhamos as soluções. As soluções, na maioria dos casos, implicam na mudança do mobiliário, que é a terceira fase. Nós tínhamos um modelo e como era um volume muito grande de móveis a gente resolveu fazer por partes; visitamos as salas de docentes, conversamos com docentes e funcionários e obtivemos deles considerações sobre o que os incomodavam em relação ao mobiliário e isso gerou uma solicitação de mobiliário diferente ao que estávamos pensando. Então tivemos que refazer o trabalho de especificação do mobiliário. Compramos algumas peças para testar e colocamos em salas de pessoas que se dispuseram a avaliar. Depois de avaliado é um processo de compra, em um processo gradativo de substituição e realocação dos móveis existentes. Entra no aspecto do conjunto; conseguimos agora comprar cadeiras melhores; e complementamos os apoios para pé; head fone e apoio para punho. (TAD 15)

A sistemática de treinamento vinculada à Comissão de Qualidade foi boa. O Jornal Quotidiano da Unidade, a partir deste mês está on-line para minimizar custos. Houve também um Programa de Controle de voz para os docentes. Foi convidado o pessoal da UNIMED para fazer palestra, orientação e exames diagnósticos para cordas vocais. Quando constatado algum problema alguns docentes passavam por um exame mais apurado. Daí em diante as pessoas deviam procurar tratamento especializado, se tivesse sido detectado um problema mais sério. Foi feito também Ginástica laboral, que faz parte do programa de ergonomia. (TAD 16)

Com o Treinamento de multiplicadores da qualidade houve uma consciência nova a respeito do que é qualidade e houve uma mudança até comportamental: não fica só vendo o que o vizinho faz errado; vai perguntar como posso ajudar e fazer melhor. (TAD 13)

A valorização dos recursos humanos, fundamentada na escuta dos relatos de vivências no trabalho cotidiano dos colaboradores, antes de qualquer mudança ou aperfeiçoamento - a efetiva participação no programa de Q\&P. (TAD 17)

Realização do I Encontro de Gestão, em 2002, no qual foi realizada a Pesquisa de Clima Organizacional, cujo resultado foi apresentado à Congregação da Unidade, na qual se detectou a necessidade de investimento no desenvolvimento de lideranças. Realização do II Workshop sobre Gestão, em 2004; Realização do Evento Pratas da Casa. (TAD 19) 
Sob o Módulo 6, de Gestão de Processos, incluíam-se os Balizadores 5, 6 e 7:

\author{
Balizador 5 - $\quad$ O aperfeiçoamento contínuo dos serviços, produtos e processos deve ser uma \\ atividade cotidiana no serviço público. \\ Balizador 6- O valor e o sacrifício de qualquer atividade devem ser constantemente \\ monitorados.
}

Balizador 7 - Bons resultados são decorrentes de processos controlados.

O melhor aproveitamento dos recursos humanos, docentes e não-docentes da Unidade; mais que dobramos os alunos da graduação; houve (160\%) de aumento: de 100 vagas na FUVEST para 260 e de 1 para 6 ( 5 cursos novos) aumentando apenas 30\% do quadro. Isso é melhora de eficiência do recurso público. A qualidade tem duas vertentes: uma, a qualidade dos objetivos fins e outra dos objetivos meios, eu citaria a redução de prazos na assistência financeira. Eu tenho uma leitura: dentro da legislação vigente é na área financeira que se pode trabalhar. (DIR 09)

Na parte administrativa que é mais simples: conseguimos o aperfeiçoamento dos processos administrativos, um aperfeiçoamento fantástico; a gestão de qualidade mostrou-se muito útil para isso; mesmo em uma autarquia, como é a Universidade de São Paulo, se consegue melhorar os processos administrativos, torná-los mais dinâmicos. O exemplo típico foi o do diploma que de 140 passos baixou para 30 passos. Na pesquisa: nós começamos a criar certas rotinas que simplificam a vida do docente, para poder dinamizar e viabilizar as pesquisas, que era um problema sério e aí esbarramos com a burocracia da universidade, que é extremamente conservadora. (DIR 11)

Na telefonia houve um resultado real de redução de custo mensais. Fizemos uma conscientização para os gastos mensais de telefone; saber qual é o teto e o que se tem que fazer para reduzir. (TAD 13)

$\mathrm{Na}$ escola pedi para efetuar as compras com material de qualidade; porque o ambiente em que estamos é importante; ele deve refletir essa qualidade; se eu não estou em um ambiente adequado, como vou exigir qualidade do meu funcionário?[...] beleza limpa, adequada, os móveis adequados, foi o que procurei fazer. Começou a surgir uma consciência da necessidade de dar o melhor aos funcionários e com isso ganhamos a confiança deles, a produção aumentou e houve muita receptividade em unir. (DIR 01)

A compra de móveis é centralizada porque assim funciona bem; na especificação de móveis existe um funcionário que entende bem de móveis, porque já trabalhou em um fábrica de móveis e ajuda a comprar os móveis de todo o instituto; não deixamos escapar nada fora de padrão; isso tem que funcionar tanto na especificação como no recebimento dos móveis. (DIR 04)

Avaliação de ergonomia de todas as compras de móveis. Um programa de ergonomia foi instituído após um workshop de ergonomia e esse programa está até hoje em vigor. Por coincidência, hoje eu conversei com o assistente administrativo, e durante o diálogo que eu estava tendo com ele, apareceu um professor que tinha ficado muito tempo no exterior e perguntou sobre a mobília da sala dele, se já havia sido providenciada. $\mathrm{O}$ assistente disse que sim e que a compra tinha sido um pouco mais demorada porque a especificação dos móveis passava pela Comissão de ergonomia; há uma rotina que envolve a Comissão de ergonomia, que é consequiência daquele programa. (DIR $05)$

A partir do Programa foi possível tomar uma série de atitudes em relação à eficiência, à economia de alguns setores e isso vêm ocorrendo naturalmente; as pessoas se engajam e fazem isso com certo prazer. (DIR 06)

Programa 5S: a gente via o material ser removido; há fotos e relatório. (DIR 10) 
O $5 \mathrm{~S}$ deu bons resultados; tivemos quase três toneladas de descarte; e só aí, pessoas que eu jamais imaginava que iam estar descartando coisas, porque eram muito apegadas às coisas; embora alguns depois iam lá e pegavam algumas coisas de outros. Foi muito bem sucedido. (TAD13)

Elaboração de rotinas de trabalho. (TAD 01)

Melhoria da infra-estrutura de ensino. (DIR 03)

Em alguns setores da instituição onde se entra hoje, e quem conheceu antes, sente um ambiente totalmente diferente; corredor cheio de tranqueira; desapareceu tudo isso quando se entra na sala tudo organizado; não é que todo instituto esteja assim, mas em alguns setores percebe-se que a eficiência aumentou muito assim como a qualidade no trabalho. (DIR 06)

Quanto ao Módulo 7, Parcerias e Alianças, que estava associado ao Balizador 8 - Parceiros devem ser desenvolvidos para a satisfação do cliente final, não foram evidenciados relatos específicos nas entrevistas realizadas.

Considerando que todo processo sempre tem duas faces, procurou-se saber se o Programa de Q\&P trouxe experiências negativas, na percepção dos funcionários. A questão sobre existência de experiências negativas em função do Programa de Qualidade e Produtividade só foi feita aos técnicos administrativos. De forma unânime, os entrevistados disseram não haver experiências negativas com o Programa. Ressaltaram, todavia, alguns problemas que encontraram para conseguir atingir mais amplamente seus objetivos. Foram destacados, entre outros: a descontinuidade, a resistência de pessoas, a falta de recursos financeiros e a falta de pessoas com conhecimento técnico necessários para o desenvolvimento do Programa. A questão proposta foi:

Questão 18.1: Cite três experiências negativas ocorridas em função do Programa de Qualidade?

A Tabela 34, a seguir, mostra os resultados encontrados. 
Tabela 34 - Problemas apontados pelos técnicos administrativos para o Programa de Qualidade: 1996 - 2006

\begin{tabular}{l|r|r}
\multicolumn{1}{c|}{ Problemas } & Freq. & \multicolumn{1}{c}{$\%$} \\
\hline Descontinuidade & 5 & 29,4 \\
\hline Falta pessoal técnico & 2 & 11,8 \\
\hline Falta de recursos & 2 & 11,8 \\
\hline Resistência & 2 & 11,8 \\
\hline Tristeza revogação Qualidade & 1 & 5,9 \\
\hline Falta de indicadores & 1 & 5,9 \\
\hline Dificuldade liberar funcionários para formação & 1 & 5,9 \\
\hline Ciúme & 1 & 5,9 \\
\hline Sobrecarga trabalho & 1 & 5,9 \\
\hline Falta de autonomia & 1 & 5,9 \\
\hline TOTAL & $\mathbf{1 7}$ & $\mathbf{1 0 0 , 0}$ \\
\hline Fon
\end{tabular}

Fonte: Dados da pesquisa, 2010

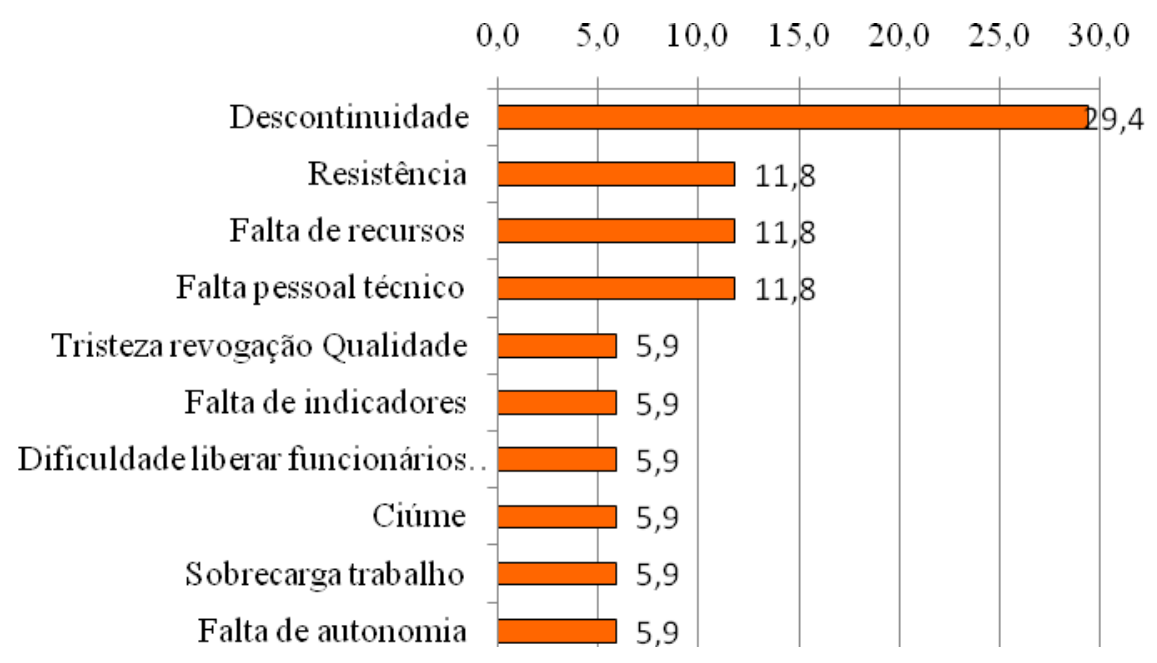

Gráfico 23 - Problemas apontados pelos técnicos administrativos para o Programa de Qualidade: 1996 - 2006

Seguem-se alguns depoimentos:

A resistência das pessoas, a falta de recursos e a falta de pessoal técnico; grupo que trabalhasse as iniciativas do programa e que conhecessem um pouco mais da teoria, do tema e da qualidade como um todo. Um grande problema é a continuidade; criamos uma grande expectativa com ótimos resultados, mas quando isso pára, as pessoas se dispersam e é difícil de resgatar. As pessoas se perguntam então se valeu a pena ter investido tanto; mas há pessoas que ainda têm muitas idéias para dar para a Unidade. Nos trabalhos em grupo, as pessoas vão dando idéias e vamos complementando. (TAD 01)

Negativo, não tive no Programa de Qualidade. Tirando a resistência que as pessoas oferecem; isso não é uma experiência negativa; isso é um fator a ser driblado e superado. Isso pode ser mesmo visto como um ponto positivo, porque elas têm senso crítico. Elas querem que comprove se é bom ou não. As experiências que tivemos foram oportunidades para aprender. (TAD 12)

As coisas morrem no meio; muda a gestão e vai tudo por água abaixo; qualidade morreu no meio do caminho; o que foi colocado só muda o nome. (TAD 09) 
A continuidade do programa; gera expectativas e não satisfaz. Questão de línguas, inglês; as pessoas solicitam isso e o programa faz um investimento por tempo limitado, para o básico (TAD 15)

Negativo, foi a decisão de novo Diretor, a partir de 2005, que descontinuou as ações em andamento do Programa, por ter uma visão diferente de qualidade. (TAD 17)

É negativo não poder dar continuidade nas coisas. Criou-se uma expectativa nos funcionários, quando fizemos as palestras e depois íamos fazer os " $5 S$ " não teve continuidade. Os funcionários estavam motivados, mas o Diretor não autorizou. Reforçou a idéia de que era mais uma coisa que não continuava; isso foi ruim. (TAD 10)

Não houve pontos negativos; minha única tristeza foi a questão da Qualidade ter sido revogada com a vinda da portaria do GESPÚBLICA. A Diretoria da Unidade entendeu que é uma Comissão que traz resultados positivos, então ela vai permanecer. (TAD 02).

Não consegue mostrar os dados para a comunidade, em função do programa; colocar indicadores para a comunidade interna. (TAD 05)

Lidar com as pessoas causa ciúme; o que não aparece fica enciumado. Em geral não teve nada de negativo. (TAD 13)

A dificuldade encontrada para a liberação dos colaboradores para capacitação e formação (TAD 17)

Muitos colaboradores viam o Programa como uma sobrecarga. (TAD 17)

Falta de recursos financeiros, falta de pessoal envolvido especialmente com a qualidade e falta de autonomia da equipe Qualidade. (TAD 19)

Não tem nenhum ponto negativo; a direção da qualidade é positiva. (TAD 06)

Como se pode observar, há um conjunto bastante disperso de problemas assinalados mais com

o processo de mudança cultural do que propriamente com o processo da Qualidade. A descontinuidade administrativa, como o mais citado, não surpreende, uma vez que tal causa é citada como um dos problemas característicos da administração pública.

Questão 24 (Questionário tipo 1) e Questão 25 (Questionário Tipo 2) - O que foi o Programa de Q\&P para sua gestão? Teve valor/impacto para a Unidade e para a USP? Para o governo? Para a sociedade? De que natureza? Onde? Como? Explique.

A Tabela 35, a seguir, procura sintetizar as respostas dadas às Questões 24 e 25, utilizando-se da grade já referenciada de Módulos de Qualidade. 
Tabela 35 - Impactos nos módulos de Qualidade

\begin{tabular}{|c|c|c|c|c|c|c|}
\hline \multirow[t]{2}{*}{ Impactos } & \multicolumn{2}{|c|}{$\begin{array}{l}\text { Docentes } \\
\text { Dirigentes }\end{array}$} & \multicolumn{2}{|c|}{$\begin{array}{c}\text { Técnicos } \\
\text { Administrativos }\end{array}$} & \multicolumn{2}{|c|}{ TOTAL } \\
\hline & Freq. & $\%$ & Freq. & $\%$ & Freq. & $\%$ \\
\hline Liderança e Envolvimento & 5 & 18,5 & 0 & 0 & 5 & 13,2 \\
\hline Planejamento & 2 & 7,4 & 1 & 9,1 & 3 & 7,9 \\
\hline Foco no Cliente e Sociedade & 4 & 14,8 & 3 & 27,3 & 7 & 18,4 \\
\hline $\begin{array}{l}\text { Desenvolvimento e Gestão de } \\
\text { Pessoas }\end{array}$ & 13 & 48,1 & 5 & 45,5 & 18 & 47,4 \\
\hline Gestão de Processos & 3 & 11,1 & 2 & 18,2 & 5 & 13,2 \\
\hline TOTAL & 27 & 100,0 & 11 & 100,0 & 38 & 100,0 \\
\hline
\end{tabular}

Fonte: Dados da pesquisa, 2010

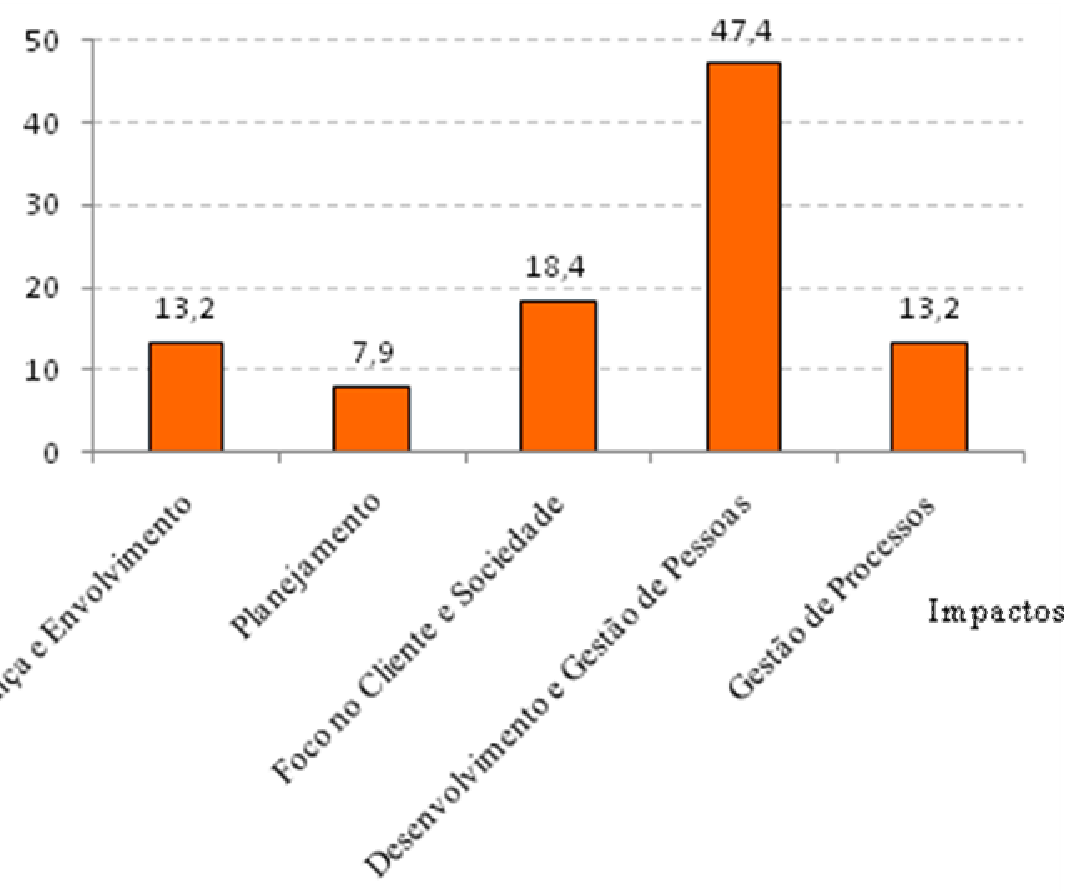

Gráfico 24 - Impactos nos módulos de Qualidade

Assim, no Módulo 1 para Liderança e envolvimento incluiu-se a participação e o envolvimento da comunidade em geral. No Módulo 2, de Planejamento, foi incluída a resposta como filosofia e estabelecimento de metas. No Módulo 3, com Foco no Cliente e Sociedade, foram incluídas respostas como: ampliação de vagas, alteração do currículo de graduação, valorização da instituição e referência para outros órgãos de governo. Na categoria de Pessoas e Qualidade de Recursos Humanos, de maior ocorrência, foram citados os impactos relativos à mudança cultural, mudança de mentalidade, tomada de consciência da responsabilidade pública, treinamento de funcionários, além de motivação dos funcionários; 
reconhecimento, aprendizado entre unidades, programas voltados aos funcionários, ginástica laboral, melhor conhecimento dos funcionários e suas reivindicações, maior conhecimento sobre a USP e as Unidades, trabalhos em equipe, ambiente mais aberto entre funcionários e interação entre eles. No Módulo relativo à Gestão de Processos foram registrados como impactos o estabelecimento de indicadores de desempenho, a melhoria do trabalho, a redução de falhas, as melhorias no setor de compras e o melhor aproveitamento de recursos públicos.

Além da especificação do tipo de impacto, alguns entrevistados só qualificaram o Programa de Qualidade como: positivo, importante, de impacto forte; de impacto relevante de valor inestimável; um deles resumiu "ter ficado muito satisfeito com o Programa".

Seguem-se alguns depoimentos de dirigentes e funcionários técnicos administrativos.

Foi prioritário na gestão para a USP; não houve praticamente nenhuma crítica e houve participação surpreendente; foi uma referência para outros órgãos do governo. Desempenho da missão, dos serviços, desempenho operacional e os pontos que a USP estava abordando eram os pontos que as secretarias de estado deveriam abordar. A USP era exemplo. (DIR 16)

O impacto maior foi na área administrativa. O corpo de docentes foi pouco afetado e os alunos muito pouco afetados. No quadro de funcionários trouxe a ênfase no treinamento de recursos humanos; foi o mais importante; os funcionários faziam muitos eventos, encontravam-se e trocavam idéias. O Programa contribuiu para ter um ambiente muito aberto entre os funcionários; foi uma das dimensões mais importantes. (DIR 15)

A Comissão Central de Recursos Humanos (CCRH), que também era de nossa alçada, acolhia os critérios do Programa de Qualidade para a carreira dos funcionários, valorizando, premiando e treinamento. O treinamento foi técnico, na área de informática, de línguas e também na socialização, na área de cultura, conhecer as atividades da Universidade e seus vários campi; os funcionários tiveram oportunidade de se expandir pessoalmente e eles retribuíam com o ganho de produtividade de modo geral e faziam trabalhos de equipe; houve outras experiências pontuais, que foram relevantes e localizadas como a da Biblioteca, USP Recicla, com ações para o meio ambiente, comunicação e outras áreas que em parceria ajudaram a desenvolver o trabalho. Houve também um filho natural da Comissão de Qualidade que foi a Comissão Permanente de Avaliação (CPA) da USP, quando se avaliou as Unidades. A filosofia de se estabelecer metas, programas, avaliar continuamente as atividades com avaliadores internos e externos também tinha a mesma filosofia do Programa de Qualidade. As Unidades definiam suas metas, indicadores e tinha-se que valorizar todas as dimensões acadêmicas. Está chegando ao mundo da academia que tem que se ter metas; nas entrevistas com professores, funcionários; é um programa paralelo que tem a mesma filosofia; tem que haver um diálogo mais fácil com os órgãos centrais. Os docentes são avaliados constantemente e a idéia é que a Unidade também deve ser avaliada constantemente; é a mesma filosofia. A nova visão da CPA, com a filosofia da qualidade foi extremamente importante e significativa. (DIR 15)

Alguns programas específicos como o de conservação de energia (PURE); em 2001, quando houve o "apagão", nós já estávamos trabalhando nisso e isso foi criado pelo Programa da Qualidade. Depois fizemos algo semelhante com o Programa de Consumo de Água (PURA). Encontrar temas e dedicar recursos sistematicamente a eles vem sendo adotado pela USP e vem sendo espalhado em órgãos públicos. Nem tudo foi inventado por nós; o Programa USP Recicla já existia antes e foi parceiro significativo e participavam em conjunto com a Qualidade. (DIR 15) 
No caso de nossa unidade houve um impacto muito grande. Ele significou uma grande mudança de mentalidade no nosso sistema. As administrações passaram a ser mais participativas com maior envolvimento da comunidade em geral. (DIR 03)

Acho que foi muito positivo porque se somou a várias outras iniciativas. É freqüente até hoje que as unidades vêm para a nossa para "aprender" como as coisas funcionam bem. Acho que temos incorporado uma cultura de que devemos fazer com qualidade o que fazemos. E que isso é melhor para todos os envolvidos. (DIR 04)

A palavra valor é muito importante; porque eu fiquei mais satisfeito; eu não acompanhava as atividades; como diretor não podia estar sempre presente; o programa era muito voltado para o setor dos funcionários e eu queria que os funcionários ficassem muito à vontade para fazer o Programa.; eles conduziam o processo, motivo pelo qual eu evitei colocar docente, mas não proibi que participassem. Mas para os funcionários entenderem que o programa era deles e para eles; eles é que deviam levar o programa adiante; a palavra valor é que me deixou satisfeito; eu ficava sempre acompanhando e pude ver que espontaneamente os funcionários começaram a valorizar muito mais a instituição e o próprio trabalho; começaram a ficar mais orgulhosos de si mesmos; aprendendo até com os próprios erros; foram vários depoimentos espontâneos de funcionários que me deixaram bastante satisfeitos; a palavra valor é importante; hoje eu vejo que os funcionários têm motivação (DIR 06).

Teve na parte interna uma motivação maior por parte dos funcionários, ficarem mais engajados na proposta da Unidade; gerou também uma publicação; há um Simpósio, que é realizado anualmente e que é gratuito e atrai cerca de 800 pessoas; tem uma participação grande dos docentes e os funcionários, em função da motivação existente. (DIR 07).

Um dos impactos foi a ampliação das vagas com um aumento proporcional muito maior do que os recursos materiais e humanos utilizados; esse foi um aumento na produtividade da Universidade. Qualidade é o melhor aproveitamento dos recursos públicos, senso lato; outro foi uma melhoria no setor de compras. (DIR 09)

Eu senti para a Unidade: abriu um espaço para a discussão e as pessoas propunham coisas; às vezes coisas simples como a segurança, por exemplo; colocar catraca na entrada muitos eram contra; esse ambiente de discutir o que é melhor para a Unidade ficou prevalecendo sempre. (DIR 10)

Foi o planejamento estratégico, incluindo qualidade, foi importante para manter a escola na vanguarda. Quanto aos cursos de MBA de Tecnologia de Qualidade para os funcionários da USP deve-se ter em mente o seguinte: para conseguir implantar um programa de qualidade tem que ter alguns princípios básicos: 1) primeiro lugar: comprometimento da alta direção é imprescindível; não é que tem que aprovar, tem que se comprometer; 2) segundo, os funcionários têm que se motivar para isso; não se consegue motivar se não se explicar o que é qualidade. Nada melhor para isso do que 3) treiná-los mostrando o que é qualidade, mostrar o quanto é importante isso para aperfeiçoar a atividade que estão exercendo no seu dia a dia. Para a Unidade poder trabalhar com qualidade, a USP precisa trabalhar com qualidade. (DIR 11)

Teve valor e impacto para a Unidade e para a USP porque mudou a cultura. e mudar a cultura da USP não é fácil. Antes na USP não tínhamos um clima para discutir gestão; alguns docentes diziam que discutir gestão é coisa de empresa não de universidade. (DIR 14)

Os funcionários técnicos administrativos, também, oferecem uma descrição abrangente dos impactos do Programa de Qualidade.

Tem valor e impacto para todos, na melhoria do trabalho, na criação, na redução de falhas; no desenvolvimento do conhecimento e da própria Universidade, por mais que algumas pessoas não vejam isso. (TAD 01) 
O Programa de Qualidade na nossa unidade teve impacto forte, os produtos dele e toda nossa experiência vai ser publicada em livro. Os alunos de uma disciplina da casa aplicaram o $5 \mathrm{~S}$ na seção de manutenção. No sistema de gestão ambiental, sete bolsistas graduados de enfermagem saem daqui com formação forte na parte ambiental, em certificação e os alunos nossos que já se formaram estão trabalhando na área na indústria farmacêutica, voltada à questão ambiental. (TAD 02)

As pessoas pararam para pensar mais. (TAD 03)

A Qualidade tem sido uma ferramenta que faz despertar os funcionários para oportunidades de melhorias, das condições de trabalho, da Unidade e da Universidade e isso reflete diretamente nas atividades fins; melhora para todos; é um círculo virtuoso. (TAD 07)

O Programa de Qualidade tem impacto relevante para a Unidade, Universidade e para a Sociedade. Quando se desenvolve um trabalho com qualidade é bom para as pessoas e para a Unidade que consegue o seu reconhecimento. Quando a biblioteca da ESALQ recebeu o Prêmio Paulista de Qualidade é bom para a Unidade, para a Biblioteca e para as pessoas também. (TAD12)

Eu acho que tem, principalmente quando mexe, como no caso da telefonia, com o bolso, que causa impacto direto no orçamento da Unidade e impacto na qualidade do trabalho; as pessoas se ligam mais à valorização de seu trabalho. (TAD13)

Os Programas de Q\&P foram, no mínimo, uma tomada de consciência da responsabilidade pública que as organizações devem assumir para com o seu público: otimização do uso dos recursos financeiros e materiais, atendimento adequado ao usuário dos serviços, melhoria dos padrões das relações do trabalho, valorização dos colaboradores e muitos outros aspectos relativos à educação e economia de recursos. (TAD17)

As ações e as atividades desenvolvidas para a identificação das necessidades, a capacitação dos servidores, a realização dos Workshops de Gestão permitiram o contato da comunidade com ferramentas de qualidade e exercício para o estabelecimento de missão, visão de futuro da Unidade. Propiciou também uma nova forma de gestão voltada para o cumprimento das diretrizes da Reitoria, o que foi de fundamental importância quando a Vice-Reitoria promoveu oficinas para o Planejamento Estratégico das Unidades. (TAD 19)

Questão 27: O que foi o Programa para você do ponto de vista pessoal e profissional?

A avaliação do Programa de Qualidade e Produtividade sob o aspecto de impacto pessoal e profissional, questionada aos técnicos administrativos, pela Questão 27, assinala um conjunto grande de aspectos, entre os quais se destacam: "muito aprendizado", "troca de experiências", "visibilidade pessoal", "ampliação de horizontes", "input para a carreira", "visão macro da Universidade".

Com um Discurso do Sujeito Coletivo (DSC), pode-se elencar de uma forma abrangente e narrativa, os depoimentos encontrados.

Foi excelente; aprendi muito, cresci muito e tive descobertas, aprendi a me expressar e tentar inovar. Profissionalmente, houve muita troca de experiências com colegas da Universidade e fora dela; participei de diversos eventos e vi experiências de empresas públicas e privadas. 
Tive maior visibilidade interna na Universidade e fora dela. Conheci mais a Universidade; consegui ver mais o macro. Como profissional foi um input grande na minha carreira; tenho gratidão muito grande ao Programa; fui indicada para o MBA da Qualidade ${ }^{11}$ os conhecimentos que adquiri foram grandes, para minha vida pessoal e principalmente no que pude aplicar na Unidade. O curso de MBA ajudou muito a comunicação entre nós; agora tem mais facilidade de discutir problemas e ter ajuda. Com uma oferta do emprego da empresa onde já trabalhara, desisti de sair da USP porque ia fazer um MBA, concedido pela USP. O curso de MBA foi muito enriquecedor, a troca de experiências foi muito rica, além de abrir um leque de amigos. Acabo aplicando o que aprendi para a vida, enriquece a gente. Amplia os horizontes; melhora a área de qualidade de vida e o funcionário fica contente.

O Programa aproximou as pessoas e fez com que todos olhassem na mesma direção. As pessoas se juntaram para algumas ações: foram feitas ações para os cachorros soltos no campus; pelo USP Recicla; fizemos bloquinhos de recados com papel já usado; compartilhamos impressoras etc. Foi uma chance de aprendizado; os funcionários aprendem e passam a enxergar diferente. Com a ginástica laboral, na área administrativa nenhum funcionário tem problemas de LER; houve melhora das dores com o exercício. Foi um aprendizado: quando fui a alguns eventos e vi exemplos como a Biblioteca de Piracicaba ganhando prêmio, quando via algumas empresas públicas que ganham prêmio. Antes tinha como opinião que serviço público não tinha qualidade; quando fui parar no serviço público comecei a ver iniciativas da Qualidade aqui e para mim foi legal. Aprendi muito com o Programa de Qualidade, não só na vida profissional e muito do que aprendi aqui levei também para a vida pessoal. Passei a ter uma visão diferente da Unidade em que trabalho e conhecer bem melhor os funcionários e a Unidade. Sou grata aos que contribuíram para a minha formação.

O Programa de Qualidade propiciou aos envolvidos a oportunidade de obter uma visão sistêmica da Unidade e da Universidade, crescimento pessoal, na administração de conflitos e maior valor agregado ao trabalho desenvolvido. O Programa força as pessoas a terem uma mentalidade de melhoria, é uma questão crônica de ficar na mesmice. Tem muita gente que se deixa levar pela acomodação; o Programa de Qualidade provoca as pessoas para repensar o que fazem e serem mais reflexivas.

\footnotetext{
${ }^{11}$ Trata-se do curso de Gestão e Tecnologias da Qualidade, organizado pelo PECE, da Escola Politécnica da USP e oferecido gratuitamente a funcionários da USP, previamente selecionados.
} 
Quanto ao conceito dado pelos dirigentes ao Programa, na própria gestão e nas posteriores, são reveladoras as questões:

Questão 22 - Que conceito daria para o Programa na Unidade na sua gestão?

Questão 23a- Conceito para a gestão posterior.

Questão 23b- Conceito para a gestão atual.

Esse conjunto de questões é analisado em bloco, pela tabela abaixo.

Tabela 36 - Avaliação do programa pelos docentes dirigentes

\begin{tabular}{l|c|c|c|c|c|c}
\hline & \multicolumn{2}{|c|}{$\begin{array}{c}\text { Gestão do } \\
\text { Entrevistado }\end{array}$} & \multicolumn{2}{c|}{$\begin{array}{c}\text { Gestão } \\
\text { Seguinte(*) }\end{array}$} & \multicolumn{2}{c}{$\begin{array}{c}\text { Gestão } \\
\text { Atual (*) }\end{array}$} \\
\hline \multicolumn{1}{c|}{ Conceito } & Freq. & \% & Freq. & $\%$ & Freq. & $\%$ \\
\hline Excelente & 4 & 28,6 & 2 & 25,0 & 3 & 37,5 \\
\hline Bom & 8 & 57,1 & 4 & 50,0 & 4 & 50,0 \\
\hline Regular/Insuficiente & 2 & 14,3 & 2 & 25,0 & 1 & 12,5 \\
\hline TOTAL & $\mathbf{1 4}$ & $\mathbf{1 0 0 , 0}$ & $\mathbf{8}$ & $\mathbf{1 0 0 , 0}$ & $\mathbf{8}$ & $\mathbf{1 0 0 , 0}$ \\
\hline
\end{tabular}

(*) em alguns casos, há superposição da gestão seguinte com a atual

Fonte: Dados da pesquisa, 2010

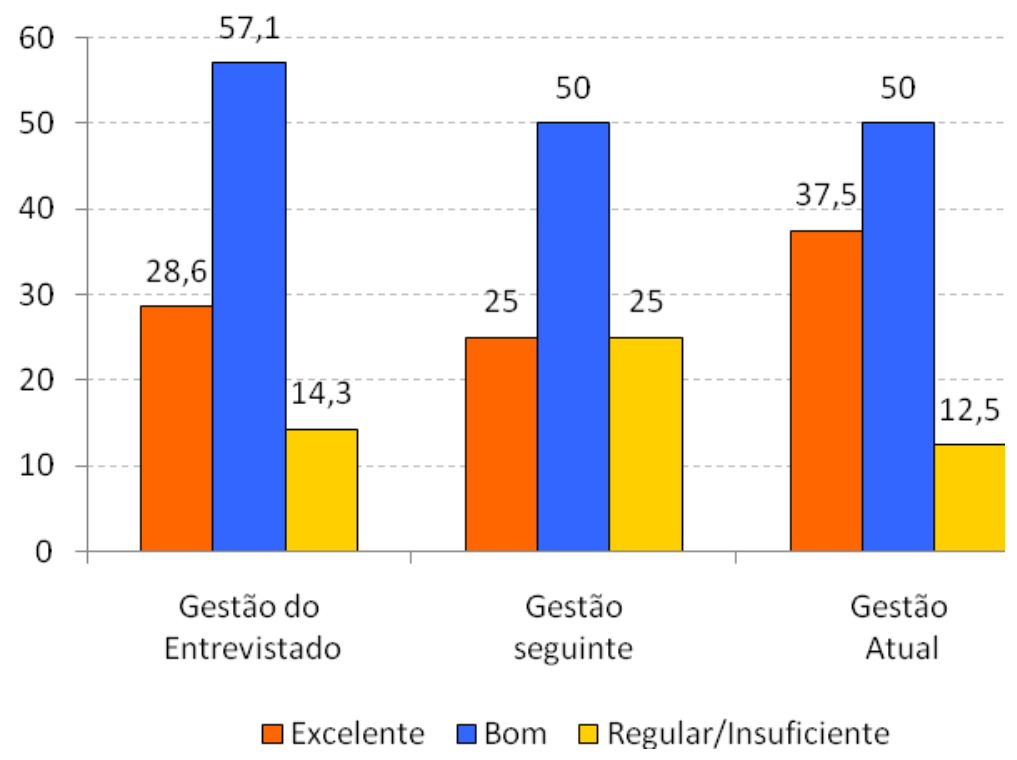

Gráfico 25 - Avaliação do programa pelos docentes dirigentes Fonte: Dados da pesquisa, 2010 
Como se observa, a maioria dos dirigentes deu um conceito excelente e/ou bom para o Programa, nas avaliações para as três situações: a própria gestão, a gestão seguinte e a gestão atual. Em alguns casos, a gestão seguinte confundia-se com a gestão atual. O número de observações cai na análise de outras gestões, que não a do próprio entrevistado. $\mathrm{O}$ entrevistador percebeu certo constrangimento dos diretores ao avaliarem gestões de seus pares. Seis dos diretores disseram não ter acompanhado as gestões posteriores.

A avaliação do Programa de Qualidade pelos técnicos administrativos pode ser verificada pelas respostas às questões:

Questão 22 - Conceito para o Programa de 1996 a 2001.

Questão 23 - Conceito para o Programa de 2001 a 2005.

Questão 24 - Conceito para o Programa de 2006 a 2008.

Tabela 37 - Avaliação do programa por técnicos administrativos

\begin{tabular}{l|r|r|r|r|r|r}
\hline \multicolumn{1}{c|}{ Período } & \multicolumn{1}{c}{$\mathbf{1 9 9 6}-\mathbf{2 0 0 0}$} & $\mathbf{2 0 0 1 - 2 0 0 5}$ & \multicolumn{2}{c}{$\mathbf{2 0 0 6}-\mathbf{2 0 0 8}$} \\
\hline \multicolumn{1}{c|}{ Avaliação } & Freq. & \multicolumn{1}{c}{$\%$} & \multicolumn{1}{c}{ Freq. } & \multicolumn{1}{c}{$\%$} & \multicolumn{1}{c}{ Freq. } & \multicolumn{1}{c}{$\%$} \\
\hline Excelente & 3 & 25,0 & 3 & 25,0 & 2 & 16,7 \\
\hline Bom & 5 & 41,6 & 8 & 66,6 & 7 & 58,3 \\
\hline Regular/Insuficiente & 4 & 33,4 & 1 & 8,4 & 3 & 25,0 \\
\hline TOTAL & $\mathbf{1 2}$ & $\mathbf{1 0 0 , 0}$ & $\mathbf{1 2}$ & $\mathbf{1 0 0 , 0}$ & $\mathbf{1 2}$ & $\mathbf{1 0 0 , 0}$ \\
\hline
\end{tabular}

Fonte: Dados da pesquisa, 2010

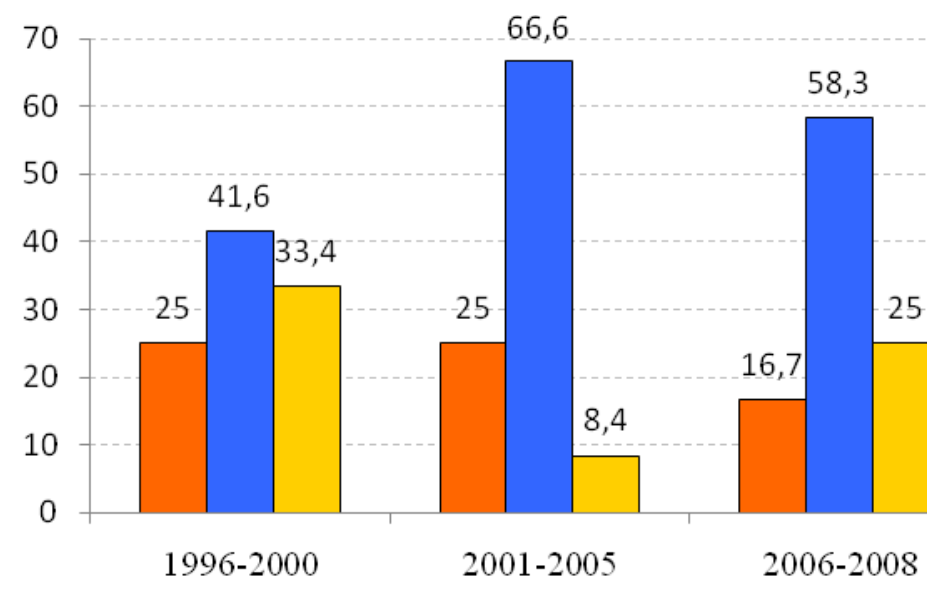

$\square$ Excelente $\square$ Bom $\square$ Regular/Insuficiente 
Tal como ocorreu com os dirigentes, os assistentes, também, apontam uma alta porcentagem para conceitos combinados de "bom" e "excelente". O percentual mais alto desses dois conceitos é verificado no período de 2001 - 2005. Esse período coincide com uma fase de amadurecimento do Programa, combinada com a ocorrência da Avaliação Institucional (AI), com princípios também voltados para a qualidade da Universidade. Como parte do processo de Avaliação Institucional houve um incentivo para diretores de Unidades e Órgãos da USP participarem de um curso de Planejamento Estratégico e em seguida elaborarem um Plano de Metas para sua Unidade.

Apresentam-se, a seguir, uma série de questões relativas às avaliações, feitas apenas para os técnicos administrativos, sobre as mudanças de condições identificadas na USP, nos dez últimos anos (em relação a 2008), ou em relação à chegada dos funcionários à USP. Complementando-se os dados quantitativos, optou-se por fazer um Discurso do Sujeito Coletivo (DSC), para abranger a grande dispersão no conteúdo das respostas.

Questão 33: Como você avalia sua aprendizagem pessoal com as atividades da Qualidade?

Tabela 38 - Aprendizagem pessoal com a Qualidade

\begin{tabular}{l|c|c}
\hline \multicolumn{1}{c}{ Aprendizagem Pessoal } & Freq. & \% \\
\hline Muita & 15 & 75,0 \\
\hline Regular/Baixa & 1 & 5,0 \\
\hline Não Houve & 4 & 20,0 \\
\hline TOTAL & $\mathbf{2 0}$ & $\mathbf{1 0 0 , 0}$ \\
\hline
\end{tabular}

Fonte: Dados da pesquisa, 2010

Com relação à aprendizagem pessoal, 75\%, ou seja, 15 dos 20 técnicos administrativos responderam que tiveram "muita" aprendizagem pessoal com as atividades da Qualidade. $20 \%$ observaram que não houve aprendizagem e 1 deles informou que a aprendizagem foi baixa.

O Discurso do Sujeito Coletivo descreve a situação, qualificando as respostas. 
Questão 34: Como se deu essa aprendizagem pessoal? (descreva)

A aprendizagem pessoal deu-se pelo interesse do tema; a semente trouxe curiosidade, o conhecimento, o desenvolvimento, o pensar crítico e a visão do futuro; assisti a palestras, fiz curso de multiplicadores da qualidade na Reitoria e o MBA na Escola Politécnica/PECE, oferecido pela USP; o programa de qualidade veio incorporar mais; hoje olho tudo por esse lado; em qualquer estabelecimento que vou, fico com o olhar crítico da realidade. É importante ter uma visão do todo, não só do meu setor. Busquei outras ferramentas; tive troca de experiências, participei de cursos e encontros como o GEFIM e o GESPE; aprendi em contato com consultores, na troca de informações com colegas e na troca de experiência com outras Unidades e outras instituições, que estavam à frente. Aprendi com pesquisa e leitura e na prática, errando e aprendendo. Fui das primeiras funcionárias a receber curso sobre a contratação por Consolidação das Leis do Trabalho (CLT), que se iniciou na USP em 1981; antes não tinha processo seletivo; as pessoas entravam por QI (“quem indica"). Também repassei os cursos que fiz aos funcionários.

Questão 35: Como você avalia a aprendizagem organizacional, da Unidade ou da USP, com as atividades da Qualidade?

Tabela 39 - Aprendizagem organizacional com a Qualidade

\begin{tabular}{l|r|r}
\multicolumn{1}{c|}{ Aprendizagem Organizacional } & Freq. & \% \\
\hline Muita & 7 & 35,0 \\
\hline Regular/Baixa & 10 & 50,0 \\
\hline Não Houve & 3 & 15,0 \\
\hline TOTAL & $\mathbf{2 0}$ & $\mathbf{1 0 0 , 0}$ \\
\hline
\end{tabular}

Fonte: Dados da pesquisa, 2010

Quanto à aprendizagem organizacional com as atividades da Qualidade, as porcentagens diferem da aprendizagem pessoal: 35\%, ou seja, 7 dos 20 entrevistados, responderam que houve "muita" aprendizagem organizacional e outros 50\%, ou seja 10 entrevistados indicaram um aprendizado organizacional "regular" com a Qualidade, enquanto 3 respondentes disseram que "não houve" aprendizagem organizacional. 
Questão 36: Como se deu essa aprendizagem organizacional? (descreva)

O Discurso do Sujeito Coletivo (DSC) forma a visão geral dos respondentes.

Percebe-se a mudança na cultura. A Unidade vem de uma cultura paternalista; viviam no mundo isolado da Unidade; depois de 2002 as pessoas foram se profissionalizando, antes eles faziam a coisa por fazer, agora estão mais interessadas nos resultados dos trabalhos. Os encontros propiciaram integração e troca de experiências. Nos encontros as pessoas percebem que tudo é muito parecido; os problemas são parecidos e as pessoas vêm que os problemas são solucionáveis; os encontros permitiam que você avalie-se em relação aos outros. $\mathrm{O}$ treinamento foi importante nos últimos 12 anos, assim como o programa de qualidade; a questão da comunicação; temos por princípio passar todas as informações a todos os funcionários, sem privilegiar qualquer segmento dos funcionários; o informativo impresso da Unidade vai anexo ao holerite de todo funcionário; é uma certeza que ele chega às mãos dele. Mesmo depois que colocamos o informativo on-line estivemos em dúvida se deveríamos manter o impresso para minimizar custos; chegamos à conclusão que era melhor manter o impresso; nele colocamos todas as informações de treinamento, das diretorias, limites de vagas e número destinado para cada departamento.

O aprendizado deu-se nos cursos, encontros, como o GEFIM, GESPE, encontro gerencial etc. A USP pensa hoje mais no seu funcionário; antes a USP não considerava os funcionários. Hoje há os grupos de trabalho para a segurança, com docentes, mas são poucos. A aprendizagem existe, mas não é colimada; não é contínua; essa aprendizagem se dá para as pessoas que mais se dedicam. Nas Unidades, coisas em comum aproximam as pessoas. Aprendemos pelo exercício e pela prática; na Unidade todos aprenderam ferramentas da Qualidade (mais ou menos 200 funcionários). Houve palestras, cursos de curta duração capacitação e treinamento específicos para as diferentes funções. Os colaboradores perceberam a importância de cada ator, colaborador, usuário e da qualidade do trabalho. $\mathrm{O}$ início das ações de qualidade influenciou diretamente a criação de um modelo de gestão baseado no planejamento estratégico da Unidade que está sendo seguido em seu plano de metas para a gestão até 2010, incluindo necessidades e ações que serão implantadas até 2013. 
O tema da competência pessoal é aferido pela questão 37.

Questão 37: Como você avalia hoje a competência pessoal dos funcionários, em relação há dez anos (melhor; igual; pior)?

Tabela 40 - Competência pessoal dos funcionários

\begin{tabular}{l|c|c}
\hline \multicolumn{1}{c|}{ Competência Pessoal } & Freq. & \multicolumn{1}{c}{$\%$} \\
\hline Melhor & 16 & 80,0 \\
\hline Igual & 04 & 20,0 \\
\hline Pior & 0 & 0,0 \\
\hline Não sabe & 0 & 0,0 \\
\hline TOTAL & $\mathbf{2 0}$ & $\mathbf{1 0 0 , 0}$ \\
\hline
\end{tabular}

Fonte: Dados da pesquisa, 2010

Pelas respostas com relação à competência pessoal dos funcionários, em relação há dez anos, $80 \%$, ou seja, 16 dos 20 entrevistados, responderam que está "melhor". Quatro entrevistados responderam que está igual.

Em uma das unidades, o funcionário reforçou que está muito melhor e é algo do qual "a gente se orgulha; os conceitos de qualidade, as pessoas pelo menos já ouviram falar; a gráfica já está sabendo de indicadores de produtividade".

Questão 38: Como e onde você identifica essa situação [de competência pessoal]?

Pode-se compor um Discurso do Sujeito Coletivo com as respostas.

Hoje se vê o profissionalismo deles [funcionários], o envolvimento e o comprometimento; não tem a coisa do funcionalismo público; já teve muito no passado e isso foi caindo. Os funcionários de nível superior repassam para outros funcionários os seus conhecimentos; os funcionários cresceram: $60 \%$ dos funcionários da Faculdade têm escolaridade superior à exigida pelo PCF (Plano de Carreira dos Funcionários). Temos funcionários de nível básico fazendo Faculdade. O curso de Multiplicadores da Reitoria foi excelente para os funcionários que nos auxiliam nas atividades dando treinamento e na organização dos eventos; nossos funcionários brigadistas são convidados para dar palestra; a brigada de incêndio foi uma conquista do SGA (Sistema de Gestão Ambiental). Hoje, os funcionários têm mais 
discernimento; estava muito comercial; trabalhavam sem muita vontade e agora a Universidade dá mais; hoje tem normas e procedimentos; tem regulamentação de forma mais clara; foi gradativo. Com mais preparo os funcionários estão mais inseridos no que a Unidade busca. Existe uma preocupação constante; quando não têm a informação eles buscam informações; dão sugestões de melhorias. Antes cada um fazia o seu e se der não faz.

A competência se vê no interesse, na motivação, nas seções e entre seções. As pessoas se habituam e vêem que é melhor trabalhar de determinada maneira; houve grande movimentação dos funcionários para buscarem aperfeiçoamento e até formação superior. Pessoas começam a se motivar para fazer supletivo, porque no passado não havia essa exigência. Os funcionários estão orientados para uma melhoria de seu setor; as pessoas participam das palestras e antes elas não iam; hoje sentem que tem resultados positivos. O $5 \mathrm{~S}$ foi muito bom. Antes, quando os funcionários viam um buraco, ninguém fazia nada e o buraco continuava lá. Hoje eles vêm o buraco e já tomam providências, terão alguma atitude positiva com relação ao problema. Isso sintetiza a competência com uma atitude pró-ativa e mais conscientização. Hoje há um desenvolvimento da própria rotina. Antes faziam o trabalho mecanicamente; hoje, com a aplicação do PDCA, eles começam a pensar. Existe hoje um posicionamento crítico dos funcionários; estão mais exigentes; não são mais cordeirinhos.

A competência é maior por duas razões: começou haver uma seleção mais rigorosa para novos contratados, que tenham boa qualificação e tenham compatibilidade com o perfil da função; em geral eles têm competências maiores das que utilizem para o trabalho; hoje eles têm mais consciência crítica. Vejo hoje uma maior valorização do trabalho. Os servidores mais antigos foram e estão sendo capacitados para o desenvolvimento do trabalho nas suas respectivas áreas de atuação. Os novos servidores contam com o programa de integração desenvolvido pelas Assistências Acadêmica, Administrativa e Financeira. As lideranças foram mais trabalhadas para que as competências individuais fossem detectadas e melhor absorvidas nas rotinas de trabalho.

Uma única voz dissonante, entre os entrevistados, percebe o funcionário da USP no trabalho visando o individual, pessoal e não o coletivo. 
Questão 39: Como você avalia hoje a competência organizacional (na entrega de melhores serviços) em relação há dez anos?

Tabela 41 - Competência organizacional

\begin{tabular}{l|r|r}
\multicolumn{1}{c|}{ Competência Organizacional } & Freq. & \multicolumn{1}{c}{$\%$} \\
\hline Melhor & 16 & 80,0 \\
\hline Igual & 02 & 10,0 \\
\hline Pior & 0 & 0,0 \\
\hline Não sabe & 02 & 10,0 \\
\hline TOTAL & $\mathbf{2 0}$ & $\mathbf{1 0 0 , 0}$ \\
\hline
\end{tabular}

Fonte: Dados da pesquisa, 2010

Pelas respostas com relação à competência organizacional, 80\% respondem que está melhor, 2 dizem estar igual e outros 2 não sabem se melhorou ou não.

Questão 40 - Como e onde você identifica essa situação? (descreva)

O Discurso do Sujeito Coletivo permite conhecer o que está por trás dessa escolha.

Vê-se isso nos resultados dos diversos setores, na questão da preocupação e redução de custos e materiais, a preocupação com a apresentação dos trabalhos; as pessoas passaram a ver os resultados e não só cumprir tabela. Hoje as coisas são menos burocráticas e está havendo mais autonomia para as Unidades; há mais agilidade; identifica problemas, pega sugestões de como melhorar e vai por tentativa. O Programa de qualidade foi importante para mudar a visão dos gerentes; a verba de treinamento não podia ser usada porque o docente não deixava. Hoje (2008) eles têm uma visão de futuro e comprometimento.

Os funcionários têm mais consciência do que fazer; antes eles faziam por fazer e hoje têm mais consciência; há ainda problema com o preparo deles; alguns funcionários ainda não têm competências na função que estão. Há dez anos nós oferecíamos bons serviços, mas hoje oferecemos um serviço muito melhor, porque antevemos as necessidades do usuário. A avaliação anual dos serviços identifica os problemas ainda existentes. O nosso diretor preocupa-se muito com a questão da informatização e a otimização dos processos. Hoje a correspondência é escaneada e passa mais rápido, porque as pessoas não são donas do papel. 
Foram implantados cursos novos, aumentando o número de vagas e sem implementação da infra-estrutura e contratação de recursos humanos para atendimento dessa nova demanda. A competência organizacional pode ser traduzida com a diminuição do retrabalho, a satisfação dos servidores, a diminuição de absenteísmo, entre outros fatores que propiciaram melhoria nos serviços executados.

Quanto à participação em tomada de decisões administrativas foi feita a Questão 41.

Questão 41: Desde que está na USP a sua participação na tomada de decisões administrativas na sua Unidade: aumentou; é a mesma ou diminuiu?

Tabela 42 - Participação em tomada de decisões

\begin{tabular}{l|c|r}
\multicolumn{1}{c|}{ Participação em Tomada de Decisões } & Freq. & \% \\
\hline Aumentou & 18 & 90,0 \\
\hline A mesma & 01 & 5,0 \\
\hline Diminuiu & 0 & 0,0 \\
\hline Não se aplica & 01 & 5,0 \\
\hline TOTAL & $\mathbf{2 0}$ & $\mathbf{1 0 0 , 0}$ \\
\hline Fonte: Dados da pesquisa 2010 & &
\end{tabular}

Fonte: Dados da pesquisa, 2010

Desde que está na USP, para 18 dos 20 entrevistados, a participação pessoal em tomada de decisões administrativas aumentou. Um deles julgou que não houve alteração, é a mesma e outra respondente, por estar aposentada, disse que a questão não se aplicava.

Questão 42: Quais são as atividades que você costuma desenvolver quando se sente participando na tomada de decisão (descritiva)?

O Discurso do Sujeito Coletivo narra atividades que eles desenvolvem, quando se sentem participando na tomada de decisão.

Participo de projetos de infraestrutura, de capacitação de recursos humanos, no âmbito da universidade; em programas institucionais como o PURA, PURE, USP Recicla; nas decisões da telefonia e no índice de custos; a Unidade foi a primeira que reduziu os custos de telefonia; com as 3 assistentes juntas despacho com a diretoria todas as questões da faculdade; nós participamos das decisões administrativas, acadêmicas e financeiras; treinamento, alocação de 
recursos para treinamento, etc. É é um trabalho de grupo. É uma verdadeira assessoria ao Diretor; houve uma interação maior com as 3 assistências; na assistência resolve-se tudo: segurança, limpeza e a parte administrativa. Tem que ouvir o grupo e a decisão tem que ser participativa. Reunimos mais dados para tomar decisões; tomamos decisões baseadas em dados e fatos.

Três questões (Q43 a Q45) tratam da interação entre funcionários, dentro da Unidade e entre os funcionários da USP.

Questão 43: Desde que está na USP, a interação entre funcionários, dentro da Unidade, aumentou, é a mesma ou diminuiu?

Tabela 43 - Interação entre funcionários na unidade

\begin{tabular}{l|r|r}
\multicolumn{1}{c|}{$\begin{array}{c}\text { Interação entre } \\
\text { Funcionários na Unidade }\end{array}$} & Freq. & \multicolumn{1}{c}{$\%$} \\
\hline Aumentou & 15 & 75,0 \\
\hline A mesma & 0 & 0,0 \\
\hline Diminuiu & 04 & 20,0 \\
\hline Não se aplica & 01 & 5,0 \\
\hline TOTAL & $\mathbf{2 0}$ & $\mathbf{1 0 0 , 0}$ \\
\hline
\end{tabular}

Fonte: Dados da pesquisa, 2010

Para 15 de 20 funcionários, ou seja, $75 \%$ deles responderam que a interação entre funcionários dentro da Unidade "aumentou"; para 5 deles "diminuiu" e 1 dos respondentes, por estar aposentada, não respondeu a questão.

Dois dos respondentes explicaram porque diminuiu:

[...] foi em função do maior número de pessoas da Unidade, mas há maior interação entre os setores.

Antigamente, com menos gente no Instituto, conhecia mais as pessoas; havia mais possibilidade de contato. Há seis anos passados eu tinha mais tempo para falar com o colega. A interação diminuiu e por isso estou fazendo um trabalho para provocar mais interação, com relação à comunicação. 
Questão 44:- Desde que está na Universidade, a interação, entre os funcionários da USP, aumentou, é a mesma ou diminuiu?

Tabela 44 - Interação entre funcionários da USP

\begin{tabular}{l|r|r}
\multicolumn{1}{c|}{$\begin{array}{c}\text { Interação entre } \\
\text { Funcionários da USP }\end{array}$} & Freq. & \% \\
\hline Aumentou & 17 & 85,0 \\
\hline A mesma & 0 & 0,0 \\
\hline Diminuiu & 02 & 10,0 \\
\hline Não se aplica & 01 & 5,0 \\
\hline TOTAL & $\mathbf{2 0}$ & $\mathbf{1 0 0 , 0}$ \\
\hline
\end{tabular}

Fonte: Dados da pesquisa, 2010

Quando a questão indaga sobre a interação entre funcionários da USP, 17 de 20 respondentes, ou seja, $88 \%$ deles afirmaram que "aumentou"; um deles disse ser "a mesma" e outro disse que "diminuiu". O funcionário que relata ter diminuído justifica isso pelo aumento no número de funcionários.

Questão 45: Quais são as atividades que você identifica de interação entre funcionários?

O Discurso do Sujeito Coletivo permite descrever as atividades identificadas nessa interação.

$\mathrm{Na}$ Unidade havia reuniões quinzenais ou semanais e a ginástica laboral trazia interação e na Universidade havia os encontros e reuniões específicas para alguns grupos e programas como o, PURA e outros que traziam interação. Os treinamentos aproximam; existia no passado certo ranço dos departamentos com a administração e hoje não tem mais. Depois do curso do MBA [refere-se ao curso da EP/PECE de Gestão e Tecnologias da Qualidade] há encontros e participação. Tenho contato com a Reitoria muito intenso; sou convidada a participar de sindicâncias, grupos de trabalho, fóruns, organizar atividade; sou muito solicitada por conta do SGA (Sistema de Gestão Ambiental) e também sou convidada a dar muitas palestras; conheço todos; quando tenho algum problema com alguma área eu preciso de ajuda e lembrome dos colegas e eles me ajudam a resolver o problema. Ficou uma rede que se ajuda no trabalho. A Qualidade propiciou tudo isso. A interação se dá na Unidade em cursos e seminários. Na USP há encontros, trabalhos de grupos e trabalhos em conjunto. 
A Qualidade entra para promover a interação. Na Unidade tem integração de funcionários novos e também de docentes novos, em grupos com o Diretor. Na Unidade temos atividades muito legais: a sala de inclusão digital, o "café comunitário", quando oferecemos um café e fazemos a comemoração de conquistas; uma vez por mês, cada um traz uma coisa e fazemos um café. Na Unidade promovemos ações para a interação com atividades como a Ginástica Laboral, que propicia momentos de descontração e bem-estar físico aos servidores; organizamos o evento "Pratas da Casa", onde são expostos os talentos de cada participante; visita de servidores da Unidade a outros "campi" para conhecimento da Universidade. Há três anos os funcionários começaram também a fazer trabalho voluntário. Há resultados e ganhos não esperados no trabalho voluntário: organizamos um bazar e as pessoas se mobilizam para doar; temos funcionários de nível operacional com dificuldade financeira e o bazar tem coisas muito boas e baratas; nada custa mais que 10 reais; as pessoas podem comprar as coisas e saem de lá muito felizes por terem podido comprar; na mobilização para que as coisas aconteçam, as pessoas esquecem as diferenças porque o bem maior é outro. Outra ação para envolver os funcionários: no final do ano pegamos no Correio cartinhas que as crianças enviam ao Papai Noel. É uma campanha do Correio já institucionalizada: próximo ao Natal (em novembro) as crianças escrevem cartas, enviam ao Correio pedindo coisas para o Natal. As pessoas ou empresas pegam as cartas e separam para dar o que as crianças pedem. $\mathrm{O}$ correio se compromete a entregar os pedidos feitos pelas crianças ou você mesmo pode levar. Essas atividades criam solidariedade e dão mais resultado que muitos treinamentos. O bazar funciona há três anos e já está institucional; neste ano arrecadamos quase 2000 reais e doamos a uma associação que cuida de crianças, vítimas de violência familiar. No dia a dia muda a relação com o funcionário que participa dessas atividades; ganho o funcionário de outra forma. É uma forma de melhorar o relacionamento interno A idéia não é ganhar louros, mas melhorar o relacionamento.

Na Universidade há muitos encontros: todos os "Gês" que vieram do GEFIM [a pessoa referese aos encontros de GESPE - Gestão de Pessoas; GIACAD - Gestão acadêmica, GEINFO Gestão de Informática, GESEC - Gestão de Secretárias etc.]. A mola mestra é a mesma em todos eles; as mesmas questões são tratadas em vários fóruns. Existe interação pontual nos encontros do GEFIM, GESPE, GESEC etc. e a interação aumentou com esses encontros. O 
GEFIM faz reuniões mensais e faz propostas de melhorias; até participamos do prêmio Mário Covas $^{12}$.

Quanto à Qualidade de Vida no Trabalho.

Questão 46: Desde que está na USP, as atividades de Qualidade de Vida no Trabalho aumentaram, são as mesmas ou diminuíram?

Tabela 45 - Atividades de Qualidade de Vida no Trabalho

\begin{tabular}{l|c|c}
\hline \multicolumn{1}{c|}{ Atividades de QVT } & Freq. & \% \\
\hline Aumentou & 15 & 75,0 \\
\hline A mesma & 04 & 20,0 \\
\hline Diminuiu & 0 & 0,0 \\
\hline Não se aplica & 01 & 5,0 \\
\hline TOTAL & $\mathbf{2 0}$ & $\mathbf{1 0 0 , 0}$ \\
\hline
\end{tabular}

Fonte: Dados da pesquisa, 2010

As atividades de Qualidade de Vida no Trabalho aumentaram 75\%, desde que está na USP, para 15 de 20 respondentes; para 20\% (4 respondentes), a situação não se alterou.

Questão 47: Quais são as atividades que você identifica como de Qualidade de Vida no Trabalho

A Tabela 46, a seguir, retrata as atividades realizadas de Qualidade de Vida no Trabalho:

12 O Governo do Estado, pelo Prêmio Mário Covas, reconhece iniciativas desenvolvidas e implantadas por equipes de servidores comprometidos com a excelência na prestação de serviços à sociedade, contribuindo para a disseminação de boas práticas e fortalecimento de políticas públicas, promovendo o desenvolvimento do Estado de São Paulo. 
Tabela 46 - Descrição de Qualidade de Vida no Trabalho

\begin{tabular}{c|l|r|r}
\hline Modelo BPSO & \multicolumn{1}{|c|}{ Atividade } & Freq. & \% \\
\hline B & Saúde e bem-estar & 5 & 20,0 \\
\hline B & Ginástica Laboral & 5 & 20,0 \\
\hline O & Treinamento/incentivo ao estudo & 5 & 20,0 \\
\hline O & Ambiente de trabalho & 5 & 20,0 \\
\hline S & Encontros /integração & 3 & 12,0 \\
\hline P & Maior diálogo com funcionários/ maior participação & 1 & 4,0 \\
\hline S & Ações de solidariedade social & 1 & 4,0 \\
\hline & TOTAL & $\mathbf{2 5}$ & $\mathbf{1 0 0 , 0}$ \\
\hline
\end{tabular}

Fonte: Dados da pesquisa, 2010

As atividades descritas se enquadram em todas as categorias do Modelo de Indicadores Empresariais de Qualidade de Vida BPSO Limongi-França (1996), que separa as ações de QVT, conforme os critérios denominados de Biológico, Psicológico, Social e Organizacional. Resumidamente, segundo o modelo citado, o critério Biológico refere-se à promoção da saúde e segurança, controle de riscos ambientais e atendimento às necessidades físicas em geral. $\mathrm{O}$ critério Psicológico volta-se à promoção da autoestima e do desenvolvimento de capacidades pessoais e profissionais. O critério Social abrange oferta de benefícios sociais obrigatórios e espontâneos e criação de oportunidades e criação de oportunidades de lazer, esportes e cultura. O critério Organizacional liga-se à valorização da imagem institucional, dos serviços e produtos e do relacionamento da organização com os empregados.

O Discurso do Sujeito Coletivo exemplifica e detalha as ações de qualidade de vida no trabalho que ocorreram no período:

Existe uma preocupação maior com o bem-estar dos funcionários e preocupação para que as pessoas trabalhem mais satisfeitas; trabalha-se pela integração e harmonia entre as pessoas; os superiores estão mais preocupados com os funcionários e o diretor pergunta se a pessoa está feliz. Para facilitar o encontro entre funcionários, o café só é servido em dois horários do dia: das $9 \mathrm{~h} 30$ às $10 \mathrm{~h} 00$ e das $15 \mathrm{~h} 30$ às $16 \mathrm{~h} 00$, na sala de convivência, com os alunos de pósgraduação. Quanto à saúde dos funcionários há o atendimento no Hospital Universitário, o exame periódico e a vacina de gripe; houve o Programa de atendimento psicossocial aos alcoólatras (GREA), para funcionários e alunos; os fisioterapeutas deram orientação sobre avaliação ergonômica. A ginástica laboral aumentou na Universidade e no Instituto e há sessões de meditação uma vez por semana. Houve uma mudança na visão do que é um bom 
ambiente de trabalho e na mudança de visão dos gestores para preocupação e atenção ao ambiente de trabalho. Há preocupação com o espaço onde o funcionário desenvolve o trabalho; iniciativas internas de melhoria de ambiente físico e a preocupação para que o funcionário se engaje. Há eventos de integração e de esclarecimento aos funcionários. Os canais são abertos para os funcionários se expressaram quando necessário; nós temos uma cultura de procurar saber o que está se passando com as pessoas; a Diretoria recebe os funcionários e há mesmo aqueles que participam do sindicato, numa boa; temos uma relação amigável com o sindicato; os funcionários estão satisfeitos; eles mostram a satisfação nos momentos de confraternização (festa junina e festa de natal), quando muitos comparecem. Há incentivo ao estudo e treinamento; procura-se dar mais capacitação para desenvolver o trabalho; há cursos e o de inglês foi um atendimento ao pedido dos funcionários.

\subsubsection{Considerações sobre a pesquisa de campo}

O grande número de questões propostas na pesquisa de campo permitiria igual número de considerações sobre vários temas. No sentido de destacar algumas delas, levantam-se aqui algumas considerações. Em um gráfico síntese destacam-se resultados sobre o conteúdo do Programa de Q\&P, que compara expectativas do Programa de Qualidade, tal como visto no início do processo ou em sua $1^{\mathrm{a}}$. fase (T1), na sua $2^{\mathrm{a}}$. fase (T2), que se denomina de rotina e no final do Programa, ou em sua $3^{\text {a }}$. fase (T3), que coincide com as experiências positivas indicadas pelos entrevistados.

Com muitas condições internas para se engendrar uma reorganização institucional, o Programa de Qualidade e Produtividade, instituído pelo Governo do Estado em dezembro de 1995, foi visto pela alta administração da USP, na época, como uma oportunidade para reforçar a busca de excelência da instituição amparada pelos princípios, métodos e valores que a filosofia da qualidade apregoava. Instituído, na USP, um mês depois, em janeiro de 1996, o Programa de Qualidade e Produtividade, apresentou algumas ações institucionais, comuns a todas as Unidades e Órgãos, e um conjunto diversificado de ações, que fizeram sentido diante das especificidades de cada um deles. A Universidade, como organização complexa, burocrática, com centralização de poder para algumas questões e grande autonomia para operacionalização de diretrizes, não interferiu nas manifestações concretas dessa filosofia em cada uma de suas unidades. 
Conduzido por uma Comissão de docentes e um técnico administrativo, o Programa de Q\&P da USP, esteve sempre ligado à alta administração da Universidade. De forma descentralizada e sempre com o aval do diretor, a implantação do Programa foi conduzida, na maior parte dos casos, pelas Comissões Internas de Qualidade, presididas, por docentes e operacionalizadas pelos funcionários técnico-administrativos, com forte atuação dos assistentes técnicos de direção. Em geral, esses atores tiveram um treinamento intensivo sobre qualidade, o que facilitou a receptividade a esse processo.

Ainda que a estratégia tivesse motivação externa, para atender uma regulamentação estadual, à qual a Universidade se subordina, os docentes tiveram reações diferenciadas. A Universidade é idealmente um local de liberdade de pensamento e discussão; embora o Programa fosse justificado como um processo que visava aumentar a eficiência da instituição e traria um melhor aproveitamento dos recursos públicos, uma filosofia já formatada, tal como a qualidade, não teria unanimidade. As resistências, todavia, não foram radicais e casos eventuais de resistência eram manifestados pela não participação nas atividades. Em geral, os docentes não participaram desses Programas institucionais porque seus interesses estavam mais voltados às atividades fins da Universidade, uma vez que é por ela que são cobrados, como, por exemplo, pela publicação de artigos. Todavia, registraram-se exceções com docentes participando ativamente no Programa de Qualidade e Produtividade.

Conduzidos prioritariamente por Comissões Internas de Qualidade, compostas por docentes e funcionários, os métodos, utilizados para levantar o que fazer na esfera de qualidade e como fazer, foram desde os mais simples, "caseiros", tal como registrado em depoimentos, até aqueles que efetivamente fazem parte de métodos e técnicas da qualidade. Embora as Comissões de Qualidade fossem presididas por docentes, o grande envolvimento e foco das ações da Qualidade foram os funcionários e a área administrativa. Se recursos específicos não existiam para as atividades do Programa de Qualidade, as ações propostas não deixaram de ser feitas por falta de recursos.

De modo geral, pode-se observar que o Programa, a partir dos depoimentos, teve mais efeitos positivos que negativos. O maior problema levantado refere-se à descontinuidade administrativa, fato que não surpreende, uma vez que são conhecidos os efeitos de mudança de gestão em órgãos públicos, tal como relatado por Meyer (1988). 
As atividades levadas a efeito no contexto da Qualidade puderam ser classificadas, segundo os Módulos de Qualidade, assim denominados nesta tese, pela combinação dos Critérios do Prêmio Nacional da Qualidade com os Balizadores de Qualidade do Serviço Público.

Quando se comparam as Expectativas quanto ao conteúdo do Programa de Qualidade e Produtividade, com as Atividades Formais e as Experiências Positivas relatadas emergem os critérios em que as ações foram mais evidentes.

Tabela 47 - Comparação de expectativas, atividades formais e experiências positivas

\begin{tabular}{|c|c|c|c|c|c|c|c|c|}
\hline & \multirow[t]{2}{*}{ Módulos de Qualidade } & \multirow[t]{2}{*}{$\begin{array}{c}\text { Critérios e } \\
\text { Balizadores }\end{array}$} & \multicolumn{2}{|c|}{$\begin{array}{l}\text { Expectativas } \\
\text { de Conteúdo } \\
\text { (T1) }\end{array}$} & \multicolumn{2}{|c|}{$\begin{array}{l}\text { Atividades } \\
\text { Formais } \\
\text { (T2) }\end{array}$} & \multicolumn{2}{|c|}{$\begin{array}{c}\text { Experiências } \\
\text { Positivas } \\
\text { (T3) }\end{array}$} \\
\hline & & & Freq. & $\%$ & Freq. & $\%$ & Freq. & $\%$ \\
\hline 1 & Liderança e Envolvimento & $\mathrm{C} 1$ e B2 & 8 & 18,2 & 3 & 10,3 & 5 & 8,9 \\
\hline 2 & Planejamento & $\mathrm{C} 2$ & 3 & 6,8 & 2 & 6,9 & 5 & 8,9 \\
\hline 3 & Foco no Cliente e Sociedade & $\mathrm{C} 3$ e B1 & 2 & 4,5 & 4 & 13,8 & 9 & 16,1 \\
\hline 4 & Informação e Análise & $\mathrm{C} 4$ e B4 & 1 & 2,3 & 2 & 6,9 & 3 & 5,4 \\
\hline 5 & Pessoas e Qualidade de RH & $\mathrm{C} 5$ e B3 & 14 & 31,8 & 14 & 48,3 & 23 & 41,1 \\
\hline 6 & Gestão de Processos & $\mathrm{C} 6, \mathrm{~B} 5, \mathrm{~B} 6$ e B7 & 16 & 36,4 & 4 & 13,8 & 11 & 19,6 \\
\hline \multirow[t]{2}{*}{7} & Parcerias e Alianças & $\mathrm{C} 7$ e B8 & 0 & 0,0 & 0 & 0,0 & 0 & 0,0 \\
\hline & Total & - & 44 & 100,0 & 29 & 100,0 & 56 & 100,0 \\
\hline
\end{tabular}

C1 a C7 - Critérios do PNQ

B1 a B8 - Balizadores do Serviço Público (1996)

Fonte: Dados da pesquisa, 2010 


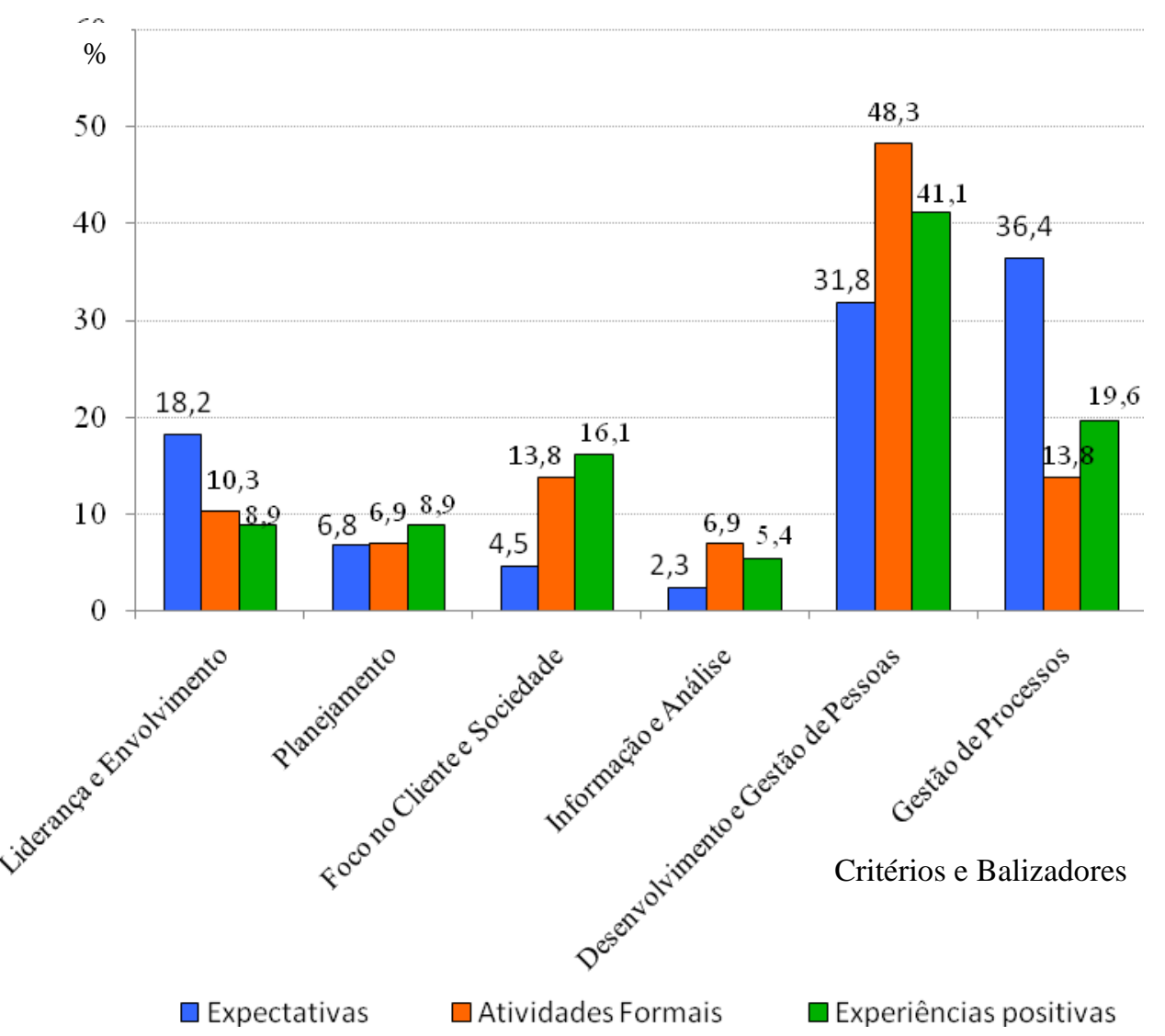

Gráfico 27 - Comparação de expectativas, atividades formais e experiências positivas

O Gráfico 27 permite uma visualização do conteúdo do Programa, classificado pelos Módulos de Qualidade, em três fases de sua implantação: no início (T1), quando havia expectativas sobre o que o Programa poderia trazer à organização; na atividade formal (T2), quando o Programa atingiu um ponto de rotina e na indicação de experiências positivas (T3), que sinaliza o que foi mais valorizado no Programa.

Assim, pode-se identificar que são os Módulos 4, Gestão e Desenvolvimento de Pessoas e 5, Gestão de Processos os de maior evidência. Na primeira fase, T1, nitidamente é o Módulo de Gestão de Processos que apresenta a maior expectativa, seguido do Módulo 4 e do Módulo 1, referente à Liderança e envolvimento. Na fase T2, de atividades formais de rotina, o Módulo de Gestão de Pessoas assume o primeiro lugar, seguido de Gestão de Processos e Foco no Cliente. Na fase T3, de experiências positivas, os módulos se mantêm na mesma ordem em relação à fase 2, mas com uma pequeno ganho para o Módulo de Gestão de Processos, sem recuperar o patamar da expectativa inicial: o percentual em expectativas era de $36,4 \%$, os em atividades formais, 13,8\% e em experiências positivas, 19,6\%. A Gestão de Processos remete, entre outros, à simplificação de processos e à desburocratização, que estão na pauta do 
governo e das instituições públicas há muito tempo e apresentam muita dificuldade em acusarem melhorias, sob o ponto de vista do usuário. Essa resistência a melhorias ligadas à desburocratização levou o Ministro Beltrão, na década de 80, a comentar que a "burocracia tem fôlego de gato".

O Módulo de Liderança, também, apresentou um valor de expectativa superior ao efetivamente apurado nas atividades formais e nas experiências positivas; os outros Módulos de Planejamento, Foco no Cliente e Sociedade e Informação e Análise tiveram valores nas atividades formais e nas experiências positivas superiores aos auferidos em expectativas.

No que se refere à Gestão de Pessoas, os valores acusam uma nítida posição superior, em relação a todos os outros Módulos.

O Gráfico 28, que compara apenas os instantes T1, de expectativas e T3, de experiências positivas, torna mais evidente algumas diferenças.

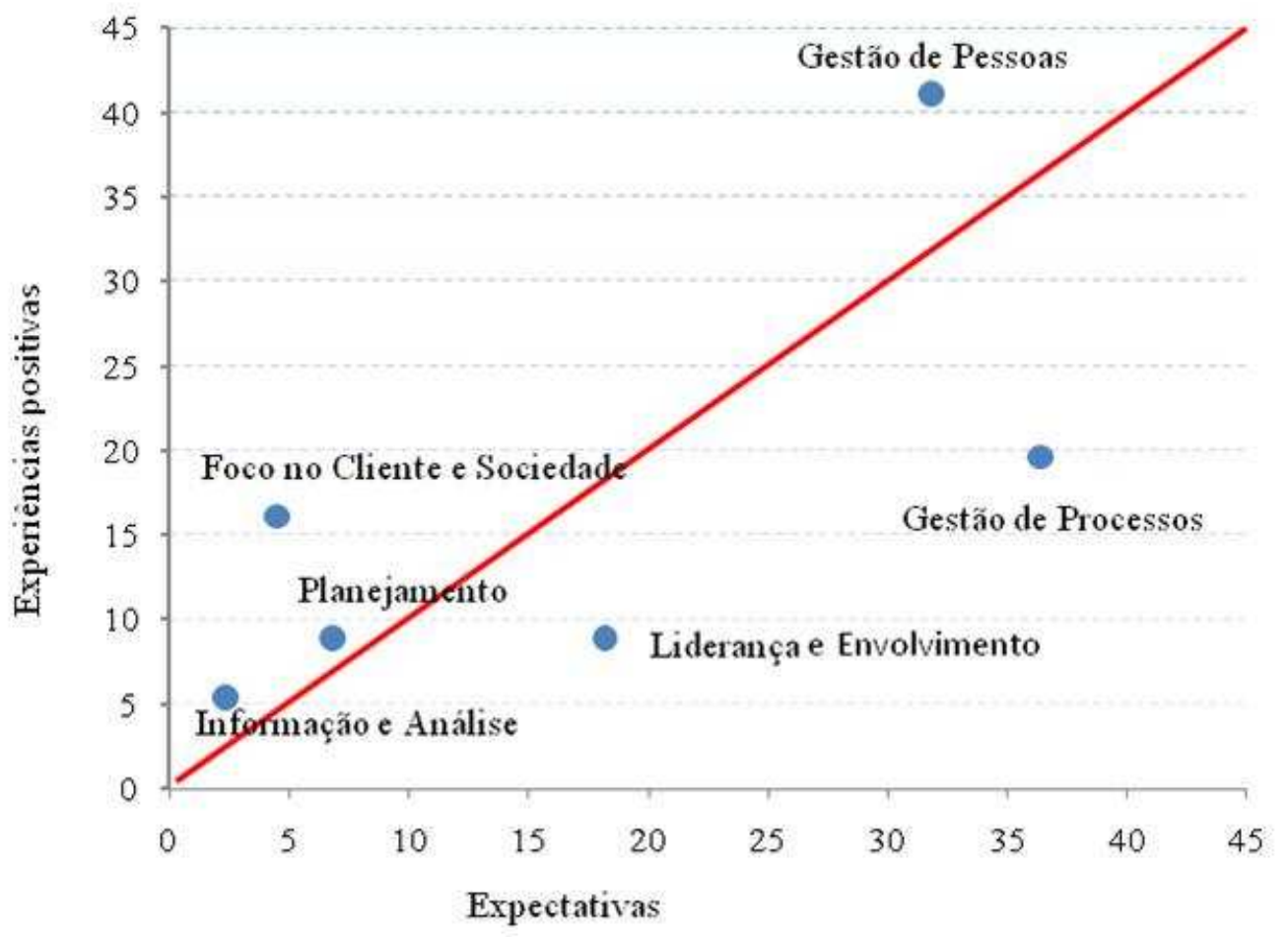

Gráfico 28 - Comparação de expectativas (T1) e experiências positivas (T3) 
Ao se projetar nos dois eixos Expectativas e Experiências Positivas pode-se identificar que os achados da pesquisa de campo evidenciaram quatro Módulos de Qualidade com experiências positivas, superiores às expectativas iniciais: Gestão de Pessoas, Foco no Cliente e Sociedade, Planejamento e Informação e Análise. No caso desses três últimos módulos, talvez isso se devesse ao fato de expectativas de melhorias serem muito baixas. Os dois outros Módulos, Liderança e Gestão de Processos, mesmo registrando evidências de experiências positivas, posicionaram-se abaixo das expectativas iniciais.

Com relação à Gestão de Processos, preconizada como um dos ícones na literatura da qualidade, ele foi objeto de preocupação de muitas unidades e tem passado por contínuas melhorias. Alguns dirigentes assinalam pontualmente ganhos em termos do número de assinaturas em processos, gerando muitas horas de economia de trabalho por mês; alteração de roteiros para tramitação do processo para execução de reformas e de serviços de engenharia e outros. A mobilização de técnicos administrativos da mesma área funcional como finanças, informática, secretárias, entre outros, tem favorecido também condições para a melhoria de processos; os encontros organizados por esses grupos de funcionários alteraram sua forma de interação, trazendo condições para um aprendizado contínuo. Pode-se ilustrar isso com os procedimentos na área de recursos humanos, que foram revisados e documentados, a partir do Programa de Qualidade e a área financeira que também se mobilizou em encontros periódicos, para discussão e implementação de melhorias nos processos.

O que se percebe, todavia, é que, embora muito tenha sido feito, a questão da burocracia ainda está presente e tem ainda muito a ser trabalhada. A manifestação concreta de que ainda havia muito por fazer foi a transformação do Programa de Qualidade e Produtividade, em 23 de fevereiro de 2007 em um Programa de Gestão Estratégica e Desburocratização na Administração da USP, GESPÚBLICA USP, reforçando, então, o foco na superação das disfunções da burocracia. Os resultados das autoavaliações da gestão das Unidades e Órgãos da USP, apresentadas no Relatório de Gestão da USP 2006 - 2009 mostram que ainda há espaço para melhorias no sistema de gestão da USP.

Com relação ao Módulo de Gestão de Pessoas, os resultados obtidos nas questões de conceitos, impactos e na percepção de mudanças na USP, com relação a: aprendizagem pessoal, aprendizagem organizacional; competência pessoal e competência organizacional; 
participação em tomada de decisões administrativas, interações entre funcionários nas Unidades e na USP e atividades de Qualidade de Vida no Trabalho, constituem-se como testemunhas de alterações conseguidas.

\subsection{A pesquisa documental}

As evidências apresentadas, nesse item, foram coletadas pela análise de fontes secundárias contemplando os seguintes documentos: site institucional da USP; matérias publicadas em jornais, revistas e livros sobre o tema; Atas de Reunião, pesquisas de monitoramento, documentos e publicações específicas da Comissão de Gestão de Qualidade da USP; vídeos de Encontros da Qualidade; Relatórios das Unidades e monografias e dissertações de servidores técnicos administrativos da USP.

Além disso, foi feito pela pesquisadora, em junho de 2008, um levantamento sistemático de sites de todas as Unidades de Ensino e Pesquisa da USP para verificar a presença de dados sobre o Programa de Qualidade de Produtividade na Unidade. Foram encontradas nove Unidades de Ensino e Pesquisa que ainda mantinham, na data, dados sobre o Programa. Na Capital eram as Unidades: FCF; FAU; EE; IP; IQ; FSP e no interior: ICMC; IFSC e FFCLRP. As outras Unidades de Ensino não tinham sites que registrassem as atividades da Comissão de Qualidade. O conteúdo dos sites existentes variava bastante: o mais simples fazia referência aos membros das Comissões e sites completos relatavam todas as atividades da Comissão de Qualidade e Produtividade da Unidade, suas atribuições, histórico, legislação etc..

Uma revisão desses sites, em dezembro de 2009, confirmou a pouca presença de seções relativas ao Programa de Qualidade. Quando existia algo, na maioria dos casos, os sites mantinham dados sucintos e desatualizados. A situação difere para sites de duas das Unidades pesquisadas no campus de São Carlos, ICMC <http://www.icmc.usp.br/cpq> e IFSC <http://qualidade.ifsc.usp.br>, que apresentam dados atualizados e completos de todas as atividades do Programa de Qualidade e Produtividade, de suas Unidades. 


\subsubsection{A modernização administrativa}

Segundo Cruz, Miranda e Regados (2006), até 1989, a USP dependia em toda sua gestão administrativa de diretrizes do governo do Estado. Internamente, a Universidade contava com uma administração tradicional para uma universidade pública de pesquisa de modelo europeu, com pouca flexibilidade e burocracia rígida e rotinizada.

A Autonomia Universitária, iniciada em fevereiro de 1989, permitiu uma maior liberdade de gestão, inclusive nas áreas de recursos humanos e finanças. Nessa condição, ganhos de produtividade, decorrentes da melhor utilização de recursos, podiam ser absorvidos pela própria Universidade, o que estimulou um constante aprimoramento da gestão financeira. Para isso foi feita uma redução do quadro de pessoal extinguindo-se o preenchimento automático de vagas, transformando parte dos recursos decorrentes dessa economia em investimento e custeio; estimulou-se, também, a captação de recursos externos e aperfeiçoaram-se os critérios de distribuição orçamentária. Assim, no período de 1989 a 2005, ocorreu redução de $10 \%$ no número de docentes e de $15 \%$ no dos servidores técnicoadministrativos, ao mesmo tempo em que se expandiram as atividades-fim, com crescimento de $44 \%$ de alunos de graduação, $63 \%$ dos de pós-graduação e aumento de $375 \%$ dos trabalhos científicos indexados pelo Institute of Scientific Information (ISI). Parte dos significativos ganhos de produtividade está, seguramente, associada ao novo modelo de gestão. A USP passou a adotar, de forma crescente, indicadores acadêmicos e administrativos para sua gestão, que são adotados, por exemplo, no seu orçamento e na análise das necessidades de contratação de pessoal.

A Autonomia Universitária, aliada à Avaliação Institucional e ao Programa de Qualidade e Produtividade tornaram-se pilares para um novo modelo de gestão mais democrático, profissional e responsável, desde o final da década de 80.

A Avaliação Institucional ocorreu na USP, segundo Cruz, Miranda e Regados (2006) em dois ciclos: 1992-1999 e 2000-2005. No primeiro deles, foram avaliados 210 Departamentos de Ensino e, no segundo, 198, sendo que, nesse caso, foram elaborados Planos de Metas de cada Unidade e Departamento, abrangendo um período de 5 a 10 anos. Esses documentos vêm sendo utilizados pelas várias instâncias da USP como subsídio para a tomada de decisões associadas à contratação de docentes, gastos com investimentos, criação de cursos, entre outros. A Avaliação Institucional, no segundo ciclo de 2000 - 2005 teve uma feição 
particular, porque foi organizada também para atender a Deliberação do Conselho Estadual de Educação, CEE n. 04/2000, que trazia elementos do Programa de Qualidade. O processo de avaliação de caráter institucional, contínuo e permanente, regulamentado por essa Deliberação tinha por finalidade acompanhar o desenvolvimento das instituições, nos seguintes aspectos: eficácia e eficiência de seu ensino; importância de seus programas de pesquisa; relevância de sua produção cultural e científica; eficácia da formação profissional; significado da importância das ações comunitárias; condições gerais e específicas dos cursos de graduação e pós-graduação e qualidade da gestão administrativa e financeira. A Avaliação Institucional proporcionou oportunidades para uma maior interação entre docentes e Unidades, provocou o aprofundamento de canais de circulação de informações e permitiu uma reflexão da própria identidade dos Departamentos e Unidades. Possibilitou, ainda, a participação da comunidade interna e externa na promoção de consensos e na definição de rumos da instituição. ${ }^{13}$

O terceiro pilar da modernização da USP foi a implementação do Programa Permanente de Qualidade e Produtividade da USP (PPQP) e detalhado em seguida.

\subsubsection{O Programa de Qualidade e Produtividade na USP}

Esse item contempla o histórico do Programa de Qualidade e Produtividade na USP e aspectos relativos a sua operacionalização, às pessoas e seu desenvolvimento, à alocação de recursos financeiros, a diagnósticos, a encontros de qualidade, aos indicadores de desempenho, reconhecimento. Os resultados do Programa, levantados em publicações e documentos, encerram esse capítulo.

Desde o início da década de 90 vinha sendo estimulado no País o Programa Brasileiro de Qualidade e Produtividade (PBQP), já descrito anteriormente. O Governo do Estado de São Paulo, em 12 de dezembro de 1995, por meio de um Decreto institucionalizou o Programa Permanente de Qualidade e Produtividade no Serviço Público que deveria ser seguido pelos órgãos públicos estaduais, inclusive as universidades estaduais, entre as quais a USP. O Decreto tinha como objetivo "propiciar ao cidadão o atendimento eficaz de suas necessidades,

13 Nesta tese não cabe o aprofundamento dessa questão que está detalhada em: USP. O processo de avaliação institucional da Universidade de São Paulo 2003 - 2005 (2005); em USP. Relatório de Gestão 2001 - 2005. Vice-Reitoria (2005) e na tese de Almeida (2004). 
por meio de um processo de melhoria contínua e permanente dos serviços prestados, com redução de custos e ganhos de produtividade."

Para dar atendimento ao Decreto, como já apresentado, a USP teve seu Programa de Qualidade e Produtividade, instituído pelo Reitor em 29 de janeiro de 1996, que nomeou também a Comissão de Gestão da Qualidade e Produtividade para coordenação dos trabalhos. O Presidente dessa Comissão acumulava as funções de Coordenador da Coordenadoria Geral de Administração (CODAGE), órgão que trata de questões administrativas da Universidade.

Dada a complexidade e estruturação da USP foi solicitado aos seus órgãos e Unidades de Ensino e Pesquisa que formassem comissões internas de qualidade para o desenvolvimento do Programa.

A Comissão da USP adotou como diretrizes da Qualidade os Critérios do Prêmio Nacional da Qualidade combinados com os Balizadores de Qualidade da Administração Pública do Estado de São Paulo, já referenciados, e denominados, nesta tese, de Módulos de Qualidade. Essas diretrizes seguiam uma sugestão do Governo do Estado, adaptada à Universidade pelos membros da Comissão responsável. Ela também organizou uma sequência de ações para promoção e operacionalização do Programa, descritas abaixo:

- $\quad$ Sensibilização da alta administração.

- $\quad$ Sensibilização da média gerência.

- $\quad$ Formação de Comissões Internas de Qualidade.

- Recursos financeiros.

- $\quad$ Desenvolvimento de Recursos Humanos.

- Diagnóstico e levantamento de problemas.

- $\quad$ Eventos Institucionais/ Encontros da Qualidade.

- $\quad$ Comunicação e Publicação.

- Indicadores de desempenho e Monitoramento das atividades.

- $\quad$ Reconhecimento de Participação no Programa de Q\&P. 
Inicia-se a descrição de cada um desses itens relacionados.

a) Sensibilização da alta administração

Considera-se na Universidade, como alta administração, o Reitor, o Vice-Reitor, PrósReitores e Diretores de todas as Unidades de Ensino e Pesquisa, institutos especializados, museus, hospitais e órgãos de direção e serviços da Universidade. É uma população que na USP abrange cerca de uma centena de dirigentes.

Para iniciar essa sensibilização, que viria facilitar a conscientização e motivação para a Qualidade nos principais dirigentes, foi promovida, em sete de maio de 1996, a palestra "Gestão pela Qualidade na Universidade", na sala solene do Conselho Universitário (órgão máximo da Universidade), marcando o início da implantação do Programa na USP. Ao abrir a sessão o Presidente da Comissão de Gestão de Q\&P da USP exortou os presentes a que "o tema da qualidade passasse a fazer parte das preocupações de nossa comunidade, no intuito de atender plenamente os recursos dos contribuintes que são utilizados na universidade."

O Reitor, na mesma sessão, enfatizou que a qualidade era uma procura nata dos que trabalhavam na USP; "a cada instante e em todas as áreas procura-se melhorar a eficiência, a eficácia, no sentido de buscar melhor qualidade para o ensino, para a pesquisa, para extensão e para a administração"; complementou, ainda, que mesmo que "as universidades estivessem longe de serem referenciais de boa qualidade de gestão, elas se constituíam em oásis comparativos dentro da administração pública em senso lato."

Essa palestra de sensibilização, apresentada por Cymbalista (1996), teve como tema as origens e aplicações da qualidade na administração pública. Nessa oportunidade e pela primeira vez no Estado, foram apresentados os Balizadores da Qualidade para o Serviço Público, que passaram a ser diretrizes da Qualidade da USP.

A Comissão de Gestão da Qualidade e Produtividade desde sua formação, em janeiro de 1996, adotou como filosofia a descentralização e a autonomia de cada Unidade e Órgão, para o desenvolvimento do Programa. Portanto, a adoção e aplicação dos Balizadores deveriam ser ajustadas à realidade de cada Unidade/Órgão. 
b) Sensibilização da média gerência

A média gerência é entendida na USP como os assistentes técnicos de direção administrativos, financeiros ou acadêmicos, que assessoravam diretamente os dirigentes de cada unidade da USP. A sensibilização da média gerência foi promovida por várias frentes: encontros sobre o tema da qualidade direcionados além dos assistentes de direção aos participantes das Comissões Internas de Qualidade que se formaram em quase todas as Unidades e Órgãos da USP; cursos de formação em conceitos e ferramentas da Qualidade e notícias veiculadas em vários meios de comunicação internos. O papel dos Diretores e Coordenadores de Unidades e Órgãos da USP foi fundamental; dados como chefes imediatos da média gerência deveriam apoiar e estimular a formação das Comissões Internas de Q\&P.

c) Formação de Comissões Internas de Qualidade

Para dar prosseguimento aos trabalhos operacionais de ações de Qualidade, por solicitação da Comissão de Gestão de Q\&P da USP, os dirigentes das Unidades e Órgãos indicaram a partir de junho de 1996 as Comissões Internas de Q\&P. Tais Comissões foram compostas só de docentes, só de funcionários técnicos administrativos, de Comissões mistas ou, ainda, algumas incluíram alunos. A comissão mista (docentes e funcionários) foi a configuração mais comumente encontrada. Os registros da CGQP apontaram uma oscilação na sua existência, composição e funcionamento em função do maior ou menor interesse demonstrado pelo dirigente a esse tipo de iniciativa.

Os registros documentais mostram a seguinte tabela, para a evolução das Comissões formadas, de 1996 a 2005 :

Tabela 48 - Consolidação das comissões internas de Qualidade

\begin{tabular}{c|c|c|c|c|c}
\hline Ano & Comissões & Docentes & $\begin{array}{c}\text { Técnicos } \\
\text { Administrativos }\end{array}$ & Alunos & $\begin{array}{c}\text { Total de } \\
\text { Participantes }\end{array}$ \\
\hline 1996 & 63 & 107 & 175 & 0 & 282 \\
\hline 1997 & 63 & 110 & 192 & 2 & 367 \\
\hline 1998 & 63 & 110 & 192 & 2 & 304 \\
\hline 2000 & 51 & 93 & 172 & 3 & 319 \\
\hline 2001 & 53 & 98 & 175 & 3 & 276 \\
\hline 2005 & 45 & 87 & 218 & 5 & 310 \\
\hline
\end{tabular}

Fonte: Dados da pesquisa, 2010 
Embora numericamente o total de membros tenha crescido ao longo do tempo, percebe-se um decréscimo no número de Comissões e de docentes envolvidos, quando considerada a variação de 1996 a 2005 e um paralelo aumento, ainda que não contínuo, no número de técnicos administrativos. Os alunos, enquanto estagiários do Programa, tiveram numericamente pouca expressão nessas Comissões, ainda que os depoimentos encontrados na pesquisa de campo atestem o seu papel contributivo ao processo.

O planejamento operacional para as atividades do programa de Qualidade nas Unidades foi, na maior parte das vezes, feito pelas Comissões Internas de Qualidade e Produtividade, que tiveram como diretriz as atribuições definidas pela Comissão de Gestão de Q\&P da USP.

Conforme USP - Relatório de Atividades de 1996 (1997, p. 10) eram atribuições das Comissões Internas: a) sensibilizar e mobilizar o público interno em temas relacionados à qualidade e produtividade; b) identificar líderes e colaboradores para realização de ações de melhorias; c) divulgar as diretrizes do Programa Permanente de Qualidade e Produtividade; d) elaborar diagnóstico da situação da Unidade/Órgão, estabelecendo prioridades de ação e metas; d) promover a revisão dos processos de trabalho; e) levantar necessidades de treinamento e g) efetivar treinamento e desenvolvimento de servidores.

As Unidades de Ensino e Pesquisa constituem-se como unidades de uma federação. Ainda que sigam, por princípio, as orientações da administração central, elas conservam uma autonomia para a operacionalização das orientações segundo as especificidades da cultura da unidade e da decisão política do dirigente local, na época. Em vista disso, ao receber essas atribuições, cada Unidade deu seu modo particular de ação ao Programa de Qualidade. Não houve um Modelo único adotado para implantação e tampouco uma maneira uniforme de atuação. Algumas Unidades não se pronunciaram sobre o Programa e não formaram as Comissões, ainda que existam evidências de terem feito e se preocupado com ações de qualidade.

As respostas dadas na pesquisa de campo evidenciaram essa diversidade, permeada pela temporalidade e espaço diferente de atuação do dirigente. Conforme o Estatuto da Universidade, os diretores das Unidades são substituídos a cada quatro anos e o modo de atuar de cada dirigente influencia nas decisões do que poderia ou não ser feito em nome do Programa. 
d) Recursos financeiros

Não houve alocação a priori de recursos financeiros específicos para as atividades do Programa de Qualidade. Todavia, na prática, a Comissão de Q\&P sempre privilegiou iniciativas estruturadas bem embasadas e apoiava com recursos as solicitações feitas.

Um aporte substancial ao Programa foi dado, indiretamente, ao se estabelecer, a partir do exercício de 1996, pela Comissão de Orçamento e Patrimônio (COP), uma alínea específica, às Unidades e Órgãos, para o desenvolvimento de recursos humanos, como Capacitação Profissional e Treinamento.

\section{e) Desenvolvimento de Recursos Humanos}

No primeiro ano do Programa, 1996, foi promovido um curso de 24 horas sobre Sistemas de Gestão da Qualidade para 133 participantes, membros das Comissões Internas de Qualidade, bem como adquiridos livros e vídeos sobre o tema, para divulgar os conceitos da filosofia da qualidade e solidificar uma linguagem comum. Também com o apoio da Fundação Instituto de Administração (FIA), foi feita a tradução dos Critérios do Prêmio Malcolm Baldrige para a Educação.

Nesse período, foi reformulada a carreira dos servidores técnicos administrativos, que, alinhada aos princípios do PPQP, passou a reconhecer como um item na avaliação de desempenho os cursos realizados pelos funcionários. Essa valorização do aprimoramento pessoal motivou os funcionários a buscarem maior qualificação, por meio de cursos bastante diversificados, dentro e fora da USP, presencial e à distância, como evidenciados na pesquisa de campo.

A alínea orçamentária criada para treinamento de funcionários técnicos e administrativos apresentou valores relativamente constantes nesse período, tendo sido utilizados, em média $55 \%$ do total disponível nos primeiros anos, elevando-se para 70\% em 2000, conforme se verifica na Tabela 49, a seguir. Quando se deflacionam os valores nominais pelo IPC da FIPE, observa-se relativa estabilidade dos valores reais. 
Tabela 49 - Descrição de recursos de treinamento em R\$

\begin{tabular}{l|c|c|c|c|c}
\hline \multicolumn{1}{c|}{ Recursos } & $\mathbf{1 9 9 6}$ & $\mathbf{1 9 9 7}$ & $\mathbf{1 9 9 8}$ & $\mathbf{1 9 9 9}$ & $\mathbf{2 0 0 0}$ \\
\hline Disponível Nominal & 900.000 & 1.361 .186 & 1.471 .540 & 1.285 .236 & 1.452 .558 \\
\hline Disponível Deflacionado & 900.000 & 1.298 .470 & 1.429 .373 & 1.149 .071 & 1.244 .161 \\
\hline Porcentagem Utilizada & 55 & 53 & 59 & 57 & 70 \\
\hline \multicolumn{1}{c|}{ Recursos } & $\mathbf{2 0 0 1}$ & $\mathbf{2 0 0 2}$ & $\mathbf{2 0 0 3}$ & $\mathbf{2 0 0 4}$ & $\mathbf{2 0 0 5}$ \\
\hline Disponível Nominal & 1.837 .633 & 1.283 .809 & 1.390 .000 & 1.390 .000 & 1.556 .800 \\
\hline Disponível Deflacionado & 1.469 .383 & 933.815 & 934.705 & 864.159 & 908.231 \\
\hline Porcentagem Utilizada & 39 & 81 & 88 & 77 & 77 \\
\hline
\end{tabular}

Fonte: Cruz, Miranda e Regados (2006)

Como se denota pelo quadro acima, a utilização dos recursos para treinamento de funcionários da USP apresentou uma queda em 2001, elevando-se para patamares de cerca de $80 \%$, posteriormente, o que demonstra maior esforço para o aprimoramento dos recursos humanos. Com exceção do ano de 2001, que apresenta valores mais elevados, os recursos disponíveis, em termos reais, mostraram estabilidade, ou seja, apesar das frequentes dificuldades orçamentárias e financeiras da USP, a ênfase no aperfeiçoamento dos servidores técnicos e administrativos foi sempre preservada, aprofundando a cada ano, os esforços realizados.

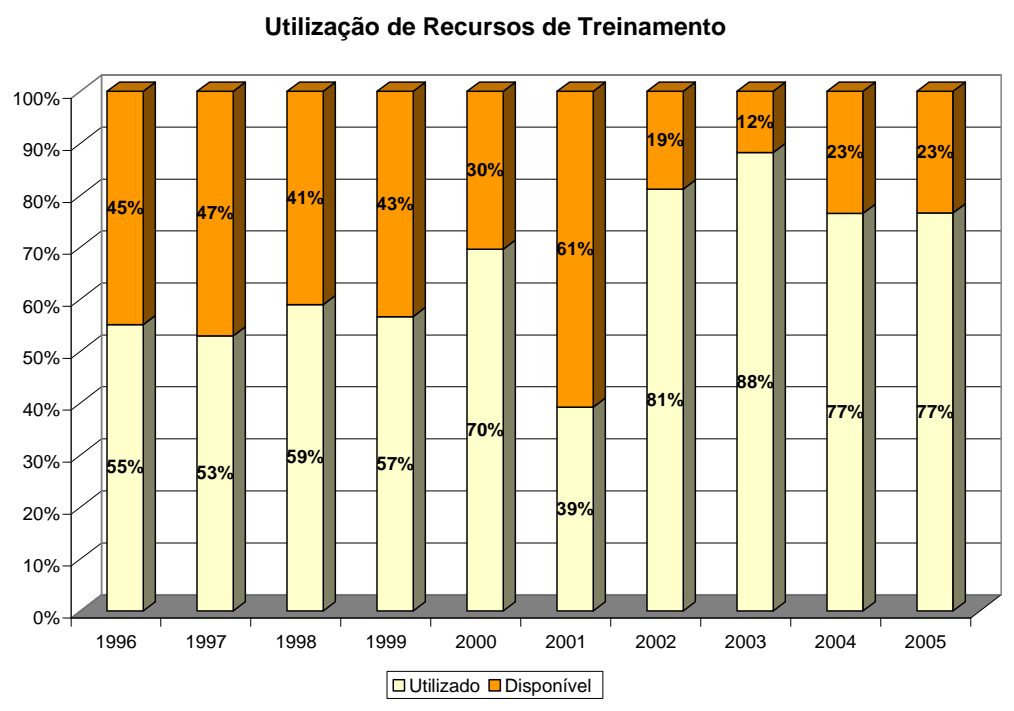

Gráfico 29 - Descrição de utilização de recursos de treinamento Fonte: Década do Programa de Qualidade e Produtividade (2005)

Como se pode observar no Gráfico 29, de 2002 a 2005, houve um redobrado incentivo na área de treinamento e desenvolvimento de recursos humanos. Segundo Uma Década do Programa de Qualidade (2005), diversos cursos foram organizados pela Seção de Treinamento e Desenvolvimento do Departamento de Recursos Humanos da CODAGE, pelo SIBi, pelo Centro de Computação Eletrônica e pela Comissão Interna de Q\&P da Reitoria, que ofereceu 
curso de Multiplicadores da Qualidade, com o apoio da Secretaria de Planejamento do Estado de São Paulo. Além disso, algumas Unidades de Ensino e Pesquisa também promoveram cursos especialmente voltados para funcionários da USP.

Nessa linha, a Escola Politécnica organizou, a partir de 2002, pelo PECE (Programa de Educação Continuada para Engenheiros), um Curso de MBA (Master Business Administration) de Gestão e Tecnologias da Qualidade, de 420 horas, para cerca de 120 funcionários da USP. A conclusão desse Curso de MBA obrigava a elaboração de monografias, que constituem material de compartilhamento de conhecimento na comunidade universitária. Em um dos apêndices, relacionam-se essas monografias e seus autores.

Também, a Faculdade de Economia e Administração (FEA) organizou duas turmas do curso de especialização de Formação Executiva para Assistentes de Direção da USP, com 120 horas de duração, de agosto a dezembro, em 2004 e em 2005, com a participação total de 83 funcionários. Com o objetivo principal de contribuir para o desenvolvimento de funcionários e melhorar a qualidade dos serviços de apoio às atividades de docência, o curso foi estruturado para contemplar as duas primeiras, das três dimensões de competências necessárias a esse grupo de pessoas: visão sistêmica, competência gerencial e competências técnicas.

Por sua vez, a CECAE, em parceria com a Faculdade de Saúde Pública e a Escola de Engenharia de São Carlos, ofereceu dois cursos de Formação de Agentes Locais de Sustentabilidade Socioambiental. Esse curso de especialização buscava estimular nos participantes o olhar e a capacidade de interpretação crítica quanto à complexidade ambiental e estimular mobilização e intervenção socioambiental nos locais de trabalho, tema esse que passou a ser cada vez mais valorizado a partir da conferência Eco Rio em 1992. O curso de 360 horas teve a participação de 73 funcionários da USP, em São Paulo e São Carlos, para funcionários, oriundos dos campi do interior (Bauru, Pirassununga, Ribeirão Preto e São Carlos). Em CECAE (2004), o Caderno de Resumos dos Projetos de Intervenção Educativa discorre sobre os resumos dos projetos apresentados no 2 o curso de especialização.

Outro curso, o de Formação de Multiplicadores de Qualidade, de 48 horas, foi organizado pela Comissão Interna de Qualidade e Produtividade da Reitoria, em parceria com a Secretaria de Economia e Planejamento do Governo do Estado de São Paulo. Em seu 
programa, eram abordados: Conceitos da Qualidade Total; Noções Gerais de Missão; Valores e Metas; Planejamento Estratégico; Fundamentos do Modelo de Gestão Pública; Critérios de Avaliação da Gestão Pública; Princípios da Qualidade e Ferramentas para a Melhoria da Qualidade. Do curso participaram funcionários da Reitoria e funcionários convidados de outras unidades da USP. Sete turmas foram realizadas, com um total de 187 funcionários, dos quais 42 eram de unidades externas à Reitoria. Os alunos elaboraram projetos em grupos, utilizando-se dos conceitos e ferramentas da Qualidade; tais projetos eram apresentados ao final do curso e operacionalizados, quando viáveis. Portanto, o curso serviu, também, como elemento incentivador para que as ações de qualidade fossem desenvolvidas na Reitoria e em outras Unidades. Abrantes (2005) descreve em detalhes essa experiência da USP.

Todos esses cursos representaram um esforço grande da USP no sentido de melhorar a qualificação de seus recursos humanos, tal como apregoava o Balizador 3 do Programa: "a melhoria dos serviços públicos é obtida pela qualidade dos recursos humanos".

\section{f) Diagnóstico e levantamento de problemas}

Para se proceder ao levantamento de problemas da USP e das Unidades, assim como levantar oportunidades de melhorias foram utilizados vários métodos e instrumentos. Colocando em prática os princípios de participação e envolvimento dos funcionários, tal como prescrito no Balizador 2 "cada um dos participantes da administração pública é responsável pela qualidade", a CGQP da USP organizou, no segundo semestre de 1996, duas atividades para fazer um diagnóstico preliminar de identificação de oportunidades de melhorias na Instituição:

a) formulário a ser preenchido internamente pelas Comissões Internas de Q\&P das Unidades e Órgãos, solicitando a especificação de Problemas e Destaques das Unidades;

b) levantamento e priorização de ações para a melhoria de qualidade e produtividade da USP, em quatro sessões de trabalhos em equipes, usando a técnica de brainstorming; Nominal Group Technique - NGT. Com 56 participantes, docentes e técnicos administrativos, das Comissões Internas de Qualidade, na capital e no interior, foram feitas 3 reuniões em São Paulo e uma no campus de São Carlos, que geraram cerca de 240 ações de melhorias, segundo USP. Programa Permanente de Qualidade (1997, v.2). 
A publicação USP. Programa Permanente de Qualidade e Produtividade. Trabalho em Equipe: relatório de consolidação de resultados (1997) é dedicada exclusivamente aos resultados dessas duas atividades organizadas na época. Analisando-se, a posteriori, observase que muitas das questões apontadas como oportunidades de melhorias, foram, a partir daí, trabalhadas em maior profundidade. Pode-se ilustrar com a questão do Treinamento, reivindicada por $63 \%$ dos participantes do NGT e 53\% dos questionários respondidos pelas Unidades. Acentuava-se a ausência, até então, de processos de formação continuada, necessários ao desempenho das funções ou atualizações diante de novas tecnologias e exigências do trabalho. Outro exemplo considerado: a partir da solicitação de integração entre funcionários, a Universidade estimulou e fez realizar inúmeros eventos institucionais de integração entre áreas funcionais, tais como finanças, recursos humanos, informática e área acadêmica.

Em 1997, uma terceira atividade foi sugerida para auxiliar no diagnóstico das Unidades: o uso do Questionário para Mapeamento de Características da Qualidade e Produtividade, inserido em publicação da Comissão de Qualidade e Produtividade da USP (1997), reforçando os Módulos de Qualidade. Deve-se observar que, à época (1996 - 1997), o tema de Qualidade e Produtividade era novo para a maioria das pessoas envolvidas no Programa. As pessoas manifestaram, nas reuniões de brainstorming, seus receios para encaminhar uma questão na esfera de suas Unidades, sem uma diretriz institucional. Para auxiliar, nessa tarefa de identificação das Oportunidades de Melhorias para as Unidades e Órgãos envolvidos no Programa, elaborou-se o referido Questionário. O documento viria, também, permitir o fortalecimento de uma linguagem comum quanto à qualidade e produtividade, permitindo maior intercâmbio de boas práticas entre as Unidades, ao mesmo tempo em que dava ensejo para o aprofundamento na análise do modelo de gestão, adotado pelas Unidades da USP, a partir dos problemas identificados com o mapeamento.

Segundo a filosofia de autonomia e "respeitando a liberdade e criatividade intrínsecas à USP", a aplicação do Questionário não foi uma referência impositiva, mas constituía em um ponto de partida com o objetivo de identificar áreas ou temas críticos e indicar prioridades de ação. 
g) Eventos Institucionais e Encontros de Qualidade

Outra atividade que veio na esteira do Programa de Q\&P e se multiplicou no período foram os eventos institucionais, para funcionários técnicos administrativos. Tais eventos além de terem a função de agentes de comunicação, sensibilização e disseminação de conhecimentos ligados à qualidade funcionaram também como elemento de integração e interação importante entre os funcionários da USP e mais recentemente até com funcionários de outras universidades. $\mathrm{O}$ modelo iniciado em 1997, pelos funcionários da área de finanças e materiais, GEFIM (Gestão Financeira e de Materiais) foi reproduzido por outros segmentos funcionais e ganhou, com o tempo, a denominação de eventos "Gês": GIACAD, Grupo de Integração de Assistentes Acadêmicos, que congregava funcionários da área acadêmica; GESPE, Gestão de Pessoas; GEINFO, Gestão de Informática, agrupava o pessoal da informática; GESEC, Gestão de Secretárias. Outros encontros tais como Encontro de Desenvolvimento Gerencial, com foco nos assistentes técnicos de direção, Encontro das Pró-Reitorias de Graduação e de PósGraduação, Encontro de Novos Funcionários, além de outros entre funcionários das Unidades tornaram-se uma constante no período em questão. A administração esperava com essas iniciativas uma melhoria contínua na atuação dos profissionais, tendo em vista uma mudança significativa na cultura da Universidade, com uma participação dos funcionários técnicos administrativos nas tomadas de decisão, tradicionalmente só atribuídas aos docentes.

Além desses eventos institucionais, no sentido de difundir especificamente conceitos e metodologias da Qualidade e Produtividade, promover a sensibilização para a estratégia da Qualidade, comunicar avanços e socializar as boas práticas das Unidades e Órgãos, a Comissão de Gestão de Q\&P organizava regularmente Encontros da Qualidade. A partir de julho de 1996, foram organizados 12 encontros em 10 anos, para cerca de 2030 participantes. Neles, palestrantes nacionais, da USP e externos, além de conferencistas estrangeiros comunicaram suas experiências com Programas de Qualidade. O público-alvo desses eventos eram os diretores de Órgãos e Unidades da USP, os membros das Comissões Internas de Q\&P, convidados de outras universidades e pessoas pertencentes a outros órgãos do Governo do Estado de São Paulo, ligadas ao tema da Qualidade. 
Tabela 50 - Encontros da Qualidade: 1996-2005

\begin{tabular}{c|c|c}
\hline Período & $\begin{array}{c}\text { Número de } \\
\text { Seminários }\end{array}$ & Participantes \\
\hline $1996-1997$ & 6 & 936 \\
\hline $1998-2001$ & 3 & 456 \\
\hline $2002-2005$ & 3 & 638 \\
\hline TOTAL & $\mathbf{1 2}$ & $\mathbf{2 0 3 0}$ \\
\hline
\end{tabular}

Fonte: Adaptado de Uma Década do Programa de Qualidade (2005)

O Gráfico 30 discrimina o número de participantes em cada um dos eventos da Qualidade, com um nítido aumento de participação no $12 \circ$ evento. Ainda que o número de participantes possa parecer alto, favorecendo a aprendizagem organizacional, o percentual face ao número de funcionários da USP, que oscilou em torno de 15.000, entre os anos de 1996 e 2005, ainda é baixo.

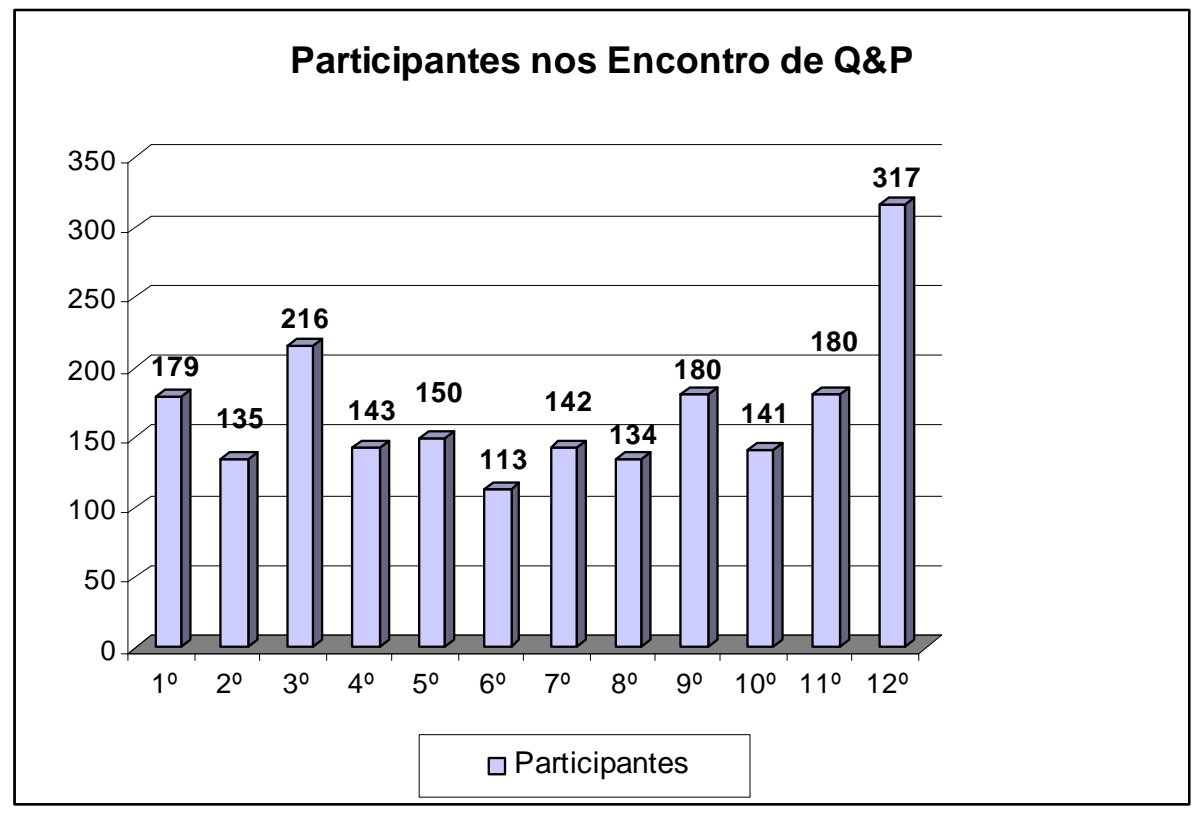

Gráfico 30 - Participantes em encontros de Q\&P

Fonte: Uma Década do Programa de Qualidade (2005)

A relação completa dos temas das palestras realizadas está apresentada nos Apêndices desta tese, adaptada da publicação da Comissão de Qualidade e Produtividade, USP. Uma Década do Programa de Qualidade e Produtividade: 1996 - 2005 (2005). 
h) Comunicação e Publicação

A Comissão de Gestão da Qualidade e Produtividade da USP fez várias publicações alinhadas com a filosofia do Programa, assim como também o fizeram as Unidades, Órgãos e/ou Comissões Internas de Qualidade. Um conjunto dessas publicações está elencado nos Apêndices.

Ainda relacionados ao Programa de Q\&P, foram publicados 25 artigos no Jornal da USP. Os artigos estão relacionados nos Apêndices, em ordem cronológica. Em geral, eles eram publicados em datas próximas a eventos marcantes, promovidos pela Comissão de Gestão da Qualidade e Produtividade da USP ou para destacar alguma ação, como, por exemplo, na oportunidade em que a biblioteca da ESALQ, em 2003, recebeu uma medalha de bronze, relativa ao Prêmio Paulista de Qualidade em Gestão. Essas medidas faziam parte da política de comunicação, sinalizando reforço e reconhecimento do valor da qualidade na instituição.

Outros artigos de divulgação do Programa da Qualidade apareceram no informativo Espaço Aberto, também da USP e no jornal interno, Reitoria Informa, que passou a circular a partir de abril de 2003. Sua criação tinha sido uma sugestão da Comissão de Qualidade da Reitoria, acatada pelos órgãos competentes.

i) Indicadores de desempenho e monitoramento das atividades

Seguindo indicações dos Balizadores da Qualidade para o Serviço Público - "as decisões devem ser direcionadas por indicadores, dados e fatos" e "o valor e o sacrifício de qualquer atividade devem ser constantemente monitorados", assim como seguindo uma tendência na política de avaliação institucional, a Comissão de Gestão da Qualidade de Q\&P fêz um estudo e desenvolveu Indicadores Gerais de Desempenho para a USP, que passou a ocupar a posição de primeira tabela do Anuário Estatístico, a partir de 1998.

Pela mesma orientação dos Balizadores da Qualidade e no sentido de prestar contas à sociedade, a USP iniciou, em 1997, a publicação USP em Números. Um cartão colorido, simples registrava os principais indicadores de desempenho da Universidade extraídos do Anuário Estatístico da USP. A partir de 1999, o USP em Números foi elaborado anualmente até 2006. Inicialmente foram feitas versões em português e em inglês; em 2001, incluiu-se 
versão em espanhol e, a partir de 2002, em francês. Para USP em Números 2006, a tiragem total foi de 12.000 exemplares, nos quatro idiomas: português, inglês, espanhol e francês. Essa peça de divulgação mostrou-se bastante útil em encontros institucionais além de ser solicitado por docentes que faziam visitas ou cursos no exterior. Outras universidades estaduais adotaram o mesmo modelo para divulgar seus principais números de desempenho, incorporando-os como uma peça complementar dos respectivos Anuários Estatísticos.

Cabe destacar, ainda, que, em 2003, para incentivar as Unidades a divulgarem sua imagem para a comunidade externa, por solicitação do Presidente da Comissão de Gestão de Qualidade e Produtividade da USP, as Unidades e Órgãos da USP elaboraram o cartão Unidade em Números, à semelhança do existente USP em Números. 56 Unidades e Órgãos da Universidade, aí incluindo, além das Unidades de Ensino e Pesquisa, os Museus, Hospitais, Prefeituras, entre outros, reuniram em um folheto e/ou cartão seus principais dados acadêmicos e administrativos, tais como número de alunos, docentes, produção científica, publicações, atendimentos hospitalares, público visitante e infraestrutura.

O conjunto constituiu uma amostra significativa dos principais dados da Universidade, dando à sociedade transparência de suas ações e reforçando com dados a imagem institucional de cada Unidade e Órgão. Algumas Unidades mantêm, até 2009, a atualização anual desses folhetos.

Além disso, com o objetivo de levantar as atividades relativas à Qualidade, desenvolvidas na USP, a Comissão de Gestão de Q\&P realizou pesquisas de monitoramento, com os dirigentes das Unidades/Órgãos nos anos de 1997 (67 respondentes), 2000 (42 respondentes), 2002 (70 respondentes) e 2004 (64 respondentes). Por meio dos questionários respondidos, podia-se ter algumas informações relevantes sobre as melhorias implementadas. As pesquisas mostraram, desde seu início, uma variação muito grande na operacionalização do Programa de Q\&P nas Unidades e Órgãos.

A publicação USP. A Década do Programa de Qualidade e Produtividade (2005) registrou os resultados da pesquisa de 2004, com respostas de 64 Unidades e Órgãos da USP, incluindo 36 questionários de Unidades de Ensino e Pesquisa. O Quadro 13, a seguir, relaciona os percentuais de percepção de melhorias para as atividades administrativas. 
Quadro 13 - Percepção dos entrevistados sobre melhorias administrativas

\begin{tabular}{|l|c|}
\hline \multicolumn{1}{|c|}{ Percepção de melhorias } & Sim (\%) \\
\hline Treinamento de funcionários & 93,8 \\
\hline Equipamentos e mobiliário & 90,6 \\
\hline Instalações físicas & 82,8 \\
\hline Biblioteca & 81,3 \\
\hline Comunicação interna & 79,4 \\
\hline Imagem institucional & 73,4 \\
\hline Sinalização interna & 71,9 \\
\hline Publicação sobre Unidade/Órgão & 68,8 \\
\hline Simplificação de rotinas & 68,8 \\
\hline Comunicação externa & 60,9 \\
\hline Sistemas de informação & 56,3 \\
\hline Documentação de procedimentos & 50,0 \\
\hline
\end{tabular}

Fonte: Adaptado de Uma Década do Programa de Qualidade (2005)

Procurando-se projetar essas referências de melhorias aos Módulos de Qualidade, nota-se uma aderência de ações de melhorias ligadas à gestão de pessoas, ao atendimento ao cliente, aos sistemas de informação e à melhoria de processos.

j) Reconhecimentos de Participação no Programa de Q\&P

O Programa de Q\&P, por duas vezes, reconheceu atuações destacadas: a primeira delas para ações de treinamento nas Unidades e a segunda, para pessoas. Tendo como base o Levantamento realizado pela Diretoria de Recursos Humanos da CODAGE, em setembro de 2000, sobre os cursos feitos para funcionários em 1999 - 2000, receberam "Destaque - Honra ao Mérito", no 8o- Encontro da Qualidade (26/04/2001), 12 Unidades/Órgãos que mais propiciaram treinamento/capacitação aos seus funcionários. Outras 14 Unidades e Órgãos foram destacados por promoverem treinamento a mais de 300 funcionários.

Os dez anos do Programa da Qualidade da USP contaram com um conjunto grande de participantes, que, por acreditarem na filosofia do Programa, por se envolveram diretamente, por colaborarem em diferentes situações, mereceram destaque especial. No 12을 Encontro da Qualidade (17/08/2005), cerca de 100 pessoas, docentes e técnicos administrativos de todos os níveis hierárquicos receberam um Diploma de Reconhecimento oferecido pela Presidência do Programa de Qualidade e Produtividade da USP. Até hoje, encontra-se na sala de alguns 
funcionários, enquadrados na parede, o diploma recebido, denotando o orgulho e apreço pelo reconhecimento recebido.

\subsubsection{Resultados do Programa de Qualidade e Produtividade}

Conforme Cruz, Miranda e Regados (2006), a USP dá sinais de alterações no seu modelo de gestão e o PPQP tomou parte nesse novo modelo, com contribuições específicas. Conforme a publicação USP. A Década do Programa de Qualidade e Produtividade (2005), os resultados são percebidos na área de recursos humanos, na infraestrutura, em equipamentos e mobiliário, nas bibliotecas, na melhoria de processos e simplificação de rotinas, na comunicação, sinalização interna e melhoria da imagem institucional, embora seja difícil aferir quantitativamente. Com o decorrer do tempo, os projetos de qualidade e produtividade foram se tornando mais específicos e focalizados.

Os procedimentos de gestão da qualidade e produtividade tiveram adoção diferenciada entre as várias Unidades e Órgãos, o que dependeu, sobretudo, do grau de comprometimento da alta administração de cada uma delas. Os valores, conceitos e diretrizes do PPQP foram institucionalizados em itens orçamentários (inclusão de uma alínea específica para treinamento) e na carreira dos servidores técnicos administrativos (inclusão de esforços de formação na avaliação de desempenho) e incorporados na cultura organizacional.

Ainda para Cruz, Miranda e Regados (2006) na USP está se consolidando um novo modelo de gestão, que conta com três pilares fundamentais: a Autonomia Universitária, a Avaliação Institucional e os esforços de aprimoramento da qualidade e produtividade, todos articulados pelo mesmo quadro conceitual de modernização organizacional. Trata-se de um processo que visa ao aumento de resultados em relação aos gastos da USP, por meio de maior flexibilização organizacional e pela adoção de práticas de gestão mais efetivas.

Os dados da pesquisa de 2004, levantados pela Comissão de Gestão da Qualidade da USP e apresentados em USP. A Década do Programa de Qualidade e Produtividade (2005) permitem elencar algumas ações de qualidade distribuídas pelas Unidades e Órgãos da USP, procurando-se enquadrá-las nos Módulos de Qualidade: 
- Liderança: Sistema de Gestão da Qualidade; elaboração de diagnóstico organizacional.

- Planejamento: elaboração de planejamento estratégico; planejamento das atividades; estabelecimento de missão, valores e metas.

- Foco no cliente: comunicação com comunidade interna e externa; imagem institucional; preservação da história da Unidade; Unidade em Números, vídeos institucionais; Boletim da Unidade; Pesquisa de Satisfação do Usuário; Biblioteca: aumento do acervo, instalação de salas de videoconferência e melhoria de organização. Adaptação das instalações para pessoas portadoras de deficiência física; uniformes para funcionários que atendem, diretamente, o público. Ambiente: melhoria nas instalações físicas e no mobiliário, salas de aula, anfiteatros e laboratórios. Sustentabilidade Ambiental: Programas PURA, PURE, USP Recicla; distribuição e incentivo ao uso de canecas duráveis, programas educativos, uso de envelope "vai e vem", uso das duas faces de papel em teses; descarte e gerenciamento de lixo; controle de qualidade da água; tratamento adequado de resíduos sólidos, químicos e infectantes; tratamento de áreas verdes e jardins e recuperação de mata ciliar.

- Gestão de Pessoas e Desenvolvimento: trabalho em equipe; programas de qualidade de vida; formação continuada; Eventos de Integração e Encontros de Qualidade. Programas de Saúde: vacinação contra gripe, orientação de higiene bucal, campanha antitabaco, orientação e combate ao uso de drogas; Ginástica Laboral; Programas de avaliação de Ergonomia. Avaliação contínua de servidores; inclusão ao mundo digital para servidores do nível básico. Exposição dos talentos dos funcionários.

- Gestão de processos: racionalização e documentação de processos administrativos; modelagem de processos críticos, documentação e descrição de procedimentos; racionalização de arquivos. Programa 5S; padronização do e-mail como meio obrigatório de comunicação; centralização de reprografia; compartilhamento de recursos de impressão. Eficiência na gestão de terceirizados.

- Informação e Análise: compra de equipamentos e/ou desenvolvimento de banco de dados e sistemas informatizados. 
Outros fatos pontuais e localizados estão também assinalados na publicação de USP. Uma Década do Programa de Qualidade e Produtividade na USP (2005):

- A Biblioteca da Escola Superior Luiz de Queiroz - ESALQ candidatou-se, em 2003, ao Prêmio Paulista de Qualidade em Gestão e obteve a medalha de bronze. Além de uma sinalização positiva para o modelo de gestão adotado, a equipe da Biblioteca viu reconhecido seu esforço. A partir desse fato, outras 11 bibliotecas integrantes do Sistema Integrado de Bibliotecas (SIBi) aderiram ao mesmo modelo. (ANDRIANI, 2001)

- O Instituto de Eletrotécnica e Energia obteve com o INMETRO a acreditação na norma NBR-ISO/17025, de dois de seus Laboratórios: de Baixa Tensão e de Compatibilidade Eletromagnética.

- A Coordenadoria de Assistência Social, o Instituto de Astronomia, Geofísica e Ciências Atmosféricas, o Centro de Práticas Esportivas e o Hospital Universitário, estruturaram-se para conseguir certificação e/ou acreditação.

- O Sistema Integrado de Bibliotecas (SIBi), a partir de 2002, instituiu o Programa de Avaliação de Qualidade (PAQ) das Bibliotecas, com o objetivo de, continuamente, avaliar a qualidade dos produtos e serviços oferecidos pelas 39 (trinta e nove) bibliotecas existentes. A partir dessa avaliação foram implementadas ações que atendiam às necessidades identificadas pelos usuários. (FERRARI; DE GRANDI, 2007)

- A Escola Politécnica, a partir do final de 2002, envolveu-se num projeto visando à construção de seu futuro. Esse projeto recebeu o nome de POLI 2015. Ligado a ele está o Projeto APA - Aperfeiçoamento de Processos Administrativos que objetiva implementar processos administrativos mais simples e racionalizados, beneficiando a comunidade universitária, a Instituição e a própria sociedade. (SANT’ANA; PIFFER, 2006)

- O Centro de Computação Eletrônica - CCE submeteu-se, em 2004, ao Prêmio Gestão SP Inovações na Gestão Pública do Estado de São Paulo. O programa realizado no CCE visava modernizar a infraestrutura do Centro de Processamento de Dados para adequá-lo às 
novas demandas de Tecnologia de Informação e Comunicação (TIC), transformando-se em um Internet Data Center.

- A prática da ginástica laboral, projeto da Comissão de Qualidade USP em parceria com o CEPEUSP, passou a ser uma rotina em várias Unidades do campus da Cidade Universitária, em São Paulo, a partir de 2003. Foi elaborada uma publicação intitulada "Manual de Orientação de Ginástica Laboral” (2005), com ampla distribuição aos funcionários da USP, para divulgação dessa prática de qualidade de vida.

- A FCF, em 2000, optou pela implementação da International Standard Organization 14001 (ISO-14001) (ABNT, 1996), com o objetivo de estabelecer uma política ambiental apropriada às suas atividades, produtos e serviços, permitindo à Unidade atingir e controlar sistematicamente o nível de desempenho ambiental, visando ao seu aprimoramento contínuo, em consonância com as iniciativas institucionais. A série de Normas ISO 14.000 especifica os elementos de um Sistema de Gestão Ambiental (SGA) e oferece ajuda prática para sua implementação ou aprimoramento. Foram proporcionados amplos treinamentos ao corpo docente, não docente e discente, com abordagens técnicas sobre as ferramentas da qualidade e comportamento para adoção de práticas voltadas à qualidade de vida no trabalho. Foram realizados nove Seminários de Qualidade e Produtividade a partir de 1997 até 2006. A ferramenta da qualidade denominada 5S foi adotada, inicialmente, nas aulas práticas de alunos e em outras áreas da administração e dos Departamentos. (PINTO e outros, 2009).

- Em 2004, o IAG instituiu o PALP, Plano de Ação Local Participativo, com a implantação do Programa 5Ss. Teve como objetivos: promover a participação e interação em todos os níveis da organização; desenvolver equipes de liderança; incentivar a criatividade; melhorar o ambiente de trabalho; aprender a lidar com mudanças e preparar o ambiente para a qualidade total, produtividade e qualidade. (ANDRADE; SILVA, 2004).

- O Programa de Qualidade da USP teve várias parcerias e "filhotes" que imprimiram força, vitalidade e auxiliaram na continuidade do Programa. Incluem-se, nesse caso, os programas: USP Recicla, Programa de Uso Racional de Água - PURA e o Programa de Uso Racional de Energia - PURE, descrito em seguida, como ilustração. 
- O Programa Permanente para o Uso Eficiente de Energia Elétrica, PURE, foi criado em 1997, em parceria da Comissão de Gestão de Qualidade e Produtividade da USP e o corpo técnico do GEPEA - Grupo de Energia do Departamento de Engenharia de Energia e Automação Elétricas da Escola Politécnica. Segundo Saidel e Favato (2007) e <www.pure.usp.br>, o PURE desenvolve a gestão da energia elétrica na USP e dissemina conceitos de uso racional e eficiente de energia na comunidade atuando em três pilares: administrativo, tecnológico e comportamental. "Suas ações têm gerado retorno financeiro e cumpre também seu papel social, ajudando a construir a consciência da utilização adequada do bem público.” A importância do Programa pode ser ilustrada pela economia de energia gerada, proporcionada pelas ações efetuadas em 10 anos do Programa: "congelamento do consumo, trazido a valores atuais representa economia de $132 \mathrm{GWh}$ acumulados e a recuperação de aproximadamente $\mathrm{R} \$ 17$ milhões com a negociação com concessionárias de energia elétrica e a sensibilização de grande parte da comunidade com a importância da eficiência energética."

A atuação da Comissão Interna de Qualidade e Produtividade da Reitoria é aqui retratada como mais um exemplo da forma de operação das Comissões Internas de Qualidade. A Comissão foi constituída, em 1996, pelo atendimento à solicitação do Reitor no início do Programa e reformulada em 2002. Nessa última formatação, era composta por 28 (vinte e oito) membros representantes dos onze órgãos que compõem a Reitoria. Tinha um escopo de atuação restrito à Reitoria e definiu seu campo de atividades a partir da utilização de ferramentas e conceitos da qualidade. Em especial, utilizou a técnica NGT (nominal group technique) de brainstorming para selecionar e priorizar suas atividades; promoveu a integração de pessoas dos vários órgãos da Reitoria e organizou cursos de Multiplicadores da Qualidade que serviram como alavancagem para iniciativas do Programa em outras Unidades da USP. Parte de suas atividades foi usada, tal como relatado na pesquisa de campo, como referência para outras Unidades.

Em 2002 e 2003, com o objetivo de fazer um diagnóstico, usando-se técnica de brainstorming, Nominal Group Technique (NGT), foram feitos levantamentos de oportunidades de melhoria comuns às várias áreas da Unidade. Dentre os principais temas levantados destacaram-se: Treinamento; Gestão de Carreira; Qualidade de Vida; Integração de Pessoas; Espaço Físico, Comunicação Interna; Segurança; Simplificação de Rotinas; Imagem Institucional; Sinalização Interna e Externa; Pesquisa de Opinião com Funcionários; 
Premiação pela Qualidade; Reciclagem de Materiais; Mural de Comunicação; Espaço Cultural; Atendimento ao Público; Trabalho em Equipe; Responsabilidade Social e Gestão Ambiental.

Conforme publicação USP. Quadriênio do Programa de Qualidade e Produtividade na Reitoria (2005), após a identificação das ações que apresentavam oportunidades de melhorias, foram constituídos grupos de trabalho, denominados de Grupos de Ação de Melhorias (GAMs) que ficaram responsáveis por implementar algumas delas. Os GAMs, sempre que pertinente, atuaram em parceria com as áreas administrativas afins para o desenvolvimento dos trabalhos.

Quadro 14 - Descrição dos Grupos de Ação de Melhorias (GAMs)

\begin{tabular}{|c|c|}
\hline GAMs & Objetivos \\
\hline GAMultiplica & $\begin{array}{l}\text { Multiplicar os princípios e temas relativos à Qualidade e Produtividade, } \\
\text { promoveu desde 2003, Curso de Formação de Multiplicadores da } \\
\text { Qualidade para apresentação de conceitos da Qualidade Total, Noções } \\
\text { Gerais de Missão, Valores, Metas, Planejamento Estratégico, Conceitos } \\
\text { envolvidos em Qualidade, Fundamentos do Modelo de Gestão Pública, } \\
\text { Critérios de Avaliação da Gestão Pública, Princípios da Qualidade e } \\
\text { Ferramentas para Melhoria da Qualidade. }\end{array}$ \\
\hline GAMQVTR & $\begin{array}{l}\text { Desenvolver, implementar e manter atividades para melhorar a } \\
\text { qualidade de vida dos funcionários, no que diz respeito à saúde, como a } \\
\text { Ginástica Laboral, atividades de integração dos funcionários e } \\
\text { desenvolver ações para melhoria das relações no ambiente de trabalho. }\end{array}$ \\
\hline GAMCultural & $\begin{array}{l}\text { Facilitar o acesso dos funcionários ao patrimônio artístico cultural da } \\
\text { USP, promovendo visitas monitoradas aos museus da USP, passeios em } \\
\text { parques e Centros Históricos; visitas às instalações de novas Unidades, } \\
\text { acompanhamento de ensaios da orquestra sinfônica da USP, entre } \\
\text { outros. Em } 2005 \text { promoveu a criação do Coral da Reitoria. }\end{array}$ \\
\hline GAMAvision & $\begin{array}{l}\text { Elaborar, instalar e manter o "Mural da Qualidade" que apresentava } \\
\text { quinzenalmente notícias de natureza geral e relativas à Qualidade. }\end{array}$ \\
\hline GAMfolheto & $\begin{array}{l}\text { Elaborar publicação sobre os diferentes órgãos que compunham a } \\
\text { Reitoria, denominada "Perfil da Reitoria - Órgãos e Atividades". }\end{array}$ \\
\hline GAMinfo & $\begin{array}{l}\text { Implantar junto com o Departamento de Administração a sinalização } \\
\text { interna da Reitoria. }\end{array}$ \\
\hline GAMEcologia & $\begin{array}{l}\text { Sensibilizar a comunidade interna quanto à importância da conservação } \\
\text { do Meio Ambiente e das ações voltadas para o Desenvolvimento } \\
\text { Sustentável. }\end{array}$ \\
\hline GAMSite & $\begin{array}{l}\text { Desenvolver um site para divulgar os objetivos, propostas e atividades } \\
\text { dos GAMs e divulgar sites parceiros que disponibilizassem informações } \\
\text { correlatas de Q\&P. }\end{array}$ \\
\hline GAMOrganograma & $\begin{array}{l}\text { Elaborar organogramas oficiais da Universidade, visando à } \\
\text { uniformização de documentos. }\end{array}$ \\
\hline
\end{tabular}

Fonte: Quadriênio de Qualidade na Reitoria (2005) 
Anualmente, com procedimentos de brainstorming eram revistas as ações em andamento e outras ações a serem implementadas. Dessa forma, utilizava-se o ciclo do PDCA (plan-do check-act), integrante da filosofia da qualidade. Uma descrição completa das atividades desenvolvidas pela Comissão Interna de Qualidade da Reitoria está contida na publicação USP. Quadriênio do Programa de Qualidade e Produtividade da Reitoria (2005).

Completa esse quadro histórico descrito, outros resgates de atividades ligadas ao tema, que estão inseridos nos Apêndices. Descrevem em duas Linhas do Tempo: 1) atividades da USP, afetas à Comissão de Gestão de Qualidade e Produtividade da USP, à Comissão de Qualidade da Reitoria e a Programas Institucionais e 2) atividades das Unidades e Órgãos. Sem a pretensão de serem exaustivas, essas Linhas do Tempo, baseadas nos documentos consultados da Comissão da Qualidade e em Relatórios das Unidades, constituem um trabalho inicial que poderá a vir a ser complementado por outros protagonistas da história da qualidade na USP.

\subsubsection{Considerações sobre a pesquisa documental}

Os casos apresentados exemplificam parte dos esforços de racionalização e de aprimoramento da utilização dos recursos disponíveis de maneira estruturada e coerente. Mantêm-se alinhados aos princípios gerais do Programa Permanente de Qualidade e Produtividade e ao quadro conceitual do novo modelo de gestão da USP.

Com relação ao foco das melhorias do Programa de Qualidade e Produtividade, elas se situaram com maior intensidade na área administrativa. Isso pode ser atribuído ao próprio posicionamento inicial da Comissão, com a Coordenadoria de Administração Geral (CODAGE). Com relação ao Programa de Avaliação Institucional (2001 - 2004), que recebeu influência do Programa de Qualidade, o foco se deslocou para as atividades fins.

Alguns programas institucionais fortes como o PURE, objetivando economia no consumo de energia, assim como o PURA, voltado à economia no consumo de água, iniciaram-se com o Programa de Qualidade e incorporaram-se à cultura organizacional, vigorando até hoje (2010) e ilustrando a mobilização da Universidade para a sustentabilidade ambiental e a economia de recursos. O Programa USP Recicla iniciou-se antes de 1996, tornando-se, em seguida, um parceiro do Programa de Qualidade. As economias advindas de programas institucionais 
como o PURE, PURA e USP Recicla têm sido documentadas, como, por exemplo, os citados por Saidel e Favato (2007).

A concretização da política de qualidade na USP significou uma diversificação muito grande de ações de Qualidade nas Unidades e Órgãos da Universidade. Encontros sistemáticos de Qualidade foram organizados para que as boas práticas ficassem conhecidas, disseminadas e copiadas, a partir de um mimetismo organizacional. Funcionaram, também, para promover reflexão sobre os fundamentos da Qualidade e Produtividade e serviram como foco aglutinador, articulador e disseminador de experiências relevantes. O conhecimento compartilhado propiciou mudanças institucionais e aperfeiçoamentos significativos em várias esferas da Universidade.

Deve-se ressaltar, ainda, que eventos institucionais de integração de funcionários como os da área financeira, acadêmica, informática, recursos humanos, secretárias, encontro gerencial, entre outros, organizados centralizadamente ou pelas Unidades, têm sido uma constante desde 1996, permitindo o estabelecimento de uma rede importante de relacionamentos que facilitam o trâmite das informações ligadas a cada segmento, formam um ambiente propício ao aprendizado individual e organizacional, provocando mudanças culturais internas significativas.

Para ilustrar outras ações ligadas à Gestão de Pessoas, destaque-se o treinamento e a capacitação que foram proporcionados pela USP e por Unidades, desde o MBA até cursos de especialização e de extensão. Cursos voltados para o desenvolvimento das pessoas trouxeram, entre outros ganhos, visões sistêmicas institucionais, desenvolvimento de espírito crítico construtivo e um maior conhecimento técnico, permitindo melhor atuação dos profissionais da USP, em suas respectivas áreas. Ainda nessa questão de recursos humanos, ficou evidenciada, pelos depoimentos, uma "mudança de mentalidade", incluindo um maior envolvimento dos funcionários e um maior profissionalismo. A inclusão de escolaridade e formação em um item de avaliação de desempenho individual estimulou o aprendizado individual.

Muitas atividades ligadas à Qualidade de Vida no Trabalho foram referenciadas, como a ginástica laboral, a adequação de mobiliário às condições ergonômicas, além de uma preocupação geral com a ambiência e o bem-estar dos funcionários, nos seus aspectos biológicos, psicológicos e sociais. 
Ainda que Qualidade na Universidade possa ser entendida sob vários aspectos em suas atividades fins e atividades meios, o Programa de Qualidade e Produtividade teve na USP, seu principal foco voltado à melhoria das atividades técnico-administrativas. O posicionamento desse Programa na Coordenadoria de Administração Geral provavelmente orientou as principais ações do Programa. Em seu início, esperava-se, predominantemente, a melhoria dos processos administrativos, com sua simplificação e racionalização, assim como economias trazidas com o melhor aproveitamento dos recursos públicos e eliminação de desperdícios. Também eram visados o desenvolvimento dos recursos humanos e a melhoria do ambiente de trabalho. 


\section{CONCLUSÕES}

A Qualidade Total, alardeada como responsável pelo desenvolvimento econômico do Japão de Pós-Guerra, foi também aclamada como responsável pelo bom desempenho das organizações nos últimos 20 anos de século $\mathrm{XX}$ ou foi, apenas, mais um modismo organizacional? Se foi uma moda e já passou, o que restou dela? O que deixou nas organizações que se aproveitaram dos princípios de sua filosofia?

A Qualidade Total, como um rótulo já não provoca tanta atração, como ocorria no passado. $\mathrm{Na}$ sua passagem pelas organizações, podem ser evocadas algumas alterações que ela deixou: reorganização dos postos de trabalho; estruturas organizacionais mais horizontais; trabalhos em equipe; melhoria contínua dos processos e maior atenção aos clientes, aos usuários e aos membros da organização.

Atualmente, o apelo da Qualidade Total, como forma gerencial, está bastante reduzido, conquanto alguns de seus princípios já estejam internalizados em muitas organizações. O que se percebe, mais recentemente, é que parte dos múltiplos princípios que estavam associados à Qualidade Total, agigantou-se e ganhou vida própria, aparecendo no ambiente organizacional com novas denominações. Aqui se enquadram a gestão do conhecimento, gestão por competências, qualidade de vida no trabalho, responsabilidade social, sustentabilidade socioambiental, entre outras. De qualquer forma, quando foi aplicada, a Qualidade Total funcionou como um agente de mudança cultural nas organizações. Ela trazia, em seu bojo, alterações nas formas de produção de produtos e serviços e nas relações de trabalho.

Que tipo de transformações ocorreram, induzidas ou impulsionadas pelo movimento da Qualidade Total? Se na produção industrial a Qualidade Total contribuiu para estimular novas forças de produção, o que provocou nas instituições de serviço e, mais especificamente, nas Universidades Públicas?

Os esforços de mudança cultural nas instituições públicas e, particularmente na Universidade, permanecem, no sentido de melhorar continuamente os serviços públicos no Brasil. $\mathrm{O}$ aprendizado obtido com a experiência da Universidade de São Paulo deve ser registrado e, de algum modo consolidado, possibilitando contribuir para a correção de erros na trajetória do 
aperfeiçoamento institucional ou, ainda, servir de exemplo para outras mudanças organizacionais, de mesmo teor. Democratizar o conhecimento, principalmente aquele advindo de organizações públicas, é contribuir com mais um retorno àqueles que as mantêm.

À semelhança do conhecimento científico, que é registrado pelas diferentes áreas do conhecimento, os relatos de experiências administrativas apresentam frutos; devem gerar, ao longo do tempo, um corpo de conhecimentos para validação de teorias. O Programa de Qualidade e Produtividade na USP, polêmico em algumas Unidades e mais facilmente absorvido em outras, é diferenciado em relação a outras universidades e órgãos públicos. A documentação dessa experiência, à luz de modelos teóricos existentes, é relevante no sentido de divulgá-la, reduzindo etapas importantes na trajetória dos que integram a comunidade de dirigentes e servidores, preocupados com a gestão eficiente da organização e do Estado.

Tendo como objetivo principal resgatar, de modo sistemático, o histórico de implantação de uma experiência que inclui elementos inovadores em termos de administração pública, duas questões iniciais foram propostas para a pesquisa desta tese: a forma de implementação de um Programa de Qualidade em uma Universidade Pública e os resultados auferidos com esse Programa, na percepção dos atores envolvidos.

Respondendo, inicialmente, à primeira questão, de como um programa de Qualidade pode ser implantado em uma Universidade Pública, pode-se afirmar que, em função das características da Universidade, com centralização e grande liberdade de ação para as unidades federadas, fica evidenciada a necessidade de uma diretriz centralizada da alta administração e uma operacionalização local das atividades de um Programa de Qualidade.

Um aspecto extremamente influenciado positivamente pelo Programa foi o treinamento e desenvolvimento dos recursos humanos. A USP, como um todo, e as Unidades, em particular, investiram maior atenção nesse aspecto com relação aos funcionários. Desde 1996, uma alínea orçamentária específica para isso foi acionada.

Quanto à percepção dos atores, no que tange aos resultados, pode-se evidenciar que, na gestão de pessoas, foi grande o esforço e incentivo para melhoria na qualificação, levando-se esse diferencial para a avaliação de desempenho dos funcionários e a preocupação com condições de Qualidade de Vida no Trabalho. As ações desenvolvidas, nesse sentido, foram inúmeras. 
Pode-se apontar como resultados comportamentais um maior envolvimento das pessoas, maior participação na tomada de decisões e mais profissionalismo dos funcionários.

Quanto aos professores, uma observação recorrente diz respeito à competência técnica dos docentes, enquanto gestores. A titulação e competência na área específica da carreira do docente nem sempre é acompanhada da necessária competência para cargos gerenciais. Isso pode sinalizar uma recomendação para aperfeiçoamentos de formação para o docente na área específica de Gestão Universitária. Uma forma de aprendizado, talvez mais aceita pelos docentes, poderia ser o incremento nas oportunidades de interação social entre pares, voltadas às questões administrativas.

A concretização de ações de mudanças é influenciada pela visão e decisões dos atores envolvidos, em especial, dos dirigentes docentes transitórios, que têm todo o poder legal para incentivar ou obstar iniciativas dessa natureza. Na Universidade, essa transição dá-se, como regra, a cada quatro anos, o que, de certa forma, torna um Programa de Qualidade vulnerável, considerando-se que um programa de mudança cultural demanda longo tempo para estabilização e internalização na cultura existente.

No caso da Universidade de São Paulo, a permanência do Presidente da Comissão de Gestão da Qualidade e Produtividade, por cerca de dez anos, gerou condições ao Programa de apresentar certa estabilidade e produzir algumas mudanças da cultura organizacional, corroborando, portanto, as considerações apresentadas no parágrafo anterior.

O que fica ainda evidente é que é preciso ter sempre um planejamento de longo prazo, que tenha o comprometimento dos dirigentes para valores fundamentais da Universidade. É preciso ter uma orientação central, uma força mobilizadora institucional para um projeto comum que leve ao constante aperfeiçoamento da Universidade, face às novas condições de um ambiente externo dinâmico. A operacionalização deve ser local, com um acompanhamento sistemático e estímulos concretos para que as novas situações desejadas se consolidem e se internalizem na cultura da Universidade.

Por outro lado, a Universidade Pública ou qualquer outra organização que tenha princípios democráticos deve considerar que mudança só se faz com os atores envolvidos e as pessoas devem estar convencidas sobre a necessidade e a pertinência das mudanças para, então, 
colaborarem. Para isso deve haver um esforço maior e cuidado na implantação ou pode-se cair na frustração de ter mais uma regulamentação não cumprida.

Embora haja diferenciação na absorção de tecnologias da Qualidade entre as Unidades, constata-se um amadurecimento do Programa de Q\&P, em vários locais. Particularmente, a constituição de uma massa crítica de funcionários com formação em Tecnologias da Qualidade, passou a interferir, positivamente, na gestão da USP. Ainda que o Programa, desde seu início, procurasse envolver todos os membros da Universidade, incluindo todos os níveis, do corpo de docentes e técnicos administrativos, a realidade mostrou um envolvimento maior dos funcionários técnicos administrativos.

Os dados da pesquisa mostram que o Programa de Qualidade e Produtividade da USP conseguiu um maior envolvimento dos funcionários na vida da Universidade como um todo. Se isso é flagrante na maioria dos entrevistados, não é possível generalizar o envolvimento para todos os níveis de funcionários técnicos administrativos e tampouco para o envolvimento dos diretores, que são chefes de passagem nas suas Unidades e Órgãos, com o poder de reforçar ou destruir todos os esforços de administrações anteriores. A aplicação dos princípios do gerenciamento da Qualidade mostrou aumentos: na produtividade; na cooperação com os usuários; no moral dos empregados; na capacidade de resolução de problemas e no compromisso com a organização. Foram sedimentados alguns aspectos, como a cultura da participação, a melhoria contínua, outros valores como visão sistêmica e compartilhamento de propósitos. Entre outros ganhos do Programa de Qualidade, ele serviu de base para desdobramentos da Universidade, como a Avaliação Institucional e o GESPÚBLICA, que veio substituí-lo em 2007.

No que tange aos objetivos específicos desta tese, foram levantados aspectos de percepção de mudanças relativas a recursos humanos da Universidade, principalmente no que se refere a: treinamento; participação; aprendizagem; competência; interação entre funcionários e qualidade de vida no trabalho.

Tais levantamentos corroboram os seguintes achados da fundamentação teórica desta pesquisa: 
- A sociedade passa a exigir melhor qualidade dos serviços nas organizações públicas, ao mesmo tempo em que os recursos públicos decrescem continuadamente. Para atender essas demandas a qualidade dos serviços públicos deve melhorar;

- A sobrevivência das organizações está atrelada ao atendimento das necessidades de seus clientes, consumidores ou usuários, ou seja, para todas as partes interessadas (stakeholders). Para maximizar a probabilidade desse resultado, importante também, é atender às necessidades das pessoas que trabalham nas organizações;

- O comportamento organizacional, somatório dos comportamentos individuais não deve ser deixado fluir como um rio, mas exige-se uma orientação e/ou uma reorientação orquestrada pela liderança. Uma comunicação eficiente pode levar a uma visão compartilhada, que favorece o cumprimento dos objetivos organizacionais;

- As transformações nas estruturas das organizações e nas práticas gerenciais estão sempre em busca de um aperfeiçoamento contínuo da instituição;

- A execução de ações de qualidade, dentro de um processo de mudança cultural, passa pela aplicação de novas técnicas e novos métodos de gestão. Ela é acompanhada de uma redefinição de responsabilidade e de competências no trabalho, evocando novas maneiras de fazer e de pensar do conjunto dos membros da organização;

- A qualidade aparece como um novo modo de racionalização do sistema organizacional, uma nova técnica gerencial, buscando maior eficiência e um melhor aproveitamento de recursos;

- A qualidade apregoa, ainda, uma transformação dos relacionamentos sociais. Novas técnicas e novos métodos de trabalho dão possibilidade de nova distribuição de saberes, favorecendo novas competências e novas aprendizagens no trabalho, possibilitando uma construção feita pelos atores;

- A mensagem disseminada pela qualidade na organização deve atingir diferentes categorias de colaboradores para que se consiga abranger o comportamento de todo o corpo social;

- A implicação de todos os membros da organização no processo de melhoria institucional demanda um conhecimento vindo da sociologia, da psicologia social para conseguir resultados com esses atores. Dirigentes e consultores de qualidade devem atentar para os aspectos afetivos, de envolvimento e compromisso para atingir seus objetivos;

- A cultura organizacional deve sofrer transformações de modo a conseguir das pessoas uma alteração no seu comprometimento afetivo para obterem um melhor desempenho; 
- A qualidade, tal como foi ao longo de sua evolução, é constituída perante um amplo espectro de representações ou de aplicações. Cada instituição pega de seu conjunto de princípios, técnicas ou prescrições aquilo que faz sentido ou que lhe é mais adequado.

Do mesmo modo que os achados da fundamentação teórica desta tese, as percepções relativas aos objetivos específicos são corroborados pelo seu levantamento empírico:

- O Programa de Qualidade e Produtividade da USP teve a função de estratégia mobilizadora, provocada por um decreto governamental (1995) e adotada de imediato pelo Reitor da época (1996), Prof. Flávio Fava de Moraes;

- Observou-se que o movimento da Qualidade, na USP, foi seminal para a emergência de uma nova mentalidade, voltada para uma visão sistêmica e um envolvimento e comprometimento de funcionários com a instituição. Todavia, não é possível generalizar essa afirmação, que não é válida para todas as Unidades e tampouco para todos os funcionários da USP.

- Existe um mimetismo organizacional natural que pode ser mais bem aproveitado e incentivado pelas lideranças da Universidade, para a elevação de patamares de excelência de gestão, em todas as instâncias.

- As mudanças contínuas da sociedade assim como as reivindicações sociais renovadas impõem à Universidade um latente estado de alerta com a vigência de forças mobilizadoras permanentes, quaisquer que sejam os nomes que se dêem a essas.

Diante desses achados, recomenda-se planejamento de longo prazo com o comprometimento dos dirigentes envolvendo valores fundamentais da Universidade e minimizando riscos da descontinuidade administrativa, que impede o aperfeiçoamento contínuo da Universidade.

Com base nas fontes de evidência utilizadas nesta tese, o que se constata é que ainda há muito a fazer, levando-se em conta o potencial de conhecimento e de experiências diluídas na USP e nem sempre exploradas para uso comum. É altamente recomendável que as boas práticas que se apresentam dispersas nas Unidades e Órgãos da USP sejam compartilhadas e socializadas. Sugere-se, ainda, que o registro escrito dessas práticas se torne uma rotina, tal qual o conhecimento científico é disseminado no meio acadêmico. Há muitos diagnósticos feitos e há muitos projetos desenvolvidos nos cursos de MBA e especialização que precisam ser mais 
bem aproveitados e colocados em prática. A gestão do conhecimento é uma vertente em que a Universidade ainda pode avançar muito.

\subsection{Limitações do estudo}

Considerando-se a natureza do método escolhido - o estudo de caso - existem limitações relacionadas às possibilidades de generalização dos resultados.

No que se refere ao levantamento de campo, deve ser observado que as entrevistas com docentes se canalizaram para dirigentes e quanto a técnicos administrativos, fixaram-se em entrevistados de nível superior. Também se deve registrar como limitação o período focalizado: 1996 - 2006, quando os dados estiveram mais acessíveis.

Cabe ressaltar a condição de proximidade do pesquisador com o objeto estudado, o que poderia levar a um viés que prejudicasse a pesquisa. Levando-se em conta essa condição, o pesquisador procurou manter objetividade e isenção necessárias ao trabalho científico.

\subsection{Contribuição para futuras pesquisas}

Quando se pensa em continuidade deste trabalho, pode-se, primeiramente, estender o estudo do processo de aperfeiçoamento da Universidade para o período posterior a 2007, tendo em vista que foram feitas autoavaliações de Unidades e Órgãos da USP, usando-se metodologia do GESPÚBLICA, compatível com os critérios abordados nesta tese.

Posteriormente, idealizar trabalhos voltados ao aprofundamento da pesquisa sobre aperfeiçoamentos da Universidade, na área administrativa, estendendo-se para todas as outras Unidades da USP e incluindo, como entrevistados, alunos, outros docentes, não dirigentes e funcionários técnicos administrativos de todos os níveis.

Outra possibilidade é voltar-se mais detalhadamente para as atividades-fins da USP, ou seja, ensino, pesquisa e extensão, utilizando-se de método de estudo de casos múltiplos ou de método quantitativo de coleta e análise de dados. 
Ainda a considerar como um trabalho de pesquisa seria a elaboração de um modelo de excelência de gestão e um instrumento de autoavaliação, específico para Universidades, fazendo-se a devida adaptação de modelos genéricos existentes.

Todas essas alternativas aplicam-se, igualmente, para estudos semelhantes em outras Universidades. 


\section{REFERÊNCIAS}

ABRANTES, M. L. Formação de multiplicadores do Programa Permanente de Qualidade e Produtividade da Universidade de São Paulo: estudo de caso da Comissão Interna da Reitoria. São Paulo: Secretaria do Planejamento do Estado de São Paulo, 2005. Mimeografado.

ABRÚCIO, F. L. O impacto do modelo gerencial na administração pública: um breve estudo sobre a experiência internacional recente. Cadernos ENAP, Brasília, n. 10, 1997.

ALBUQUERQUE, L. G. Competitividade e recursos humanos. Revista de Administração, São Paulo, v. 27, n. 4, p. 16 - 29, out./dez.,1992.

; LIMONGI-FRANÇA, A. C. Estratégia de recursos humanos e gestão da qualidade de vida no trabalho: o stress e a expansão do conceito de qualidade total. Revista de Administração da USP, São Paulo, v. 33, n. 2, p. 40-51, 1998.

ALMEIDA, M. I. R. Planejamento estratégico para unidades e departamentos da USP: uma proposta de arquitetura, modelo e condução do processo. 2004. Tese Livre-docência. Departamento de Administração da Faculdade de Economia Administração e Contabilidade, Universidade de São Paulo, São Paulo, 2004.

AMARAL, A. Sistemas de Avaliação. In: Educação brasileira. Brasília: Conselho de Reitores das Universidades Brasileiras - CRUB, v. 16, n. 32, p. 221 - 232, jan./ jul. 1994.

ANDERSON, J. C.; RUNGTUSANATHAM, M; SCHROEDER, R.G. A theory of quality management underlying the Deming management method. Academy of Management Review, v. 19, n. 3, p. 472-509, 1994.

ANDRADE, L. C.; SILVA, O. G. Implantação do programa de qualidade dentro de uma unidade da Universidade de São Paulo: um estudo de caso. Monografia. Escola Politécnica/PECE. MBA em Gestão e Tecnologias da Qualidade. São Paulo: USP, 2004.

ANDRIANI, C. S. Modelo de gestão pública: conceitos e linguagem. Campinas: Diagrama Consultoria Empresarial, 2001. 162 p.

ANGARITA, A. Abertura do seminário. A Reforma administrativa. Cadernos FUNDAP, São Paulo, n. 22, p. 7-8, 2002.

ANUÁRIO ESTATÍSTICO USP. Universidade de São Paulo. Coordenadoria de Administração Geral. São Paulo: CODAGE/USP, 1997.

Universidade de São Paulo. Coordenadoria de Administração Geral. São Paulo: CODAGE/USP, 2008.

Universidade de São Paulo. Coordenadoria de Administração Geral. São Paulo: CODAGE/USP, 2009.

ANUÁRIO ESTATÍSTICO. UNICAMP. Universidade Estadual de Campinas. Campinas: UNICAMP, AEPLAN, 2009. 
ANUÁRIO ESTATÍSTICO UNESP. Universidade Estadual Paulista Júlio de Mesquita Filho, vol.1 (2001) - São Paulo: UNESP, APLO, 2009.

ARCAYA, O. G. Democracia y desarrollo economico y social: consideraciones sobre las condiciones politicas para una nueva politica economia en América Latina. In: KLIKSBERG, B. (Comp.). Pobreza, un tema impostergable: nuevas respuestas a nivel mundial. Caracas: CLAD/PNUD, 1994.

ASSOCIAÇÃO BRASILEIRA DE NORMAS TÉCNICAS. ABNT. NBR 8402: 1994. Gestão da qualidade e garantia da qualidade: terminologia. Rio de Janeiro, 1994.

ISO 9004:2000: sistemas de gestão da qualidade: diretrizes para melhoria de desempenho. Rio de Janeiro, 2000.

BALDRIGE NATIONAL QUALITY PROGRAM. Criteria for performance excellence. Gaithersburg: NIST/Department of Commerce, 2006.

BALLERY, E. Évolution de la qualité: le bilan, vingt ans après! Qualité en Mouvement, n. 62, févr./mars., 2004.

BARDIN, L. Análise de conteúdo. Lisboa: Edições 70, 1994.

BARZELAY, M. The new public management: a bibliographical essay for Latin American (and other) scholars. In: CONGRESSO INTERNACIONAL DEL CLAD: la Reforma Del Estado y de La Administración Pública, 5., 2000. Santo Domingo. Anais... Rep. Dominicana, 2000 .

BASTOS, C. R. Curso de teoria do Estado e ciência política. $4^{\text {a }}$. ed. São Paulo: Saraiva, 1999.

BATISTA, F. F. Avaliação da gestão pública no contexto da reforma do aparelho do Estado. Brasília: IPEA, 1999.

BENNIS, W. G. Organizações em Mudança. Tradução Maria Grazia Linhares. São Paulo: Atlas, 1976. 213 p.

BERGER, P. L.; LUCKMANN, T. A construção social da realidade: tratado de sociologia do conhecimento. 25a . ed. Tradução de Floriano de Souza Fernandes. Petrópolis: Vozes, 2005. $248 \mathrm{p}$.

BERNOUX, P. Sociologie du changement: dans les entreprises et les organisations. Paris: Éditions du Seuil, 2004. 308 p.

BIANCHI, M. L. P.; MIRANDA, O. (Orgs.). Início do Programa GESPÚBLICA USP: 2006 - 2007. Programa de Gestão Estratégica e Desburocratização na Administração da USP - GESPÚBLICA USP. São Paulo: USP, 2007.

BRASIL. Decreto n. 3.507, de 13 de junho de 2000. Dispõe sobre o estabelecimento de padrões de qualidade do atendimento ao cidadão. Brasília, DF, 2000.

Decreto n. 5.378, de 23 de fevereiro de 2005. Institui o Programa Nacional de Gestão Pública e Desburocratização - GESPÚBLICA e o Comitê Gestor do Programa 
Nacional de Gestão Pública e Desburocratização, e dá outras providências. Brasília, DF, 2005.

Ministério da Administração Federal e Reforma do Estado. Plano diretor da reforma do aparelho do Estado. Brasília: Presidência da República/Câmara da Reforma do Estado/MARE, 1995. 83 p.

Ministério da Administração Federal e Reforma do Estado. A reforma do Estado dos anos 90: lógica e mecanismo de controle. Brasília, MARE/Secretaria da Reforma do Estado, 1997.

- Ministério da Administração Federal e Reforma do Estado. QPAP - Programa da qualidade e participação na administração pública: termo de referência. Brasília, 1998.

Ministério da Economia, Fazenda e Planejamento. Termo de Referência de 26 de junho de 1990. Dispõe sobre o Programa brasileiro de qualidade e produtividade. Brasília: Diário Oficial da União, publicado em 28 de junho de 1990.

- Ministério da Economia, Fazenda e Planejamento. Programa da qualidade no serviço público. Brasília, 1990.

. Ministério da Educação. Lei de diretrizes e bases da educação nacional. Lei n. 9.394, de 20 de dezembro de 1996.

. Ministério do Planejamento, Orçamento e Gestão. Instrumento de avaliação da gestão pública. Brasília, 2000.

- Ministério do Planejamento, Orçamento e Gestão. Secretaria de Gestão. GESPÚBLICA. Programa Nacional de Gestão Pública e Desburocratização. Prêmio Nacional da Gestão Pública - PQGF. Critérios de excelência do Prêmio Qualidade do Governo Federal: instrumento de avaliação. Brasília: Ministério do Planejamento, 2003.

Ministério do Planejamento, Orçamento e Gestão. Secretaria de Gestão. Programa Nacional de Gestão Pública e Desburocratização. - GESPÚBLICA: documento de referência - ciclo 2006. Brasília: MP, GESPÚBLICA, SEGES, 2006. 40 p. (Cadernos GESPÚBLICA, n. $1)$.

Ministério do Planejamento, Orçamento e Gestão. Secretaria de Gestão. Programa nacional de gestão pública e desburocratização. - GESPÚBLICA: Prêmio Nacional da Gestão Pública PQGF. Brasília: MP, GESPÚBLICA, SEGES, 2006. 56 p. (Cadernos GESPÚBLICA, n. 2).

- Ministério do Planejamento, Orçamento e Gestão. Secretaria de Gestão. GESPÚBLICA. Programa Nacional de Gestão Pública e Desburocratização. Prêmio Nacional da Gestão Pública - PQGF. Instrumento para avaliação da gestão pública: ciclo 2006. Brasília: Ministério do Planejamento/Secretaria de Gestão, 2006. 62 p.

Ministério do Planejamento, Orçamento e Gestão. Portal Gestão Pública. Documento de Referência. Brasília: Gespública, 2007.

Ministério do Planejamento, Orçamento e Gestão. Portal Gestão Pública. Disponível em: <http://www.gespublica.gov.br>. Acesso em: 2 abr./2009. 
BRASIL. Presidência da República. Casa Civil. Subchefia para Assuntos Jurídicos. Lei n. 8.078, de 11 de setembro de 1990, de Proteção ao Consumidor. Brasília, DF, 1990.

BRESSER-PEREIRA, L. C. Da administração pública burocrática à gerencial. a reforma do Estado na América Latina e no Caribe. In: SEMINÁRIO INTERNACIONAL A REFORMA DO ESTADO NA AMÉRICA LATINA E NO CARIBE, 1996, Brasília. Anais... Brasília: MARE/BID/ONU, 1996.

Reforma do Estado para a cidadania: a reforma gerencial brasileira na perspectiva internacional. São Paulo: Editora 34; Brasília: ENAP, 1998. 368 p.

; PACHECO, R. S. A Reforma do Estado Brasileiro e o desenvolvimento. Revista Eletrônica sobre a Reforma do Estado, Salvador, n. 3, set./nov., 2005.

; SPINK, P. (Orgs.). Reforma do Estado e administração pública gerencial. 7. ed. Rio de Janeiro: Fundação Getúlio Vargas, 2006. 316 p.

BROWN, M. G. O sistema Baldrige da qualidade. Tradução: Priscila Martins Celeste e Marisa do Nascimento Paro. São Paulo: Makron Books, 1995. 383 p.

BUCCELLI, R. L. Gestão financeira e orçamentária nas universidades estaduais paulistas. In: TOVOLI, E. M.; SEGATTO, J. A; NOGUEIRA, M. A. (Orgs.). Gestão Universitária. Araraquara: Laboratório Editorial/FCL/UNESP; São Paulo: Cultura Acadêmica Editora, p. 91 $-100,2005$.

CARVALHO, M. M.; PALADINI, E. P. (Orgs.). Gestão da qualidade: teoria e casos. Rio de Janeiro: Elsevier, 2005. 355 p.

CARVALHO, M. S. M. V.; TONET, H. C. Qualidade na administração pública. Revista de Administração Pública, Rio de Janeiro, v. 28 n. 2, p. 137-152, abr./jun., 1994.

CHARLE, C.; VERGER, J. História das universidades. São Paulo: Editora da Universidade Estadual Paulista, 1996.

CHAUÍ, M. A Universidade em Ruínas. In: TRINDADE, H. (Org.) Universidade em Ruínas: na república dos professores. Petrópolis, RJ: Vozes / Rio Grande do Sul: CIPEDES, 1999 , p. $211-222$.

A universidade pública sob nova perspectiva. Revista Brasileira de Educação, Rio de Janeiro, n. 24, set./dez., 2003. Disponível em: 〈http://www.scielo $>$. Acesso em: 30/04/2009.

CECAE. Caderno de resumos dos projetos de intervenção educativa. 2o Curso de Especialização Formação de Agentes Locais de Sustentabilidade Sócio-Ambiental. São Paulo: USP CECAE, 2004.

CENTRO LATINOAMERICANO DE ADMINISTRACIÓN PARA EL DESARROLLO CLAD. Uma nova gestão pública para América Latina. 1998. Disponível em: <http://www.clad.Org.ve>. Acesso em: 8/01/2008.

COLLIS, J.; HUSSEY, R. Pesquisa em administração: um guia prático para alunos de graduação e pós-graduação. Tradução: Lucia Simonini. 2. ed. Porto Alegre: Bookman, 2005. 
CONSELHO DE ORIENTAÇÃO TÉCNICA - CONORT. Programa da Qualidade e Produtividade da UNICAMP. Relatório Geral: janeiro 1996 a abril 1998. Campinas: UNICAMP, 1998.

CORTE, M. B. Avaliação institucional de organizações estaduais: método de autoavaliação para a gestão de organizações públicas do ensino fundamental. 2006. Dissertação (Mestrado em Administração)-Universidade Paulista, São Paulo.

COURPASSON, D. Le changement est un outil politique. Revue Française de Gestion, n. 120, p. 24 -36, sept./oct., 1998. Numéro spécial.

CRESWELL, J. W. Research design: qualitative, quantitative and mixed methods approaches. 2. ed. London: Sage, 2002.

CROSBY, P. B. Qualidade é investimento: a arte de garantir a qualidade. Tradução: Áurea Weisenberg. 2. ed. Rio de Janeiro: José Olympio, 1986. 327 p.

CRUZ, H. N. (Coord.). Relatório de Gestão: 1994 - 2001. Coordenadoria de Administração Geral. São Paulo: CODAGE-USP, 2001. 40 p.

A Experiência da Universidade de São Paulo com a autonomia financeira. In: SEMINÁRIO SOBRE REFORMA UNIVERSITÁRIA. Porto Alegre: Universidade Federal do Rio Grande do Sul, 9 junho 2004. 12 p. Mimeografado.

; MIRANDA, O. M. Z.; REGADOS, D. O programa de qualidade e produtividade e o novo modelo de gestão da USP. São Paulo: 2006, mimeografado.

CUNHA, L. A. O ensino superior no octênio FHC. Educação e sociedade, vol. 24, n. 82, Campinas, abr./2003.

CYMBALISTA, M. Gestão pela qualidade e a universidade. In: ENCONTRO DE QUALIDADE E PRODUTIVIDADE DA USP, 1., Anais... São Paulo: Universidade de São Paulo, 1996.

DEAN, J. W.; BOWEN, D. E. Management theory and total quality. Improving research and practice through theory development. Academy of Management Review, v. 19, n. 3, p. 392 418, 1994.

DELPINO, R.; BALZAN, N. C. Educação Superior: a qualidade total em questão. Revista de Avaliação da Educação Superior, ano 12, vol. 12, n. 1, p. 73 - 89, mar./2007.

DEMERS, C.; HAFSI, T.; JORGENSEN, J. Strategic Change: Key Challenges. Apostila de aula: Gestão de Mudança Estratégica, PPGA-UFRGS, out./1996.

DEMING, W. E. Quality, Productivity and Competitive Position. Massachusetts Institute of Technology, 1982.

Qualidade: a revolução da administração. Tradução: Clave Comunicações e Recursos Humanos. Rio de Janeiro: Marques-Saraiva, 1990. 367 p.

DENZIN, N. K.; LINCOLN, Y. O planejamento da pesquisa qualitativa: teorias e abordagens. 2. ed. Porto Alegre: Artmed, 2006. 432 p. 
DOLCI, D. B. A influência das mudanças organizacionais nos sistemas de informação. 2005. Tese (Doutorado)-Escola de Administração, Universidade Federal do Rio Grande do Sul, Porto Alegre, 2005.

DOUCET, C. La qualité. 2. ed. Paris: Presses Universitaires de France, 2007. . (Que sais je?)

DRUCKER, P. F. Introdução à administração. São Paulo: Pioneira, 1984.

EASTERBY-SMITH, M. et al. Pesquisa gerencial em administração: um guia para monografias, dissertações, pesquisas internas e trabalhos em consultoria. São Paulo: Pioneira, 1999.

EISENHARDT, K. M. Building theories from case study research. Academy of Management Review, v. 14, n. 4, p. 532-550, 1989.

FAORO, R. Os donos do poder. Porto Alegre: Globo. São Paulo: EDUSP, 2001.

FALCONI CAMPOS, V. Gerência da qualidade total. Belo Horizonte: Fundação Cristiano Ottoni, 1989.

TQC: controle da qualidade total (no estilo japonês). Belo Horizonte: Fundação Christiano Ottoni/Escola de Engenharia da UFMG, 1992. 230 p.

O verdadeiro poder: práticas que conduzem a resultados revolucionários. Nova Lima: INDG Tecnologia e Serviços Ltda., 2009. 158 p.

FARIA, J. H. Círculos de controle da qualidade. Revista de Administração, São Paulo, v. 19, n. 3, p. 9-16, jul./set., 1984.

FEIGENBAUM, A. V. Controle da qualidade total. São Paulo: Makron Books, 1995.

FERNANDES, A. A.; COSTA NETO, P. O significado do TQM e modelos de implementação. Gestão e Produção, v. 3, n. 2, p. 173-187, ago./1996.

FERNANDES, C. A reforma administrativa no Brasil: oito anos de implementação do Plano Diretor - 1995 - 2002. In: CONGRESO DEL CLAD, 7, 2002, Lisboa. Anais... Lisboa, 2002.

FERRARI; A. D.; DE GRANDI, M. E. Convergência da gestão estratégica para a gestão da qualidade: análise da implementação do novo modelo de gestão do Sistema Integrado de Bibliotecas da Universidade de São Paulo. Monografia. Escola Politécnica/PECE. MBA em Gestão e Tecnologias da Qualidade. São Paulo: USP, 2007.

FERREIRA, Aurélio B. de H. Novo dicionário básico da língua portuguesa. Rio de Janeiro: Nova Fronteira, 1995.

FEY, R.; GOGUE, J. M. La maîtrise de la qualité industrielle. Paris: Les Editions d'organization, 1984.

FLEURY, M. T. L. O desvendar da cultura de uma organização - uma discussão metodológica. In: . Cultura e poder nas organizações. São Paulo: Atlas, 1989, p. $15-27$. 
Cultura organizacional: os modismos, as pesquisas, as intervenções: uma discussão metodológica. Revista de Administração, São Paulo, v. 24, n. 1, p. 3-9, jan. /mar., 1989.

Cultura da Qualidade e mudança organizacional. Revista de Administração de Empresas, São Paulo, v. 33, n. 2, p. 26-34, mar./abr., 1993.

; FISCHER, R. M. Cultura e poder nas organizações. São Paulo: Atlas, 1990.

; FLEURY, A. Aprendizagem e inovação organizacional: as experiências de Japão, Coréia e Brasil. São Paulo: Atlas, 1995.

FOLHA DE SÃO PAULO. Collor lança programa de produtividade. São Paulo, 8 nov./1990. Folha de Economia. Caderno B, p. 16.

FREITAG, M. Le Naufrage de l'Université. Paris: Éditions de La Découverte, 1996.

FUENTES, V. Custos do ensino superior: um ensaio para a Universidade de São Paulo. Tese (Doutorado). Faculdade de Economia, Administração e Contabilidade, Universidade de São Paulo, São Paulo, 1997.

FUNDAÇÃO DO DESENVOLVIMENTO ADMINISTRATIVO - FUNDAP. Pesquisa: estudos da administração pública paulista: perfil dos quadros de direção, assessoramento e assistência técnica. Cadernos FUNDAP, São Paulo, v. 1, n. 1, p. 5-30, jun./1981.

. Um novo Estado para São Paulo: subsídios para um projeto de reforma administrativa. São Paulo: FUNDAP, 1994. 105 p.

FUNDAÇÃO NACIONAL DA QUALIDADE - FNQ. Conceitos fundamentais da excelência em gestão. São Paulo: FNQ, 2006.

Critérios de excelência: o estado da arte da gestão para a excelência do desempenho e para o aumento da competitividade. Prêmio Nacional da Qualidade. São Paulo: FNQ, 2006. $59 \mathrm{p}$.

FUNDAÇÃO PRÊMIO NACIONAL DE QUALIDADE - FPNQ. Critérios de excelência. São Paulo: FNQ, 2003.

Rumo à excelência: critérios para a avaliação de desempenho e diagnóstico organizacional. São Paulo: FNQ, 2005.

GAGLIARDI, P. The creation and change of organizational cultures: a conceptual framework. Organizational Studies, v. 7, n. 2, 1986.

GARVIN, D. A. How the Baldrige award really works. Harvard Business Review, v. 69, n. 6, p. 80-93, Nov./Dec., 1991.

GARVIN, D. A. Gerenciando a qualidade: a visão estratégica e competitiva. Tradução; João Ferreira Bezerra de Souza. Rio de Janeiro: Qualitymark, 1992, 357 p.

GERSICK, C. Revolutionary Change Theories: a multilevel exploration of the punctuated equilibrium paradigm. Academy of Management Review, v. 16, n. 1, 1991. 
GIL, A. Métodos e técnicas de pesquisa social. 5. ed. São Paulo: Atlas, 1999.

Como elaborar projetos de pesquisa. 4. ed. São Paulo: Atlas, 2002.

GODOY, A. S. A pesquisa qualitativa e sua utilização em administração de empresas. Revista de Administração de Empresas, v. 35, n. 4, p. 65-71, jul./ago., 1995.

GODOI, C. K.; BANDEIRA-de-MELLO, R.; SILVA, A. B. (Orgs.). Pesquisa qualitativa em estudos organizacionais: paradigmas, estratégias e métodos. São Paulo: Saraiva, 2006. $460 \mathrm{p}$.

GOODE, W. J. Métodos em pesquisa social. Tradução: Carolina Martuscelli Bori. 7. ed. São Paulo: Nacional, 1979.

HAELSBART, R. Blocos internacionais de poder. São Paulo: Contexto, 1990.

HAHN, N. S. Reforma do setor público em São Paulo: 1995 - 1998. 1998. 154 f. Tese (Doutorado)-Fundação Getúlio Vargas, São Paulo.

HARARI, O. Let's end the program-of-the month syndrome: approaching change as focuses process, not as collage of programs. Management Review. v. 80, n. 8, p. 46, Aug./1991.

HARDY, C.; FACHIN, R. Gestão estratégica na universidade brasileira: teoria e casos. Porto Alegre: Editora da Universidade/UFRGS. 2. ed. 2000, p. 207 -211.

HARRISON, D. Gestion integrale de la qualité: univers des acteurs et contexte d'innovation. Labour/Le Travail, v. 43, p. 147-169, Spring 1999. Disponível em: http://allbusiness.com/management/150171-1.html. Acesso em: 24/01/2008.

HART, C.; SCHLESINGER, L. Total quality management and the human resource professional: applying the Baldrige framework to Human. Human Resource Management, v. 30, n. 4, p. 433-454, Winter 1991.

HAYES, B. E. Medindo a satisfação do cliente: desenvolvimento e uso de questionários. Tradução: Luiz Liske. Rio de Janeiro: Qualimark, 1995, 228 p.

HERZOG, J. People: the critical factor in managing change. Journal of systems management, v. 42, n. 3, p. 6-11, Mar./1991.

HUERTAS, F. O método PES. Entrevista com Matus. Tradução: de Giselda Barroso Sauveur. São Paulo: FUNDAP, 1996, 139 p.

HUEY, J. Nothing is impossible (paradigm shifting). Fortune, v. 124, n.7, p. 90 - 94, 23 Sept./1991.

INSTITUTO NACIONAL DE ESTUDOS E PESQUISAS EDUCACIONAIS ANÍSIO TEIXEIRA - INEP. Resumo Técnico. Censo da Educação Superior 2007. Brasília, DF, 2009.

ISHIKAWA, K. What is total quality control? The Japonese way. New Jersey: Prentice Hall, 1985. $216 \mathrm{p}$. 
JAMBART, C. Gestion de la qualité: la norme ISO 9001:2000 em pratique. Paris: Economica, 2007, 106 p.

JAMES, L. G. Using the criteria and process of the Malcolm Baldrige National Quality award for improving educational institutions. In: SEMINÁRIO INTERNACIONAL DE GESTÃO PELA QUALIDADE EM UNIVERSIDADE, 1997, Santa Catarina, Anais... Santa Catarina: UFSC, 1997. CD-ROM.

JASINKI, J. Atingindo a excelência de desempenho em educação com os critérios do Malcolm Baldrige Institute. In: SEMINÁRIO INTERNACIONAL DA QUALIDADE NA EDUCAÇÃO, 2., 1998, Limeira. Anais... Limeira: Fundação Limeira, 1998.

JICK, T. D. Mixing qualitative and quantitative methods: triangulation in action. Administrative Science Quarterly, v. 24, p. 602-611, Dec./1979.

JORNAL DA USP. Um programa para motivar a criatividade, n. 350, p. 3, 1996.

JUDSON, A. S. Relações humanas e mudanças organizacionais. 3. ed. São Paulo: Atlas, 1980.

JURAN, J. M.. Product quality: a prescription for the West. Part I: training and improvement programs. Product Quality Management Review, v. 70, n. 6, p. 9 - 14, June/1981.

. Product quality: a prescription for the West. Part II: upper-management leadership and employee relations. Product Quality Management Review, v. 70, n. 7, p. 57-61, July/ 1981.

Planejamento para a qualidade. São Paulo: Pioneira, 1990.

. A qualidade desde o projeto: os novos passos para o planejamento da qualidade em produtos e serviços. São Paulo: Pioneira, 1992.

Pioneira, 1993.

Juran na liderança pela qualidade. Tradução: João Mário Csillag. 2. ed. São Paulo:

. Qualidade no século XXI. HSM Management, n. 3, p. 96-104, jul./ago., 1997.

KUHN, T. S. A estrutura das revoluções científicas. São Paulo: Perspectiva, 2003.

LAWRENCE, P.; LORSCH, J. O desenvolvimento de organizações: diagnóstico e ação. Tradução: Meyer Stilman. São Paulo: Edgard Blücher, 1972.

LAKATOS, E. M.; MARCONI, M. A. Fundamentos de metodologia científica. 6. ed. São Paulo: Atlas, 2005.

LEFRÈVE, F.; LEFRÈVE, A. M. C. Discurso do sujeito coletivo. Caxias do Sul: EDUCS, 2003, $256 \mathrm{p}$.

LEITE, M. G. Qualidade no setor público: uma alternativa sistematizada de implantação. São Paulo: Empresas \& Tendências, p. 25 - 27, set./1994. 
LEITE, N. P. Comprometimento e gestão de pessoas em empresas brasileiras com estruturas organizacionais remotas. 2008. Tese (Doutorado). Departamento de Administração da Faculdade de Economia, Administração e Contabilidade. Universidade de São Paulo.

LEVY, E.; DRAGO, P. A. (Orgs.). Gestão pública no Brasil contemporâneo. São Paulo: FUNDAP/Casa Civil, 2005, 448 p.

LIMA, P. D. B. As Instituições como fator de mudança na reforma do aparelho do Estado no Brasil. 1999. Dissertação (Mestrado)-Universidade de Brasília.

Excelência em gestão pública: a trajetória e a estratégia do gespública. Rio de Janeiro: Qualimark, 2007, 248 p.

LIMONGI-FRANÇA, A. C. Indicadores empresariais de qualidade de vida no trabalho: esforço empresarial e satisfação dos empregados no ambiente de manufaturas com certificação ISO 9000. 1996. 246 f. Tese (Doutorado)-Faculdade de Economia, Administração e Contabilidade. Universidade de São Paulo.

Interfaces da qualidade de vida no trabalho na administração de empresas. 2001. 247 f. Tese (Livre Docência). Faculdade de Economia, Administração e Contabilidade. Universidade de São Paulo.

$139 \mathrm{p}$.

Comportamento organizacional: conceitos e práticas. São Paulo: Saraiva, 2006.

Práticas de recursos humanos: conceitos, ferramentas e procedimentos. São Paulo: Atlas, 2007. $267 \mathrm{p}$.

MACEDO, A. R. Os desafios da universidade brasileira neste início de século. Revista de Cultura IMAE, ano 5, n.13, p. 33 - 37, jan./jun., 2005.

MALCOLM BALDRIGE NATIONAL QUALITY AWARD. Education pilot criteria. Milwaukee: American Society for Quality Control, 1995.

MARCOVITCH, J. A universidade (im)possível. São Paulo: Futura, 1998, 182 p.

MARTINS, G. A. Estudo de caso: uma estratégia de pesquisa. São Paulo: Atlas, 2006, 101 p.

MARTINS, H. F. Uma análise dos paradigmas de administração pública à luz do contexto do estado social. Revista de Parcerias Estratégicas, ano 1, v. 1, maio/1996.

O plano gestão pública para um Brasil de todos: em busca de uma nova geração de transformação da gestão pública. In: CONGRESSO INTERNACIONAL DEL CLAD SOBRE LA REFORMA DEL ESTADO Y DE LA ADMINISTRACIÓN PÚBLICA, 8, Anais... Panamá, 2003.

MARTINS, L. Reforma da administração pública e cultura política no Brasil: uma visão geral. Texto para discussão. Brasília: MARE/ENAP, 1997, 61 p. 
MARTINS, R. A.; TOLEDO, J. C. Proposta de modelo para elaboração de programas de gestão para a qualidade total. Revista de Administração, v. 33, n. 2, p. 52-59, abr./jun., 1998.

MATTAR, N. J. A. Metodologia científica na era da informática. São Paulo: Saraiva, 2002.

MAURÍCIO, B. M. Escola de Administração da UFBA: a trajetória de um centro de referência nacional. 2004. Dissertação (Mestrado). Universidade Federal da Bahia.

MAXIMIANO, A. C. Teoria geral de administração. 3. ed. São Paulo: Atlas, 2002.

MEDAUAR, O. Direito administrativo moderno. Revista dos Tribunais, p. 440, 2. ed. rev. e atual, 1998.

MEIRELLES, H. L. Direito administrativo brasileiro. 18. ed. São Paulo: Malheiros, 1993.

MELO, R; MACEDO, R; MEDEIROS, D. A adoção da gestão de mudanças para a implementação da melhoria contínua da qualidade. In: ENCONTRO NACIONAL DE ENGENHARIA DE PRODUÇÃO - ENEGEP, 28., Rio de Janeiro. Anais... Rio de Janeiro, 2008.

MERTON, R. Sociologia: teoria e estrutura. São Paulo: Mestre Jou, 1970.

MEYER, V. Considerações sobre o planejamento estratégico na universidade. In: FINGER, A.P. (Org.). Universidade: organização, planejamento, gestão. Florianópolis: UFSC/NUPEAU, 1988, 88p.

MINTZBERG, H. Estrutura e dinâmica das organizações. 2. ed. Lisboa: Publicações Dom Quixote, 1999, 533 p.

Criando organizações eficazes: estruturas em cinco configurações. Tradução: Ciro Bernardes. São Paulo: Atlas, 1995.

AHLSTRAND, B.; LAMPEL, J. Safari de estratégia: um roteiro pela selva do planejamento estratégico. Tradução: Nivaldo Montigelli Jr. Porto Alegre: Bookman, 2000.

MIGUEL, P. A. C. A Report on comparing quality and business excellence awards: part 1: systems of operations, core values and assessment criteria. Gaithersburg: National Institute of Standards and Technology/Baldrige National Quality Program, 2004.

. Comparing the Brazilian national quality award with some of the major prizes. The TQM Magazine, v. 13, n. 4, p. 260-272, 2001.

MOLLER, C. O lado humano da qualidade: maximizando a qualidade de produtos e serviços através do desenvolvimento das pessoas. Tradução: Nivaldo Montingelli Jr. 10. ed. São Paulo: Pioneira, 1996, 185 p.

MONTANA, P. J.; CHARNOV, B. H. Administração. Tradução: Robert Brian Taylor; revisão técnica: Reinaldo O. da Silva. São Paulo: Saraiva, 1999. 
MORGAN, G. Imagens da organização. Tradução: Cecília Whitaker Bergamini e Roberto Coda. São Paulo: Atlas, 2006.

MORGAN, J. S. Administração da mudança: as estratégias para tirar proveito da mudança. Tradução: José Ricardo Brandão Azevedo. Rio de Janeiro: Zahar, 1976.

MOTTA, P. R. Transformação organizacional: a teoria e a prática de inovar. Rio de Janeiro: Qualitymark, 1998.

NOGUEIRA, M. A. Sofrimento organizacional, democracia e gestão universitária. In: TOVOLI, E. M.; SEGATTO, J. A; NOGUEIRA, M. A. (Orgs.). Gestão Universitária. Araraquara: Laboratório Editorial/FCL/UNESP. São Paulo: Cultura Acadêmica, p. 19-67, 2005.

OBADIA, I. J.; VIDAL, M. C. R; MELO, P. F. F. Uma abordagem adaptativa de intervenção para mudança organizacional. Gestão da Produção, São Carlos, v. 14, n. 1, p. 125-138, jan./abr., 2007.

OKUMUS, F. A framework to implement strategies in organizations. Management Decision, v. 41, n. 9, 2003, p. 871 - 882. Disponível em: <http://www.emeraldinsight.com. Acesso em: $14 / 05 / 2008$.

OSBORNE, D.; GAEBLER, T. Reinventando o governo: como o espírito empreendedor está transformando o setor público. Tradução: Sérgio Bath e Ewandro Magalhães Júnior. Brasília: MH Comunicação, 1994.

OUCHI, W. Teoria Z: como as empresas enfrentam o desafio japonês. Tradução: Auriphebo Berrance Simões. 10. ed. São Paulo: Nobel, 1986, 293 p.

PETTIGREW, A. M. Context and action in the transformation of the firm. Journal of Management Studies, v. 24, n. 6, p. 649-670, nov./1987.

A Cultura da organização é administrável? In: FLEURY, M. T.; FISCHER, R. M. Cultura e poder nas organizações (coordenadoras). São Paulo: Atlas, 1990, p. 145-153.

.On studying organizational cultures. Administrative Science Quarterly, v. 24, p.570 - 581, Dec./1979.

.The character and significance of strategy process research. Strategic Management Journal, v. 13, p. 5 - 16, 1992.

PICHAULT, F.; NIZET, J. Les pratiques de gestion des resources humaines. Paris: Éditions du Seuil, 2000, 333 p.

PINTO, T. J. A.; VITOLO, M.; TENUTA FILHO, A.; MARDEGAN, Y. M. Sistema de gestão ambiental. Rio de Janeiro: Guanabara Koogan, 2009.

PRZEWORSKI, A. On the design of the State: a principal-agent perspective. In: SEMINÁRIO REFORMA DO ESTADO NA AMÉRICA LATINA E NO CARIBE, 1996, Brasília. Anais... Brasília: Ministério da Administração e Reforma do Estado/Banco Interamericano de Desenvolvimento/Organização das Nações Unidas, 1996. 
QUINN, J. B. Strategies for change: logical incrementalism. USA: Richard D. Irwin, 1980.

REEVES, C. A.; BEDNAR, D. Defining quality: alternatives and implications. Academy of Management Review, v. 19, n. 3, p. 419-445, 1994.

REZENDE, F. C. A nova gestão pública, performance e reinvenção das instituições: um desafio para a Reforma do Estado. Revista Reforma Gerencial, n.4, p. 27-28, nov./ 1998.

Por que reformas administrativas falham? RBCS, v.17, n. 50, p. 123-142, out./2002.

RICHARDSON, R. J. et al. Pesquisa social: métodos e técnicas. 3. ed. São Paulo: Atlas, 1999, 334 p.

ROBBINS, S. P. O processo administrativo: integrando teoria e prática. São Paulo: Atlas, 1981.

Mudança organizacional e administração do estresse. Comportamento organizacional. Rio de Janeiro: LTC, 1999, p. 394-423.

; COULTER, M. Administração. Rio de Janeiro: PHB, 1998.

ROMANELLI, O. O. História da educação no Brasil: 1930 - 1973. 24. ed. Rio de Janeiro: Vozes, 2000.

ROSENBERG, G. Desempenho global da Fundação Osvaldo Cruz: um instrumento de auto-avaliação. 2002. Dissertação (Mestrado)-Universidade Federal do Rio de Janeiro.

SAIDEL, M. A.; FAVATO, L. B. Gestão pública de energia elétrica: programa permanente para o uso eficiente de energia elétrica na USP. In: CONGRESSO BRASILEIRO DE EFICIÊNCIA ENERGÉTICA - CBEE, 2007. Anais eletrônicos... Disponível em: <http://www.pure.usp.br>. Acesso em: 28/11/2009.

SAINSAULIEU, R. L'identité au travail: les effects de l'organisation. PARIS: Fondation Nationale des Sciences Politiques, 1997.

SANT'ANA, E. D.; PIFFER, M. I. Desburocratização da administração pública: uma experiência na área de ensino superior. Artigo de Conclusão de Curso MBA - Gestão de Operações, Produtos e Serviços. Fundação Carlos Alberto Vanzolini, São Paulo, 2006.

SANTANA, A. A reforma do Estado no Brasil: estratégia e resultados. In: CONGRESSO INTERNACIONAL DEL CLAD SOBRE LA REFORMA DEL ESTADO Y DE LA ADMINISTRATION PUBLICA, 7., Lisboa. Anais... Lisboa, 2002.

SANTANA, M. W. A administração pública e seus modelos: também modismos? Conjuntura e Planejamento, n. 134, p. 38-47, jul./2005.

SÃO PAULO. (Estado). Decreto n. 29.598/1989. Dispõe sobre providências visando a autonomia universitária. São Paulo: Diário Oficial, v. 99, n. 23, 03/02/89.

Decreto n. 40.536, de 12/12/1995. Institui o Programa Permanente de Qualidade e Produtividade no Serviço Público. São Paulo: Diário Oficial, v. 105, n. 237, 13/12/1995. 
SÃO PAULO (Estado) Grupo Executivo da Qualidade e Produtividade. Manual de orientação do Programa Permanente da Qualidade e Produtividade no Serviço Público. São Paulo: FUNDAP, 1996. 48 p.

(Governo). Fundação do Desenvolvimento Administrativo, v. 1, n. 1, jun./ 2004, $41 \mathrm{p}$.

SARAPH, J. V; BENSON, P. G.; SCROEDER, R. G. An instrument for measuring the critical factors of quality management. Decision Sciences, v. 20, n. 4, p. 810-829, Fall/1989.

SCHEIN, E. H. Coming to a new awareness of organizational culture. Sloan Management Review, v. 25, n. 2, p. 3-16, winter/1984.

SCHEIN, E. H. Organizational culture and leadership. 2. ed. California: Jossey-Bass, 1992.

SCHWARTZMAN, S. O ensino superior no Brasil - 1998. Brasília: INEP, 1998.

Os desafios da educação no Brasil. In: SCHWARTZMAN, S.; BROCK, C. (Orgs.). Os desafios da educação no Brasil. Tradução: Ricardo Silveira. Rio de Janeiro: Nova Fronteira, 2005, p. 9 - 51.

A Universidade de São Paulo e a questão universitária no Brasil. In: STEINER, J. E.; MALNIC, G. (Orgs.). Ensino Superior: conceito e dinâmica. São Paulo: Editora da Universidade de São Paulo, 2006, p. 25 - 40.

SCHWELL, E. Inovação no governo e no setor público: desafios e implicações para a liderança. Revista do Serviço Público, v. 56, n. 3, p. 259-276, jul./set., 2005.

SCROFERNEKER, C. M. A. Os (Des) caminhos da comunicação na implantação do programa de qualidade total na universidade brasileira. 2000. Tese (Doutorado) -Escola de Comunicação e Artes. Universidade de São Paulo.

SELLTIZ, C.; WRIGHTSMAN, L. S.; COOK, S. W.; KIDDER, L. H. Métodos de pesquisa nas relações sociais. 2. ed. São Paulo: EPU, 2005.

SHEWHART, W. A. Les fondements de la maîtrise de la qualité. Tradução e apresentação: Jean Marie Gogue. Paris: Economica, 1989.

SHIBA, S. et al. TQM: quatro revoluções na gestão da qualidade. Porto Alegre: Artes Médicas, 1997.

SILVA FILHO, R. L. L. Autonomia das universidades públicas. In: Ensino Superior: conceito \& dinâmica. São Paulo: EDUSP, 2006.

SPINK, P. K. Continuidade e descontinuidade em organizações públicas: um paradoxo democrático. Cadernos FUNDAP, v. 7, n. 13, p. 57-65, abr./1987.

STAKE, R. Case Studies. In: DENZIN, N.; LINCOLN, K.; YVONNA, S. Strategies of Qualitative Inquiry. 2. ed. Thousand Oaks: Sage Publications, 2003. 
STEVANATO, L. A. Um estudo sobre as influências do programa de qualidade sobre a cultura da organização. 1997. Dissertação (Mestrado em Administração de Empresas)Faculdade de Economia, Administração e Contabilidade. Universidade de São Paulo.

TARAGANO, J. Qualidade em organizações educacionais: uma nova proposta de critérios de avaliação. 1996. Dissertação (Mestrado)-Universidade Mackenzie, São Paulo.

TAYLOR, F. W. Princípios de administração científica. Tradução: Arlindo Vieira Ramos. 7. ed. São Paulo: Atlas, 1987, 137 p.

TEIXEIRA, H. J.; SANTANA, S. M. Remodelando a gestão pública. São Paulo: Edgard Blücher, 1994.

TEIXEIRA, H. J.; SALOMÃO, S. M.; TEIXEIRA, C. J. Fundamentos de administração: a busca do essencial. Rio de Janeiro: Elsevier. 2010, 346 p

TELLES, R. A efetividade da "Matriz de Amarração", de Mazzon nas pesquisas em administração. Revista de Administração da USP, v. 36, n. 4, p. 64-72, out./dez, 2001.

THÉVENET, M. A cultura de empresa hoje em dia. Revista de Administração, v. 26, n. 2, p. 32-39, abr./jun., 1991.

THIOLLENT, M. Metodologia de pesquisa-ação. 12. ed. São Paulo: Cortez, 2003.

TOLEDO, J. C. CCQ: círculos de controle de qualidade. Informática \& Administração, p. 12-20, 1984.

TOLOVI JR., J. Por que os programas de qualidade falham? RAE, v. 34, n. 6, p. 6-11, nov./dez., 1994.

. Os novos paradigmas da administração. RAE Ligth, maio/jun., 1995. Suplemento.

TORQUATO JR., S.; ARAÚJO, M. A. D. Avaliação do programa 5 "S" em uma instituição de Ensino. Revista de Gestão USP, v. 15, p. 79-97, abr./jun., 2008.

TRIVIÑOS, A. N. S. Introdução à pesquisa em ciências sociais. São Paulo: Atlas, 1987, $175 \mathrm{p}$.

TURCHI, L. M. Qualidade total: afinal do que estamos falando? Texto para Discussão. Brasília: IPEA, n. 459, fev./1997.

UNESP. Plano de desenvolvimento institucional. VOORWALD, H. J. C. (Coordenador). São Paulo: UNESP, 2009.

- Programa permanente de gestão da qualidade UNESP. A busca contínua da excelência. Caderno 1. São Paulo: UNESP, 1998.

UNIVERSIDADE DE SÃO PAULO. Comissão de Gestão da Qualidade e Produtividade da USP. Programa permanente de qualidade e produtividade da USP. São Paulo: USP, 1997. v.1: Relatório de atividades de 1996. 
UNIVERSIDADE DE SÃO PAULO. Comissão de Gestão da Qualidade e Produtividade da USP. Programa permanente de qualidade e produtividade da USP. São Paulo: USP, 1997. v.2:. Trabalho em equipe: Relatório de Consolidação de Resultados: Trabalho em Equipe.

Comissão de Gestão da Qualidade e Produtividade da USP. Programa permanente de qualidade e produtividade da USP. São Paulo: USP, 1997. v.3: Questionário para mapeamento de características da qualidade e produtividade.

. Comissão de Gestão da Qualidade e Produtividade da USP. Programa permanente de qualidade e produtividade da USP. São Paulo: USP, 1998. v.4: Relatório Anual de Atividades de 1997.

. Comissão de Gestão da Qualidade e Produtividade da USP. Programa permanente de qualidade e produtividade da USP. São Paulo: USP, 2001. v.5: 8o Encontro de Qualidade e Produtividade. Palestras Apresentadas.

. Comissão de Gestão da Qualidade e Produtividade da USP. Programa permanente de qualidade e produtividade da USP. São Paulo: USP, 2001. v.6: Iniciativas de Qualidade na USP: 1996 a 2001.

. Comissão de Gestão da Qualidade e Produtividade da USP. Programa permanente de qualidade e produtividade da USP. São Paulo: USP, 2001. v.7: Balanço Geral. Seis anos de atividades: 1996 - 2001.

Comissão de Gestão da Qualidade e Produtividade da USP. Programa permanente de qualidade e produtividade da USP. CRUZ, H. N.; MIRANDA, O. M. (Orgs.). São Paulo: USP, 2005. v.8. Uma década do Programa de Qualidade e Produtividade na USP: 1996 $-2005.56 \mathrm{p}$.

. Estatuto. Secretaria Geral da USP (Org.). 4. ed. revista e atualizada. São Paulo: USP, 2005. $90 \mathrm{p}$.

Portaria GR n. 2.985, de 29/01/1996. Institui na USP a Comissão de Gestão de Qualidade e Produtividade. São Paulo: D.O.E., 01/02/1996.

Portaria GR n. 3.673, de 09/03/2006. Modifica a Portaria GR 2985 de 29/01/1996, que instituiu na USP a Comissão de Gestão de Qualidade e Produtividade. São Paulo: D.O.E., $11 / 03 / 2006$.

Portaria GR n. 3735, de 23/02/2007. Institui o Programa de Gestão Estratégica e Desburocratização na Administração da USP - GESPÚBLICA USP. São Paulo: D.O.E., 24/02/2007.

Programa Permanente de Qualidade e Produtividade. Comissão Interna de Qualidade e Produtividade da Reitoria. Quadriênio do Programa de Qualidade e Produtividade da Reitoria: 2002-2005. Olga Miranda (Coord.). São Paulo: Comissão Interna de Qualidade e Produtividade da Reitoria, 2005, 54 p.

. USP 1993 - 1997. Relatório da gestão do Reitor Flávio Fava de Moraes. São Paulo: CCS, 1997. 
UNIVERSIDADE DE SÃO PAULO. Comissão Permanente de Avaliação. O processo de avaliação institucional da Universidade de São Paulo 2003-2005. São Paulo: CPA, 2005. $123 \mathrm{p}$.

. Relatório de Gestão USP: 2005 - 2009. São Paulo: 2009, 144 p.

. Relatório de Gestão 2001 - 2005. Vice-Reitoria. São Paulo: CCS, 2005.

UNIVERSIDADE ESTADUAL DE CAMPINAS. Coordenadoria Geral da Universidade. Avaliação institucional 2004-2008: formulário para avaliação interna. Campinas: Unicamp, 2008, 49 p.

VERGARA, S. C. Métodos de pesquisa em administração. 3. ed. São Paulo: Atlas, 2008.

VOKURKA, R.; STADING, G. L.; BRAZEAL, J. A. Comparative analysis of national and regional quality awards. Quality Progress, v. 33, n. 8, p. 41-49, 2000.

YIN, R. K. Estudo de caso: planejamento e métodos. Tradução: Daniel Grassi. 3. ed. Porto Alegre: Bookman, 2005, 212 p.

YOSHINO, M. Japan's managerial system: tradition and innovation. Massachusetts: MIT Press, 1968, 292 p.

WOOD JR., T. (Coord.). Mudança organizacional. 4. ed. São Paulo: Atlas, 2004, 334 p.

ZACARELLI, S. Comentários sobre o trabalho de Peter Blau. RBAE, n.2, v. 2, p. 29-30, jul./dez., 1984. 

APÊNDICES 



\section{APÊNDICES}

A Modelos de Roteiro de Entrevista Semiestruturada

A1 - Tipo 1: Docentes

A2 - Tipo 2: Técnicos Administrativos

B Linha do Tempo: Atividades do Programa de Qualidade e Produtividade:

$1996-2006$

B1 - Atividades da USP

B2 - Unidades e Órgãos

C Programação dos Encontros de Qualidade e Produtividade da USP: 1996 - 2006

D Publicações ligadas ao Programa de Qualidade e Produtividade: 1996 - 2006

E Levantamento de artigos de Jornal da USP sobre o Programa de Qualidade e Produtividade: 1996 - 2007

F Monografias de funcionários USP do curso de MBA de Gestão e Tecnologias da Qualidade da Escola Politécnica/PECE: 2004 - 2008. 

APÊNDICE A

Modelos de Roteiro de Entrevista Semiestruturada:

A1 - Tipo 1: Docentes

A2 - Tipo 2: Técnicos Administrativos 



\title{
APÊNDICE A1 Modelo de Roteiro de Entrevista Semiestruturada:
} Tipo 1:- Docentes \\ 01-A Unidade na sua gestão aderiu ao Programa de Qualidade da USP? Por quê? \\ 02-O que se esperava do Programa em linhas gerais, como conteúdo? \\ 03-A qualidade de vida no trabalho (QVT) estava incluída nesse conteúdo? \\ 04-O que significava para você QVT? \\ 05-Qual era o contexto (interno/externo) da Unidade na época? \\ 06-Como foi o modelo de implantação do processo de qualidade na Unidade? \\ 07-Como se lembra da receptividade interna ao Programa de Qualidade? \\ 08-Havia recursos financeiros alocados para o Programa? \\ 09-Se sim, era alguma porcentagem específica do orçamento? \\ 10-Foi delineada uma estrutura administrativa para sustentá-lo? \\ 11-Havia um poder decisório definido para o Programa? \\ 12-Existiam áreas específicas envolvidas no Programa? \\ 13-Existiam funcionários especialmente envolvidos com as atividades da Qualidade? \\ 14-Havia métodos para identificar necessidades de melhorias na Unidade? \\ 15-Existiam atividades formais denominadas ou vindas do Programa de Qualidade? \\ 16-Existia um controle ou monitoramento dos resultados das atividades do Programa de Qualidade? \\ 17-Existiam indicadores de produtividade na Unidade? \\ 18-Cite 3 experiências positivas que ocorreram na sua Unidade, em função do programa de Q\&P. \\ 19-Como Você explica a diferença de adesão ao Programa de Q\&P entre as Unidades da USP? \\ 20-O Programa de Qualidade é um Programa típico de longo prazo. Como lidar com este fato na \\ Unidade, que troca o comando a cada 4 anos. \\ 21-Pensaria hoje em fazer algo diferente do que foi feito no Programa de Qualidade da Unidade? \\ Se sim, em que aspectos? \\ 22-Que conceito daria para o Programa na Unidade na sua gestão?
(1) Excelente
(2) Bom
(3) Regular
(4) Insuficiente \\ 23-O Senhor acompanhou o Programa após sair da Unidade? \\ (1) Não 2 Sim - 23-a-Que conceito daria para o Programa na Unidade na gestão seguinte a sua?

$$
\begin{aligned}
& \text { (1) Excelente } 2 \text { Bom } 3 \text { Regular } \quad \text { 4) Insuficiente } \\
& \text { 23-b-Que conceito daria para o Programa na Unidade na gestäo atual? } \\
& \begin{array}{llll}
\text { 1) Excelente } & \text { 2) Bom } & \text { 3) Regular } & \text { 4) Insuficiente }
\end{array}
\end{aligned}
$$

24-O que foi o Programa de Q\&P para sua gestão? Tem valor/impacto para a Unidade e para a USP? Para o governo? Para a sociedade? De que natureza? Onde? Como? Explique.

25-O próprio governo estadual desarticulou o Programa de Qualidade após algum tempo. Como o Senhor vê isso?

Outros comentários: 



\section{APÊNDICE A2 Modelo de Roteiro de Entrevista Semiestruturada:} Tipo 2: Técnicos Administrativos

\section{PESQUISA: PROGRAMA DE QUALIDADE NA USP}

$\begin{aligned} & \text { Pesquisa Acadêmica - Olga Miranda - FEA-USP } \\ & \text { Para obtenção do título de Doutor em Administração-2008 }\end{aligned}$
$\begin{aligned} & \text { ENTREVISTADO: } \\ & \text { Tel: }\end{aligned}$

Roteirode Perguntas

Bloco-1 - Programa de Qualidade e Produtividade

01-A sua Unidade atual aderiu ao Programa de Qualidade da USP? Por quê?

02-O que se esperava do Programa em linhas gerais, como conteúdo?

03-A qualidade de vida no trabalho (QVT) estava incluída nesse conteúdo?

04-O que significava para você QVT?

05-Qual era o contexto (interno/externo) da Unidade no início do Programa?

06-Como foi o modelo de implantação do processo de qualidade na Unidade?

07-Como se lembra da receptividade interna ao Programa de Qualidade?

08-Havia recursos financeiros alocados para o Programa?

o9-Se sim, era alguma porcentagem específica do orçamento?

10-Foi delineada uma estrutura administrativa para sustentar o Programa de Qualidade e Produtividade?

11-Havia um poder decisório definido para o Programa?

12-Existiam áreas específicas envolvidas no Programa?

13-Existiam funcionários especialmente envolvidos com as atividades da Qualidade?

De que nivel (superior; técnico; básico)? De que funções?

14-Havia métodos para identificar necessidades de melhorias na Unidade?

15-Existiam atividades formais denominadas ou vindas do Programa de Qualidade?

16-Existia um controle ou monitoramento dos resultados das atividades do Programa de Qualidade?

17-Existiam indicadores de produtividade na Unidade?

18-Cite 3 experiências positivas que ocorreram na sua Unidade, em função do programa de Q\&P.

18.1-Cite 3 experiências negativas que ocorreram na sua Unidade ou na USP, em função do programa de Q\&P.

19-Como Você explica a diferença de adesão ao Programa de Q\&P entre as Unidades da USP?

20-O Programa de Qualidade é um Programa típico de longo prazo. Como lidar com este fato na

Unidade, que troca o comando a cada 4 anos.

21-Pensaria hoje em fazer algo diferente do que foi feito no Programa de Qualidade da Unidade? Se sim, em que aspectos?
22-Que conceito daria para o Programa na Unidade de 1996 a 2001 ?
1) Excelente
(2) Bom
(3) Regular
(4) Insuficiente
(5. Não estava aqui
6. Não Sei

23-Que conceito daria para o Programa na Unidade de 2001 a 2005 ?
1) Excelente
2. Bom
(3) Regular
(4.) Insuficiente
(5) Não estava aqui
6. NãoSel

24-Que conceito daria para o Programa na Unidade de 2006 a 2008 ?
(1) Excelente
(2) Bom
(3) Regular
4. Insuficiente
(5) Não estava aqui
6 NãoSei 
25-O que tem sido o Programa de Q\&P para a Unidade? Tem valor/impacto para a Unidade e para a USP? Para o governo? Para a sociedade? De que natureza? Onde? Como? Explique.

26-O governo estadual desarticulou o Programa de Qualidade após algum tempo. Como Você vê isso? 27-O que foi o Programa para você do ponto de vista pessoal e profissional?

\section{Bloco-2 - Atividades de Treinamento/Desenvolvimento}

28-Você teve cursos / treinamento especificos da área de qualidade

$$
\text { (1) Não } 2 \text { Sim }
$$

29-Cursos de treinamento em qualidade foram oferecidos pela:
(1) Reitoria
(2) Unidade
(3.) Fora da unidade
(4) Fora da USP
(5) Presencial
6. à Distância

30-Se desejar, faça algum comentário sobre atividades de treinamento/desenvolvimento

Bloco-3 - Participação na Comissão de Qualidade e Produtividade da Unidade ou atividades de qualidade:

31-Como você classifica sua participação junto à Comissão de Qualidade e Produtividade ou nas atividades de qualidade da Unidade:

(1) Contínua 2. Intermitente (3) Em vários projetos 4) Em um projeto 5 Muito rara 6 Não participei 32-Se participa: quais são as atividades na área da qualidade que você costuma participar (descritiva):

\section{Bloco-4 - Aprendizagem}

33-Como você avalia sua aprendizagem pessoal com as atividades da Qualidade:
1 Muita
2. Regular
3) Baixa
(4) Não houve

34-Como se deu essa aprendizagem pessoal (descreva)

35-Como você avalia a aprendizagem organizacional, da Unidade ou da USP, com as atividades da Qualidade:

$$
\text { (1) Muita } 2 \text { Regular } 3 \text { Baixa Näo houve }
$$

36-Como se deu essa aprendizagem organizacional (descreva)

\section{Bloco-5 - Competência}

37-Em geral, como você avalia hoje a competência pessoal dos funcionários, em relação há dez anos atrás

$$
\text { (1) Melhor } 2 \text { Igual } 3 \text { Pior seidizer }
$$

38-Como e onde você identifica essa situação (descreva):

39-Em geral, como você avalia hoje a competência organizacional (na entrega de melhores serviços), em relação há dez anos atrás:

$$
\text { 1) Meihor } 2 \text { Igual } \text { Pior Não sei dizer }
$$

40-Como e onde você identifica essa situação (descreva):

\section{Bloco-6 - Participação em tomada de decisões}

41-De modo geral, desde que está na USP a sua participação na tomada de decisões administrativas de sua Unidade:

$$
\text { (1) Aumentou } 2 \text { é a Mesma 3) Diminuiu }
$$

42-Quais são as atividades que você costuma desenvolver quando se sente participando na tomada de decisão (descritiva) 


\section{Bloco-7 - Interação entre funcionários}

43-De modo geral, a interação entre funcionários dentro da Unidade, desde que está na USP

(1) Aumentou 2.É a mesma 3 Diminuiu

44-De modo geral, a interação entre os funcionários da USP, desde que está na Universidade:

1) Aumentou 2. É a mesma 3) Diminuiu

45-Quais são as atividades que você identifica de interação entre funcionários (descritiva)

\section{Bloco-8 - Qualidade de Vida no Trabalho}

46-De modo geral, desde que você está na USP, as atividades de Qualidade de Vida no Trabalho:

1) Aumentaram 2São as mesmas (3) Diminuiram

47-Quais são as atividades que você identifica como de Qualidade de Vida no Trabalho (descritiva)

\section{Bloco-9 - Participação no GESPÚBLICA}

48-Como você classifica sua participação junto ao Programa GESPÚBLICA:

(1) Contínua 2) Intermitente 3 Em vários projetos (4) Em um projeto 5 Muito rara 6 Não participei 49-Se participa: em quais atividades você costuma participar no GESPÚBLICA (descritiva)

Bloco-10 - Identificação

50-Unidade:

52-Sexo (1) Masculino (2) Feminino

53-Idade
55-Cargo de Supervisão

1. Não 2: Sim-56-Qual o nº de Subordinados?

\section{4-Função}

51-Departamento Divisão-Seção

57-Quantos anos tem de vida profissional ativa? (anos)

58-Há quanto tempo trabalha na USP? (anos)
59-Há quanto tempo trabalha nesta unidade? (anos)
6o-Há quanto tempo atual? (anos) esta na função
61-Já trabalhou em outra unidade da USP

1) Não 2 Sim-62-Qual
63 - Grau de Instrução
(1) Ensino Fundamental
4. Especialização 65-Qual
(2. Ensino Médio
5. Mestrado 66-Qual
3 Ensino Superior 64-Qual
6. Doutorado 67-Qual 



\section{APÊNDICE B}

B Linha do Tempo: Atividades do Programa de Qualidade e Produtividade: 1996-2006.

B1 Linha do Tempo: Atividades do Programa de Qualidade e Produtividade da USP: 1996-2006.

B2 Linha do Tempo: Unidades e Órgãos da USP

Para a compreensão das muitas atividades que foram empreendidas pelo Programa de Qualidade e Produtividade da USP são elencadas, na sequência, Linhas do Tempo, distribuídas cronologicamente por ano, de 1996 a 2006, com fatos relevantes de sua história.

O APÊNDICE B1 apresenta atividades da USP, compreendidas ações da:

1. Comissão de Gestão de Qualidade e Produtividade da USP;

2. Comissão de Qualidade da Reitoria e

3. Programas Institucionais.

O APÊNDICE B2 elenca atividades das Unidades e Órgãos da USP, apresentadas para os mesmos anos, conforme data de ocorrência.

As fontes utilizadas para esse levantamento foram publicações e pesquisas de monitoramento (2000, 2002 e 2004) da Comissão de Gestão de Qualidade e Produtividade da USP e Relatórios das Unidades e Órgãos da USP. 

APÊNDICE B1 -

\section{Linha do Tempo: Atividades do Programa de Qualidade e Produtividade da USP: 1996-2006}

\begin{tabular}{|l|l|}
\hline \multicolumn{2}{|c|}{1995} \\
\hline Governador do Estado: Mário Covas \\
\hline Antecedentes & $\begin{array}{l}\text { Sensibilização. Lançamento pelo Governo do Estado de São Paulo, do } \\
\text { Programa de Qualidade, com participação da alta administração do Governo do } \\
\text { Estado de São Paulo (12/12). }\end{array}$ \\
\hline $\begin{array}{l}\text { DEMINÉRIO } \\
\text { LEGISLAÇÃO } \\
\text { ESTADUAL }\end{array}$ & $\begin{array}{l}\text { Publicação do Decreto Estadual n. 40.536, instituindo o Programa de } \\
\text { Qualidade e Produtividade no Serviço Público (13/12). Divulga objetivos do } \\
\text { Programa e define responsabilidades e estrutura de funcionamento em cada } \\
\text { nível da administração estadual. Universidades também são afetadas, como } \\
\text { autarquias especiais. }\end{array}$ \\
\hline
\end{tabular}

\section{6}

Gestão Reitor: Prof. Flávio Fava de Moraes (26/11/1993 - 125/11/1997)

1. Comissão de Gestão de Qualidade e Produtividade da USP

\begin{tabular}{|c|c|}
\hline DIRETRIZ USP & $\begin{array}{l}\text { Portaria do Reitor, GR 2985, instituindo o Programa Permanente de Qualidade } \\
\text { e Produtividade na Universidade de São Paulo }(29 / 01) \text {. }\end{array}$ \\
\hline ESTRUTURA & $\begin{array}{l}\text { Designação, pelo Reitor da USP, da Comissão de Gestão da Qualidade } \\
\text { Produtividade, composta por } 5 \text { professores }(29 / 01) \text {. }\end{array}$ \\
\hline DIRETRIZ & $\begin{array}{l}\text { Circular interna da Criação da Comissão de Gestão de Qualidade e } \\
\text { Produtividade e solicitação de ampla divulgação das atividades no âmbito de } \\
\text { cada Unidade/Órgão }(23 / 2) \text {. }\end{array}$ \\
\hline PALESTRA & $\begin{array}{l}\text { Palestra "Gestão pela Qualidade e a Universidade", pelo Prof. Melvin } \\
\text { Cymbalista (EP/USP), como marco do início de implantação do Programa de } \\
\text { Q\&P na USP. Presença do Reitor e Diretores das Unidades. Apresentação dos } \\
\text { Balizadores da Qualidade no Serviço Público. (07/05). }\end{array}$ \\
\hline ESTRUTURA & $\begin{array}{l}\text { Designação, por Diretores e Coordenadores de cada Unidade e Órgão da USP, } \\
\text { de } 63 \text { Comissões Internas de Q\&P: } 282 \text { pessoas: } 107 \text { docentes e } 175 \text { servidores } \\
\text { técnicos administrativos. (junho). }\end{array}$ \\
\hline \multirow{2}{*}{$\begin{array}{l}\text { PLANEJAMENTO } \\
\text { DIAGNÓSTICO }\end{array}$} & $\begin{array}{l}\text { Levantamento de Problemas e Destaques, a partir de formulários preenchidos } \\
\text { pelas Comissões Internas de Q\&P. }\end{array}$ \\
\hline & $\begin{array}{l}\text { Diagnóstico: } 4 \text { reuniões com } 56 \text { representantes das Comissões de Qualidade } \\
\text { utilizando brainstorming, com Nominal Group Technique (NGT), para } \\
\text { levantamento e priorização de ações para a melhoria da Qualidade e } \\
\text { Produtividade da USP. }\end{array}$ \\
\hline \multirow{2}{*}{ ENCONTRO } & $\begin{array}{l}\text { 1 Encontro sobre Gestão da Qualidade e Produtividade da USP: } 179 \\
\text { participantes. }(02 / 07) \text {. }\end{array}$ \\
\hline & $\begin{array}{l}\text { 2- Encontro sobre Gestão da Qualidade e Produtividade da USP: } 135 \\
\text { participantes. (30/08). }\end{array}$ \\
\hline
\end{tabular}


continuação

\begin{tabular}{|l|l|}
\hline TREINAMENTO & $\begin{array}{l}\text { Sistema de Gestão da Qualidade, pela Fundação Vanzolini: 133 funcionários. } \\
\text { (set/out) }\end{array}$ \\
\hline $\begin{array}{l}\text { RECURSOS } \\
\text { FINANCEIROS }\end{array}$ & $\begin{array}{l}\text { Estabelecimento pela Comissão de Orçamento e Patrimônio, de uma alínea } \\
\text { específica para o desenvolvimento dos Recursos Humanos, com capacitação } \\
\text { profissional e treinamento, para Unidades e Órgãos. }\end{array}$ \\
\hline 2. Comissão de Q\&P da Reitoria da USP (1996) \\
\hline ESTRUTURA & Formação da Comissão de Q\&P da Reitoria da USP \\
\hline 3. Programas Institucionais (1996) \\
\hline \multicolumn{2}{|l|}{$\begin{array}{l}\text { Instituída por Portaria CODAGE n. 11/96 a Comissão de Reestruturação dos } \\
\text { Sistemas de Gestão Administrativa e Financeira (Comissão GEFIM) para rever } \\
\text { e otimizar procedimentos da área administrativa, de orçamento, contabilidade, } \\
\text { compras, almoxarifado e afins e propor novas rotinas. }\end{array}$} \\
\hline PROCESSOS & $\begin{array}{l}\text { Revisão e simplificação de procedimentos e publicação do Manual de } \\
\text { Procedimentos de Recursos Humanos: DRH. }\end{array}$ \\
\hline GESTÃO AMBIENTAL & Parceria do Programa de Qualidade com USP RECICLA. \\
\hline
\end{tabular}

\section{7}

Gestão Reitor: Prof. Jacques Marcovitch ( 26/11/1997 - 25/11/2001)

1. Comissão de Gestão de Qualidade e Produtividade da USP

\begin{tabular}{|c|c|}
\hline \multirow{2}{*}{ DIRETRIZ } & $\begin{array}{l}\text { Módulos da Qualidade: Critérios do Prêmio Nacional da Qualidade e } \\
\text { Balizadores de Qualidade do Serviço Público. }\end{array}$ \\
\hline & $\begin{array}{l}\text { Publicação da tradução dos Critérios do Prêmio Malcom Baldrige para a } \\
\text { Educação: coordenação Prof. Helio Janny Teixeira (FEA/USP). }\end{array}$ \\
\hline DIAGNÓSTICO & $\begin{array}{l}\text { Solicitação às Unidades de preenchimento do Questionário para Mapeamento } \\
\text { de Características da Qualidade e Produtividade das Unidades e Órgãos, usando } \\
\text { como referência os Módulos de Qualidade, para nortear elaboração de Plano } \\
\text { Diretor de Qualidade. }\end{array}$ \\
\hline \multirow{4}{*}{ ENCONTRO } & $\begin{array}{l}3^{\circ} \text { Encontro sobre Gestão da Qualidade e Produtividade da USP (19/03): } 216 \\
\text { participantes. }\end{array}$ \\
\hline & $\begin{array}{l}4^{\circ} \text { Encontro sobre Gestão da Qualidade e Produtividade da USP (14/05): } 143 \\
\text { participantes. }\end{array}$ \\
\hline & $\begin{array}{l}5^{\circ} \text { Encontro sobre Gestão da Qualidade e Produtividade da USP (14/08): } 150 \\
\text { participantes. }\end{array}$ \\
\hline & $\begin{array}{l}6^{\circ} \text { Encontro sobre Gestão da Qualidade e Produtividade da USP (29/10): } 113 \\
\text { participantes. }\end{array}$ \\
\hline RECURSOS MATERIAIS & $\begin{array}{l}\text { Formação e distribuição de um acervo de livros e vídeos, a todos os campi, } \\
\text { sobre o tema Qualidade e Produtividade. }\end{array}$ \\
\hline \multirow{4}{*}{ PUBLICAÇÃO } & $\begin{array}{l}\text { Relatório de Atividades do Programa de Qualidade e Produtividade } 1996 \\
\text { (fevereiro). }\end{array}$ \\
\hline & Trabalho em Equipe: Relatório de Consolidação de Resultados (março). \\
\hline & $\begin{array}{l}\text { Questionário para Mapeamento de Características da Qualidade e } \\
\text { Produtividade (abril). }\end{array}$ \\
\hline & Filipeta USP em Números: português e inglês. 1a edição. \\
\hline
\end{tabular}


continuação

\begin{tabular}{|c|c|}
\hline COMUNICAÇÃO & $\begin{array}{l}\text { Apresentação de Painéis com mostra de publicações originárias do Programa } \\
\text { de Qualidade, durante o 6o Encontro de Qualidade e Produtividade. (29/10) }\end{array}$ \\
\hline $\begin{array}{l}\text { PESQUISA } \\
\text { MONITORAMENTO }\end{array}$ & $\begin{array}{l}\text { Na Direção das Unidades e Órgãos da USP, para atualização de dados das } \\
\text { Comissões Internas de Q\&P e levantamento de melhorias realizadas } \\
\text { (monitoramento). }\end{array}$ \\
\hline TREINAMENTO & $\begin{array}{l}\text { Em várias áreas: } 7470 \text { funcionários, sendo } 1.224 \text { em cursos específicos de } \\
\text { Qualidade. }\end{array}$ \\
\hline \multirow{3}{*}{ RECONHECIMENTO } & $\begin{array}{l}\text { Honra ao Mérito por Capacitação em Qualidade, às Unidades e Órgãos: EERP, } \\
\text { ESALQ, FORP, PCLQ, FCF, FEA, FSP e IB. }\end{array}$ \\
\hline & $\begin{array}{l}\text { Honra ao Mérito por Treinamento e Capacitação às Unidades e Órgãos, que } \\
\text { mais atenderam funcionários: CECAE, FCF, FEA, IB, IEB, IP, IQ, EERP, } \\
\text { ESALQ, FORP, ICMC, IQSC, PCAPS, PCLQ. }\end{array}$ \\
\hline & $\begin{array}{l}\text { Honra ao Mérito por esforço de Treinamento a funcionários USP: CCE, DRH e } \\
\text { SIBi. }\end{array}$ \\
\hline \multicolumn{2}{|c|}{ 2. Comissão de Q\&P da Reitoria da USP (1997) } \\
\hline COMUNICAÇÃO & $\begin{array}{l}\text { Elaboração de Painéis com mostra de publicações originárias do Programa de } \\
\text { Qualidade da Reitoria, no 6o- Encontro de Qualidade e Produtividade da USP. }\end{array}$ \\
\hline \multirow{3}{*}{ PUBLICAÇÃO } & Registro de Diplomas: Normas e Procedimentos I. \\
\hline & Registro de Diplomas: Normas e Procedimentos II. \\
\hline & $\begin{array}{l}\text { Registro de Diplomas: Normas e Procedimentos III. Pós-Graduação. Expedição } \\
\text { de diplomas de livre docente e professor titular. Revalidação e registro de } \\
\text { diplomas de estrangeiros. }\end{array}$ \\
\hline \multicolumn{2}{|c|}{ 3. Programas Institucionais (1997) } \\
\hline PROCESSO & $\begin{array}{l}\text { SAT. Sistema Administrativo de Transporte: racionalização e renovação da } \\
\text { frota de veículos. }\end{array}$ \\
\hline ESTRUTURA & $\begin{array}{l}\text { Institucionalização do SAUSP - Sistema de Arquivos da USP - } \\
\text { RUSP/CODAGE, pela Portaria GR n. 3083, para organização e padronização } \\
\text { de documentos por meio de normas e procedimentos. }\end{array}$ \\
\hline GESTÃO AMBIENTAL & $\begin{array}{l}\text { PURE. Criado pela Portaria GR n. 3062, o Programa Permanente para o Uso } \\
\text { Eficiente de Energia Elétrica na USP (15/05). }\end{array}$ \\
\hline ENCONTRO & $\begin{array}{l}1 \text { 1 Encontro Gestão Financeira e de Materiais:GEFIM, para promover } \\
\text { discussão e troca de experiências na área financeira e de materiais. (fev): } 603 \\
\text { participantes. }\end{array}$ \\
\hline
\end{tabular}

\begin{tabular}{|l|l|}
\hline \multicolumn{2}{|c|}{1998} \\
\hline Gestão Reitor: Prof. Jacques Marcovitch (26/11/1997-25/11/2001) \\
\hline 1. Comissão de Gestão de Qualidade e Produtividade da USP \\
\hline ENCONTRO & $\begin{array}{l}\text { 7o Encontro sobre Gestão da Qualidade e Produtividade (04/11): 142 } \\
\text { participantes. }\end{array}$ \\
\hline $\begin{array}{l}\text { INFORMAÇÃO } \\
\text { MONITORAMENTO }\end{array}$ & $\begin{array}{l}\text { Projeto. Estudo e Desenvolvimento de Indicadores Gerais de Desempenho para } \\
\text { a USP, incluídos no Anuário Estatístico. }\end{array}$ \\
\hline
\end{tabular}


continuação

\begin{tabular}{|l|l|}
\hline \multirow{2}{*}{ PUBLICAÇÃO } & Relatório Anual de Atividades de 1997 (junho). \\
\hline 2. Comissão de Q\&P da Reitoria da USP (1998) \\
\hline \multicolumn{2}{|l}{ 3. Programas Institucionais (1998) } \\
\hline \multirow{2}{*}{ GESTÃO AMBIENTAL } & Parceria com USP RECICLA. \\
\cline { 2 - 2 } & PURE. Programa Permanente para o Uso Eficiente de Energia Elétrica na USP. \\
\cline { 2 - 2 } & PURA. Início de implantação do Programa de Uso Racional de Água na USP. \\
\hline
\end{tabular}

\begin{tabular}{|l|l|}
\hline \multicolumn{2}{|c|}{1999} \\
\hline Gestão Reitor: Prof. Jacques Marcovitch ( 26/11/1997 - 25/11/2001) \\
\hline 1. Comissão de Gestão de Qualidade e Produtividade da USP \\
\hline PUBLICAÇÃO & Filipeta USP em Números: português e inglês. \\
\hline 2. Comissão de Q\&P da Reitoria da USP (1999) \\
\hline \multicolumn{2}{|c|}{ Programas Institucionais (1999) } \\
\hline \multirow{3}{*}{ GESTÃO AMBIENTAL } & Parceria com USP RECICLA. \\
\cline { 2 - 2 } & PURE. Programa Permanente para o Uso Eficiente de Energia Elétrica. \\
\cline { 2 - 2 } & PURA. Início de implantação do Programa de Uso Racional de Água. \\
\hline \multirow{2}{*}{ ENCONTRO } & $\begin{array}{l}\text { 2o Encontro de Gestão Financeira e de Materiais: GEFIM (jan/fev): 666 } \\
\text { participantes }\end{array}$ \\
\hline
\end{tabular}

\begin{tabular}{|l|l|}
\hline \multicolumn{2}{|c|}{2000} \\
\hline Gestão Reitor: Prof. Jacques Marcovitch $(26 / 11 / 1997-25 / 11 / 2001)$ \\
\hline 1. Comissão de Gestão de Qualidade e Produtividade da USP \\
\hline $\begin{array}{l}\text { PESQUISA } \\
\text { MONITORAMENTO }\end{array}$ & $\begin{array}{l}\text { Nas Unidades/Órgãos da USP, para atualização de dados das Comissões } \\
\text { Internas de Q\&P e levantamento de melhorias realizadas (monitoramento). }\end{array}$ \\
\hline PUBLICAÇÃO & Filipeta USP em Números: português e inglês. \\
\hline \multirow{2}{*}{ RECONHECIMENTO } & $\begin{array}{l}\text { Honra ao Mérito por Treinamento e Capacitação às Unidades e Órgãos que } \\
\text { atenderam mais funcionários: RUSP, EP, FE, FFLCH, SIBi, EESC, EERP, } \\
\text { ESALQ, FCFRP, FMRP, FOB, PCAPS, PCARP, PCASC. }\end{array}$ \\
\hline 2. Comissão de Q\&P da Reitoria da USP (2000) \\
\hline 3. Programas Institucionais (2000) \\
\hline \multirow{2}{*}{ GESTÃO DE PESSOAS } & $\begin{array}{l}\text { Movimentação de Carreira de técnicos administrativos. Pela primeira vez é } \\
\text { considerado o critério de escolaridade. }\end{array}$ \\
\hline \multirow{2}{*}{ ANUÁRIO ESTATÍSTICO } & Inserção do Anuário Estatístico da USP na INTERNET. \\
\hline \multirow{2}{*}{ GESTÃO AMBIENTAL } & Parceria com USP RECICLA. \\
\cline { 2 - 3 } & PURE. Programa Permanente para o Uso Eficiente de Energia Elétrica. \\
\cline { 2 - 3 } & PURA. Programa de Uso Racional de Água. \\
\hline
\end{tabular}


2001

Gestão Reitor: Prof. Jacques Marcovitch ( 26/11/1997 - 25/11/2001)

1. Comissão de Gestão de Qualidade e Produtividade da USP

\begin{tabular}{|l|l|}
\hline APOIO FINANCEIRO & Ginástica Laboral: parceria PCAB e FOB. \\
\hline COMUNICAÇÃO & $\begin{array}{l}\text { Criação de um site sobre o Programa Permanente de Qualidade na USP } \\
\text { (junho). }\end{array}$ \\
\hline 8o Encontro sobre Gestão da Qualidade e Produtividade da USP (26/04): 134 \\
participantes.
\end{tabular}

ENCONTRO participantes.

9o Encontro sobre Gestão da Qualidade e Produtividade da USP (13/09): 180 participantes.

COMUNICAÇÃO $\quad$ Painéis de Iniciativas de Qualidade nas Unidades/Órgãos, no 9º Encontro de Qualidade e Produtividade (13/09).

Iniciativas de Qualidade na USP (setembro).

PUBLICAÇÃO

Balanço Geral: Seis anos de atividades: 1996-2001 (novembro).

Filipeta USP em Números: português, inglês e espanhol.

2. Comissão de Q\&P da Reitoria da USP (2001)

COMUNICAÇÃO $\quad$ Unidades/Órgãos, no Encontro de Sensibilização e Comunicação. 9o- Encontro
de Qualidade e Produtividade (13/09)

TREINAMENTO $\quad$ Participação no Programa de Educação Continuada em Qualidade de Vida.

PUBLICAÇÃO $\quad$ Regimento de Pós-Graduação da USP, com Portarias, resoluções e material do PROCESSOS $\quad$ Regimento geral da USP e do Estatuto.

3. Programas Institucionais (2001)

Instituição da Ouvidoria de Serviços Públicos na USP, na Reitoria (29/03), em cumprimento à Lei n. 10.294, de 20/04/1999.

ESTRUTURA

Implantação do Sistema de Arquivo na Reitoria - RUSP.

1o Encontro do Grupo de Integração de Assistentes Acadêmicos: GIACAD (jul): 54 participantes.

INTEGRAÇÃO $\quad$ 1º Encontro de Gestão de Pessoas: GESPE (out): 128 participantes.

3- Encontro Gestão Financeira e de Materiais: GEFIM, Rumo à Excelência. (jul): 541 participantes.

Parceria com USP RECICLA.

GESTÃO AMBIENTAL

PURE. Programa Permanente para o Uso Eficiente de Energia Elétrica.

PURA. Programa de Uso Racional de Água. 
2002

\begin{tabular}{|l|l|}
\hline \multicolumn{2}{|l|}{ Gestão Reitor: Prof. Adolpho José Melfi (26/11/2001 - 25/11/2005) } \\
\hline 1. Comissão de Gestão de Qualidade e Produtividade da USP \\
\hline $\begin{array}{l}\text { PESQUISA } \\
\text { MONITORAMENTO }\end{array}$ & $\begin{array}{l}\text { Nas Unidades e Órgãos da USP, para atualização de dados das Comissões } \\
\text { Internas de Q\&P e levantamento de melhorias realizadas. (monitoramento). }\end{array}$ \\
\hline PUBLICAÇÃO & Filipeta USP em Números: português, inglês, espanhol e francês. \\
\hline TREINAMENTO & $\begin{array}{l}\text { 1-Turma Curso de MBA de Gestão e Tecnologias da Qualidade (EP/PECE) } \\
\text { para funcionários da USP: } 39 \text { funcionários. São Paulo. }\end{array}$
\end{tabular}

2. Comissão de Q\&P da Reitoria da USP (2002)

\begin{tabular}{|c|c|}
\hline ESTRUTURA & $\begin{array}{l}\text { Nova Composição da Comissão Interna de Qualidade e Produtividade da } \\
\text { Reitoria ( } 28 \text { membros, } 14 \text { titulares e } 13 \text { suplentes). }\end{array}$ \\
\hline $\begin{array}{l}\text { PLANEJAMENTO } \\
\text { DIAGNÓSTICO }\end{array}$ & $\begin{array}{l}\text { Reunião de Planejamento. Identificação de oportunidades de melhorias, usando } \\
\text { brainstorming, com metodologia Nominal Group Technique (NGT). }\end{array}$ \\
\hline ESTRUTURA & $\begin{array}{l}\text { Criação de } 4 \text { Grupos de Ações de Melhorias (GAMs): GAMultiplica, } \\
\text { GAMAvision, GAMfolheto, GAMinfo. }\end{array}$ \\
\hline \multirow{3}{*}{ ENCONTRO } & $\begin{array}{l}\text { 1o Encontro da Qualidade e Produtividade da Reitoria (18/06): } 178 \\
\text { participantes. }\end{array}$ \\
\hline & $\begin{array}{l}2^{-} \text {Encontro da Qualidade e Produtividade da Reitoria (19/09): } 169 \\
\text { participantes. }\end{array}$ \\
\hline & $\begin{array}{l}\text { 3o Encontro da Qualidade e Produtividade da Reitoria (21/11): } 161 \\
\text { participantes. }\end{array}$ \\
\hline PALESTRA & Apresentação de 4 palestras de interesse geral. GAMultiplica. \\
\hline TREINAMENTO & $\begin{array}{l}\text { Curso de Formação de Multiplicadores de Qualidade. Parceria GAMultiplica } \\
\text { com Secretaria de Economia e Planejamento do Governo do Estado de São } \\
\text { Paulo.Duas turmas: } 54 \text { participantes. }\end{array}$ \\
\hline \multirow{2}{*}{$\begin{array}{l}\text { PUBLICAÇÃO } \\
\text { COMUNICAÇÃO }\end{array}$} & Perfil da Reitoria Órgãos e Atividades. GAMfolheto. \\
\hline & Relatório de Atividades da Comissão de Q\&P da Reitoria. \\
\hline QVT SAÚDE & Meditação Dirigida (1ํo ano): 20 participantes. \\
\hline QVT CULTURA & Evento anual Prata da Casa. \\
\hline \multirow{3}{*}{ INFRAESTRUTURA } & $\begin{array}{l}\text { Comunicação. Instalação do Mural da Qualidade na Reitoria. GAMaVision - } \\
\text { Parceria com DA. }\end{array}$ \\
\hline & $\begin{array}{l}\text { Demarcação de vagas para deficientes ao redor do Prédio da Reitoria, além das } \\
\text { passagens para pedestres e guias rebaixadas. Parceria com DA. }\end{array}$ \\
\hline & $\begin{array}{l}\text { Segurança. Transferência dos terminais bancários para o interior do Prédio da } \\
\text { Reitoria. Parceria com DA. }\end{array}$ \\
\hline \multirow{2}{*}{ GESTÃO AMBIENTAL } & $\begin{array}{l}\text { USP Recicla. Encontro Educativo com Funcionários da Limpeza. Diagnóstico } \\
\text { do lixo (1ํ- ano) - GAM Ecologia. }\end{array}$ \\
\hline & Oficina de Reciclagem de Papel. GAM Ecologia. \\
\hline
\end{tabular}


continuação

\begin{tabular}{|l|l|}
\hline \multirow{3}{*}{ 3. Programas Institucionais (2002) } \\
\hline \multirow{3}{*}{ GESTÃO AMBIENT } & 1o Encontro de Integração Gerencial (jul): 175 participantes. \\
\cline { 2 - 2 } & $\begin{array}{l}\text { 2o Encontro do Grupo de Integração de Assistentes Acadêmicos: GIACAD } \\
\text { (set): 76 participantes. }\end{array}$ \\
\hline & Parceria com USP RECICLA. \\
\cline { 2 - 2 } & PURE. Programa Permanente para o Uso Eficiente de Energia Elétrica. \\
\cline { 2 - 2 } & PURA. Implantação do Programa de Uso Racional de Água. \\
\hline
\end{tabular}

\section{3}

Gestão Reitor: Prof. Adolpho José Melfi (26/11/2001 25/11/2005)

1. Comissão de Gestão de Qualidade e Produtividade da USP

\begin{tabular}{|c|c|}
\hline APOIO FINANCEIRO & Ginástica Laboral: FCF, EP, FM, IF, IO, SIBi e RUSP. \\
\hline $\begin{array}{l}\text { PLANEJAMENTO } \\
\text { DIAGNÓSTICO }\end{array}$ & $\begin{array}{l}\text { Levantamento de Oportunidades de Melhorias: } 1^{\text {a }} \text { turma do Curso de Gestão e } \\
\text { Tecnologia da Qualidade - PECE. }\end{array}$ \\
\hline ENCONTRO & 10을 Encontro de Qualidade e Produtividade da USP (25/11): 141 participantes. \\
\hline PUBLICAÇÃO & Filipeta USP em Números: português, inglês, espanhol e francês. \\
\hline GESTÃO AMBIENTAL & Gestão Ambiental. Encontro Educativo com Funcionários da Limpeza ( $1^{\circ}$ ano). \\
\hline
\end{tabular}

2. Comissão de Q\&P da Reitoria da USP (2003)

\begin{tabular}{|c|c|}
\hline LIDERANÇA & Definição da Missão da Comissão de Qualidade e Produtividade da Reitoria. \\
\hline \multirow[t]{2}{*}{ PALESTRA } & Palestra de Experiências da Qualidade na USP. 10ํㅡㄹ Encontro: DF. \\
\hline & Palestras de sensibilização da Qualidade e de interesse geral (8). \\
\hline PUBLICAÇÃO & 1ํ Folheto sobre a Comissão de Q\&P da Reitoria. \\
\hline \multirow[t]{2}{*}{ TREINAMENTO } & $\begin{array}{l}\text { Curso de Formação de Multiplicadores de Qualidade. Parceria GAMultiplica } \\
\text { com Secretaria de Economia e Planejamento do Governo do Estado de São } \\
\text { Paulo. } 1 \text { Turma: } 35 \text { participantes. }\end{array}$ \\
\hline & $\begin{array}{l}\text { Curso de Inglês instrumental (nível básico) e Oratória - Parceria GAMultiplica, } \\
\text { CODAGE/DRH. }\end{array}$ \\
\hline PROCESSOS & $\begin{array}{l}\text { Elaboração de Organogramas oficiais. Parceria com o Gabinete do Reitor, } \\
\text { Secretaria Geral, Consultoria Jurídica, Pró-Reitorias de Graduação e Pós- } \\
\text { Graduação. GAM Organograma. }\end{array}$ \\
\hline \multirow[b]{2}{*}{ QVT SAÚDE } & Início de Ginástica Laboral. \\
\hline & Meditação Dirigida (2º ano) 20 participantes - GAMQVTR. \\
\hline \multirow{5}{*}{ QVT CULTURA } & $\begin{array}{l}\text { Acesso dos funcionários da Reitoria à Biblioteca da Faculdade de Filosofia, } \\
\text { Ciências e Letras - GAM Cultural. }\end{array}$ \\
\hline & $\begin{array}{l}\text { Ensaio da Orquestra Sinfônica da USP - Eficiência do Trabalho em Equipe. } \\
\text { GAMcultural. }\end{array}$ \\
\hline & $\begin{array}{l}\text { Visita ao campus São Paulo: Conhecendo a USP (184 participantes) - GAM } \\
\text { Cultural. }\end{array}$ \\
\hline & Evento anual Prata da Casa. GAM Cultural. \\
\hline & Elaboração da Árvore de Natal interativa - GAM QVTR. \\
\hline
\end{tabular}


continuação

\begin{tabular}{|c|c|}
\hline GESTÃO AMBIENTAL & $\begin{array}{l}\text { USP Recicla. Encontro Educativo com Funcionários da Limpeza. Diagnóstico } \\
\text { do lixo (2ªno) - GAM Ecologia. }\end{array}$ \\
\hline \multicolumn{2}{|c|}{ 3. Programas Institucionais (2003) } \\
\hline COMUNICAÇÃO & Criação do Jornal Reitoria Informa. \\
\hline \multirow[b]{2}{*}{ ENCONTRO } & 2 Encontro Gestão de Informática: GEINFO (Nov.): 100 participantes. \\
\hline & $\begin{array}{l}\text { 4 }^{\circ} \text { Encontro Gestão Financeira e de Materiais: GEFIM (jul./ago.): } 650 \\
\text { participantes. }\end{array}$ \\
\hline \multirow{3}{*}{ GESTÃO AMBIENTAL } & Parceria com USP RECICLA. \\
\hline & PURE. Programa Permanente para o Uso Eficiente de Energia Elétrica. \\
\hline & PURA. Implantação do Programa de Uso Racional de Água. \\
\hline $\begin{array}{l}\text { AVALIAÇÃO } \\
\text { INSTITUCIONAL }\end{array}$ & $\begin{array}{l}\text { Encontros para Avaliação Institucional. Atendimento a Deliberação Conselho } \\
\text { Estadual de Educação 04/2000. }\end{array}$ \\
\hline
\end{tabular}

\begin{tabular}{|c|c|}
\hline \multicolumn{2}{|r|}{2004} \\
\hline \multicolumn{2}{|c|}{ Gestão Reitor: Prof. Adolpho José Melfi (26/11/2001 - 25/11/2005) } \\
\hline \multicolumn{2}{|c|}{ 1. Comissão de Gestão de Qualidade e Produtividade da USP } \\
\hline APOIO FINANCEIRO & Ginástica Laboral para FAU, IAG e RUSP. \\
\hline ENCONTRO & 11을 Encontro da Qualidade e Produtividade da USP (17/08): 180 participantes. \\
\hline $\begin{array}{l}\text { PESQUISA } \\
\text { MONITORAMENTO }\end{array}$ & $\begin{array}{l}\text { Nas Unidades e Órgãos da USP, para atualização de dados das Comissões } \\
\text { Internas de Q\&P e levantamento de melhorias realizadas. (monitoramento). }\end{array}$ \\
\hline PUBLICAÇÃO & Filipeta USP em Números: português, inglês, espanhol e francês. \\
\hline QVT CULTURA & Evento Comemorativo ao Dia Internacional da Mulher (08/03). GAMcultural. \\
\hline \multirow{2}{*}{ TREINAMENTO } & $\begin{array}{l}\text { 2- Turma do Curso de MBA de Gestão e Tecnologias da Qualidade } \\
\text { (EP/PECE), para funcionários da USP: } 40 \text { funcionários. São Paulo. }\end{array}$ \\
\hline & $\begin{array}{l}\text { Participação no Curso de Formação Executiva para Assistentes de Direção da } \\
\text { USP, oferecido pela FEA. }\end{array}$ \\
\hline \multicolumn{2}{|c|}{ 2. Comissão de Q\&P da Reitoria da USP (2004) } \\
\hline PALESTRA & Experiências da Qualidade na USP - participação no 11ํㅡㄹ Encontro. \\
\hline TREINAMENTO & $\begin{array}{l}\text { Curso de Formação de Multiplicadores de Qualidade. Parceria GAMultiplica } \\
\text { com Secretaria de Economia e Planejamento do Governo do Estado de São } \\
\text { Paulo. } 2 \text { Turmas: } 64 \text { participantes. }\end{array}$ \\
\hline \multirow{2}{*}{ PUBLICAÇÃO } & 2 Folheto sobre a Comissão de Q\&P da Reitoria. \\
\hline & Perfil da Reitoria Órgãos e Atividades - GAMfolheto. \\
\hline \multirow{3}{*}{ QVT SAÚDE } & Avaliação Audiológica de funcionários da Reitoria - GAM QVTR. \\
\hline & Ginástica Laboral. GAMQVTR. \\
\hline & Meditação Dirigida (20 participantes) - GAMQVTR. \\
\hline \multirow{2}{*}{ QVT CULTURA } & Evento anual Prata da Casa - GAMcultural. \\
\hline & Apresentação Sarau Literário-Musical - GAMcultural. \\
\hline \multirow[t]{2}{*}{ QVT INTEGRAÇÃO } & $\begin{array}{l}\text { Café com Agenda (ano de início) - } 2 \text { eventos com } 502 \text { participantes - GAM } \\
\text { QVTR. }\end{array}$ \\
\hline & Elaboração (2ª ano) da Árvore de Natal interativa. GAM QVTR. \\
\hline
\end{tabular}


continuação

\begin{tabular}{|c|c|}
\hline GESTÃO AMBIENTAL & $\begin{array}{l}\text { Encontro Educativo do Programa USP Recicla e Comissão Interna de Q\&P da } \\
\text { Reitoria (lançamento de canecas duráveis) - } 150 \text { participantes. }\end{array}$ \\
\hline \multicolumn{2}{|c|}{ 3. Programas Institucionais (2004) } \\
\hline \multirow{4}{*}{ ENCONTRO } & 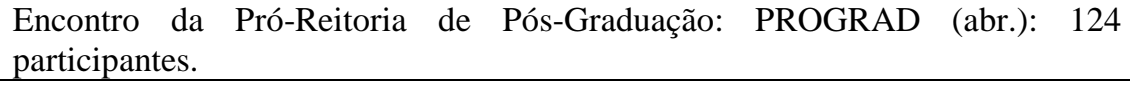 \\
\hline & 1\% Encontro GESEC. Gestão de Secretárias (set.): 93 participantes. \\
\hline & 2- Encontro GESPE (nov./dez.): 155 participantes. \\
\hline & 3- Encontro GEINFO. Gestão de Informática (dez.): 100 participantes. \\
\hline \multirow{3}{*}{ GESTÃO AMBIENTAL } & Parceria com USP RECICLA. \\
\hline & PURE. Programa Permanente para o Uso Eficiente de Energia Elétrica. \\
\hline & PURA. Implantação do Programa de Uso Racional de Água. \\
\hline $\begin{array}{l}\text { AVALIAÇÃO } \\
\text { INSTITUCIONAL }\end{array}$ & $\begin{array}{l}\text { Encontros de Avaliação Institucional. Resultados Preliminares e Avaliação } \\
\text { Externa. }\end{array}$ \\
\hline
\end{tabular}

\section{5}

Gestão Reitor: Prof. Adolpho José Melfi (26/11/2001 - 25/11/2005)

1. Comissão de Gestão de Qualidade e Produtividade da USP

\begin{tabular}{|c|c|}
\hline \multirow[b]{2}{*}{ APOIO FINANCEIRO } & Ginástica Laboral na RUSP. \\
\hline & $\begin{array}{l}\text { Publicação Manual de Orientação de Ginástica Laboral, elaborado pelo } \\
\text { CEPEUSP- (trabalho desenvolvido em } 9 \text { unidades desde 2003). }\end{array}$ \\
\hline ENCONTRO & 12º Encontro de Qualidade e Produtividade da USP (17/08). 317 participantes. \\
\hline PALESTRA & $\begin{array}{l}\text { Palestras de Sensibilização da Qualidade e de interesse geral. GAMmultiplica e } \\
\text { DRH. }\end{array}$ \\
\hline TREINAMENTO & $\begin{array}{l}\text { 3- Turma. Curso de MBA de Gestão e Tecnologias da Qualidade (EP/PECE), } \\
\text { para funcionários da USP: } 43 \text { funcionários. Ribeirão Preto. }\end{array}$ \\
\hline RECONHECIMENTO & $\begin{array}{l}\text { Reconhecimento por Diploma às pessoas que se envolveram no Programa de } \\
\text { Qualidade, no } 12^{\circ} \text { Encontro de Qualidade e Produtividade da USP. }\end{array}$ \\
\hline \multirow{3}{*}{ PUBLICAÇÃO } & Filipeta USP em Números: português, inglês, espanhol e francês. \\
\hline & Folheto USP Indicadores Gerais 2004. \\
\hline & Uma Década do Programa de Qualidade na USP: 1996-2005. \\
\hline GESTÃO AMBIENTAL & $\begin{array}{l}\text { USP Recicla. Encontro Educativo com Funcionários da Limpeza ( } 2^{\circ} \text { ano. } \\
\text { GAMecologia. }\end{array}$ \\
\hline \multicolumn{2}{|c|}{ 2. Comissão de Q\&P da Reitoria da USP (2005) } \\
\hline \multirow{2}{*}{ COMUNICAÇÃO } & $\begin{array}{l}\text { Comunicação Visual. Implantação de nova sinalização das áreas internas e } \\
\text { externas da Reitoria. Parceria DA. }\end{array}$ \\
\hline & $\begin{array}{l}\text { Projeto de reestruturação e atualização do site da Comissão Interna de } \\
\text { Qualidade e Produtividade da Reitoria. Parceria DI. }\end{array}$ \\
\hline ENCONTRO & Integração de Novos Funcionários. Parceria DRH. (outubro) \\
\hline TREINAMENTO & $\begin{array}{l}\text { Curso de Formação de Multiplicadores de Qualidade. Parceria GAMultiplica } \\
\text { com Secretaria de Economia e Planejamento do Governo do Estado de São } \\
\text { Paulo. 2- Turmas: } 57 \text { participantes. }\end{array}$ \\
\hline
\end{tabular}


continuação

\begin{tabular}{|c|c|}
\hline \multirow{4}{*}{ PALESTRA } & \\
\hline & $\begin{array}{l}\text { Experiências da Qualidade na USP - participação no } 12^{\circ} \text { Encontro da } \\
\text { Qualidade e Produtividade da USP. SAUSP. }\end{array}$ \\
\hline & Palestra Reforma Previdenciária - CJ. \\
\hline & $\begin{array}{l}\text { Participação da Comissão de Qualidade da Reitoria no Encontro dos Novos } \\
\text { Funcionários. }\end{array}$ \\
\hline PUBLICAÇÃO & 3o Folheto da Comissão de Q\&P da Reitoria. \\
\hline QVT SAÚDE & Ginástica Laboral na RUSP. \\
\hline \multirow{18}{*}{ QVT CULTURA } & Visita ao Museu Paulista (Ipiranga). Série Conhecendo a USP. GAM Cultural. \\
\hline & Criação do Coral da Reitoria - GAM Cultural. \\
\hline & Apresentação Coral USP Reitoria em vários Eventos. \\
\hline & $\begin{array}{l}\text { Visita a USP LESTE. Série Conhecendo a USP - (79 participantes) - GAM } \\
\text { Cultural }\end{array}$ \\
\hline & Evento Comemorativo ao Dia Internacional da Mulher - GAM Cultural. \\
\hline & $\begin{array}{l}\text { Visita ao Museu Republicano da Convenção de Itu. Série Conhecendo a USP. } \\
\text { GAM Cultural. }\end{array}$ \\
\hline & $\begin{array}{l}\text { Visita ao Museu de Arte Contemporânea - MAC. Série Conhecendo a USP - } \\
\text { GAM Cultural. }\end{array}$ \\
\hline & $\begin{array}{l}\text { Visita ao Museu de Arqueologia e Etnologia - MAE. Série Conhecendo a USP- } \\
\text { GAM Cultural. }\end{array}$ \\
\hline & Visita ao Museu de Zoologia. Série Conhecendo a USP. GAM Cultural. \\
\hline & Evento anual Prata da Casa - GAM Cultural. \\
\hline & Visita ao Parque CiênciaTec. Série Conhecendo a USP. GAM Cultural. \\
\hline & Visita à Casa de Dona Yayá. Série Conhecendo a USP. GAM Cultural. \\
\hline & $\begin{array}{l}\text { Visita ao Engenho São Jorge dos Erasmos. Série Conhecendo a USP. GAM } \\
\text { Cultural. }\end{array}$ \\
\hline & $\begin{array}{l}\text { Visita ao Centro Histórico Bolsa do Café e Museu do Café (Santos). GAM } \\
\text { Cultural. }\end{array}$ \\
\hline & $\begin{array}{l}\text { Visita ao Jardim Botânico do Instituto de Biociências. Série Conhecendo a } \\
\text { USP. GAM Cultural. }\end{array}$ \\
\hline & Visita ao campus da USP Leste. Série Conhecendo a USP. GAM Cultural. \\
\hline & $\begin{array}{l}\text { Concerto da OSUSP com regência de Carlos Moreno em evento sobre } \\
\text { liderança, trabalho em equipe e desempenho. GAM Cultural. }\end{array}$ \\
\hline & Apresentação Sarau de Viola Caipira. GAM Cultural. \\
\hline QVT INTEGRAÇÃO & Evento Café com Agenda (300 participantes) GAM QVTR. \\
\hline \multirow{4}{*}{ GESTÃO AMBIENTAL } & USP Recicla. Diagnóstico do lixo (3o ano) - GAM Ecologia. \\
\hline & $\begin{array}{l}\text { USP Recicla. Encontro Educativo de lançamento da Coleta Seletiva (170 } \\
\text { participantes) GAMecologia. }\end{array}$ \\
\hline & $\begin{array}{l}\text { USP Recicla. Recolhimento centralizado de cartuchos de impressora na RUSP. } \\
\text { GAM Ecologia. }\end{array}$ \\
\hline & Projeto Piloto de Coleta Seletiva de Lixo na Reitoria da USP - GAM Ecologia. \\
\hline \multicolumn{2}{|c|}{ 3. Programas Institucionais (2005) } \\
\hline \multirow{5}{*}{ ENCONTRO } & Encontro de Integração de Novos Funcionários (out): 141 participantes. \\
\hline & Encontro da Pós-Reitoria de Graduação: INTEGRAD (set): 100 participantes. \\
\hline & 2o- Encontro de Gestão de Secretárias: GESEC (set): 400 participantes. \\
\hline & 4o Encontro de Gestão de Informática: GEINFO (dez): 100 participantes. \\
\hline & $\begin{array}{l}\text { 5o Encontro Gestão Financeira e de Materiais: GEFIM (jul./ago.): } 725 \\
\text { participantes. }\end{array}$ \\
\hline
\end{tabular}


continuação

\begin{tabular}{|l|l|}
\hline \multirow{3}{*}{ GESTÃO AMBIENTAL } & Parceria com USP RECICLA. \\
\cline { 2 - 2 } & PURE. Programa Permanente para o Uso Eficiente de Energia Elétrica. \\
\cline { 2 - 2 } & PURA. Implantação do Programa de Uso Racional de Água. \\
\hline AVALIAÇÃO & $\begin{array}{l}\text { Encontro de Avaliação Institucional. Encerramento do Processo de Avaliação } \\
\text { INSTITUCIONAL }\end{array}$ \\
\hline
\end{tabular}

\section{6}

Gestão Reitora: Profa. Suely Vilela (25/11/2005 - 25/01/2010)

1. Comissão de Gestão de Qualidade e Produtividade da USP

\begin{tabular}{|l|l|}
\hline MODIFICAÇÃO & Portaria GR n. 3673 (09/03) altera o Programa de Qualidade e Produtividade da \\
\hline
\end{tabular} PROGRAMA DE Q\&P $\quad$ USP e designa nova Comissão.

GESPÚBLICA

Lançamento do GESPÚBLICA - Programa de Gestão Estratégica e Desburocratização na Administração da USP (novembro.) e instituído formalmente por Portaria GR n. 3735 de 23/02/2007, substituindo o Programa de Qualidade e Produtividade da USP. 

APÊNDICE B2: Linha do Tempo: Atividades do Programa de Qualidade e Produtividade das Unidades e Órgãos: 1996-2006

\begin{tabular}{|l|l|}
\hline \multicolumn{2}{|c|}{1996} \\
\hline ESTRUTURA & $\begin{array}{l}\text { Formação da Comissão de Qualidade e Produtividade da RUSP, FORP, FFCLRP, } \\
\text { FZEA e outras. }\end{array}$ \\
\hline INFRAESTRUTURA & $\begin{array}{l}\text { Biblioteca. Aquisição de projetores multimídia, retro projetores, videocassetes, } \\
\text { televisores, aparelho de som, máquina fotográfica, microcomputadores e } \\
\text { implementação do Auditório da Biblioteca: FOB. }\end{array}$ \\
\hline
\end{tabular}

\begin{tabular}{|c|c|}
\hline \multicolumn{2}{|r|}{1997} \\
\hline ESTRUTURA & $\begin{array}{l}\text { Formação da Comissão Interna de Qualidade e Produtividade: EERP, FAU, FCF, } \\
\text { EESC, ESALQ, PCLQ e CIAGRI. }\end{array}$ \\
\hline SGQ & Implantação de Sistema de Gestão da Qualidade (SGQ) voltado a ISO 17025: IEE. \\
\hline \multirow{2}{*}{ PLANEJAMENTO } & $\begin{array}{l}\text { Elaboração de Plano Diretor, com participação de docentes, alunos e funcionários: } \\
\text { ICMC. }\end{array}$ \\
\hline & Elaboração de Plano Diretor: EEFE. \\
\hline DIAGNÓSTICO & Levantamento de ações de melhoria: FZEA \\
\hline SEMINÁRIO & I Seminário de Qualidade e Produtividade da FCF (setembro). \\
\hline \multirow{2}{*}{ TREINAMENTO } & Treinamento. Processo de identificação de alvos de ações de melhorias: FMRP. \\
\hline & Treinamentos (19 cursos, 80 horas e 333 participações): FCF. \\
\hline \multirow{4}{*}{ PALESTRA } & $\begin{array}{l}\text { Experiências da Qualidade na USP. Participação no 3- Encontro de Qualidade e } \\
\text { Produtividade da USP: CENA, CODAGE/DRH, IEE, CECAE (19/03) }\end{array}$ \\
\hline & $\begin{array}{l}\text { Experiências da Qualidade na USP. Participação no } \text { 40 }^{\circ} \text { Encontro de Qualidade e } \\
\text { Produtividade da USP: EEFE e FZEA. (14/04) }\end{array}$ \\
\hline & $\begin{array}{l}\text { Experiências da Qualidade na USP. Participação no 5o Encontro de Qualidade e } \\
\text { Produtividade da USP. CODAGE/DF, EP e HRAC (14/08). }\end{array}$ \\
\hline & $\begin{array}{l}\text { Experiências da Qualidade na USP. Participação no 6o Encontro - de Qualidade e } \\
\text { Produtividade da USP: EESC, SIBi, FMRP e ICMC (29/10). }\end{array}$ \\
\hline PUBLICAÇÃO & $\begin{array}{l}\text { Exposição de Painéis com amostra de publicações originárias do Programa de } \\
\text { Qualidade. 6o Encontro de Qualidade e Produtividade: CECAE, EEFE, FE, SIBi e } \\
\text { ESALQ (29/10). }\end{array}$ \\
\hline COMUNICAÇÃO & Criação do Informativo: EEFE. \\
\hline
\end{tabular}

\begin{tabular}{|l|l|}
\hline \multicolumn{2}{|c|}{1998} \\
\hline ESTRUTURA & Formação da Comissão de Qualidade e Produtividade da FCFRP. \\
\hline SEMINÁRIO & II Seminário de Qualidade e Produtividade da FCF. \\
\hline TREINAMENTO & Treinamentos (15 cursos, 50 horas e 167 participações): FCF. \\
\hline PALESTRA & $\begin{array}{l}\text { Experiências da Qualidade na USP. Participação no 7o Encontro de Qualidade e } \\
\text { Produtividade: FMRP: ESALQ e EP (04/11). }\end{array}$ \\
\hline INFRAESTRUTURA & $\begin{array}{l}\text { Biblioteca. Ampliação do espaço físico, expansão da rede de informática, } \\
\text { remodelação do auditório, novos mobiliários e circuito fechado de TV: FOB. }\end{array}$ \\
\hline
\end{tabular}




\begin{tabular}{|l|l|}
\hline \multicolumn{2}{|c|}{1999} \\
\hline SGQ & $\begin{array}{l}\text { Início de implantação do Sistema de Gestão da Qualidade (SGQ): Biblioteca da } \\
\text { ESALQ }\end{array}$ \\
\hline SEMINÁRIO & III Seminário de Qualidade e Produtividade da FCF. \\
\hline TREINAMENTO & Treinamentos (4 cursos, 70 horas e 93 participações): FCF. \\
\hline
\end{tabular}

\begin{tabular}{|l|l|}
\hline \multicolumn{2}{|c|}{2000} \\
\hline SEMINÁRIO & IV Seminário de Qualidade e Produtividade da FCF. (novembro) \\
\hline TREINAMENTO & Treinamentos (14 cursos, 215 horas e 237 participações): FCF. \\
\hline
\end{tabular}

\begin{tabular}{|c|c|}
\hline \multicolumn{2}{|r|}{2001} \\
\hline \multirow{4}{*}{ ESTRUTURA } & Criação da Comissão de Qualidade de Vida: FZEA. \\
\hline & Instituição de Comissão de Qualidade e Produtividade: FOB. \\
\hline & $\begin{array}{l}\text { Criação do Programa de Educação Continuada em Qualidade de Vida: EE, EERP, } \\
\text { ESALQ,/PCLQ/CIAGRI, FCF, FCFRP, FEA, FFCLRP, FO, FORP e IEB. }\end{array}$ \\
\hline & $\begin{array}{l}\text { Terceirização dos serviços de reprografia e limpeza e parte dos Serviços de } \\
\text { Vigilância: FFCLRP. }\end{array}$ \\
\hline \multirow{4}{*}{ PLANEJAMENTO } & Levantamento das necessidades de treinamento: EE e FORP. \\
\hline & Elaboração de Planejamento Estratégico: SIBi. \\
\hline & Elaboração de Plano Diretor: FFCLRP. \\
\hline & $\begin{array}{l}\text { II Workshop de Interação de Competências, com participação de todos os } \\
\text { funcionários: ICMC. }\end{array}$ \\
\hline SEMINÁRIO & V Seminário de Qualidade e Produtividade da FCF. (junho). \\
\hline SENSIBILIZAÇÃO & Divulgação do Programa de Qualidade à Comunidade: FMRP. \\
\hline DIAGNÓSTICO & $\begin{array}{l}\text { Levantamento de sugestões para ações de Qualidade (380 respostas): FMRP. } \\
\text { Uso de Caixa de sugestões e brainstorming, com Nominal Group Technique (NGT) }\end{array}$ \\
\hline $\begin{array}{l}\text { DEFINIÇÃO } \\
\text { MISSÃO }\end{array}$ & $\begin{array}{l}\text { Definição de Missão, Visão e Valores da Comissão de Gestão de Qualidade e } \\
\text { Produtividade da ESALQ/PCLQ/CIAGRI e do Laboratório de Ecologia Animal da } \\
\text { ESALQ. }\end{array}$ \\
\hline \multirow{10}{*}{ TREINAMENTO } & Curso de Atendimento Especial aos Usuários: 330 participantes - FCF \\
\hline & Atualização de funcionários da manutenção: FORP. \\
\hline & Atendimento a $100 \%$ da demanda para cursos específicos: FFCLRP. \\
\hline & Composição da Comissão Assessora para Gerenciamento de Treinamentos: FORP. \\
\hline & $\begin{array}{l}\text { Curso na linha Pichon Riviere para melhoria no trabalho em grupo; curso de Idiomas } \\
\text { e curso de informática: FMRP. }\end{array}$ \\
\hline & Cursos de Inglês, cursinho pré-vestibular e MBA a funcionários: FEA. \\
\hline & Cursos diversos (156 funcionários): EERP. \\
\hline & $\begin{array}{l}\text { Diversos Cursos e treinamentos para melhoria da qualidade (301 participantes): } \\
\text { FCFRP. }\end{array}$ \\
\hline & $\begin{array}{l}\text { Valorização dos Recursos Humanos, com utilização de } 100 \% \text { da verba de } \\
\text { treinamento de funcionários: EE. }\end{array}$ \\
\hline & $\begin{array}{l}\text { Reuniões por teleconferência (5), treinamento funcionário (2) e Qualidade no } \\
\text { Atendimento (30): FEARP. }\end{array}$ \\
\hline
\end{tabular}


continuação

\begin{tabular}{|c|c|}
\hline \multirow{5}{*}{ TREINAMENTO } & \\
\hline & Treinamento de Atendimento ao Paciente para atendentes: FORP. \\
\hline & $\begin{array}{l}\text { Capacitação de grupos operativos e aplicação de Técnica Nominal Group Technique } \\
\text { para grupo de convidados usuários da Faculdade: FMRP. }\end{array}$ \\
\hline & $\begin{array}{l}\text { Treinamentos diversos: atendimento ao cliente, motivação e liderança, informática e } \\
\text { legislação: FEA. }\end{array}$ \\
\hline & $\begin{array}{l}\text { Treinamento em Gestão Ambiental: } 3 \text { cursos de } 100 \text { horas ( } 25 \text { participantes). } 1 \text { Curso } \\
\text { de Q\&P de } 8 \text { horas (110 participantes). Outros cursos, } 80 \text { horas (110 participantes): } \\
\text { FCF. }\end{array}$ \\
\hline PALESTRA & $\begin{array}{l}\text { Palestras aos funcionários sobre temas relativos à qualidade (5s, Tratamento do lixo, } \\
\text { Biosegurança, Sexualidade e AIDS e outros temas de saúde): FCFRP. }\end{array}$ \\
\hline PESQUISA & Pesquisa de Clima Organizacional: FEA. \\
\hline RECONHECIMENTO & 1을êmio ISO - 14001: FCF. \\
\hline \multirow{5}{*}{ INFORMAÇÃO } & Informatização do Controle Administrativo: FORP. \\
\hline & $\begin{array}{l}\text { Avanço na Informática com compra de equipamento e desenvolvimentos de } \\
\text { sistemas: EERP. }\end{array}$ \\
\hline & $\begin{array}{l}\text { Estruturação da Seção de Informática e atualização tecnológica de Hardware e } \\
\text { Software: FFCLRP. }\end{array}$ \\
\hline & Implantação do Sistema Delphos, com melhorias na área de informática: EE. \\
\hline & Melhorias na informática, com aquisição e máquinas e criação de homepage: FOB. \\
\hline \multirow{2}{*}{ PUBLICAÇÃO } & Elaboração de Manual Informativo para servidores: FORP. \\
\hline & Respondemos suas dúvidas sobre Gestão Ambiental: FCF. \\
\hline \multirow{7}{*}{ PROCESSOS } & Aprimoramento do Serviço de Compras: FMRP \\
\hline & $\begin{array}{l}\text { Roteiro para tramitação de processo para execução de reformas e serviços de } \\
\text { engenharia: FMRP. }\end{array}$ \\
\hline & Elaboração do Regimento da Comissão de Biosegurança: FOB. \\
\hline & Elaboração do Regimento Comissão de Ética em Pesquisa: FOB. \\
\hline & Unificação de prontuários: FORP. \\
\hline & Elaboração de Regimento próprio: EERP.. \\
\hline & $\begin{array}{l}\text { Aplicação da Ferramenta da Qualidade 5S: ESALQ, PCLQ e CIAGRI, FCF e } \\
\text { FCFRP. }\end{array}$ \\
\hline \multirow{7}{*}{ INFRAESTRUTURA } & Implantação de Sala de Computação para alunos de pós-graduação: FORP. \\
\hline & $\begin{array}{l}\text { Inauguração da SIBiNet - rede de Serviços do SIBi/USP (biblioteca virtual, Dedalus } \\
\text { na Web, revistas eletrônicas, bases de dados on-line): - SIBi. }\end{array}$ \\
\hline & Melhoria de instalações físicas e de mobiliário: IEB. \\
\hline & Modernização e reforma de prédios: FEA. \\
\hline & $\begin{array}{l}\text { Reforma e adequação dos espaços físicos e intervenções para facilitar locomoção dos } \\
\text { portadores de deficiências: FFCLRP. }\end{array}$ \\
\hline & Renovação de espaços, móveis e equipamentos: FOB. \\
\hline & Renovação e aumento de frota da faculdade: FFCLRP. \\
\hline \multirow[t]{3}{*}{ QVT SAÚDE } & $\begin{array}{l}\text { Projeto Vivendo em Grupo Harmoniosamente, com o objetivo de proporcionar aos } \\
\text { participantes contatos baseados no respeito mútuo e na conscientização das } \\
\text { diferenças individuais: FO. }\end{array}$ \\
\hline & Atividades voltadas para o bem-estar do funcionário: FOB. \\
\hline & Ginástica Laboral aos funcionários. Parceria da PCAB com a FOB. \\
\hline QVT CULTURAL & $\begin{array}{l}\text { Visita cultural, promovida pela FZEA, à exposição do MASP - Egito Faraônico - } \\
\text { Terra dos Deuses. }\end{array}$ \\
\hline \multirow{2}{*}{ QVT INTEGRAÇÃO } & Comemoração de datas festivas: FOB. \\
\hline & Café da manhã simples diariamente. Parceria da PCAB com a FOB. \\
\hline \multirow{2}{*}{$\begin{array}{l}\text { GESTÃO } \\
\text { AMBIENTAL }\end{array}$} & $\begin{array}{l}\text { Início de Implantação do Sistema de Gestão Ambiental: ISO } 14001 \text { - FCF. } \\
\text { Criação de logotipo. }\end{array}$ \\
\hline & Ações ligadas à Gestão Ambiental: EP e FMRP. \\
\hline
\end{tabular}




\section{2}

\begin{tabular}{|c|c|}
\hline & \\
\hline \multirow{2}{*}{ PLANEJAMENTO } & $\begin{array}{l}\text { POLI } 2015 \text { - Planejamento de programa de mudanças para elevar o padrão de } \\
\text { qualidade de todas as atividades desenvolvidas: EP. }\end{array}$ \\
\hline & $\begin{array}{l}\text { 1- Encontro das Chefias Administrativas Rancho Silvestre: EP ( } 45 \text { participantes), } \\
\text { para levantamento de problemas da área administrativa. }\end{array}$ \\
\hline SEMINÁRIO & VI Seminário de Qualidade e Produtividade da FCF. (junho). \\
\hline \multirow{3}{*}{ TREINAMENTO } & Curso na linha Pichon Riviere, para melhoria de trabalho em grupo: FMRP. \\
\hline & Cursos de Informática e Idiomas: FMRP. \\
\hline & $\begin{array}{l}\text { Curso de Formação de Agentes Locais de Sustentabilidade Socioambiental (73 } \\
\text { funcionários): CECAE. }\end{array}$ \\
\hline $\begin{array}{l}\text { FOCO NO } \\
\text { CLIENTE }\end{array}$ & Programa de Avaliação da Qualidade (PAQ) dos Serviços de Bibliotecas: SIBi. \\
\hline COMUNICAÇÃO & Projeto de Comunicação Visual: EERP. \\
\hline \multirow[b]{2}{*}{ PUBLICAÇÃO } & Filipeta Unidade em Números: FZEA. \\
\hline & $\begin{array}{l}\text { Programa de Gestão da Qualidade da Faculdade de Medicina de Ribeirão Preto. } \\
\text { 2002- 2003: FMRP. }\end{array}$ \\
\hline \multirow[t]{2}{*}{ PROCESSOS } & $\begin{array}{l}\text { Projeto APA para propor e implementar melhoria de processos. Associado ao } \\
\text { Projeto POLI 2015: EP. }\end{array}$ \\
\hline & Gestão de Projetos: SIBi. \\
\hline \multirow[t]{2}{*}{ QVT CULTURAL } & $\begin{array}{l}\text { Visita cultural dos funcionários à 17o Bienal Internacional do Livro em São Paulo: } \\
\text { FZEA. }\end{array}$ \\
\hline & Visita cultural dos funcionários ao Zoológico de São Paulo: FZEA. \\
\hline
\end{tabular}

\begin{tabular}{|c|c|}
\hline \multicolumn{2}{|r|}{2003} \\
\hline ESTRUTURA & Criação do Grupo Intersetorial de Melhoria - GIM: FMRP. \\
\hline SGQ & Implantação de Sistema de Gestão da Qualidade (SGQ): FZEA e IME. \\
\hline \multirow{3}{*}{ PLANEJAMENTO } & Elaboração de Plano de Metas: FAU. \\
\hline & II Workshop em Gestão Estratégica: FCFRP. \\
\hline & 1-Reunião de Planejamento Anual: EEFE. \\
\hline SEMINÁRIO & VII. Seminário de Qualidade e Produtividade da FCF. (agosto). \\
\hline \multirow{3}{*}{ ENCONTRO } & $\begin{array}{l}\text { 1o Encontro de Sistemas de Gestão da Qualidade das Unidades de Ensino da USP: } \\
\text { FMRP. (maio e setembro). }\end{array}$ \\
\hline & $\begin{array}{l}\text { Encontro de Integração dos servidores para geração de resultados com foco nas } \\
\text { metas do Instituto: IF. }\end{array}$ \\
\hline & I Encontro de Melhoria das Condições Ergonômicas: ICMC (agosto). \\
\hline \multirow[b]{2}{*}{ PALESTRA } & Palestra Ferramentas da Qualidade: FCFRP. \\
\hline & $\begin{array}{l}\text { Experiências da Qualidade na USP - participação no 10ํ Encontro: ESALQ e } \\
\text { FZEA.( 25/11). }\end{array}$ \\
\hline \multirow{6}{*}{ TREINAMENTO } & $\begin{array}{l}\text { Participação na 3a Turma do Curso de Formação de Multiplicadores de Qualidade, } \\
\text { promovido pelo GAMultiplica da Reitoria: ECA, EEFE, FMVZ, FZEA, IAG e IGc. }\end{array}$ \\
\hline & $\begin{array}{l}\text { Treinamento. Curso A importância do autoconhecimento e do autogerenciamento } \\
\text { para a tomada de decisões responsáveis: IP. }\end{array}$ \\
\hline & Curso na linha Pichon Rivière, para melhoria no trabalho em grupo - FMRP. \\
\hline & $\begin{array}{l}\text { Cursos de aprimoramento profissional, idiomas e outros: IB, FMRP, FFCLRP e } \\
\text { IFSC. }\end{array}$ \\
\hline & Projeto de Treinamento de Combate a Incêndio: IFSC. \\
\hline & Cursos para sensibilização ao Programa de Q\&P: IB. \\
\hline
\end{tabular}


continuação

\begin{tabular}{|c|c|}
\hline \multirow{3}{*}{ PUBLICAÇÃO } & Filipeta de Missão, Valores e Visão da DIBD da ESALQ, PCLQ e CIAGRI. \\
\hline & Publicação do Programa de Gestão da Qualidade da FMRP. \\
\hline & $\begin{array}{l}\text { Publicação do Trabalho - "A Faculdade de Ciências Farmacêuticas da USP e a } \\
\text { Questão Ambiental": FCF. }\end{array}$ \\
\hline PROCESSOS & Melhoria de Fluxograma do Processo de Compras: FMRP. \\
\hline \multirow{2}{*}{ RECONHECIMENTO } & $\begin{array}{l}\text { Recebimento de Medalha de Bronze do Prêmio Paulista de Qualidade da Gestão e } \\
\text { Certificado de Qualidade no Serviço Público: Biblioteca da ESALQ. }\end{array}$ \\
\hline & $\begin{array}{l}\text { Homenagem aos servidores aposentados do IF. Reconhecimento e valorização do } \\
\text { trabalho e dedicação dispensados ao IF. }\end{array}$ \\
\hline \multirow{2}{*}{ QVT SAÚDE } & Dia de Alerta contra o uso de Álcool e Drogas na USP: IFSC. \\
\hline & Ginástica Laboral: FCF, EP, FM, IF, IO, SIBi e RUSP. \\
\hline \multirow{2}{*}{ QVT CULTURAL } & $\begin{array}{l}\text { Qualidade de Vida no Trabalho. Apresentação da Orquestra Sinfônica da USP para } \\
\text { Campanha do Agasalho } 2003 \text { - FZEA. }\end{array}$ \\
\hline & $\begin{array}{l}\text { Visita cultural à Exposição "Os Guerreiros de Xian e os Tesouros da Cidade } \\
\text { Proibida": FZEA. }\end{array}$ \\
\hline $\begin{array}{l}\text { QVT } \\
\text { RESPONSABILIDADE } \\
\text { SOCIAL }\end{array}$ & Lançamento da Campanha Sou Cidadão Planetário: IP. \\
\hline QVT INTEGRAÇÃO & 2- Oficina de Integração: IP. \\
\hline \multirow{6}{*}{$\begin{array}{l}\text { GESTÃO } \\
\text { AMBIENTAL }\end{array}$} & Debates e seminários na área de Responsabilidade Socioambiental: IFSC. \\
\hline & Implantação do Programa de Coleta Seletiva : FCF (agosto) \\
\hline & Lançamento e Distribuição de canecas duráveis: IFSC e IP. \\
\hline & Oficina Artesanal de reciclagem de papel: IP. \\
\hline & Semana Integrada do meio ambiente do Programa USP Recicla: IP. \\
\hline & 2004 \\
\hline \multirow{6}{*}{ ESTRUTURA } & Criação da Comissão de Qualidade e Produtividade: IGc, IME, IO, IQ. \\
\hline & $\begin{array}{l}\text { Criação da Comissão Integrada de Qualidade e Produtividade do Campus USP de } \\
\text { Bauru - FOB/PCAB/HRAC. }\end{array}$ \\
\hline & $\begin{array}{l}\text { Criação da Comissão de Orçamento e Patrimônio para orientar o Planejamento } \\
\text { financeiro e a aplicação dos recursos do IME. }\end{array}$ \\
\hline & $\begin{array}{l}\text { Criação da Comissão Permanente de Espaço do IME - realização de estudos e } \\
\text { soluções para a ampliação do espaço físico. }\end{array}$ \\
\hline & $\begin{array}{l}\text { Criação da Seção de Qualidade e Processos, ligado ao Serviço de Planejamento e } \\
\text { Gestão: EP. }\end{array}$ \\
\hline & $\begin{array}{l}\begin{array}{l}\text { Criação de Secretaria de Projetos, para auxiliar pesquisadores na área } \\
\text { administrativa: IME. }\end{array} \\
\end{array}$ \\
\hline \multirow{4}{*}{ SGQ } & $\begin{array}{l}\text { Método do Sistema de Gestão de Qualidade da Fundação Douglas Andreani - } \\
\text { FMRP. }\end{array}$ \\
\hline & Participação do Programa de Qualidade do Governo Federal: FOB. \\
\hline & Sistema de Gestão Ambiental: melhoria e otimização de processos e práticas - FCF. \\
\hline & $\begin{array}{l}\text { Candidatura ao Prêmio de Gestão Pública e Cidadania da Fundação Getúlio Vargas, } \\
\text { pela Implementação do Sistema de Gestão Ambiental: FCF. }\end{array}$ \\
\hline \multirow{3}{*}{ PLANEJAMENTO } & Organização e Elaboração do Plano Diretor de Desenvolvimento de Pessoas: FOB. \\
\hline & 2- Reunião de Planejamento Anual: EEFE. \\
\hline & Levantamento das necessidades de Treinamento - FFCLRP e FOB. \\
\hline DIAGNÓSTICO & Avaliação contínua dos setores: ICMC. \\
\hline
\end{tabular}


continuação

\begin{tabular}{|c|c|}
\hline SENSIBILIZAÇÃO & $\begin{array}{l}\text { Desenvolvimento do Programa de Qualidade para envolvimento de todos da } \\
\text { organização: IF. }\end{array}$ \\
\hline \multirow{4}{*}{ ENCONTRO } & III Workshop em Gestão Estratégica: FCFRP. \\
\hline & $\begin{array}{l}\text { Workshop - Integração e compartilhamento de experiências para o aperfeiçoamento } \\
\text { dos diversos processos administrativos - FORP. }\end{array}$ \\
\hline & $\begin{array}{l}2^{\circ} \text { Encontro de Secretários do Campus de Ribeirão Preto (120 secretários): } \\
\text { FFCLRP. }\end{array}$ \\
\hline & Encontro para a discussão dos sistemas de gestão: ESALQ e PCLQ. \\
\hline \multirow{5}{*}{ PALESTRA } & $\begin{array}{l}\text { Ciclo de Palestras. Melhoria nos processos de gestão, melhoria no clima } \\
\text { organizacional: IF. }\end{array}$ \\
\hline & Encontros e palestras de sensibilização sobre o Programa de Qualidade: FOB. \\
\hline & $\begin{array}{l}\text { Experiências da Qualidade na USP - participação no 11ํ Encontro: ESALQ, CCE, } \\
\text { COSEAS e FCF. }\end{array}$ \\
\hline & Palestras aos funcionários sobre saúde bucal: FORP. \\
\hline & $\begin{array}{l}\text { Palestras e apresentações focando Qualidade no trabalho e motivação pessoal e } \\
\text { profissional: FFLCH. }\end{array}$ \\
\hline \multirow{17}{*}{ TREINAMENTO } & $\begin{array}{l}\text { Ciclo de vídeos: melhoria de processo, aprimoramento de rotinas, administração de } \\
\text { tempo, clima organizacional. ICMC. }\end{array}$ \\
\hline & $\begin{array}{l}\text { Criação do Curso de Formação Executiva para Assistentes de Direção da USP: } \\
\text { FEA. }\end{array}$ \\
\hline & $\begin{array}{l}\text { Curso de Formação Executiva para Assistentes de Direção da USP, oferecido pela } \\
\text { FEA. }\end{array}$ \\
\hline & Curso na linha Pichon Riviere, para melhoria no trabalho em grupo: FMRP. \\
\hline & $\begin{array}{l}\text { Cursos diversos de aprimoramento profissional, conhecimentos gerais em } \\
\text { administração, idiomas, informática: EESC, FEARP, FFCLRP, FMRP, IB, IFSC, } \\
\text { IME, IQ e IQSC }\end{array}$ \\
\hline & Cursos de informática para pessoas com necessidades especiais: ESALQ e PCLQ. \\
\hline & Cursos para sensibilização ao Programa de Q\&P: IB. \\
\hline & $\begin{array}{l}\text { Ferramentas da Qualidade (brainstorming, 5W/1H, PDCA, Análise de campos de } \\
\text { forças): IF, FZEA. }\end{array}$ \\
\hline & $\begin{array}{l}\text { Participação no Curso de Formação de Multiplicadores de Qualidade da Reitoria: } \\
\text { EP, FAU, FCF, FE, FFLCH, FO HU e IME. }\end{array}$ \\
\hline & $\begin{array}{l}\text { Participações no curso "Agente local de sustentabilidade socioambiental 2003- } \\
\text { 2004": IFSC. }\end{array}$ \\
\hline & Programa de Desenvolvimento de Líderes: FAU. \\
\hline & Promoção de curso de Alfabetização para funcionários da USP e terceirizados: FO. \\
\hline & Treinamento para os funcionários da Biblioteca: IME. \\
\hline & Treinamentos técnicos e comportamentais com servidores: IF. \\
\hline & $\begin{array}{l}\text { Funcionários cursando Doutorado: EERP, EESC, EP, ESALQ, FCF, FE, FFCLRP, } \\
\text { FM, FO, FOB, FSP, FZEA, IF, IP, IQ e PCLQ. }\end{array}$ \\
\hline & $\begin{array}{l}\text { Funcionários cursando Mestrado: ECA, EEFE, EERP, EESC, EP, ESALQ, FCF, } \\
\text { FD, FE, FEA, FEARP, FFCLRP, FM, FO, FOB, FORP, FSP, FZEA, IF, IFSC, IP, } \\
\text { IQ e PCLQ. }\end{array}$ \\
\hline & $\begin{array}{l}\text { Funcionários cursando MBA - ECA, EEFE, EERP, EESC, ESALQ, FCFRP, } \\
\text { FEARP, FFCLRP, FMRP, FMVZ, FO, FOB, FORP, ICMC, IFSC, IME, IP e } \\
\text { PCLQ. }\end{array}$ \\
\hline
\end{tabular}


continuação

\begin{tabular}{|c|c|}
\hline \multirow{4}{*}{ COMUNICAÇÃO } & Divulgação da Biblioteca por meio de folders: IME. \\
\hline & Melhoria na Comunicação interna e ou externa: IF, IQ, FD. \\
\hline & Projeto gráfico para homepage: FMRP. \\
\hline & Elaboração de Vídeo institucional: IAG. \\
\hline \multirow{2}{*}{ INFORMAÇÃO } & $\begin{array}{l}\text { Instalação e aparelhamento de vários laboratórios de computação, ligados às redes } \\
\text { Unix e Linux: IME. }\end{array}$ \\
\hline & $\begin{array}{l}\text { Introdução ao Mundo Digital: cursos de informática aos funcionários que tem } \\
\text { pouco acesso a microcomputadores: FE. }\end{array}$ \\
\hline PUBLICAÇÃO & Filipeta FAU em números: FAU. \\
\hline \multirow{13}{*}{ PROCESSOS } & $\begin{array}{l}\text { Implementação do Projeto Sistema de Gestão da Qualidade (SDG): } 14 \text { bibliotecas } \\
\text { do SIBi, com metodologia da Consultoria Diagrama, da Fundação Douglas } \\
\text { Andreani (semelhante à utilizada pela Biblioteca da ESALQ). }\end{array}$ \\
\hline & $\begin{array}{l}\text { Descrição de funções, rotinas e fluxogramas de todos os setores da unidade e } \\
\text { Agendas-memória - IAG. }\end{array}$ \\
\hline & Plano de Ação Local Participativo - PALP. Implantação do Programa 5 S: IAG. \\
\hline & $\begin{array}{l}\text { Aplicação da Ferramenta 5S: EDUSP, FEA, FFLCH, FO, FMRP, HU, ICMC, IF, } \\
\text { IGc, IQ, e MAC. }\end{array}$ \\
\hline & $\begin{array}{l}\text { Revisão, Análise, Mapeamento e Padronização de Processos: ECA, FEARP, FORP, } \\
\text { FMRP, ICMC e IF. }\end{array}$ \\
\hline & Redução de custos com cópia reprográfica: FEARP. \\
\hline & Estabelecimento de Rotinas e Procedimentos - ECA. \\
\hline & Completado o mapeamento dos processos do Serviço de Compras: FMRP. \\
\hline & $\begin{array}{l}\text { Elaboração do Guia do Usuário - Procedimento de Compras no Mercúrio Web e } \\
\text { Guia para Cadastro de Cursos no Sistema Apolo: FMRP. }\end{array}$ \\
\hline & $\begin{array}{l}\text { Implantação "Administração visível" - folha de verificação, mapeamento do } \\
\text { processo: FMRP. }\end{array}$ \\
\hline & Padronização dos processos e procedimentos da área financeira: FE. \\
\hline & Planejamento para o uso dos recursos de treinamento: ICMC. \\
\hline & Política de Racionalização e otimização de recursos: IME. \\
\hline \multirow{11}{*}{ INFRAESTRUTURA } & Construção de Creche: FSP. \\
\hline & Construção de novo prédio: FD, IQ, IME. \\
\hline & Expansão e atualização de equipamentos eletrônicos e laboratoriais: EESC. \\
\hline & Implantação de Seção de Reprografia: IME. \\
\hline & $\begin{array}{l}\text { Inauguração da Matemateca, materiais didáticos produzidos pelo MAT/MAP: } \\
\text { IME. }\end{array}$ \\
\hline & $\begin{array}{l}\text { Inauguração do laboratório para alunos de pós-graduação do Departamento de } \\
\text { Matemática Aplicada - IME. }\end{array}$ \\
\hline & $\begin{array}{l}\text { Pintura nas dependências da faculdade e reformas de diversos espaços para atender } \\
\text { melhor às necessidades: IQ. }\end{array}$ \\
\hline & $\begin{array}{l}\text { Reforma da rede elétrica, reforma das salas de Audiovisual, Biblioteca, Secretaria } \\
\text { de Projetos, Atlética e Seção de Alunos e do Auditório Jacy Monteiro - IME. }\end{array}$ \\
\hline & Reformulação do Jardim - FSP. \\
\hline & Sala para instalação do arquivo permanente: EERP. \\
\hline & Segurança do acervo: IME. \\
\hline
\end{tabular}




\begin{tabular}{|c|c|}
\hline & continuação \\
\hline \multirow{10}{*}{ QVT SAÚDE } & Campanha de Vacinação contra a Gripe: FE. \\
\hline & Campanha contra Febre Maculosa: ESALQ e PCLQ. \\
\hline & $\begin{array}{l}\text { Campanha de Vacinação Hepatite B, Dupla, Tríplice viral para docentes, alunos e } \\
\text { funcionários: FORP. }\end{array}$ \\
\hline & Dia do Alerta contra o uso de Álcool e Drogas na USP: IQSC. \\
\hline & Exercício de alongamento e relaxamento: FFLCH. \\
\hline & Ginástica Laboral: FAU e IAG. \\
\hline & $\begin{array}{l}\text { Instituição de Comissão Antitabagista. 1'- Unidade onde é Proibido Fumar nas suas } \\
\text { dependências: FSP. }\end{array}$ \\
\hline & Levantamento das condições ergonômicas: ICMC. \\
\hline & Orientação de saúde bucal à comunidade carente: FO. \\
\hline & Saúde Coletiva - FOB. \\
\hline \multirow{6}{*}{$\begin{array}{l}\text { QVT } \\
\text { RESPONSABILIDADE } \\
\text { SOCIAL }\end{array}$} & Responsabilidade Social. Projeto Pequeno Cidadão: ESALQ e PCLQ. \\
\hline & $\begin{array}{l}\text { Responsabilidade Social. Facilitar vínculos entre os Projetos de Graduação para } \\
\text { conclusão de curso e necessidades identificadas na sociedade: EP. }\end{array}$ \\
\hline & Programa Universidade Aberta à Terceira Idade: IME. \\
\hline & Projetos Comunitários: FZEA. \\
\hline & Programa Avizinhar: IME. \\
\hline & $\begin{array}{l}\text { Centro Minerva de Empreendedorismo. Disseminar o empreendedorismo na } \\
\text { Comunidade USP: EP. }\end{array}$ \\
\hline \multirow{3}{*}{ QVT CULTURA } & Formação de Coral: FSP, ESALQ e PCLQ. \\
\hline & Teatro: ESALQ/PCLQ. \\
\hline & Restauração de obras raras, conservação e preservação do acervo: IME. \\
\hline \multirow{5}{*}{ QVT INTEGRAÇÃO } & 1- Café da Manhã aos servidores: um por semana: IB. \\
\hline & $\begin{array}{l}\text { Café da manhã aos funcionários das áreas de limpeza, zeladoria e conservação: } \\
\text { FORP. }\end{array}$ \\
\hline & $\begin{array}{l}\text { Evento de integração dos servidores para geração de resultados com foco nas metas } \\
\text { do Instituto: IF. }\end{array}$ \\
\hline & Programa de Integração de Novos Servidores: FE. \\
\hline & Promovendo integrações das áreas: ECA. \\
\hline \multirow{2}{*}{ RECONHECIMENTO } & Homenagem aos docentes e funcionários que receberam Prêmios: FCFRP. \\
\hline & Premiação de professores: IME. \\
\hline \multirow{5}{*}{ GESTÃO AMBIENTAL } & $\begin{array}{l}\text { PURA. Programa de Uso Racional de Água: CDCC, CISC, ECA, ESALQ/PCLQ, } \\
\text { FCF, FZEA, ICMC, IME, IP, PCASC, PCARP, PCO. }\end{array}$ \\
\hline & $\begin{array}{l}\text { PURE. Programa de Uso Racional de Energia: CDCC, CISC, ECA, ESALQ/PCLQ, } \\
\text { FCF, FOB, FZEA, ICMC, IFSC, IME, IP, PCAPS, PCARP e PCO. }\end{array}$ \\
\hline & USP Recicla. Distribuição de canecas duráveis. EERP. \\
\hline & $\begin{array}{l}\text { USP Recicla. Ações do Programa: ECA, EE, ESALQ/PCLQ, FCF, ICMC, IP, } \\
\text { PCAPS, PCARP e PCO. }\end{array}$ \\
\hline & Implantação de Coleta Seletiva de Lixo: FZEA. \\
\hline
\end{tabular}


2005

\begin{tabular}{|c|c|}
\hline \multicolumn{2}{|r|}{2005} \\
\hline CERTIFICAÇÃO & Laboratórios certificados na Norma NBR-ISO/17025 - IEE. \\
\hline SGA & $\begin{array}{l}\text { Sistema de Gestão Ambiental (SGA). Formação de Brigada de Incêndio: FCF } \\
\text { (agosto). }\end{array}$ \\
\hline \multirow{5}{*}{ PLANEJAMENTO } & Desenvolvimento de Diagnóstico organizacional: FFCLRP. \\
\hline & III Workshop de Interação de Competência: ICMC. \\
\hline & 3a - Reunião de Planejamento Anual: EEFE. \\
\hline & Encontro para elaboração de Plano de Metas: FZEA. \\
\hline & $\begin{array}{l}\text { Diagnóstico e elaboração de relatório sobre as adequações a serem realizadas nos } \\
\text { prédios da FCF para vistoria do Corpo de Bombeiros: FCF. }\end{array}$ \\
\hline \multirow[t]{2}{*}{ SEMINÁRIO } & VIII Seminário de Qualidade e Produtividade da FCF. (agosto). \\
\hline & Exercício simulado do "Plano de Abandono de Edificação" - FCF. \\
\hline \multirow{6}{*}{ TREINAMENTO } & $\begin{array}{l}\text { Curso de Formação de Multiplicadores de Qualidade promovido pelo } \\
\text { GAMultiplica/RUSP - CCS, CEUMA, COESF, FD, FMVZ, .IB e PCO. }\end{array}$ \\
\hline & $\begin{array}{l}\text { Participação de funcionários no Curso de Formação Executiva para Assistentes } \\
\text { de Direção da USP, oferecido pela FEA - COESF, COSEAS, EE, EERP, FM, } \\
\text { HU, IMT, MP, MZ, PCARP, PCO, EACH. }\end{array}$ \\
\hline & Cursos de Idiomas - FMRP. \\
\hline & Formação de Brigada de Incêndio: FCF. \\
\hline & Programa de Desenvolvimento de Líderes: FOB. \\
\hline & Programa de Gestão por Processos (parceria com o INPQ): EE. \\
\hline PALESTRA & $\begin{array}{l}\text { Experiências da Qualidade na USP - participação no 12º Encontro da Qualidade } \\
\text { e Produtividade da USP: CEPEUSP, FEA, SIBi, EDUSP,IAG e ICMC.(17/08). }\end{array}$ \\
\hline COMUNICAÇÃO & $\begin{array}{l}\text { Implantação de nova sinalização visual nas áreas internas e externas. Parte 1: } \\
\text { FCF. }\end{array}$ \\
\hline \multirow{3}{*}{ PUBLICAÇÃO } & Órgãos e atividades. Perfil da Faculdade de Odontologia. \\
\hline & Prestação de Serviços à Comunidade da Faculdade de Odontologia. \\
\hline & $\begin{array}{l}\text { Manual de Orientação de Ginástica Laboral (trabalho desenvolvido em } 9 \\
\text { unidades desde 2003) - CEPEUSP. }\end{array}$ \\
\hline \multirow[t]{2}{*}{ PROCESSOS } & $\begin{array}{l}\text { Melhoria em Procedimentos de convênio, cooperação e estímulo à mobilidade } \\
\text { estudantil e de docente: FD. }\end{array}$ \\
\hline & Sistema de Gestão da Qualidade - Gestão por processos: FZEA. \\
\hline QVT ERGONOMIA & Implementação das recomendações de laudo ergonômico - ICMC. \\
\hline QVT INTEGRAÇÃO & Integração. Projeto de Integração para a Comunidade do IAG. \\
\hline \multicolumn{2}{|r|}{2006} \\
\hline ESTRUTURA & Formação de Nova Comissão de Qualidade e Produtividade: IFSC. \\
\hline PLANEJAMENTO & 4르 Reunião de Planejamento Anual: EEFE. \\
\hline SEMINÁRIO & IX Seminário de Qualidade e Produtividade da FCF. \\
\hline TREINAMENTO & Programa de Formação e Multiplicadores da Qualidade: IFSC. \\
\hline \multirow{2}{*}{ COMUNICAÇÃO } & Boletim eletrônico IFSComunica: IFSC. \\
\hline & Implantação de nova sinalização visual nas áreas internas. Parte 2: FCF. \\
\hline INFORMAÇÃO & Desenvolvimento de Sistemas de Informação: FD. \\
\hline PROCESSOS & Aplicação da Ferramenta 5S: IFSC. \\
\hline \multirow{2}{*}{ GESTÃO AMBIENTAL } & Diagnóstico e adequação de descartes de efluentes na rede de esgoto: FCF. \\
\hline & Formação de Brigada de Incêndio: FCF (maio). \\
\hline
\end{tabular}

Fonte: Pesquisa de Monitoramento da Comissão de Gestão de Qualidade e Produtividade e Relatórios das Unidades, 2010 



\section{APÊNDICE C - Programação dos Encontros de Qualidade e Produtividade da USP:}

1996 - 2005

Nos 12 encontros realizados pelo Programa Permanente de Qualidade e Produtividade da USP, com 2.030 participantes, foram feitas 70 apresentações, sendo 29 (vinte e nove) palestras sobre temas gerais de Qualidade e 41 (quarenta e uma) apresentações de experiências internas da Qualidade. Vinte e seis (26) desses últimos relatos foram de experiências do campus da Capital e 15 (quinze) de Unidades dos campi do interior. O público-alvo desses encontros foram os diretores de Órgãos e Unidades da USP, os integrantes das Comissões Internas de Q\&P, convidados de outras Universidades e pessoas pertencentes a outros órgãos do Governo do Estado de São Paulo e interessadas no tema da Qualidade.

Anterior a esses Encontros promovidos pela Comissão de Gestão de Qualidade e Produtividade, houve um Seminário para o lançamento do Programa de Qualidade e Produtividade da USP, em 07/05/1996, com a abertura feita pelo Reitor Prof. Flávio Fava de Moraes e uma palestra proferida pelo Prof. Melvin Cymbalista, docente da Escola Politécnica, para diretores e coordenadores de Órgãos da USP.

A relação aqui apresentada foi adaptada da publicação do Programa Permanente de Qualidade e Produtividade da Universidade de São Paulo (2005), Uma Década do Programa de Qualidade e Produtividade na USP: 1996 - 2005, organizada por Cruz e Miranda (2005).

1ํ ENCONTRO - 02/07/1996

- Apresentação do Programa e dos membros da Comissão de Qualidade e Produtividade da USP. Prof. Flávio Fava de Moraes (Reitor da USP)

- Gestão Pública e Balizadores. Prof. Hélio Janny Teixeira (FEA).

2을 ENCONTRO - 30/08/1996

- Consolidação dos Destaques e Problemas. Prof. Hélio Nogueira da Cruz (Coordenador da CODAGE)

- Ações e Planos na Área de Informática: 1994 - 1997. Prof. Imre Simon (CCI/IME) 
3ํㅡㄹ ENCONTRO - 19/03/1997

- Abertura pelo Reitor Prof. Flávio Fava de Moraes

- Atividades de 1996 e Propostas para 1997. Prof. Hélio Nogueira da Cruz (Coordenador da CODAGE)

- O futuro das Universidades Públicas Brasileira. Prof. Simon Schwartzman (Presidente do IBGE)

- CODAGE e o Departamento de Recursos Humanos. Profa. Helena M. C. Carmo Antunes (Diretora do Departamento de Recursos Humanos da CODAGE).

- USP Recicla. Prof. Guilherme Ary Plonsky (CECAE) e Patrícia Blauth (CECAE)

- Centro de Energia Nuclear na Agricultura. Prof. Carlos Clemente Cerri (CENA)

- Instituto de Eletrotécnica e Energia. Eng. Luis Carlos Lopes (IEE)

4- ENCONTRO - 14/05/1997

- Abertura: Prof. Hélio Nogueira da Cruz (Presidente da Comissão de Gestão da Q\&P USP)

- Relato das atividades da Comissão de Q \& P da USP. Prof. Hélio Janny Teixeira (FEA)

- Utilizando o Critério Baldrige para melhorar os Resultados Educacionais. Profa. Linda G. James (Diretora de avaliação da State Technical Institute de Memphis - USA)

- Um Caminho para o Futuro. Maurício Biazotto Corte (Coordenador do Comitê da Educação da Fundação para o Prêmio Nacional da Qualidade e Superintendente da Fundação Limeira)

- Primeiros passos para a melhoria. Prof. Marcus Antonio Zanetti (FZEA)

- O processo de elaboração de Plano Diretor. Prof. Dalberto Luiz de Santo (EEFE).

5o ENCONTRO - 14/08/1997

- Relato das atividades da Comissão de Q\&P da USP. Prof. Hélio Nogueira da Cruz (Coordenador da CODAGE)

- Gestão Integrada de Telecomunicações. Prof. Antonio Marcos de Aguirra Massola (EP)

- A qualidade e as mudanças na cultura organizacional - Profa. Maria Tereza Leme Fleury (FEA)

- A experiência da Universidade Tecnológica Nacional (detentora do Prêmio Nacional da Qualidade em1995, na Argentina). Eng. Juan Carlos Jesus Piter e Eng. Leonidas Rodolfo Anselmino

- Hospital de Pesquisa e Reabilitação de Lesões Labiopalatais de Bauru. Sra. Salete São Bernardo Aversano (HRAC) - $5^{\circ}$ ENCONTRO.

- O Ensino no Ensino de Engenharia. Prof. Sérgio Brandi (EP)

- Área de Finanças e Materiais da USP. Sr. Luis Antonio Teixeira (CODAGE/DF) 
6을 ENCONTRO - 29/10/1997

- A experiência da USP no Programa de Qualidade e Produtividade do Governo.

- Prof. Hélio Nogueira da Cruz e Prof. Hélio Janny Teixeira (FEA)

- A experiência do Tribunal de Contas do Município de São Paulo na gestão pela Qualidade Total. Conselheiro Eurípedes Sales (TCMSP)

- Relações do Trabalho e Desenvolvimento da Gestão das Atividades-Meio. Profa. Helena Lúcia Alves de Lima Furtado (FMRP)

- Instituto de Ciências Matemáticas e da Computação. Prof. Hildebrando Munhoz Rodrigues e Prof. Paulo Veiga (ICMC)

- Centro de Recursos Hídricos da Escola de Engenharia de São Carlos. Ivan Bueno (EESC)

- Faculdade de Medicina de Ribeirão Preto. Profa. Maria Cristina Roque Barreira (FMRP)

- Experiência Institucional da Qualidade: Projeto de Modernização do SIBi/USP. Sra. Rosaly Favero Krzyzanowsky e Sra. Regina Célia Baptista Belluzo (SIBi)

Paralelamente às apresentações foram expostos painéis com uma amostra das publicações originárias do Programa de Qualidade e um conjunto de notícias do que acontece nas Unidades e Órgãos. Foram apresentadas contribuições da Faculdade de Educação, Faculdade de Educação Física, da ESALQ, do SIBi, do CECAE, da RUSP, do DRH e do GEFIM, entre outras.

\section{7을 ENCONTRO - 04/11/1998}

- Atividades da Comissão de Gestão de Q\&P da USP em 1998: Ênfase em Indicadores de desempenho para a Universidade. Prof. Hélio Nogueira da Cruz (Coordenador da CODAGE)

- DATAPOLI: ferramenta de apoio às atividades administrativas dos Departamentos. Prof. Luiz Natal Rossi (EP)

- A experiência norte-americana em gestão da qualidade no ensino superior e iniciativas da FMRP. Profa. Helena Lúcia Alves de Lima Furtado (FMRP)

- As ações da Qualidade e Produtividade na ESALQ. Prof. Marcos Milan (ESALQ)

\section{8o ENCONTRO - 26/04/2001}

- O Programa de Qualidade e Produtividade na USP. Prof. Hélio Nogueira da Cruz (Coordenador da CODAGE)

- Atividades e Tendências da Qualidade. Prof. Clóvis Alvarenga Netto (EP)

- Avaliação Institucional. Prof. Adolpho José Melfi (Vice-Reitor da USP)

- A Pesquisa e a Ação de Qualidade na FEA. Profa. Maria Tereza Fleury e Profa. Ana Cristina Limongi França (FEA)

- Comissão Interna de Q \& P da FCF - Trajetória e Perspectivas. Profa. Terezinha de Jesus Andreoli Pinto (FCF)

- Processo de Acreditação no Hospital Universitário. Dra. Pubenza Lopez Castellanos (HU)

- Experiência Institucional da Qualidade ESALQ/USP. Prof. Marcos Milan, Prof. José Otávio Brito e Márcia Saad (ESALQ). 
9o- ENCONTRO - 13/09/2001

- Balanço Geral de 6 anos do Programa de Qualidade na USP. Prof. Hélio Nogueira da Cruz (Vice-Reitor da USP)

- Questão Ambiental dentro da Gestão da Qualidade. Prof. Hélio Janny Teixeira (FEA)

- Os Papéis da Universidade na Sociedade do Conhecimento. Profa. Elizabeth Balbachevsky (NUPES)

- O Modelo de Excelência na Gestão Pública. Francisco Sérgio Ferreira Jardim (DFA)

- Programa de Racionalização na USP. Prof. Antonio Marcos de Aguirra Massola (EP)

- A experiência da Qualidade no CEPEUSP. Prof. Go Tani e João Carlos Kanaan

- Programa Integrado de Qualidade no HRAC. Prof. Heli Benedito Brosco e Silvia Amália Cardoso Santos. (HRAC)

- O Programa de Qualidade de Gestão da FMRP. Prof. Ayrton Custódio Moreira e Profa. Helena Lúcia Alves de Lima Furtado. (FMRP)

Nesse Encontro, além das apresentações, foi feita uma mostra de Painéis, elaborados pelas Unidades e Órgãos da USP para apresentar de uma forma gráfica ou descritiva as suas "Iniciativas de Qualidade". O conjunto de Painéis foi transformado na 6o- publicação do Programa de Qualidade, com o título de "Iniciativas de Qualidade na USP”, editado em setembro de 2001, que permite visualizar o que se fazia, em nome da Qualidade, nessa data. Houve 27 entidades participantes, com um total de 46 Painéis. Participaram dessa mostra, entre as Unidades de Ensino e Pesquisa: EE, EERP, EP, ESALQ, FCF, FCFRP, FEA, FFCLRP, FO, FOB e FORP. Como Centro e Instituto Especializado: CENA e IEB. Entre os Hospitais: HRAC e HU. Como Museus: MAC e MP. Entre os Órgãos Centrais de Direção e Serviço: CECAE, CEPEUSP, CIAGRI, CIRP, COSEAS, PCAB, PCALQ, PCARP, RUSP e SIBi.

10 으CONTRO - 25/11/2003

- O MBA de Qualidade da Escola Politécnica e Reflexos na Qualidade da USP. Prof. Adherbal Caminada Netto (EP)

- Programa de Qualidade na Reitoria. Olga Miranda (Vice-Reitoria)

- Qualidade de Vida e Produtividade na FZEA. Prof. José Bento Sterman Ferraz (FZEA)

- Retrospectiva e Perspectivas do GEFIM. Luiz Antonio Teixeira (CODAGE/DF)

- O Sistema DIBD e os desafios do Prêmio Paulista de Qualidade de Gestão. Prof. Marcos Millan e Marcia Saad (ESALQ)

Com o objetivo de projetar sua imagem institucional, as 56 Unidades e Órgãos da USP elaboraram o cartão Unidade em Números, à semelhança do existente USP em Números. Foram reunidos, em um folheto ou cartão, os seus principais dados acadêmicos e administrativos, tais como: número de alunos; docentes; produção científica; publicações; atendimentos hospitalares; público visitante; infraestrutura etc. Algumas Unidades, até 2009, atualizavam e publicavam, anualmente, esses folhetos. 
11을 ENCONTRO - 17/11/2004

- Qualidade e a metáfora do barco a remo. Prof. Clóvis Alvarenga Netto (FEA)

- Certificações no Sistema ISO: Perspectivas para a Universidade de São Paulo. Prof. José Joaquim do Amaral Ferreira (EP)

- Os Grupos de Ação de Melhoria (GAM's) na Reitoria. Olga Miranda/ Yara Breda Mourão/ Rosana Simone (Reitoria)

- Implantação do Sistema de Gestão de Qualidade em um Restaurante Universitário da Divisão de Alimentação. Roseane Pagliaro Avegliano (COSEAS)

- A experiência da ESALQ e seus desdobramentos. Prof. Marcos Milan e Marcia Saad (ESALQ)

- Gestão da Qualidade na Área de Tecnologia da Informação. Mauro César Bernardes (CCE)

- Sistema de Gestão Ambiental na Faculdade de Ciências Farmacêuticas: Rumo à Certificação ISO 14 001. Profa. Terezinha de Jesus Andreoli Pinto (FCF)

12을 ENCONTRO - 17/08/2005

- Qualidade na SABESP. Márcia Arce Parreira Martinelli (SABESP)

- Uma Década do Programa de Qualidade na USP. Prof. Hélio Nogueira da Cruz (ViceReitor da USP)

- A Ginástica Laboral no Programa de Qualidade da USP. Profa. Patrícia Sakai e Prof. Christian Klausener (CEPEUSP)

- Plano Participativo no Instituto Astronômico e Geofísico - IAG. Prof. Jacques Raymond Daniel Lépine e Profa. Márcia Ernesto (IAG)

- Implementação dos 5’S na Editora da USP. Marcos Bernardini, Cinzia Araújo e Ivete Silva (EDUSP)

- Boa-Aula e Bom Dia-a-Dia. Maria de Lourdes Medeiros (FEA)

- Qualidade no Instituto de Ciências Matemáticas e de Computação. Prof. Plácido Zoega Táboas (ICMC)

- SAUSP- Gestão de Documentos \& Gestão no SIBi/USP. Profa. Joanna Wilhelmina (CODAGE/DA)

- Implementação do Programa de Gestão no SIBi/USP. Adriana Ferrari (SIBi)

- Multiplicadores da Qualidade no Programa da Reitoria. Profa. Maria Luiza Abrantes (Secretaria do Planejamento do Estado de São Paulo)

Nesse encontro, foi distribuído o Manual de Orientação de Ginástica Laboral, organizado pelo CEPEUSP. A publicação complementava o trabalho do Projeto de Ginástica Laboral, realizado pelo CEPEUSP em parceria com a Comissão de Q\&P da USP, em 9 Unidades da USP, desde outubro de 2003.

Nessa mesma oportunidade, foram conferidos diplomas de reconhecimento a cerca de 100 pessoas que se envolveram no Programa de Qualidade e Produtividade da USP. 



\section{APÊNDICE D - Publicações ligadas ao Programa de Qualidade e Produtividade}

Incluem-se, nesse item, publicações elaboradas pela Comissão de Gestão de Qualidade e Produtividade e outras feitas pelas Unidades e Órgãos da USP.

\begin{tabular}{|c|c|c|}
\hline DATA & DESCRIÇÃO & RESPONSÁVEL \\
\hline 1997 & Registro de Diplomas Normas e Procedimentos I & Comissão Q\&P Reitoria \\
\hline 1997 & Registro de Diplomas Normas e Procedimentos II & Comissão Q\&P Reitoria \\
\hline 1997 & $\begin{array}{l}\text { Registro de Diplomas. Normas e Procedimentos III Pós- } \\
\text { Graduação. Expedição de diplomas de livre docente e professor } \\
\text { titular. Revalidação e registro de Diplomas de estrangeiros }\end{array}$ & Comissão Q\&P Reitoria \\
\hline 1997 & Relatório de Atividades de 1996 (v.1) & CGQP USP \\
\hline 1997 & $\begin{array}{l}\text { Trabalho em equipe: relatório de consolidação de Resultados } \\
\text { (v.2) }\end{array}$ & CGQP USP \\
\hline 1997 & $\begin{array}{l}\text { Questionário para Mapeamento de Características da Qualidade } \\
\text { e Produtividade (v.3) }\end{array}$ & CGQP USP \\
\hline 1997 & $\begin{array}{l}\text { Programa Permanente para o Uso eficiente de Energia } \\
\text { elétrica na USP }\end{array}$ & Programa PURE \\
\hline 1997 & Sistema de Arquivo da USP (SAUSP) & CODAGE/DA \\
\hline 1997 & Gestão Financeira e de Materiais da USP (GEFIM) & CODAGE/GEFIM \\
\hline 1998 & Relatório Anual de atividades de 1997 (v.4) & CGQP USP \\
\hline 2000 & Rumo à Acreditação Hospitalar: 5S & Hospital Universitário \\
\hline 2001 & D’Olho na Qualidade & Hospital Universitário \\
\hline 2001 & Gestão Ambiental: ISO 14.001 & $\mathrm{FCF}$ \\
\hline 2001 & $\begin{array}{l}\text { Palestras apresentadas no } 8^{\circ} \text { Encontro de Qualidade e } \\
\text { Produtividade da USP (v.5) }\end{array}$ & CGQP USP \\
\hline 2001 & Iniciativas de Qualidade na USP (v.6) & CGQP USP \\
\hline 2001 & Balanço Geral. Seis anos de atividades: 1996 - 2001 (v.7) & CGQP USP \\
\hline 2002 & Relatório de Atividades (v.1) & Comissão Q\&P Reitoria \\
\hline 2002 & Perfil da Reitoria. Órgãos e Atividades (v.2) & Comissão Q\&P Reitoria \\
\hline 2003 & Programa de Gestão da Qualidade & FMRP \\
\hline 2003 & $\begin{array}{l}\text { Missão, Valores e Visão da Divisão de Biblioteca e } \\
\text { Documentação }\end{array}$ & ESALQ/DIBD \\
\hline 2004 & Perfil da Reitoria. Órgãos e Atividades (v.3) & Comissão Q\&P Reitoria \\
\hline 2005 & Perfil da Faculdade de Odontologia. Órgãos e Atividades & $\mathrm{FO}$ \\
\hline 2005 & Prestação de Serviços à Comunidade & FO \\
\hline 2005 & Ginástica Laboral. Manual de Orientação & CEPEUSP \\
\hline 2005 & $\begin{array}{l}\text { Quadriênio do Programa de Qualidade e Produtividade da } \\
\text { Reitoria: } 2002-2005 \text { (v.4) }\end{array}$ & Comissão Q\&P Reitoria \\
\hline 2005 & $\begin{array}{l}\text { Uma década do Programa de Qualidade e produtividade na } \\
\text { USP: } 1996-2005 \text { (v.8) }\end{array}$ & CGQP USP \\
\hline
\end{tabular}

Fonte: Dados de pesquisa documental, 2010 



\section{APÊNDICE E - Levantamento de artigos do Jornal da USP sobre o Programa de Qualidade e Produtividade: 1996-2007}

\begin{tabular}{|c|c|c|}
\hline & DATA & NOME DO ARTIGO \\
\hline 01 & Ano XI, n.350, 27/05 a 02/06/1996, p.3 & Um programa para motivar criatividade \\
\hline 02 & Ano XII, n. 377, 17 a 23/02/1997, p.3 & DRH amplia formação do $2^{\circ}$ grau \\
\hline 03 & Ano XII, n. 377, 17 a 23/02/1997, p. 4 & Em busca da gestão ideal \\
\hline 04 & Ano XII, n. 381, 17 a 23/03/1997, p. 3 & $\begin{array}{l}\text { Um encontro para avaliar qualidade } \\
\text { Universidade }\end{array}$ \\
\hline 05 & Ano XII, n.391, 26/5 a 1\%/06/1997, p. 3 & Boas ideias são a base de tudo \\
\hline 06 & Ano XIII, n. 399, 11 a 17/08/1997, p. 4 & Para produzir mais e melhor \\
\hline 07 & Ano XIII, n.406, 29/9 a 5/10/1997, p. 2 & Afinal o que é produtividade? \\
\hline 08 & Ano XIII, n.410, 27/10 a 2/11/1997, p.3 & Um balanço de dois anos de atividades \\
\hline 09 & Ano XV, n.524, 2 a 8/10/2000, p. 3 & Anuário entra na Internet \\
\hline 10 & Ano XV, n. 548, 23 a 29/04/2001, p. 3 & Uma Iniciativa para avaliar a Universidade \\
\hline 11 & Ano XV, n.552, 28/5 a 3/06/2001, p. 5 & USP dá início a plano de racionamento \\
\hline 12 & Ano XV, n. 566, 10 a 16/09/2001, p.6 & Programa estimula atitude positiva \\
\hline 13 & Ano XV, n. 568, 24 a 30/09/2001, p. 6 & Para produzir com qualidade \\
\hline 14 & Ano XVIII, n.611, 02 a 8/09/2002, p.13 & Por um serviço de qualidade \\
\hline 15 & Ano XIX, n. 667, 24 a 30/11/2003, p.5 & Mais excelência, mais eficiência \\
\hline 16 & Ano XIX, n. 671, 12 a 18/01/2004, p.1,2 & $\begin{array}{l}\text { Uma medalha para a eficiência. A participação da } \\
\text { USP no Prêmio Paulista de Qualidade da Gestão }\end{array}$ \\
\hline 17 & Ano XIX, n. 671, 12 a 18/01/2004, p. 4 & Aplausos para a eficiência \\
\hline 18 & Ano XX, n. 707,16 a 21/11/2004, p. 6 & Cada vez mais e melhor \\
\hline 19 & Ano XXI, n.730, 27/06 a 3/07/2005,p.5 & 5o Gefim acontece em Pirassununga \\
\hline 20 & Ano XXI, n.735, 15 a 21/08/2005, p. 1,6 & $\begin{array}{l}\text { Encontro avalia qualidade na USP. } \\
\text { Mais qualidade, melhores resultados }\end{array}$ \\
\hline 21 & Ano XXI, n. 736,22 a 28/08/2005, p. 20 & O desafio da qualidade \\
\hline 22 & Ano XXI, n.737, 29/8 a 4/09/2005 p.11 & Pausa para o relaxamento \\
\hline 23 & Ano XXII, n. 801, 2 a 8/07/2007, p. 5 & História de sucesso e muita economia \\
\hline 24 & Ano XXIII, n.803, 30/7 a 5/8/2007, p.1,6 & $\begin{array}{l}\text { A nova medalha da ESALQ. } \\
\text { Piracicaba dá o exemplo }\end{array}$ \\
\hline 25 & Ano XXIII, n.810, 24 a 30/09/2007, p. 14 & A coleta seletiva do lixo na USP \\
\hline
\end{tabular}

Fonte: Levantamento de pesquisa do banco de dados do Jornal da USP, 2010 



\section{APÊNDICE F - Monografias de funcionários USP do curso de MBA de Gestão e} Tecnologias da Qualidade da Escola Politécnica/PECE: 2004-2008

\begin{tabular}{|c|c|}
\hline & 2004 \\
\hline 01 & $\begin{array}{l}\text { Rita de Cássia Silva Dias. } \\
\text { Novos Conceitos de Treinamento e Desenvolvimento (T\&D), Auxiliando na Solução de Problemas } \\
\text { em Atividades Diárias de Trabalho nas Organizações }\end{array}$ \\
\hline 02 & $\begin{array}{l}\text { João A.A. Salla; Lídia G. B. Pinheiro; Paulo Nakati; Peter Greiner Junior. } \\
\text { Entraves ao Empowerment no Setor Público Brasileiro: O caso das Unidades de Ensino e Pesquisa da } \\
\text { Universidade de São Paulo }\end{array}$ \\
\hline 03 & $\begin{array}{l}\text { Nilta M. S. Miglioli e Yara. Lima Mardegan. } \\
\text { Análise do Campo de Força Organizacional: Aplicação de Técnicas Avançadas na Implantação de } \\
\text { Sistema de Gestão da Qualidade nas Unidades de Ensino e Órgãos }\end{array}$ \\
\hline 04 & $\begin{array}{l}\text { Lucilene C. Andrade; Orminda G. da Silva. } \\
\text { Implantação do Programa de Qualidade dentro de uma Unidade da USP: Um Estudo de Caso }\end{array}$ \\
\hline 05 & $\begin{array}{l}\text { Araci E. da Costa; Eliane F. T. Xavier; Silvia Amália C. Santos. } \\
\text { Implantação do Núcleo Integrado para o Desenvolvimento de Pessoas }\end{array}$ \\
\hline 06 & $\begin{array}{l}\text { Cleber J. Lupachini; Clélia A. Celino; Eloíde A. Carneiro. } \\
\text { Padronização de Processo na Seção de Graduação em duas Unidades da USP }\end{array}$ \\
\hline 07 & $\begin{array}{l}\text { Soraya B. L. Raspantini. } \\
\text { Identificação dos Fatores Limitantes na Implantação de um Sistema de Gestão da Qualidade na } \\
\text { Faculdade de Zootecnia e Engenharia de Alimentos - Gestão por Processos. Um estudo de caso }\end{array}$ \\
\hline 08 & $\begin{array}{l}\text { Edileusa R. Bede; Vera Nice Barbosa. } \\
\text { Compras na Universidade de São Paulo: Uma Análise Crítica }\end{array}$ \\
\hline 09 & $\begin{array}{l}\text { Márcia R. M. Saad; Maria Cristina O. Villela. } \\
\text { Administração por Processos em Bibliotecas Universitárias: Um Estudo de Caso }\end{array}$ \\
\hline 10 & $\begin{array}{l}\text { Fábio Ribeiro; Ivan Bueno; João Carlos Kanaan. } \\
\text { Novos Conceitos de Atendimento ao Cliente e aos Fornecedores nos Processos de Aquisição }\end{array}$ \\
\hline 11 & $\begin{array}{l}\text { Antonio José dos Prazeres; Joaquim Basílio Filho; Noé B. de Souza. } \\
\text { O Lazer como Instrumento de Qualidade e Produtividade }\end{array}$ \\
\hline 12 & $\begin{array}{l}\text { Ari E. D. Ferreira; Débora O. Martinez; Fernanda P. M. de Souza; Tânia D. Correa. } \\
\text { Pontos Fortes e Pontos Fracos para Implantação do Sistema de Gestão de Qualidade }\end{array}$ \\
\hline 13 & $\begin{array}{l}\text { Jose A.de Jesus Filho; Neuza C. T. Barros; Regina C. Zemella; Welson G. Barbosa Junior. } \\
\text { Desenvolvimento e Capacitação de Recursos Humanos - O caso da Poli }\end{array}$ \\
\hline 14 & $\begin{array}{l}\text { Roberto Nunes. } \\
\text { Análise da Implantação de um Sistema de Qualidade em Restaurante Universitário - Estudo de Caso }\end{array}$ \\
\hline 15 & $\begin{array}{l}\text { Helena Lucia Alves de L. Furtado. } \\
\text { Sistema de Gestão da Qualidade em Universidade Pública: Faculdade de Medicina de Ribeirão Preto } \\
\text { - Universidade de São Paulo }\end{array}$ \\
\hline 16 & $\begin{array}{l}\text { Reginaldo Monteiro da Silva. } \\
\text { Estudo Qualitativo da Estratégia Financeira em Entidades Públicas: O Caso da FSP/USP }\end{array}$ \\
\hline
\end{tabular}


continuação

\begin{tabular}{|c|c|}
\hline & 2006 \\
\hline 17 & $\begin{array}{l}\text { Dorival Pegoraro Júnior;Márcia R. G. dos Santos. } \\
\text { O museu Paulista da USP e os Desafios para a Gestão da Qualidade em Museu }\end{array}$ \\
\hline 18 & $\begin{array}{l}\text { Ana R. Clemente; Aureni Clemente; Jorge A. Gruda; Mary Francis L. Godoy. } \\
\text { Gestão da Qualidade de Centro de Computação Eletrônica da USP - Estudo de caso. }\end{array}$ \\
\hline 19 & $\begin{array}{l}\text { Márcia Regina de Sá. } \\
\text { Avaliação da Qualidade de ensino; Estudo aplicado aos egressos da Pós-Graduação Stricto Senso da } \\
\text { escola de Educação Física e Esporte da USP no período de } 1979 \text { a } 2007 .\end{array}$ \\
\hline 20 & $\begin{array}{l}\text { Maria Aparecida L. de Oliveira; João Braz Martins Júnior; José Ricardo Barbosa. } \\
\text { Modelo para a implantação de um sistema de Gestão com foco na qualidade total no restaurante da } \\
\text { Prefeitura da cidade Universitária da Coordenadoria de Assistência Social da Universidade de São } \\
\text { Paulo: Manual da Qualidade e procedimentos }\end{array}$ \\
\hline 21 & $\begin{array}{l}\text { Décio G. da Silva; Marisa A. Bento; Patricia M. Mattar; Patricia S.dos Santos. } \\
\text { Proposta de um Plano de Ação Para Otimizar o Tempo de Resposta do Processo Aquisitivo em } \\
\text { Órgão da Administração Pública Federal. }\end{array}$ \\
\hline 22 & $\begin{array}{l}\text { Claudia R.R. Denani; Ivan D. Martins; Leonice M.S.de Farias. } \\
\text { Implantação do sistema de Gestão da Qualidade no Serviço de Tesouraria da FFLCH da USP: um } \\
\text { Estudo de Caso. }\end{array}$ \\
\hline 23 & $\begin{array}{l}\text { Luiz Carlos C. Santana; Márcia R. B. Gameiro; Rosa T. T. Plaza. } \\
\text { Metodologia para Gerenciamento Eletrônico de Documentos - GED, com Aplicação no Serviço de } \\
\text { Cadastro de Fornecedores da Universidade de São Paulo. }\end{array}$ \\
\hline 24 & $\begin{array}{l}\text { Ana Maria A. Farinha; Cecílio de Souza; Meire C. Antunes. } \\
\text { A Relevância do Perfil do Profissional de Museu: Uma Proposta para o MAC USP }\end{array}$ \\
\hline 25 & $\begin{array}{l}\text { Lucia J. Ribeiro; Marcos A. de A. Santos; Odete M. Rocha. } \\
\text { Motivação e Satisfação do Funcionário da USP: Estudo de Caso na Implantação de Uma Nova } \\
\text { Unidade }\end{array}$ \\
\hline 26 & $\begin{array}{l}\text { Adriana C. Ferrari; Márcia E. G. de Grandi. } \\
\text { Convergência da Gestão Estratégica para a gestão da qualidade: Análise da implementação do novo } \\
\text { modelo de gestão do sistema integrado de bibliotecas da universidade de São Paulo }\end{array}$ \\
\hline 27 & $\begin{array}{l}\text { Ana Paula Curi. } \\
\text { Projeta CORA - SAÚDE: Coordenação de Referência no Agendamento: Mudança de paradigma para } \\
\text { os Processos hospitalares em um hospital escola. }\end{array}$ \\
\hline 28 & $\begin{array}{l}\text { Marilza A. R. Tognetti. } \\
\text { Análise das redes complexas da produção e gestão do conhecimento técnico, científico e artístico da } \\
\text { Universidade de São Paulo. }\end{array}$ \\
\hline 29 & $\begin{array}{l}\text { Salete S. B. Aversano; Cybelle A. Fontes. } \\
\text { Implantação da Gestão pela qualidade em serviços: Saúde: estudo de caso na Clínica de } \\
\text { Fonoaudióloga da FOB - USP }\end{array}$ \\
\hline 30 & $\begin{array}{l}\text { Ligiana C. C. Damiano; Vitória A. Gonçalves. } \\
\text { O mapeamento dos processos da DIBD / ESALQ: Assegurando a qualidade através da especificação } \\
\text { dos produtos }\end{array}$ \\
\hline 31 & $\begin{array}{l}\text { Jurema Santos; Maria da Gloria Silva; M. Guiomar do Nascimento; Rosangela N. Colombo. } \\
\text { Treinamento e Desenvolvimento - Um Estudo de Caso em } 18 \text { unidades e Órgãos da Universidade de } \\
\text { São Paulo. }\end{array}$ \\
\hline
\end{tabular}


continuação

\begin{tabular}{|c|c|}
\hline & 2008 \\
\hline 32 & $\begin{array}{l}\text { Érika L. V. Costa. } \\
\text { A Internacionalização da Universidade de São Paulo: uma análise do processo nas Unidades do } \\
\text { Campus de Ribeirão Preto }\end{array}$ \\
\hline 33 & $\begin{array}{l}\text { Luiz C. Dotta ; Filipe G. Mesquita. } \\
\text { Estudo sobre reciclagem e processo de descarte de equipamentos de informática em desuso em } \\
\text { unidades de ensino e pesquisa dos campi da USP de São Carlos e de Ribeirão Preto }\end{array}$ \\
\hline 34 & $\begin{array}{l}\text { Mauricio Schiabel; Rui C. Guimarães. } \\
\text { Proposta de implementação de modificação na interface das requisições de compras de materiais e } \\
\text { serviços no sistema mercúrio da Universidade de São Paulo }\end{array}$ \\
\hline 35 & $\begin{array}{l}\text { Maria Paula H. Thomas; Silvana Pagotto. } \\
\text { Plano Estratégico de Metas da Faculdade de Zootecnia e Engenharia de Alimentos da Universidade } \\
\text { de São Paulo: Uma Análise Crítica }\end{array}$ \\
\hline 36 & $\begin{array}{l}\text { Daniel F. C. Franco; Eliete F. Yoshii. } \\
\text { Um estudo da Relação Cliente-fornecedor entre órgãos da Administração Pública: o caso } \\
\text { ESALQ/PCLQ. }\end{array}$ \\
\hline 37 & $\begin{array}{l}\text { André R. B. de Lima; Cláudia R. B.de Avila. } \\
\text { Melhoria na Qualidade do Serviço Prestado pelas Firmas Terceirizadas Área de Limpeza, na } \\
\text { FFCLRP / USP. }\end{array}$ \\
\hline 38 & $\begin{array}{l}\text { Rosali F. M. A. Silva; Sandra C. Campos; Zelma B. Borges. } \\
\text { Gestão da Informação e do Conhecimento: um estudo sobre a medição do desempenho nos processos } \\
\text { de aquisição na modalidade Pregão, do tipo presencial, na USP }\end{array}$ \\
\hline 39 & $\begin{array}{l}\text { Adriana P. da Silva; Alexandre C. Mazzola. } \\
\text { Implementação de um sistema de Gestão da Qualidade na Assistência Técnica Acadêmica do } \\
\text { Instituto de Química de São Carlos da Universidade de São Paulo. }\end{array}$ \\
\hline 40 & $\begin{array}{l}\text { Elaine L.Vilela;Gustavo B. Faria; Rosilene Laiola. } \\
\text { O papel da Tecnologia da informação na Gestão Por Processos nas Unidades de Ensino da USP; } \\
\text { Estudo de caso da Escola de Enfermagem - USP. }\end{array}$ \\
\hline 41 & $\begin{array}{l}\text { Geraldo Pereira Júnior; Maria Adelaide A. Mestriner; Maria Lúcia A. Attar. } \\
\text { Construção e Implementação do Balanced Scorecard (BSC) na divisão de Biblioteca e documentação } \\
\text { da ESALQ / USP: Estudo de caso Exploratório }\end{array}$ \\
\hline 42 & $\begin{array}{l}\text { Gilson Thomazine; Silvio Rosa; Waldir Quintino. } \\
\text { Uma receita para Implementar Qualidade nas áreas da Faculdade de Medicina de Ribeiro Preto - } \\
\text { USP. }\end{array}$ \\
\hline 43 & $\begin{array}{l}\text { Célia A.A. Pizeta; Fátima A. B. Castro; Paulo C. Britisqui. } \\
\text { Comunicação Interna nas Unidades do Campus de Ribeirão Preto - USP }\end{array}$ \\
\hline 44 & $\begin{array}{l}\text { Agnaldo Veneroso; Eulina C. Alencar. } \\
\text { Avaliação } 360 \text { Graus no processo de aquisição na Universidade de São Paulo por licitação na } \\
\text { modalidade pregão }\end{array}$ \\
\hline 45 & $\begin{array}{l}\text { Magali C. C. Oliveira; Marta M. Castro. } \\
\text { Melhoria de Desempenho Profissional com Qualidade na Capacitação de Servidores }\end{array}$ \\
\hline 46 & $\begin{array}{l}\text { Elza M. A. S. Faria; Ivani Francisco. } \\
\text { Qualidade de Vida no trabalho: Estudo de Caso da Escola de Educação Física e Esporte e do Instituto } \\
\text { de Astronomia, Geofísica e Ciências Atmosféricas da Universidade de São Paulo }\end{array}$ \\
\hline 47 & $\begin{array}{l}\text { Vânia A. da Silva; Regina C. S. M. Teles. } \\
\text { Transformações Geradas pelas Tecnologias de Informação da USP - Campus de Ribeirão Preto. }\end{array}$ \\
\hline
\end{tabular}



ANEXOS 

ANEXOS

A Organogramas

A1 Organograma Geral da USP

A2 Organograma da Reitoria

A3 Organograma da Unidade

B Decretos/ Portarias/Leis

B1 Decreto Estadual n. 40536 de 12/12/1995 - Institui o Programa Permanente de Qualidade e Produtividade no Serviço Público

B2 Portaria USP, GR n. 2985 de 29/01/1996 - Institui o Programa Permanente de Qualidade e Produtividade na USP

B3 Deliberação Estadual CEE n. 04 de 14/04/2000 - Avaliação Institucional de Universidades

B4 Decreto Federal n. 5378 de 23/02/2005- Institui o Programa Nacional de Gestão Pública e Desburocratização - GESPÚBLICA

B5 Portaria USP, GR n. 3673 de 09/03/2006 - Modificação da Portaria 2985 de $29 / 01 / 1996$

B6 Portaria USP, GR n. 3735 de 23/02/2007 - Institui o Programa de Gestão Estratégica e Desburocratização na Administração da USP - GESPÚBLICA USP 



\section{A - Organogramas}

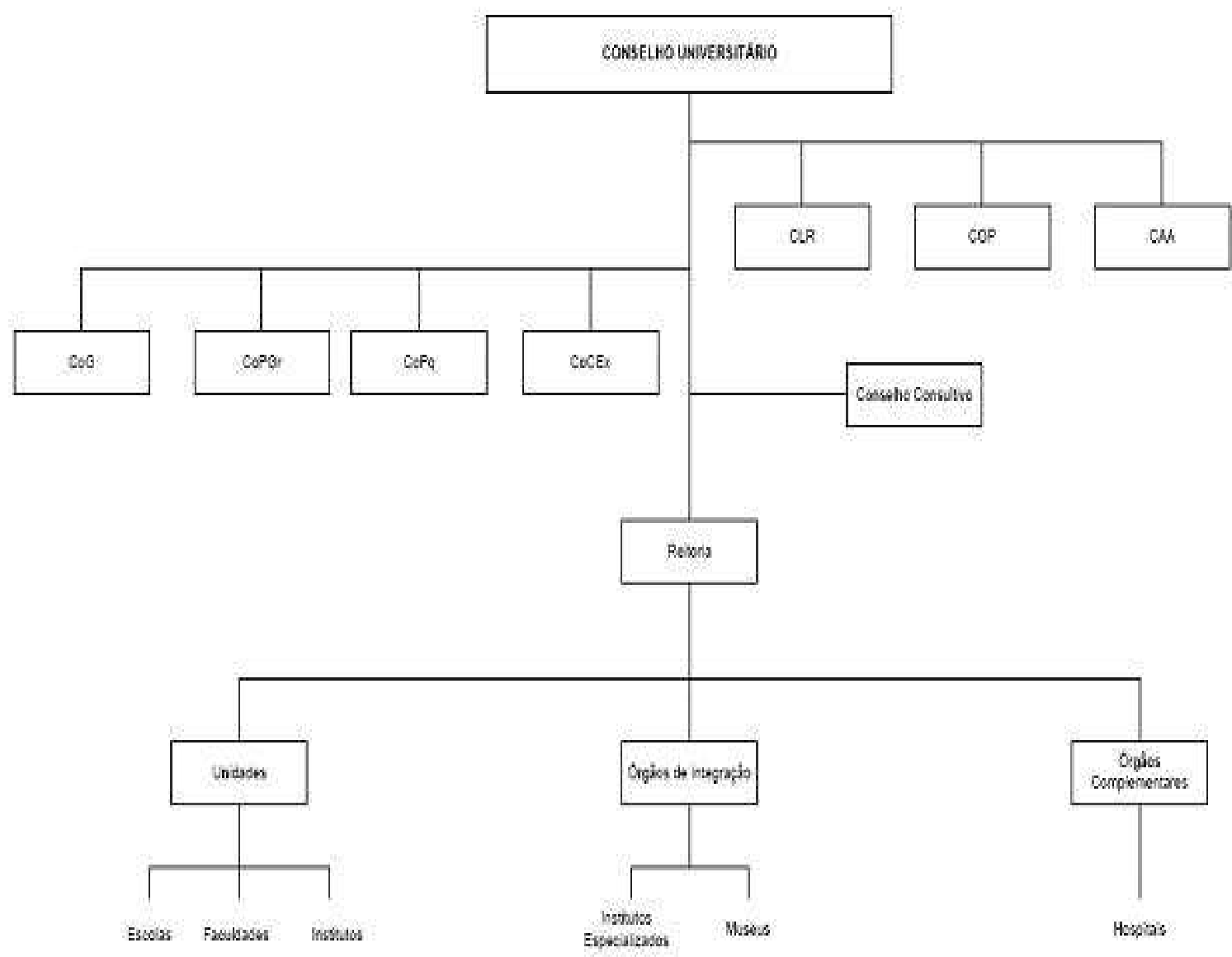

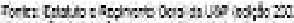

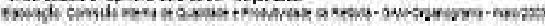

A1 Organograma Geral da USP 



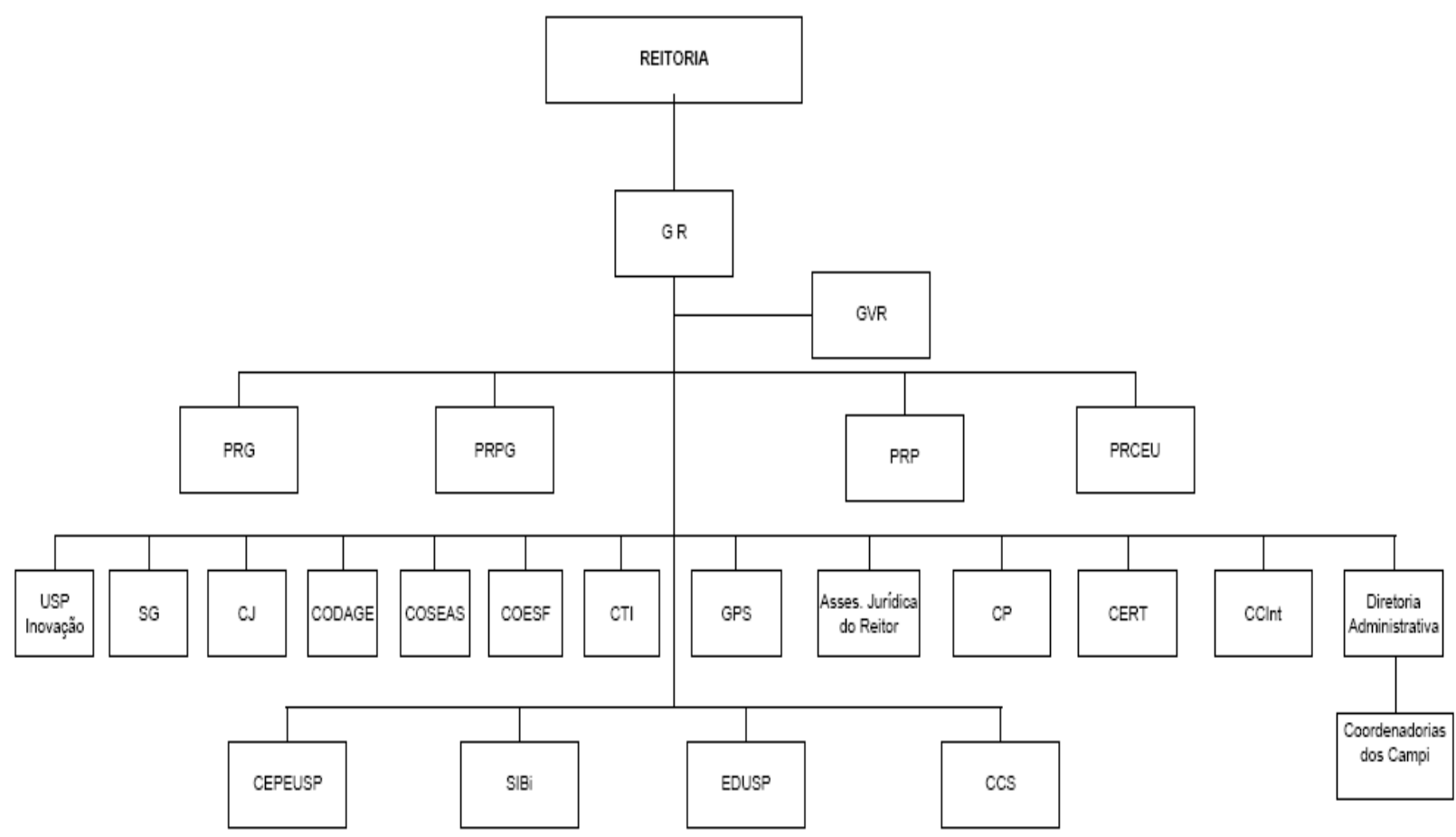

$\begin{array}{ll}\text { GR } & \text { - Gabinete do Reitor } \\ \text { GVR } & \text { - Gabinete do Vice-Reitor } \\ \text { PRG } & \text { - Pró-Reitoria de Graduação } \\ \text { PRPG } & \text { - Pró-Reitoria de Pós-Graduação } \\ \text { PRP } & \text { - Pró-Reitoria de Pesquisa } \\ \text { PRCEU } & \text { - Pro-Reitoria de Cultura e Extensão Universitária } \\ \text { SG } & \text { - Secretaria Geral } \\ \text { CJ } & \text { - Consultoria Juríica } \\ \text { CODAGE } & \text { - Coordenadoria de Administraçāo Geral } \\ \text { COSEAS } & \text { - Coordenadoria de Assistência Social } \\ \text { COESF } & \text { - Coordenadoria do Espaço Físico da USP }\end{array}$

$\begin{array}{ll}\text { GPS } & \text { - Grupo de Planejamento Setorial } \\ \text { CP } & \text { - Comissäo de Planejamento } \\ \text { CERT } & \text { - Comissäo Especial de Regimes de Trabal ho } \\ \text { CCInt } & \text { - Comissắo de Cooperaçăa Internacional } \\ \text { CEPEUSP } & \text { - Centro de Práticas Esportivas da USP } \\ \text { SIBi } & \text { - Sistema Integrado de Bibliotecas da USP } \\ \text { EDUSP } & \text { - Editora da USP } \\ \text { CCS } & \text { - Coordenadoria de Comunicaçăo Social } \\ \text { CTI } & \text { - Coordenadoria de Tecnologia da Informação } \\ \text { USP Inovação - Agència USP de Inovaçăa }\end{array}$

Coordenadorias dos Campi

COCESP - Coordenadoria do Campus da Capital do Estado de Săo Paulo

CCB - Coordenadoria do Campus de Bauru

CCLQ - Coordenadoria do Campus 'Luz de Queiroz'

CCPs - Coordenadoria do Campus de Pirassununga

CCRP - Coordenadoria do Campus de Ribeiräo Preto

$\operatorname{CCSC}$ - Coordenadoria do Campus de São Carlos

CCL - Coordenadoria do Campus de Lorena

CQSD - Coordenadoria do Quadrilátero Saúde/Direito

\section{A2 Organograma da Reitoria}





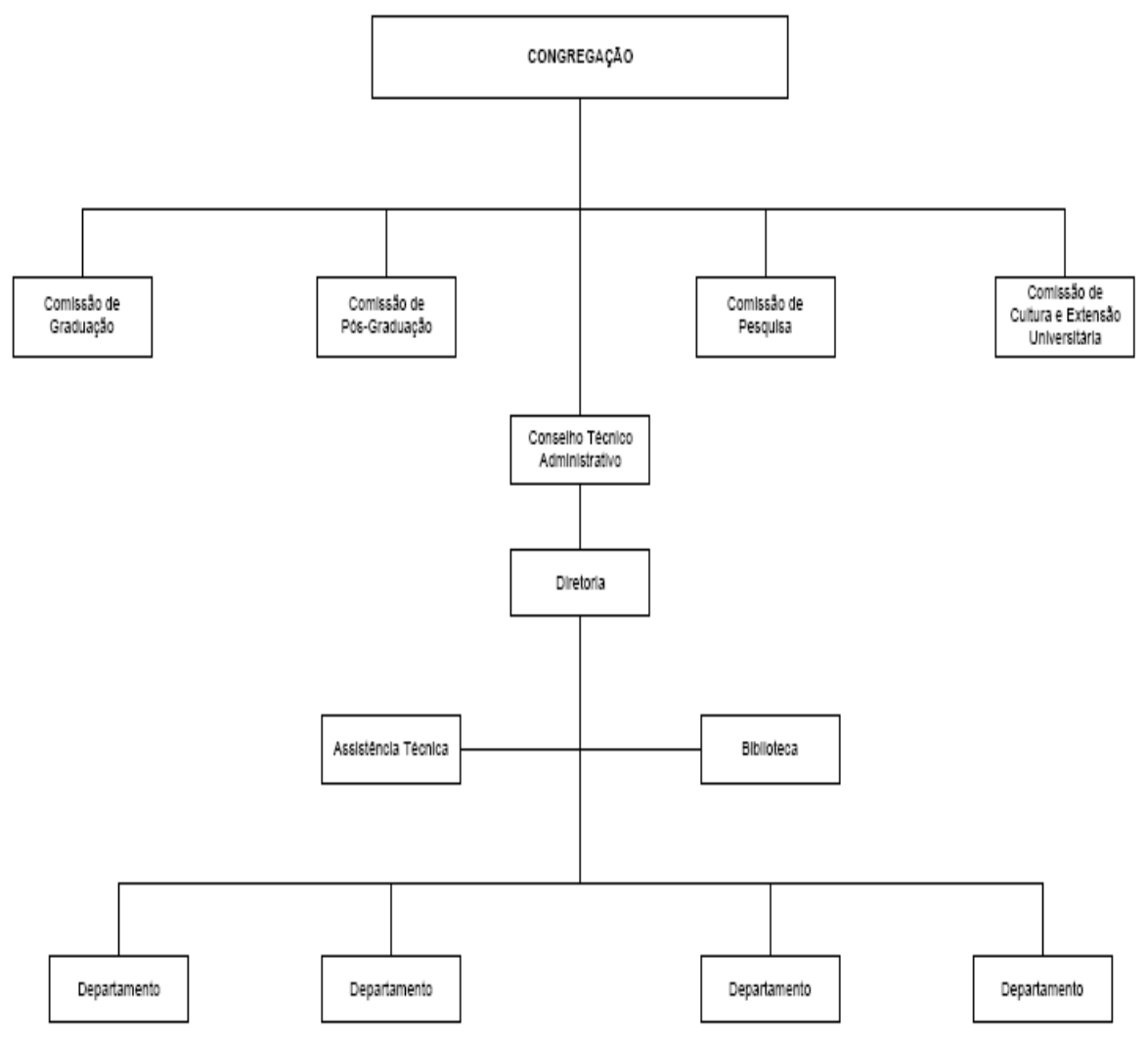

A3 Organograma da Unidade 



\section{B- Decretos/ Portarias/Leis}

B1 Decreto Estadual n. 40536 de 12/12/95 - Institui o Programa Permanente de Qualidade e Produtividade no Serviço Público

\begin{tabular}{|l|}
\hline Publicação: Diário Oficial v.105, n.237, 13/12/1995 \\
\hline \hline Gestão: Mário Covas \\
\hline \hline Revogações: \\
\hline \hline Alterações: \\
\hline \hline Órgão: \\
\hline Categoria: Administração Pública \\
\hline \hline Termos Descritores: \\
POLÍTICAS ADMINISTRATIVAS; SERVIÇOS PÚBLICOS;
\end{tabular}

Institui o Programa Permanente da Qualidade e Produtividade no Serviço Público e dá providências correlatas

MÁRIO COVAS, Governador do Estado de São Paulo, no uso de suas atribuições legais,

Considerando o compromisso deste Governo com a qualidade na relação Estado/Sociedade;

Considerando que as ações governamentais no sentido de promover a melhoria da qualidade e produtividade da Administração Pública devem ser executadas de forma contínua, sistemática e integrada;

Considerando que o ser humano, destinatário maior dessas ações, é, também, enquanto servidor ou empregado público, o principal agente de promoção da melhoria da qualidade; e

Considerando que a implantação, em todos os órgãos e entidades, de programa da qualidade e produtividade, com a participação ampla dos servidores e empregados públicos, encontra-se entre as prioridades da Administração previstas na Lei no 9.173, de 18 de julho de 1995, 


\section{Decreta:}

Artigo 1- - Fica instituído, no Estado de São Paulo, o Programa Permanente da Qualidade e Produtividade no Serviço Público, com o objetivo de, progressivamente, propiciar ao cidadão o atendimento eficaz de suas necessidades, por meio de um processo de melhoria contínua e permanente dos serviços prestados, com redução de custos e ganhos de produtividade.

Parágrafo único - O Programa instituído por este artigo abrangerá os órgãos e entidades da Administração Pública Estadual, Direta e Indireta, inclusive as autarquias de regime especial.

Artigo 2o- - Para a consecução de seu objetivo, o Programa Permanente da Qualidade e Produtividade no Serviço Público desenvolverá suas atividades de forma contínua, sistemática e integrada, em especial no sentido de:

I - melhorar a qualidade e alterar as espécies dos serviços prestados, em função das carências e solicitações da comunidade, em cada momento;

II - propiciar, às pessoas que trabalham nos diversos órgãos e entidades, o desenvolvimento de seus valores humanos e dos conhecimentos funcionais essenciais para a qualidade e produtividade;

III - obter o envolvimento e o comprometimento de todos os agentes públicos com a qualidade e produtividade, quaisquer que sejam os cargos, funções ou empregos ocupados;

IV - propiciar aos cidadãos os meios que lhes permitam exercer os seus direitos de receberem serviços com a necessária qualidade;

$\mathrm{V}$ - $\quad$ minimizar os desperdícios e os erros;

VI - incorporar os avanços do conhecimento científico e tecnológico considerados imprescindíveis à melhoria da qualidade e produtividade;

VII - promover os ajustamentos organizacionais que favoreçam a prestação de serviços com qualidade e produtividade;

VIII- inovar nas maneiras de atender as necessidades do cidadão, simplificar procedimentos, inclusive de gestão, e proceder as transformações essenciais à qualidade com produtividade. 
Artigo 3o - São responsáveis pela efetivação do Programa Permanente da Qualidade e Produtividade no Serviço Público:

I - os Secretários de Estado e o Procurador Geral do Estado;

II - os Secretários Adjuntos;

III - os Chefes de Gabinete;

IV - os dirigentes das unidades orçamentárias e de despesa;

V - os dirigentes das entidades da Administração Indireta, inclusive das autarquias de regime especial;

VI - todos os servidores e empregados da Administração Pública Estadual, Direta e Indireta, inclusive as autarquias de regime especial.

Artigo 4- - O Programa Permanente da Qualidade e Produtividade no Serviço Público conta, para o desempenho de atividades específicas, com as seguintes unidades:

I - junto ao Gabinete do Governador, o Conselho Superior da Qualidade e Produtividade;

II - junto à Secretaria do Governo e Gestão Estratégica, na Unidade de Gestão Estratégica:

a) o Conselho de Coordenação, previsto no inciso II do artigo 4- do Decreto n. 39.914, de 11 de janeiro de 1995;

b) o Grupo Executivo da Qualidade e Produtividade;

III - junto a cada Gabinete de Secretário de Estado e ao Gabinete do Procurador Geral do Estado, o Comitê Coordenador da Qualidade e Produtividade;

IV- junto a unidades integrantes das estruturas dos órgãos e entidades da Administração Pública Estadual, Direta e Indireta, inclusive das autarquias de regime especial, as Comissões de Gestão da Qualidade e Produtividade.

Artigo 5- - O Conselho Superior da Qualidade e Produtividade, presidido pelo Governador do Estado, composto dos seguintes membros:

I - Secretário do Governo e Gestão Estratégica;

II - Secretário da Justiça e da Defesa da Cidadania;

III - Secretário da Administração e Modernização do Serviço Público;

IV - Secretário da Ciência, Tecnologia e Desenvolvimento Econômico;

V - Secretário da Saúde; 
VI - Secretário da Educação;

VII - Secretário da Segurança Pública.

Artigo 6- - Ao Conselho Superior da Qualidade e Produtividade cabe:

I - estabelecer, periodicamente, diretrizes e prioridades para o Programa Permanente da Qualidade e Produtividade no Serviço Público;

II - acompanhar o andamento do Programa, com vistas a, em especial:

a) garantir o cumprimento das diretrizes e prioridades a que se refere o inciso anterior;

b) promover os ajustamentos que se fizerem necessários, a cada momento, para viabilizar a consecução de seu objetivo, definido pelo artigo $1^{\circ}$ deste decreto;

III - aprovar o emblema do Programa.

Artigo 7- Ao Conselho de Coordenação, da Unidade de Gestão Estratégica, da Secretaria do Governo e Gestão Estratégica, além das atribuições que lhe são conferidas pelo artigo 7o do Decreto n. 39.914, de 11 de janeiro de 1995, cabe coordenar, orientar e avaliar o Programa Permanente da Qualidade e Produtividade no Serviço Público.

Artigo 8- - O Grupo Executivo da Qualidade e Produtividade formado pelos seguintes órgãos e entidade:

I - Instituto Paulista da Qualidade, da Secretaria da Justiça e da Defesa da Cidadania;

II - Departamento de Ciência e Tecnologia, da Secretaria da Ciência, Tecnologia e Desenvolvimento Econômico;

III - Fundação do Desenvolvimento Administrativo - FUNDAP, vinculada à Secretaria da Administração e Modernização do Serviço Público.

§ 1 - Os dirigentes dos órgãos e da entidade a que se refere este artigo designarão os respectivos servidores e empregados que deverão se dedicar, prioritária ou exclusivamente, às atividades do Grupo Executivo da Qualidade e Produtividade.

§ 2- - A critério e por designação do Secretário do Governo e Gestão Estratégica, o Grupo Executivo da Qualidade e Produtividade poderá ser formado, ainda, por servidores ou empregados públicos em exercício na Pasta ou que vierem a ser afastados de outros órgãos ou entidades da Administração Pública Estadual. 
Artigo 9o - Ao Grupo Executivo da Qualidade e Produtividade cabe:

I - fornecer suporte ao Programa Permanente da Qualidade e Produtividade no Serviço Público, em especial:

a) prestando os serviços de apoio que se fizerem necessários ao adequado funcionamento do Conselho Superior da Qualidade e Produtividade e do Conselho de Coordenação, da Unidade de Gestão Estratégica, da Secretaria do Governo e Gestão Estratégica;

b) auxiliando o Conselho de Coordenação, em caráter permanente, no desenvolvimento das atividades necessárias à conscientização e mobilização para a qualidade e produtividade;

c) orientando e apoiando ações específicas em cada órgão e entidade da Administração Pública Estadual, Direta e Indireta, inclusive de autarquia de regime especial;

II - operacionalizar o desenvolvimento do Programa, relatando, periodicamente, ao Conselho de Coordenação o andamento das atividades dos Comitês Coordenadores da Qualidade e Produtividade, das Secretarias de Estado e da Procuradoria Geral do Estado.

Parágrafo único - No desempenho de suas atribuições, o Grupo Executivo da Qualidade e Produtividade poderá contar com o apoio de instituições que desenvolvam metodologia da qualidade e produtividade, pesquisas e treinamento.

Artigo 10 - Os Comitês Coordenadores da Qualidade e Produtividade, presididos pelos Secretários Adjuntos das respectivas Pastas, serão constituídos a critério e por designação de cada Secretário de Estado, considerando, porém: I - a oportunidade e conveniência da representatividade dos órgãos integrantes da estrutura da Secretaria e das entidades a ela vinculadas; II - as prioridades do Programa Permanente da Qualidade e Produtividade no Serviço Público.

Parágrafo único - Na constituição do Comitê Coordenador da Qualidade e Produtividade, do Gabinete do Procurador Geral do Estado, também serão observados os princípios definidos por este artigo, cabendo a Presidência ao Procurador Geral do Estado Adjunto. 
Artigo 11 - Aos Comitês Coordenadores da Qualidade e Produtividade cabe, no âmbito das respectivas Pastas e das entidades da Administração Indireta, inclusive autarquias de regime especial, a elas vinculadas:

I - coordenar, orientar, acompanhar e avaliar a implementação do Programa Permanente da Qualidade e Produtividade no Serviço Público;

II - manter o Conselho de Coordenação, da Unidade de Gestão Estratégica, da Secretaria do Governo e Gestão Estratégica, por meio do Grupo Executivo da Qualidade e Produtividade, permanentemente informado a respeito do andamento e da evolução das atividades do Programa;

III - incentivar a participação dos servidores e empregados, buscando a contínua conscientização em prol da qualidade e produtividade.

Parágrafo único - O disposto neste artigo compreende também as ações dos Comitês Coordenadores da Qualidade e Produtividade em relação às Comissões de Gestão da Qualidade e Produtividade.

Artigo 12 - As Comissões de Gestão da Qualidade e Produtividade serão constituídas mediante atos específicos das seguintes autoridades, em seus respectivos âmbitos de atuação: I - Secretários de Estado; II - Procurador Geral do Estado; III - dirigentes de entidades da Administração Pública Estadual Indireta, inclusive de autarquias de regime especial.

Parágrafo único - A critério de cada autoridade, a competência prevista neste artigo poderá ser delegada, mediante ato expresso.

Artigo 13 - Na constituição das Comissões de Gestão da Qualidade e Produtividade, as autoridades a que se refere o artigo anterior, deverão considerar, em cada caso:

I - as especificidades dos órgãos e entidades; II - as prioridades do Programa Permanente da Qualidade e Produtividade no Serviço Público. 
Artigo 14 - Às Comissões de Gestão da Qualidade e Produtividade cabe, em suas respectivas áreas de atuação:

I - promover a implementação do Programa Permanente da Qualidade e Produtividade no Serviço Público, com a efetiva participação dos servidores e empregados, utilizando a metodologia que considerar mais adequada às suas peculiaridades;

II - manter os Comitês Coordenadores da Qualidade e Produtividade das respectivas Pastas permanentemente informados a respeito do andamento e da evolução das atividades do Programa;

III - avaliar, periodicamente, a implementação do Programa, oferecendo subsídios para o seu contínuo aperfeiçoamento.

Artigo 15 - Serão constituídos dentro do prazo de 30 (trinta) dias, contados a partir da data da publicação deste decreto: I - todos os Comitês Coordenadores da Qualidade e Produtividade; II - as Comissões de Gestão da Qualidade e Produtividade consideradas prioritárias.

Artigo 16 - Cabe aos representantes da Fazenda do Estado nas entidades da Administração Indireta, inclusive autarquias de regime especial, bem como ao Conselho de Defesa dos Capitais do Estado - CODEC, a adoção das providências necessárias ao cumprimento deste decreto.

Artigo 17 - Este decreto entrará em vigor na data de sua publicação.

Palácio dos Bandeirantes, 12 de dezembro de 1995.

\section{MÁRIO COVAS}

Antônio Angarita, Secretário do Governo e Gestão Estratégica.

João Marcelo Fiorezi Gonçalves. Secretário de Esportes e Turismo

Publicado na Secretaria de Estado do Governo e Gestão Estratégica, aos 12 de dezembro de 1995. 



\section{B2 Portaria USP - GR n. 2985 de 29/01/96 - Institui Programa Permanente de Qualidade e Produtividade na USP}

PORTARIA GR n. 2985, DE 29 DE JANEIRO DE 1996. (D.O.E. - 01/02/1996)

(Esta portaria foi REVOGADA pela Portaria GR-3735/2007)

Institui na Universidade de São Paulo a Comissão de Gestão da Qualidade e Produtividade.

O Reitor da Universidade de São Paulo, usando de suas atribuições legais, tendo em vista o disposto no Decreto n. 40.536, de 12/12/95, baixa a seguinte:

\section{PORTARIA:}

Artigo 1ำ - Fica instituída, na Universidade de São Paulo, a Comissão de Gestão da Qualidade e Produtividade.

Artigo 2- - A Comissão instituída pela presente Portaria tem a competência fixada no Artigo 14 do Decreto n. 40.536, de 12/12/95.

Artigo 3- - Os membros da Comissão de Gestão da Qualidade e Produtividade serão designados por Ato do Reitor, que escolherá dentre eles o seu Presidente.

Artigo 4ㅜ - Esta Portaria entrará em vigor na data de sua publicação (Proc. USP n. 95.1.52846.1.2).

Reitoria da Universidade de São Paulo, 29 de janeiro de 1996.

FLÁVIO FAVA DE MORAES

Reitor 



\section{B3 Deliberação Estadual CEE n. 04/00 de 14/04/2000 - Avaliação Institucional de universidades}

Dispõe sobre o processo de avaliação de universidade e de centro universitário do sistema estadual de ensino.

O CONSELHO ESTADUAL DE EDUCAÇÃO, no uso de suas atribuições, com fundamento no inciso XIV do Art. 2o da Lei Estadual n. 10.403, de 6 de julho de 1971, no Art. 46 da Lei n. 9.394, de 20 de dezembro de 1996 e na Indicação CEE n. 04/2000, aprovada em 22 de março de 2000,

Delibera:

Art.1- - O processo de avaliação de universidade e de centro universitário do sistema estadual de ensino previsto no artigo $4^{\circ}$ da Deliberação CEE no 4/99 é regulamentado por esta Deliberação.

Parágrafo único - As instituições abrangidas por esta Deliberação compreendem as universidades e centros universitários estaduais ou municipais já existentes, ou que venham a ser instituídos pelo Poder Público.

Art. 2o - O processo de avaliação, de caráter institucional, contínuo e permanente, regulamentado por esta Deliberação, tendo como finalidades:

I. orientar, acompanhar e fiscalizar o desenvolvimento das instituições;

II. analisar periodicamente o nível de desempenho e atualização institucional, principalmente quanto aos seguintes aspectos:
a) eficácia e eficiência do seu ensino;
b) importância dos seus programas de pesquisa;
c) relevância de sua produção cultural e científica
d) eficácia da formação profissional;
e) significado da importância das ações comunitárias; 
f) condições gerais e específicas dos cursos de graduação e pós-graduação;

g) qualidade da gestão administrativa e financeira.

Art. 3- - O processo de avaliação será interno e desenvolvido em três etapas:

I. até um ano, a contar da vigência desta Deliberação, ou do ato de credenciamento de nova instituição, deverá ser encaminhado ao CEE o Planejamento Geral dos trabalhos de avaliação interna da instituição para um período de cinco anos, com o respectivo cronograma;

II. ao final do terceiro ano, deverá ser encaminhado ao CEE relatório dos trabalhos já realizados;

III.ao final do quinto ano, deverá ser encaminhado o relatório geral da execução com as respectivas conclusões.

§ 10 - O relatório geral deverá explicitar, de forma clara e sucinta, as suas realizações, bem como a indicação de obstáculos detectados que impediram a execução, a ampliação ou a melhoria de suas atividades de ensino, pesquisa e extensão.

§ 2ㅜ - O não atendimento ao determinado neste artigo implicará suspensão da tramitação de quaisquer processos da instituição junto ao $\mathrm{CEE}$ até o seu efetivo cumprimento, independentemente de outras medidas cabíveis.

§ 3o - O ciclo de avaliação institucional deverá ter continuidade com as etapas previstas nestes artigos.

Art. 4- - A metodologia da avaliação interna será estabelecida pela universidade ou centro universitário de forma abrangente, podendo considerar o conjunto da instituição, as formas de gestão, as diferentes áreas do conhecimento ou departamentos ou unidades equivalentes, bem como os órgãos complementares e os setores equivalentes.

Art. 5- - A avaliação interna qüinqüenal constituirá requisito fundamental no processo de recredenciamento junto ao Conselho Estadual de Educação, bem como para reconhecimento dos cursos da universidade e dos centros universitários. 
Art. 6- - A universidade e o centro universitário deverão submeter a avaliação interna à(s) comissão(ões) externa(s) de pares, cujos Pareceres, após visita à instituição, deverão integrar os relatórios.

Art. 7- - Os relatórios circunstanciados da avaliação de universidade e de centro universitário, na forma desta Deliberação, deverão ser apreciados por comissão de cinco especialistas, indicada pela Câmara de Educação Superior e, posteriormente, por ela analisados, mediante Parecer do Conselheiro Relator e pelo Conselho Pleno, dando-se ciência à instituição.

Art. 8- - Esta Deliberação entrará em vigor na data de sua publicação, após devidamente homologada, revogando-se as disposições em contrário.

\section{DELIBERAÇÃO PLENÁRIA}

O CONSELHO ESTADUAL DE EDUCAÇÃO aprova, por unanimidade, a presente Deliberação. Sala "Carlos Pasquale", em 22 de março de 2.000.

\section{ARTHUR FONSECA FILHO Presidente}

Homologada por Res. SE de 13/4/2000, publ. no DOE em 14/4/2000, Seção I, pág. $10 / 11$.

INDICAÇÃO CEE n. 04/2000 - CES - Aprovada em 22/03/2000

PROCESSO CEE n.: 141/2000

INTERESSADOS: Conselho Estadual de Educação/Câmara de Educação Superior

ASSUNTO: Avaliação de universidade e de centro universitário do sistema de ensino do Estado de São Paulo

\section{RELATORES :}

Cons. Heraldo Marelim Vianna

Cons. Flávio Fava de Moraes

CONSELHO PLENO 


\section{RELATÓRIO}

As universidades e os centros universitários, partícipes da formação do pensamento crítico da sociedade, não estão isentos das várias formas e processos de avaliação. A avaliação, no caso, visa mostrar à sociedade, inclusive à própria comunidade acadêmica, o papel social da instituição, refletido pela qualidade do seu ensino e a relevância de seu programa de pesquisas e a importância do seu programa de extensão. A avaliação das universidades e centros universitários, à semelhança do que já está em curso nas demais instituições isoladas de educação superior do sistema de ensino do Estado de São Paulo, mais do que simples obrigação, é um dever institucional.

O processo de avaliação das instituições isoladas de educação superior do sistema estadual de ensino no Estado de São Paulo já se acha regulamentado pelo Conselho Estadual de Educação - CEE. Agora, pela presente, o Conselho Estadual de Educação do Estado de São Paulo procura dimensionar, em nova Deliberação, a problemática da avaliação em universidade e em centro universitário do sistema estadual de ensino do Estado de São Paulo que estão sob sua jurisdição. Assim fazendo, o Conselho Estadual de Educação cumpre determinação da Lei n. ${ }^{\circ}$ 9.394, de 20 de dezembro de 1996, que estabelece as Diretrizes e Bases da Educação Nacional e da legislação estadual pertinente ao assunto.

O ensino superior precisa pensar nas transformações sociais, econômicas, culturais, científicas e tecnológicas que o mundo atual vem sofrendo, num contexto altamente globalizado e até mesmo antecipar medidas e transformações para enfrentar o presente processo de mudança que provoca intenso impacto na área educacional. Esse proceder exige prioritariamente que se repensem as próprias instituições de ensino superior.

A avaliação interna (auto-avaliação) está associada à gestão institucional e a todas aquelas atividades ligadas ao uso efetivo dos produtos da avaliação. Na ausência de um processo de avaliação interna, componente essencial à gestão e à sua lógica, a instituição se desfigura na sua essência. As instituições universitárias, por essas razões, precisam adquirir experiência em avaliação interna e aprender com a crítica que dela emane, aprimorando o seu trabalho. Repetir a experiência de outras instituições, de culturas diferentes da nossa, pode significar a descaracterização dos resultados. A 
experiência de outros contextos é válida, mas como inspiradora de novas ações, que devem considerar as peculiaridades de cada instituição. Nunca se parte do nada, mas é forçoso que experiências exteriores sejam vistas sob a ótica de problemas contextualizados.

A avaliação interna identifica-se com um conjunto de atividades para obter dados e informações que, depois de analisados, são relacionados ao funcionamento da instituição ou ao de seus segmentos. A avaliação interna, envolvendo todo o corpo funcional da instituição (alunos, professores, pesquisadores e administradores) vai, assim, determinar em que medida se opera a concretização dos objetivos institucionais, permitindo, desse modo, que se compreenda, efetivamente, a eficácia do conjunto institucional ou de suas partes constituintes.

As universidades e os centros universitários, independentemente de ações governamentais, começam a assumir cada vez mais a iniciativa de determinar a qualidade do seu ensino, da sua orientação profissional, a relevância de suas pesquisas e o impacto social das ações desenvolvidas junto à sociedade, que nelas deposita suas melhores expectativas como agentes de transformação. A avaliação institucional vai caracterizar de forma sistemática os êxitos e os malogros, bem como as necessidades institucionais por meio da própria comunidade acadêmica, que define suas metas e padrões de excelência, com vista ao aprimoramento e à qualidade da instituição.

A própria comunidade deve definir, assim, sua metodologia de avaliação, sem esquecer que a avaliação interna deve complementar-se por avaliações externas, realizadas por intermédio de consultoria, por instituições educacionais públicas ou privadas, ou mesmo por especialistas, nacionais ou estrangeiros, que, por seu saber, experiência e projeção na comunidade acadêmica e/ou científica e tecnológica, possam colaborar efetivamente para que as instituições voltadas para a educação superior possam alcançar seus desejados fins.

A avaliação interna é um processo permanente de levantamento de informações sobre a realização ou não das metas estabelecidas para a concretização dos objetivos educacionais, científicos, tecnológicos e sociais. Para obtenção dessas informações, a 
instituição deve gerar padrões e referenciais que possibilitem a definição da qualidade esperada dos seus diversos segmentos. A avaliação interna é, também, uma ação solidária, realizada por grupos constituídos e sob a liderança de coordenadores, objetivando o planejamento organizacional e o acompanhamento dos trabalhos a serem desenvolvidos.

O planejamento deve estabelecer os aspectos prioritários, determinar os recursos necessários aos trabalhos e definir o fluxo e o cronograma do desenvolvimento das ações. A organização do processo de avaliação, com o equacionamento dos vários e diferentes trabalhos a serem desempenhados pelos membros do grupo, define responsabilidades, estabelece um programa e caracteriza as várias atividades individuais e de grupos. A avaliação interna deverá, portanto, ter diferentes focos: alunos (graduação e pós-graduação); professores (docência, pesquisa e extensão); gestão acadêmica, administrativa e financeira; programas de extensão e prestação de serviços; produção científica e cultural.

É necessário lembrar que a avaliação pode envolver diferentes metodologias, em razão de vários fatores e, dependendo da escala da missão avaliadora, pode ser por universidade ou centro universitário, por Área de Conhecimento (Ciências Humanas e Sociais, Biológicas, Exatas), por Departamentos, por Órgãos Complementares (Institutos Especializados, Museus, Hospitais, etc. ...), e por Setores Administrativos (Financeiro, Patrimonial, Recursos Humanos, ...). Além disso, devem a universidade e o centro universitário considerar outros fatores, como distribuição geográfica (diferentes "campi") e similaridade de unidades (mais de uma Medicina, Odontologia, Física, Química, Engenharia etc. ...). A metodologia da avaliação institucional ficará a cargo da universidade e do centro universitário.

O controle da seqüência anteriormente apresentada implica revisão dos primeiros resultados alcançados, a verificação da ocorrência de consensos sobre as tarefas desenvolvidas e a elaboração de relatórios parciais, a serem analisados pelo grupo central, responsável pela condução do processo de avaliação interna. 
Em diferentes momentos, impõem-se a revisão dos dados existentes e a coleta de novos elementos de informação e opiniões para alimentar um banco de dados que, juntamente com as decisões relacionadas a programas, políticas e práticas, serão de importância para o planejamento institucional e a elaboração de relatórios analíticos que incluam, também, as necessidades institucionais.

A qualidade em educação, pesquisa e extensão, é resultante da interação de diferentes variáveis, envolvendo corpo docente, discente e de apoio adequados, bem como infraestrutura física e a existência de insumos que possibilitem a ocorrência de um desenvolvimento plenamente satisfatório, além de mecanismos que garantam integração ao contexto social, à comunidade em que se situa e com a qual interage.

A gestão e a administração referem-se a todos aqueles elementos que permitem a formulação, a execução e a avaliação do Projeto Educacional da instituição. Essa parte da avaliação interna incidirá, também, e mais explicitamente, sobre organização administrativa, aspectos financeiros, agentes educativos (diversas categorias de professores), relações com o corpo discente e a comunidade. Essa dimensão atentará para os importantes processos de relações humanas.

Os aspectos pedagógicos englobam diferentes modos de agir, envolvendo docentes, alunos e a própria comunidade, no sentido de garantir a qualidade do processo educacional e a eficácia institucional. A instituição não pode ignorar o contexto em que se situa, devendo a avaliação interna incorporar análises de suas relações com a comunidade.

A avaliação interna, na conceituação que se desenvolve no presente documento, é, assim, um procedimento de todo o complexo educacional - professores, alunos, corpo administrativo e a própria comunidade - visando a uma reflexão e análise em relação às metas definidas no Projeto Educacional, por intermédio da consideração de todos os elementos e circunstâncias que possam afetar a qualidade da educação. 
A avaliação interna resulta em juízos de valor sobre diferentes aspectos a partir de indicadores específicos, apresentando em sua análise elementos qualitativos e quantitativos que integram um todo único. A avaliação interna servirá de retroalimentação para que a instituição possa superar seus problemas e, ao mesmo tempo, tenha condições de ampliar seus mecanismos de aprimoramento, nos termos da sua filosofia e da sua missão educacional.

A avaliação interna terá um caráter intrínseco ao longo dos tempos e a cada cinco anos poderão ser confrontados seus resultados e definidas novas metas de implementação do Projeto Educacional e planejadas novas seqüências de ações, sempre buscando a qualidade máxima possível. A avaliação interna realizada em períodos qüinqüenais será elemento fundamental no processo de recredenciamento junto ao Conselho Estadual de Educação, devendo ser anexada ao referido processo para fins de exame. Após a publicação da Deliberação proposta pela presente Indicação, ter-se-á: (1) prazo de um ano para que as universidades e centros universitários encaminhem ao Conselho Estadual de Educação - CEE o primeiro plano geral de seus trabalhos de avaliação interna (para cinco anos, como se fosse um plano plurianual) e mais o respectivo cronograma; (2) ao final do $3^{\circ}$ ano, as instituições deverão encaminhar ao Conselho Estadual de Educação um relatório parcial, informando o cumprimento das metas contidas no organograma para esse prazo e uma síntese dos resultados até então obtidos; (3) ao final do $5^{\circ}$ ano, as instituições deverão encaminhar ao CEE, para análise, o relatório global de execução do seu planejamento auto-avaliativo, com uma síntese dos resultados da avaliação; (4) o Conselho Estadual de Educação designará comissão de pelo menos cinco especialistas, de áreas diversas, com a função de assessorar a Câmara de Educação Superior na análise dos relatórios. O Parecer do Conselheiro Relator será discutido e aprovado pela Câmara de Educação Superior, sendo, posteriormente, submetido à apreciação do Pleno do Conselho Estadual de Educação e então encaminhado à Instituição.

\section{CONCLUSÃO}

Propõe-se o Projeto de Deliberação anexo.

São Paulo, 1ํo de março de 2000. 
a)Cons. Heraldo Marelim Vianna. Relator

a)Cons. Flávio Fava de Moraes. Relator

DECISÃO DA CÂMARA

A CÂMARA DE EDUCAÇÃO SUPERIOR adota, como sua Indicação, os votos dos Relatores.

Presentes os Conselheiros: Bernardete Angelina Gatti, Dárcio José Novo, Flávio Fava de Moraes, Heraldo Marelim Vianna, José Mário Pires Azanha, Luiz Roberto Dante, Sonia Aparecida Romeu Alcici e Vagner José Oliva.

Sala das Sessões, em 1o- de março de 2000.

a) Cons- Sonia Aparecida Romeu Alcici. Presidente

\section{DELIBERAÇÃO PLENÁRIA}

O CONSELHO ESTADUAL DE EDUCAÇÃO aprova, por unanimidade, a presente Indicação. Sala "Carlos Pasquale", em 22 de março de 2.000.

ARTHUR FONSECA FILHO. Presidente

Homologada por Res. SE de 13/4/2000, publicado no D.O.E. em 14/4/2000, Seção I, pág. 10/11. 



\title{
B4 Decreto Federal n. 5378 de 23/02/05- Institui o Programa Nacional de Gestão Pública e Desburocratização - GESPÚBLICA
}

\author{
Institui o Programa Nacional de Gestão \\ Pública e Desburocratização - GESPÚBLICA \\ e o Comitê Gestor do Programa Nacional de \\ Gestão Pública e Desburocratização, e dá \\ outras providências.
}

O PRESIDENTE DA REPÚBLICA, no uso da atribuição que lhe confere o art. 84, inciso VI, alínea "a", da Constituição,

\section{DECRETA:}

Art.1 - Fica instituído o Programa Nacional de Gestão Pública e Desburocratização GESPÚBLICA, com a finalidade de contribuir para a melhoria da qualidade dos serviços públicos prestados aos cidadãos e para o aumento da competitividade do País.

Art. 2ㅜ - O GESPÚBLICA deverá contemplar a formulação e implementação de medidas integradas em agenda de transformações da gestão, necessárias à promoção dos resultados preconizados no plano plurianual, à consolidação da administração pública profissional voltada ao interesse do cidadão e à aplicação de instrumentos e abordagens gerenciais, que objetivem:

I - eliminar o déficit institucional, visando ao integral atendimento das competências constitucionais do Poder Executivo Federal;

II - promover a governança, aumentando a capacidade de formulação, implementação e avaliação das políticas públicas;

III- promover a eficiência, por meio de melhor aproveitamento dos recursos, relativamente aos resultados da ação pública;

IV - assegurar a eficácia e efetividade da ação governamental, promovendo a adequação entre meios, ações, impactos e resultados; e

$\mathrm{V}$ - promover a gestão democrática, participativa, transparente e ética. 
Art. 3- - Para consecução do disposto nos arts. $1^{\circ}$ e $2^{2}$, o GESPÚBLICA, por meio do Comitê Gestor de que trata 0 art. $7^{\circ}$, deverá:

I - mobilizar os órgãos e entidades da administração pública para a melhoria da gestão e para a desburocratização;

II - apoiar tecnicamente os órgãos e entidades da administração pública na melhoria do atendimento ao cidadão e na simplificação de procedimentos e normas;

III - orientar e capacitar os órgãos e entidades da administração publica para a implantação de ciclos contínuos de avaliação e de melhoria da gestão; e

IV - desenvolver modelo de excelência em gestão pública, fixando parâmetros e critérios para a avaliação e melhoria da qualidade da gestão pública, da capacidade de atendimento ao cidadão e da eficiência e eficácia dos atos da administração pública federal.

Art. 4- - Os critérios para avaliação da gestão de que trata este Decreto serão estabelecidos em consonância com o modelo de excelência em gestão pública.

Art. 5ำ - A participação dos órgãos e entidades da administração pública no GESPÚBLICA dar-se-á mediante adesão ou convocação.

§ 1- - Considera-se adesão para os efeitos deste Decreto o engajamento voluntário do órgão ou entidade da administração pública no alcance da finalidade do GESPÚBLICA, que, por meio da auto-avaliação contínua, obtenha validação dos resultados da sua gestão.

§ 2⿳- Considera-se convocação a assinatura por órgão ou entidade da administração pública direta, autárquica ou fundacional, em decorrência da legislação aplicável, de contrato de gestão ou desempenho, ou o engajamento no GESPÚBLICA, por solicitação do Ministro de Estado do Planejamento, Orçamento e Gestão, em decorrência do exercício de competências vinculadas a programas prioritários, definidos pelo Presidente da República.

Art. 6- - Poderão participar, voluntariamente, das ações do GESPÚBLICA pessoas e organizações, públicas ou privadas.

Parágrafo único - A atuação voluntária das pessoas é considerada serviço público relevante, não remunerado. 
Art. 70 - Fica instituído o Comitê Gestor do Programa Nacional de Gestão Pública e Desburocratização, no âmbito do Ministério do Planejamento, Orçamento e Gestão, com o objetivo de formular o planejamento das ações do GESPÚBLICA, bem como coordenar e avaliar a execução dessas ações.

Art. 8- - O Comitê Gestor terá a seguinte composição:

I - um representante do Ministério do Planejamento, Orçamento e Gestão, que o coordenará; e

II - um representante da Casa Civil da Presidência da República.

\$1- - O Ministro de Estado do Planejamento, Orçamento e Gestão indicará quinze órgãos ou entidades da administração pública, com notório engajamento em ações ligadas à qualidade da gestão e à desburocratização, cujos representantes integrarão o Comitê Gestor.

§2⿳- Os membros a que se referem o caput e o $\S 1^{1^{\circ}}$, titulares e suplentes, serão indicados pelos dirigentes dos órgãos ou entidades representados e designados pelo Ministro de Estado do Planejamento, Orçamento e Gestão.

§3 - O mandato dos membros do Comitê Gestor será de dois anos, permitida a recondução.

Art. 9- - Ao Comitê Gestor compete:

I - propor ao Ministro de Estado do Planejamento, Orçamento e Gestão o planejamento estratégico do GESPÚBLICA;

II - articular-se para a identificação de mecanismos que possibilitem a obtenção de recursos e demais meios para a execução das ações do GESPÚBLICA;

III - constituir comissões setoriais e regionais, com a finalidade de descentralizar a gestão do GESPÚBLICA;

IV - monitorar, avaliar e divulgar os resultados do GESPÚBLICA;

V - certificar a validação dos resultados da auto-avaliação dos órgãos e entidades participantes do GESPÚBLICA; e

VI - reconhecer e premiar os órgãos e entidades da administração pública, participantes do GESPÚBLICA, que demonstrem qualidade em gestão, medida pelos resultados institucionais obtidos. 
Art. 10. - Ao Coordenador do Comitê Gestor compete:

I - cumprir e fazer cumprir este Decreto e as decisões do Colegiado;

II - constituir grupos de trabalho temáticos temporários;

III - convocar e coordenar as reuniões do Comitê; e

IV - exercer o voto de qualidade no caso de empate nas deliberações.

Art. 11. - A participação nas atividades do Comitê Gestor, das comissões e dos grupos de trabalho será considerada serviço público relevante, não remunerado.

Art. 12. - A Secretaria de Gestão do Ministério do Planejamento, Orçamento e Gestão exercerá as funções de Secretaria-Executiva do Comitê Gestor.

Art. 13. - Este Decreto entra em vigor na data de sua publicação.

Art. 14. - Ficam revogados os Decretos $n^{\text {os }} 83.740$, de 18 de julho de 1979 , e $\underline{3.335 \text {, de } 11 \text { de }}$ janeiro de 2000.

Brasília, 23 de fevereiro de 2005; $184^{\circ}$ da Independência e $117^{\circ}$ da República.

LUIZ INÁCIO LULA DA SILVA

Nelson Machado

José Dirceu de Oliveira e Silva

Este texto não substitui o publicado no D.O.U. de 24/02/2005. 
B5 Portaria GR n. 3673 de 09/03/06 - Modificação da Portaria n. 2985 de 29/01/1996

(D.O.E. - 11/03/2006)

Dispõe sobre a modificação da Portaria GR n. 2985, de 29/01/1996, que instituiu na Universidade de São Paulo a Comissão de Gestão da Qualidade e Produtividade.

A Reitora da Universidade de São Paulo, usando de suas atribuições legais, tendo em vista o disposto no Decreto Estadual n. 40.536, de 12/12/1995, e considerando

- o compromisso da Universidade de São Paulo com a qualidade na relação USP/Sociedade;

- que ações devem ser promovidas no sentido de que a melhoria da qualidade e produtividade seja executada de forma contínua, sistemática e integrada;

- que o ser humano, destinatário maior dessas ações, é, também, enquanto docente ou funcionário da Universidade, o principal agente de promoção da melhoria da qualidade, baixa a seguinte

\section{PORTARIA:}

Artigo 1 - A Comissão de Gestão da Qualidade e Produtividade da Universidade de São Paulo, instituída pela Portaria GR n. 2985, de 29/01/1996, tem como objetivos:

I - melhorar a qualidade e alterar as espécies dos serviços prestados, em função das carências e solicitações da comunidade, em cada momento;

II - propiciar, às pessoas que trabalham nas diversas Unidades e Órgãos, o desenvolvimento de seus valores humanos e dos conhecimentos funcionais essenciais para a qualidade e produtividade;

III - obter o envolvimento e o comprometimento de todos os docentes e funcionários com a qualidade e produtividade, quaisquer que sejam os cargos ou funções ocupados;

IV - propiciar aos cidadãos os meios que lhes permitam exercer os seus direitos de receberem serviços com a necessária qualidade; 
V - minimizar os desperdícios e os erros;

VI - incorporar os avanços do conhecimento científico e tecnológico considerados imprescindíveis à melhoria da qualidade e produtividade;

VII - promover os ajustamentos organizacionais que favoreçam a prestação de serviços com qualidade e produtividade;

VIII - inovar nas maneiras de atender as necessidades do cidadão, simplificar procedimentos, inclusive de gestão, e proceder às transformações essenciais à qualidade com produtividade.

Artigo 2o - Compete à Comissão de Gestão da Qualidade e Produtividade da Universidade de São Paulo, em suas respectivas áreas de atuação:

I - promover a implementação do Programa Permanente da Qualidade e Produtividade, com a efetiva participação dos docentes e funcionários, utilizando a metodologia que considerar mais adequada às suas peculiaridades;

II - manter as Comissões Internas da Qualidade e Produtividade das Unidades e Órgãos da USP permanentemente informadas a respeito do andamento e da evolução das atividades do Programa;

III - avaliar, periodicamente, a implementação do Programa, oferecendo subsídios para o seu contínuo aperfeiçoamento.

Artigo 3o - Os membros da Comissão de Gestão da Qualidade e Produtividade serão designados por Ato do Reitor, que escolherá dentre eles o seu Presidente e o seu Secretário Executivo.

Artigo 4ํ- - Esta Portaria entrará em vigor na data de sua publicação, ficando revogadas as disposições em contrário (Proc. USP n. 95.1.52846.1.2).

Reitoria da Universidade de São Paulo, 09 de março de 2006.

\section{SUELY VILELA}

Reitora 


\title{
B6 Portaria USP, GR n. 3735 de 23/02/2007 - Institui o Programa de Gestão Estratégica e Desburocratização na Administração da USP - GESPÚBLICA USP
}

(D.O.E. - 24/02/2007)

\author{
Institui na Universidade de São Paulo o \\ GESPÚBLICA USP - Programa de \\ Gestão Estratégica e Desburocratização \\ na Administração da USP, dá outras \\ providências e revoga as Portarias GR n ${ }^{\circ} \mathrm{s}$ \\ $\underline{2985}$, de 29 de janeiro de 1996 , e $\underline{3673}$, \\ de 09 de março de 2006.
}

A Reitora da Universidade de São Paulo, usando de suas atribuições legais, tendo em vista o disposto no Decreto Federal n. 5.378, de 23 de fevereiro de 2005, e no Decreto Estadual n. 51.467, de 02 de janeiro de 2007, e considerando:

- o compromisso da Universidade de São Paulo com o adequado funcionamento da sua administração e com a qualidade dos serviços prestados ao cidadão e à sociedade; e

- a necessidade de elaboração e implementação de projetos visando simplificar os procedimentos e minimizar os entraves burocráticos que possam comprometer a qualidade da prestação dos serviços referidos, baixa a seguinte

\section{PORTARIA:}

Artigo 10 - Fica instituído na Universidade de São Paulo o GESPÚBLICA USP - Programa de Gestão Estratégica e Desburocratização da Administração na USP, com o objetivo de otimizar procedimentos e aperfeiçoar a prestação de serviços da Universidade aos cidadãos e à sociedade.

Artigo 2- - O GESPÚBLICA USP deverá contemplar a formulação e a implementação de medidas integradas em agendas de transformações da gestão, necessárias à promoção de resultados para a consolidação da administração voltada ao interesse do cidadão e à aplicação de instrumentos e abordagens gerenciais, que objetivem: 
I - promover a governança, aumentando a capacidade de formulação, implementação e avaliação das políticas de gestão;

II - promover a eficiência, por meio de melhor aproveitamento dos recursos, relativamente aos resultados das ações da Universidade;

III - assegurar a eficácia e a efetividade da gestão, promovendo a adequação entre meios, ações, impactos e resultados; e

IV - promover a gestão democrática, participativa, transparente e ética.

Artigo 3- - Para consecução do disposto nos Artigos. 1ำ e 2º o GESPÚBLICA USP, por meio da Comissão Central de que trata o Artigo 5o-, deverá:

I - solicitar a colaboração das Unidades e dos Órgãos da USP para a melhoria da gestão e para a desburocratização;

II - incentivar as Unidades e os Órgãos da USP a implementar ações de melhoria do atendimento ao cidadão e de simplificação de procedimentos e normas;

III - orientar e capacitar as Unidades e os Órgãos da USP para a implantação de ciclos contínuos de avaliação e de melhoria da gestão; e

IV - utilizar modelo de excelência em gestão como referência, fixando parâmetros e critérios, de acordo com as especificidades das atividades da USP, para a avaliação e melhoria da qualidade da gestão, da capacidade de atendimento ao cidadão e da eficiência e eficácia dos atos da administração da Universidade.

Artigo 4- - A participação de Unidades e Órgãos da USP no GESPÚBLICA USP dar-se-á mediante adesão.

Parágrafo único - Considera-se adesão, para os efeitos desta Portaria, a participação voluntária de Unidades e Órgãos da USP no alcance da finalidade do GESPÚBLICA USP, que, por meio da auto-avaliação contínua, obtenha validação dos resultados da sua gestão.

Artigo 5- - Fica instituída, junto ao Gabinete da Reitora da USP, a Comissão Central do GESPÚBLICA USP - Programa de Gestão Estratégica e Desburocratização da Administração da USP, com o objetivo de formular o planejamento das ações do citado Programa, bem como coordenar e avaliar a execução dessas ações. 
Artigo 6- - Os membros da Comissão Central serão designados por Ato da Reitora, que escolherá dentre eles o seu Presidente, ficando assegurada a indicação de pelo menos um representante de cada um dos campi da USP.

§ 10 - A Comissão Central poderá convidar para participar de suas sessões, sem direito de voto, pessoas que, por seus conhecimentos e experiência profissional, possam contribuir para a discussão das matérias em exame.

§ 2- - A Comissão Central contará com um Secretário Executivo, a ser designado também por Ato da Reitora.

Artigo 7º - À Comissão Central compete:

I - propor aos dirigentes das Unidades e dos Órgãos da USP a composição de Comitês Locais do GESPÚBLICA USP, com a finalidade de descentralizar a gestão do referido Programa;

II - monitorar e divulgar os resultados do GESPÚBLICA USP; e

III - reconhecer e premiar as Unidades e os Órgãos da USP, participantes do GESPÚBLICA USP, que demonstrem qualidade em gestão, medida pelos resultados institucionais obtidos.

Artigo 8- - Ao Presidente da Comissão Central compete:

I - cumprir e fazer cumprir esta Portaria e as decisões da Comissão Central;

II - organizar Grupo de Ação Executiva para cada área prioritária, com a participação de representantes das Unidades e dos Órgãos da USP diretamente afetos ao desenvolvimento dos trabalhos;

III - designar o Coordenador de cada Grupo de Ação Executiva, ao qual incumbirá o acompanhamento dos trabalhos e a apresentação de cronograma contendo as etapas, prazos e resultados;

IV - convocar e coordenar as reuniões da Comissão Central; e

$\mathrm{V}$ - exercer o voto de qualidade no caso de empate nas deliberações.

Artigo 9- - Esta Portaria entrará em vigor na data de sua publicação, ficando revogadas as disposições em contrário, em especial as Portarias GR nº $\underline{2985}$, de 29 de janeiro de 1996, e $\underline{3673}$, de 09 de março de 2006.

Reitoria da Universidade de São Paulo, 23 de fevereiro de 2007.

SUELY VILELA

Reitora 